\title{
Przedsiębiorczość w warunkach kryzysu gospodarczego
}

Entrepreneurship in the conditions of economic crisis 
Uniwersytet Pedagogiczny im. Komisji Edukacji Narodowej w Krakowie Instytut Geografii Zakład Przedsiębiorczości i Gospodarki Przestrzennej

\title{
Przedsiębiorczość - Edukacja
} $\mathrm{Nr} 9$

\author{
Pedagogical University of Cracow \\ Institute of Geography \\ Department of Entrepreneurship and Spatial Management
}

Entrepreneurship - Education No. 9 


\title{
Przedsiębiorczość w warunkach
}

\section{kryzysu gospodarczego}

\author{
pod redakcją
}

Zbigniewa Zioło i Tomasza Rachwała 
Redaktor naczelny: prof. dr hab. Zbigniew Zioło

Zastępca redaktora naczelnego: dr Tomasz Rachwał

Rada Redakcyjna: Monika Borowiec, Roy Canning, Paweł Czapliński, Sławomir Dorocki, Wiesława Gierańczyk, Bronisław Górz, Anatol Jakobson, Sławomir Kurek, Matthias Pilz, Tomasz Rachwał (zastępca przewodniczącego), Natalia M. Syssoeva, Zdeněk Szczyrba, Anna I. Szymańska (sekretarz), Anna Tobolska, Krzysztof Wach, Krzysztof Wiedermann, Małgorzata Zdon-Korzeniowska, Zbigniew Zioło (przewodniczący)

Redakcja naukowa tomu: Zbigniew Zioło, Tomasz Rachwał

Publikacja dofinansowana przez Ministra Nauki i Szkolnictwa Wyższego, wydana przy wspótudziale Komisji Geografii Przemystu Polskiego Towarzystwa Geograficznego

Lista recenzentów współpracujących: Antoni Fajferek, Jerzy Kitowski, Tomasz Komornicki, Sławomir Kurek, Przemysław Śleszyński, Marek Więckowski

Projekt okładki: Maciej Galiński

Projekt graficzny i opracowanie graficzne: Jarosław Naus, Iwona Gałuszka

Opracowanie redakcyjne i redakcja językowa: Aleksandra Kowalczyk-Pryczkowska

Współpraca redakcyjna: Anna I. Szymańska

Skład i lamanie: Nowa Era Sp. z o.o.

Tłumaczenie wprowadzenia i korekta tekstów w języku angielskim: Multi Lingua, Joanna Maria Olejek www.multilingua.edu.pl

Oświadczenie o wersji pierwotnej: wersja drukowana jest wersją pierwotną.

Strona internetowa $\mathrm{z}$ dostępem do pełnych tekstów i informacjami dla autorów: www.p-e.up.krakow.pl

Kontakt z redakcją:

Anna I. Szymańska

Zakład Przedsiębiorczości i Gospodarki Przestrzennej, Instytut Geografii

Uniwersytet Pedagogiczny w Krakowie

ul. Podchorążych 2, 30-084 Kraków, p. 426

tel. (+48) 1266262 50, faks (+48) 126626243

e-mail: pe@up.krakow.pl

ISBN 978-83-267-1631-7

ISSN 2083-3296

(C) Copyright by Wydawnictwo Nowa Era w Warszawie \& Zakład Przedsiębiorczości i Gospodarki Przestrzennej IG UP w Krakowie

Warszawa - Kraków 2013

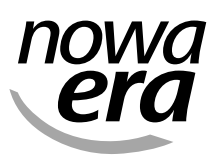

Nowa Era Sp. z o.o.

Aleje Jerozolimskie 146 D, 02-305 Warszawa

tel. 225702580 , faks 225702581

www.nowaera.pl, e-mail: nowaera@nowaera.pl

Druk i oprawa: 


\section{Wprowadzenie}

Trwający w gospodarce światowej kryzys wpływa na zmiany uwarunkowań i możliwości rozwoju działalności gospodarczej w poszczególnych krajach oraz układach regionalnych i lokalnych. W różnym zakresie obejmuje on przedsiębiorstwa, sektory gospodarcze, struktury instytucjonalne i segmenty życia społecznego. Jego efektem jest zmniejszenie produkcji i działalności usługowej, ograniczenie możliwości poprawnego funkcjonowania instytucji oraz pogarszanie się poziomu i jakości życia różnych grup społecznych. Ograniczanie działalności gospodarczej prowadzi do zmniejszenia zasilania finansowego instytucji państwowych, ograniczenia rozmiarów rynku pracy oraz zmniejszenia zasobów finansowych gospodarstw domowych. W konsekwencji wpływa to na ograniczenie chłonności rynku na określone produkty i usługi, co z kolei prowadzi do osłabienia działalności instytucji finansowych w zakresie udzielania kredytów, zarówno na cele inwestycyjne, jak i na cele konsumpcyjne, dla potencjalnych kredytobiorców.

Należy nadmienić, że współczesny kryzys na polu ekonomii odbierany jest bardzo różnie. Jedni traktują go jako ostatni etap cyklu koniunkturalnego, po którym nastąpi rozwój gospodarczy, inni przewidują, że będzie trwał dłużej, a jeszcze inni, że da on początek kolejnemu kryzysowi. Niepewność w tym zakresie sprawia, iż krajowe przedsiębiorstwa dysponujące sporymi zasobami finansowymi nie wykazują tendencji do rozwijania działalności inwestycyjnej. Podobnie społeczeństwo, dysponujące zgromadzonymi znacznymi zasobami finansowymi, nie wykazuje tendencji do ich aktywizacji rynkowej. Do tej właśnie bardzo aktualnej problematyki nawiązują autorzy artykułów zamieszczonych w niniejszym, dziewiątym numerze serii „Przedsiębiorczość - Edukacja”.

W artykule wprowadzającym przedstawiono koncepcję modelową uwarunkowań rozwoju przedsiębiorczości w warunkach kryzysu gospodarczego, ze szczególnym uwzględnieniem zmian miejsca przedsiębiorstwa w strukturze gospodarki rynkowej, oraz przejawy wpływu kryzysu na gospodarkę. Rozważania teoretyczne zobrazowano w nim wieloma przykładami empirycznymi, dotyczącymi wpływu kryzysu na wybrane dziedziny życia gospodarki krajowej i gospodarek wybranych krajów (Z. Zioło). W kolejnym artykule ekonomiczna analiza skutków kryzysu została rozpatrzona w szerszej perspektywie nauki Kościoła katolickiego, z uwzględnieniem pozycji ładu moralnego w biznesie (M. Borowiec). Autor następnej pracy pokazuje, że poważnym ograniczeniem dla prowadzenia działalności gospodarczej są obowiązujące instrumenty prawne. W ostatnich latach ulegały one częstym zmianom, związanym także z systemem podatkowym, co w małym stopniu motywowało do rozwijania działalności gospodarczej (P. Mężykowski). Szczególne znaczenie dla prowadzenia i rozwoju działalności gospodarczej mają w miarę stałe regulacje prawne związane zwłaszcza z systemem ulg podatkowych (P.M. Woroniecki). Znaczącą rolę w stwarzaniu korzystnych warunków dla rozwijania przedsiębiorczości odgrywają też instytucje publiczne oraz działalność edukacyjna prowadzona w formie różnego typu szkoleń (S. Dorocki, A. Świętek). Duże znaczenie dla rozwijania działalności gospodarczej mają również instytucje finansowe, szczególnie ich oferty kredytowe na rachunku bieżącym i kredytowym oraz kredyty inwestycyjne (W. Sadkowski).

Kolejna grupa artykułów obrazuje wpływ kryzysu na zmiany funkcjonowania firm, instytucji i sektorów gospodarczych. Przedstawione analizy dotyczą: zachowań organizacyjnych mikrofirm (D. Janczewska), podmiotów ekonomii społecznej (S. Sanetra-Półgrabi), możliwości rozwoju sektora turystyki (S. Dorocki, P. Brzegowy; K. Ziółkowska-Weiss), gospodarstw 
agroturystycznych (S. Dorocki, A.I. Szymańska, M. Zdon-Korzeniowska) i usług motoryzacyjnych (M. Włodarczyk, J. Janczewski). Kryzys gospodarczy powoduje też zmiany funkcjonalne i rewitalizację obszarów miejskich (J. Gałka, N. Grad), zmiany technologiczne w budownictwie (M. Płaziak) oraz zmiany priorytetów inwestycyjnych w przemyśle obronnym (P.L. Wilczyński).

Trzeci ważny obszar badawczy stanowiły dla autorów działania edukacyjne mające na celu przygotowanie odpowiednich kadr dla prowadzenia działalności gospodarczej nie tylko w warunkach kryzysowych, ale także w warunkach postępującego procesu rozwoju gospodarczego w przyszłości. Podkreślają to rozważania związane z określaniem nowych kierunków kształcenia, w tym edukacji w zakresie przedsiębiorczości (K. Wach; T.T. Brzozowski). Dobrym tego przykładem jest prezentacja opinii partnerów społecznych, dotycząca wskazań kształtowania kompetencji osobistych i społecznych dla sektora handlu detalicznego (S. Kurek, T. Rachwał, W. Kilar) oraz możliwości kształtowania inicjatyw klastrowych w systemie poradnictwa zawodowego (A. Pradela). Tom kończy analiza kierunków kształcenia w szkolnictwie wyższym w odniesieniu do rynku pracy oraz propozycje pewnych zmian w tym zakresie (D. Piróg).

Oddając niniejszy tom Czytelnikom, mamy nadzieję, że przedstawione w nim prace prezentujące kształtowanie przedsiębiorczości w warunkach kryzysu gospodarczego mogą przyczynić się do rozszerzenia i pogłębienia tej problematyki w edukacji szkolnej i akademickiej. Podkreślają one dużą złożoność i bardzo rozległy obszar badawczy dla tej problematyki, który powinien być rozszerzany i pogłębiany w kolejnych studiach. Ma to nie tylko szczególne znaczenie dla osłabiania obecnych negatywnych skutków kryzysu gospodarczego, ale także powinno służyć rozwojowi społeczno-gospodarczemu i kulturowemu w następnych latach i przyspieszać proces kształtowania społeczeństwa informacyjnego. Dlatego wszystkich zainteresowanych podjętą problematyką bardzo serdecznie zapraszamy do współpracy. Liczymy na konstruktywne uwagi i propozycje nowych kierunków badawczych. 


\section{Introduction}

The ongoing economic crisis alters the conditions and possibilities of developing business enterprises in individual countries, as well as local and regional groups. It concerns, in varying degrees, businesses, economic sectors, institutions and areas of social life. The crisis negatively affects production and services, limits the possibilities of adequate functioning of institutions, and causes the level and quality of life of various social groups to deteriorate. Limiting the economic activity leads also to lesser funding for state institutions, a decrease in size of the labour market, as well as a reduction of household budgets. This results in limiting market absorption of certain products and services, which, in turn, weakens financial institutions with regard to granting both consumer and investment loans, which ultimately affects all potential borrowers.It should also be added that the modern crisis is met with varying opinions in the field of economy. Some think of it as the final stage of an economic cycle, which is to be followed by a period of economic development, while others predict that the current crisis will last longer, or that it will give birth to a new economic downturn. This uncertainty prevents domestic enterprises with substantial financial means from developing their investment activities. Similarly, the general society, in possession of substantial assets, is not exhibiting signs of market activity either. Authors of the articles presented in the following, ninth volume of „Przedsiębiorczość - Edukacja” ['Entrepreneurship - Education'], comment on this very current topic.

The introductory article presents a model concept of conditions for developing entrepreneurship in an economic crisis, with special attention given to changes of the position of a business within the structure of the market economy, as well as the influence of the crisis on the economy in general. Theoretical considerations are illustrated with numerous empirical examples, presenting the influence of the crisis on selected areas of the Polish economy, as well as the economies of other, selected countries (Z. Zioło). In the next article, an economic analysis of the effects of the crisis is conducted from the perspective of the teachings of the Catholic Church, including the position of moral order in business (M. Borowiec). The author of the following text shows that existing legal instruments are a significant detriment to business activity. They have undergone frequent changes in recent years, connected also with the tax system, which does not motivate businesses to develop their economic activity (P. Mężykowski). Consistent legal regulations, especially regarding the system of tax reliefs, are especially significant for maintaining and developing enterprises (P.M. Woroniecki). Furthermore, public institutions, as well as educational activities, conducted in the form of various types of training courses, also play a major role in creating conditions beneficial to developing entrepreneurship (S. Dorocki, A. Świętek). Finally, the influence of financial institutions on businesses, most importantly in the areas of overdraft, credit account, and investment credit, cannot be ignored (W. Sadkowski).

A further group of articles presents the way in which the crisis is altering the functioning of businesses, institutions and entire sectors of the economy. The presented analyses concern: organizational activities of micro-enterprises (D. Janczewska), subjects of social economy (S. Sanetra-Półgrabi), possibilities of developing the tourism sector (S. Dorocki, P. Brzegowy; K. Ziółkowska-Weiss), and agrotourism farms (S. Dorocki, A.I. Szymańska, M. Zdon-Korzeniowska), as well as automotive services (M. Włodarczyk, J. Janczewski). The economic crisis creates functional changes in urban areas, and revitalizes them (J. Gałka, N. Grad), introduces technological changes in the area of construction (M. Płaziak), and alters investment priorities in the defence industry (P.L. Wilczyński). 
Educational activities, aimed at training managers, skilled not only in conducting business in the conditions of crisis, but also during future processes of progressing economic development, constitute the third area of research, important from the point of view of the authors. The above is exemplified by considerations on new directions of education, including entrepreneurship education (K. Wach; T.T. Brzozowski), and by a presentation of opinions of social partners, concerning the directions of forming personal and social competences, important from the point of view of the retail sector (S. Kurek, T. Rachwał, W. Kilar), as well as the possibilities of creating cluster initiatives in the career guidance system (A. Pradela). The volume finishes with an analysis of fields of study in higher education, in relation to the labour market, and propositions of certain changes in this area (D. Piróg).

By presenting the following volume to our readers, we are hoping that the articles contained therein, describing the development of businesses in the conditions of crisis, will help to widen and expand this subject area, in both school, and university education. These articles underline significant complexity of the discussed topic, and cover a wide research area, which should be broadened and expanded in the course of further studies. This is significant not only from the point of view of limiting the current, negative impact of the economic crisis, but may also serve to enhance the social, economic and cultural development in coming years, as well as accelerate processes of forming an information society. And so, everyone interested in the topics covered in the following volume is invited to join us. We are open to constructive criticism, and propositions of new research directions. 


\section{Uwarunkowania rozwoju}

\section{firm w okresie}

\section{kryzysu gospodarczego}

The conditions of development of companies in times of an economic crisis 


\author{
Zbigniew Zioło \\ Uniwersytet Pedagogiczny \\ im. Komisji Edukacji Narodowej \\ w Krakowie
}

\title{
Uwarunkowania rozwoju przedsiębiorczości w warunkach kryzysu gospodarczego
}

\author{
The conditions for entrepreneurship development during an economic crisis
}

\begin{abstract}
Streszczenie
W pracy główną uwagę zwrócono na: określenie miejsca przedsiębiorczości w strukturze gospodarki rynkowej, przejawy wpływu kryzysu na gospodarkę narodową, proces upadłości przedsiębiorstw, wpływ sytuacji kryzysowej na rynek pracy, zachowania wybranych sektorów gospodarki w nasilającej się sytuacji kryzysowej, sytuację finansową przedsiębiorstw, uwarunkowania instytucjonalne rozwoju działalności gospodarczej i procesy migracji.
\end{abstract}

\begin{abstract}
The following paper focuses mainly on determining the characteristic role of entrepreneurship in the structure of market economy, the impact of recession symptoms on national economy, bankruptcy processes of companies, the impact of recession on the labour market, performance of selected sectors of economy in a deepening recessions, the financial condition of companies, institutional factors of economic growth and migration processes.
\end{abstract}

Słowa kluczowe: gospodarka narodowa; kryzys; migracje; przedsiębiorczość

Key words: national economy; recession; migrations; entrepreneurship

\section{Wprowadzenie}

Nasilająca się sytuacja kryzysowa stwarza odmienne możliwości prowadzenia działalności gospodarczej zarówno dla światowych koncernów, dużych i średnich przedsiębiorstw, jak i dla małych firm zwykle o funkcjach lokalnych. Dlatego szczególnie ważnym zagadnieniem jest coraz precyzyjniejsze poznawanie mechanizmu funkcjonowania gospodarki oraz doskonalenie umiejętności ciągłego poszukiwania przez przedsiębiorstwo swojego miejsca w różnych strukturach zmieniającego się rynku. Znaczącą rolę w tym zakresie odgrywa wykształcanie postaw przedsiębiorczych, które umożliwią zdobywanie umiejętności wykorzystania wiedzy teoretycznej i praktycznej dla osiągania sukcesów, oraz rozwijanie działalności gospodarczej. Na tym tle możemy przyjąć, że przedsiębiorczość przejawia się w umiejętności wykorzystania wiedzy dla zdobycia określonych zasobów kapitałowych i finansowych.

Po przyjęciu powyższych założeń celem niniejszych rozważań jest określenie uwarunkowań dla rozwoju przedsiębiorczości oraz ich zmian w latach kryzysu gospodarczego, a na tym tle zarysowanie tendencji przemian gospodarki krajowej i zachowań podmiotów gospodarczych. 
Problematyka genezy, przebiegu i skutków kryzysu gospodarczego oraz możliwości wyjścia z niego jest przedmiotem zainteresowań naukowców z wielu dyscyplin naukowych, a także elit politycznych i społeczeństwa, które w największym stopniu odczuwa negatywne konsekwencje kryzysu. Z pozycji różnych szkół ekonomicznych określane są jego przyczyny oraz prezentowane są różne możliwości ograniczania jego negatywnych skutków, a następnie poszukiwania najefektywniejszych dróg wychodzenia z niego. Problematyka ta znalazła się także w kręgu zainteresowań geografii przemysłu i wydaje się, że należy ją rozwijać na gruncie edukacji przedsiębiorczości.

\section{Miejsce przedsiębiorstwa w strukturze gospodarki rynkowej}

Zachowanie przedsiębiorstwa w gospodarce nawiązuje do reguł mikroekonomicznych, gdyż celem jego działalności jest wypracowanie maksymalnego zysku. W strukturze przedsiębiorstwa podejmowane są samodzielne decyzje, podporządkowane własnym interesom, które równocześnie związane są z ponoszeniem przez nie określonego ryzyka. Przedsiębiorstwo funkcjonuje i rozwija się w określonym otoczeniu innych przedsiębiorstw, instytucji, uwarunkowań rynkowych, społecznych, które wynikają z określonych celów krajowej i międzynarodowej polityki gospodarczej (Zioło, 1988, 1994; Rachwał, 2001). Układ ten kształtuje się zgodnie z regułami makroekonomicznymi, które przy wykorzystaniu odpowiednich instrumentów ekonomicznych zwracają główną uwagę na podnoszenie efektywności gospodarki narodowej. W tej sytuacji w procesie kształtowania gospodarki zaznaczają się obiektywne konflikty występujące między dążeniami przedsiębiorstwa a dążeniami gospodarki narodowej ${ }^{1}$.

Przedsiębiorstwo w strukturze gospodarki jest jednym z ważnych elementów, które oddziałują na otoczenie, jednak otoczenie także w istotnym stopniu wpływa na jego możliwości rozwojowe (m.in. Misztal, Zioło, 1998; Zioło, Rachwał, 2009, 2010, 2011a, 2011b). W niniejszych rozważaniach ograniczymy się do wybranych cech wpływających w istotnym stopniu na uwarunkowania funkcjonowania przedsiębiorstwa w warunkach kryzysu gospodarczego (ryc. 1).

Kształtowanie działalności produkcyjnej bądź usługowej w podstawowym stopniu uzależnione jest od rozmiarów rynku, który tworzą: gospodarstwa domowe, inne przedsiębiorstwa odbierające lub dostarczające surowce, półfabrykaty czy gotowe elementy służące do montażu, a także różnego rodzaju instytucje publiczne i in. Rynek ten w zależności od potencjału ekonomicznego przedsiębiorstwa może mieć zasięg lokalny, regionalny, krajowy lub międzynarodowy.

$\mathrm{Na}$ rozmiary chłonności rynku w zasadniczym stopniu wpływają gospodarstwa domowe, które stwarzają popyt na oferowane produkty. Siła oddziaływania gospodarstw na rynek zależy od wielkości środków finansowych płynących do nich z różnorodnych źródeł zasilania. Źródła te reprezentują głównie: dochody z pracy ludności aktywnej zawodowo, niezarobkowe źródła utrzymania, dochody z pracy za granicą, dochody z pracy w szarej strefie, zgromadzone wcześniej własne oszczędności oraz możliwości kredytowe oferowane przez instytucje finansowe.

Dla przedsiębiorstwa przy podejmowaniu działalności gospodarczej (produkcyjnej, usługowej) ważnym zagadnieniem są źródła zasilania finansowego, które reprezentują instytucje finansowe (banki, giełda), możliwości sprzedaży zbędnych zasobów (np. terenów, budynków, budowli), budżet państwa czy własne zasoby zgromadzone w bankach. W tym zakresie

\footnotetext{
${ }^{1}$ Przejawia się to m.in. w tym, że przedsiębiorstwa chciałyby płacić do budżetu państwa jak najmniejsze kwoty podatków i różnych opłat, a budżet państwa chciałby pozyskać jak największe dochody płynące z działalności przedsiębiorstw. Podobnie celem przedsiębiorstw jest racjonalizacja zatrudnienia, a celem gospodarki narodowej jest wzrost rynku pracy, dążenie do ograniczania bezrobocia i zmniejszania związanej z nim pomocy budżetowej.
} 
Ryc. 1. Miejsce przedsiębiorstwa w strukturze gospodarki rynkowej

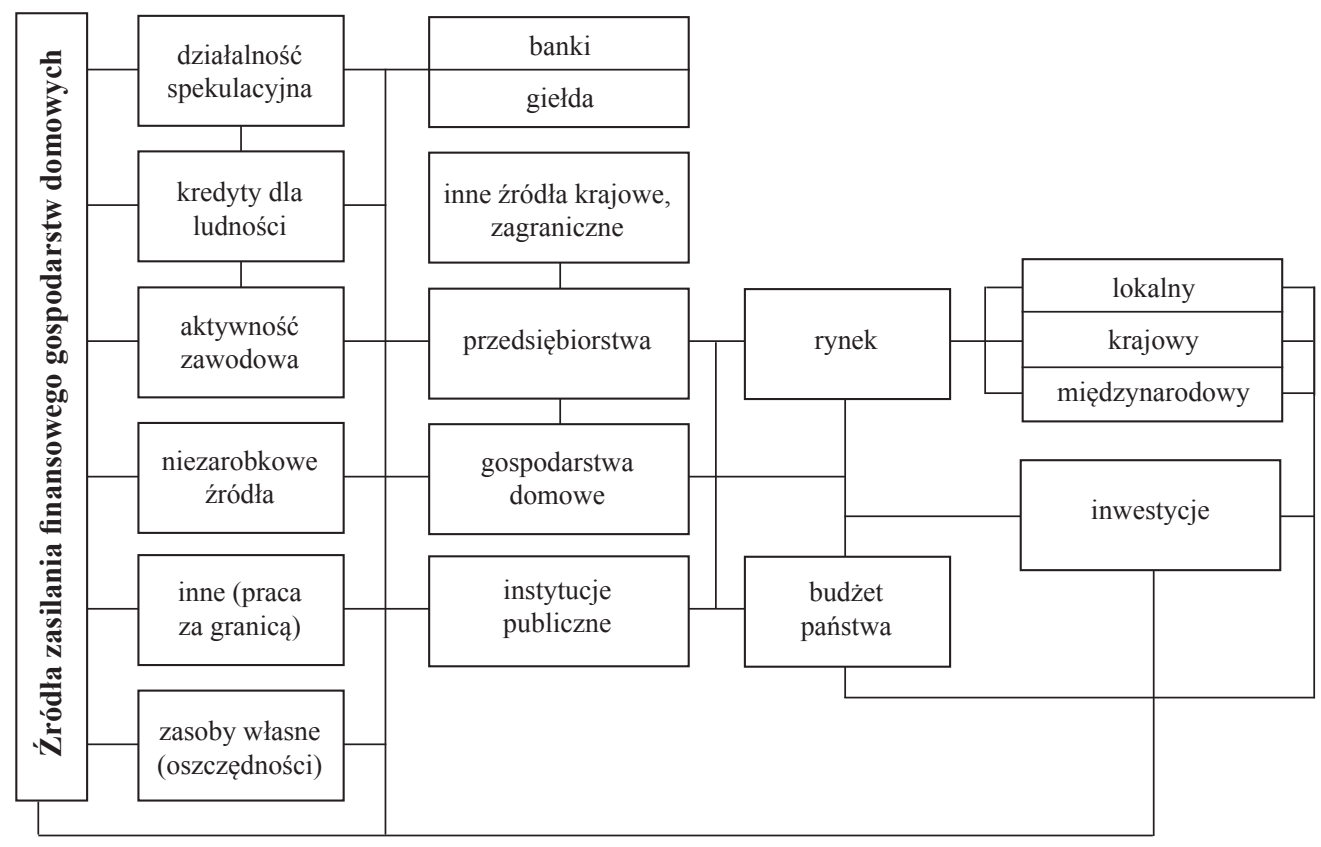

Źródło: opracowanie własne.

szczególnie istotne miejsce w otoczeniu przedsiębiorstwa zajmuje budżet państwa, którego rozmiary zależą od wartości opłat przedsiębiorstw (wynikających z wielkości produkcji), wielkości zasilania finansowego gospodarstw domowych, zgromadzonych zasobów oraz chłonności rynku, wpływającego na rozmiary różnego rodzaju podatków pośrednich (np. VAT). Rozmiary budżetu umożliwiają w znacznym stopniu: pobudzanie działalności gospodarczej przedsiębiorstw, instytucji publicznych i finansowych, zagwarantowanie odpowiedniego poziomu zasilania finansowego gospodarstw domowych (słabych ekonomicznie, zasiłki dla bezrobotnych, pomoc dla najuboższych i in.), a także aktywizację rynku zbytu produktów (np. dotacje do zakupu nowych samochodów czy zmniejszenia wielkości podatków pośrednich) lub aktywizację rynku pracy.

Znaczącą rolę odgrywają inwestycje produkcyjne i infrastrukturalne prowadzone przez przedsiębiorstwa i instytucje. Dzięki nim powstają nowe miejsca pracy, które zwiększają stopień aktywizacji zasobów pracy, ograniczają bezrobocie i zmniejszają konieczność wydatków na zasiłki dla ludności, a w konsekwencji wpływają na podnoszenie jakości życia ludności.

W sytuacji kryzysowej w zarysowanym układzie zaznaczają się pewne zakłócenia powiązań funkcjonalnych zachodzących między wyróżnionymi elementami strukturalnymi gospodarki, w tym relacji przedsiębiorstwa z elementami jego otoczenia. Głównym czynnikiem zachwiania wykształconych relacji funkcjonalnych są najczęściej ograniczenia wielkości przepływów strumieni kapitałowo-finansowych i produktów lub zmiana kierunków ich przepływu wywołanych przez decyzje polityki społeczno-gospodarczej czy polityki zagranicznej (ryc. 2). Zmniejszanie zasobów finansowych społeczeństwa wpływa na ograniczanie chłonności rynku. Powoduje to zmniejszanie zapotrzebowania na wyroby i usługi, a w konsekwencji ograniczanie produkcji, ograniczanie zasilania finansowego gospodarstw domowych i budżetu, ograniczanie działalności kredytowej, trudności w realizacji przepływów finansowych między podmio- 
Ryc. 2. Przyczyny i konsekwencje sytuacji kryzysowej dla rozwoju przedsiębiorczości

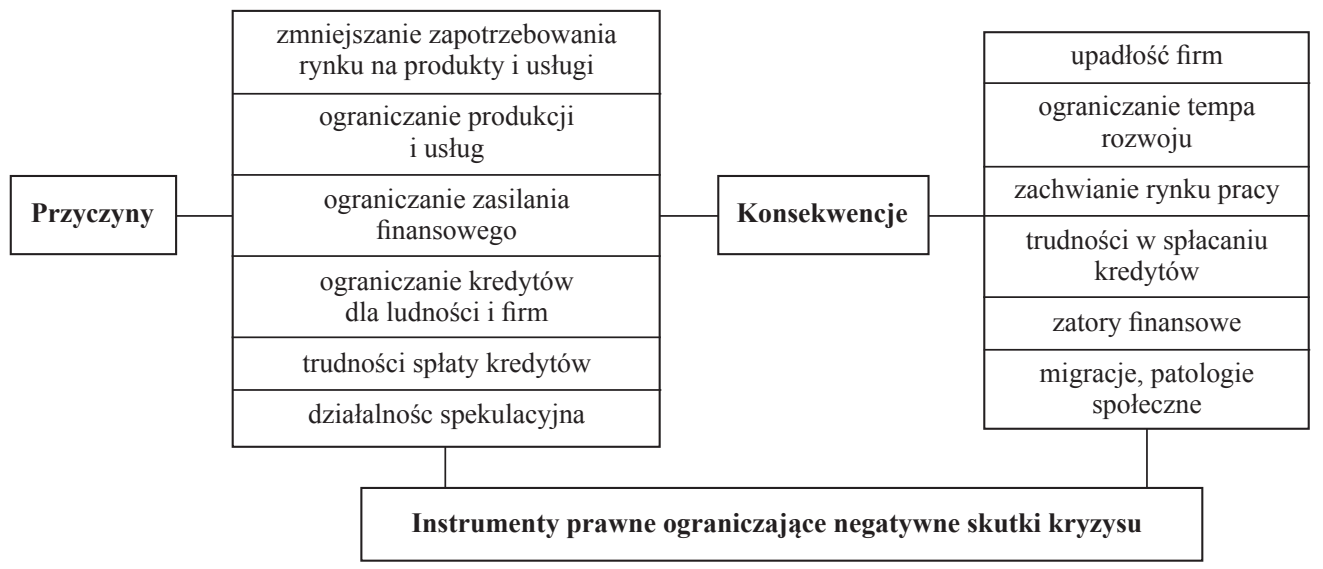

Źródło: opracowanie własne.

tami gospodarczymi (zatory płatnicze), aktywizację działalności spekulacyjnej, a także radykalizację zachowań społecznych.

W konsekwencji prowadzi to do upadłości firm, a następnie do ograniczania tempa wzrostu gospodarczego, kurczenia się rynku zbytu gotowych produktów i oferowanych usług, zmniejszania poziomu zatrudnienia, recesji na rynku pracy, nasilania się bezrobocia. Ograniczenia finansowe wynikające $\mathrm{z}$ tego tytułu sprawiają trudności w spłacaniu kredytów, uaktywniają migrację zarobkową ludności, nasilają drenaż najbardziej wartościowych zasobów pracy oraz wpływają na rozwój zjawisk patologii społecznej.

Sytuacja ta wpływa na zmianę istniejących i pojawianie się nowych instrumentów prawnych mających na celu ograniczanie negatywnych skutków kryzysu. Trudności w tym zakresie związane są głównie z malejącymi wpływami finansowymi do budżetu, a równocześnie rosnącymi potrzebami budżetowymi państwa, które są niezbędne dla ograniczania negatywnych zjawisk kryzysowych. Jedynym wyjściem w takiej sytuacji jest zaciąganie przez państwo nowych kredytów oraz nasilanie systemu fiskalnego prowadzącego do zwiększania obciążeń finansowych przedsiębiorstw i ludności. Sytuację tego typu mogą pogarszać braki w zakresie umiejętności prowadzenia dialogu społecznego oraz rosnące żądania, często wynikające z pojawiania się działań populistycznych pewnych grup ${ }^{2}$.

\section{Przejawy wpływu kryzysu na gospodarkę}

Wyrazem wzrostu potencjału ekonomicznego, a także zmienności warunków rozwoju przedsiębiorczości, są wahania dynamiki produktu krajowego brutto (PKB) ${ }^{3}$. W latach przedkryzy-

${ }^{2}$ Ilustracją tego jest niezadowolenie mieszkańców Grecji oraz Hiszpanii, a także ucieczka przedsiębiorstw do tzw. rajów podatkowych i migracja najbogatszych obywateli do krajów o niższych stopach podatkowych. Na przykład w wyniku kryzysu najbogatsi Francuzi zostali obciążeni 75-procentowym podatkiem od dochodów, stąd część z nich zmieniła miejsce zamieszkania na kraje o niższych stopach podatkowych, takich jak Rosja, w której wynoszą one tylko 13\%.

3 „PKB obrazuje końcowy rezultat działalności wszystkich podmiotów gospodarki narodowej; równa się sumie wartości dodanej brutto wszystkich sektorów własności albo sektorów instytucjonalnych lub sumie dochodów wartości dodanej brutto wszystkich sekcji, działów powiększonej o podatki od produktów i pomniejszonej o dotacje do produktów" (GUS, 2010: 736). 
sowych gospodarka krajowa na tle krajów europejskich odznaczała się znaczącym wzrostem, co ilustruje stosunkowo wysoka dynamika PKB, która systematycznie rosła z 103,9 w 2003 r. do 106,8 w 2007 r., gdy w tym czasie kraje dominujące w światowej gospodarce odznaczały się niższym tempem wzrostu (tab. 1). Dynamika wzrostu PKB Stanów Zjednoczonych zmniejszała się z 103,5 do 101,9, a Niemiec zwiększała się z 99,8 do 103,7. Intensywniejszym wzrostem charakteryzowały się kraje grupy BRIC (Brazylia, Rosja, Indie, Chiny). W analizowanym okresie dynamika wzrostu PKB gospodarki Brazylii wzrosła od 101,1 do106,1, Chin od 110,0 do114,2, Indii od 108,4 do 109,6, a Rosji od 107,3 do 108,2 i państwa te znacznie przewyższały wzrost dynamiki światowej, która charakteryzowała się wzrostem od 102,7 do 104,1. Podkreśla to wolniejsze tempo wzrostu dominujących gospodarek światowych i znacznie intensywniejszy wzrost krajów BRIC, które wyrastają na nowe światowe bieguny wzrostu ekonomicznego.

W latach kryzysu nastąpił znaczny spadek dynamiki PKB w gospodarce światowej z 104,0 w 2007 r. do 98,0 w 2009 r. W 2009 r. spośród krajów UE tylko Polska odznaczała się wzrostem PKB, do 101,7, natomiast w pozostałych krajach występowała recesja, a dynamika ich gospodarek znacznie spadła i wahała się od 98,3\% (Cypr) do (82,3\% (Łotwa). W tymże roku dynamika gospodarki dominujących krajów na świecie zmniejszyła się: we Francji do 97,3\%, w Stanach Zjednoczonych do 96,5\%, w Wielkiej Brytanii do 95,1\% i w Niemczech do 94,9\%. Odmiennymi tendencjami charakteryzowały się gospodarki krajów BRIC. Dynamika gospodarki chińskiej nieco spadła, ze 114,2 do 109,1, gospodarki indyjskiej ze 109,6 do 107,7, brazylijskiej do 99,8 i rosyjskiej do 92,1. Podkreśla to bardzo duże zróżnicowanie przestrzenne recesji gospodarczej, która w największym stopniu objęła Stany Zjednoczone i kraje europejskie, a tylko osłabiła gospodarkę Chin i Indii.

W gospodarce polskiej zaznaczyło się w tym czasie różnicowane tempo wzrostu (tab. 2). W latach 2008-2012 wyróżniają się cztery okresy odznaczające się różnymi tendencjami dynamiki PKB. Od pierwszego kwartału 2008 r. do pierwszego kwartału 2009 r. następował systematyczny spadek dynamiki PKB z 6,3 do 0,4, po czym do czwartego kwartału 2009 r.

Tab. 1. Dynamika PKB Polski na tle dominujących gospodarek światowych

\begin{tabular}{|l|c|c|c|c|c|c|c|c|}
\hline \multicolumn{1}{|c|}{ Kraje } & $\mathbf{2 0 0 3}$ & $\mathbf{2 0 0 4}$ & $\mathbf{2 0 0 5}$ & $\mathbf{2 0 0 6}$ & $\mathbf{2 0 0 7}$ & $\mathbf{2 0 0 8}$ & $\mathbf{2 0 0 9}$ & $\mathbf{2 0 1 0}$ \\
\hline Polska & 103,9 & 105,3 & 103,6 & 106,2 & 106,8 & 105,1 & 101,7 & 103,9 \\
\hline Stany Zjednoczone & 102,5 & 103,5 & 103,1 & 102,7 & 101,9 & 99,7 & 96,5 & 103,0 \\
\hline W. Brytania & 103,0 & 103,0 & 102,2 & 102,7 & 102,7 & 99,9 & 95,1 & 101,4 \\
\hline Francja & 101,1 & 102,5 & 101,8 & 102,5 & 102,3 & 99,9 & 97,3 & 101,5 \\
\hline Niemcy & 99,8 & 101,2 & 100,7 & 103,7 & 103,3 & 101,1 & 94,9 & 103,7 \\
\hline Chiny & 110,0 & 110,1 & 111,3 & 112,7 & 114,2 & 109,6 & 109,1 & 110,3 \\
\hline Indie & 108,4 & 108,3 & 109,3 & 109,4 & 109,6 & 105,1 & 107,7 & 109,7 \\
\hline Brazylia & 101,1 & 105,7 & 103,2 & 104,0 & 106,1 & 105,1 & 99,8 & 107,5 \\
\hline Rosja & 107,3 & 107,2 & 106,4 & 108,2 & 108,1 & 105,2 & 92,1 & 104,0 \\
\hline Świat & 102,7 & 104,1 & 103,6 & 104,1 & 104,0 & 101,7 & 98,0 & \\
\hline
\end{tabular}

Źródło: opracowanie własne na podstawie roczników statystycznych GUS z lat 2007-2011. 
Tab. 2., ryc. 3. Dynamika polskiego PKB w latach 2008-2012

\begin{tabular}{|c|c|c|}
\hline Rok & Kwartal & Dynamika \\
\hline 2008 & I & 6,3 \\
\cline { 2 - 3 } & II & 6,1 \\
\cline { 2 - 3 } & III & 5,2 \\
\cline { 2 - 3 } & IV & 3,2 \\
\hline 2009 & I & 0,4 \\
\cline { 2 - 3 } & II & 1,0 \\
\cline { 2 - 3 } & III & 1,6 \\
\cline { 2 - 3 } & IV & 3,2 \\
\hline 2010 & I & 2,7 \\
\cline { 2 - 3 } & II & 3,7 \\
\cline { 2 - 3 } & III & 4,2 \\
\cline { 2 - 3 } & IV & 4,7 \\
\hline 2011 & I & 4,6 \\
\cline { 2 - 3 } & II & 4,2 \\
\cline { 2 - 3 } & III & 4,2 \\
\cline { 2 - 3 } & IV & 4,3 \\
\hline 2012 & I & 3,6 \\
\cline { 2 - 3 } & II & 2,3 \\
\hline & III & 1,4 \\
\hline & IV & 0,7 \\
\hline
\end{tabular}

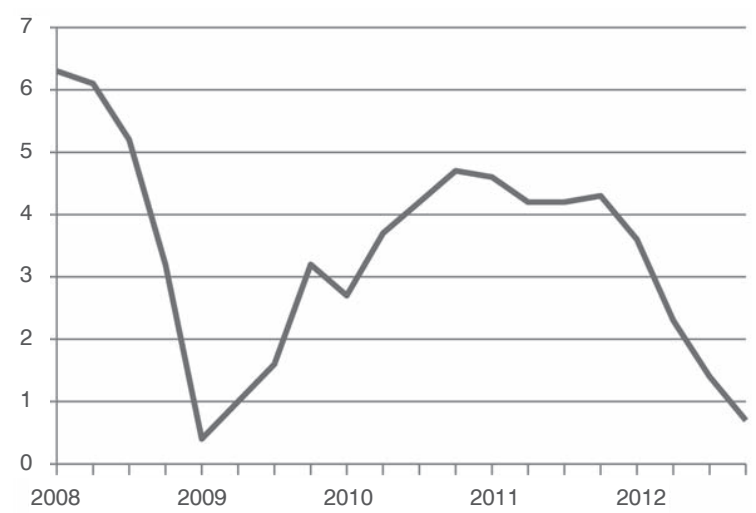

Źródło: Bank Danych Lokalnych GUS.

wzrósł do 4,7 i na zbliżonym poziomie utrzymywał się do czwartego kwartału 2011 r., a następnie nastąpiła ponowna recesja do 0,7 w czwartym kwartale $2012 \mathrm{r}$. Załamania te w pewnym stopniu związane są z sezonowością działalności niektórych przedsiębiorstw, zwłaszcza budowlanych, dla których miesiące zimowe nie są korzystne, a także z kurczącymi się wydatkami finansowymi społeczeństwa wobec wizji zbliżającego się kryzysu.

\section{Upadłość przedsiębiorstw}

W zasadniczym stopniu na osłabienie dynamiki rozwoju gospodarczego wpływa upadek krajowych firm. W latach 2004-2012 proces upadłości przebiegał z różnym nasileniem i objął łącznie 6,5 tys. firm (tab. 3). Początkowo w warunkach rozwoju gospodarczego (2004-2008) liczba upadających firm systematycznie zmniejszała się z 1163 do 425 . Dokonywała się wówczas pewna selekcja, obejmująca firmy bez silnych podstaw ekonomicznych, których lokalizacje nie zawsze były racjonalne, oraz firmy powstałe jeszcze w latach gospodarki centralnie sterowanej, które miały trudności w dostosowaniu się do nowych warunków wdrażania gospodarki rynkowej. Ponowny wzrost upadłości firm do liczby 877 w 2012 r. nastąpił w wyniku nasilającego się kryzysu, który stwarzał niekorzystne uwarunkowania związane głównie z ograniczaniem płynności finansowej oraz spadającym popytem, wywołanym w znacznym stopniu zubożeniem społeczeństwa i ograniczeniem eksportu. 
Tab. 3., ryc. 4. Liczba upadłych firm w Polsce w latach 2004-2012

\begin{tabular}{|c|c|c|}
\hline Rok & $\begin{array}{c}\text { Liczba } \\
\text { upadłych } \\
\text { firm }\end{array}$ & $\begin{array}{c}\text { Dynamika } \\
\text { w stosunku } \\
\text { do roku } \\
\text { poprzedniego }\end{array}$ \\
\hline 2004 & 1163 & 100,0 \\
\hline 2005 & 861 & 74,0 \\
\hline 2006 & 648 & 75,3 \\
\hline 2007 & 480 & 74,1 \\
\hline 2008 & 425 & 88,5 \\
\hline 2009 & 673 & 158,4 \\
\hline 2010 & 691 & 102,7 \\
\hline 2011 & 730 & 105,6 \\
\hline 2012 & 877 & 120,1 \\
\hline
\end{tabular}

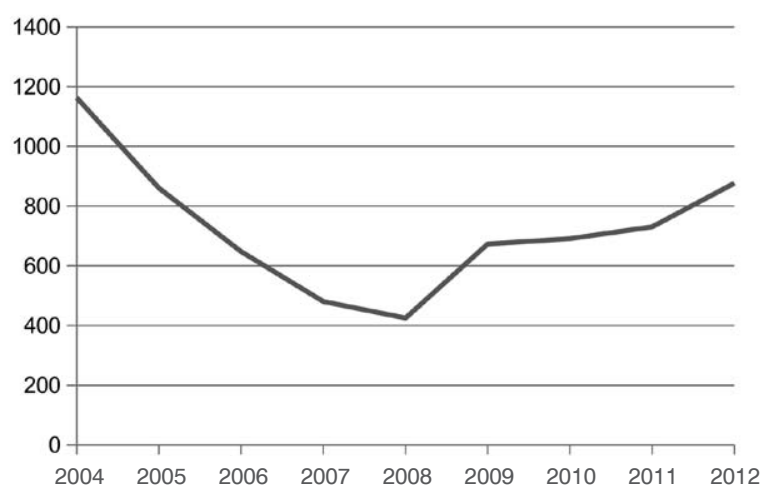

Źródło: opracowanie własne na podstawie danych GUS z lat 2004-2012.

W okresie nieznacznego ożywienia gospodarczego w dynamice upadłości firm uwidaczniły się wyraźne wahania. W 2011 r. od stycznia do maja można było zaobserwować w miarę wyrównane tendencje $\mathrm{w}$ upadłości firm, a następnie nasilenie się tego procesu zaznaczyło się od czerwca do lipca, po czym w kolejnych miesiącach do końca grudnia nastąpiło jego osłabienie (tab. 4). Upadło wówczas wiele firm, które nie mogły znaleźć swojego miejsca w warunkach ponownego nasilenia się sytuacji kryzysowej. W 2012 r. już silniej zaznaczył się wpływ kryzysu gospodarczego, który pociągnął za sobą nasilenie zjawiska upadłości firm. Likwidowały swoją działalność głównie małe podmioty gospodarcze związane z handlem detalicznym, które nie były w stanie sprostać konkurencji dużych marketów. Ich liczba zmniejszyła się z 128,6 tys. w 2009 r. do 110,0 w roku 2011. Upadały także firmy budowlane, co związane było z ograniczeniami działalności inwestycyjnej przedsiębiorstw, zmniejszaniem się popytu na nowe mieszkania oraz zatorami płatniczymi wynikającymi głównie z budowy autostrad. Wielu głównych wykonawców nie było bowiem w stanie wypłacać należnych kwot za wykonane prace przez mniejsze przedsiębiorstwa i przedsiębiorstwa słabsze kapitałowo.

Proces upadłości z różnym nasileniem zaznaczył się w krajowej przestrzeni gospodarczej, czego wyrazem jest znaczne zmniejszenie liczby firm na terenie poszczególnych województw (tab. 5). W 2011 r., od stycznia do października, najwięcej firm upadło na terenie województwa mazowieckiego - 135 - a w tym samym okresie w 2012 r. liczba upadłości zwiększyła się do 163, czyli do 120,7\%. Upadłości te obejmowały odpowiednio 21,5\% i 21,1\% ogólnej liczby upadłych firm na terenie kraju. Następnie znaczący wzrost upadłości wystąpił na terenach najbardziej rozwiniętych województw: śląskiego, gdzie liczba upadłych firm zwiększyła się z 78 do 83, a także wielkopolskiego i dolnośląskiego. Łącznie obejmowały one odpowiednio $33,8 \%$ i 33,1\% upadających firm na terenie kraju.

Najsilniejsza dynamika upadłości zaznaczyła się na terenach najsłabiej rozwiniętych województw, podlaskiego, gdzie liczba upadających firm zwiększyła się ponad trzykrotnie (z 6 do 21), świętokrzyskiego (ponaddwukrotnie), lubelskiego (blisko dwukrotnie) i kujawsko-pomorskiego. Jedynie na terenie województwa łódzkiego zaznaczyło się osłabienie tempa upadłości firm, a ich liczba zmniejszyła się z 32 do 30 . W przestrzeni krajowej proces upadłości w obu okresach 
Tab. 4. Firmy ogłaszające upadłość w Polsce w latach 2011-2012

\begin{tabular}{|c|c|c|c|c|}
\hline \multirow{2}{*}{ Rok } & \multirow{2}{*}{ Miesiące } & \multirow{2}{*}{$\begin{array}{c}\text { Liczba firm ogłaszających } \\
\text { upadłość }\end{array}$} & \multicolumn{2}{|r|}{ Dynamika } \\
\hline & & & styczeń $=100$ & miesiąc poprzedni $=100$ \\
\hline \multirow{12}{*}{2011} & $\mathrm{I}$ & 64 & 100,0 & 100,0 \\
\hline & II & 59 & 92,2 & 92,2 \\
\hline & III & 70 & 109,4 & 118,6 \\
\hline & IV & 62 & 96,9 & 88,6 \\
\hline & $\mathrm{V}$ & 63 & 98,4 & 101,6 \\
\hline & VI & 57 & 89,1 & 90,5 \\
\hline & VII & 76 & 118,8 & 133,3 \\
\hline & VIII & 56 & 87,5 & 73,7 \\
\hline & IX & 64 & 100,0 & 114,3 \\
\hline & $\mathrm{X}$ & 56 & 87,5 & 87,5 \\
\hline & $\mathrm{XI}$ & 62 & 96,9 & 110,7 \\
\hline & XII & 41 & 64,1 & 66,1 \\
\hline \multirow{12}{*}{2012} & $\mathrm{I}$ & 66 & 103,1 & 161,0 \\
\hline & II & 71 & 110,9 & 107,6 \\
\hline & III & 74 & 115,6 & 104,2 \\
\hline & IV & 64 & 100,0 & 86,5 \\
\hline & $\mathrm{V}$ & 82 & 128,1 & 128,1 \\
\hline & VI & 68 & 106,3 & 82,9 \\
\hline & VII & 70 & 109,4 & 102,9 \\
\hline & VIII & 73 & 114,1 & 104,3 \\
\hline & IX & 52 & 81,3 & 71,2 \\
\hline & $X$ & 91 & 142,2 & 175,0 \\
\hline & XI & 86 & 134,4 & 94,5 \\
\hline & XII & 80 & 125,0 & 93,0 \\
\hline
\end{tabular}

Ryc. 5. Liczba firm ogłaszających upadłość w Polsce

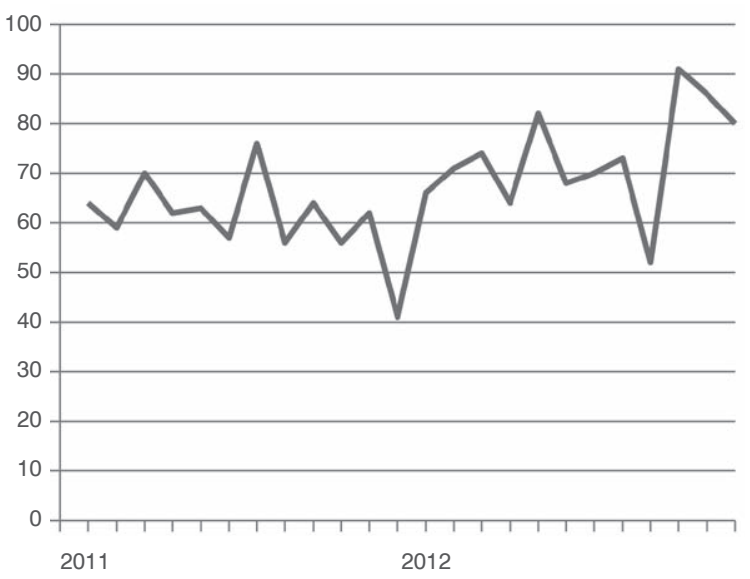

Źródło: Reda-Jakima (2013: B3). 
Tab. 5. Upadłość polskich firm wg województw

\begin{tabular}{|l|c|c|c|}
\hline \multirow{2}{*}{ Województwa } & \multicolumn{2}{|c|}{ Liczba upadłości w okresie I-X } & \multirow{2}{*}{ Dynamika 2011-2012 } \\
\cline { 2 - 4 } & $\mathbf{2 0 1 1}$ & $\mathbf{2 0 1 2}$ & 120,7 \\
\hline Mazowieckie & 135 & 163 & 114,3 \\
\hline Dolnośląskie & 77 & 88 & 149,1 \\
\hline Wielkopolskie & 57 & 85 & 106,4 \\
\hline Śląskie & 78 & 83 & 118,2 \\
\hline Zachodniopomorskie & 55 & 65 & 105,6 \\
\hline Małopolskie & 54 & 57 & 122,6 \\
\hline Pomorskie & 31 & 38 & 138,5 \\
\hline Kujawsko-pomorskie & 26 & 36 & 93,8 \\
\hline Lódzkie & 32 & 30 & 193,3 \\
\hline Lubelskie & 15 & 29 & 122,2 \\
\hline Warmińsko-mazurskie & 18 & 22 & 105,0 \\
\hline Podkarpackie & 20 & 21 & 350,0 \\
\hline Podlaskie & 6 & 21 & 200,0 \\
\hline Świętokrzyskie & 6 & 12 & 120,0 \\
\hline Opolskie & 10 & 12 & 157,1 \\
\hline Lubuskie & 7 & 11 & \\
\hline
\end{tabular}

Źródło: Więcław (2010).

przebiegał z bardzo zbliżonym nasileniem, co ilustruje wysoka wartość współczynnika korelacji między upadłościami w pierwszym i drugim okresie, która wyniosła 0,984.

Relatywnie najmocniej upadłości zaznaczyły się na terenach województw słabiej rozwiniętych, natomiast najwyższy spadek potencjału w strukturze krajowej wystąpił na obszarach województw stojących na najwyższym poziomie rozwoju. W układach regionalnych w najpoważniejszym stopniu na upadłość firm wpływały zatory płatnicze, które szczególnie silnie zaznaczyły się w budownictwie, handlu, działalności finansowej i telekomunikacji; ograniczanie chłonności rynku, które najmocniej zaznaczyły się w województwach słabiej rozwiniętych, a także mało spójny system instrumentów prawnych i słabość organów państwowych ${ }^{4}$.

\section{Sytuacja kryzysowa na rynku pracy}

W konsekwencji sytuacji kryzysowej prowadzącej do ograniczenia działalności i upadku firm nastąpiły znaczne ograniczenia rozmiarów rynku pracy, czego wyrazem jest wahająca się i stosunkowo wysoka stopa bezrobocia (tab. 6). W latach 2002-2008 systematycznie spadała ona z 19,5 do 9,1 a następnie w latach kryzysu na koniec września 2012 r. wzrosła do 12,4 i, według prognoz, będzie nadal wzrastać.

\footnotetext{
${ }^{4}$ Ilustracją tego może być np. upadek poznańskiej firmy informatycznej „Bestcom”. Po siedmiu latach śledztwa i licznych aresztowaniach zniszczono dochodową firmę (podobnie jak wcześniej firmę R. Kluski), w wyniku czego straciło pracę ponad 75 osób. Firma ta miała ok. $120 \mathrm{mln}$ rocznego obrotu oraz podpisane umowy na otwarcie około 200 sklepów. Później, w wyniku procesu, przedsiębiorcy zostali przez sąd uniewinnieni. Należy wnosić, że podobne inne przykłady podważają wśród społeczeństwa autorytet kraju jako państwa prawa (Wybranowski, 2012, 2013).
} 
Tab. 6., ryc. 6. Zmiany stopy bezrobocia w Polsce w latach 2002-2012

\begin{tabular}{|c|c|}
\hline Rok & $\begin{array}{c}\text { Stopa } \\
\text { bezrobocia }\end{array}$ \\
\hline 2002 & 19,5 \\
\hline 2003 & 19,5 \\
\hline 2004 & 19,1 \\
\hline 2005 & 17,7 \\
\hline 2006 & 15,5 \\
\hline 2007 & 11,9 \\
\hline 2008 & 9,1 \\
\hline 2009 & 10,8 \\
\hline 2010 & 11,4 \\
\hline 2011 & 11,8 \\
\hline 2012 & 12,4 \\
\hline
\end{tabular}

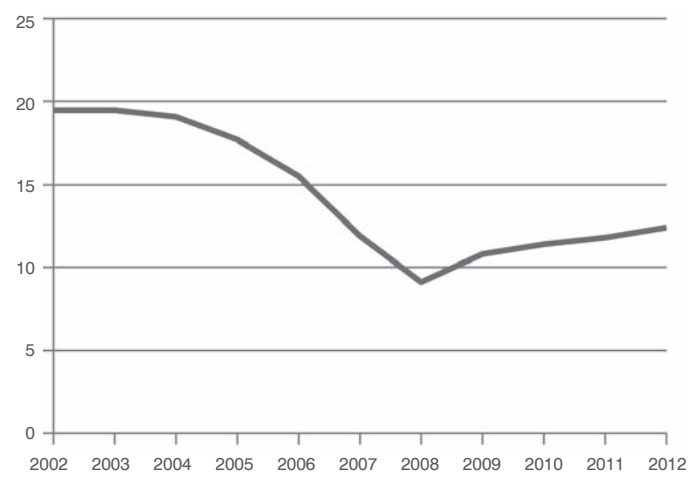

Źródło: opracowanie własne na podstawie roczników statystycznych GUS z lat 2002-2012.

Bezrobocie jest bardzo szybko reagującym zjawiskiem na zmieniające się warunki rozwoju (tab. 7). Od października 2011 r. do stycznia 2012 r. stopa bezrobocia systematycznie wzrastała z 11,8 do 13,2 i na tak wysokim poziomie utrzymywała się do marca $2012 \mathrm{r}$. W pewnym stopniu na ten stan wpłynęła sezonowa działalność wielu przedsiębiorstw. W następnych miesiącach letnich do sierpnia zaznaczył się spadek stopy bezrobocia do 12,3 i na zbliżonym poziomie stopa bezrobocia utrzymywała się do października 2012 r.

Tab. 7., ryc. 7. Zmiany stopy bezrobocia w Polsce od sierpnia 2011 do października 2012 r.

\begin{tabular}{|c|c|c|}
\hline \multirow{4}{*}{ Rok } & Miesiące & $\begin{array}{c}\text { Stopa } \\
\text { bezrobocia }\end{array}$ \\
\hline \multirow{4}{*}{2011} & VIII & 11,8 \\
\cline { 2 - 3 } & IX & 11,8 \\
\cline { 2 - 3 } & $\mathrm{X}$ & 11,8 \\
\cline { 2 - 3 } & $\mathrm{XI}$ & 12,1 \\
\cline { 2 - 3 } & $\mathrm{XII}$ & 12,5 \\
\hline \multirow{7}{*}{ I } & $\mathrm{I}$ & 13,2 \\
\cline { 2 - 3 } & $\mathrm{II}$ & 13,4 \\
\cline { 2 - 3 } & $\mathrm{III}$ & 13,3 \\
\cline { 2 - 3 } & $\mathrm{IV}$ & 12,9 \\
\cline { 2 - 3 } & $\mathrm{V}$ & 12,6 \\
\cline { 2 - 3 } & $\mathrm{VI}$ & 12,3 \\
\cline { 2 - 3 } & $\mathrm{VII}$ & 12,3 \\
\cline { 2 - 3 } & $\mathrm{VIII}$ & 12,4 \\
\cline { 2 - 3 } & $\mathrm{IX}$ & 12,4 \\
\cline { 2 - 3 } & $\mathrm{X}$ & 12,5 \\
\hline
\end{tabular}

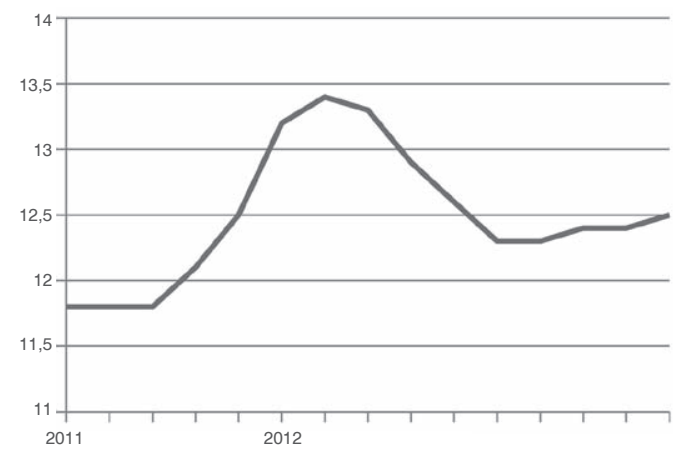

Źródło: GUS (2013a). 
W przestrzeni krajowej proces ten charakteryzuje się dużą zmiennością. Ilustruje to wartość stopy bezrobocia, która na terenach poszczególnych województw wahała się od 9,1 do 19,5, oraz liczba bezrobotnych przypadających na jedną ofertę pracy, wahająca się od 30 do 113 (tab. 8).

Najniższymi wskaźnikami bezrobocia odznaczały się województwa: wielkopolskie $(9,1)$, mazowieckie $(10,2)$, śląskie $(10,4)$, małopolskie $(10,6)$, które na swoim obszarze mają wykształcone dominujące w kraju metropolie. Natomiast najwyższymi wartościami charakteryzują się województwa wschodniego pogranicza (warmińsko-mazurskie - 19,5 i podkarpackie 15,1), województwa: lubuskie $(15,1)$ i kujawsko-pomorskie $(16,7)$, które jeszcze nie wykształciły na swoim obszarze znaczących metropolii a także województwo zachodniopomorskie $(16,7)$, położone z dala od stolicy, które nie wykorzystuje jeszcze w należytym stopniu swojego położenia w przestrzeni europejskiej i możliwości wyjścia z recesji upadającego przemysłu.

Trudności na rynku pracy ilustruje także wskaźnik określający liczbę bezrobotnych przypadających na 1 etat. W kraju wynosi on 45 osób, a na terenie poszczególnych województw wahał się od 115 do 25. Najtrudniejszymi warunkami możliwości zatrudnienia charakteryzują się województwa wschodniego pogranicza: podlaskie (gdzie na 1 etat przypada 113 bezrobotnych), warmińsko-mazurskie (93 bezrobotnych na 1 etat), podkarpackie (75), lubelskie (63) oraz łódzkie (70). Natomiast najkorzystniejszymi warunkami w tym zakresie odznaczają się województwa stosunkowo najlepiej rozwinięte: śląskie (gdzie na jedną ofertę przypada 25 bezrobotnych), dolnośląskie (30), małopolskie (38), wielkopolskie (41) oraz najsilniej powiązane z zachodnimi rynkami pracy województwo opolskie (34).

Tab. 8. Stopa bezrobocia w Polsce (koniec września 2012 r.)

\begin{tabular}{|l|c|c|c|}
\hline \multicolumn{1}{|c|}{ Województwa } & $\begin{array}{c}\text { Stopa } \\
\text { bezrobocia }\end{array}$ & $\begin{array}{c}\text { Liczba } \\
\text { bezrobotnych } \\
\text { na } \mathbf{1} \text { ofertę pracy }\end{array}$ & $\begin{array}{c}\text { Przeciętne miesięczne } \\
\text { wynagrodzenia } \\
\text { brutto w zl }\end{array}$ \\
\hline Wielkopolskie & 9,1 & 41 & 3461,11 \\
\hline Mazowieckie & 10,2 & 53 & 4562,84 \\
\hline Śląskie & 10,4 & 25 & 3856,24 \\
\hline Małopolskie & 10,6 & 38 & 3512,20 \\
\hline Pomorskie & 12,4 & 42 & 3736,28 \\
\hline Dolnośląskie & 12,5 & 30 & 3708,18 \\
\hline Lubelskie & 13,0 & 63 & 3358,71 \\
\hline Łódzkie & 13,2 & 70 & 3430,50 \\
\hline Opolskie & 13,2 & 34 & 3362,20 \\
\hline Podlaskie & 13,8 & 113 & 3100,62 \\
\hline Świętokrzyskie & 14,8 & 52 & 3170,50 \\
\hline Podkarpackie & 15,1 & 75 & 3179,85 \\
\hline Lubuskie & 15,1 & 29 & 3252,90 \\
\hline Kujawsko-pomorskie & 16,7 & 49 & 3422,93 \\
\hline Zachodniopomorskie & 16,7 & 59 & 3136,24 \\
\hline Warmińsko-mazurskie & 19,5 & 93 & \\
\hline
\end{tabular}

Źródło: GUS (2013b). 
Tab. 9. Dynamika dochodów ludności

\begin{tabular}{|c|c|c|c|}
\hline \multirow{2}{*}{ Rok } & Kwartal & $\begin{array}{c}\text { Dynamika dochodów } \\
\text { brutto }\end{array}$ & $\begin{array}{c}\text { Dynamika konsumpcji } \\
\text { prywatnej }\end{array}$ \\
\hline \multirow{3}{*}{2011} & I & $-1,4$ & 3,7 \\
\cline { 2 - 4 } & II & $-0,2$ & 3,6 \\
\cline { 2 - 4 } & III & 1,9 & 3,0 \\
\cline { 2 - 4 } & IV & 2,4 & 2,1 \\
\hline \multirow{2}{*}{2012} & I & $-1,9$ & 2,1 \\
\cline { 2 - 4 } & II & & 1,9 \\
\hline
\end{tabular}

Źródło: Kamińska (2012).

Ograniczanie rynku pracy oraz sytuacja kryzysowa wpłynęły na zmiany tempa dochodów brutto (tab. 9). W pierwszym kwartale 2011 r. dochody spadły o 1,4, a w drugim - o 0,2. Nieznaczny ich wzrost zaznaczył się w czwartym kwartale 2011 r., o 2,4, po czym w pierwszym kwartale 2012 r. spadły o 1,9.

Wpłynęło to na systematyczny spadek dynamiki konsumpcji prywatnej z 3,7 w pierwszym kwartale 2011 r. do 1,9 w drugim kwartale 2012 r. Spadek ten w znacznym stopniu ograniczył popyt na oferowane produkty i wpłynął na dalsze ograniczenia rozmiarów rynku. Było to w pewnym zakresie wynikiem zmniejszania i różnicowania przestrzennego zasilania finansowego gospodarstw domowych. Na koniec września 2012 r. przeciętne dochody miesięcznych wynagrodzeń brutto wahały się od 3,1 tys. w województwie świętokrzyskim i warmińsko-mazurskim oraz 3,2 tys. w województwie podkarpackim i lubuskim do 3,9 w województwie śląskim i 4,5 w województwie mazowieckim (tab. 8).

Wartości tych cech w różnym stopniu różnicują krajową przestrzeń ekonomiczną, co ilustrują wskaźniki zmienności. W najmniejszym stopniu przestrzeń krajową różnicuje przeciętne miesięczne wynagrodzenie, dla którego wartość współczynnika zmienności była najniższa i wynosiła - 10,5, bardziej różnicuje wskaźnik zmienności stopy bezrobocia - 20,4, a najsilniej wskaźnik zmienności liczby bezrobotnych na jedną ofertę pracy - 44,9\%. Podkreśla to szczególnie duży niedobór miejsc zatrudnienia w stosunku do zasobów pracy.

Bardzo zróżnicowane relacje zachodzące między wartościami analizowanych cech występują w poszczególnych województwach, co podkreślają wartości wskaźników korelacji. Najsilniejsze związki zachodzą między stopą bezrobocia a przeciętnym wynagrodzeniem, dla których wartość wskaźnika korelacji była ujemna i wynosiła $(-0,639)$, co oznacza, że w miarę zwiększania się stopy bezrobocia malało przeciętne miesięczne wynagrodzenie brutto. Również ujemna, ale słabsza, korelacja zachodziła między przeciętnym wynagrodzeniem z liczbą bezrobotnych przypadającą na jedną ofertę $(-0,298)$. Natomiast dodatnią korelacją cechowała się stopa bezrobocia i liczba bezrobotnych przypadająca na jedną ofertę, dla której wskaźnik korelacji wyniósł 0,471. Oznacza to, że im wyższe bezrobocie, tym więcej bezrobotnych przypadło na jedno miejsce pracy.

Duże różnicowanie wartości wskaźników oraz relacji zachodzących między nimi wskazuje na dużą żywiołowość tych procesów i przez działania polityki społeczno-gospodarczej winny być one stopniowo ograniczane. W tej sytuacji należy przyjąć, że dalsze ograniczanie strumieni finansowych płynących do gospodarstw domowych oraz postępująca inflacja w zasadniczym stopniu będą nadal ograniczać popyt, nasilać negatywne zjawiska ubóstwa i patologii społecznej. 


\section{Sytuacja wybranych sektorów gospodarczych}

Nasilająca się sytuacja kryzysowa nie stwarzała korzystnych warunków dla pobudzania rozwoju przedsiębiorczości i w różnym stopniu wpływała na zmiany zachowań poszczególnych działów przemysłu (tab. 10). W latach 2011-2012, od stycznia do lipca, odznaczały się one różną zmiennością w zakresie płacy realnej, zatrudnienia, wartości sprzedaży i wydajności pracy. W analizowanym okresie dynamika płacy realnej w poszczególnych działach wahała się od $-3,8$ do 3,4. Najpoważniejszy spadek płacy nastąpił w produkcji komputerów i urządzeń elektrycznych $(-3,8)$, budownictwie $(-2,8)$ i farmacji $(-2,6)$, a w nich średnia płaca w lipcu wahała się od 3,4 tys. zł do 5,3 tys. zł. Natomiast najwyższy wzrost płacy realnej zaznaczył się w produkcji maszyn i urządzeń $(3,4 \%)$, produkcji mebli $(1,5 \%)$, produkcji chemikaliów i wyrobów chemicznych $(1,4 \%)$, przy przeciętnej płacy wahającej się w tych działach od 3,7 tys. zł do 4,5 tys. zł.

W poszczególnych działach poważnym spadkiem odznaczało się zatrudnienie, dzięki któremu najłatwiej można wpływać ma obniżenie kosztów działalności. Stąd dynamika zatrudnienia najbardziej obniżyła się w produkcji odzieży $(-8,3)$, produkcji napojów $(-6,4)$, mebli $(-4,6)$, farmacji $(-3,7)$ i produkcji komputerów $(-3,5)$. Sytuacja ta ma związek w znacznym stopniu ze zmniejszeniem zasobów finansowych gospodarstw domowych, w wyniku czego dużo osób rezygnowało m.in. z zakupu leków (zwłaszcza ludzie starsi). Podobnie trudności na rynku pracy, głównie wśród ludzi młodych, miały związek z ograniczeniem możliwości zakupu mieszkań, co w zasadniczym stopniu wpłynęlo także na spadek produkcji mebli, a w wyniku kryzysu europejskiego - również na ich eksport. Równocześnie wśród biedniejszej części społeczeństwa wzrosło zainteresowanie zakupem tańszej odzieży importowanej z krajów azjatyckich, co wpłynęło na ograniczenie zatrudnienia.

Dużym zróżnicowaniem odznaczała się wartość sprzedaży, co wynika ze zmieniającej się chłonności rynku na oferowane produkty. Szczególnie dużym wzrostem charakteryzowała się

Tab. 10. Zmiana wybranych cech ekonomicznych wg sektorów gospodarczych

\begin{tabular}{|l|c|c|c|c|}
\hline \multirow{2}{*}{ Sektory } & \multicolumn{3}{c|}{ Zmiana od I-VII 2011 do I-VII 2012 } \\
\cline { 2 - 5 } & realnej płacy & zatrudnienia & $\begin{array}{c}\text { wartości } \\
\text { sprzedaży }\end{array}$ & $\begin{array}{c}\text { wydajności } \\
\text { pracy }\end{array}$ \\
\hline Ogółem w firmach od 10 osób & 0,0 & 0,4 & $\mathrm{x}$ & $\mathrm{x}$ \\
\hline Górnictwo & $-0,2$ & 2,2 & $-6,9$ & $-8,9$ \\
\hline Produkcja artykułów spożywczych & $-0,3$ & $-0,3$ & 7,6 & 11,2 \\
\hline Produkcja napojów & $-0,5$ & $-6,4$ & 5,1 & 12,3 \\
\hline Produkcja odzieży & 1,1 & $-8,3$ & 1,0 & 10,1 \\
\hline $\begin{array}{l}\text { Produkcja chemikaliów i wyrobów } \\
\text { chemicznych }\end{array}$ & 1,4 & $-0,3$ & 10,8 & 10,5 \\
\hline Farmacja & $-2,6$ & $-3,7$ & $-8,3$ & $-5,2$ \\
\hline $\begin{array}{l}\text { Produkcja komputerów i wyrobów } \\
\text { elektronicznych }\end{array}$ & $-3,8$ & $-3,5$ & 1,4 & 5,1 \\
\hline Produkcja maszyn i urządzeń & 3,4 & $-1,9$ & 10,5 & 8,4 \\
\hline Motoryzacja & 0,0 & 1,4 & $-3,9$ & $-5,8$ \\
\hline Meble & 1,5 & $-4,6$ & $-5,5$ & $-1,0$ \\
\hline Budownictwo & $-2,8$ & 3,6 & 4,8 & 1,2 \\
\hline Handel detaliczny & 0,6 & 1,4 & $\mathrm{x}$ & $\mathrm{x}$ \\
\hline
\end{tabular}

Źródło: Fandrejewska (2012). 
sprzedaż odzieży, która zwiększyła się o 10,5. Wpłynęła na to produkcja wyrobów o wyższym standardzie, która kierowana jest do ludzi młodych, do bogatszej części społeczeństwa oraz na eksport $^{5}$. Wzrosła także o 10,5 sprzedaż maszyn i urządzeń, wśród z których znaczący udział miały produkty wpływające na zwiększenie wydajności pracy oraz kierowane na eksport. Finansowe ograniczenia zakupów artykułów trwałego użytku wpłynęły na wzrost zakupu drożejących artykułów spożywczych $(7,6)$. Najpoważniejszym spadkiem sprzedaży odznaczają się: wspomniane już wyroby farmaceutyczne $(-8,3)$, meble $(-4,6)$ oraz produkty górnictwa $(-6,9)$, w tym kruszywa na budowę dróg i autostrad.

W wielu działach znacząco wzrosła wydajność pracy, szczególnie w produkcji napojów (o 12,3), artykułów spożywczych (o 11,2) oraz produkcji chemikaliów i odzieży. Było to możliwe dzięki wprowadzaniu do firm nowych i bardziej wydajnych urządzeń, które przyczyniły się z kolei do redukcji zatrudnienia. Natomiast spadek wydajności pracy w farmacji i motoryzacji wynika z czasowego ograniczenia produkcji oraz chęci utrzymania pracowników i przygotowywania się do wzrostu produkcji w okresie wychodzenia z kryzysu. Działy te wymagają stosunkowo wysoko wykwalifikowanej kadry, o którą może być trudno w latach ożywienia gospodarczego.

W warunkach kryzysu zmieniająca się i niepewna sytuacja gospodarcza w kraju i w UE wpływała na różne zachowania przedsiębiorców (pracodawców). Spadek popytu na oferowane produkty wpływa z reguły na ograniczanie liczby pracowników, czego dokonuje się najczęściej w drodze redukcji zatrudnienia. Wobec znacznego obciążenia ekonomicznego przedsiębiorstw w wypadku zwolnień pracodawcy bardziej pesymistycznie oceniali możliwości wzrostu popytu na oferowane produkty, aniżeli okazało się to w rzeczywistości. W konsekwencji w 2012 r. zgłaszali oni znacznie większe zwolnienia grupowe niż zwolnienia, które rzeczywiście się odbyły (tab. 11). Od stycznia do lipca planowali wzrost zwolnień grupowych z 4,5 tys. pracu-

Tab. 11. Planowane i realizowane zwolnienia grupowe w $2012 \mathrm{r}$.

\begin{tabular}{|c|c|c|}
\hline Miesiące & $\begin{array}{c}\text { Zglaszane } \\
\text { zwolnienia przez } \\
\text { pracodawców }\end{array}$ & $\begin{array}{c}\text { Realizacja } \\
\text { zwolnień przez } \\
\text { pracodawców }\end{array}$ \\
\hline I & 4532 & 2111 \\
\hline II & 6692 & 2121 \\
\hline III & 4003 & 1892 \\
\hline IV & 6002 & 2190 \\
\hline V & 6958 & 2796 \\
\hline VI & 7586 & 3371 \\
\hline VII & 9206 & 2617 \\
\hline VIII & 6987 & 3012 \\
\hline IX & 5696 & 6315 \\
\hline X & 6834 & 4119 \\
\hline XI & 4958 & 3711 \\
\hline Razem & 69454 & 34255 \\
\hline
\end{tabular}

Źródło: Fandrejewska (2013: B5).

\footnotetext{
5 Jak pisze W. Raczkowski (2013), ubrania z małych firm odzieżowych zakładanych przez młodych Polaków noszą ludzie na całym świecie. Szczególnie interesująca historia dotyczy marki już światowej „Local Heroes” założonej w lutym 2012 r., którą stworzyły dwie 20-letnie dziewczyny. Wytwarzane przez nie wyroby kierowane do rówieśników są droższe, ale wyróżniają się bardzo dobrą jakością oraz oryginalnymi wzorami i sprzedawane są głównie za pośrednictwem Internetu.
} 
jących do 9,2 tys., a następnie ich spadek do 3,7 tys. w listopadzie, podczas gdy w rzeczywistości początkowo zwolnienia objęły od 2,1 tys. pracowników do 2,6 tys., a następnie osiągnęły 3,7 tys. Podkreśla to dużą niepewność występującą na rynku, która wymusza na przedsiębiorcach dużą ostrożność w zatrudnianiu nowych pracowników. Wynika to być może ze wcześniejszych doświadczeń dotyczących dużych obciążeń związanych ze zwalnianiem pracowników, dlatego tą drogą wolą zmniejszać granice ryzyka.

Kryzys nie wpłynął negatywnie na rozwój sektora usług biznesowych. Najlepsze dla lokalizacji tego typu działalności są metropolie dysponujące dużymi zasobami wysoko wykwalifikowanych kadr, dużym doświadczeniem i innowacyjnością oraz niższymi kosztami pracy w stosunku do światowych metropolii. Dzięki tym czynnikom oraz rozwiniętej infrastrukturze telekomunikacyjnej krajowe metropolie stają się coraz bardziej atrakcyjne dla rozwijania tego typu działalności na rzecz światowych korporacji. W latach 2003-2012 liczba centrów systematycznie rosła (z 69 do 350, czyli był to ponadpięciokrotny wzrost) i stworzono miejsca pracy dla ok. 100 tys. pracowników. Na koniec 2011 r. w centrach zlokalizowanych w Krakowie pracowało 19,4 tys. osób, w Warszawie - 14,2 tys., we Wrocławiu - 12,6 tys., w Trójmieście - 8,0 tys., Łodzi - 7,7 tys., aglomeracji śląskiej - 6,9 tys., w Poznaniu - 5,0 tys.

W ramach redukcji kosztów wiele korporacji planuje przenoszenia swojej działalności z Singapuru do Polski. Przewiduje się dalszy rozwój usług o charakterze analitycznym, co wymaga wdrażania nowych rozwiązań technologicznych oraz kształcenia przyszłych pracowników. Dzięki temu Polska jest drugim krajem po Indiach o największej liczbie specjalistów do realizacji nowoczesnych usług biznesowych, mającym pracowników o coraz wyższym poziomie wykształcenia i znajomości języków obcych. Należy zaznaczyć, że ten sektor w znacznym stopniu nawiązuje do współczesnych tendencji rozwoju cywilizacyjnego, przyczyniając się do kształtowania społeczeństwa informacyjnego i budowania gospodarki opartej na wiedzy. Stąd w małym stopniu wpływać będzie na niego sytuacja kryzysowa, tym bardziej, że umożliwia on zwiększanie wydajności pracy.

\section{Sytuacja finansowa}

Sytuacja kryzysowa ograniczająca możliwości rozwoju przedsiębiorczości prowadzi z jednej strony do pojawiania się zadłużenia, a z drugiej strony - do zwiększenia oszczędzania w gospodarstwach domowych i przedsiębiorstwach.

W warunkach kurczenia się rynków pracy oraz relatywnego spadku siły nabywczej gospodarstw domowych znacznie rośnie zadłużenie Polaków w kredytach konsumpcyjnych (tab. 12). Szczególnie silny wzrost zaznaczył się w latach rozwoju ekonomicznego (2005-2009), kiedy wartość tych kredytów zwiększyła się z 49,1 mld zł do 127,6 mld zł, czyli ponaddwuipółkrotnie. W miarę stabilne warunki zatrudnienia i możliwości wzrostu płacy, a także oferowane różnorodne produkty instytucji finansowych zachęcały do zaciągania kredytów, zwłaszcza na zakup mieszkań, budowę domów i ich wyposażenie. Zmniejszenie zainteresowania kredytami nastąpiło w latach kryzysu. W latach 2010-2012 zadłużenie spadło z 141,3 mld zł do 127,1 mld zł. Redukcja zatrudnienia i ograniczanie wzrostu wynagrodzeń bardzo często uniemożliwiały spłaty zaciągniętych kredytów oraz stawiały gospodarstwa domowe w kłopotliwej sytuacji. Pojawiły się także większe problemy z zaciąganiem kredytów związane z ograniczaniem tego typu działalności szczególnie przez banki z kapitałem zagranicznym, które w sytuacji kryzysowej kierują swoje aktywa do krajów, w których są siedziby ich zarządów.

Ważnym czynnikiem możliwości ożywienia gospodarczego są zasoby finansowe przedsiębiorstw, które mogą być przeznaczone na nowe inwestycje i tworzenie nowych miejsc pracy, zasoby finansowe gospodarstw domowych, których uruchomienie pozwala na pobudzenie 
Tab. 12. Zadłużenie Polaków w kredytach konsumpcyjnych w latach 2005-2012

\begin{tabular}{|c|c|c|c|}
\hline \multirow{2}{*}{ Rok } & \multirow{2}{*}{$\begin{array}{c}\text { Wartość } \\
\text { w mld zl }\end{array}$} & \multicolumn{2}{|c|}{ Dynamika } \\
\cline { 3 - 4 } & & rok poprzedni $=\mathbf{1 0 0}$ & $\mathbf{2 0 0 5}=\mathbf{1 0 0}$ \\
\hline I 2005 & 49,1 & 100,0 & 100,0 \\
\hline I 2006 & 59,2 & 120,6 & 120,6 \\
\hline I 2007 & 72,4 & 122,3 & 147,5 \\
\hline I 2008 & 96,3 & 133,0 & 196,1 \\
\hline I 2009 & 127,6 & 132,5 & 259,9 \\
\hline I 2010 & 140,9 & 110,4 & 287,0 \\
\hline I 2011 & 141,3 & 100,3 & 287,8 \\
\hline I 2012 & 137,1 & 97,0 & 279,2 \\
\hline IX 2012 & 133,9 & 97,7 & 272,7 \\
\hline
\end{tabular}

Źródło: Semciuk (2012, 10-11 listopada: 8; 2012, 13 listopada: 23).

rynku, oraz stabilność gospodarcza i polityczna kraju, gwarantująca stałość uwarunkowań działalności gospodarczej i rozwoju przedsiębiorczości.

Część firm krajowych odznacza się poważnymi zasobami finansowymi, ale część charakteryzuje się poważnym zadłużeniem (tab. 13). Oszczędności firm wynikają z chęci uniknięcia ryzyka związanego z kredytowaniem przez instytucje finansowe oraz braku stabilności gospodarczej. Wpływa to w zasadniczym stopniu na chęć utrzymania zgromadzonych środków, które mogą okazać się bardzo przydatne w latach ożywienia gospodarczego i wychodzenia z kryzysu. W wyniku chwiejnej sytuacji gospodarki światowej i braku jasnych reguł funkcjonowania gospodarki krajowej oszczędności, którymi dysponują firmy, wykazywały systematyczny wzrost. W latach 2005-2011 zwiększyły się one z $101 \mathrm{mld}$ zł do 183 mld zł, tj. do 181,2\%. Równocześnie w tym czasie w wielu firmach w coraz szybszym tempie rosło zadłużenie z 119 mld zł do 232 mld zł, tj. do 195,0\%.

Z badań prowadzonych z trzecim kwartale 2011 r. wynika, że spośród barier rozwoju działalności przedsiębiorcy na czoło wysuwają: niski popyt rynku (14\%), wzrost cen surowców (11,2\%), wysokość opłat, w tym wahania kursów walutowych $(9,9 \%)$, zatory płatnicze $(6,8 \%)$ oraz nasilającą się konkurencję (6,8\%). Natomiast wśród barier prowadzenia firm za najważniejsze uważają: skomplikowane procedury prawne $(35 \%)$, niejasne prawo $(33 \%)$, zły system podatkowy (29\%), wysokie koszty pracy (14\%) oraz wysokie koszty finansowania, nasilającą się konkuren-

Tab. 13. Sytuacja finansowa firm krajowych w latacj 2005-2011

\begin{tabular}{|c|c|c|c|c|}
\hline Rok & $\begin{array}{c}\text { Oszczędności } \\
\text { firm w mld zl }\end{array}$ & $\begin{array}{c}\text { Zadłużenie firm } \\
\mathbf{w} \text { mld zl }\end{array}$ & $\begin{array}{c}\text { Dynamika } \\
\text { oszczędności }\end{array}$ & $\begin{array}{c}\text { Dynamika } \\
\text { zadłużenia }\end{array}$ \\
\hline 2005 & 101 & 119 & 100,0 & 100,0 \\
\hline 2006 & 127 & 136 & 125,7 & 114,3 \\
\hline 2007 & 144 & 168 & 142,6 & 141,2 \\
\hline 2008 & 151 & 216 & 149,5 & 181,5 \\
\hline 2009 & 166 & 207 & 164,4 & 173,9 \\
\hline 2010 & 183 & 204 & 181,2 & 171,4 \\
\hline 2011 & 183 & 232 & 181,2 & 195,0 \\
\hline
\end{tabular}

Źródło: Koniunktura coraz słabsza (2011). 
cję, niski popyt na produkty i usługi, brak środków na rozwój, biurokracja, niedobór pracowników o odpowiednich kwalifikacjach zawodowych, nierzetelność kontrahentów i brak wsparcia ze strony rządu.

W konsekwencji głównym źródłem finansowania działalności różnej wielkości firm są środki własne, a w mniejszym stopniu kredyty. Szczególnie wysokim udziałem środków własnych charakteryzują się mikrofirmy, które opierają się na nich w 56,8\%, a także małe firmy $(42,9 \%)$ i średnie firmy $(43,6 \%)$. Natomiast z kredytów bankowych korzysta odpowiednio $22,8 \%, 27,3 \%$ i $24,9 \%$ firm $^{6}$. Stworzenie warunków wpływających na wykorzystanie własnych zasobów finansowych może być ważnym czynnikiem zdynamizowania rozwoju gospodarczego, które jest możliwe głównie dzięki stabilności rozwoju przedsiębiorczości w warunkach ograniczanie wspomnianych barier rozwoju działalności i barier w zakresie prowadzenia firm.

Rynek krajowy w znacznym stopniu może także pobudzić aktywizacja zasobów finansowych ludności. W zależności od potrzeb mogą być one przeznaczone na konsumpcję, inwestycje lub pozostawione jako oszczędności. W obecnej sytuacji ekonomicznej gospodarstwa domowe dysponują znacznymi środkami finansowymi, na co wskazują rosnące wartości depozytów zgromadzonych w instytucjach finansowych (tab. 14). W latach 2011-2012 z miesiąca na miesiąc wartość depozytów systematycznie rosła z 423,9 mld zł do 505, 2 mld zł, tj. do 119,2\% ${ }^{7}$. Szczególnie wysoka dynamika zaznaczała się od maja do grudnia 2011 r., nastąpił wzrost z 100,7 do 102,9, po czym była niższa: od 99,8 do 100,1. W obawie przed nasilającym się kryzysem ekonomicznym gospodarstwa domowe, podobnie jak firmy, oszczędzały swoje zasoby finansowe na wypadek pogarszającej się kondycji ekonomicznej rodzin. Najpewniejszym środkiem zabezpieczenia były relatywnie korzystne stopy procentowe oferowane zwłaszcza przez banki związane z kapitałem zagranicznym. Wyższe stopy procentowe tych banków wynikały z potrzeb finansowych krajów, na terenie których zlokalizowane były ich siedziby zarządów. Stąd atrakcyjniejsze dla lokowania oszczędności były oddziały banków zagranicznych aniżeli banki z kapitałem krajowym, oferujące znacznie niższe odsetki ${ }^{8}$. Oszczędności społeczeństwa nie wspierały więc rozwoju gospodarki krajowej, ale gospodarki innych krajów. Wydaje się, że jest to wyrazem braku umiejętności racjonalnego zarządzania zgromadzonymi oszczędnościami społeczeństwa przez krajowe elity gospodarcze i polityczne.

\footnotetext{
${ }^{6}$ Według badań z października 2012 r. na najbliższe miesiące planuje utrzymać obecny poziom zatrudnienia $54 \%$ firm, nieznaczną i znaczną redukcję zatrudnienia planuje $30 \%$ firm, a tylko $3 \%$ planuje znaczny wzrost zatrudnienia. Natomiast rezygnację z planów inwestycyjnych przewiduje $34 \%$ firm, a nieznaczne inwestycje - 37\% (Błaszczak, 2012).

${ }^{7} \mathrm{O}$ rozmiarach oszczędności gospodarstw domowych świadczy porównanie ich do wartości PKB. W $2010 \mathrm{r}$. PKB w Polsce wynosiło 469,3 mld dol., co przy aktualnym kursie ( 1 dolar $=$ ok. 3 zł) wynosi 1407,9 mld zł. Przy takim założeniu wartość depozytów - 505,2 mld zł - stanowi 35,9\%.

8 Jednym z ważnych instrumentów mających na celu ograniczanie oszczędności i wzrost popytu wewnętrznego (zakupów) jest regulowanie stopy procentowej przez Radę Polityki Pieniężnej. Od listopada ubiegłego roku czterokrotnie obniżała ona stopy procentowe o 0,25 punktów procentowych. Wpływa to na ograniczania oszczędności i wzrost obrotów rynkowych. Na kryzys w kraju w zasadniczym stopniu wpływa otoczenie zewnętrzne, zwłaszcza kryzys w strefie euro. Firmy ograniczają inwestycje i produkcję, co przekłada się na pogarszanie się sytuacji na rynku pracy. Trudności na rynku pracy i wzrost bezrobocia oraz zmniejszanie się podwyżek płac i zarobków powodują zmniejszenie popytu konsumpcyjnego. W konsekwencji w grudniu 2012 r. nastąpił spadek wartości towarów o 10,6\%, a zakupy zmniejszyły się o 2,5\% i częściowo czynione były z wcześniej zgromadzonych oszczędności. Trudno o zwiększenie popytu, jeżeli tempo wzrostu płac i inflacja były na tym samym poziomie $-2,4 \%$ (Baj, 2013).
} 
Tab. 14. Depozyty gospodarstw domowych w Polsce w latach 2011-2012

\begin{tabular}{|c|c|c|c|c|}
\hline Lata & Miesiące & $\begin{array}{l}\text { Wartość depozy- } \\
\text { tów w mld zl }\end{array}$ & $\begin{array}{l}\text { Miesiąc } \\
\text { poprzedni } \\
=100\end{array}$ & $\begin{array}{c}\text { Dynamika } \\
\text { (I } 2011=\mathbf{1 0 0})\end{array}$ \\
\hline \multirow{12}{*}{2011} & I & 423,9 & 100,0 & 100,0 \\
\hline & II & 430,4 & 101,5 & 101,5 \\
\hline & III & 433,7 & 100,8 & 102,3 \\
\hline & IV & 434,5 & 100,2 & 102,5 \\
\hline & $\mathrm{V}$ & 432,7 & 99,6 & 102,1 \\
\hline & VI & 435,9 & 100,7 & 102,8 \\
\hline & VII & 440,1 & 101,0 & 103,8 \\
\hline & VIII & 445,4 & 101,2 & 105,1 \\
\hline & IX & 452,4 & 101,6 & 106,7 \\
\hline & $X$ & 456,4 & 100,9 & 107,7 \\
\hline & XI & 464,4 & 101,8 & 109,6 \\
\hline & XII & 478,0 & 102,9 & 112,8 \\
\hline \multirow{11}{*}{2012} & $\mathrm{I}$ & 486,2 & 101,7 & 114,7 \\
\hline & II & 488,1 & 100,4 & 115,1 \\
\hline & III & 487,3 & 99,8 & 115,0 \\
\hline & IV & 486,2 & 99,8 & 114,7 \\
\hline & $\mathrm{V}$ & 488,9 & 100,6 & 115,3 \\
\hline & VI & 493,1 & 100,9 & 116,3 \\
\hline & VII & 494,7 & 100,3 & 116,7 \\
\hline & VIII & 498,3 & 100,7 & 117,6 \\
\hline & IX & 499,2 & 100,2 & 117,8 \\
\hline & $X$ & 504,5 & 101,1 & 119,0 \\
\hline & $\mathrm{XI}$ & 505,2 & 100,1 & 119,2 \\
\hline
\end{tabular}

Ryc. 9. Wzrost liczby depozytów w gospodarstwach domowych (w mld zł)

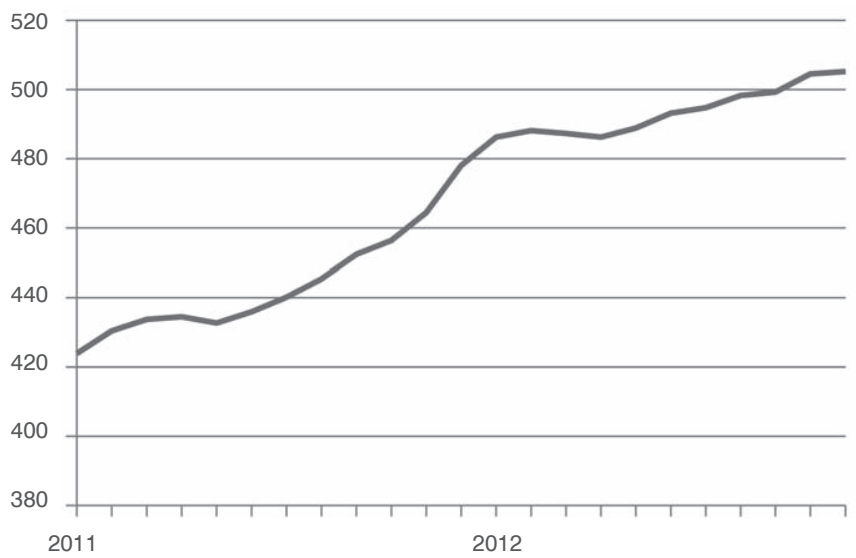

Źródło: Krześniak (2013: 10B). 


\section{Uwarunkowania instytucjonalne}

Znaczącą barierą dla rozwoju przedsiębiorczości jest jakość uwarunkowań stwarzanych przez instytucje państwowe. Wskazuje na to ocena możliwości rozwoju przedsiębiorczości przez Bank Światowy. Na 183 badane kraje Polska pod względem analizowanych cech zajmowała stosunkowo odległe miejsca. Pod względem: wolności gospodarczej nasz kraj zajmował 62 pozycję, pod względem możliwości odzyskania należności od podmiotów gospodarczych i instytucji znajdował się na 87 pozycji, pod względem rejestrowania nieruchomości na 89, pod względem systemu opłacania podatków na 128, a pod względem uzyskania zezwolenia na budowę zajmował 160 pozycję 9 .

Równocześnie Polska jest atrakcyjna dla przejęć przez kapitał światowy. Na maksymalną liczbę punktów - 100 - ma 92 punkty i zajmuje pierwsze miejsce w Europie pod względem jakości kapitału ludzkiego (wg opinii Polacy są bardzo dobrze wykształceni i posiadają wysokie kwalifikacje zawodowe). Wysoko, na 92 punkty, ocenione zostały również warunki demograficzne naszego kraju, a na 89 punktów - wzrost PKB.

Pod względem regulacji prawno-politycznych (liczba formalności, które trzeba spełnić przy zakładaniu działalności gospodarczej) oceniono Polskę tylko na 29 punktów, a pod względem liczby dni oczekiwania na decyzję w sprawie nabycia aktywów przez jedną firmę od innej już tylko na 7 punktów $^{10}$.

Znaczną przeszkodą w rozwoju przedsiębiorczości jest jakość aparatu fiskalnego i prawniczego, który doprowadza do upadków wiele dobrze rozwijających się firm, przykładami są firmy Optimus w Nowym Sączą, stocznie ${ }^{11}$, Bestcom w Poznaniu, Atrax w Gdańsku, wrocławski dystrybutora sprzętu komputerowego JTT Computer, PHUP w Chmielniku, sieć kantorów Comti i in.

Przedstawione bariery rozwoju przedsiębiorczości wynikają także ze słabości władzy, która nie jest w stanie ich usunąć na gruncie właściwie uchwalonego i egzekwowania prawa. W znacznym stopniu spowodowane jest to także niechęcią lub niskimi kwalifikacjami niektórych przedstawicieli władzy oraz brakiem odpowiedzialności niektórych przedstawicieli administracji za popełnione błędy, które przyczyniają się do ograniczania działalności lub upadku dobrze prosperujących podmiotów gospodarczych i niszczenia związanych z nimi przedsiębiorców ${ }^{12}$. Jest to związane silnie z urzędniczą mentalnością przyjętą często przez nowe elity z lat centralnego systemu gospodarowania, kiedy to urzędnicy zobowiązani byli do niszczenia obywateli najbardziej aktywnych na polu rozwijania działalności gospodarczej. Równocześnie z trudem dociera do nich świadomość, że to przedsiębiorcy, a nie politycy w głównej mierze przyczyniają się do rozwoju ekonomicznego kraju. Dlatego należy się zgodzić z opinią A. Górala,

${ }^{9}$ Podobnie w ocenie Heritage Foudation pod względem wolności gospodarczej Polska zajęła 64 miejsce (Wybranowski, 2011, 2012).

${ }^{10}$ Nadto pod względem wielkości i wzrostu PKB oceniono Polskę na 89 punktów, pod względem stabilności politycznej - na 84 punkty, pod względem technologicznych czynników wzrostu (eksport wyrobów techniki zaawansowanej) - 74 punkty, jakości dróg - 64 punkty, podczas gdy Czesi otrzymali maksymalną wartość 100 punktów (Woźniak, 2012).

${ }^{11}$ Por. Gadomski (2011).

${ }^{12}$ Należy się zastanowić, co zostaje z człowieka, który niesłusznie jest zatrzymany, przesłuchiwany i opisywany przez środki masowego przekazu jako nieuczciwy przedsiębiorca, a następnie po 5-7 latach zostaje w wyniku kolejnego procesu uniewinniony, oraz jakie to budzi reperkusje społeczne i w jakim stopniu przyczynia się do odgraniczenia wiarygodności państwa przez społeczeństwo (por. np. Wybranowski, 2012, 2013; Pietryga, 2013). 
prezesa i udziałowca Asseco Poland ${ }^{13}$, który tak wypowiedział się na temat polskiego patriotyzmu: „Dziś o dobrobycie i przyszłości każdego państwa decyduje gospodarka [...]. Powinniśmy współpracować w celu budowania silnych polskich firm i naszej gospodarki. [...] jako kraj na dorobku potrzebujemy przemyślanej dyskusji o ekonomii i gospodarce. [...] z podziwem przyglądam się rządom, które aktywnie wspierają rozwój rodzimych firm. [...] podczas ostatnich 20 lat nie zbudowaliśmy prawdziwie globalnych polskich firm. To gospodarka jest prawdziwym spoiwem społeczeństwa w krajach wysoko rozwiniętych"14.

Również braki budżetowe gmin i sposoby zarządzania na szczeblu lokalnym nie stwarzają korzystnych warunków dla rozwijania się małych firm. Gminy wyznaczają zazwyczaj maksymalne stawki podatkowe za przejmowane przez małe podmioty gospodarcze nieruchomości, które wcześniej zostały opuszczane, a nawet niekiedy zostały już poważnie zdewastowane i wymagają doprowadzenia mediów (wody, kanalizacji, prądu). Ze strony przedsiębiorców wymaga to poniesienia poważnych nakładów na remonty ${ }^{15}$. Gminy nie biorą pod uwagę, że przejmowanie i modernizacja zdekapitalizowanych budynków ogranicza ich dalszą dekapitalizację i podnosi jakość fizjograficzną układu lokalnego.

Oznacza to, że bardzo poważne zadanie stoi przed władzami publicznymi, które powinny traktować problemy gospodarcze jako podstawowy cel swojego działania. Wymaga to jednak przebudowy myślenia oraz umiejętności posługiwania się wiedzą ekonomiczną, która pozwoli na kreowanie wspierających instrumentów prawnych oraz ograniczania możliwości zjawisk patologicznych zarówno w biznesie, jak i w strukturach społecznych.

\section{Procesy migracji}

Należy wnosić, iż w niedalekiej przyszłości w gospodarce krajowej pojawi się nowy czynnik ograniczający rozwój przedsiębiorczości, którym będą braki kadrowe. Pod koniec 2013 r. należy się liczyć z tym, że rozpocznie się wychodzenie z kryzysu i nastąpi pobudzenie gospodarcze. Najwcześniej proces ten zaznaczy się na terenie krajów ekonomicznie rozwiniętych (Niemiec, Wielkiej Brytanii, Francji), co pociągać będzie za sobą wzrost ich zapotrzebowania na nowych pracowników. Dopiero później zaznaczy się osłabienie kryzysu w krajach słabiej rozwiniętych, w tym w Polsce. Niewątpliwie nasili to migracje zarobkowe z Polski do krajów zachodnich, które wraz z wychodzeniem z kryzysu stwarzać będą nowe, bardziej konkurencyjne miejsca pracy. Nastąpi więc odpływ z naszego kraju zwłaszcza młodych i lepiej wykształconych pracowników do krajów zachodnich, które już wcześniej stwarzały dla nich atrakcyjne miejsca pracy. Procesy migracji zarobkowej zaznaczały się także w okresie niewielkiego ożywienia gospodarczego. W latach 2011-2012 liczba emigrantów z Polski wzrosła z 1,6 mln osób do 1,7 mln. Najpopularniejsze kierunki migracji obejmowały tradycyjnie Wielką Brytanię (wzrost

\footnotetext{
${ }^{13}$ Asseco Poland zaliczana jest do światowej czołówki firm informatycznych, działa w kilkudziesięciu krajach na całym świecie, w 2011 r. zajmowała 51 pozycję wśród 2000 największych polskich przedsiębiorstw, mając przychody ze sprzedaży w wysokości blisko 3 mld zł, kapitał własny - 9,5 mld zł, zatrudniając 14,5 tys. pracowników i mając wypracowany wynik netto w wysokości 0,6 mld zł (Polskie przedsiębiorstwa. Lista 2000, 2012). W 2012 r., wg szacunków, wartość przychodów ze sprzedaży wyniosła ponad $5 \mathrm{mld}$ zł.

${ }^{14}$ Następnie na gruncie gospodarki i funkcjonowania firm autor przedstawia własną ideę budowania patriotyzmu gospodarczego jako niezbędnego czynnika rozwoju pastwa i społeczeństwa w nowych uwarunkowaniach gospodarki rynkowej (Góral, 2013).

15 Organy władzy lokalnej nie biorą pod uwagę, że przejmowane budynki nie spełniają norm przeciwpożarowych i sanitarnych (Pogroszewska, 2013).
} 
Tab. 15. Najpopularniejsze kierunki migracji Polaków w latach 2011 i 2012 (w tys.)

\begin{tabular}{|l|c|r|r|r|r|}
\hline \multirow{2}{*}{ Kraj } & \multirow{2}{*}{$\mathbf{2 0 1 1}$} & \multirow{2}{*}{$\mathbf{2 0 1 2}$} & \multirow{2}{*}{ Dynamika } & \multicolumn{2}{c|}{ Udzial } \\
\cline { 5 - 6 } & & & & $\mathbf{2 0 1 1}$ & $\mathbf{2 0 1 2}$ \\
\hline W. Brytania & 580 & 625 & 107,8 & 35,4 & 36,4 \\
\hline Niemcy & 440 & 470 & 106,8 & 26,9 & 27,4 \\
\hline Irlandia & 133 & 120 & 90,2 & 8,1 & 7,0 \\
\hline Holandia & 92 & 95 & 103,3 & 5,6 & 5,5 \\
\hline Włochy & 92 & 94 & 102,2 & 5,6 & 5,5 \\
\hline Francja & 60 & 62 & 103,3 & 3,7 & 3,6 \\
\hline Norwegia & 50 & 56 & 112,0 & 3,1 & 3,3 \\
\hline Belgia & 45 & 47 & 104,4 & 2,7 & 2,7 \\
\hline Hiszpania & 38 & 40 & 105,3 & 2,3 & 2,3 \\
\hline Szwecja & 33 & 36 & 109,1 & 2,0 & 2,1 \\
\hline Austria & 29 & 25 & 86,2 & 1,8 & 1,5 \\
\hline Dania & 19 & 21 & 110,5 & 1,2 & 1,2 \\
\hline Grecja & 16 & 15 & 93,8 & 1,0 & 0,9 \\
\hline Czechy & 7 & 7 & 100,0 & 0,4 & 0,4 \\
\hline Finlandia & 3 & 2 & 66,7 & 0,2 & 0,1 \\
\hline Portugalia & 1 & 1 & 100,0 & 0,1 & 0,1 \\
\hline Razem & 1638 & 1716 & 104,8 & 100,0 & 100,0 \\
\hline
\end{tabular}

Źródło: Maciejewicz, Kadłuczka (2011); Ćwiek (2012).

Tab. 16. Zarobki w Europie w 2010 r.

\begin{tabular}{|l|c|c|l|c|c|}
\hline \multicolumn{1}{|c|}{ Kraj } & $\begin{array}{c}\text { Zarobki } \\
\text { (euro w tys. } \\
\text { rocznie) }\end{array}$ & $\begin{array}{c}\text { Bezrobocie } \\
\text { (w procentach) }\end{array}$ & Kraj & $\begin{array}{c}\text { Zarobki } \\
\text { (euro w tys. } \\
\text { rocznie) }\end{array}$ & $\begin{array}{c}\text { Bezrobocie } \\
\text { (w procentach) }\end{array}$ \\
\hline Norwegia & 28,6 & 3,4 & Hiszpania & 15,9 & 21,0 \\
\hline Luksemburg & 27,1 & 4,5 & Grecja & 11,2 & 15,0 \\
\hline Austria & 25,7 & 4,0 & Portugalia & 10,9 & 12,2 \\
\hline Belgia & 25,5 & 7,4 & Słowenia & 9,3 & 8,4 \\
\hline Dania & 25,2 & 7,2 & Łotwa & 8,3 & 16,2 \\
\hline Niemcy & 24,9 & 6,1 & Czechy & 7,1 & 6,5 \\
\hline Holandia & 24,4 & 4,1 & Estonia & 6,4 & 13,8 \\
\hline Finlandia & 23,3 & 7,8 & Słowacja & 5,7 & 13,4 \\
\hline Szwecja & 22,4 & 7,5 & Węgry & 5,7 & 9,9 \\
\hline Irlandia & 21,9 & 14,2 & Polska & 5,4 & 9,0 \\
\hline W. Brytania & 20,7 & 7,7 & Litwa & 4,5 & 16,3 \\
\hline Francja & 20,3 & 7,7 & Rumunia & 3,2 & 7,0 \\
\hline Włochy & 18,4 & 8,0 & Bułgaria & 2,2 & 11,4 \\
\hline
\end{tabular}

Źródło: Bojanowski, Bednarek (2011: 25). 
emigracji z 580 tys. do 625 tys. osób), Niemcy (wzrost emigracji z 440 tys. do 470 tys.osób), a następnie Irlandię, Holandię, Włochy, Francję i in. (tab.15). Proces ten nasilać będzie deficyt zasobów pracy w tych krajach, na co wskazuje stosunkowo niski poziom bezrobocia, np. w $2010 \mathrm{r}$. w Niemczech stopa bezrobocia wynosiła 6,1\%, w Wielkiej Brytanii 7,7\%, Holandii 4,1\%, Norwegii 3,4\%. Dodatkowym czynnikiem aktywizującym migrację są relatywnie wysokie płace w tych krajach. Podczas gdy w 2010 r. przeciętne roczne zarobki w Polsce wynosiły 5,4 tys. euro, to w Norwegii wynosiły one 28,6 tys. euro, w Niemczech $-24,9$ tys., w Holandii 24,4 tys., a w Wielkiej Brytanii - 20,7 tys. (tab. 16) ${ }^{16}$. Między wysokością zarobków w tych krajach a stopą bezrobocia zachodzi wyraźna prawidłowość, a mianowicie w miarę spadku stopy bezrobocia rosną zarobki, co ilustruje wartość wskaźnika korelacji $(-0,532)$.

Należy wnosić, że na proces ten wpływać będzie także zarysowująca się niekorzystna sytuacja na krajowym rynku pracy. Przewiduje się, że w 2013 r. stopa bezrobocia będzie wynosić 13,0\%, a dopiero następnie zacznie spadać do 11,1\% w 2016 r., co oznacza, że stosunkowo długo utrzymywać się będą trudności w zakresie aktywizacji zawodowej ludności na krajowym rynku pracy ${ }^{17}$.

\section{Zakończenie}

Zarysowany problem uwarunkowania rozwoju przedsiębiorczości w warunkach kryzysu gospodarczego i wybrane przykłady wskazują na bardzo złożony mechanizm kształtowania tego zjawiska. W celu podejmowania racjonalnych działań wpływających na pobudzanie rozwoju przedsiębiorczości mechanizm ten należy w miarę precyzyjnie poznać i upowszechnić zarówno wśród przedstawicieli władzy, jak i w społeczeństwie. Wydaje się, że główną przyczyną współczesnego stanu są niezbyt sprawnie działające reguły demokracji, w których brakuje konkurencji intelektualnej i umiejętności posługiwania się wiedzą przez znaczną część elit politycznych, wybieranych przez słabo ekonomicznie wyedukowane społeczeństwo ${ }^{18}$. Wyrazem tego może być podejmowanie zastępczych problemów przez władze ustawodawcze oraz niewiele dające spory polityczne, w których brak treści gospodarczych. Wynika to niewątpliwie z faktu, iż na temat zastępczo podejmowanych spraw może dyskutować każdy, natomiast dyskusje merytoryczne o tym, jak wyprowadzić kraj z kryzysu i przygotować do wejścia w fazę ożywienia gospodarczego, wymagają już poważnej wiedzy ekonomicznej, społecznej i o zmieniających się uwarunkowaniach międzynarodowych. W miejsce obecnych, czasem sztucznie wywoływanych sporów, elity polityczne powinny podjąć stale aktualny problem, mianowicie jak budować nowoczesne państwo w warunkach wkraczania w informacyjną fazę rozwoju. Dlatego na wszystkich szczeblach edukacji i w środkach masowego przekazu coraz większego znaczenia powinno nabierać przekazywanie wiedzy z zakresu kształtowania postaw przedsiębiorczych w zmieniającym się otoczeniu europejskim i światowym, które można wykorzystać dla intensyfikowania procesów rozwoju społecznego, gospodarczego i kulturowego kraju, a także układów regionalnych i lokalnych. Podstawowym celem tych działań winno być kształtowanie społeczeństwa informacyjnego i gospodarki opartej na wiedzy.

\footnotetext{
$\overline{16}$ Por. Macierewicz, Kadłuczka (2011).

${ }^{17}$ Jeżeli przewidywania te okażą się trafne i nie dokona się znaczniejszego przyspieszenia rozwoju gospodarczego, to należy się liczyć z bardzo negatywnym zjawiskiem ubytku głównie młodych i najlepiej wykształconych pracowników, co znacznie osłabiać będzie możliwości rozwijania gospodarki w latach pokryzysowych (Cieślak-Wróblewska, 2012).

18 Połowa Polaków twierdzi, że ma za mało koniecznej wiedzy, by prowadzić własną działalność gospodarczą (Błaszczak, 2012, 1 sierpnia).
} 


\section{Literatura}

Baj, L. (2013, 7 lutego). Stopy procentowe znowu w dół o ćwiartkę. Kiedy koniec obniżek?. Gazeta Wyborcza.

Błaszczak, A. (2012, 12 listopada). Rosną obawy najmniejszych firm. Rzeczpospolita.

Błaszczak, A. (2012). Kurs na przedsiębiorczość. Rzeczpospolita.

Bojanowski, M., Bednarek, M. (2011, 8 sierpnia). Praca u podstaw. Gazeta Wyborcza, 25.

Cieślak-Wróblewska, A. (2012, 14 września). Nieprędki powrót szybkiego wzrostu. Rzeczpospolita.

Ćwiek, J. (2012, 26 września). Polacy znów masowo rmigrują do Londynu. Rzeczpospolita.

Fandrejewska, A. (2012, 27 sierpnia). Nie widać końca redukcji płac. Rzeczpospolita, B2-3.

Fandrejewska, A. (2013, 11 stycznia). Mniej zwolnień niż zapowiedzi. Rzeczpospolita, B5.

Gadomski, W. (2011, 11 lutego). Państwo zniszczyło stocznie. Gazeta Wyborcza.

GUS. (2010). Rocznik Statystyczny RP, Warszawa.

GUS. (2013a). Zatrudnienie i wynagrodzenia w gospodarcze narodowej w 2012 r., Warszawa.

GUS. (2013b). Zatrudnienie i wynagrodzenia w gospodarce narodowej w I-III kwartale 2012 r., Warszawa.

Góral, A. (2013, 4 lutego). Patriota płaci podatki w Polsce. Rzeczpospolita.

Kamińska, A. (2012, 24 sierpnia). Pensje nie wystarczają, Polacy sięgają po oszczędności. Rzeczpospolita B.

Koniunktura coraz słabsza. (2011, 22-23 października). Rzeczpospolita B.

Krześniak, M. (2013, 9 stycznia). Odsetki od lokat będą topniały. Rzeczpospolita, 10B.

Macierewicz, P., Kadłuczka, J. (2011, 8 sierpnia; 2012, 26 czerwca). Wyjeżdżają i nie wracają. Gazeta Wyborcza.

Misztal, S., Zioło, Z. (red.). (1998). Dorobek polskiej geografii przemystu. Komisja Geografii Przemysłu Polskiego Towarzystwa Geograficznego, Instytut Geografii WSP im. Komisji Edukacji Narodowej w Krakowie, Wydawnictwo Krakowskiego Oddziału PAN, Warszawa - Kraków.

Pietryga, T. (2013, 6 lutego). Przedsiębiorcy i myśliwi. Rzeczpospolita.

Pogroszewska, M. (2013, 7 lutego). Podatek od rudery bez taryfy ulgowej. Rzeczpospolita.

Polskie przedsiębiorstwa. Lista 2000 (2012, 24 października), Rzeczpospolita.

Rachwał, T. (2001). Problematyka kwestionariusza badań funkcjonowania przedsiębiorstwa przemysłowego w okresie transformacji systemu gospodarowania. Prace Komisji Geografii Przemystu Polskiego Towarzystwa Geograficznego, 2, 49-57.

Raczkowski, W. (2013). Szyją i promują Polskę, Przegląd, 5.

Reda-Jakima, Z. (2013, 9 stycznia). Liczba upadłości rośnie szybciej niż w Hiszpanii. Rzeczpospolita, B3.

Semciuk, M. (2012, 10-11 listopada). Niepewny koniec kredytowej smuty w polskich bankach. Gazeta Wyborcza, 8.

Semciuk, M. (2012, 13 listopada). Urzędy stworzą bat na lichwę?. Gazeta Wyborcza, 23.

Więcław, E. (2010, 6 stycznia). Źle zarządzane firmy będą znikać. Rzeczpospolita.

Woźniak, A. (2012, 26 września). Polska wysoko w rankingu atrakcyjności przejęć. Rzeczpospolita.

Wybranowski, W. (2011, 23 listopada). Walczą o wolność gospodarczą. Rzeczpospolita.

Wybranowski W. (2012, 17 lutego). Przedsiębiorcy bez ochrony. Rzeczpospolita.

Wybranowski, W. (2012, 23 lipca). Siedem lat gehenny przedsiębiorców. Rzeczpospolita.

Wybranowski, W. (2013, 9 marca). Zabójczy ciężar podatku. Rzeczpospolita.

Zioło, Z. (1988). Funkcjonowanie i rozwój przedsiębiorstwa przemysłowego w przestrzeni geograficznej.

W: Z. Zioło (red.). Zakład przemysłowy w akademickim kształceniu nauczycieli geografi, Materiały i sprawozdania nr 16, COMSN, WSP w Krakowie, Kraków: Wydawnictwo Naukowe WSP, 8-24.

Zioło, Z. (1994). Zmiana roli przestrzeni geograficznej w procesie transformacji systemu gospodarowania. W: Z. Zioło (red.). Zachowania przestrzenne przemysłu w zmieniajacych się warunkach gospodarowania, Komisja Geografii Przemysłu Polskiego Towarzystwa Geograficznego, 14-21.

Zioło, Z., Rachwał, T. (red.). (2008). Przedsiębiorczość w gospodarce opartej na wiedzy, Przedsiębiorczość-Edukacja, 4. 
Zioło, Z., Rachwał, T. (red.). (2009). Wpływ globalizacji i integracji europejskiej na transformację struktur przemysłowych, Prace Komisji Geografii Przemystu Polskiego Towarzystwa Geograficznego, 12.

Zioło, Z., Rachwał, T. (red.). (2010). Przedsiębiorczość w warunkach integracji europejskiej, Przedsiębiorczość - Edukacja, 6.

Zioło, Z., Rachwał, T. (red.). (2011a). Wpływ kryzysu na zachowania przedsiębiorstw oraz przemiany struktur regionalnych, Prace Komisji Geografii Przemystu Polskiego Towarzystwa Geograficznego, 17.

Zioło, Z., Rachwał, T. (red.). (2011b). Przedsiębiorczość w warunkach globalizacji, Przedsiębiorczość - Edukacja, 7.

Zbigniew Zioło, dr nauk przyrodniczych, dr hab. i prof. nauk ekonomicznych, Uniwersytet Pedagogiczny im. Komisji Edukacji Narodowej w Krakowie, Instytut Geografii, Zakład Przedsiębiorczości i Gospodarki Przestrzennej.

Zainteresowania badawcze: gospodarka przestrzenna, geografia ekonomiczna, polityka społeczno-gospodarcza, ekonomika i polityka rozwoju regionalnego.

Zbigniew Zioło, ScD, PhD, Prof of Economics. Pedagogical University of Cracow, Institute of Geography, Department of Entrepreneurship and Spatial Management.

Research interests: spatial management, economic geography, socio-economic policy, economics and policy of regional development.

Adres/Address: Uniwersytet Pedagogiczny w Krakowie, Instytut Geografii

Zakład Przedsiębiorczości i Gospodarki Przestrzennej

ul. Podchorążych 2, 30-084 Kraków, Polska

e-mail: ziolo@up.krakow.pl 


\title{
Monika Borowiec
}

Uniwersytet Pedagogiczny

im. Komisji Edukacji Narodowej

w Krakowie

\section{Etyka chrześcijańska w ksztaltowaniu ladu moralnego w biznesie w warunkach kryzysu społeczno-gospodarczego}

\author{
The role of Christian ethics in shaping the moral order of business during \\ a socio-economic crisis
}

\begin{abstract}
Streszczenie
Postępujące procesy globalizacji w znacznym stopniu przyczyniają się do nasilenia różnego rodzaju sytuacji kryzysowych w światowym systemie społeczno-gospodarczym. Za układ odniesienia dla oceny pojawiających się kryzysów gospodarczych, nasilających się procesów globalizacji oraz roli człowieka w rozwoju cywilizacyjnym przyjęto naukę społeczną Kościoła katolickiego. W świetle powyższych przesłanek w niniejszym artykule podjęto próbę refleksji nad powołaniem liderów biznesu i możliwościami kształtowania relacji pomiędzy życiem moralnym a aktywnym uczestnictwem w życiu społeczno-gospodarczym. W artykule podano przykłady różnych inicjatyw podejmowanych przez środowiska chrześcijańskie w celu upowszechniania zasad moralnych w aktywności społeczno-gospodarczej.
\end{abstract}

\begin{abstract}
Globalization processes are often thought to generate various critical situations in the global socio-economic system. In the article, the social doctrine of the Catholic Church is used as a point of reference for the processes of increasing globalization and emerging economic crisis. The main purpose is to formulate principles, which should be followed by business leaders, willing to make efforts to reconcile possible contradictions between moral imperatives, and the requirements of conducting everyday economic practices. The article presents examples of various initiatives, aimed at promoting Christian moral principles in the course of socio-economic activity.
\end{abstract}

Słowa kluczowe: etyka chrześcijańska; kryzys społeczno-gospodarczy

Key words: Christian ethics; socio-economic crisis

\section{Wprowadzenie}

Postępujące procesy globalizacji w znacznym stopniu przyczyniają się do nasilenia różnego rodzaju sytuacji kryzysowych w światowym systemie społeczno-gospodarczym. Problematyka przyczyn i konsekwencji tych procesów jest przedmiotem pogłębionych badań wielu dyscyplin wiedzy i coraz częściej jest rozważana w świetle zasad etycznych oraz społecznej nauki Kościoła (Singer, 1998; Mariański, 2000; Zwoliński, 2000; Borowiec, 2006; Galata, 2007; Adamczyk, 2008; Brzozowski, 2010, 2011). Bardzo istotne wydaje się, aby to aktualne oraz zyskujące na znaczeniu zagadnienie zostało podjęte w procesie edukacyjnym na różnych poziomach 
kształcenia. Podkreślić należy, że kształtowaniu etycznych postaw gospodarowania przestrzenią społeczno-gospodarczą szczególnie sprzyjają treści nauczania przedmiotu podstawy przedsiębiorczości. T.T. Brzozowski (2012), zwracając uwagę na znaczenie kształtowania postaw etycznych uczniów, podkreśla, że w procesie edukacji poza wyposażaniem młodego człowieka w wiedzę i umiejętności należy zmierzać do kształtowania człowieka mądrego. Mądrość tę należy rozumieć jako odpowiedzialność za siebie i innych, która wynika z myślenia i działania w kategoriach moralnych. Ogromną rolę w tym procesie ma zatem do odegrania nauczyciel, który powinien być jednym z pierwszych i ważnych „mistrzów” ucznia (Szewczyk, 1999). Aby nauczyciel, poza samym przekazywaniem wiedzy, mógł pełnić funkcję wychowawcy moralnego, stawać się autorytetem dla młodego człowieka, w sposób odpowiedzialny pomagać w jego pełnym rozwoju, sam musi być człowiekiem mądrym życiowo i postępującym zgodnie z zasadami etycznymi. Człowiek mądry będzie zdolny do postrzegania swojego późniejszego miejsca pracy jako kontynuacji procesu nauczania, wychowania i dojrzewania do wielu zadań, które mają kształtować jego charakter i przemieniać sytuację społeczno-gospodarczą pozostającą w zasięgu jego wpływu.

Za układ odniesienia dla oceny pojawiających się kryzysów gospodarczych, nasilających się procesów globalizacji i roli człowieka w rozwoju cywilizacyjnym można przyjąć naukę społeczną Kościoła katolickiego zawartą m.in. w encyklikach papieskich, zwłaszcza Jana Pawła II. Zwracał on uwagę na podstawowe znaczenie etosu w życiu człowieka i apelował, aby różnym dziedzinom życia społeczno-gospodarczego nadać nową jakość moralną przez odniesienie do osoby i do jej relacyjnego wyrażania się, w celu zapewnienia istnienia i rozwoju „na miarę człowieka" (Królikowski, 2011). Podobnie Benedykt XVI w encyklice Caritas in veritate (2009: 19) zauważa, że „społeczeństwo coraz bardziej zglobalizowane zbliża nas, ale nie czyni nas braćmi”. Obecny kryzys gospodarki światowej skłonił Kościół do ponownego zabrania głosu w sprawach społecznych. We wspomnianej encyklice Benedykt XVI nie wnika w bezpośrednie przyczyny załamania rynków finansowych, ale proponuje szerszą refleksję nad kierunkami rozwoju świata, w tym relacji międzynarodowych, wskazując podstawowe warunki rozwoju człowieka (Adamiec, 2009).

Wydaje się, że kryzys gospodarczy jest przejawem innych kryzysów, przede wszystkim kryzysu obyczajów i kultury, a więc etosu. Jan Paweł II wielokrotnie i zdecydowanie podkreślał w swoim nauczaniu, że u podstaw zamętu w dzisiejszym świecie legł grzech i jego bagatelizowanie, zarówno w wymiarze osobistym, jak i społecznym. Podkreślał także, że globalizacja ekonomii wymaga globalizacji odpowiedzialności. W odpowiedzi na współczesne sytuacje kryzysowe w Tryptyku społecznym obejmującym trzy encykliki społeczne, tj. Laborem exercens, Sollicitudo rei socialis i Centesimu annus, podkreślał fundamentalną, twórczą i odnawiającą rolę cnót oraz wartości duchowych dla człowieka i życia społeczno-gospodarczego oraz koniczność rozwiązywania problemów z perspektywy chrześcijańskiej. Wydaje się, że w sytuacji obecnego kryzysu gospodarczego dokumenty te nie tracą na aktualności, a wręcz nabierają jeszcze większego znaczenia i powinny stać się przedmiotem pogłębionych studiów wskazujących na prawdziwe źródła współczesnych kryzysów dotykających poszczególnych ludzi, jak i cały system społeczno-gospodarczy.

W świetle powyższych przesłanek w niniejszym artykule podjęto refleksję nad powołaniem liderów biznesu oraz możliwościami kształtowania relacji pomiędzy życiem moralnym a aktywnym uczestnictwem w życiu społeczno-gospodarczym. W artykule przedstawiono podstawowe dokumenty Kościoła katolickiego podejmujące problematykę etyki życia społeczno-gospodarczego oraz różnego rodzaju chrześcijańskich ruchów, stowarzyszeń oraz organizacji biznesowych starających się wprowadzać w życie społeczną naukę Kościoła katolickiego. 
Podjęcie niniejszej problematyki w odniesieniu do współczesnych sytuacji kryzowych na świecie nawiązuje również do rozpoczętego 11 października 2012 r., w 50. rocznicę otwarcia Soboru Watykańskiego II, Roku Wiary w Kościele katolickim. Benedykt XVI, ogłaszając to wydarzenie w liście Porta Fidei, określił je jako „czas zintensyfikowanej refleksji na temat wiary", który ma przyczynić się do bardziej świadomego i ożywionego przywiązania do ewangelii, zwłaszcza w warunkach głębokich przemian społeczno-gospodarczych. Dzień rozpoczęcia Roku Wiary wiąże się także z 20. rocznicą opublikowania Katechizmu Kościoła katolickiego, który jest jednym z najważniejszych owoców Soboru Watykańskiego II i obejmuje również treści odnoszące się do powołania i uczestnictwa człowieka w życiu społeczno-gospodarczym.

\section{Etyka życia społeczno-gospodarczego w świetle nauczania Kościoła katolickiego}

W związku ze wspomnianymi inicjatywami, wpisującymi się w dzieło tzw. nowej ewangelizacji, ważne wydaje się podjęcie próby spojrzenia na kryzys społeczno-gospodarczy jako, w pewnym sensie, konsekwencję nasilającego się kryzysu etycznego. M. Leśniak (2012) podkreśla za J.E. Alveyem (2000), że przyczyna kryzysów gospodarczych tkwi w rozdzieleniu moralności od ekonomii jako nauki, które to rozdzielenie następowało powoli i było związane z zastosowaniem metodologii nauk ścisłych w ekonomii oraz uproszczeń w sposobie postrzegania świata. Teoria ekonomii skoncentrowała się na analizie, wyjaśnianiu, opisywaniu i tworzeniu schematów prawidłowości w procesach ekonomicznych bez dokonywania ich oceny moralnej. Podobne poglądy reprezentuje A. Sen (1987: 7), laureat Nagrody Nobla w dziedzinie ekonomii w 1998 r., który uważa, że „ekonomia może być jednocześnie nauką matematyczną i moralną”.

Do problematyki tej odnosi się również dokument Powołania lidera biznesu. Należy podkreślić, że w dokumencie tym po raz pierwszy Kościół zwraca się wprost do liderów biznesu oraz wszystkich uczestników życia gospodarczego, zapraszając ich do refleksji nad ich powołaniem oraz misji, jaką mają do zrealizowania w świecie pełnym napięć społeczno-gospodarczych. W dniach 24-26 lutego 2011 r. odbyło się w Rzymie ważne seminarium pt. „Caritas in veritate: logika daru i znaczenie biznesu” zorganizowane przez Papieską Radę „Iustitia et Pax” we współpracy z Instytutem Myśli Społecznej im. Johna A. Ryana, działającym przy Centrum Studiów Katolickich Uniwersytetu św. Tomasza oraz Fundacją Ecophilos i stanowiło ono kontynuację badań organizacji gospodarczych w świetle encykliki społecznej Caritas in Veritate papieża Benedykta XVI. Podczas tych obrad podjęto decyzję o przygotowaniu podręcznika dla nauczycieli akademickich pomocnego w formacji oraz nauczaniu w szkołach i na uczelniach wyższych, który podejmowałby problematykę ,,powołania” przedsiębiorców. Dokument Powołanie lidera biznesu, jak sugerują autorzy, może stać się pewną pomocą dla nauczycieli przedsiębiorczości przez inspirację uczniów i studentów do podejmowania działalności gospodarczej zgodnej z zasadami nauki społecznej Kościoła oraz pogłębionej refleksji nad powołaniem zawodowym.

Należy zauważyć, że tej aktualnej problematyce poświęcona była także konferencja naukowa, która odbyła 18 października 2012 r. na Uniwersytecie Papieskim Jana Pawła II w Krakowie. Zorganizowano ją z inicjatywy Duszpasterstwa Przedsiębiorców i Pracodawców „Talent” pod patronatem Jego Eminencji Ks. Kardynała Stanisława Dziwisza Metropolity Krakowskiego.

Podczas konferencji ks. dr hab. J. Żelazny przedstawił sylwetkę św. Grzegorza Wielkiego jako patrona ludzi biznesu. W świetle jego dzielności podkreślono wielkie znaczenie w zarządzaniu takich cech lidera biznesu, jak: umiejętność doboru ludzi uczciwych, sumiennych i zdolnych do pełnienia powierzonych funkcji, udzielania szerokiej autonomii w działaniach, a zarazem obecności i kontroli, posiadania wizji na przyszłość, bardzo dobrej znajomości uwarunkowań ekonomicznych i prawnych. Zwracano również uwagę, że nagromadzenie kom- 
petencji nie sprzyja zarządzaniu i podkreślano takie cechy zarządcy, jak: takt, roztropność, troska o wszystkich podwładnych, odwaga wizji i działań niekonwencjonalnych, niepodważanie autorytetu ludzi, którym powierzono funkcje kierownicze, zagrożenia płynące z nadmiernego zadłużania. Podobnie W. Krówczyński z International Coach wskazywał na ważne cechy lidera biznesu, takie jak: orientacja na cel, prawość charakteru, silne zaangażowanie w sprawy zespołu, postrzeganie spraw z szerszej perspektywy, innowacyjność, wytrwałość, uporządkowanie i komunikatywność (http://www.intercoach.pl).

W dokumencie Powołania lidera biznesu sformułowano sześć zasad biznesu dla trzech wyróżnionych celów przedsiębiorczości, za jakie uznano zaspokojenie potrzeb świata przez tworzenie towarów oraz rozwój usług, organizowanie dobrej i wydajnej pracy oraz tworzenie trwałego bogactwa i jego sprawiedliwy podział. Wskazują one na cel biznesu, jakim nie jest wyłącznie wytwarzanie zysku, ale rozwój przedsiębiorstwa jako wspólnoty ludzi zdążających do zaspokojenia swoich potrzeb i służącej całemu społeczeństwu (Jan Paweł II, Centesimus annus). Choć jest to niezwykle rzadkie, zwłaszcza w literaturze ekonomicznej, określenie w odniesieniu do firm czy korporacji, to na taki charakter wskazuje etymologia słów firma czy korporacja.

W świetle rozważań podjętych w dokumencie sformułowano następujące postulaty w odniesieniu do liderów biznesu:

1. Czynienie wielkich dzieł przez ludzi, którzy uwierzą, że w dużym stopniu od ich talentów, zaangażowania i podjętych trudnych wyzwań zależą zmiany sytuacji społeczno-gospodarczej.

2. Wierność zasadom i prawe przywództwo w przedsiębiorstwie.

3. Postawa służby.

4. Zdrowe środowisko moralno-kulturowe.

5. Oferowanie produktów i usług, które zaspokajają autentyczne ludzkie potrzeby.

6. Tworzenie dobrobytu w zrównoważony sposób.

7. Organizowanie dobrej i wydajnej pracy, m.in. przez właściwy stosunek do pracownika i odpowiedni system motywacji.

8. Tworzenie firmy jako wspólnoty osób, które łączą prawidłowe relacje.

9. Postawa dawania.

10. Uznanie Bożego pochodzenia norm moralnych i szanowanie godności człowieka, ponieważ tylko na bazie wspólnych wartości można budować trwale, wspierając integralny rozwój człowieka.

Do fundamentalnych zasad etycznych w biznesie należą ludzka godność i dobro wspólne. Wynika z tego, że każdy człowiek ma prawo i obowiązek podążać za swoim powołaniem i dążyć do osobistego spełniania w relacji z innymi ludźmi, a zatem każdy ma też obowiązek unikania zachowań, które przeszkadzają w rozwoju innych osób oraz pomagania innym w rozwoju i odpowiedzialności za innych.

Począwszy od encykliki Leona XIII Rerum novarum z 1891 r., w kolejnych dokumentach podejmowano wiele kwestii społecznych. Warto wspomnieć, że w przygotowaniu i propagowaniu tej encykliki duże zasługi miał włoski socjolog i ekonomista Giuseppe Tonilo, beatyfikowany w 2012 r. Postulował on konieczność zaangażowania chrześcijan w życie społeczno-gospodarcze i dążył do afirmacji moralnych wartości oraz stworzenia systemu ekonomii zgodnego z założeniami chrześcijańskimi, czemu dał wyraz w pracy Traktat ekonomii społecznej (Piątek, 2012). Do kwestii robotniczej bezpośrednio odnosi się Encyklika Quadragesimo anno Piusa XI, wydana w czterdziestolecie Rerum novarum, następnie Jan XXIII w Mater et magistra rozważa kwestię sprawiedliwości społecznej, głównie w odniesieniu do rolników, a w Pacem in terris określa zasady pokoju i porządku międzynarodowego, Paweł VI w Populorum progressio analizuje różne aspekty sprawiedliwego postępu. Problematyka tych 
dokumentów została podjęta w konstytucji duszpasterskiej o Kościele w świecie współczesnym Gaudium et spes, która obejmuje złożone zagadnienia życia politycznego, ekonomicznego i społecznego. Problematyka społeczna została następnie przypomniana i pogłębiona w Tryptyku społecznym Jana Pawła II.

U źródeł tych wszystkich dokumentów znajduje się problematyka wolności człowieka, która została dana i zadana człowiekowi i powołuje go do przyjęcia prawdy oraz dobra. ,Wolność jest sobą, jest wolnością w takiej mierze, w jakiej jest urzeczywistniana przez prawdę o dobru. Tylko wtedy ona sama jest dobrem. Jeżeli wolność przestaje być związana z prawdą, a uzależnia prawdę od siebie, tworzy logiczne przesłanki, które mają szkodliwe konsekwencje moralne" (Jan Paweł II, 2005: 51). Należy zwrócić uwagę na bardzo ważną kwestię związaną z wolnością, jaką podejmuje Jan Paweł II w encyklice Sollicitudo rei socialis, a mianowicie problematykę kryzysu koncepcji „ekonomicznej” związanej ze słowem rozwój (Encykliki Ojca Świętego Jana Pawła II, 2009: 469, 471, 477, 481). Przyjmuje on, że „samo nagromadzenie dóbr i usług, nawet z korzyścią dla większości, nie wystarcza do urzeczywistnienia ludzkiego szczęścia. W konsekwencji także dostęp do wielorakich rzeczywistych dobrodziejstw, jakich w ostatnim czasie dostarczyły wiedza i technika, łącznie z informatyką, nie przynosi ze sobą wyzwolenia spod wszelkiego rodzaju zniewolenia. Przeciwnie, doświadczenie niedawnych lat uczy, że jeśli cała wielka masa zasobów i możliwości oddana do dyspozycji człowieka nie jest kierowana »zmysłem moralnym« i zorientowana na prawdziwe dobro rodzaju ludzkiego, łatwo obraca się przeciw człowiekowi - jako zniewolenie [...] Rozwój nie tylko ekonomiczny mierzy się i ukierunkowuje według tej rzeczywistości powołania człowieka widzianego całościowo, czyli według jego »parametru« wewnętrznego [...] współpraca nad rozwojem człowieka, całego człowieka i każdego człowieka jest bowiem obowiązkiem wszystkich wobec wszystkich i powinna być zarazem powszechna na całym świecie [...] staje się oczywiste, że rozwój, jego planowanie, użycie zasobów i sposób ich wykorzystania nie mogą być oderwane od poszanowania wymogów moralnych”. Jak podkreśla M. Krupa (2009: 176-177), Jan Paweł II stwierdzał - „należy zauważyć, że w sytuacji, w której nie istnieje żadna ostateczna prawda, będąca przewodnikiem dla działalności politycznej i nadająca jej kierunek, łatwo o instrumentalizacje idei i przekonań dla celów, jakie stawia sobie władza. Historia uczy, że demokracja bez wartości łatwo się przemienia w jawny lub zakamuflowany totalitaryzm”.

Problematyka norm moralnych i ich znaczenia dla życia społeczno-gospodarczego i politycznego podjęta została szeroko w encyklice Veritatis splendor (Encykliki Ojca Świętego Jana Pawła II, 2009, s. 812, 813). „Stanowczość, z jaką Kościół broni uniwersalnych i niezmiennych norm moralnych, nie ma bynajmniej celu umniejszać człowieka, ale służyć jego prawdziwej wolności: skoro nie istnieje wolność poza prawdą lub przeciw niej, należy uznać, że kategoryczna - to znaczy nie dopuszczająca ustępstw ani kompromisów - obrona absolutnie niezbywalnych wymogów, jakie wypływają z osobowej godności człowieka, jest drogą do wolności i warunkiem samego jej istnienia [...] wobec norm moralnych, które zabraniają popełniania czynów wewnętrznie złych, nie ma dla nikogo żadnych przywilejów ani wyjątków. Nie ma żadnego znaczenia, czy ktoś jest władcą świata, czy ostatnim »nędzarzem« na tej ziemi: wobec wymogów moralnych wszyscy jesteśmy absolutnie równi [...] wobec szerzenia się groźnych form niesprawiedliwości społecznej i gospodarczej oraz korupcji politycznej, które dotykają całe kraje i narody, narasta oburzenie wielkiej rzeszy ludzi, których podstawowe prawa zostały podeptane i znieważone, coraz powszechniejsza i pilniejsza jest też »potrzeba radykalnej odnowy« jednostek i społeczeństw, zdolnej zapewnić sprawiedliwość, solidarność, uczciwość i jawność".

Źródeł godności pracy należy upatrywać w jej podmiotowym, a nie przedmiotowym wymiarze i przyjąć, że praca jest dla człowieka, a nie człowiek dla pracy i jej organizacja może 
pomagać lub szkodzić pracownikowi w jego rozwoju (Pius XI, Quadragesimo anno, Jan Paweł II, Laborem exercens). Encyklika Laborem exercens rozpoczyna się słowami „Z pracy swojej ma człowiek pożywać chleb codzienny i przez pracę ma się przyczyniać do ciągłego rozwoju nauki i techniki, a zwłaszcza nieustannego podnoszenia poziomu kulturalnego i moralnego społeczeństwa, w którym żyje jako członek braterskiej wspólnoty [...]. Więcej wart jest człowiek z racji tego, czym jest, niż ze względu na to co posiada. Podobnie warte więcej jest to wszystko, co ludzie czynią dla wprowadzenia większej sprawiedliwości, szerszego braterstwa, bardziej ludzkiego uporządkowania dziedziny powiązań społecznych, aniżeli postęp techniczny. Albowiem postęp ten może tylko dostarczać niejako materii do udoskonalenia człowieka, ale sam przez się tego udoskonalenia nie urzeczywistnia" (Encykliki Ojca Świętego Jana Pawła II, 2009: 143, 209).

Powszechnie przyjmuje się, że najważniejszą przeszkodą w służbie na rzecz dobra wspólnego na poziomie osobistym jest rozdźwięk między wiarą a codziennym prowadzeniem działalności biznesowej, który może skutkować nadmiernym przywiązaniem do sukcesu i braku równowagi we wszystkich sferach życia. Lider biznesu spójny wewnętrznie przez swoje świadectwo może przekształcać środowisko i przezwyciężać negatywne zjawiska (Król, Leśniak, 2012). Liderzy biznesu, którzy w życiu zawodowym nie widzą służebnej roli wobec innych ludzi i Boga, będą starali się wypełnić tę pustkę jakimś substytutem, a ich życie nie będzie przebiegało w sposób harmonijny i zintegrowany, co w konsekwencji odbije się na prowadzonej działalności oraz na pozostałych sferach życia. Aspiracje zawodowe mogą być źródłem prawdziwego sukcesu i satysfakcji, jeśli są zgodne z powołaniem, a decyzje motywowane są czymś więcej niż tylko osiągnięciem sukcesu finansowego. „Komu wiele dano, od tego wiele wymagać się będzie, a komu wiele powierzono, tym więcej od niego żądać będą" (Łk 12,48). Nie powinno zatem budzić najmniejszych wątpliwości powołanie liderów biznesu do czynienia wielkich dzieł oraz pomnażania i koncentracji nie tylko kapitału, ale też talentów i cnót. Jeśli lider biznesu przyjmie, że jedynym kryterium działania w biznesie jest maksymalizacja zysków, grozi to uczynieniem z tego biznesu „złotego cielca”, czyli popełnianiem grzechu bałwochwalstwa i uleganiem złudnej idei pozornego oraz krótkotrwałego sukcesu wynikającego z pobudek egoistycznych, pychy i chciwości lub nasilonych różnego rodzaju zachowań lękowych. „Uważajcie i strzeżcie się wszelkiej chciwości, bo nawet gdy ktoś ma [wszystkiego] w nadmiarze, to życie jego nie zależy od jego mienia" (Łk 12, 15). Zysk jest niezbędny do rozwoju przedsiębiorstwa, ale ,nastawienie wyłącznie na zysk, gdy jest on osiągany nagannymi sposobami, a jego ostatecznym celem nie jest dobro wspólne, rodzi ryzyko zniszczenia bogactwa i spowodowanie ubóstwa" (Benedykt XVI, Caritas in veritate: 21).

Chrześcijańskich liderów biznesu zwykle motywuje znacznie więcej czynników niż sukces finansowy firmy czy własny interes ${ }^{1}$. Autentyczna wiara zawsze ma implikacje społeczne. Tworzenie właściwej organizacji pracy, zwiększanie innowacyjności, ulepszanie struktur społecznych i gospodarczych powinno uświadamiać wielką odpowiedzialność za tak wielkie powołanie do uczestniczenia w dziele stworzenia. Skutkować to powinno rozwojem przywództwa służebnego, umiejętności rozeznawania i instynktu nadprzyrodzonego.

$\overline{1}$ „Życie gospodarcze nie powinno zmierzać jedynie do pomnażania wyprodukowanych dóbr i zwiększania zysku czy wpływów; przede wszystkim powinno służyć osobom, całemu człowiekowi i wspólnocie ludzkiej. Działalność gospodarcza, prowadzona zgodnie z właściwymi jej metodami i prawami, powinna być podejmowana w granicach porządku moralnego, zgodnie ze sprawiedliwością społeczną, by odpowiedzieć na zamysł Boży względem człowieka” (Katechizm Kościoła katolickiego, 2009: 557). 
Próbę stworzenia biblijnego przewodnika do zarabiania, wydawania, oszczędzania, inwestowania, obdarowywania i wychodzenia z długów podjął m.in. H. Dayton (2008), wydając książkę Twoje pieniądze się liczą. Wskazuje on, że w Biblii jest ok. 500 wersetów poświęconych modlitwie, nieco mniej poświeconych wierze, a ponad 2350 poświeconych pieniądzom i posiadaniu rzeczy. Podkreślić należy, że autor jest współzałożycielem Crow Financal Ministries, które powstało w 2000 r. z połączenia dwóch organizacji: Crown Ministries, założonej przez niego w 1985 r., oraz Christian Financial Concepts, założonej w 1976 r. przez Larrego Burketa. W Polsce inicjatywa ta istnieje od 2008 r. pod nazwą Edukacja Finansowa Crown, a jej celem jest przybliżanie zasad finansowych zawartych w Słowie Bożym przez różnego rodzaju konferencje i szkolenia. Problematyka sytuacji społeczno-gospodarczej i chrześcijańskiej wizji ekonomii podjęta została także przez profesora teologii W.T. Cavanaughta (2008) w pozycji Pożarci. Gospodarka a powołanie chrześcijańskie i wydaje się, że zawarte w niej spostrzeżenia mogłyby stać się inspiracją do dyskusji na temat możliwości wdrażania w życie społeczno-gospodarcze ewangelicznych zasad. Wydaje się, że w sytuacji kryzysowej warto sięgnąć do biblijnej przypowieści m.in. o nieuczciwym zarządcy, której główne przesłanie, tkwi w tym, aby chrześcijanie żyjący w strukturach społeczno-gospodarczych z taką samą zapobiegliwością i przedsiębiorczością umieli zadbać o swoje życie wieczne, jak nieuczciwy zarządca zadbał o swoją ziemską przyszłość (Łk 16, 1-8).

Należy zdawać sobie sprawę z zagrożeń płynących ze źle ukierunkowanego kształtowania postaw przedsiębiorczych, a mianowicie z jednej strony pokusy całkowitego i wyłącznego oparcia na własnych talentach: kreatywności, innowacyjności, wiedzy, umiejętnościach itd., a $\mathrm{z}$ drugiej strony do przeceniania konieczności szybkiego osiągnięcia sukcesu w biznesie, zwłaszcza niewłaściwie rozumianego sukcesu. Może to powodować rozwój negatywnych cech charakteru, takich jak: egoizm, pycha, pogoń za zaszczytami, niezdrowa rywalizacja, przecenianie możliwości oraz znaczne ograniczenie umiejętności wchodzenia w przestrzeń duchową i wypełniania nią codzienności, a także przez zaburzenie równowagi pomiędzy pracą a innymi sferami życia, prowadzić do problemów zdrowotnych i egzystencjalnych. W konsekwencji może być źródłem kryzysów osobistych, społecznych i gospodarczych. Wydaje się, że warto podjąć refleksję nad słowami Ratzingera (2007: 279) „człowiek staje się bardziej sobą nie przez to, co czyni, ale przez to, co otrzymuje", nie przez to co osiąga, ale przez to, co przyjmuje. Umiejętność przyjmowania pozwala na kształtowanie umiejętności dzielenia. Prawdziwy sukces w działalności gospodarczej oparty na wartościach moralnych nie może być utożsamiany wyłącznie z sukcesem finansowym (Pawlas, 2006; Rachwał, 2006).

Katechizm Kościoła katolickiego stwierdza „w dziedzinie gospodarczej nakaz poszanowania ludzkiej godności oznacza, że należy praktykować cnotę »umiarkowania«, aby ograniczać przywiązanie do dóbr tego świata; cnotę »sprawiedliwości«, aby respektować prawa bliźniego i oddać mu to, co się mu należy; cnotę »solidarności« [...]”. Do zachowań i czynów, które sprzeciwiają się ludzkiej godności należy: kradzież, umyślne przetrzymywanie rzeczy pożyczonych lub znalezionych, oszustwo w handlu, niesprawiedliwe wynagradzanie za pracę, podnoszenie cen, wykorzystujące niewiedzę lub pilne potrzeby innych, przywłaszczanie sobie i wykorzystywanie do prywatnych celów dóbr należących do społeczeństwa lub przedsiębiorstwa, złe wykonywanie pracy, oszustwa podatkowe, fałszowanie czeków i rachunków, nadmierne wydatki, marnotrawstwo itp., a dalej jest napisane, że siódme przykazanie zabrania czynów i przedsięwzięć, które kierując się jakąkolwiek motywacją - egoistyczną czy ideologiczną, handlową czy totalitarną - prowadzą do zniewolenia ludzi, do przesłonięcia ich osobowej godności, jak gdyby byli towarem (Encykliki Ojca Świętego Jana Pawła II, 2009: 815-816).

Podkreślić należy, że orędzie społeczne ewangelii nie powinno być traktowane jako teoria, ale przede wszystkim jako podstawa działania i zachęta do niego (Jan Paweł II, Tryptyk spo- 
łeczny, 2011: 249). Słowa „wszystko, co uczyniliście jednemu z tych braci najmniejszych, Mnieście uczynili” (Mt 25, 40) powinny skłaniać do aktywnego uczestniczenia w życiu społeczno-gospodarczym, przez co orędzie społeczne Kościoła może zyskać wiarygodność. Jest oczywistym, że wcielanie w życie nauki płynącej z ewangelii zawsze napotyka na ogromne wewnętrzne i zewnętrzne trudności, ale dla chrześcijanina jest to największe wyzwanie, powołanie i jasno określona wskazówka działania. Jeśli celem życia chrześcijanina jest osiągnięcie doskonałości, czyli świętości życia „Bądźcie więc świętymi, bo Ja jestem Święty!” (Kpł 11, 45) i „bądźcie więc wy doskonali, jak doskonały jest Ojciec wasz niebieski” (Mt 5, 48), to w tym należy upatrywać prawdziwego sukcesu człowieka, do którego prowadzić powinny spójne działania podejmowane we wszystkich sferach życia. Jakkolwiek odejście od tej prawdy umożliwia odnoszenie często łatwiejszych, bardziej dochodowych i spektakularnych sukcesów, to trzeba pamiętać, że zwykle są one krótkotrwałe, pozorne, zbudowane na niewłaściwych fundamentach. „Wy udajecie przed ludźmi, że jesteście sprawiedliwi, ale Bóg zna wasze serca. To zaś, co w mniemaniu ludzkim jest wielkie, w Bogu budzi obrzydzenie" (Łk 16, 15).

Podstawę refleksji na temat możliwości i skutków wdrażania w życie cnót ewangelicznych mogłaby stanowić analiza życia i dorobku polityków, przedsiębiorców czy przedstawicieli różnych zawodów, którzy swoją działalność traktowali nie tylko w wymiarze ekonomicznym. Podkreślić należy, że wśród inicjatorów europejskich procesów integracyjnych ważną rolę odgrywali ci, którzy w aktywności politycznej, gospodarczej i społecznej inspirowani byli nauką chrześcijańską, służbą Bogu, Kościołowi i Ojczyźnie. W uznaniu świętości życia, w 1993 r. w Trydencie, rozpoczął się na szczeblu diecezjalnym proces beatyfikacyjny Alcide De Gasperiego, a Roberta Schumana w 1985 r. w Metzu. Jan Paweł II mówił: „Czyż nie ma znaczenia fakt, że wśród głównych propagatorów jedności kontynentu europejskiego byli tacy ludzie [...] jak De Gasperi, Adenauer, Schuman, ([...] ożywiani głęboką wiarą chrześcijańską?) Czyż nie z ewangelicznych wartości wolności i solidarności czerpali oni inspirację dla swego odważnego planu?" (http://ekai.pl/).

\section{Chrześcijańskie ruchy, stowarzyszenia i organizacje biznesowe}

$\mathrm{Na}$ coraz większe zapotrzebowanie na kształtowanie relacji pomiędzy życiem moralnym a biznesem wskazują: rozwijające się współcześnie ruchy, stowarzyszenia, organizacje, m.in. Ekonomia Komunii Ruchu Focolare, Międzynarodowa Unia Chrześcijańskich Przedsiębiorców, Polskie Stowarzyszenie Chrześcijańskich Przedsiębiorców, Międzynarodowa Społeczność Biznesmenów Pełnej Ewangelii - Chrześcijanie w Biznesie, Legatus, Woodstock Business Conference, Towarzystwo Dzieł (CDO) ruchu Comunione e Liberazione, Stowarzyszenie Kultury Chrześcijańskiej im. Ks. Piotra Skargi, Duszpasterstwo Przedsiębiorców i Pracodawców „Talent”, które coraz bardziej uaktywniają swoją działalność w Polsce.

Pierwszy ze wspomnianych - Ruch Focolare - został zapoczątkowany przez Chiarę Lubich w Trydencie w północnych Włoszech w czasie II wojny światowej. Od początku jego istnienia praktykowano w nim komunię dóbr na wzór pierwszych gmin chrześcijańskich (Grochmal, 2011). Ruch Focolari zamiast kultury „posiadania” proponuje kulturę „dawania” i w działalności ekonomicznej propaguje całościowe spojrzenie na człowieka w duchu ewangelii (http://focolare.pl/). Inspiracją dla rozwoju ruchu było przyjęcie przesłania, że miłość wzajemna prowadzi do jedności, o jaką Jezus prosił Ojca: ,[...] aby wszyscy stanowili jedno, jak Ty, Ojcze, we Mnie, a Ja w Tobie, aby i oni stanowili w Nas jedno, aby świat uwierzył, żeś Ty Mnie posłał” (J 17, 21). Przyjęto zatem, że aby budować jedność z drugim człowiekiem, potrzeba szczególnego rodzaju relacji międzyludzkich i w dążeniu do jednoczenia dla członków ruchu podstawą jest antropo- 
logia chrześcijańska. Ważnym wydarzeniem w rozwoju ruchu był rok 1991 r., kiedy Chiara Lubich, odwiedzając wspólnoty Ruchu w Brazylii, zderzyła się z ogromnymi potrzebami i nierównościami społecznymi w tym kraju i zaczęła rozważać sposoby na pomnożenie kapitału w celu zaradzenia potrzebom najuboższych ludzi. Niewątpliwie inspirację czerpała także z encykliki Centesimus annus, w której Jan Paweł II zwracał m.in. uwagę na to, że system ekonomiczny powinien szanować prawo do swobodnej inicjatywy, prawo do stowarzyszania się, respektować we wszystkich dziedzinach prawa człowieka i łączyć prawo do własności prywatnej z powszechnym przeznaczeniem dóbr. Koncepcja Ruchu wiąże się z koniecznością przemiany mentalności i nadaje nowy kierunek działaniom ekonomicznym. Członkowie Ruchu podejmują różnorodne inicjatywy, zakładając lub rozwijając przedsiębiorstwa produkcyjne i usługowe czy spółdzielnie w duchu kultury dawania. Właściciele, po zapewnieniu sprawiedliwej zapłaty dla siebie samych i współpracowników oraz po odłożeniu funduszy potrzebnych do dalszego rozwoju i konsolidacji przedsiębiorstwa, zamiast gromadzić swoje zyski, oddają je do wspólnoty. W ten sposób uzyskane fundusze dzielone są zarówno na potrzeby ludzi ubogich jak i na cele formacji kolejnych członków, którzy swoim życiem i podejmowaną działalnością gospodarczą przyczyniać się będą do nowych przemian społeczno-gospodarczych.

Jakkolwiek przedsiębiorstwa prowadzone na zasadach ekonomii komunii wydają się funkcjonować ,pod prąd” współczesnym kryteriom ekonomii, to ich celem nie jest odrzucenie istniejących prawidłowości ekonomicznych, ale wskazywanie na właściwą drogę uzyskania zysków i ich wykorzystania. Ludzie inspirowani duchowością Ruchu Focolari stawiają w centrum swojej działalności gospodarczej człowieka i relacje międzyludzkie, a unikają wszelkich zachowań sprzecznych z miłością ewangeliczną. Należy podkreślić, że w przedsiębiorstwach zarządzanych według zasad ekonomii komunii następuje zmiana kultury organizacyjnej w aspekcie antropologicznym, ekonomicznym, kulturowym i duchowym. Przedsiębiorstwa te, przy całej swojej różnorodności, przybierają różne formy prawne przewidziane przez prawodawstwo w danym kraju. Powstają szkoły, biura projektowe i konsultingowe, firmy informatyczne i menadżerskie, gabinety lekarskie i małe przychodnie, biura porad prawnych, a także zakłady produkcyjne, nierzadko zatrudniające dziesiątki czy setki pracowników. Formą własności tych przedsiębiorstw jest własność prywatna, prowadzą one zwykłą działalność gospodarczą w oparciu o zasady gospodarki rynkowej, ale starają się realizować zalecenia katolickiej nauki społecznej w zakresie podmiotowości pracy.

Projekt Ruchu spotkał się z bardzo pozytywną odpowiedzią na całym świecie. W ciągu 50 lat istnienia Ruch Focolare rozprzestrzenił się na 182 państwa, obejmuje 5 mln członków i posiada 89 stałych centrów znajdujących się w Europie (29), Afryce (25), Ameryce (19), Azji (13) i Oceanii (3) (http://focolare.pl/). W okresie pierwszych 2 lat od propozycji projektu powstało w świecie ponad 300 przedsiębiorstw działających w duchu tzw. Ekonomii Komunii (EK), a po 10 latach w 2002 r. było ich ponad 750. Jak wskazują dane Komisji Światowej Ekonomii Komunii zyski przekazane jako pomoc dla potrzebujących przez firmy EK w latach 1994-2002 wzrosły ponaddwukrotnie z 5,5 tys. euro do 11,4 tys. euro, a w 2008 r. na pomoc potrzebującym przekazano aż 1,1 mln euro. W Polsce działają na razie tylko trzy przedsiębiorstwa tego typu, a teoretyczne rozważania na temat ekonomi komunii będą podstawą rozprawy habilitacyjnej dr. S. Grochala. Zauważa on, że do idei ekonomii komunii nawiązuje Benedykt XVI w encyklice Caritas in veritate (2009), pisząc ,przezwyciężenie niedorozwoju wymaga pracy nie tylko nad polepszeniem transakcji opierających się na wymianie, nie tylko nad przesunięciami struktur opiekuńczych natury publicznej, ale przede wszystkim nad stopniowym otwarciem się, w kontekście światowym, na formy działalności ekonomicznej charakteryzujące się elementami bezinteresowności i komunii”. 
Kolejną organizacją wspierającą i skupiającą ludzi biznesu kierujących się nauką chrześcijańską w działalności gospodarczej jest Legatus. Organizacja ta została założona w 1987 r. przez Toma Monaghana - właściciela sieci pizzerii działających na całym świecie, który poczuł potrzebę dzielenia się z innymi przedsiębiorcami swoim doświadczeniem i wartościami, według których prowadził swoją firmę. Organizacja skupia katolickich właścicieli firm i ich współmałżonków na comiesięcznym forum, wspomaga ich rozwój osobisty i duchowy, oferuje wsparcie przez unikalną sieć podobnie myślących katolików, którzy mają wpływ na światowe rynki gospodarcze. Zapewnia wsparcie dla ponad 2 tys. firm, w 60 oddziałach głównie Stanach Zjednoczonych, a także w Kanadzie i Irlandii. Łącznie skupia ok. 5 tys. członków. John Roth, sekretarz generalny stowarzyszenia, jest odpowiedzialny za rozszerzanie Legatusa na Polskę - pierwsze oddziały mają powstać w Katowicach i Krakowie.

W 1931 r. w Rzymie w 40. rocznicę wydania encykliki Rerum novarum zainicjowana została Międzynarodowa Unia Chrześcijańskich Przedsiębiorców (UNIAPAC z franc. UNion Internationaledes Associations PAtronales Catholiques), głównie przez organizacje katolickich przedsiębiorców z Francji, Belgii i Holandii. W 1948 r. unia została poszerzona o kraje z Ameryki Łacińskiej, a w 1958 r. powołano jej stały międzynarodowy sekretariat w Brukseli. UNIAPAC skupia ponad 16 tys. członków z 26 różnych organizacji oraz osoby niezrzeszone z różnych regionów świata, głównie z Europy, Ameryki Łacińskiej, a ostatnio także z Afryki (http://www. uniapac.org/). Do UNIAPAC należy Polskie Stowarzyszenie Chrześcijańskich Przedsiębiorców, które czerpie w swojej działalności inspirację z chrześcijańskich norm moralnych (http:// pschp.pl/).

Międzynarodowa Społeczność Biznesmenów Pełnej Ewangelii - Chrześcijanie w Biznesie (FGBMFI) działa od ponad 50 lat w blisko 160 krajach, również w Polsce i skupia polityków oraz przedstawicieli różnych zawodów. Spotkania służą budowaniu większej miłości i jedności chrześcijan (http://biznesmeni.pl/).

Woodstock Business Conference działa przy niezależnym instytucie badawczym Woodstock Theological Center przy Georgetown Univercity i stanowi międzynarodową sieć skupiającą 16 oddziałów, których członkowie spotykają się raz w miesiącu w celu dyskusji na temat problematyki zagadnień etycznych w biznesie i wymiany doświadczeń w zakresie przenoszenia wartości etycznych do funkcjonowania korporacji. Poza tym jej członkowie mają możliwość uczestniczenia w różnego rodzaju sympozjach, rekolekcjach, działalności naukowej, edukacyjnej i wydawniczej (http://woodstock.georgetown.edu/).

Comunione e Liberazione (Komunia i Wyzwolenie) jest ruchem kościelnym założonym 1954 r. we Włoszech przez księdza Luigi Giussaniego, ówczesnego profesora Wydziału Teologicznego w Mediolanie. Szybko rozpowszechnił się on w całych Włoszech, a dzisiaj obecny jest już w ponad 70 krajach (m.in. w Hiszpanii, Niemczech, USA, Kanadzie, Brazylii) (http:// www.clonline.org/; http://comunione.wordpress.com/). W Polsce wspólnoty tego ruchu znajdują się w ok. 40 miastach, m.in. w Białymstoku, Katowicach, Krakowie, Legnicy, Lublinie, Łodzi, Opolu, Rzeszowie, Świdnicy, Warszawie i we Wrocławiu.

Idea Towarzystwa Dziel (Compagnia delle Opere - CDO) została założona w 1986 r. przez osoby z ruchu Comunione e Liberazione (CL), jak i osoby spoza CL. Głównym zadaniem, jakie sobie postawiły, jest ,promowanie i ochrona godnej obecności ludzi i ich pracy w świecie biznesu, a także obecność przedsiębiorstw i dzieł w społeczeństwie, sprzyjając takiej koncepcji rynku i reguł nim rządzących, które rozumiałyby i szanowały jednostkę ludzką we wszystkich aspektach, wymiarach i momentach jej życia" (art. 1 ze Statutu CDO). CDO zrzesza ok. 34 tys. podmiotów gospodarczych. Główna siedziba CDO znajduje się w Mediolanie, posiada biura także we wszystkich regionach Włoch i działa w 17 innych krajach świata. Powołanie w Polsce 
związku pracodawców pod nazwą Towarzystwo Dzieł było m.in. efektem wizyty przedstawicieli CDO w Warszawie w 2003 r. W Polsce Towarzystwo Dzieł zrzesza zarówno przedsiębiorców związanych ze wspólnotami ruchu Komunia i Wyzwolenie, jak również inne osoby prowadzące własne firmy, którym bliskie jest chrześcijańskie pojmowanie pracy. Do najważniejszych przedsięwzięć realizowanych przez CDO na skalę międzynarodową należą:

- Przyjaźń Między Narodami - jedno z największych w Europie wydarzeń o charakterze kulturalno-społecznym organizowane w Rimini. Gromadzi corocznie kilkaset tysięcy uczestników, w tym wielu znamienitych przedstawicieli różnych religii i kultur, polityków, ekonomistów, naukowców, artystów i przedsiębiorców z całego świata.

- Targi Rzemiosła - odbywające się raz w roku w Mediolanie (na ostatnich 14 targach było obecnych ok. 3 tys. wystawców ze 107 krajów).

- Matching - inicjatywa realizowana od 2005 r., której celem jest zachęcanie do bezpośrednich kontaktów i relacji między przedsiębiorcami. Inicjatywa ta pomaga w realizacji wzajemnych interesów, ułatwia poszukiwanie dostawców, klientów, partnerów i jest nieocenioną pomocą w nawiązywaniu kontaktów biznesowych. Matching odbywa się raz w roku w Fieramilano Rho (MI), jest wydarzeniem wspierającym małe i średnie przedsiębiorstwa (ostatnie „dopasowywanie” objęło 2,2 tys. przedsiębiorstw z 42 krajów i wygenerowało ponad 40 tys. spotkań, a uczestnicy wzięli udział w 12 seminariach i 46 warsztatach).

Stowarzyszenie Kultury Chrześcijańskiej im. Ks. Piotra Skargi powstało w lipcu 1999 r. w Krakowie, z inspiracji działających na świecie Stowarzyszeń Obrony Tradycji, Rodziny i Własności (TFP) (http://www.piotrskarga.pl/). Jako organizacja pozarządowa o inspiracji katolickiej w swoich działania opiera się na nauczaniu Kościoła katolickiego oraz wskazaniach wynikających z dekretu soborowego Apostolicam Actuositatem o apostolstwie świeckich. W $2001 \mathrm{r}$. w celu usprawnienia działalności przy Stowarzyszeniu Kultury Chrześcijańskiej została powołana fundacja o nazwie Instytut Edukacji Społecznej i Religijnej im. Ks. Piotra Skargi. Stowarzyszenie zmierza do obrony zasad chrześcijańskich w życiu publicznym przez działalność społeczną, religijno-oświatową, kulturalną i charytatywną. W 2002 r. w trosce o chrześcijańskie dziedzictwo Europy, Instytut wraz ze współpracującymi organizacjami katolików świeckich z Francji, Włoch, Niemiec, Hiszpanii, Portugalii i Austrii powołał Federację Pro Europa Christiana z siedzibą w Strasburgu, której celem jest promowanie wartości i zasad moralnych wypływających z Chrześcijaństwa wśród narodów Europy, a w szczególności wśród młodzieży.

Towarzystwa Biznesowe skupiają ludzi biznesu w celu zwiększania obrotów firm, m.in. dzięki networkingowi oraz rozwojowi własnych umiejętności w różnych dziedzinach (prelekcje ekspertów) (http://towarzystwobiznesowe.pl). Członkowie Towarzystwa przyjmują, że ważny czynnik działania w biznesie stanowią ideały chrześcijańskie i z tego powodu na spotkania regularnie zapraszani są przedstawiciele różnych fundacji, dzieł miłosierdzia oraz innych organizacji pozarządowych, aby podzielić się własnym doświadczeniem oraz wspólnie oddawać się lekturze klasyki duchowości odwołującej się do aktywności zawodowej, zwłaszcza biznesowej. Jak zakłada założyciel Towarzystwa, jego funkcjonowanie ma przyczynić się do znacznego zwiększenia etycznych milionerów w Polsce.

Duszpasterstwo Przedsiębiorców i Pracodawców „Talent” jest prowadzone przez Księży Sercanów i nawiązuje do nowatorskiej działalności na tym polu ich założyciela ks. Leona Dehona. Pierwsze spotkanie duszpasterstwa odbyło się w grudniu 1999 r., a obecnie współpracuje z nim około 2 tys. przedsiębiorców. Zmierza ono do kształtowania modelu „moralnego menedżera", przyjmując, że bycie chrześcijańskim przedsiębiorcą czy pracodawcą wymaga nie tylko profesjonalizmu i skuteczności, ale również określonych predyspozycji duchowych i moralnych. Oferta takiej formacji i współpracy jest skierowana do osób odpowiedzialnych za kształt życia gospodarczego w Polsce: przedsiębiorców, pracodawców, prowadzących dzia- 
łalność gospodarczą, menedżerów, dyrektorów oraz osób odpowiedzialnych za kierowanie zespołami pracowników. Duszpasterstwo pomaga w pogłębieniu życia duchowego, szukaniu odpowiedzi na pytania przedsiębiorców dotyczące: etyki w biznesie, pogłębiania znajomości społecznej nauki Kościoła, rozwoju zawodowego przez wymianę doświadczeń oraz integrowania środowiska chrześcijańskich przedsiębiorców. Spotkania nie łączą się z popieraniem jakiejś partii czy stowarzyszenia ani nie są też związane z organizowaniem zbiórek, nawet na najbardziej szlachetne cele.

Rozwój tego typu inicjatyw świadczy, o tym, że wbrew dość powszechnej opinii możliwe jest prowadzenie ,życia niepodzielonego” przez przedsiębiorców, a działalność gospodarcza realizowana zgodnie z zasadami ewangelii może być nie tylko źródłem zasilania finansowego, ale i głębokiej satysfakcji płynącej z realizowanego powołania i przekształcania systemu społeczno-gospodarczego. Podkreślić należy, że rozwój przedsiębiorstwa i zwiększanie kapitału jest obowiązkiem przedsiębiorcy i nie koliduje z nauką chrześcijańską, na co wskazywać może poza wspomnianymi inicjatywami, przykład Roberta Ouimeta, kanadyjskiego milionera, który w książce autobiograficznej pt. Wszystko zostało wam powierzone (2010), opisuje jak Święta Matka Teresa stała się doradcą w sprawach zarządzania jego firmą. Robert Ouimet rozważał rozdanie swojego majątku ludziom potrzebującym, ale przed podjęciem tej decyzji powstrzymała go Matka Teresa, do której udał się po poradę. Przekonywała go wielokrotnie, aby rozwijał swoją firmę i zapewniała, że uprzywilejowanie z powodu wykształcenia czy posiadanego majątku nie powinno być źródłem poczucia winy. Zwracała jednak uwagę, że wszystko zostało nam powierzone przez Boga i zdamy rachunek z tego, jakimi byliśmy zarządcami, a zatem człowiek powinien żyć w postawie wdzięczności i świadomości obdarowania. Matka Teresa, podczas odwiedzin w fabryce Ouimeta, zwróciła też uwagę na jego odpowiedzialność za pracujących w firmie ludzi i podkreślała, aby wszystko w firmie służyło ich wszechstronnemu rozwojowi.

\section{Zakończenie}

W świetle przedstawionych rozważań istotnym wydaje się, aby kryzys gospodarczy rozpatrywać także w kategoriach wielkiej szansy dla rozwoju zarówno, osobistego, jak i zawodowego, a w konsekwencji społeczno-gospodarczego. Kryzys może stać się ważnym przełomem w prowadzonej działalności gospodarczej, sprzyjającym dokonaniu reorientacji działalności gospodarczej i wyzwaniem do podejmowania nowych strategii, doskonalenia struktur, zwiększania innowacyjności, podnoszenia kwalifikacji czy przekwalifikowania. Sytuacja kryzysowa to także okazja do głębszego przemyślenia dokonywanych wyborów, podejmowanych inwestycji, budowanych strategii oraz dostrzeżenia szerszej perspektywy rzeczywistości, pochylenia się nad prawdziwymi wartościami i cnotami, takimi jak: miłość, miłosierdzie, wierność, prawda, uczciwość, pokora, odpowiedzialność, bezinteresowność, umiejętność tracenia, oparcia swojego szczęścia na czymś więcej niż zabezpieczenie finansowe, ukazania prawdy o dotychczas budowanych relacjach międzyludzkich, zarówno w najbliższym rodzinnym otoczeniu, jak również w życiu zawodowym i ich faktycznej siły przetrwania w okresie kryzysu. Do wiernych świeckich należy „ożywianie rzeczywistości doczesnych przez chrześcijańskie zaangażowanie, powinni oni okazać się tu świadkami i tymi, którzy wprowadzają pokój i sprawiedliwość" (Katechizm Kościoła katolickiego, 2009: 560). Wydaje się, że procesy globalizacji sprzyjają rozwojowi różnych nowych inicjatyw podejmowanych przez środowiska chrześcijańskie i zaangażowaniu wiernych świeckich w układy życia politycznego oraz społeczno-gospodarczego poprzez działania ukierunkowane na rzecz dobra wspólnego, zgodne z orędziem ewangelicznym i nauczaniem Kościoła, przez co mogą stać się szansą na odwrócenie negatywnych konsekwencji kryzysu ekonomicznego. 


\section{Literatura}

Adamczyk, J. (2008). Społeczna odpowiedzialność przedsiębiorstw. Warszawa: Teoria i Praktyka PWN. Adamiec, J. (2009). Encyklika Caritas in veritate w odpowiedzi na kryzys gospodarczy. Indos, Biuro Analiz Sejmowych, zagadnienia społeczno-gospodarcze, nr 22 (69).

Alvey, J.E. (2000). An introduction to economics as a moral science, International Jurnal of Social Economics, vol. 27, Iss. 12.

Benedykt, XVI (2009). Encyklika Caritas in veritate. O integralnym rozwoju ludzkim w miłości i prawdzie. Kraków: Wydawnictwo M.

Borowiec, M. (2006). Etyczne aspekty globalizacji w procesie kształtowania przedsiębiorczości. Przedsiębiorczość - Edukacja, 2, 185-192.

Brzozowski, T.T. (2010). Rola i zasadność społecznej odpowiedzialności biznesu w warunkach integracji europejskiej. Przedsiębiorczość - Edukacja, 6, 113-125.

Brzozowski, T.T. (2011). Globalizacja a wykluczenie społeczne. Etyczna i kulturowa geneza procesu marginalizacji. Przedsiębiorczość-Edukacja, 7, 173-186.

Brzozowski, T.T. (2012). Przedsiębiorczość jako postawa wobec innych i świata w kontekście procesu budowania płaszczyzny dla dialogu interpersonalnego. Perspektywa pedagogiczno-kulturowa. Przedsiębiorczość- Edukacja, 8, 115-126.

Cavanaugh, W.T. (2008). Pożarci. Gospodarka a powołanie chrześcijańskie, Warszawa: Fronda.

Dayton, H. (2008). Twoje pieniadze się licza, Warszawa: Edukacja Finansowa Crown.

Encykliki Ojca Świętego Jana Pawła II (2009). Kraków: Wydawnictwo ZNAK.

Galata, S. (2007). Biznes w przestrzeni etycznej. Motywy, metody, konsekwencje, Warszawa: DIFIN.

Grochmal, S. (2013, 29 maja). Ekonomia komunii - propozycja Ruchu Focolari. Pozyskano z: http:// dziennikparafialny.p1/2011/ekonomia-komunii-propozycja-ruchu-focolari/.

Jan Paweł II (2005), Pamięć i tożsamość, Rozmowy na przełomie tysiacleci. Kraków: Wydawnictwo ZNAK.

Jaworek, A. (red.). (2011). Ku Bożej chwale, Kraków: Wydawnictwo Księży Sercanów DEHON.

Katechizm Kościoła katolickiego, (2009). II wydanie poprawione, Poznań: Wydawnictwo PALLOTTINUM.

Król, P., Leśniak, M. (2012). Kościół o powołaniu lidera biznesu, W: M. Leśniak, G. Piątek, P. Król (red.), Etyka i duchowość pracodawcy XXI wieku, 30-lecie encykliki Jana Pawta II Laborem exercens. Kraków: Wydawnictwo UNUM, 81-88.

Królikowski, J. (2011). Przyszłość społeczności ludzkiej, W: Jan Paweł II, Tryptyk społeczny. Kraków: Wydawnictwo Księży Sercanów DEHON, 7-12.

Krupa, M., (2009). Rozwiązanie kwestii głodu w świecie w świetle zasad katolickiej nauko społecznej, Kraków: Papieska Akademia Teologiczna.

Leśniak, M. (2012). Odpowiedzialność w świecie biznesu na podstawie nauczania społecznego Kościoła. W: M. Leśniak, G. Piątek, P. Król (red.), Moralna odpowiedzialność ludzi biznesu. Kraków: Wydawnictwo UNUM, 57-80.

Mariański, J. (2000). Moralne wymiary wolnego rynku w świetle społecznego nauczania Kościoła. Ateneum Kapłańskie, 134, z. 1.

Papieska Rada IUSTITIA ET PAX, (2012). Powołanie lidera biznesu. Refleksja, Kraków: Wydawnictwo Księży Sercanów DEHON.

Pawlas, B. (2006). Jak być dobrym szefem?, Przedsiębiorczość - Edukacja, 2, 199-203.

Piątek, G. (2012). Giuseppe Tonilo błogosławiony ekonomista, W: M. Leśniak, G. Piątek, P. Król (red.), Moralna odpowiedzialność ludzi biznesu. Kraków: Wydawnictwo UNUM.

Pismo Święte Starego i Nowego Testamentu. Biblia Tysiąclecia, (2008). Wydanie piąte, Poznań: Wydawnictwo PALLOTINUM.

Pius XI, Quadragesimo Anno 1931, thum. ks. J. Piwowarczyk, (1935). Poznań.

Rachwał, M.M., Rachwał, T. (2006). Wartości moralne podstawą prawdziwego sukcesu menadżera. Przedsiębiorczość - Edukacja, 2, 193-198.

Ratzinger, J. (2007). Wprowadzenie w chrześcijaństwo, tł. Z. Włodkowa, Kraków: Wydawnictwo ZNAK. 
Sen, A. (1987). On Ethics and Economics, Oxford: Basil Blackwell.

Singer, P. (1998). Przewodnik po etyce, Warszawa: Książka i Wiedza.

Szewczyk, K. (1999). Wychowywać człowieka mąrego. Zarys etyki nauczycielskiej, Łódź: PWN.

Ouimet, R. (2010). Wszystko zostało wam powierzone. Autobiografia niezwykłego szefa przedsiębiorstwa ze wstępem Kardynała Dziwisza, Kraków: Wydawnictwo AA.

Zwoliński, A. (2000). Katolicka nauka społeczna o liberalizmie, Polona Sacra, 7.

\section{Źródla internetowe}

http://comunione.wordpress.com/kilka-slow-o-cl

$\mathrm{http}: / /$ towarzystwobiznesowe.pl

http://woodstock.georgetown.edu/about/welcome.html

http://www.biznesmeni.pl

http://www.clonline.org/

http://www.ekai.pl/europa/dziedzictwo/x16950/alcide-de-gasperi/?print=1

http://www.focolare.pl

http://www.intercoach.pl/omnie.html

http://www.piotrskarga.pl/o-nas,4728,1.html

http://www.pschp.pl

http://www.uniapac.org/

Monika Borowiec, dr, Uniwersytet Pedagogiczny im. Komisji Edukacji Narodowej w Krakowie, Instytut Geografii, Zakład Przedsiębiorczości i Gospodarki Przestrzennej.

Doktor nauk o Ziemi w zakresie geografii, adiunkt w Instytucie Geografii Uniwersytetu Pedagogicznego w Krakowie. Jej zainteresowania badawcze koncentrują się wokół problematyki gospodarki opartej na wiedzy, roli szkolnictwa wyższego i ośrodków naukowych w procesie kształtowania społeczeństwa informacyjnego, procesów transformacji społeczno-gospodarczej, ze szczególnym uwzględnieniem procesów globalizacji i integracji europejskiej, a także problematyki przedsiębiorczości.

Monika Borowiec, PhD, Pedagogical University of Cracow, Institute of Geography, Department of Entrepreneurship and spatial Management.

$\mathrm{PhD}$ in Natural Sciences (Geography), adiunkt (assoc. prof) at The Pedagogical University of Cracow, Institute of Geography. Scientific interests: knowledge-based economy, role of higher education and academic centers in processes of socio-economic transformation, processes of globalization and European integration.

Adres/Address: Uniwersytet Pedagogiczny w Krakowie, Instytut Geografii

Zakład Przedsiębiorczości i Gospodarki Przestrzennej

ul. Podchorążych 2, 30-084 Kraków, Polska

e-mail: borowiec@up.krakow.pl 
Piotr Możyłowski

Wyższa Szkoła Nauk Społecznych

i Technicznych w Radomiu

\title{
Prawno-administracyjne bariery prowadzenia dzialalności gospodarczej w Polsce w świetle opinii przedsiębiorców oraz raportów Doing Business
}

\author{
Legal and administrative barriers to business in Poland in the light \\ of the opinions of entrepreneurs and the 'Doing Business' reports
}

\begin{abstract}
Streszczenie
Jednym z czynników warunkujących konkurencyjność przedsiębiorstw i innych podatników oraz niezakłócony przebieg jej rozwoju jest bezpieczeństwo prawne podmiotów prowadzących działalność gospodarczą. Wyraża się ono m.in. w zachowaniu wymogu stabilności i spójności opodatkowania. Ustawodawca musi zapewnić podatnikowi możliwość poznania jego uprawnień i obowiązków podatkowych, zanim staną się one obowiązującymi i wymagalnymi. Podmioty objęte podatkiem muszą być pewne, że trwałość obowiązywania prawa podatkowego podlega ochronie, która stanowić będzie jednocześnie ochronę ich interesów. Stąd też wynikać będzie podstawowa zasada stabilności obowiązywania prawa, która odnosi się nie tylko do prawa podatkowego, ale także do innych dziedzin prawa. Przepisy prawa, regulujące uprawnienia i obowiązki, zależne są przede wszystkim od zmieniających się warunków ustrojowych, społecznych i ekonomicznych. W niniejszym artykule podjęto próbę wskazania najważniejszych barier prowadzenia działalności gospodarczej wymienianych przez przedsiębiorców, jak i inne instytucje, w tym Bank Światowy. Podjęto zarazem próbę podsumowania ocen, jakie otrzymuje polskie ustawodawstwo podatkowe tak ze strony ekspertów Banku Światowego, jak i - a może przede wszystkim - ze strony polskich przedsiębiorców. Coroczne raporty Banku Światowego Doing Business oraz badania ankietowe przedsiębiorców ukazują stan polskiego ustawodawstwa w zakresie opodatkowania, co stanowi doskonałe źródło do wskazania słabych stron sytemu podatkowego oraz możliwości jego poprawy. W opracowaniu tym skupiono się w szczególności na systemie podatkowym jako tym, który może być instrumentem wpływającym pozytywnie lub negatywnie na gospodarkę oraz na rozwój przedsiębiorczości.
\end{abstract}

\begin{abstract}
One of the factors improving the competitiveness of factories and small business is, among others, legal security. This is represented by stability and cohesiveness of the tax system. Legislature must ensure that taxpayers are aware of their rights and duties, before tax is applicable. Entities covered by the tax system must be certain that the stability of the tax law is protected, and that their interests are secured as well. Hence, the result should take form of a basic principle of stability of law, which applies not only to tax regulations, but also to other legal areas. Law governing the powers and duties is primarily dependent on the changing political, social and economic situations. This article attempts to identify the most important barriers, indicated by businessmen, and various institutions, including
\end{abstract}


the World Bank. The article also contains a summary of ratings received by the Polish tax legislation system, provided by World Bank experts, and, perhaps more importantly, by Polish entrepreneurs. Annual reports of the World Bank, and the 'Doing Business' surveys present the situation of Polish entrepreneurs in the field of tax legislation and may serve as an excellent source for identifying weaknesses in the tax system and possibilities for its improvement. This study focuses in particular on the tax system, as the one which can positively or negatively affect the economy, and development of entrepreneurship.

Słowa kluczowe: bariery podatkowe; działalność gospodarcza; opinie; raport; system podatkowy

Key words: tax barriers; economic activity; review; report; tax system

\section{Wprowadzenie}

Jednym z czynników warunkujących konkurencyjność przedsiębiorstw i innych podatników oraz niezakłócony przebieg tego rozwoju jest bezpieczeństwo prawne podmiotów prowadzących działalność gospodarczą. Wyraża się ono m.in. w zachowaniu wymogu stabilności i spójności opodatkowania. Ustawodawca musi zapewnić podatnikowi możliwość poznania jego uprawnień i obowiązków podatkowych, zanim staną się one obowiązującymi i wymagalnymi. Podmioty objęte podatkiem muszą być pewne, że trwałość obowiązywania prawa podatkowego podlega ochronie, która stanowić będzie jednocześnie ochronę ich interesów. Stąd też wynikać będzie podstawowa zasada stabilności obowiązywania prawa, która odnosi się nie tylko do prawa podatkowego, ale także do innych dziedzin prawa. Przepisy prawa, regulujące uprawnienia i obowiązki, zależne są przede wszystkim od zmieniających się warunków ustrojowych, społecznych i ekonomicznych.

O reformie i o tym, jak powinien być zbudowany system podatkowy, dyskutuje się w Polsce od lat, jednakże dyskusja ta nie przyniosła jak dotąd pożądanych efektów. Co jakiś czas jest mowa o tym, jak ma wyglądać system podatkowy i jak ma być zbudowany (z ilu podatków, jakie znaczenie mają mieć poszczególne podatki). Jednakże nie zawsze $w$ tych debatach przedstawia się kwestię, w jakim kierunku powinny iść przeobrażenia obecnie istniejącego systemu podatkowego (np. jak ukształtować system, aby uległ ograniczeniu stopień jego fiskalizmu, a z drugiej strony zapewnić wystarczające dochody na realizację funkcji państwa) (Szołno-Koguc, 2001: 202; Szczodrowski, 2003: 97). Można stwierdzić, iż do dziś nie określono, jakie funkcje powinien spełniać system podatkowy w Polsce. Czy ma to być tylko funkcja fiskalna, czy może redystrybucyjna albo gospodarcza?

Analizując historię istnienia polskiego systemu podatkowego, na myśl przychodzą dwie przyczyny wpływające na taką sytuację, a mianowicie zmiana ustroju gospodarczego z gospodarki centralnie planowanej na gospodarkę rynkową oraz członkostwo Polski w Unii Europejskiej. Oczywiście należy mieć na uwadze fakt, iż nie tylko polskie prawo podatkowe uległo znacznemu skomplikowaniu. To właśnie wstąpienie Polski w struktury Unii Europejskiej wywarło znaczący wpływ na obecny kształt przepisów podatkowych. Niestety, trzeba w tym miejscu wskazać jednoznacznie, iż pomimo niekwestionowanych zalet samej UE, jest to Wspólnota bardzo zbiurokratyzowana, tworząca dużą liczbę przepisów regulujących funkcjonowanie życia (w tym właśnie prawo podatkowe).

To, czy stabilność prawa podatkowego, przyjętego w warunkach zmiany ustroju politycznego i gospodarczego będzie trwała, zależy od wartości materialnej i jakości legislacyjnej tego prawa. Wartość materialną ma prawo podatkowe wyrażające racjonalną i spójną koncepcję systemu podatkowego (Arent, 2007: 219). Zaś miarą jakości legislacyjnej prawa podatkowego jest takie jego opracowanie, uchwalenie i ogłoszenie, aby zachować zasady przyzwoitej legislacji. Jeśli nowe prawo jest miernej jakości legislacyjnej, to konieczne staje się dokonywanie 
w nim zmian. Jeżeli zaś zmiany te będą mieć charakter doraźny, incydentalny czy przypadkowy i okazjonalny, to ich efektem będzie powstanie prawa podatkowego, opartego na licznych aktach normatywnych.

Warto w tym miejscu zaznaczyć, iż obecnie kwestie podatkowe obrosły w liczne nieporozumienia, przeinaczenia i stereotypy. Wygłaszane na ten temat poglądy są często wynikiem nie tyle obiektywnej wiedzy, ile czasami gry interesów. Dlatego autor w tym miejscu pragnie zaznaczyć, iż czytelnik może w pewnych częściach pracy odnaleźć odmienne opinie od tych prezentowanych przez ośrodki badawcze. Będą to jednak opinie wynikające ze zdobytych doświadczeń zawodowych autora jako pracownika urzędu skarbowego. W niniejszym artykule podjęto próbę wskazania najważniejszych barier w prowadzeniu działalności gospodarczej wymienianych przez przedsiębiorców, jak i inne instytucje, w tym Bank Światowy. W opracowaniu skupiono się jednak w szczególności na systemie podatkowym jako tym, który może być instrumentem wpływającym pozytywnie lub negatywnie na gospodarkę oraz na rozwój przedsiębiorczości. I to teraz, w dobie kryzysu gospodarczego.

\section{System podatkowy w rankingach Doing Business 2007-2011}

Polska, jak wiele innych krajów Europy i świata, jest poddawana ciągłym ocenom. Ocen tych dokonują nie tylko zrzeszenia przedsiębiorców, ale także organizacje międzynarodowe. Jedną z instytucji dokonujących przeglądu i zarazem oceny polskiej gospodarki jest Bank Światowy (coroczne raporty Doing Business). W tabeli 1 przedstawiono pozycję Polski pod względem warunków prowadzenia biznesu w rankingu Banku Światowego Doing Business.

Dane przedstawione w tabeli 1 wskazują na sfery życia gospodarczego, w których powinny nastąpić zmiany. Osoby pracujące nad nowymi przepisami, regulującymi prowadzenie działalności gospodarczej, powinny jak najszybciej zwrócić na te wyniki uwagę. Refleksja powinna być taka, że należy jak najszybciej likwidować bariery administracyjno-prawne. Analizując poszczególne wskaźniki uwzględnione w raporcie, można zauważyć, że na przestrzeni 5 lat

Tab. 1. Pozycja Polski w rankingach Doing Business 2007-2011

\begin{tabular}{|c|c|c|c|c|c|c|c|c|c|c|c|c|}
\hline \multirow{2}{*}{$\begin{array}{c}\text { Wyszcze- } \\
\text { gólnienie } \\
\text { Doing } \\
\text { Business }\end{array}$} & \multirow{2}{*}{$\begin{array}{c}\text { Liczba } \\
\text { państw } \\
\text { objętych } \\
\text { badaniem }\end{array}$} & \multirow{2}{*}{$\begin{array}{c}\text { Pozycja Polski } \\
\text { w rankingu } \\
\text { dotyczącym } \\
\text { latwości } \\
\text { prowadzenia } \\
\text { działalności } \\
\text { gospodarczej }\end{array}$} & \multicolumn{10}{|c|}{$\begin{array}{c}\text { Pozycja Polski w odniesieniu do } 10 \text { wskaźników } \\
\text { mających wiodące znaczenie dla prowadzenia } \\
\text { dzialalności gospodarczei }\end{array}$} \\
\hline & & & $1 \%$ & $2 *$ & $3 *$ & $4 \%$ & $5^{*}$ & 6* & $7 *$ & 8* & 9* & $10 *$ \\
\hline 2007 & 175 & 75 & 114 & 146 & 49 & 86 & 65 & 33 & 71 & 102 & 112 & 85 \\
\hline 2008 & 178 & 74 & 134 & 156 & 81 & 81 & 25 & 33 & 133 & 42 & 68 & 91 \\
\hline 2009 & 181 & 72 & 145 & \begin{tabular}{|l|}
157 \\
\end{tabular} & 69 & 86 & 27 & 38 & \begin{tabular}{|l|}
147 \\
\end{tabular} & 41 & 71 & 85 \\
\hline 2010 & 183 & 72 & 117 & \begin{tabular}{|l|}
164 \\
\end{tabular} & 76 & 88 & 15 & 41 & 151 & 42 & 75 & 85 \\
\hline 2011 & 183 & 63 & 126 & 160 & 82 & 86 & 8 & 46 & 128 & 46 & 87 & 81 \\
\hline
\end{tabular}

$1^{*}$ - rozpoczęcie działalności gospodarczej, $2^{*}$ - zezwolenia i koncesje, głównie na budowę budynków i budowli,

$3^{*}$ - zatrudnianie i zwalnianie pracowników, $4^{*}$ - rejestracja tytułu własności, $5^{\star}$ - uzyskanie kredytu,

$6^{\star}$ - ochrona inwestorów, $7^{\star}$ - podatki, $8^{\star}$ - obrót transgraniczny, 9* - egzekwowanie wykonania postanowień kontraktu, 10* - likwidacja lub upadłość przedsiębiorstw.

Źródło: Raport Banku Światowego Doing Business 2009-2011; Ostaszewski (2010: 213). 
Polska poprawiła swoje wyniki w niektórych aspektach życia gospodarczego, takich jak: łatwość rozpoczynania działalności gospodarczej, uzyskanie kredytu czy obrót transgraniczny. Niewielkie wahania pozycji w rankingu można zauważyć w takich kwestiach, jak rejestrowanie tytułów własności czy likwidacja przedsiębiorstw. Jednak w kwestiach zatrudniania i zwalniania pracowników czy podatkach, czyli tam, gdzie powinna nastąpić zdecydowana poprawa, występują nieznaczne wahania w pozycjach rankingu. Ocena Polski w następnych latach powinna ulec znacznej poprawie, a następnie pewnej stabilizacji. Nie możemy stwarzać też takiej sytuacji, że w jednym roku uzyskujemy dobre wyniki w rankingach, a następnie nie wprowadzamy żadnych pozytywnych zmian. Oczywiście należy pamiętać, że w kategorii obciążeń fiskalnych można uwzględniać nie tylko wysokość samych podatków, ale także częstotliwość, z jaką przedsiębiorcy są zobowiązani je uiszczać oraz całą biurokrację związaną z przygotowaniem odpowiednich formularzy podatkowych (Kalinowska, 2008: 195). Jednak tak niskie oceny to nie skutek wysokich podatków, bo te są dość niskie na tle innych krajów UE, ale czasu związanego z wypełnianiem obowiązków podatkowych czy ich egzekwowaniem. Na rycinie 1 przedstawiono czas potrzebny na przygotowanie dokumentów związanych z podatkiem dochodowym od osób prawnych w Polsce i w wybranych krajach europejskich.

Analizując wskazane raporty, można wysnuć wniosek, że to wysoki stopień skomplikowania przepisów przekłada się na długi czas niezbędny do załatwienia wszelkich formalności związanych z płaceniem podatków i zarazem przyczynia się do hamowania rozwoju przedsiębiorczości oraz rzekomo tworzy niekorzystny klimat dla inwestycji. Poniżej zostanie przedstawiony czas niezbędny, aby wypełnić obowiązki podatkowe w Polsce i w krajach OECD (ryc. 2).

Jak łatwo zauważyć, wypełnianie formalności podatkowych zajmuje w Polsce 175 godzin rocznie. Nie jest to wynik najgorszy, jeśli spojrzymy na takie kraje, jak Włochy, Czechy lub Węgry. Są też opinie, mówiące, że system podatkowy w Niemczech jest bardziej skomplikowany niż w Polsce, gdzie więc u nas tkwi problem? Czyżby Niemcy lepiej znali się na przepisach podatkowych, skoro potrzebują o 70 godzin mniej na wypełnienie dokumentacji podat-

Ryc. 1. Liczba godzin w roku potrzebnych na wypełnienie formalności związanych z podatkiem dochodowym od osób prawnych w Polsce na tle wybranych krajów Europy w 2009 r.

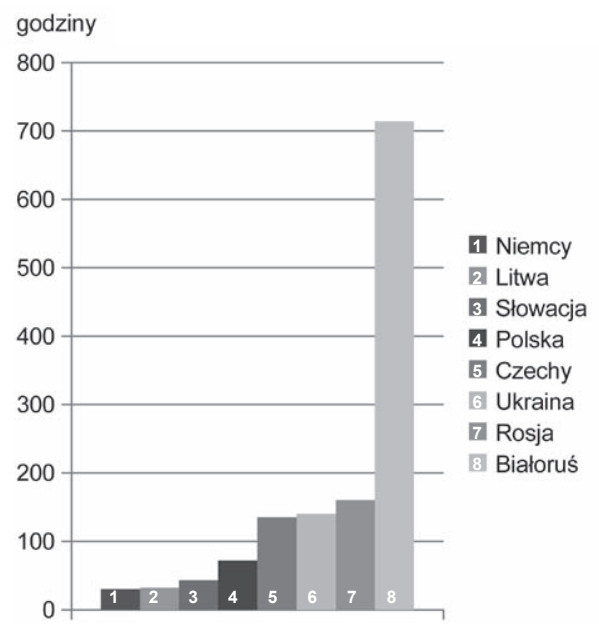

Źródło: Paying Taxes 2010. The globar picture. 
Ryc. 2. Liczba godzin w roku potrzebnych na wypełnienie formalności związanych z obliczaniem i wpłatą podatków w Polsce na tle wybranych krajów Europy w 2009 r.

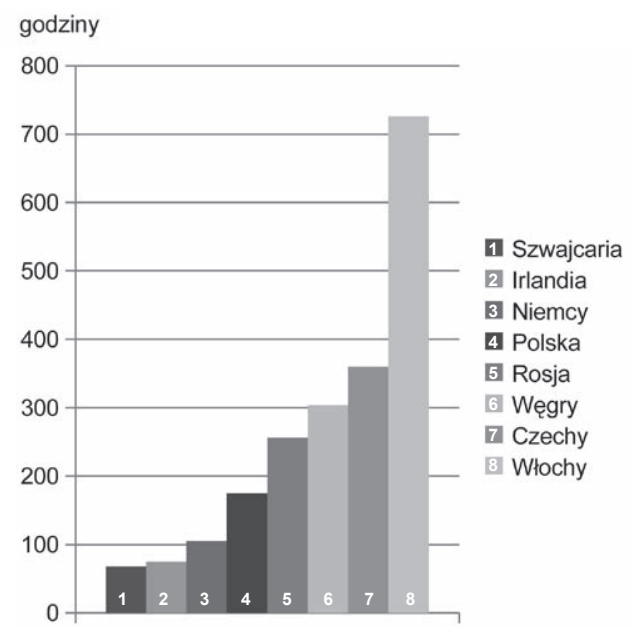

Źródło: Paying Taxes 2010. The globar picture.

kowej? A może niemieccy księgowi i doradcy podatkowi mają większą wiedzę niż polscy? Zapewne wszystko to po trochu. Jednak jest jeszcze jeden aspekt występujący w rozliczeniach. W Niemczech urzędnicy skarbowi mają większe możliwości pomocy podatnikowi niż w Polsce. W naszym kraju pracownik urzędu skarbowego nie ma żadnej możliwości, wręcz jest to zabronione, aby pomóc podatnikowi wypełnić formularz podatkowy. Jedyną możliwością uzyskania większej pomocy ze strony urzędników jest przybycie do urzędu skarbowego w tzw. dni otwarte (soboty), które są organizowane przez Ministerstwo Finansów od kilku lat.

Jednak analizując dokładniej dane zawarte w raportach Banku Światowego, w tym Doing Business 2010, dowiadujemy się, iż w Polsce przedsiębiorca musi dokonać w ciągu roku 40 płatności podatkowych. Jeśli przyjąć w uproszczeniu, że część osób dokonuje płatności w kasie urzędu skarbowego i potrzebuje na to 1 godzinę, to da nam to liczbę dodatkowych 40 godzin. W połączeniu z danymi zawartymi na rycinie 2 daje nam to już sporą liczbę 215 godzin potrzebnych na wypełnienie obowiązków podatkowych. Jak łatwo policzyć, przedsiębiorca, który sam chce zajmować się sprawami podatkowymi, musi na to przeznaczyć bez mała 1,5 miesiąca. W tym czasie mógłby pracować na rzecz swojej firmy i być może dalej ją rozwijać. Oczywiście autor zdaje sobie sprawę, iż niektórzy czytelnicy powiedzą, że może zatrudnić firmę księgową lub doradcę podatkowego ${ }^{1}$. Ale czy o to w tym wszystkim chodzi? Chyba nie.

${ }^{1}$ Doświadczenia zawodowe autora wskazują na taką właśnie praktykę stosowaną przez większość przedsiębiorców. Nie są oni w stanie samodzielnie poprowadzić rozliczeń podatkowych czy wystąpić z wnioskiem o wydanie interpretacji indywidualnej, dlatego muszą korzystać z usług doradców podatkowych i prawników. Ponadto kwestie te są znane bardzo dobrze autorowi z uwagi na fakt, iż pochodzi on z rodziny przedsiębiorców (i to z ponad trzydziestoletnimi tradycjami). Prowadząc działalność gospodarczą opodatkowaną, np. stawką podstawową i obniżoną VAT, a także zwolnioną, przedsiębiorcy nie są w stanie wykonać wszystkich obliczeń samodzielnie. Jeśli jeszcze w działalności pojawi się leasing, kredyt czy factoring, to rozliczenia podatkowe stają się coraz bardziej skomplikowane i pracochłonne. 
Najlepiej pod tym względem wypada Szwajcaria, w której na wypełnienie obowiązków podatkowych potrzeba 68 godzin. Nieźle na tle Polski wypadają: Irlandia (75 godz.), Niemcy (105) i Dania (135). Według raportu gorsi od Polski są np. Hiszpanie, którym potrzeba 603 godzin na wypełnienie obowiązków podatkowych, i Włosi, którzy muszą poświęcić ponad 700 godzin.

Ekonomiści sporządzający przytaczany raport wskazują także na małą transparentność rozwiązań podatkowych, co stwarza szereg okazji „do ucieczki przed podatkami”. Mało czytelne a zarazem skomplikowane przepisy, zachęcają do nadużyć i ukrywania dochodów podatkowych (Kamińska, 2006: 58). Właśnie na niestabilność i skomplikowanie przepisów podatkowych wskazują raporty Banku Światowego.

\section{Podatki i system podatkowy w opinii polskich przedsiębiorców}

Od kilku lat polscy przedsiębiorcy podnoszą problem skomplikowanego systemu podatkowego, szczególnie w części dotyczącej ulg i zwolnień. Od 2001 r. Polska Konfederacja Pracodawców Prywatnych Lewiatan (PKPP Lewiatan) prowadzi badania wśród właścicieli oraz zarządzających małymi i średnimi przedsiębiorstwami poświęcone identyfikacji barier rozwoju MŚP. Lista dziesięciu najważniejszych czynników utrudniających działalność małych i średnich przedsiębiorstw jest od 7 lat niezmienna (zmianie ulega jedynie ich kolejność w rankingu). Z badań Monitoring kondycji sektora MŚP, które Polska Konfederacja Pracodawców Prywatnych Lewiatan prowadziła już po raz kolejny, wynika, że bariery funkcjonowania małych i średnich przedsiębiorstw w Polsce nie zmieniły się (ryc. 3).

Ryc. 3. Najważniejsze bariery w rozwoju MŚP w Polsce*

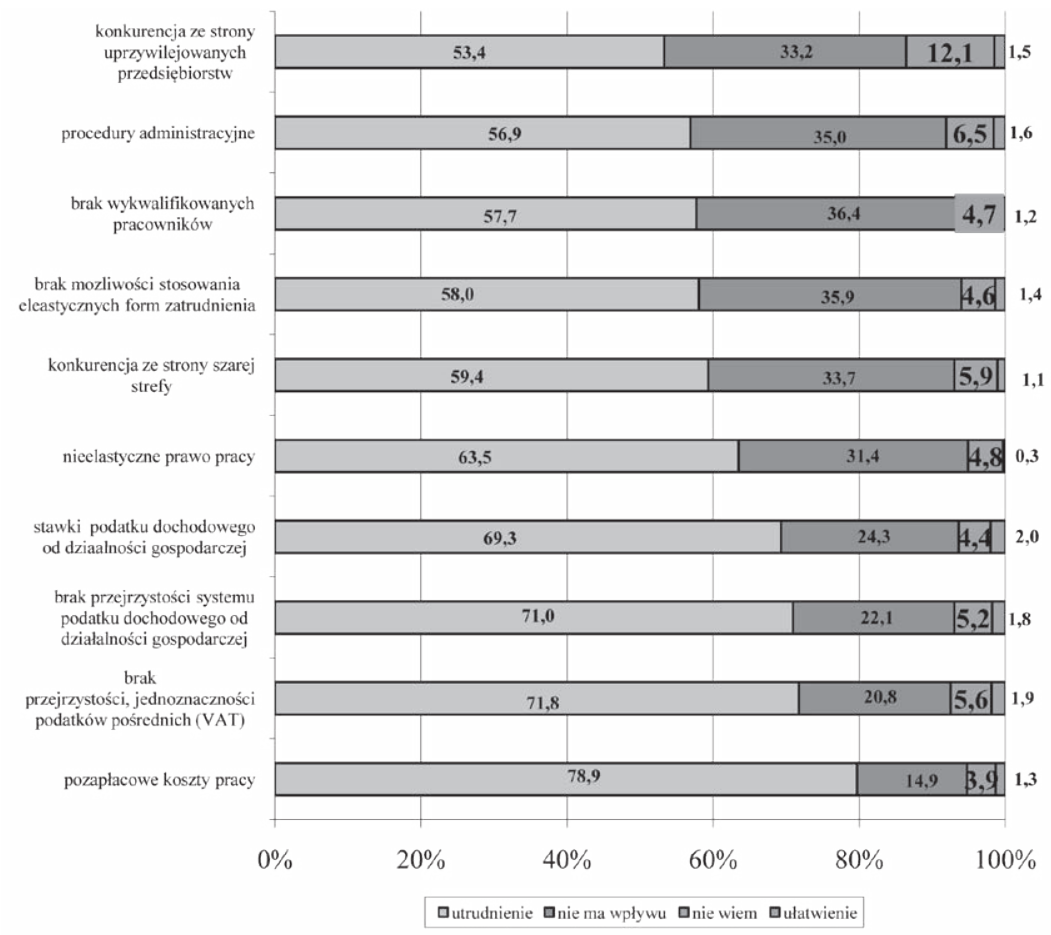

*dane dotyczą badań przeprowadzonych przez PKPP Lewiatan

Źródło: Starczewska-Krzysztoszek (2008: 37). 
Ryc. 4. Bariery administracyjne w prowadzeniu działalności gospodarczej

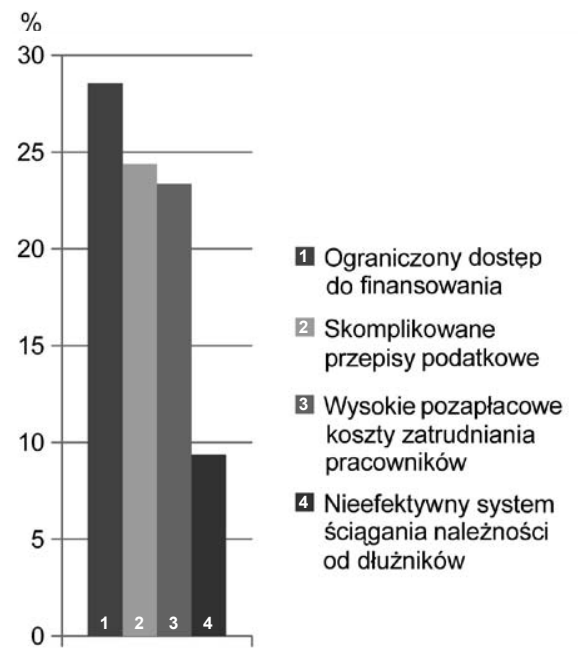

Źródło: DGP, 07.10.2011.

Wśród wskazanych barier kluczowe miejsce zajmuje zła jakość prawa podatkowego (dotyczącego podatków pośrednich i bezpośrednich) oraz koszty stosowania prawa podatkowego. W opinii małych i średnich przedsiębiorstw istniejący w Polsce system podatkowy, jak i wysokość podatków, tworzą poważne bariery w rozwoju MŚP i wpływają na ich sytuację ekonomiczną (Chądrzyński, 2007: 130). Niepokojący może być fakt, że przedsiębiorcy mniej obawiają się konkurencji ze strony szarej strefy niż obowiązujących podatków oraz liczby ich zmian. Również badania przeprowadzone przez Tax Care i Idea Bank wskazują, iż oprócz ograniczonego dostępu do finansowania działalności gospodarczej największą barierą administracyjną są właśnie nieprecyzyjne i skomplikowane przepisy podatkowe. Wskazało na nie ponad $24 \%$ ankietowanych przedsiębiorców. Autor w tym miejscu pragnie zwrócić uwagę na fakt, iż przepisy podatkowe - i nie tylko - tworzone są w większej części przez polityków, którzy niekoniecznie muszą się na nich znać. Owszem, ustawy niejednokrotnie są przygotowywane przez zespół specjalistów czy naukowców, jednakże ostateczny kształt przepisy uzyskują w parlamencie. Niestety, brak profesjonalizmu i wiedzy doprowadził do takiej właśnie sytuacji, że część przepisów jest nienajlepszej jakości.

Warto w tym miejscu wskazać na nieprofesjonalne działania ministra finansów. A chodzi o podwyższenie stawki podatku od towarów i usług na określony czas, jak i na nieuregulowane sprawy z samochodami wykorzystywanymi w działalności gospodarczej. Na okres 2 lat został wprowadzony przepis uniemożliwiający odliczanie VAT od użytkowanych samochodów osobowych i tych z „kratką"2. Minister tłumaczył to potrzebą zbilansowania budżetu państwa. Dziś wydaje się - a wręcz można tak twierdzić - że miało to spowodować zwiększenie docho-

\footnotetext{
${ }^{2}$ Okres ten niestety z końcem 2012 r. został przedłużony na rok następny, czyli 2013. Bazując na swoim doświadczeniu, autor przypuszcza, że kwestie te nie zostaną uregulowane także w następnym roku z uwagi na sytuację budżetu państwa. Proces ten może jedynie przyspieszyć ewentualna „groźba” nałożenia kar na Polskę przez Komisję Europejską.
} 
dów budżetu kosztem przedsiębiorców. Teraz docierają do podatników informacje, że Ministerstwo Finansów chce zmienić przepisy - nie tylko podatkowe, ale i ruchu drogowego - aby w ogóle wyeliminować możliwość odliczania VAT od zakupów związanych z użytkowaniem takich samochodów. Takie działania nie wpływają pozytywnie na odbiór tworzonych przepisów i nie zwiększają ogólnego zaufania do państwa.

Polska należy do krajów o wysokiej relacji składek płaconych przez pracowników i pracodawców na świadczenia społeczne do PKB. Pozapłacowe koszty pracy, tzw. klin podatkowy, stanowią w Polsce blisko $40 \%$ obciążeń związanych z zatrudnianiem pracownika. O ich wysokości decydują podatki dochodowe oraz składki na ubezpieczenie społeczne opłacane zarówno przez pracodawców, jak i przez zatrudnionych. W konsekwencji wynagrodzenie otrzymywane przez przeciętnego polskiego pracobiorcę stanowi jedynie $60 \%$ kosztów, jakie pokrywa pracodawca (Rosiński, 2008: 86-87). Jednak na pozytywną opinię zasługuje fakt, iż Polska znalazła się w grupie państw, które w ciągu ostatniej dekady najbardziej zredukowały obciążenia nakładane na pracę. Między 2000 a 2010 r. zmniejszyły się one z 41,9\% do 34\%. Duży wpływ na ten wynik miało obniżenie składki rentowej w 2007 r. oraz redukcja i wprowadzenie dwóch stawek podatku dochodowego (PIT) w 2009 r. Największy udział w klinie podatkowym w Polsce miały ubezpieczenia społeczne i zdrowotne, gdyż stanowią one ponad $30 \%$ łącznego kosztu pracy. Natomiast wielkość obciążenia podatkiem dochodowym zależy od osiągniętego dochodu i kształtuje się od zaledwie kilku procent przy najniższym dochodzie do kilkudziesięciu procent po przekroczeniu II i III progu podatkowego. Reformy systemów podatkowych z lat 2008-2009 pozwoliły wyraźnie obniżyć pozapłacowe koszty pracy także w takich państwach, jak: Turcja, Czechy, Finlandia, Słowacja czy Luksemburg.

Składki w Polsce w relacji do podatków są dość wysokie, co istotnie zwiększa koszty pracy, osłabia popyt na pracę i zapewne przyczynia się do wysokiego bezrobocia. Składki na ubezpieczenie społeczne są podstawowym czynnikiem kosztów pracy. Postulowane obniżenie składki, co zresztą częściowo się stało poprzez obniżenie składki rentowej, miało zwiększyć podaż pracy, niestety jednocześnie zmniejszałoby środki dostępne na wypłatę świadczeń. Dylemat ten bardzo ostro występuje w Polsce i jak do tej pory nie został rozwiązany ${ }^{3}$.

Mnogość aktów prawnych, rozporządzeń, niejednokrotnie niejasnych, wymagających wykładni, stanowi poważną trudność dla przedsiębiorców, szczególnie drobnych. Podobny problem dotyczy regulacji prawnych. Poważną trudnością dla prowadzących działalność gospodarczą są często zmieniające się przepisy oraz utrudniony dostęp do tekstów obowiązujących rozwiązań prawnych. Zmusza to niejednokrotnie właścicieli firm do zatrudniania bądź korzystania z usług specjalistów z dziedziny prawa czy księgowości, co z kolei powoduje wzrost, często znaczny, kosztów prowadzenia działalności gospodarczej (Tomkiewicz, 2005).

Dla ponad 70\% MŚP bardzo istotną barierą rozwoju jest brak przejrzystości i jednoznaczności podatków pośrednich (VAT i akcyza) oraz podatków od działalności gospodarczej (CIT, PIT). Właściciele małych i średnich przedsiębiorstw uważają, że brak czytelności w regulacjach podatkowych zwiększa ryzyko działalności gospodarczej i generuje koszty, które w sposób nieuzasadniony obciążają ich działalność, zmniejszając tym samym konkurencyjność. Ma to oczywiście duże znaczenie, bowiem przepisy regulujące opodatkowanie działalności niejednokrotnie są umieszczane w kilku aktach prawnych. Wywołuje to sytuację, w której podatnik, jak i urzędnik skarbowy, muszą sięgać do kilku przepisów lub nawet aktów prawnych, aby

\footnotetext{
${ }^{3}$ Doprowadził w końcu do ostrej dyskusji na temat sensu istnienia dwóch filarów ubezpieczeniowych, tj. OFE i ZUS, i wprowadzono zmiany w tym zakresie. Ponadto, aby ratować budżet państwa oraz fundusz rentowy w ZUS, od 2012 r. podniesiono wysokość składki rentowej płaconej przez pracodawcę.
} 
ustalić obowiązki związane z opodatkowaniem. Często wskazuje się też na niekompetencję pracowników administracji podległej ministrowi finansów. Jednak sami pracownicy też mają kłopoty ze stosowaniem ciągle zmieniającego się prawa. Szanowny Czytelnik zapewne nie wie, że zmiany w przepisach są dokonywane bez konsultacji z pracownikami bezpośrednio zajmującymi się stosowaniem przepisów podatkowych. Autor, jak i jego współpracownicy w swojej ponad 10-letniej karierze urzędnika tylko raz lub dwa razy został zapytany o opinię na temat projektu aktu prawnego. Niestety było to tylko rozporządzenie, a nie ustawa. W przypadku tworzenia ustaw urzędnicy bezpośrednio stosujący przepisy, spotykający się z podatnikami, od których niejednokrotnie słyszą potrzebę wprowadzenia zmian, nie biorą w tym procesie bezpośredniego udziału. A być może zebrane i uwzględnione opinie na temat przepisów pozwoliłyby stworzyć w miarę dobrze prosperujące prawo.

Przepisy podatkowe zawarte w ustawach są i były zmieniane wielokrotnie. Obowiązujące ustawy podatkowe pochodzą nawet z 1983 r. Ze względu na czas obowiązywania najdłużej funkcjonuje ustawa o podatku od spadków i darowizn z 1983 r. (29 lat) oraz ustawa o podatku rolnym z 1984 r. (28 lat). Najkrócej obowiązuje ustawa podatkowa o podatku tonażowym z 2006 r. oraz ustawy uchwalone w 2004 r., tj. ustawa o podatku od towarów i usług oraz ustawa o podatku akcyzowym. Aby lepiej zobrazować czytelnikowi ogrom zmian dokonywanych w przepisach podatkowych, autor dokonał oszacowania liczby zmian w ustawach. Jak zostało to pokazane na poniższej rycinie, podatność poszczególnych ustaw na zmiany nie była jednakowa (ryc. 5$)^{4}$.

Na czołowe i mało chlubne miejsce wysuwają się pod tym względem ustawy o podatkach dochodowych. Ustawa o podatku dochodowym od osób fizycznych była w ciągu 20 lat zmieniana 180 razy, zaś ustawa o podatku dochodowym od osób prawnych była zmieniana 137 razy (Kosikowski, 2007: 127). Dla porównania można wskazać ustawę o podatku od spadków i darowizn, która obowiązuje od ponad ćwierć wieku i była zmieniana około 20 razy czy podatek rolny, który zmieniono 19 razy. Ale już ustawę o podatku akcyzowym zmieniano 16 razy od 2008 r. Przepisy Ordynacji podatkowej od 1997 r. zmieniano ponad 100 razy. Wskazanie innych niechlubnych rekordów również nie sprawia trudności. Można znów wskazać ustawę o podatku dochodowym od osób fizycznych, która w samym tylko roku 2005 była zmieniana aż 18 razy. Podobne wyniki miała ustawa o podatku dochodowym od osób prawnych, którą w 2004 r. nowelizowano 16 razy (w porównaniu do 15 zmian w 1997 r.) $)^{5}$. Można by rzec w tym miejscu, że kilka zmian - od jednej do trzech czy czterech - to symboliczne wyniki. Jednak jeśli spojrzeć na to od strony zasad tzw. przyzwoitej legislacji, są to wyniki niedopuszczalne. Próbę oszacowania liczby zmian dokonywanych w przepisach podjął także PKPP Lewiatan. Jak wynika z dokonanych obliczeń od 1 maja 2004 r. w Polsce dokonano ponad 12400 zmian w przepisach podatkowych, uchwalając jednocześnie 378 nowelizacji ustaw podatkowych.

Prawie $60 \%$ przedsiębiorców zapytanych o najbardziej uciążliwe dla nich przepisy prawa wskazuje przede wszystkim ustawę o VAT oraz ustawę o PIT i CIT. Zaznaczyć w tym miejscu należy, iż począwszy od 2011 r. stawka podatku od towarów i usług należy do najwyższych w Europie, bowiem wynosi ona $23 \%$. Barierą dla prawie $70 \%$ przedsiębiorców też jest wysokość stawki podatku dochodowego. Co prawda od 2004 r. obowiązuje w Polsce 19\% podatku od

\footnotetext{
${ }^{4}$ Autor pragnie w tym miejscu zaznaczyć, iż na rycinie przedstawione są zmiany ogłaszane w dziennikach ustaw, a nie poszczególne, jednostkowe przepisy, bo tych zmian było zdecydowanie więcej.

${ }^{5}$ Choć należy także w tym miejscu wskazać na ponad 40 zmian przepisów dotyczących ustawy o podatku od towarów i usług (wraz z przepisami znajdującymi się w rozporządzeniach), które wprowadzono $\mathrm{w}$ pierwszej połowie $2011 \mathrm{r}$.
} 
Ryc. 5. Liczba zmian w ustawach podatkowych do $2011 \mathrm{r}$.

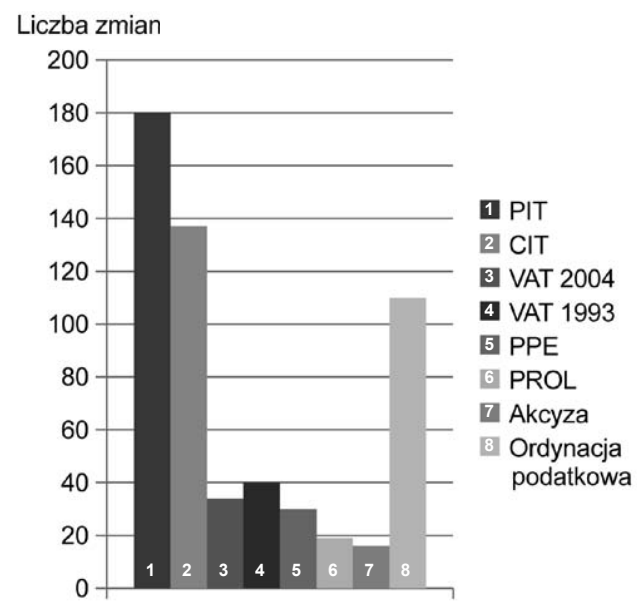

Źródło: opracowanie własne na podstawie dzienników ustaw oraz wskazanych ustaw.

działalności gospodarczej, ale nie jest to już poziom konkurencyjny. W takich krajach, jak Irlandia, Cypr, Estonia, Łotwa, Litwa czy Węgry, stawka podatku CIT jest niższa niż w Polsce (Zagórska, 2011: 2). Wzrost gospodarczy osiągany w tych krajach (poza Węgrami, których problemy tkwią nie w podatkach, a w finansach publicznych w ogóle) pozwala na postawienie tezy o zależności między niskim poziomem danin publicznych a wysokim tempem wzrostu PKB.

Dodatkowo wiele problemów związanych z rozliczaniem VAT rodzą: skomplikowana konstrukcja ustawy czy niejasna klasyfikacja towarów i usług a w związku z tym trudności w określeniu stawki podatku. Wskazać również w tym miejscu należy na moment powstania zobowiązania podatkowego jako jednej z przyczyn kłopotów finansowych przedsiębiorców i trudności w rozliczeniach z budżetem państwa. A to dlatego, że już w chwili sprzedaży i wystawienia faktury przedsiębiorcy są zobowiązani do odprowadzenia podatku od towarów oraz usług, nawet jeżeli kupujący zwleka z płatnością lub nie uregulował jej w ogóle. Wprawdzie ustawa o VAT przewiduje możliwość skorzystania z tzw. „ulgi na złe długi”, pozwalającej odzyskać zapłacony do urzędu skarbowego podatek po wystawieniu faktur, które nie zostały uregulowane. Jednak próba odzyskania podatku podnosi stopień skomplikowania rozliczeń podatkowych.

Nie można w tych dywagacjach pominąć przepisów regulujących podatki dochodowe. $\mathrm{Na}$ wysokość podatku ma wpływ kilka czynników. Najważniejsze z nich to: stawka podatku oraz zakres opodatkowania. Dużą rolę odgrywają także: konstrukcja przychodów, elastyczny katalog kosztów uzyskania przychodów, wysokość odpisów amortyzacyjnych oraz możliwość rozliczania strat z lat ubiegłych. Różnica pomiędzy nominalną a efektywną stawką podatku zależy od możliwości wykorzystania przez podatników ulg i odliczeń. Na znaczne obciążenia podatkowe wpływała duża liczba nierentownych przedsiębiorstw, a także rygorystycznie określone kryteria przyznawania ulg inwestycyjnych w okresach ich obowiązywania. I znów w tym miejscu można wskazać na niezgodne z prawem wspólnotowym stanowisko ministra finansów, który twierdzi, iż przedsiębiorca działający w specjalnej strefie ekonomicznej nie ma prawa do rozliczenia straty z tytułu prowadzonej działalności gospodarczej. Powoduje to oczywiście, iż 
w tej sytuacji przedsiębiorca działający w specjalnej strefie ekonomicznej znajduje się w gorszym położeniu niż przedsiębiorcy działający poza nią ${ }^{6}$.

Wpływ na nieefektywne działania przedsiębiorstw opodatkowanych podatkiem dochodowym od osób prawnych mają różnice w obliczaniu dochodów do celów rachunkowych i do celów podatkowych. Ustawa o rachunkowości nakłada na podmioty gospodarcze obowiązek ujednoliconego sposobu prowadzenia ksiąg rachunkowych oraz sporządzania bilansu i rachunku wyników według określonych zasad. Zaś ustawa o podatku dochodowym od osób prawnych szczegółowo określa sposób obliczania dochodu stanowiącego podstawę opodatkowania. W ustawie wskazane są także pozycje przychodów i kosztów, które należy w tym rachunku uwzględnić.

Poza tym występuje dużo różnic między ujęciem księgowym a ujęciem podatkowym poszczególnych pozycji, zwłaszcza po stronie kosztów. Do kosztów przeznaczonych na cele podatkowe nie wlicza się zapłaconych przez firmę odszkodowań, wydatków związanych z naruszeniem przepisów o ochronie środowiska czy rezerw tworzonych w ciężar kosztów. Katalog ten jest dość duży. Zweryfikowany dochód przeznaczony na cele podatkowe jest zazwyczaj wyższy niż dochód wykazywany w księgowości. Uregulowania takie zmuszają firmy do poszukiwania kosztów, które niejednokrotnie są nieefektywne z punktu widzenia rachunkowości, ale przynoszą efekty do celów podatkowych.

Ustawy o podatku dochodowym od osób fizycznych i prawnych zawierają katalogi wydatków, które w rozumieniu ustawodawcy nie stanowią kosztów uzyskania przychodów. Artykuły wykluczające poszczególne wydatki z kosztów uzyskania przychodów są tak rozbudowane i niejasne, że już stają się nieczytelne nie tylko dla zwykłego podatnika, ale i dla specjalistów. Niepokojące jest również to, że katalog ten cały czas jest poszerzany. Niestety nie idzie za tym próba usystematyzowania czy wprowadzenia jakiejś logicznej struktury przepisów. Po prostu wprowadza się kolejne zmiany i już. Taka niejasność przepisów prowadzi niejednokrotnie do konfliktów na linii urząd skarbowy - podatnik, gdzie to ten drugi zobowiązany jest wykazać, iż poniesione wydatki są prawidłowe i stanowią koszty uzyskania przychodów. Niekiedy konflikt ten musi rozstrzygnąc sąd ${ }^{7}$.

W tych warunkach w gospodarce można zaobserwować specyficzną ewolucję systemu podatkowego. Przepisy podatkowe wielokrotnie były zmieniane. Zmiany te były nakierowane na coraz większą restrykcyjność i szczelność systemu podatkowego, szczególnie w zakresie VAT oraz podatku dochodowego od osób fizycznych. Jednak nie miały one ustabilizować gospodarki ani w średnim, ani tym bardziej w długim okresie. W większości związane były z cyklem wyborczym, i, jak wyżej wspomniano, z obietnicami politycznymi, a większość zmian dokonywanych w podatkach i parapodatkach miała charakter doraźny, a nie zaplanowany.

Można więc dojść do wniosków, że system podatkowy działa nieprawidłowo, a stan prawa podatkowego w Polsce jest niski, gdyż o jego kształcie decydują osoby niemające ku temu odpowiedniej wiedzy i doświadczenia. Jak twierdzi M. Kosek-Wojnar, takie działania przybierają formę radosnej twórczości, tak rządu, jak i parlamentarzystów (Kosek-Wojnar, 2012: 176). Nie można zapomnieć, że parlamentarzystów w karkołomnych zmaganiach z prawem podatkowym wspiera minister finansów. Dlatego ważne jest, aby ministrowie finansów i osoby im

\footnotetext{
${ }^{6}$ Warto było wspomnieć o tym problemie, bowiem w pewnym sensie wypacza on sens istnienia specjalnych stref ekonomicznych. Jednak szczegółowe jego omówienie wykracza poza ramy niniejszego opracowania.

${ }^{7}$ Oczywiście powyższe przykłady nie wyczerpują tematu i stanowią pewien zalążek do dalszych badań na temat ademptoryzacji polskiego systemu podatkowego w Polsce.
} 
doradzające zrozumiały, że podatnicy nie mogą być zaskakiwani zmianami. Raz dane słowo nie powinno być zmieniane, tak jak dzieje się to dziś.

Powyższe opinie potwierdzają także raporty przygotowywane przez Ministerstwo Gospodarki. Wskazano w nich, iż przepisy prawa podatkowego są oceniane najgorzej. Przedsiębiorcy uregulowania prawne w zakresie podatków oceniają jako najgorsze w obszarze prowadzenia działalności gospodarczej. Według Ministerstwa Gospodarki negatywnie o podatkach wypowiedziało się $44 \%$ respondentów, w tym 11\% przedsiębiorców oceniło przepisy jako bardzo złe (Przedsiębiorczość..., 2010: 118).

\section{Zakończenie}

Stan prawa podatkowego w Polsce budzi wiele kontrowersji, zarówno wśród praktyków, jak i teoretyków prawa podatkowego. Faktem jest skomplikowane i niekonsekwentne tworzenie prawa podatkowego. Taki stan rzeczy jest m.in. następstwem tego, że o kształcie systemu oraz prawa podatkowego, tak jak napisano wcześniej, decydują siły polityczne, i to, że nasi delegaci do parlamentu mają ogromny wpływ na zatwierdzanie oraz wprowadzanie w życie nowych koncepcji prawa podatkowego. Niewątpliwie opracowanie i wdrożenie właściwego systemu podatkowego nie jest sprawą łatwą, ale z pewnością nie można tego robić metodą prób i błędów. Niestety, na taką taktykę wskazuje analiza różnych zmian przeprowadzonych w okresie 1989-2012, a w szczególności dane przedstawione w niniejszym artykule. Częste nieprzemyślane koncepcje określonych rozwiązań prawnych podlegały poprawie dopiero w trakcie ich realizacji, i to w tempie niepozwalającym na pełną ocenę praktycznych efektów opodatkowania w sferze gospodarczej i prawnej.

Polski system podatkowy wykazuje charakterystyczną cechę współczesnych systemów podatkowych, czyli brak stabilności. Stabilność, z którą można powiązać także akceptowalność podatków, spełnia w znacznej mierze pozostałe zasady podatkowe i dla twórców systemu podatkowego dążenie do takiego stanu rzeczy powinno być priorytetem. Ciągłe zmiany w ustawach podatkowych, niejednokrotne wprowadzanie nieracjonalnych ulg i innych przywilejów coraz bardziej komplikowały poszczególne podatki. To wszystko powodowało ciągłe poprawianie i doprecyzowywanie przepisów podatkowych, i - jak już powiedziano wcześniej - prowadziło do niestabilności systemu podatkowego. Oczywiście należy w tym miejscu jasno powiedzieć, że system podatkowy musi podlegać ewolucji, ze względu na zmieniające się warunki gospodarcze czy społeczne. Jednak uproszczenie przepisów spowoduje ograniczenie możliwości manipulacji podatkowych, a zarazem usprawni funkcjonowanie podatników. Zjawisko to można zaobserwować w Polsce, bowiem zmiany podatkowe uchwalane są w każdym roku podatkowym.

Mówiąc o stabilności opodatkowania, należy podkreślić fakt, iż uproszczenie przepisów podatkowych zmniejszy koszty ich stosowania tak po stronie podatników, jak i aparatu skarbowego. A to przyczyni się do większej jego efektywności. Uproszczenie poszczególnych podatków zmniejszy obciążenia podatkowe oraz usprawni rozliczenia na drodze podatnik urząd skarbowy. Stabilność i przejrzystość przepisów podatkowych umożliwiają długofalowe planowanie, ponieważ podatnicy nie są zaskakiwani ciągłymi zmianami w przepisach.

Trudno wypracować jednoznaczne kryterium oceny zarówno konstrukcji teoretycznych, jak i konkretnych rozwiązań praktycznych. Obywatele, w tym naukowcy, uogólniają często swoją wiedzę na temat funkcjonowania systemu podatkowego przez pryzmat doświadczeń z urzędem skarbowym. Takie podejście i postawy niejednokrotnie zamazują szerszą perspektywę spojrzenia na system podatkowy jako na instrument, który może wspierać długofalowy, zrównoważony rozwój kraju. Ważnym wyznacznikiem każdego systemu podatkowego, jak wcześniej o tym pisano, jest także jego stabilność, gdyż nadmierna zmienność wprowadza dodatkowy element 
ryzyka, przy którym inwestorzy i przedsiębiorcy nie mogą podejmować decyzji racjonalnych w długim horyzoncie czasowym. To z kolei przekłada się na funkcjonowanie i rozwój całej gospodarki. W tym kontekście istotne jest tworzenie jak najszerszej bazy podatkowej warunkującej poziom stawek podatkowych i pozwalającej działać wszystkim podmiotom w takim samym otoczeniu zewnętrznym (zbyt wysokie podatki oraz skomplikowanie przepisów powodują przenoszenie części działalności do szarej strefy).

W obecnych warunkach należy i powinno się kontynuować wdrażanie już zapoczątkowanych rozwiązań w zakresie systemu podatkowego polegające na:

- unowocześnieniu i uproszczeniu systemu podatkowego,

- redukcji stawki podstawowej w podatku od towarów i usług, a nie jej podnoszeniu, jak to czynił rząd od 2011 r.,

- poszerzeniu bazy podatkowej w sposób zgodny z zasadami podatkowymi (czyli objęciu opodatkowaniem nowych grup podatników), a nie zgodnie z zasadą, że zwiększamy obciążenia tym, którzy już płacą,

- harmonizacji przepisów podatkowych z regulacjami Unii Europejskiej,

- uporządkowaniu przepisów ustaw podatków dochodowych pod względem wydatków niestanowiących kosztów uzyskania przychodów,

- zaprzestaniu prowadzenia polityki ograniczania możliwości odliczania podatku VAT naliczonego od coraz większej liczby towarów i usług,

- uporządkowaniu kwestii zakupów samochodów firmowych oraz odliczania od ich użytkowania podatku VAT,

- doprowadzeniu do ujednolicenia przepisów podatkowych z przepisami o rachunkowości.

\section{Literatura}

Arent, A. (2007). Ocena wybranych warunków stosowania rozwiązań podatkowych dla przedsiębiorców. W: J. Głuchowski, A. Pomorska, J. Szołno-Koguc (red.), Podatkowe i niepodatkowe źródła finansowania zadań publicznych. Lublin: Wydawnictwo KUL.

Bank Światowy \& PricewatehuseCoopers (2010). Paying Taxes 2010. The globar picture. Pozyskano z: http://www.doingbusiness.org/.

Chądrzyński, M. (2007). Główne bariery rozwoju i funkcjonowania małych i średnich przedsiębiorstw na obszarach wiejskich województwa łódzkiego. Przedsiębiorczość - Edukacja, 3.

Kamińska, W. (2006). Wpływ procesów transformacji na rozwój małych firm prywatnych w Polsce. Przedsiębiorczość - Edukacja, 2.

Kosikowski, C. (2007). Podatki. Problem władzy i podatników. Warszawa: Wydawnictwo LexisNexis.

Kosek-Wojnar, M. (2012). Zasady podatkowe w teorii i praktyce. Warszawa: Wydawnictwo PWE.

Ministerstwo Gospodarki. (Lipiec 2010). Przedsiębiorczość w Polsce. Warszawa.

Ostaszewski, J. (red.). (2010). Finanse. Warszawa: Wydawnictwo Difin.

Raport Banku Światowego Doing Business 2008-2011.

Rosiński, R. (2008). Polski system podatkowy. Poszukiwanie optymalnych rozwiązań. Warszawa: Wydawnictwo Difin.

Starczewska-Krzysztoszek, M. (2008). Konkurencyjność sektora MŚP 2007. Raport z badań, PKPP Lewiatan, Warszawa.

Szczodrowski, G. (2003). Polski system podatkowy. Strategia transformacji. Gdańsk: Wydawnictwo UG.

Szołno-Koguc, J. (2000). Reforma polskiego systemu podatkowego 1990-1995: założenia a realizacja, Lublin: Wydawnictwo UMCS. 
Tomkiewicz, J. (2005). Polityka fiskalna a proces formowania się kapitału w gospodarkach posocjalistycznych. W: J. Tomkiewicz (red.), Finanse publiczne a wzrost gospodarczy. Warszawa: Wydawnictwo WSPiZ im. L. Koźmińskiego.

Zagórska, J. (2011). Bariery rozwoju matych i średnich przedsiębiorstw. Administracyjno-prawne aspekty prowadzenia działalności gospodarczej, PARP, Warszawa.

ZPP. (2011). Raport 2012 - Warunki prowadzenia firm w Polsce, Warszawa: Centrum im. A. Smitha.

\section{Źródla internetowe}

www.radapodatkowa.pl

Piotr Możyłowski, dr nauk ekonomicznych. Wyższa Szkoła Nauk Społecznych i Technicznych w Radomiu. W latach 2001-2013 pracował w Pierwszym Urzędzie Skarbowym w Radomiu na stanowisku inspektora w Dziale Egzekucji Administracyjnej. Od 2012 r. pracuje jako wykładowca w Wyższej Szkole Nauk Społecznych i Technicznych w Radomiu oraz Wyższej Szkole Handlowej im. S. Batorego w Piotrkowie Trybunalskim. Zainteresowania badawcze koncentrują się na obciążeniach publicznoprawnych MMŚP, barierach podatkowych prowadzenia działalności gospodarczej oraz ich wpływu na wielkość szarej strefy. W kręgu zainteresowań oprócz powyższego pozostaje zarządzanie należnościami oraz windykacja.

Piotr Możyłowski, PhD in Economic Science, Academy of Social and Technical Sciences in Radom. In the years 2001-2013 has worked in the First Revenue Office in Radom as an inspector in the Department of Enforcement Administration. From 2012, works as a lecturer at the School of Social Sciences and Technology in Radom and the School of them. S. Batory Piotrkow. Research interests are focused on public duty of SME sector, tax barriers to economic activity and its impact on the size of the shadow economy. In addition to the above, interest remain to debt management and debt recovery.

Adres/Address: Wyższa Szkoła Nauk Społecznych i Technicznych w Radomiu ul. Wodna 13/21, 26-600 Radom, Polska e-mail: piotr.mozylowski@gmail.com 
Pawel Marek Woroniecki

Uniwersytet Jagielloński

\title{
Ulgi podatkowe jako czynnik wspierający podmioty gospodarcze w okresie dekoniunktury rynkowej
}

\section{Tax reliefs as an instrument of supporting economic agents during a market recession}

\begin{abstract}
Streszczenie
Artykuł prezentuje wybrane ulgi podatkowe skierowane w szczególności do przedsiębiorców. Polski ustawodawca wprowadził wiele ulg podatkowych i niektóre z nich mogą być szczególnie pomocne w okresie dekoniunktury rynkowej.

W pierwszej kolejności w artykule zostało wyjaśnione pojęcie ulga podatkowa. Ponadto artykuł prezentuje niektóre regulacje zawarte w wybranych aktach prawnych. W szczególności opisuje on kluczowe rozwiązania prawne związane z ulgami podatkowymi, które wynikają z Ustawy z dnia 29 sierpnia 1997 r. Ordynacja podatkowa. W artykule wspomina się także o niektórych rozwiązaniach prawnych zawartych zwłaszcza w Ustawie z dnia 15 lutego 1992 r. o podatku dochodowym od osób prawnych oraz w Ustawie z dnia 20 października 1994 r. o specjalnych strefach ekonomicznych. W tym kontekście należy podkreślić, że podmioty gospodarcze mogą korzystać z ulg podatkowych tylko pod pewnymi warunkami wprowadzonymi przez polskiego ustawodawcę. $Z$ tego też powodu bardzo ważne jest wskazanie prawnych przesłanek ich wykorzystywania. Kwestie te zostały bliżej przeanalizowane $\mathrm{w}$ artykule.
\end{abstract}

\begin{abstract}
The paper presents selected tax reliefs, designed particularly for entrepreneurs. The Polish legislature has introduced a great many tax reliefs, and some of them can be particularly helpful during market recession.

Firstly, the meaning of the term 'tax relief' is explained in the article. Furthermore, the paper presents certain legal regulations, found in selected legal acts. In particular, it describes significant legal solutions connected with tax reliefs, which result from the Tax Ordinance Act of 29th August 1997. In addition, the article touches upon legal solutions, introduced especially in the Corporate Income Tax Act of 15th February 1992 and in the Special Economic Zones Act of 20th October 1994. In this context, it must be emphasized that economic agents may enjoy tax reliefs only under certain conditions, introduced by the Polish legislature. That is why it is very important to designate the legal prerequisites for taking advantage of them. These matters are closely analysed in the paper.
\end{abstract}

Słowa kluczowe: dekoniunktura rynkowa; podmioty gospodarcze; ulgi podatkowe Key words: market recession; economic agents; tax reliefs

\section{Wprowadzenie}

Bez wątpienia okres dekoniunktury rynkowej uwydatnia znaczenie różnego rodzaju ulg podatkowych. Celem niniejszego opracowania jest przedstawienie w sposób syntetyczny wybranych 
ulg podatkowych, które są dostępne dla podmiotów gospodarczych. W tym kontekście warto podkreślić, że rozwój zarówno pojedynczych firm, jak i gospodarek poszczególnych krajów uzależniony jest w dużej mierze od obowiązującego systemu podatkowego (Wisła, 2004: 191).

$\mathrm{Na}$ wstępie niezbędne jest wskazanie, czym - w aspekcie prawnym - są ulgi podatkowe. W literaturze przedmiotu wskazuje się, że ulgi takie „polegają na ograniczeniu wielkości obciążenia podatkowego - w określonych przypadkach - w stosunku do obciążenia przyjętego za przeciętne w danym podatku" (Brzeziński, 2008: 63). Wśród ulg podatkowych wyodrębnia się m.in. ulgi systemowe, czyli takie, które zostały przez ustawodawcę włączone do unormowań regulujących poszczególne podatki (Brzeziński, 2008: 63; Mastalski, 2011: 47).

Ponadto, w ogólnych przepisach regulujących zobowiązania podatkowe jest mowa o traktowaniu podatników w sposób ulgowy (Brzeziński, 2008: 63). Trzeba tutaj wspomnieć w szczególności o rozdziale 7a Ustawy z dnia 29 sierpnia $1997 \mathrm{r}$. Ordynacja podatkowa (tekst jednolity: Dz.U. z dnia 3 lipca 2012 r., poz. 749 z późniejszymi zmianami), zatytułowanym Ulgi w splacie zobowiąań podatkowych, który jest zamieszczony w dziale III tej ustawy noszącym tytuł Zobowiazania podatkowe. W rozdziale tym ustawodawca zawarł - podobnie zresztą jak w artykułach 22 i 48 Ordynacji podatkowej - regulacje będące ulgami uznaniowymi, które opierają się na uznaniu administracyjnym (Etel, 2009: 232, 235, 310-311, 371; zob. też: Gruszczyński, 2011: 211 oraz Dauter, 2011: 308-310, 381-383, 385). Ulgi uznaniowe, jak również zwolnienia uznaniowe, odwołują się do określonych sytuacji faktycznych, których ustalenie następuje w ramach postępowania podatkowego. Chodzi w szczególności o to, że przepisy prawne mogą wymieniać pewne stany faktyczne - przy użyciu mało precyzyjnych sformułowań wskazujących np. na sytuację majątkową podatnika - które muszą stać się udziałem podatnika, aby organ podatkowy miał prawo zastosować w stosunku do niego daną ulgę lub zwolnienie (Mastalski, 2011: 47-48).

Bardzo ważny podział ulg podatkowych (a także zwolnień podatkowych) nawiązuje do celu, jaki został im przypisany przez ustawodawcę. W tym zakresie wyodrębnia się ulgi/zwolnienia gospodarcze, społeczne i inne (Nykiel, 2002: 191). Te pierwsze mają za zadanie przynieść odpowiednie zmiany w systemie gospodarczym. Może tutaj chodzić m.in. o polepszenie kondycji ekonomicznej podmiotów gospodarczych, wzrost eksportu, wzrost oszczędności, generowanie inwestycji. Z kolei ulgi/zwolnienia społeczne mają pomóc w osiągnięciu pewnych celów społecznych (Nykiel, 2002: 191-192).

Oprócz teoretycznych objaśnień terminu ulga podatkowa w polskim systemie prawnym występuje także normatywne ujęcie tego terminu. Zamieszczone jest ono w art. 3 pkt 6) Ordynacji podatkowej, który stanowi, że ilekroć mówi się w tej ustawie na temat ulg podatkowych, pojęcie to należy utożsamiać z określonymi w przepisach podatkowych zwolnieniami, odliczeniami, obniżkami albo zmniejszeniami, które po zastosowaniu będą skutkowały tym, że podstawa opodatkowania lub też wysokość samego podatku ulegną zmniejszeniu (spod pojęcia ulga podatkowa powyższy przepis wyłącza jednak operację polegającą na obniżeniu - o kwotę podatku naliczonego - kwoty podatku należnego, w ujęciu regulacji dotyczących podatku od towarów i usług, oraz inne odliczenia, które są elementem konstrukcyjnym tego podatku). Termin ulga podatkowa, występujący w tytule niniejszego opracowania, obejmuje swoim zakresem znaczeniowym również treść tego pojęcia wynikającą z art. 3 pkt 6) Ordynacji podatkowej.

\section{Dekoniunktura rynkowa a zaawansowane rozwiązania technologiczne (ujęcie podatkowe)} W okresie kryzysu gospodarczego przedsiębiorcy starają się na różne sposoby przetrwać na rynku. Niewątpliwie wprowadzenie zaawansowanych rozwiązań technologicznych jest czynnikiem, który może w tym bardzo pomóc. Tego rodzaju działania mają swoje konsekwencje 
podatkowe. Należy tutaj wspomnieć przede wszystkim o rozwiązaniach wynikających z Ustawy z dnia 15 lutego 1992 r. o podatku dochodowym od osób prawnych (tekst jednolity: Dz.U. z 2011 r. nr 74, poz. 397 z późniejszymi zmianami). W myśl art. 18b ust. 1 tej ustawy, wydatki, które podatnik poniósł na nabycie nowych technologii, podlegają odliczeniu od podstawy opodatkowania, która została ustalona w myśl art. 18 ustawy o podatku dochodowym od osób prawnych. Trzeba w tym miejscu wyjaśnić, co ustawodawca rozumie pod pojęciem nowe technologie. Otóż, zgodnie z ust. 2 wspomnianego wyżej art. 18b, tego rodzaju technologie to - w rozumieniu art. 18b ust. 1 - przyjmująca formę wartości niematerialnych i prawnych wiedza technologiczna (chodzi tutaj zwłaszcza o rezultaty badań i prac rozwojowych), dzięki której możliwe jest tworzenie nowych wyrobów lub usług (lub też udoskonalanie już istniejących), i której okres stosowania na świecie nie przekracza ostatnich pięciu lat, co musi znaleźć potwierdzenie w opinii wydanej przez jednostkę naukową (jednostka ta musi być niezależna od podatnika) w rozumieniu Ustawy z dnia 30 kwietnia 2010 r. o zasadach finansowania nauki (Dz.U. z 2010 r. nr 96, poz. 615 z późniejszymi zmianami). Jednostki naukowe to, w myśl art. 2 pkt 9 lit. a)-f) ustawy o zasadach finansowania nauki, podmioty zajmujące się w sposób ciągły prowadzeniem badań naukowych lub prac rozwojowych, które jednocześnie można zakwalifikować do jednej z określonych w tym przepisie form organizacyjnych, to znaczy do podstawowych jednostek organizacyjnych uczelni, jednostek naukowych Polskiej Akademii Nauk, instytutów badawczych, Polskiej Akademii Umiejętności, funkcjonujących na obszarze Polski instytutów naukowych o charakterze międzynarodowym, które zostały powołane na podstawie odrębnych przepisów, jak również do innych jednostek organizacyjnych spełniających ustawowo określone warunki.

Znaczenie powyższych regulacji podatkowych, dotyczących nowych technologii, wzmacnia fakt, że - jak podkreśla się w literaturze przedmiotu - polską gospodarkę cechuje stosunkowo niski stopień innowacyjności (Ciborowski, 2005: 314). Jednocześnie trwały rozwój państwa opiera się na innowacyjności samych obywateli, jak i całej gospodarki oraz administracji publicznej (Frąckowiak, 1999: 11).

Wracając do unormowań zawartych w ustawie o podatku dochodowym od osób prawnych, należy zwrócić uwagę na ust. 2a (zawarty w art. 18b tej ustawy), który to przepis precyzuje, że pod pojęciem nabywanie nowej technologii należy rozumieć nie tylko nabycie praw do wspomnianej wyżej wiedzy technologicznej przez zawarcie umowy dotyczącej ich przeniesienia, ale także korzystanie $\mathrm{z}$ praw do takiej wiedzy. Jeżeli chodzi o ustalenie wielkości odliczenia, to - zgodnie $\mathrm{z}$ art. $18 \mathrm{~b}$ ust. 4 analizowanej ustawy - podstawą tego ustalenia jest kwota zrealizowanych przez podatnika wydatków na nabycie wspomnianej technologii, które zostały uwzględnione „w wartości początkowej, w części, w jakiej została zapłacona podmiotowi uprawnionemu w roku podatkowym, w którym nową technologię wprowadzono do ewidencji środków trwałych oraz wartości niematerialnych i prawnych lub w roku następującym po tym roku, oraz w której nie została zwrócona podatnikowi w jakiejkolwiek formie". Gdy w roku, który poprzedza rok wprowadzenia nowej technologii do wspomnianej wyżej ewidencji, podatnik wpłacił zadatki lub przedpłaty na konto wydatków służących nabyciu nowej technologii, wówczas ustawa o podatku dochodowym od osób prawnych przewiduje, że mają one zostać uznane za poniesione w tym roku, w którym nowa technologia została wprowadzona do ewidencji środków trwałych oraz wartości niematerialnych i prawnych (art. 18b ust. 5 tej ustawy).

W pewnych okolicznościach ustawa o podatku dochodowym od osób prawnych odbiera podatnikowi prawo do dokonywania odliczeń, mających związek z nabywaniem nowej technologii. Sytuacja taka ma miejsce, w myśl art. 18 b ust. 8 pkt 1), 2) i 3) tej ustawy, gdy podatnik umieścił nową technologię w wymienionej wyżej ewidencji i w okresie krótszym niż trzy lata 
podatkowe (początkiem biegu tego terminu jest koniec roku podatkowego, w ramach którego nowa technologia została wprowadzona do ewidencji): inne podmioty uzyskały od niego (w dowolnej formie lub części) prawa do takiej technologii (jednakże odliczenia mogą być dokonywane w przypadku, gdy przeniesienie prawa jest następstwem przeobrażeń w zakresie formy prawnej oraz działań polegających na łączeniu lub podziale dotychczasowych przedsiębiorców - realizowanych w oparciu o regulacje zawarte w Kodeksie spótek handlowych) albo nastąpi ogłoszenie upadłości podatnika obejmującej likwidację majątku (lub też postawiony on będzie w stan likwidacji), albo zostaną mu zwrócone - w dowolnej formie - wydatki na nową technologię.

Podatnik nie ma natomiast prawa do odliczeń w przypadku, gdy była przez niego prowadzona działalność (ustawodawca precyzuje, że chodzi tutaj o prowadzenie działalności w roku podatkowym lub roku go poprzedzającym), w oparciu o zezwolenie, na obszarze objętym specjalną strefą ekonomiczną (art. 18b ust. 3 ustawy o podatku dochodowym od osób prawnych) ${ }^{1}$.

Należy w tym miejscu podkreślić, iż funkcjonowanie w ramach wspomnianych wyżej specjalnych stref ekonomicznych również posiada swoje konsekwencje podatkowe, które nie są bez znaczenia dla podatników funkcjonujących w okresie dekoniunktury rynkowej.

\section{Specjalne strefy ekonomiczne}

Podstawowym aktem prawnym dotyczącym funkcjonowania specjalnych stref ekonomicznych w Polsce jest Ustawa z dnia 20 października 1994 r. o specjalnych strefach ekonomicznych (tekst jednolity: Dz.U. z 2007 r. nr 42, poz. 274 z późniejszymi zmianami). Specjalna strefa ekonomiczna to - w myśl art. 2 wymienionej wyżej ustawy - ,wyodrębniona zgodnie z przepisami ustawy, niezamieszkała część terytorium Rzeczypospolitej Polskiej, na której terenie może być prowadzona działalność gospodarcza na zasadach określonych ustawą".

Zgodnie z art. 3 pkt 1), 2), 3), 4), 5), 6), 7) ustawy o specjalnych strefach ekonomicznych, utworzenie strefy może nastąpić celem zdynamizowania rozwoju ekonomicznego określonego obszaru Polski, zwłaszcza przez rozwinięcie wybranych gałęzi działalności gospodarczej, rozwinięcie nowych koncepcji z zakresu techniki i technologii oraz ich zastosowanie w gospodarce, rozwinięcie działalności eksportowej, podniesienie poziomu konkurencyjności produkowanych wyrobów oraz dostarczanych usług, kreowanie dodatkowych miejsc pracy oraz zagospodarowywanie występującego mienia przemysłowego, istniejącej infrastruktury gospodarczej czy zasobów naturalnych, które pozostają niewykorzystane (w przypadku zasobów naturalnych musi być przestrzegana zasada równowagi ekologicznej).

Osoby fizyczne lub prawne, które prowadzą działalność gospodarczą na terenie specjalnej strefy ekonomicznej w granicach zezwolenia, są w dogodnej sytuacji podatkowej, bowiem dochody z takiej działalności podlegają zwolnieniu od podatku dochodowego, przy czym zasady takiego zwolnienia regulują odpowiednie przepisy podatkowe, tj. o podatku dochodowym od osób fizycznych lub prawnych (art. 12 ustawy o specjalnych strefach ekonomicznych).

Jeżeli chodzi o wspomnianą wyżej ustawę o podatku dochodowym od osób prawnych, to jej art. 17 ust. 1 pkt 34) stanowi, że od podatku wolne są dochody (z uwzględnieniem jednak postanowień zawartych w art. 17 ust. 4-6 ustawy o podatku dochodowym od osób prawnych), które przynosi działalność gospodarcza realizowana na obszarze specjalnej strefy ekonomicznej w oparciu o zezwolenie wskazane w art. 16 ust. 1 ustawy o specjalnych strefach ekono-

\footnotetext{
${ }^{1} \mathrm{Na}$ temat odliczeń od podstawy opodatkowania wydatków zrealizowanych przez podatnika z tytułu nabycia nowych technologii zob. też art. $18 \mathrm{~b}$ ust. 6, 7, 9, 10 i 11 ustawy o podatku dochodowym od osób prawnych.
} 
micznych, z tym że zakazane jest, aby wysokość pomocy publicznej, która jest udzielana w postaci takiego zwolnienia, była wyższa od wielkości tego rodzaju pomocy dla przedsiębiorcy, dozwolonej dla terenów spełniających warunki dla otrzymania pomocy w najwyższej wysokości, w myśl odrębnych regulacji. Podatnikowi zwolnienie to przysługuje, jak stanowi art. 17 ust. 4 ustawy o podatku dochodowym od osób prawnych, jedynie z tytułu dochodów, jakie przynosi mu działalność prowadzona na obszarze specjalnej strefy ekonomicznej, przy czym ten sam art. 17 w ust. 5 stanowi, że konsekwencją cofnięcia wymienionego wyżej zezwolenia jest utrata przez podatnika prawa do zwolnienia oraz obowiązek uiszczenia podatku za pełny okres, w którym z takiego zwolnienia podatkowego korzystał (obowiązki podatnika powstałe wskutek cofnięcia zezwolenia szczegółowo reguluje ust. 6 zawarty w omawianym art. 17 ustawy o podatku dochodowym od osób prawnych). Analogiczne regulacje do przedstawionych wyżej unormowań zawartych w ustawie o podatku dochodowym od osób prawnych występują w art. 21 ust. 1 pkt 63a) i ust. 5a, 5b i 5c Ustawy z dnia 26 lipca 1991 r. o podatku dochodowym od osób fizycznych (tekst jednolity: Dz.U. z dnia 3 kwietnia 2012 r., poz. 361 z późniejszymi zmianami), która to ustawa reguluje, zgodnie z jej art. 1, opodatkowanie tym podatkiem dochodów osób fizycznych.

Ze wspomnianego wyżej art. 16 ust. 1 ustawy o specjalnych strefach ekonomicznych wynika, że do korzystania z pomocy publicznej, która jest udzielana w myśl tej ustawy, wymagane jest zezwolenie na prowadzenie działalności gospodarczej na obszarze określonej strefy dające uprawnienie do korzystania z takiej pomocy. Nie można przy tym zapominać, że - w myśl art. 19a ustawy o specjalnych strefach ekonomicznych - tego rodzaju działalność gospodarcza przedsiębiorcy podlega kontroli stosownie do regulacji zawartych w rozdziale 5 Ustawy z dnia 2 lipca 2004 r. o swobodzie działalności gospodarczej (tekst jednolity: Dz.U. z 2010 r. nr 220, poz. 1447 z późniejszymi zmianami).

\section{Ulgi przewidziane w Ordynacji podatkowej (wybrane kwestie)}

Jak już wspomniano, bardzo istotne regulacje dotyczące ulg podatkowych zostały przez ustawodawcę przewidziane w rozdziale 7a Ordynacji podatkowej, który nosi tytuł Ulgi w spłacie zobowiazań podatkowych (art. 67a-67e). Rozdział 7a umiejscowiony jest w dziale III tej ustawy.

Artykuł 67a § 1 pkt 1), 2) i 3) Ordynacji podatkowej przewiduje, że na wniosek złożony przez podatnika, organ podatkowy, z zastrzeżeniem postanowień zawartych w art. 67b Ordynacji podatkowej, może zadecydować o odroczeniu terminu zapłaty podatku lub o rozłożeniu na raty jego zapłaty, o odroczeniu lub rozbiciu na raty zapłaty zaległości podatkowej łącznie z odsetkami wynikającymi ze zwłoki lub odsetek wskazanych w decyzji wymienionej w art. 53a Ordynacji podatkowej, a także może zadecydować - w odniesieniu do zaległości podatkowych, odsetek za zwłokę lub opłaty prolongacyjnej - o ich umorzeniu w całości lub w części, przy czym wszelkie wspomniane wyżej działania organ podatkowy może przedsięwziąć jedynie wówczas, gdy jest to uzasadnione z uwagi na ważny interes podatnika lub interes publiczny. Przytoczone powyżej rozwiązania prawne prezentuje w sposób syntetyczny tabela 1 .

Warto w tym miejscu zaznaczyć, że jako nadpłatę należy potraktować sytuację, w której dany podmiot płaci zaległość podatkową objętą umorzeniem lub odsetki za zwłokę (opłatę prolongacyjną) nim objęte (Dauter, 2011: 378). Wzmiankowany art. 67a Ordynacji podatkowej precyzuje $\mathrm{w} \S 2$, że wskutek umorzenia zaległości podatkowej następuje też umorzenie odsetek za zwłokę, przy czym umorzeniu podlega całość odsetek lub też są one umarzane w części, w jakiej umorzono samą zaległość podatkową.

Przedstawione regulacje wymagają pewnych dodatkowych wyjaśnień. W szczególności słusznie podkreśla się w literaturze przedmiotu, że zawartość składanego przez podatnika 
Tab. 1. Wybrane ulgi przewidziane w Ordynacji podatkowej

\begin{tabular}{|c|c|}
\hline Ulga & Podstawa prawna \\
\hline Odroczenie terminu płatności podatku & \multirow{2}{*}{ art. 67a § 1 pkt 1) Ordynacji podatkowej } \\
\hline Rozłożenie zapłaty podatku na raty & \\
\hline $\begin{array}{l}\text { Odroczenie lub rozłożenie na raty zapłaty zaległości podat- } \\
\text { kowej wraz z odsetkami za zwłokę lub odsetek określonych } \\
\text { w decyzji wskazanej w art. 53a Ordynacji podatkowej }\end{array}$ & art. 67a $\S 1$ pkt 2) Ordynacji podatkowej \\
\hline Umorzenie w całości lub w części zaległości podatkowych & \multirow{3}{*}{ art. 67a § 1 pkt 3) Ordynacji podatkowej } \\
\hline Umorzenie w całości lub w części odsetek za zwłokę & \\
\hline Umorzenie w całości lub w części opłaty prolongacyjnej & \\
\hline
\end{tabular}

Źródło: opracowanie na podstawie art. 67a § 1 Ustawy z dnia 29 sierpnia 1997 r. Ordynacja podatkowa (tekst jednolity: Dz.U. z dnia 3 lipca 2012 r., poz. 749 z późniejszymi zmianami).

wniosku o udzielenie ulgi w spłacie zobowiązań podatkowych, jest dla organu podatkowego wiążąca, a zatem niedopuszczalna jest np. sytuacja polegająca na tym, że organ odracza termin płatności podatku, choć wnioskodawca zwracał się o rozłożenie jego zapłaty na raty (Etel, 2009: 372).

Wymieniony wyżej art. 53a Ordynacji podatkowej wyznacza, w $\S 1$, sposób postępowania organu podatkowego w przypadku stwierdzenia przez niego (w ramach postępowania podatkowego po upływie roku podatkowego lub ewentualnie jakiegoś innego okresu rozliczeniowego), że podatnik nie złożył deklaracji chociaż był do tego zobowiązany, kwota zaliczek odbiega od tej która została ujęta w deklaracji lub nie doszło do zapłaty zaliczek w całości lub w części. Wówczas, zgodnie z dyspozycją tegoż art. 53a § 1, „organ ten wydaje decyzję, w której określa wysokość odsetek za zwłokę na dzień złożenia zeznania podatkowego za rok podatkowy lub inny okres rozliczeniowy, a w przypadku niezłożenia zeznania w terminie odsetki na ostatni dzień terminu złożenia zeznania, przyjmując prawidłową wysokość zaliczek na podatek". Całość powyższych regulacji zawartych w rzeczonym art. 53a § 1 znajduje odpowiednie zastosowanie w odniesieniu do zaliczek na podatek od towarów i usług (stanowi o tym art. 53a § 2 Ordynacji podatkowej).

W przytoczonym art. 67a $\S 1$ Ordynacji podatkowej ustawodawca wspomina o ważnym interesie podatnika i interesie publicznym. W doktrynie prawa zwraca się uwagę, iż są to terminy niejednoznaczne (Etel, 2009: 232; Dauter, 2011: 309, 382), przy czym kluczowy „wpływ na sprecyzowanie tych pojęć ma orzecznictwo sądowe" (Etel, 2009: 232). Należy też odnotować, że w myśl art. 67c § 1 Ordynacji podatkowej, regulacje zawarte w jej art. 67a § 1 pkt 1) i pkt 2) (chodzi tutaj o odraczanie terminu zapłaty podatku lub o rozkładanie jego zapłaty na raty, jak również o odraczanie lub rozkładanie na raty zapłaty zaległości podatkowej łącznie z odsetkami powstałymi wskutek zwłoki lub o odsetki wskazane w decyzji określonej w art. 53a Ordynacji podatkowej) i art. 67b (zob. niżej) trzeba odpowiednio stosować do należności, które przypadają od płatników i inkasentów. Natomiast wyżej wymieniony art. 67a znajduje w całości odpowiednie zastosowanie (tak samo zresztą, jak i cały art. 67b) do należności, które przypadają od spadkobierców podatnika lub płatnika oraz osób trzecich (art. 67c § 2 Ordynacji podatkowej).

Trzeba również podkreślić, że - zgodnie z art. 49 § 1 Ordynacji podatkowej - na skutek wydania decyzji w oparciu o art. 67a $\S 1$ pkt 1) lub pkt 2) pojawia się nowy termin zapłaty, przy czym jest nim dzień, w którym należy, w myśl wspomnianej decyzji wydanej na podstawie 
art. $67 \mathrm{a} \S 1$ pkt 1) lub pkt 2), uiścić odroczony podatek lub zaległość podatkową włącznie z odsetkami za zwłokę albo uiścić poszczególne raty, na które rozłożono podatek lub zaległość podatkową włącznie z odsetkami za zwłokę. Jednocześnie, jak stanowi art. 49 § 2 Ordynacji podatkowej, nieuiszczenie przez podatnika, w terminie wynikającym z takiej decyzji, wymienionych wyżej należności (w przypadku rozłożenia świadczenia na raty wystarczy, że choćby jedna $\mathrm{z}$ rat nie zostanie zapłacona) skutkuje tym, że terminem zapłaty podatku lub zaległości podatkowej podlegającej odroczeniu lub rozłożeniu na raty staje się odpowiednio termin wynikający z art. $47 \S 1-3$ Ordynacji podatkowej. Powyższe regulacje zamieszczone w art. $49 \S 1$ i $\S 2$ znajdują odpowiednie zastosowanie do należności płatników lub inkasentów, które zostały rozłożone na raty (art. 49 § 3 Ordynacji podatkowej). Artykuł 49 zawarty jest w rozdziale 4 zatytułowanym Terminy płatności objętym działem III Ordynacji podatkowej. W rozdziale tym znajduje się też art. 48, który w $§ 1$ stanowi, że terminy określone przepisami prawa podatkowego mogą być przez organ podatkowy - na wniosek podatnika - odraczane w sytuacjach, gdy jest to uzasadnione ważnym interesem podatnika lub interesem publicznym (odroczenie takie nie znajduje jednak zastosowania do wszystkich terminów - wyliczenie wyjątków poprzez wskazanie odpowiednich artykułów Ordynacji podatkowej objętych tym wyłączeniem zawiera tenże art. $48 \S 1$ ). Jak stanowi art. 48 § 2 Ordynacji podatkowej, powyższe regulacje zawarte $\mathrm{w}$ art. $48 \S 1$ mają odpowiednie zastosowanie także do terminów odnoszących się do płatników lub inkasentów. Uważa się, że możliwość odraczania terminów, unormowana w art. 48 Ordynacji podatkowej, stanowi rodzaj ulgi w spłacie podatków (Etel, 2009: 310, 371).

\section{Podmioty przyznające ulgi}

Kolejna kwestia, której nie można pominąć, dotyczy określenia podmiotów uprawnionych do przyznawania ulg wymienionych w rozdziale 7a Ordynacji podatkowej. Otóż na mocy art. 67e Ordynacji podatkowej określenie właściwości rzeczowej organów podatkowych w zakresie udzielania ulg w spłacie zobowiązań podatkowych musi nastąpić w ramach rozporządzenia ministra właściwego do spraw finansów publicznych, który w tej kwestii musi uwzględnić takie czynniki, jak: wielkość kwoty stanowiącej przedmiot ulgi i terminy wpłat dotyczące podatku lub też zaległości podatkowej. Trzeba w tym miejscu odwołać się do postanowień Rozporzadzenia Ministra Finansów z dnia 22 sierpnia 2005 r. w sprawie właściwości organów podatkowych (Dz.U. z 2005 r. nr 165, poz. 1371 z późniejszymi zmianami), które to rozporządzenie (dalej: rozporządzenie MF z dnia 22 sierpnia 2005 r.) - jak wynika z jego treści - zostało wydane między innymi w oparciu o wspomniany wyżej art. 67e Ordynacji podatkowej. W rozporządzeniu tym zawarty jest rozdział 4 zatytułowany Właściwość rzeczowa organów podatkowych $w$ sprawach związanych ze stosowaniem ulg $w$ spłacie zobowiązań podatkowych, obejmujący tylko $\S 15$. Zgodnie z $\S 15$ ust. 1 pkt 1), 2), 3), 4) i 5) rozporządzenia MF z dnia 22 sierpnia 2005 r., organy podatkowe, do których kompetencji należy - w myśl odrębnych regulacji - ustalanie lub określanie zobowiązań wynikających z podatków, opłat i niepodatkowych należności budżetowych (wszystkie te świadczenia rozporządzenie określa pojęciem podatki) są również właściwe w sprawach polegających na: a) zwalnianiu podmiotów będących płatnikami z obowiązku poboru podatku lub poboru zaliczek na podatek, b) ograniczaniu poboru zaliczek na podatek, c) całościowym lub częściowym umarzaniu zaległości podatkowych, opłaty prolongacyjnej lub odsetek z tytułu zwłoki (w sprawach wymienionych w powyższych punktach a), b) i c) organy podatkowe są właściwe bez ograniczenia kwoty), d) odraczaniu terminu zapłaty oraz rozkładaniu zapłaty podatku na raty, e) odraczaniu oraz rozkładaniu na raty takich świadczeń, jak zapłata zaległości podatkowej łącznie z odsetkami z tytułu zwłoki lub odsetek wynikających z decyzji wskazanej w omówionym wyżej art. 53a Ordynacji 
podatkowej, przy czym w sprawach wymienionych w powyższych punktach d) i e) organy podatkowe są właściwe bez ograniczenia zarówno co do kwoty, jak i co do okresu spłaty (w kwestii właściwości rzeczowej organów podatkowych w innych sprawach objętych rozdziałem 4 - zob. $\S 15$ ust. 2 i 3 rozporządzenia MF z dnia 22 sierpnia 2005 r.).

\section{Szczególne rozwiązania prawne dotyczące ulg}

Z kolei art. 67b § 1 pkt 1), 2) i 3) Ordynacji podatkowej daje organowi podatkowemu możliwość udzielenia - na wniosek podatnika, który prowadzi działalność gospodarczą - ulg w spłacie zobowiązań podatkowych, wymienionych w art. 67a Ordynacji podatkowej, które: a) nie są pomocą publiczną, b) są pomocą de minimis ${ }^{2}$, c) są pomocą publiczną udzielaną na realizację określonych zamierzeń. Podkreśla się w literaturze przedmiotu, że nie zawsze jest pomocą publiczną ulga w spłacie podatków, którą uzyskuje podmiot prowadzący działalność gospodarczą, a organy podatkowe, które podejmują rozstrzygnięcia w kwestii tego rodzaju ulg, muszą w każdym przypadku badać, czy ewentualnie takiej ulgi nie należałoby uznać za pomoc publiczną (Etel, 2009: 382). Organ podatkowy musi zatem już na wstępie sprawdzić charakter wnioskowanej pomocy (Dauter, 2011: 390). Trzeba jednocześnie zwrócić uwagę na fakt, że pojęcie pomoc publiczna jest precyzowane przede wszystkim w przepisach unijnych (zob.: Dauter, 2011: 390 i nast. oraz Etel, 2009: 380 i nast.).

Przed przystąpieniem do bardziej szczegółowej analizy powyższych kwestii należy sprecyzować pojęcie działalność gospodarcza, do którego odwołuje się wspomniany wyżej art. 67b. Otóż art. 3 pkt 9) Ordynacji podatkowej precyzuje, że pod pojęciem działalność gospodarcza należy rozumieć wszelką działalność zarobkową w takim znaczeniu, o jakim mówią regulacje o swobodzie działalności, wliczając w to praktykowanie wolnego zawodu, jak również wszelką inną działalność zarobkową, która jest prowadzona we własnym imieniu i na rachunek własny lub cudzy (chodzi tutaj nawet o takie przypadki, gdy dana działalność nie została zakwalifikowana przez odrębne ustawy do działalności gospodarczej lub gdy takie ustawy nie zaliczają do grona przedsiębiorców osoby, która takową działalność prowadzi). Z kolei art. 2 ustawy o swobodzie działalności gospodarczej wskazuje, że działalność gospodarcza to ,zarobkowa działalność wytwórcza, budowlana, handlowa, usługowa oraz poszukiwanie, rozpoznawanie i wydobywanie kopalin ze złóż, a także działalność zawodowa, wykonywana w sposób zorganizowany i ciągły". Z pojęciem działalność gospodarcza skorelowane jest pojęcie przedsiębiorca. W myśl art. $4 \S 1$ ustawy o swobodzie działalności gospodarczej, przedsiębiorcami - w rozumieniu tej ustawy - są wykonujące we własnym imieniu taką działalność: 1) osoby (chodzi tutaj zarówno o osoby fizyczne, jak i prawne) i 2) jednostki organizacyjne bez osobowości prawnej (taka jednostka musi jednak posiadać zdolność prawną przyznaną przez odrębną ustawę). Jak stanowi natomiast art. 4 § 2 ustawy o swobodzie działalności gospodarczej, wspólnicy spółki cywilnej uważani są również - w zakresie prowadzonej przez te podmioty działalności gospodarczej - za przedsiębiorców.

Wracając do rozwiązań przyjętych w art. 67b Ordynacji podatkowej, trzeba zwrócić uwagę, że przepis ten, w $§ 1$ pkt 3) lit. a)-m), określa różne zamierzenia, których realizacji musi służyć udzielenie - stanowiących pomoc publiczną - ulg w spłacie zobowiązań podatkowych. Jednym z warunków dopuszczalności udzielenia tego rodzaju ulgi jest to, aby była ona związana $\mathrm{z}$ realizacją któregoś z tych przedsięwzięć (Etel, 2009: 389). Warto przy tym pamiętać, że zgodnie

\footnotetext{
${ }^{2} \mathrm{~W}$ odniesieniu do pomocy de minimis, art. 67b § $1 \mathrm{pkt}$ 2) Ordynacji podatkowej stanowi, że udzielanie ulg stanowiących taką pomoc następuje ,,w zakresie i na zasadach określonych w bezpośrednio obowiązujących aktach prawa wspólnotowego dotyczących pomocy w ramach zasady de minimis".
} 
z art. 67b $\S 1$ pkt 3 lit. m) Ordynacji podatkowej, organ podatkowy może przyznawać ulgi podatkowe będące pomocą publiczną udzielaną na inne zamierzenia wskazane przez Radę Ministrów na podstawie $\S 6$ zamieszczonego w omawianym art. $67 \mathrm{~b}$. W myśl tego przepisu (art. 67b § 6) Rada Ministrów jest uprawniona do określenia, w formie rozporządzenia, odmiennego niż wymienione w art. 67b § 1 pkt 3) lit. a)-1) Ordynacji podatkowej przeznaczenia pomocy w postaci przyznawanych ulg w spłacie zobowiązań podatkowych (chodzi o ulgi wskazane w art. 67a Ordynacji podatkowej), jak również do określenia szczegółowych warunków, na jakich tego rodzaju ulgi są przyznawane dla przeznaczeń wskazanych przez Radę Ministrów, włącznie z wymienieniem sytuacji, w których udzielane ulgi przyjmują postać pomocy indywidualnej, uwzględniając unijne unormowania dotyczące dopuszczalności i warunków udzielania przez państwo pomocy.

Ordynacja podatkowa wprowadza szczególne regulacje w zależności od tego, o jakie zamierzenie (zamierzenia) chodzi. I tak w myśl § 2 wspomnianego wyżej art. 67b, w sytuacji, gdy chodzi o zamierzenie wskazane w art. 67b $§ 1$ pkt 3) lit. a) Ordynacji podatkowej (zamierzenia te to naprawienie szkód spowodowanych klęskami żywiołowymi lub innymi nadzwyczajnymi zdarzeniami) ulg w spłacie zobowiązań podatkowych (chodzi o ulgi wskazane w art. 67a Ordynacji podatkowej) można udzielić w formie pomocy indywidualnej albo też w ramach programów pomocowych uregulowanych odrębnymi przepisami.

Z kolei zgodnie z art. 67b $\S 3$ Ordynacji podatkowej w przypadku zamierzeń wskazanych w rzeczonym art. 67b $\S 1$ pkt 3 ) lit. b), c), d), e), f), g), i), j), k), l) (są to następujące zamierzenia: zapobieganie poważnym zakłóceniom w gospodarce o charakterze ponadsektorowym lub likwidacja takich zakłóceń, wspieranie polskich przedsiębiorców prowadzących działalność stanowiącą część przedsięwzięcia gospodarczego, które jest podejmowane w interesie europejskim, promowanie oraz wspieranie zarówno kultury i dziedzictwa narodowego, jak również nauki oraz oświaty, przekazanie rekompensaty za wykonywanie - powierzonych w oparciu o odrębne przepisy - usług, które są świadczone w ogólnym interesie gospodarczym, szkolenie, zatrudnienie, restrukturyzacja, ochrona środowiska, prace badawczo-rozwojowe, regionalna pomoc publiczna) można udzielać ulg w spłacie zobowiązań podatkowych wymienionych w art. 67a Ordynacji podatkowej w postaci pomocy indywidualnej zgodnej z rządowymi lub samorządowymi programami albo można ich udzielać w ramach programów pomocowych, które są określone w odrębnych regulacjach.

Natomiast stosownie do art. 67b § 4 Ordynacji podatkowej, w przypadku zamierzenia wskazanego w art. 67b § 1 pkt 3) lit. h) Ordynacji podatkowej, to znaczy związanego z rozwojem małych i średnich przedsiębiorstw, można udzielać ulg w spłacie zobowiązań podatkowych, o których wspomina art. 67a Ordynacji podatkowej, po dopełnieniu szczegółowych wymogów ustalonych w oparciu o $\S 5$ analizowanego art. 63b. Należy w tym miejscu odwołać się do Rozporzadzenia Rady Ministrów z dnia 31 marca 2009 r. w sprawie udzielania niektórych ulg $w$ spłacie zobowiazań podatkowych stanowiacych pomoc publiczna na rozwój małych i średnich przedsiębiorstw (Dz.U. z 2009 r. nr 59, poz. 488), które zostało wydane właśnie w oparciu o art. 67b § 5 Ordynacji podatkowej, o czym informuje ono we wstępie. Rozporządzenie to (dalej: rozporządzenie RM z dnia 31 marca 2009 r.), zgodnie z jego § 1, ustala dokładne wymogi związane z udzielaniem ,ulg w spłacie zobowiązań podatkowych stanowiących pomoc publiczną na rozwój małych i średnich przedsiębiorstw w zakresie inwestycji, usług doradczych i udziału w targach lub wystawach, do której mają zastosowanie przepisy rozporządzenia Komisji (WE) nr 800/2008 z dnia 6 sierpnia 2008 r. uznającego niektóre rodzaje pomocy za zgodne ze wspólnym rynkiem w zastosowaniu art. 87 i 88 Traktatu (ogólne rozporządzenie w sprawie wyłączeń grupowych) (Dz.Urz. UE L 214 z 09 sierpnia 2008 r., s. 3), [...], 
na podstawie art. 67a i art. 67b $§ 1$ pkt 3 lit. h ustawy z dnia 29 sierpnia 1997 r. - Ordynacja podatkowa, w formie odroczenia terminu płatności podatku" i w pozostałych formach przewidzianych w art. 67a $§ 1$ pkt 1), 2) i 3) Ordynacji podatkowej, włącznie z określeniem sytuacji, gdy udzielanie ulg przyjmuje postać pomocy indywidualnej. Poniżej przedstawiono wybrane rozwiązanie prawne zawarte we wskazanym wyżej rozporządzeniu Rady Ministrów w sprawie udzielania niektórych ulg w spłacie zobowiązań podatkowych stanowiących pomoc publiczną na rozwój małych i średnich przedsiębiorstw.

Do pewnych kategorii pomocy rozporządzenie RM z dnia 31 marca 2009 r. nie znajduje zastosowania (zob. § 3 tego rozporządzenia). Co więcej, nie każdy mały i średni przedsiębior$\mathrm{ca}^{3}$ może skorzystać z pomocy określonej tym rozporządzeniem, o czym stanowi ono w $\S 4$. Otóż w myśl $\S 4$ ust. 1 pkt 1) tego rozporządzenia, mały i średni przedsiębiorca nie może otrzymać takiej pomocy, jeżeli jest on zagrożony. Zgodnie z § 4 ust. 2 pkt 1), 2) i 3) wspomnianego rozporządzenia, mały i średni przedsiębiorca uznawany jest za przedsiębiorcę zagrożonego wówczas, gdy wypełnia poniższe warunki: a) doszło do utraty więcej niż 50\% zarejestrowanego kapitału, z czego więcej niż 25\% utracono w ciągu poprzedzających dwunastu miesięcy (warunek ten dotyczy spółek z ograniczoną odpowiedzialnością), lub b) więcej niż $50 \%$ kapitału zgodnie ze sprawozdaniem finansowym zostało utracone, z czego więcej niż $25 \%$ utracono w ciągu poprzedzających dwunastu miesięcy (warunek ten znajduje zastosowanie do spółki charakteryzującej się tym, że przynajmniej część jej członków odpowiada za jej zobowiązania w sposób nieograniczony), lub c) wypełnia przesłanki warunkujące objęcie spółki postępowaniem upadłościowym (ten warunek odnosi się do każdego rodzaju spółki). Szczególna sytuacja została uregulowana w $\S 4$ ust. 3 rozporządzenia RM z dnia 31 marca 2009 r., który stanowi, że w przypadku, gdy okres, w którym mały i średni przedsiębiorca prowadzi działalność jest krótszy niż trzy lata, wówczas nie może on zostać uznany za zagrożonego przedsiębiorcę, chyba że mały i średni przedsiębiorca wypełnia warunek wymieniony we wspomnianym wyżej punkcie c).

Ponadto, nie można udzielić i wypłacić pomocy przewidzianej w rozporządzeniu RM z dnia 31 marca 2009 r. przedsiębiorcy, który został zobowiązany do zwrotu pomocy na podstawie wcześniejszej decyzji wydanej przez Komisję Europejską, w której uznano niezgodność pomocy z prawem i ze wspólnym rynkiem ( 4 ust. 1 pkt 2) rozporządzenia RM z dnia 31 marca 2009 r.). Natomiast $\S 6$ ust. 1 pkt 1) lit. a) i b), pkt 2) i 3) wspomnianego wyżej rozporządzenia określa przeznaczenie pomocy (chodzi o pomoc wymienioną w $\S 1$ tego rozporządzenia) dla przedsiębiorców wskazując, że można jej udzielić na inwestycje (rozporządzenie precyzuje, iż może to nastąpić w stosunku do kosztów inwestycji, mających związek z jej realizacją, lub w stosunku do kosztów płacy na stanowiskach pracy stworzonych jako bezpośrednia konsekwencja takiej inwestycji), na usługi doradcze, których realizacją zajmują się doradcy zewnętrzni oraz na udział w określonych wydarzeniach (chodzi tutaj o targi lub wystawę). Należy jednak pamiętać, że warunkiem udzielenia wspomnianej wyżej pomocy dla małego i średniego przedsiębiorcy jest to, aby wniosek w sprawie udzielenia ulgi w spłacie zobowiązań podatkowych został przez niego złożony, zanim zostaną rozpoczęte prace nad inwestycją lub inne działania, na które taka pomoc może zostać udzielona ( 6 ust. 2 rozporządzenie RM z dnia 31 marca 2009 r.).

Pojęcie inwestycji zostało zdefiniowane w $§ 5$ pkt 2) rozporządzenia RM z dnia 31 marca 2009 r. Od razu należy nadmienić, iż zgodnie z tym przepisem, jeżeli przedmiotem nabycia są

\footnotetext{
${ }^{3}$ W myśl $§ 5$ pkt 1 rozporządzenia RM z dnia 31 marca 2009 r., występujące w tym rozporządzeniu pojęcie maty $i$ średni przedsiębiorca oznacza „odpowiednio małego i średniego przedsiębiorcę spełniającego warunki określone w załączniku I do rozporządzenia Komisji (WE) nr 800/2008”.
} 
jedynie akcje lub udziały przedsiębiorstwa, to wówczas takiego działania nie można uważać za inwestycję. W rozumieniu tego aktu prawnego, przez pojęcie inwestycja należy rozumieć dwie kategorie działań. Po pierwsze, pojęcie inwestycja należy utożsamiać z inwestycją w rzeczowe aktywa trwałe lub też w wartości niematerialne i prawne powiązane z organizacją nowego przedsiębiorstwa, rozbudowywaniem już istniejącego, różnicowaniem jego produkcji w drodze wprowadzania kolejnych nowych towarów lub też z gruntowną modyfikacją cyklu produkcyjnego w ramach istniejącego przedsiębiorstwa ( $\$ 5$ pkt 2) lit. a) rozporządzeniu RM z dnia 31 marca 2009 r.). Po drugie, zgodnie z $\S 5$ pkt 2) lit. b) omawianego rozporządzenia, inwestycja oznacza nabywanie likwidowanego przedsiębiorstwa lub takiego, które byłoby zlikwidowane w przypadku, gdyby nie nastąpiło jego nabycie, z tym, że chodzi tutaj o sytuację, w której nabywcą przedsiębiorstwa jest inwestor niezależny od zbywcy (wymóg, aby środki były nabyte przez niezależnego inwestora nie znajduje zastosowania w sytuacji, gdy przekazywane przedsiębiorstwo małego przedsiębiorcy otrzymuje rodzina pierwotnego właściciela - ewentualnie pierwotnych właścicieli - lub byli pracownicy).

\section{Udzielanie ulg w przypadkach wyjątkowych}

Wracając do regulacji zawartych w Ordynacji podatkowej, trzeba wspomnieć, że w myśl jej art. 67d § 1 pkt 1), 2), 3) i 4), istnieje - w pewnych okolicznościach - możliwość udzielenia $\mathrm{z}$ urzędu przez organ podatkowy ulg w spłacie zobowiązań podatkowych wymienionych w art. 67a $\S 1$ pkt 3) Ordynacji podatkowej (chodzi tutaj o zastosowanie ulgi polegającej na umorzeniu - w całości lub w części - zaległości podatkowych, odsetek za zwłokę lub opłaty prolongacyjnej). Te okoliczności, zgodnie z rzeczonym art. 67d § 1 pkt 1), 2), 3) i 4), polegają na tym, że: a) istnieje przypuszczenie (ma być ono uzasadnione), iż postępowanie egzekucyjne nie przyniesie kwoty przekraczającej wielkość wydatków egzekucyjnych, b) wielkość zaległości podatkowej jest co najwyżej równa pięciokrotności kosztów upomnienia w ramach postępowania egzekucyjnego, c) nie doszło do zaspokojenia zaległości podatkowej w ukończonym postępowaniu likwidacyjnym lub upadłościowym, d) doszło do śmierci podatnika, po którym nie został żaden majątek lub zostały ruchomości, z których nie prowadzi się egzekucji w oparciu o odrębne przepisy albo pozostały przedmioty codziennego użytku domowego o łącznej wartości co najwyżej równej pięciu tysiącom złotych, i równocześnie nie ma spadkobierców (chodzi tutaj o innych spadkobierców niż Skarb Państwa lub jednostka samorządu terytorialnego) i nie można orzec wobec osoby trzeciej o jej odpowiedzialności podatkowej. Jeżeli doszło do sytuacji wymienionych w punktach c) i d), wówczas decyzję, którą umorzono zaległość podatkową, należy pozostawić w aktach sprawy (art. 67d § 2 Ordynacji podatkowej), przy czym regulacja ta, jak i unormowania wskazane we wspomnianych wyżej punktach c) i d), znajdują odpowiednie zastosowanie do umarzania zaległości tak płatnika, jak i inkasenta (art. 67d § 3 Ordynacji podatkowej).

Kończąc prezentację unormowań przyjętych w Ordynacji podatkowej, należy jeszcze wspomnieć o art. 22 tej ustawy, w którym to przepisie znalazły się rozwiązania prawne będące ulgami uznaniowymi (Etel, 2009: 232, 235, 371; zob. też: Gruszczyński, 2011: 211). W myś1 art. $22 \S 2$ pkt 1) i pkt 2) Ordynacji podatkowej, płatnik może zostać zwolniony przez organ podatkowy (działający na wniosek podatnika) z obowiązku pobrania podatku w sytuacji, gdyby taki pobór stanowił zagrożenie dla ważnych interesów podatnika, a zwłaszcza jego egzystencji, lub w sytuacji, gdy zostanie przez podatnika uprawdopodobnione, iż kwota pobranego podatku byłaby niewspółmiernie wysoka w porównaniu do kwoty podatku należnego za rok podatkowy lub za inny okres rozliczeniowy.

Ponadto, zgodnie z art. $22 \S 1$ pkt 1) i pkt 2) Ordynacji podatkowej, ministrowi właściwemu do spraw finansów publicznych przysługuje uprawnienie (jest ono realizowane przez wydanie odpowiedniego rozporządzenia): a) do zaniechania (w całości lub w części) poboru podatków 
(ustawa wymaga określenia rodzaju podatku, okresu, którego dotyczy zaniechanie, oraz kręgu podatników, do których zaniechanie ma zastosowanie), b) do zwolnienia pewnych grup płatników z obowiązku poboru podatków lub zaliczek na podatki (w tym zakresie wymagane jest określenie terminu wpłaty podatku i wynikających z takiego zwolnienia obowiązków informacyjnych leżących po stronie podatników, chyba że na podatniku spoczywa obowiązek przeprowadzenia rozliczenia takiego podatku w okresie rocznym lub w innym okresie rozliczeniowym), przy czym uprawnienia te, wskazane w punktach a) i b), mogą być realizowane, o ile jest to uzasadnione interesem publicznym lub ważnym interesem podatników (zob. też inne regulacje dotyczące działań organu podatkowego, zawarte w $\S 2 \mathrm{a}, \S 5$ i § 6 artykułu 22 Ordynacji podatkowej). Jednocześnie, w odniesieniu do rozporządzenia wskazanego w wyżej wymienionym punkcie a), ustawodawca zamieścił w art. 22 1a Ordynacji podatkowej następujące zastrzeżenie: ,Rozporządzenie [...], dotyczące zaniechania poboru podatku od podatników prowadzących działalność gospodarczą, którzy w wyniku zaniechania poboru podatku staną się beneficjentami pomocy w rozumieniu przepisów o postępowaniu w sprawach dotyczących pomocy publicznej, stanowiące pomoc publiczną, zawiera program pomocowy, określający przeznaczenie i warunki dopuszczalności pomocy publicznej”.

\section{Zakończenie}

W czasie dekoniunktury rynkowej podmioty gospodarcze szczególnie chętnie i w szerokim zakresie korzystają z różnego rodzaju ulg podatkowych wprowadzonych przez ustawodawcę. W niniejszym opracowaniu skoncentrowano się zwłaszcza na rozwiązaniach prawnych wynikających z Ordynacji podatkowej. W ramach tej ustawy omówiono przede wszystkim regulacje prawne zawarte $\mathrm{w}$ rozdziale 7 a pod tytułem Ulgi w spłacie zobowiazań podatkowych (rozdział ten stanowi fragment działu III Ordynacji podatkowej). Nie można jednak zapominać, że pewne istotne regulacje prawne dotyczące prezentowanej problematyki zostały przez polskiego ustawodawcę zamieszczone również w innych aktach prawnych. Wybrane unormowania zamieszczone w tych aktach również zostały uwzględnione w niniejszym opracowaniu.

\section{Akty prawne}

Ustawa z dnia 26 lipca 1991 r. o podatku dochodowym od osób fizycznych (tekst jednolity: Dz.U. z dnia 3 kwietnia 2012 r., poz. 361 z późniejszymi zmianami).

Ustawa z dnia 15 lutego 1992 r. o podatku dochodowym od osób prawnych (tekst jednolity: Dz.U. z 2011 r. nr 74, poz. 397 z późniejszymi zmianami).

Ustawa z dnia 20 października 1994 r. o specjalnych strefach ekonomicznych (tekst jednolity: Dz.U. z 2007 r. nr 42, poz. 274 z późniejszymi zmianami).

Ustawa z dnia 29 sierpnia 1997 r. Ordynacja podatkowa (tekst jednolity: Dz.U. z dnia 3 lipca 2012 r., poz. 749 z późniejszymi zmianami).

Ustawa z dnia 2 lipca 2004 r. o swobodzie działalności gospodarczej (tekst jednolity: Dz.U. z 2010 r. nr 220, poz. 1447 z późniejszymi zmianami).

Ustawa z dnia 30 kwietnia 2010 r. o zasadach finansowania nauki (Dz.U. z 2010 r. nr 96, poz. 615 z późniejszymi zmianami).

Rozporządzenie Ministra Finansów z dnia 22 sierpnia 2005 r. w sprawie właściwości organów podatkowych (Dz.U. z 2005 r. nr 165, poz. 1371 z późniejszymi zmianami).

Rozporzadzenie Rady Ministrów z dnia 31 marca 2009 r. w sprawie udzielania niektórych ulg w spłacie zobowiazań podatkowych stanowiacych pomoc publiczna na rozwój matych i średnich przedsiębiorstw (Dz.U. z 2009 r. nr 59, poz. 488). 


\section{Literatura}

Brzeziński, B. (2008). Wprowadzenie do prawa podatkowego. Toruń: Towarzystwo Naukowe Organizacji i Kierownictwa „,Dom Organizatora”.

Ciborowski, R. (2005). Uwarunkowania konwergencji technologicznej Polski. W: Z. Dach, A. Pollok (red.), Gospodarka Polski po 15 latach transformacji. Kraków: Polskie Towarzystwo Ekonomiczne, 303-322.

Dauter, B. (2011). W: S. Babiarz, B. Dauter, B. Gruszczyński, R. Hauser, A. Kabat, M. Niezgódka-Medek, Ordynacja podatkowa. Komentarz. Warszawa: Wydawnictwo LexisNexis Polska Sp. z o.o.

Etel, L. (2009). W: C. Kosikowski, L. Etel, R. Dowgier, P. Pietrasz, M. Popławski, S. Presnarowicz, Ordynacja podatkowa. Komentarz. Warszawa - Kraków: LEX a Wolters Kluwer business.

Frąckowiak, J. K. (1999). Polityka wspierania innowacyjności w Polsce - nowe założenia, wymiar regionalny. W: B. Marciniec, J. Guliński (red.), Parki naukowe i technologiczne. Polska perspektywa. Science and technology parks. The Polish perspective. Materiaty prezentowane na międzynarodowej konferencji. Poznań, 19-21 marca 1998. Poznań: Wydawnictwo Poznańskie, 11-14.

Gruszczyński, B. (2011). W: S. Babiarz, B. Dauter, B. Gruszczyński, R. Hauser, A. Kabat, M. Niezgódka-Medek, Ordynacja podatkowa. Komentarz. Warszawa: Wydawnictwo LexisNexis Polska Sp. z o.o.

Mastalski, R. (2011). Prawo podatkowe. Warszawa: Wydawnictwo C.H. Beck.

Nykiel, W. (2002). Cele i funkcje ulg i zwolnień podatkowych. W: praca zbiorowa, Regulacje prawno-podatkowe i rozwiazania finansowe. Pro publico bono. Księga jubileuszowa Profesora Jana Gtuchowskiego. Toruń: Towarzystwo Naukowe Organizacji i Kierownictwa „Dom Organizatora”, 189-195.

Wisła, R. (2004). Możliwości zarządzania ryzykiem fiskalnym przedsiębiorstwa. W: S. Owsiak (red.), Polityka fiskalna państwa i jej wptyw na finanse przedsiębiorstw. Bielsko-Biała: Wydawnictwo Wyższej Szkoły Bankowości i Finansów w Bielsku-Białej, 188-196.

Paweł Marek Woroniecki, dr nauk prawnych, Uniwersytet Jagielloński, Katedra Polityki Gospodarczej, Wydział Prawa i Administracji.

Ukończył studia prawnicze na Wydziale Prawa i Administracji Uniwersytetu Jagiellońskiego w Krakowie. Po odbyciu studiów doktoranckich na tym samym wydziale uzyskał stopień naukowy doktora nauk prawnych. Obecnie pracuje na stanowisku asystenta w Katedrze Polityki Gospodarczej na Wydziale Prawa i Administracji Uniwersytetu Jagiellońskiego. Jego zainteresowania badawcze dotyczą funkcjonowania systemu finansów publicznych oraz działalności podmiotów gospodarczych.

Pawel Marek Woroniecki, PhD in Law, Jagiellonian University in Cracow, Faculty of Law and Administration, Chair of Economic Policy.

Paweł Marek Woroniecki graduated in Legal Studies at the Faculty of Law and Administration of the Jagiellonian University in Cracow. Obtained a PhD in Law, after completing doctoral studies at the same faculty. Presently employed in the position of assistant at the Chair of Economic Policy of the Faculty of Law and Administration of the Jagiellonian University. Research interests of the author include: functioning of the public finance system, and activities of economic agents.

Adres/Address:

Uniwersytet Jagielloński w Krakowie, Wydział Prawa i Administracji

Katedra Polityki Gospodarczej

ul. Bracka 12, 31-005 Kraków, Polska

e-mail: pawel.woroniecki@uj.edu.pl 


\author{
Sławomir Dorocki, Agnieszka Świętek \\ Uniwersytet Pedagogiczny \\ im. Komisji Edukacji Narodowej \\ w Krakowie
}

\title{
Działania wybranych instytucji publicznych na rzecz wsparcia przedsiębiorczości w dobie kryzysu gospodarczego w Polsce
}

\author{
The functioning of selected public institutions for supporting entrepreneurship \\ during an economic crisis in Poland
}

\begin{abstract}
Streszczenie
Najbardziej wyraźnym i dotkliwym efektem współczesnego kryzysu gospodarczego dla polskiego społeczeństwa jest zwiększające się bezrobocie, które pociąga za sobą negatywne skutki nie tylko gospodarcze, lecz również społeczne. Jednym ze sposobów skutecznej walki z recesją gospodarczą i spadkiem zatrudnienia jest pobudzanie i wspieranie przedsiębiorczości. Rozwój przedsiębiorczości wydaje się najlepszym narzędziem do walki z bezrobociem, gdyż nie skupia się na łagodzeniu doraźnych skutków związanych z utratą pracy, lecz koncentruje się na walce z jego przyczyną. Przedsiębiorczość, w dobie kryzysu, powinna działać w trzech obszarach gospodarki. Są to: promowanie postawy przedsiębiorczej wśród ludzi młodych, rozwój innowacyjności w przedsiębiorstwach (ucieczka „do przodu”) oraz stymulowanie samozatrudnienia.

W artykule autorzy koncentrują się na ostatnim z wymienionych działań mających na celu zmniejszenie stopy bezrobocia w Polsce, tj. pobudzaniu przedsiębiorczości przez zachęcanie do podejmowania samodzielnej działalności gospodarczej. W analizie przedstawione zostały działania wybranych instytucji publicznych wspierających osoby chcące założyć i prowadzić własną działalność gospodarczą. Przedstawiając działalność poszczególnych urzędów, autorzy wskazują możliwości, z których mogą skorzystać potencjalni przedsiębiorcy. Wykazane zostały m.in. rodzaje udzielanego wsparcia, wielkość i ilość środków przekazywanych na rozpoczęcie działalności oraz skuteczność owej pomocy, również w ocenie samych przedsiębiorców.
\end{abstract}

\begin{abstract}
The most distinct and painful effect of the present economic crisis for the Polish society is the increasing unemployment, which causes negative consequences, not only economic, but above all - social. One of the ways to fight of economic recession and the decline in employment is encouraging and supporting entrepreneurship. Development of entrepreneurship seems to be the best way to fight unemployment, because it does not focus on mitigating its effects, but concentrates on defeating its direct cause. Entrepreneurship in times of crisis should concentrate on three areas of the economy: promotion of entrepreneurial attitudes among young people, development of innovation in enterprises (escape "forward") and stimulation of self-employment.

In this article, the authors focus on that last way of reducing the rate of unemployment in Poland stimulation of entrepreneurship, so as to create new businesses. In the analysis, the actions of selected public institutions, which assist individuals wishing to set up and run their own business, are presented. By outlining the activities of various institutions, authors demonstrate the possibilities which potential entrepreneurs can take advantage of. Among other types of support, the article de-
\end{abstract}


scribes the size and quantity of grants for setting up a business, and the effectiveness of this form of assistance, also in the opinion of new entrepreneurs.

Słowa kluczowe: kryzys gospodarczy; PARP; publiczne wsparcie przedsiębiorczości; urzędy pracy

Key words: economic crisis; PARP; public support for entrepreneurship; employment agency

\section{Wprowadzenie}

Wszechobecne słowo kryzys zdążyło nam się już osłuchać, by nie powiedzieć - znudzić. Już cztery lata minęły od symbolicznego rozpoczęcia kryzysu 15 września 2008 r., kiedy to nastąpił krach na giełdzie papierów wartościowych na Wall Street. Katalizatorem kryzysu finansowego było ogłoszenie bankructwa przez Lehman Brothers, czwarty pod względem wielkości amerykański bank inwestycyjny. Dla rynków finansowych, a dalej - gospodarek poszczególnych krajów - pociągnęło to za sobą konsekwencje o skali światowej. Od tamtej pory informacje o kryzysie, jego przyczynach, przebiegu, konsekwencjach, politycznych szczytach, ekonomicznych prognozach i skutkach towarzyszą nam stale, głównie za pośrednictwem poruszających ten temat mediów. Czy chcemy jednak tego, czy nie, zdarzenia makroekonomiczne mają w dobie globalnej gospodarki bezpośredni wpływ na nasze codzienne życie. Abstrahując od przewidywań i nie wdając się w dyskusję o tym, kiedy kryzys w Polsce się skończy, czy może jeszcze w ogóle się nie zaczął, autorzy skupili się w niniejszym artykule na jego ważnym i niezaprzeczalnym efekcie, jakim jest rosnące bezrobocie oraz przedsiębiorczości jako orężu walki z tym problemem.

Przedmiotem badań autorów i jednocześnie niniejszej pracy są działania wybranych instytucji publicznych na rzecz wsparcia przedsiębiorczości w dobie kryzysu gospodarczego w Polsce. Szczegółowym celem podjętej pracy było określenie zakresu i ocena działania instytucji państwowych w postaci urzędów pracy oraz Polskiej Agencji Rozwoju Przedsiębiorczości (PARP) w zakresie wsparcia udzielanego osobom zakładającym działalność gospodarczą. Badania obejmowały analizę przygotowywanych przez wojewódzkie urzędy pracy Regionalnych planów na rzecz zatrudnienia, analizę danych statystycznych zgromadzonych w raporcie Ministerstwa Pracy i Polityki Socjalnej (MPiPS), analizę i ocenę działań tych instytucji w zakresie wsparcia przedsiębiorczości oraz studium przypadku Grodzkiego Urzędu Pracy w Krakowie, które posłużyło do weryfikacji teoretycznych założeń zawartych w planach działania urzędu. W analizach brano pod uwagę najbardziej aktualne, dostępne dane. Jedynie część z nich obejmuje wyłącznie okres 2008-2010, gdyż takie dane zawarto w cennym dla autorów raporcie MPiPS Badanie ogólnopolskie nt. stosowanej formy aktywizacji zawodowej bezrobotnych, jaka jest przyznawanie środków Funduszu Pracy na podjęcie działalności gospodarczej, ze względu na to, że rok 2008 był początkową datą kryzysu finansowego.

\section{Wspieranie przedsiębiorczości w walce z rosnącą stopą bezrobocia}

Zwiększająca się stopa bezrobocia jest niezaprzeczalnie najbardziej widocznym i dotkliwym efektem kryzysu gospodarczego dla każdego społeczeństwa (Batorska, 2005; Dorocki, 2011). Dzieje się tak, gdyż wywołuje ona negatywne skutki nie tylko ekonomiczne, ale nade wszystko - społeczne. Pierwszą konsekwencją utraty pracy dla pracownika i jego rodziny jest pogorszenie standardu życia. W parze z nim następuje pogorszenie stanu psychicznego bezrobotnego, o bardzo różnym nasileniu, uzależnionym od licznych czynników: sytuacji rodzinnej, materialnej czy odporności psychicznej. W skrajnych przypadkach utrata pracy i trudności ze znalezieniem nowego zatrudnienia są przyczyną depresji, nałogów, a nawet problemów z prawem. Pogorszenie stanu psychicznego prowadzić może także do różnych form izolacji 
społecznej. Osoby bezrobotne, z racji ograniczonych środków i obniżonego poczucia własnej wartości, ograniczają uczestnictwo w życiu społecznym, kulturalnym czy politycznym lub w ogóle go nie podejmują. Bezrobocie ma zatem szereg poważnych negatywnych konsekwencji społecznych.

W latach 1990-2012 (ostatnie dane za wrzesień 2012 r.) stopa bezrobocia w Polsce ulegała wahaniom od 6,1\% w roku 1990 do maksymalnego poziomu 20\% w latach 2003 i 2004. Od 2004 r. bezrobocie w Polsce spadało aż do roku 2008, kiedy to osiągnęło najniższy od czasu „uwolnienia” polskiej gospodarki poziom 9,5\% (ryc. 1). Od roku 2008, co pokrywa się z oficjalnie przyjmowaną datą rozpoczęcia kryzysu, stopa bezrobocia w Polsce nie gwałtownie, ale jednak wzrosła. W latach 2010 i 2011, tak jak i w ostatnim badanym miesiącu (wrzesień 2012 r.) wynosiła ona $12,5 \%$.

Zdaniem autorów, najlepszym narzędziem do walki z bezrobociem, w szczególności w dobie kryzysu, jest wspieranie rozwoju przedsiębiorczości. Jest tak, ponieważ rozwój przedsiębiorczości nie tylko powoduje łagodzenie skutków bezrobocia, jak czynią to doraźne działania wspierające, w szczególności te oparte na jednorazowych daninach państwowych, lecz na walce z jego przyczyną - utratą pracy. Dodatkowym czynnikiem przemawiającym za pobudzeniem aktywności gospodarczej są kłopoty finansowe państwa, które w okresie kryzysu są tym bardziej odczuwalne i wpływają na obniżenie możliwości interwencyjnych władz publicznych.

Wspieranie przedsiębiorczości zdaniem autorów, w szczególności w okresie trudności gospodarczych, powinno skupiać się na trzech elementach:

- promowaniu, szczególnie wśród ludzi młodych, postawy przedsiębiorczej,

- rozwoju przedsiębiorstw na bardzo różnych polach (,ucieczce do przodu”),

- dążeniu do zakładania własnej działalności gospodarczej (szczególnie przez osoby młode, bezrobotne) w celu uzyskania samozatrudnienia i tworzenia nowych miejsc pracy.

Promowanie postawy przedsiębiorczej wśród ludzi młodych winno rozpoczynać się jak najwcześniej. Jak wynika z badań nad szkolnymi programami nauczania z zakresu przedsiębiorczości w latach 2009-2012, prowadzonymi w wybranych regionach Polski, Niemiec oraz Szkocji, w wielu regionach wskazanych trzech krajów nauczanie przedsiębiorczości rozpoczyna się dopiero w szkołach średnich. Przedsiębiorczość jako samodzielny przedmiot szkolny nie występuje na etapie edukacyjnym gimnazjum (i jego odpowiedników w innych krajach), a jedynie wybrane treści związane z kształtowaniem wiedzy i postaw przedsiębiorczych pojawiają się na innych zajęciach, co zdaniem autorów badań powinno ulec zmianie. Jak dowodzą

Ryc. 1. Zmiany poziomu stopy bezrobocia w Polsce w latach 1990-2012

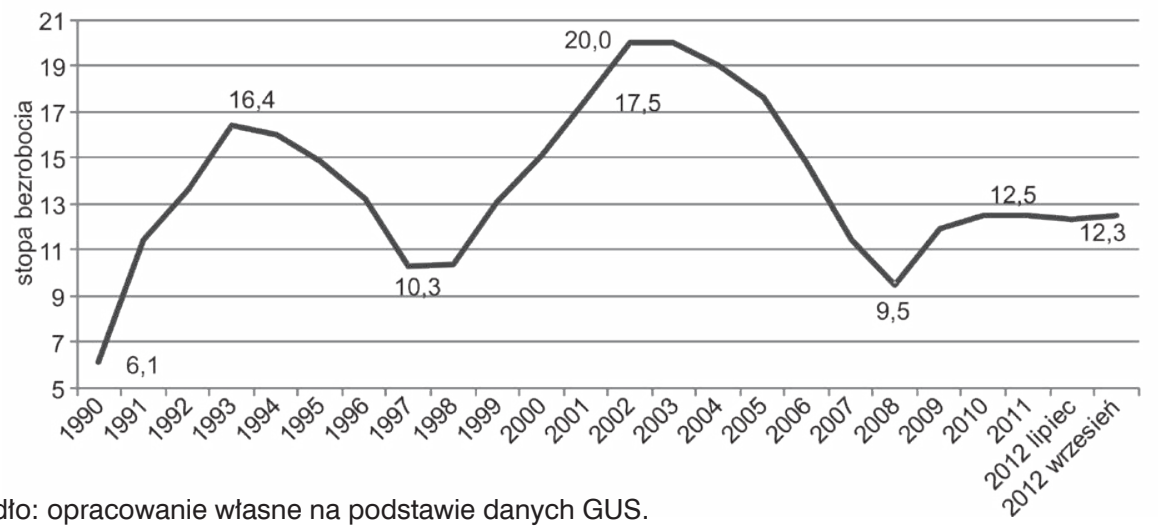

Źródło: opracowanie własne na podstawie danych GUS. 
przytoczone badania, zróżnicowany jest również zakres i obszar podejmowanej tematyki z przedsiębiorczości - w Szkocji tematyka zajęć skupia się na możliwościach znalezienia zatrudnienia lokalnie, $\mathrm{z}$ uwzględnieniem miejscowej struktury zatrudniania, a w Niemczech tematyka zajęć obejmuje szersze spojrzenie na gospodarkę, otoczenie rynkowe i uwzględnia zbiorowe kompetencje (Berger i in., 2012). W Polsce zagadnienia dotyczące przedsiębiorczości pojawiają się w gimnazjum w ramach przedmiotu wiedza o społeczeństwie, a następnie w szkole średniej na lekcjach przedmiotu podstawy przedsiębiorczości. Od bieżącego roku szkolnego dodatkowo tematyka ta będzie realizowana na zupełnie nowym przedmiocie ekonomia w praktyce.

Kształcenie w zakresie przedsiębiorczości, pomimo wskazywanych wad i potrzeby zmian, podlega jednak pozytywnym zmianom. To bardzo istotne, gdyż wybory dokonywane przez uczniów szkół średnich, dotyczące dalszej ścieżki kształcenia, powinny uwzględniać nie tylko ich zainteresowania, lecz także przyszłość na rynku pracy. Świadome planowanie swojego rozwoju zawodowego i wybór dalszego kierunku kształcenia na tak powszechnie wybieranych dziś studiach wyższych powinny być jednym z zadań przedmiotu podstawy przedsiębiorczości. W pewnym zakresie zadanie to już wydaje się być po części realizowane, gdyż młodzi ludzie, wybierając kierunek kształcenia, coraz częściej dokonują wyborów świadomych, uwzględniających przyszłość zawodową. Przykładem niech będą choćby wyniki badań przeprowadzonych w 2011 r. wśród 1347 studentów geografii 12 polskich uczelni państwowych. Badani studenci, zapytani o to, gdzie planują poszukiwać pracy po studiach, w zdecydowanej większości wybierali miejsca, których zdobycie związane jest z ukończonym kierunkiem studiów. Zadeklarowali oni plan poszukiwania pracy w: administracji państwowej i samorządowej (12,7\%), biurach planowania przestrzennego $(11,4 \%)$, szkolnictwie $(10,9 \%)$, przedsiębiorstwach geodezyjnych i kartograficznych (10,1\%) lub w założonej przez siebie działalności (9,5\%) (Piróg, 2012). Warto przy tym zaznaczyć, że cenna z punktu widzenia rynku pracy byłaby reorientacja celów współczesnych szkół wyższych w zakresie kształcenia akademickiego. Sytuacja społeczno-gospodarcza wymusza na nich zaprzestanie koncentrowania się wyłącznie na kształceniu elity intelektualnej (Piróg, 2012) i uwzględnianie w profilach kształcenia również przygotowania do wykonywania konkretnych zawodów lub prowadzenia działalności gospodarczej, z czym wiele uczelni nie może się jednak pogodzić.

Drugim wskazanym przez autorów zadaniem instytucji wspierających przedsiębiorczość w dobie kryzysu gospodarczego jest pomoc przedsiębiorstwom w ,ucieczce do przodu”, rozumianej przez autorów jako ucieczka przed konsekwencjami kryzysu dzięki rozwojowi przedsiębiorstwa (Dąbrowski, 2010). Rozwój przedsiębiorstw w różnych zakresach, jak choćby produktowym czy organizacyjnym, sprawia, że stają się one bardziej konkurencyjne na rynku, przez co mają większą szansę na przetrwanie niekorzystnej koniunktury (Zioło, 2007). Wsparcie przedsiębiorstw powinno zatem nie skupiać się na pomocy w zakładaniu działalności, lecz na wsparciu ich rozwoju, biorąc pod uwagę zasadę: „Kto nie idzie do przodu, ten się cofa”, jakże aktualną w dobie kryzysu.

Ostatnim, najbardziej, można by powiedzieć, tradycyjnym zadaniem instytucji wspierających przedsiębiorczość wskazanym przez autorów jest pomoc w dążeniu do zakładania własnej działalności gospodarczej. Zła sytuacja na rynku pracy paradoksalnie może być motorem do tworzenia nowych miejsc pracy przez samych zainteresowanych. Osoby przedsiębiorcze, nie znajdując zatrudnienia lub otrzymując propozycje pracy znacznie poniżej swoich kwalifikacji, mogą wybierać działalność gospodarczą jako sposób na samozatrudnienie, tworząc przy okazji nowe miejsca pracy. Zgodnie z danymi GUS, w Polsce od roku 2004 do 2010 liczba nowo rejestrowanych podmiotów gospodarczych z roku na rok zwiększała się (ryc. 2). W roku 2004 nowych podmiotów zarejestrowano poniżej 200, w latach 2006 i 2007 ich liczba utrzymywała się na poziomie 250, 
a w roku 2010 zarejestrowano ich 350 . W ostatnim roku liczba nowych podmiotów spadła do 300. Wsparcie dla otwierających nowe przedsiębiorstwa powinno być kierowane zatem po pierwsze w celu przeciwdziałania rozpoczynającej się niekorzystnej tendencji spadkowej w dynamice nowo otwieranych przedsiębiorstw, a po drugie w celu dobrego przygotowania przyszłych przedsiębiorców do działalności, co zmniejszy odsetek firm nieprzeżywających pierwszego roku działalności.

Ryc. 2. Dynamika zmiany zgłoszeń liczby nowych podmiotów gospodarczych w Polsce w latach 2003-2011

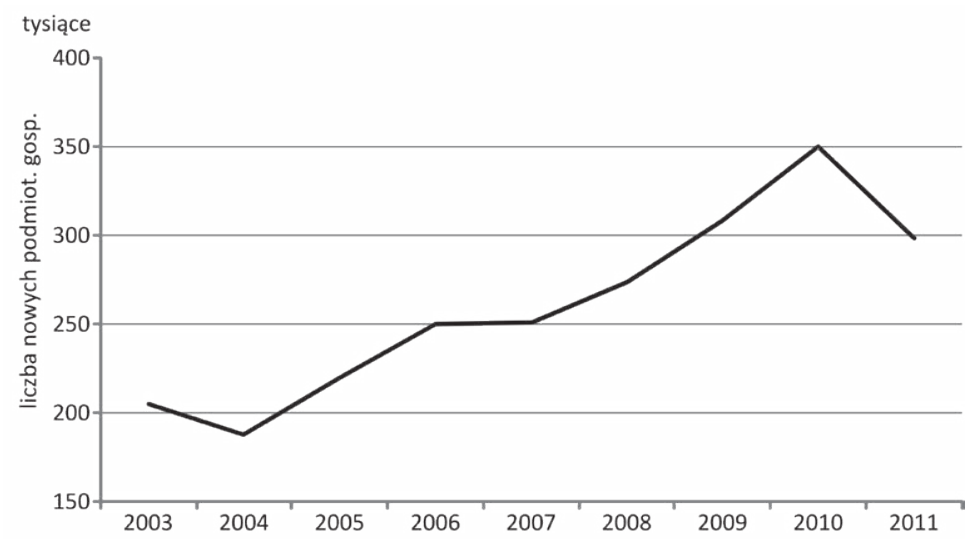

Źródło: opracowanie własne na podstawie danych GUS.

Godne uwagi jest również przestrzenne zróżnicowanie dynamiki poziomu zgłoszeń nowych podmiotów gospodarczych w Polsce w badanych latach, gdyż jest ono w porównaniu ze średnią krajową bardzo duże. Próbując wskazać prawidłowości przestrzenne, należy zauważyć, że najwyższą dynamiką zgłoszeń nowych podmiotów charakteryzują się powiaty województwa małopolskiego oraz powiaty ciągnące się południkowym pasem centralnych części województw: pomorskiego, kujawsko-pomorskiego, wielkopolskiego i dolnośląskiego (ryc. 3). Z kolei najsłabszą dynamikę wykazują w większości powiaty położone przy wschodniej granicy kraju

Ryc. 3. Dynamika zgłoszeń nowych podmiotów gospodarczych w powiatach Polski w latach 2003-2011

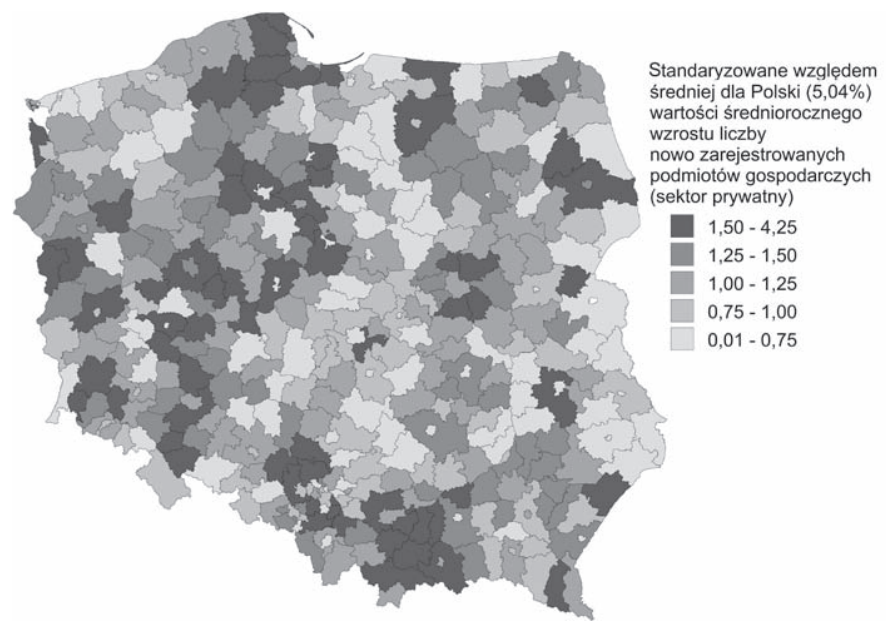

Źródło: opracowanie własne na podstawie danych GUS. 
(z wyjątkami takimi, jak powiat białostocki) oraz znów w południkowym pasie ciągnącym się zachodnimi krańcami województwa warmińsko-mazurskiego i mazowieckiego, przez województwo łódzkie, po województwo świętokrzyskie.

Abstrahując jednak od zróżnicowania przestrzennego i wracając do działań instytucji na rzecz przedsiębiorczości, należy stwierdzić, że praktyka pokazuje, że wskazane przez autorów potrzebne działania często nie są efektywne, a generalnie rzecz biorąc pomoc przedsiębiorcom w Polsce ma bardzo ograniczony charakter. Jak wynika $\mathrm{z}$ badań przeprowadzonych przez PARP $\mathrm{w}$ grudniu 2009 r., polscy przedsiębiorcy w niewielkim stopniu znają i korzystają z pomocy instytucjonalnej. Badania obejmujące próbę 1205 przedsiębiorstw wskazują, że 56\% z nich nie korzystało z żadnej zewnętrznej pomocy w czasie rozpoczynania i późniejszego prowadzenia własnej działalności. Instytucjami, z których pomocy najczęściej korzystały przedsiębiorstwa, były banki komercyjne (26\%) - zapewne głównie w zakresie udzielania pożyczek i kredytów - oraz urzędy pracy (9\%). $\mathrm{Z}$ pomocy pozostałych instytucji przedsiębiorcy korzystali w bardzo ograniczonym zakresie. Jedyne wskazane przez nich instytucje to urzędy miasta/gminy (2\%), Państwowy Fundusz Rehabilitacji Osób Niepełnosprawnych (PFRON), PARP oraz Agencja Rozwoju Regionalnego (ARR) - po 1\% (Orłowski i in., 2010). Pierwotną przyczyną tak słabego wykorzystania oferowanej pomocy jest zapewne słaba wiedza i niedocierająca do przedsiębiorców informacja o dostępnych formach pomocy. Świadczy o tym choćby badanie przeprowadzone przez MPiPS, z którego wynika przykładowo, że o najczęściej wykorzystywanej pomocy urzędów pracy, jaką jest możliwość otrzymania środków na rozpoczęcie działalności, 1/3 badanych przedsiębiorców (ubiegających się o nie) dowiedziała się od rodziny/znajomych, a zaledwie 31,9\% - z informacji dostępnych publicznie (Badanie ogólnopolskie..., 2011).

Wyniki te dały autorom powód do przeprowadzenia analizy pomocy oferowanej przez państwowe instytucje wspierania przedsiębiorczości, w której to analizie autorzy skupili się na dwóch głównych narzędziach: urzędach pracy oraz PARP. Urzędy pracy zostały wybrane do analizy jako instytucje, z których jak się okazuje, przedsiębiorcy korzystają najczęściej. Państwowa Agencja Rozwoju Przedsiębiorczości została natomiast wybrana spośród wskazywanych przez przedsiębiorców pozostałych instytucji jako narzędzie, którego głównym zadaniem jest wspieranie przedsiębiorczości (w przypadku ARR, PFRON, urzędów miasta/gminy działania te są jedynie jednymi z licznych innych działań tych instytucji i mają bardzo ograniczony zakres).

\section{Urzędy pracy}

Zakres działania urzędów pracy corocznie określany jest przez każdy wojewódzki urząd pracy w przygotowywanych planach zwanych Regionalnymi planami działania na rzecz zatrudnienia. Plany te są ogólnodostępne i publikowane na stronach internetowych urzędów, choć z przeprowadzonej przez autorów analizy wynika, że nie wszystkie urzędy dbają o częstą aktualizację danych (na stronach kilku urzędów zamieszczone były plany na 2011 r., a nie na rok bieżący). Analiza zapisów Regionalnych planów... wojewódzkich urzędów pracy na 2012 i 2011 r. (plany z 2011 r. brano pod uwagę, gdy nie było dokonanej aktualizacji) pokazuje, że każdy wojewódzki UP zakłada podjęcie działań na rzecz wspierania przedsiębiorczości, jednak zakres pomocy urzędów w planach określony jest z bardzo zróżnicowanym stopniem szczegółowości. W niektórych planach wyszczególnione są konkretne działania skierowane do określonych grup odbiorców, często z zasadami realizacji, celem działania i szczegółowymi wymaganiami w stosunku do chcących zeń skorzystać. Inne plany zawierają jedynie ogólne cele działania urzędów, zapisane hasłowo. We wszystkich jednak planach, zarówno szczegółowych, jak i ogólnych, pojawiają się działania na rzecz wspierania przedsiębiorczości. 
Najczęstsze cele zawarte w planach wojewódzkich UP to:

- promowanie przedsiębiorczości w regionie,

- wsparcie osób bezrobotnych dążących do rozpoczęcia działalności gospodarczej przez środki finansowe i wsparcie szkoleniowe,

- wsparcie istniejących przedsiębiorstw w dążeniu do zwiększania liczby stałych miejsc pracy,

- włączenie działania na rzecz rozwoju innowacyjnej gospodarki przez wsparcie transferu wiedzy z instytucji naukowych do przedsiębiorstw.

Najbardziej znaczącą i najczęściej wykorzystywaną formą pomocy, jaką urzędy pracy oferują osobom chcącym rozpocząć własną działalność gospodarczą, są środki na jej rozpoczęcie pochodzące z Funduszu Pracy. Jak wynika z raportu MPiPS (Badanie ogólnopolskie..., 2011), wysokość środków przeznaczanych na ten cel w latach 2008-2010 stale rosła. W roku 2008 wynosiła ona niecałe $700000 \mathrm{zl}$, natomiast w roku 2010 już dwukrotnie więcej - blisko 1400000 zł. Wzrosła również liczba osób, które skorzystały z tej formy pomocy urzędu pracy. W roku 2008 środki otrzymało 52160 bezrobotnych, a w roku 2010 o połowę więcej - 77020 wnioskujących (ryc. 4).

Z racji dużo większego przyrostu wielkości środków w stosunku do liczby wnioskujących wzrosła również średnia wysokość środków przyznanych wnioskującemu z 13400 zł w roku 2008 do 18040 zł w roku 2010. Pomimo wskazanych wzrostów zarówno wysokości środków ogółem, jak i średnich wartości przyznawanych poszczególnym wnioskującym, są one nadal bardzo niskie. Wielkość przyznawanych środków w stosunku do potrzeb osób rozpoczynających działalność gospodarczą jest w przypadku ogromnej większości z nich bardzo nikła.

Ryc. 4. Wielkość dofinansowania ze środków Funduszu Pracy na podjęcie działalności gospodarczej przez bezrobotnych oraz liczba osób, które otrzymały dofinansowanie w latach 2008-2010

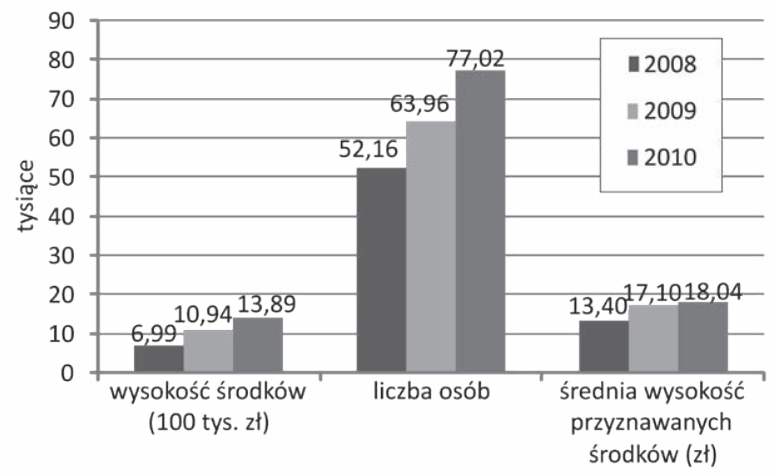

Źródło: Badanie ogólnopolskie... (2011).

Ciekawym zagadnieniem jest również przestrzenny rozkład wielkości przyznawanych środków i osób rozpoczynających działalność z pomocą Funduszu Pracy (ryc. 5). W badanych latach 2008-2011, największe nakłady na rozpoczęcie działalności przez wnioskujących przeznaczono w województwie mazowieckim (ponad 400 tys. zł). Drugie pod tym względem było województwo śląskie (ponad 350 tys. zł), a trzecie - województwo wielkopolskie (niecałe 300 tys. zł). Najmniejsze nakłady natomiast przeznaczono na ten cel w województwach lubuskim i podlaskim (niewiele ponad 90 tys. zł).

Inny rozkład przyjmują wielkości kosztów poniesionych przez urzędy pracy na rozpoczęcie jednej działalności. Wielkości te wahają się jednak nieznacznie w badanych latach od 16 do 17 tys. zł (ryc. 6). 
Ryc. 5. Środki z Funduszu Pracy przyznane bezrobotnym na założenie działalności gospodarczej w latach 2008-2011* oraz liczba osób, które uruchomiły działalność gospodarczą dzięki Funduszowi Pracy

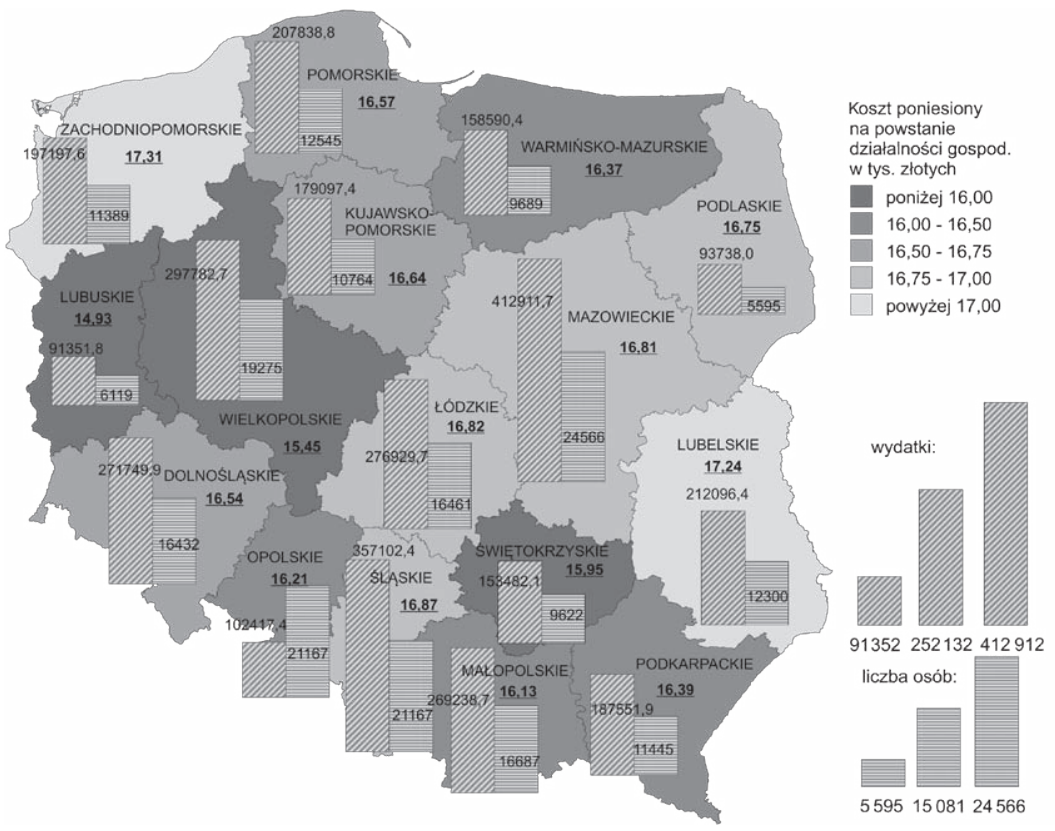

Źródło: opracowanie własne na podstawie: Badanie ogólnopolskie... (2011).

Ryc. 6. Zależność pomiędzy nakładami dla bezrobotnych z Funduszu Pracy a liczbą osób, które uruchomiły własną działalność gospodarczą dzięki Funduszowi Pracy w latach 2008-2011

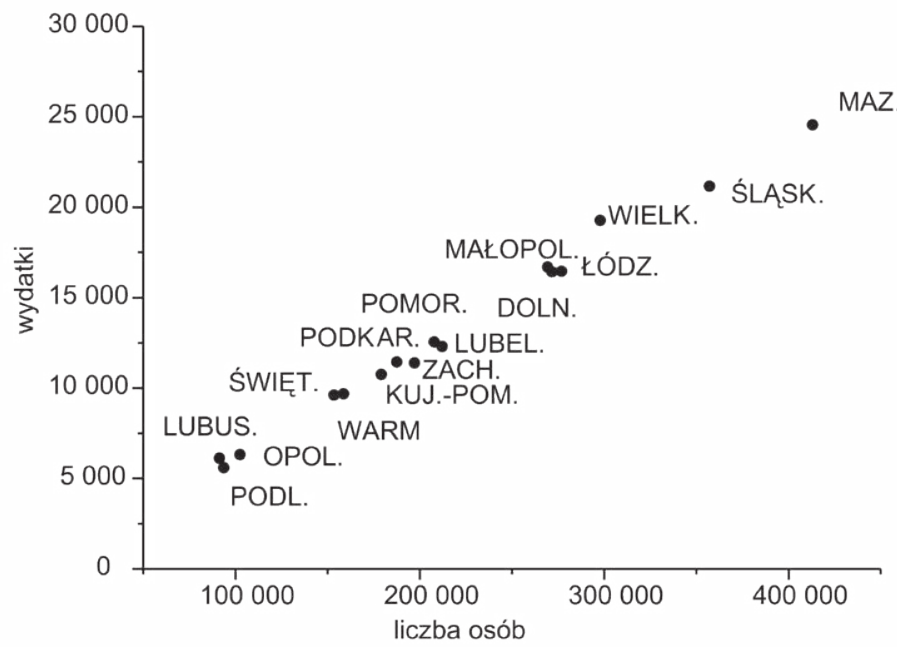

Źródło: opracowanie własne na podstawie: Badanie ogólnopolskie... (2011). 
Niemniej jednak, liczba nowych przedsiębiorców, którzy skorzystali ze środków z Funduszu Pracy wśród ogółu rozpoczynających działalność gospodarczą jest znacząca. W latach 2008-2010 największy udział wśród wszystkich nowych przedsiębiorców stanowili oni w województwie lubuskim - aż 34\%, zachodniopomorskim - 29\%, wielkopolskim - 28\%, kujawsko-pomorskim i świętokrzyskim - po 27\%. Jedynie w województwie łódzkim (16\%), podkarpackim (17\%) i warmińsko-mazurskim (19\%) stanowili poniżej 20\% nowych przedsiębiorców (ryc. 7).

Ryc. 7. Udział osób rozpoczynających działalność gospodarczą z wykorzystaniem środków z Funduszu Pracy w ogóle rozpoczynających działalność gospodarczą w latach 2008-2010

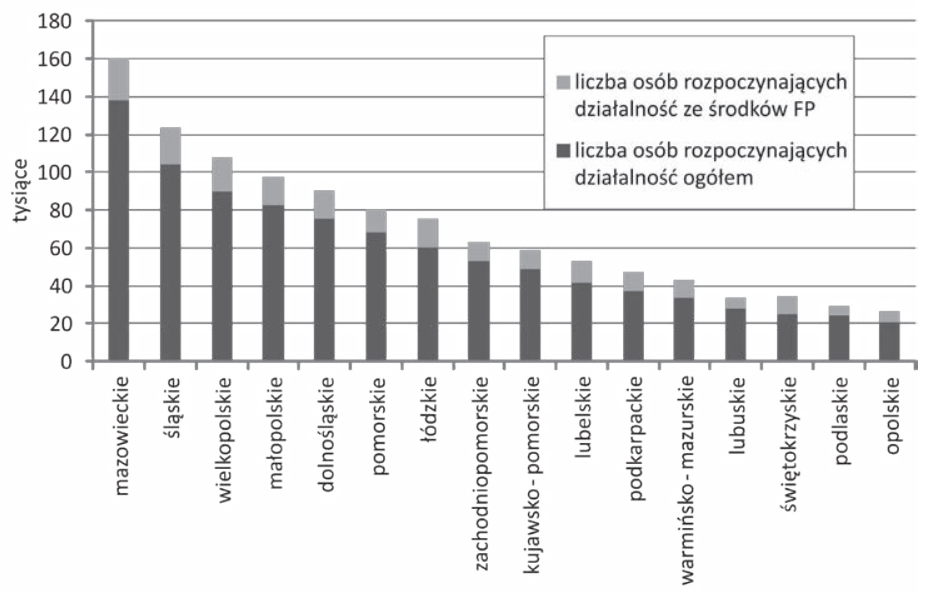

Źródło: Opracowanie własne na podstawie: Badanie ogólnopolskie... (2011).

Oprócz najpopularniejszej formy w postaci środków na rozpoczęcie działalności, ubiegający się o nie korzystają również z innych form pomocy oferowanych przez urząd pracy. Najczęściej korzystają ze szkoleń zawodowych (43,1\%), staży lub praktyk zawodowych $(21,6 \%)$, rzadziej z pośrednictwa pracy $(7,2 \%)$, porad lub doradztwa zawodowego $(6,5 \%)$ oraz warsztatów/zajęć grupowych z zakresu aktywnego poszukiwania pracy $(5,9 \%)$ (ryc. 8).

Ryc. 8. Korzystanie przez ubiegających się o dotacje na rozpoczęcie działalności z form wsparcia urzędów pracy

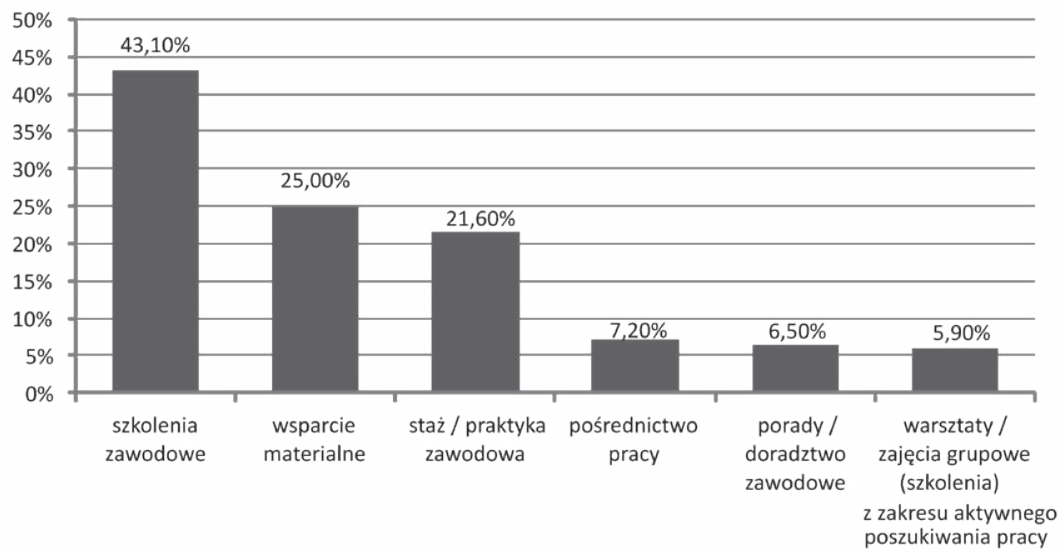

Źródło: Opracowanie własne na podstawie: Badanie ogólnopolskie... (2011). 
Najważniejszą z punktu widzenia rozpoczynających działalność jest oferta szkoleniowa. Zgodnie z wynikami badań nad zakresem tematycznym szkoleń oferowanych przez powiatowe urzędy pracy zawartych w raporcie MPiPS (Badanie ogólnopolskie..., 2011), wśród szkoleń mających tematycznie związek z zakładaniem działalności urzędy pracy najczęściej proponują szkolenia z zakresu: podstaw przedsiębiorczości $(67,6 \%)$, informacji o formalnościach związanych z rozpoczęciem i prowadzeniem działalności gospodarczej $(63,6 \%)$ oraz praktycznych porad związanych z prowadzeniem działalności gospodarczej (57,6\%). Ponad 1/3 urzędów oferuje natomiast szkolenia z zakresu: sposobu rozliczania przyznawanych środków (39\%), poprawnego przygotowania wniosków o dofinansowanie działalności gospodarczej (pod względem formalnym) (39\%), poprawnego przygotowania wniosków o dofinansowanie działalności gospodarczej (pod względem merytorycznym: analiza szans i zagrożeń, analiza rynku) (35,7\%), warunków przyznawania dofinansowań na rozpoczęcie działalności (36,2\%) (Badanie ogólnopolskie..., 2011).

Jak wynika z analizy, oferta szkoleń dla rozpoczynających działalność występuje w wielu urzędach pracy, ale nie jest ona bogata i bardzo skoncentrowana na pozyskiwaniu środków na działalność.

Warto jednak dodać, że wyniki oceny (przez badanych w 2011 r.) pomocy urzędów pracy w podjęciu decyzji o rozpoczęciu działalności gospodarczej i przygotowaniu wniosku o dofinansowanie były bardzo wysokie: średnio 4,35 (w skali 1-5) (Badanie ogólnopolskie..., 2011). Co bardzo istotne, a przemawiające również na korzyść pomocy z urzędu pracy wśród badanych przedsiębiorców, którzy rozpoczęli działalność gospodarczą z udziałem ich wsparcia finansowego w latach 2008-2011, aż 85\% osób nadal prowadzi tę działalność. „Przeżywalność” tych nowych firm jest zatem wysoka. Czy wpływ na ten wynik miały szkolenia przygotowujące przedsiębiorców do prowadzenia działalności, a prowadzone przez urzędy pracy? Niestety, nie można tego jednoznacznie stwierdzić.

Po dokonaniu analizy zapisów Regionalnych planów na rzecz zatrudnienia i zgromadzonych danych statystycznych autorzy postanowili skonfrontować zapisy i przeważający, pozytywny obraz wyłaniający się ze statystyk z rzeczywistością. W tym celu udali się do Grodzkiego Urzędu Pracy w Krakowie, by sprawdzić jego ofertę dla potencjalnych przedsiębiorców. Niestety, okazało się, że uzyskanie pomocy nie jest takie proste i wymaga spełnienia licznych warunków. Po pierwsze, jak w przypadku wszystkich urzędów pracy, by skorzystać z pomocy należy być zarejestrowanym jako osoba bezrobotna. W Krakowie, by starać się o pomoc należy mieć status bezrobotnego przez minimum miesiąc. Kierowanie pomocy do osób bezrobotnych jest zdaniem autorów działaniem mało celowym. Bezrobotni, a zatem osoby, które prawdopodobnie dłuższy czas nie mogły poradzić sobie ze znalezieniem pracy na rynku, mogą okazać się zbyt mało przedsiębiorczy, by prowadzić własną działalność gospodarczą. Poza tym wymóg bycia bezrobotnym zapewne skłania osoby do zarejestrowania się na bezrobociu tylko dla skorzystania z oferty dla przyszłych przedsiębiorców (strata czasu i pieniędzy...).

Innymi wymaganiami, które należy spełnić, aby otrzymać pomoc, to bycie zameldowanym w Krakowie oraz brak odmowy przy proponowanych dotychczas ofertach pracy (a zatem trzeba cierpliwie wytrzymać miesiąc na bezrobociu, licząc na to, że nie znajdzie się żadna praca, co jednak nie jest trudne, bo ofert nie jest zbyt dużo). Co jednak bardziej istotne, o środki może starać się bezrobotny, który nie otrzymał dotychczas środków z Funduszu Pracy oraz nie prowadził działalności gospodarczej w okresie ostatnich 12 miesięcy. Po spełnieniu wszystkich wymagań, by otrzymać pomoc i środki na rozpoczęcie działalności z krakowskiego urzędu pracy należy przejść kilka etapów, z których każdy kończy się zaopiniowaniem urzędowej komisji. Najpierw należy złożyć wniosek, a następnie pójść na szkolenie. Po jego zaliczeniu i zakwalifikowaniu się do następnego etapu, należy napisać biznesplan swojej działalności. Jest on opiniowany i na podstawie oceny komisji oraz w zależności od liczby chętnych bezrobotny ewentualnie dostaje środki na działalność, 
którą zobowiązuje się prowadzić min. 12 miesięcy (inaczej środki podlegają zwrotowi). Środki muszą być oczywiście wydatkowane zgodnie z wytycznymi urzędu (np. wg zasad krakowskiego UP można z nich pokryć maksymalnie trzy czynsze, nie wolno finansować usług świadczonych przez rodzinę itd.). Co najdziwniejsze, bezrobotny, składając wniosek, musi mieć tytuł prawny do lokalu, w którym działalność ma być prowadzona, oraz posiadać, jeśli są wymagane, niezbędne zezwolenia i koncesje. Pierwszy z wymogów sprawia, że bezrobotny powinien posiadać lokal lub np. umowę najmu lokalu. Zakładając drugi wariant, musi zawrzeć umowę z wyprzedzeniem, przed złożeniem wniosku i płacić za wynajem lokalu przez cały czas starania się o dotację, nie mając jeszcze nawet założonej działalności gospodarczej. Drugi wymóg natomiast jest wręcz absurdalny - większość zezwoleń/ koncesji uzyskuje się bowiem na konkretną działalność gospodarczą, przy czym należy spełnić szereg określonych warunków. Niech przykładem będzie choćby najbardziej popularna koncesja - na sprzedaż napojów alkoholowych. Żeby uzyskać taką koncesję, należy się o nią starać jako przedsiębiorstwo, posiadać tytuł prawny do lokalu spełniającego określone wymagania oraz pozytywny odbiór stacji sanitarno-epidemiologicznej. Jak zatem widać, jest to niemożliwe, gdy jest się osobą bezrobotną składającą wniosek do UP.

Wszystkie wymienione przeszkody w otrzymaniu pomocy z urzędu pracy tracą jednak zupełnie swoje znaczenie w obliczu informacji, jaką uzyskaliśmy w szczerych rozmowach z pracownikami krakowskiego urzędu pracy, podczas których bez ogródek poinformowali nas oni, że składanie wniosku teraz (połowa września) nie ma sensu. Okazuje się bowiem, że w jednym z największych polskich miast środki na dofinansowanie działalności w urzędzie pracy kończą się już we wrześniu, a o kolejne można starać się dopiero od stycznia.

Pozytywna ocena pomocy urzędów pracy dla rozpoczynających działalność gospodarczą wyłaniająca się z początkowych analiz statystyk, raportu MPiPS i zapisów Regionalnych planów na rzecz zatrudnienia w konfrontacji z realiami przykładowego, krakowskiego urzędu pracy zdecydowanie się zatem zmienia...

\section{Polska Agencja Rozwoju Przedsiębiorczości}

W drugiej części opracowania pochylono się nad działaniami realizowanymi przez PARP. Jest to instytucja rządowa powstała w 2000 r., której zadaniem jest zarządzanie funduszami z budżetu państwa i Unii Europejskiej, przeznaczonymi na wspieranie: przedsiębiorczości, innowacyjności i rozwoju zasobów ludzkich. Działania Agencji koncentrują się głównie na stymulowaniu i kreowaniu postaw przedsiębiorczych. Zgodnie z głoszonymi hasłami: „PARP - wspiera przedsiębiorców w realizacji ich wizji” czy „PARP - partnerem w drodze do sukcesu Twojej Firmy" celem działania agencji jest realizacja programów wspierających działalność małych i średnich przedsiębiorstw (MŚP), rozwój regionalny i zasobów ludzkich oraz wykorzystywanie i rozwój nowych technologii i innowacji.

Agencja posiada dobrze rozbudowane usługi online, co w znaczący sposób zwiększa dostępność do jej oferty. Każdy zainteresowany w czterech krokach może odnaleźć programy realizowane przez Agencję, wśród których znajdują się programy pomocne w założeniu własnej firmy. Ofertę taką można odnaleźć zarówno w ofercie skierowanej do kandydata na przedsiębiorcę, jak i przedsiębiorcy lub pracownika. Określając potrzeby, można odnaleźć pozycje: „chcę założyć firmę”, jak i ,chcę ponownie założyć”. Osobno określone są oferty z zakresu wiedzy o tym, jak założyć firmę, jak prowadzić firmę, lub skąd pozyskać środki na start. Spośród wszystkich programów oferowanych przez PARP przeanalizowano pod kątem zakładania własnej działalności gospodarczej cztery wybrane: bazę ofert szkoleniowych - Inwestycja w kadry, pomoc informacyjną i doradczą ośrodków Krajowego Systemu Usług (KSU), akademię i publikacje PARP oraz Centralną Ewidencję i Informację o Działalności Gospodarczej (CEIDG). 
Ryc. 9. Liczba szkoleń PARP w latach 2009-2012 (A) oraz ich tematyka (B)

A.

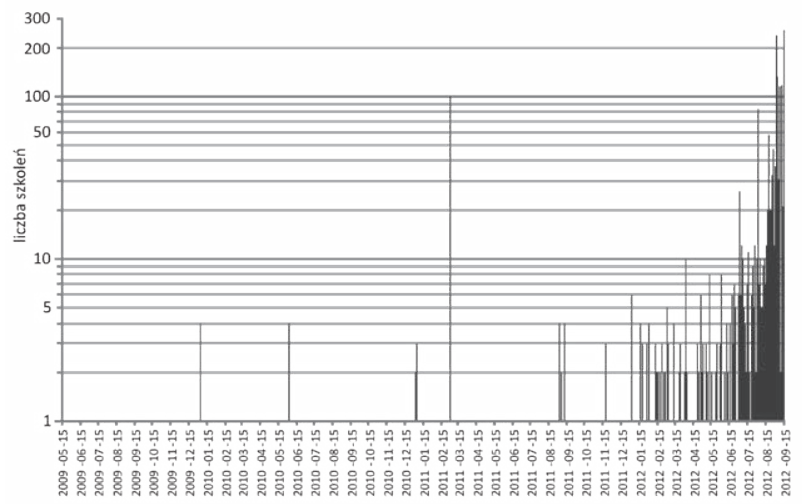

B.

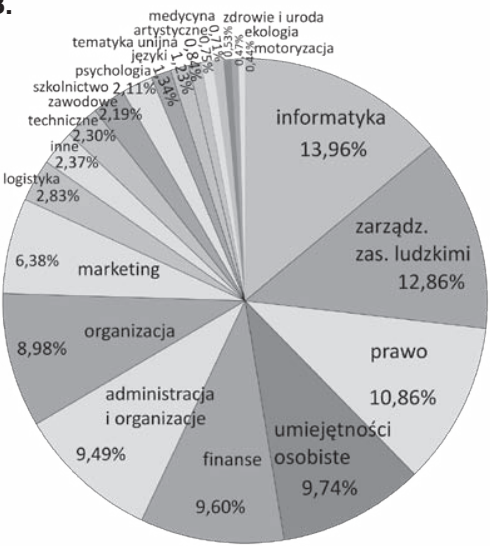

Źródło: opracowanie danych na podstawie kwerendy ofert PARP.

W pierwszej kolejności autorzy poddali analizie oferty szkoleniowe oferowane przez program „Inwestycje w kadry)”, w ramach którego przeanalizowano 1332 oferowane tematy kursów i szkoleń realizowanych na terenie całego kraju. Do 2012 szkolenia były prowadzone sporadyczne, a największe ich natężenie datuje się od połowy 2012 r. (ryc. 9A). Spośród ofert szkoleń najwięcej poświęcono informatyce i zarządzaniu zasobami ludzkimi (ryc. 9B). Brak natomiast jest propozycji odnoszących się do rozpoczynania własnej działalności gospodarczej. W układzie powiatowym szkolenia prowadzane są głównie w największych miastach. Wynika to zapewne $\mathrm{z}$ istniejącego tam zaplecza oraz dużej liczby potencjalnych klientów. Jednakże to peryferie są bardziej narażone na spowolnienie gospodarcze związane z kryzysem światowym. Dlatego wydaje się bardzo niekorzystnym brak szkoleń na północy - Warmia i Mazury oraz Pomorze Środkowe - czyli w obszarach o największej stopie bezrobocia (ryc. 10).

Ryc. 10. Lokalizacja szkoleń PARP (A) i rozmieszenie ośrodków KSU na tle stopy bezrobocia (B)

A.

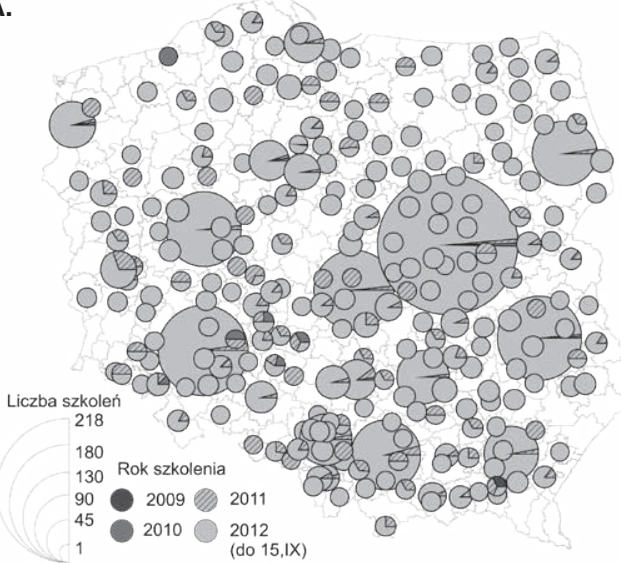

B.

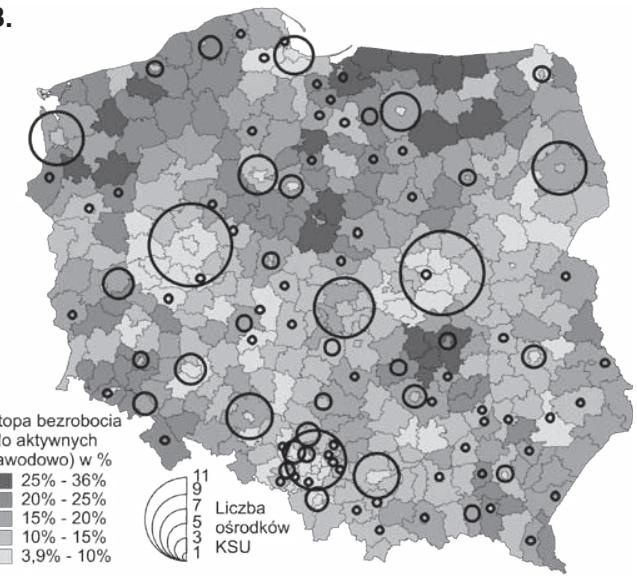

Źródło: opracowanie danych na podstawie kwerendy ofert PARP i KSU. 
Spośród 1332 szkoleń zrealizowanych i zaplanowanych do końca 2012 r. znaleziono tylko 5 szkoleń związanych z zakładaniem własnej działalności gospodarczej. Na szkoleniach tych oferowano wiedzę z zakresu zarówno procesu rejestracji działalności gospodarczej, jak i jej prowadzenia. Pomijając jednak merytoryczną stronę szkoleń, skierowane one były głównie do ściśle określonych grup ludności. Byli to bezrobotni, osoby zwalniane z pracy (branża wojskowa), osoby do 25 roku życia lub powyżej 50 roku życia oraz kobiety i niepełnosprawni. W pozostałych przypadkach szkolenia były płatne i kosztowały od 4 tys. do 5 tys. zł. Następował więc proces marginalizacji wybranych grup społecznych prowadzący do ich dyskryminacji na rynku pracy (Osuch, Dwojak, 2009). Lokalizacja szkoleń również była nierównomiernie rozmieszona na terenie Polski. Szkolenia obejmowały głównie mieszkańców powiatów na południu Polski: tarnowskiego, limanowskiego, dąbrowskiego, suskiego, gliwickiego, a także Tarnobrzegu i województwa zachodniopomorskiego. Zauważyć należy, że szkolenia skierowane były w szczególności do grup osób silnie narażonych na bezrobocie, co ograniczało w znacznym stopniu dostęp do szkoleń dla tzw. przeciętnego człowieka, również w aspekcie wydłużenia wieku emerytalnego (Kurek, Rachwał, 2011).

Poza przedstawionymi działaniami szkoleniowymi, w PARP prowadzone są także programy informacyjne i doradcze realizowane w ramach powołanego do życia w 1996 r. Krajowego Systemu Usług. System składa się z ok. 200 zarejestrowanych ośrodków, świadczących usługi wspierające polskich przedsiębiorców. Misją ośrodków jest rozwój przedsiębiorstw przez zapewnienie najwyższej jakości usług w kluczowych obszarach wymagających wsparcia państwa. W ramach KSU świadczone są usługi dla przedsiębiorców z zakresu informacji oraz doradztwa dla przedsiębiorców i osób zamierzających rozpocząć działalność gospodarczą w ramach Punktów Konsultacyjnych KSU oraz z zakresu działań proinnowacyjnych dla przedsiębiorców w ramach Krajowej Sieci Innowacji. System oferuje również usługi finansowe, takie jak udzielanie poręczeń kredytów lub pożyczek dla przedsiębiorców, oraz usługi pilotażowe w zakresie ochrony środowiska i finansowania zwrotnego dla mikro- i małych przedsiębiorców. Wśród ośrodków KSU znajdują się zarówno Punkty Konsultacyjne, jak i ośrodki Krajowej Sieci Innowacji.

Punkty Krajowego Systemu Usług zostały w dużej minerze sfinansowane ze środków unijnych w ramach projektu ,Wsparcie systemu kompleksowych usług informacyjnych dla przedsiębiorców oraz osób zamierzających rozpocząć działalność gospodarczą poprzez finansowanie sieci Punktów Konsultacyjnych (PK)”, realizowanego w okresie od września 2008 r. do kwietnia 2012 r. w ramach PO KL. Celem projektu było zapewnienie dostępności usług dla przedsiębiorców i osób zamierzających rozpocząć działalność gospodarczą. W ramach podjętych działań oferowano usługi informacyjne z zakresu szeroko rozumianego rozwoju przedsiębiorczości, w tym dostępnych form wsparcia, świadczonych przez współpracujące ze sobą instytucje w ramach Krajowego Systemu Usług. W okresie realizacji projektu PK KSU obsłużyły 188568 klientów i zrealizowały 218541 usług.

Analizując rozmieszenie podmiotów KSU, można zauważyć, że punkty konsultacyjne i ośrodki zlokalizowane są na obszarze niemal całej Polski z niewielką przewagą części południowej (ryc. 11A). Jednakże wydaje się, że podobnie jak w przypadku miejsca prowadzonych szkoleń PARP, pominięte zostały regiony północno-wschodnie kraju i środkowe - Pomorza, czyli regiony najbardziej zagrożone bezrobociem, posiadające najniższy współczynnik aktywności ekonomicznej (Makieła, 2007), w których to takie działania wydają się jak najbardziej pożądane (Rachwał, 2010). 
Ryc. 11. Lokalizacja Punktów Konsultacyjnych KSU (A) i udział usług biznesowych dostępnych dla osób rozpoczynających działalność gospodarczą dostępnych w poszczególnych województwach w 2012 r. (B)

A.

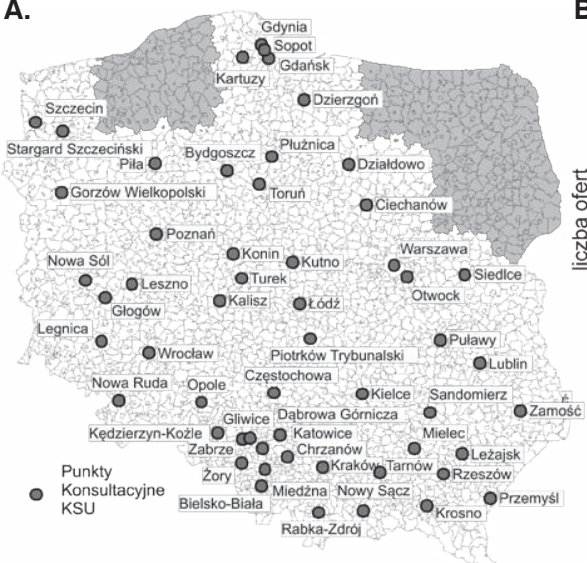

B.

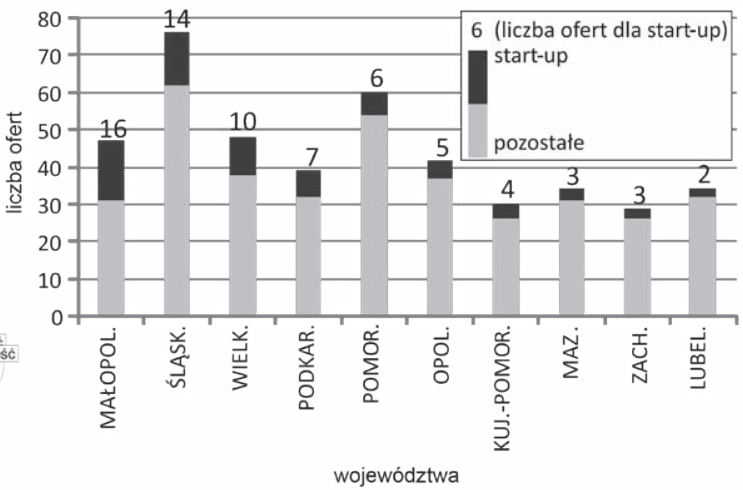

Źródło: opracowanie danych na podstawie kwerendy ofert KSU.

Spośród ofert systemu najbardziej przydatny dla osób planujących założyć własną działalność gospodarczą jest program „Wsparcie dla nowych firm”. Ta bezpłatna oferta realizowana jest przez 330 konsultantów w 51 Punktach Konsultacyjnych KSU i skierowana jest do początkujących przedsiębiorców. Wśród ofert KSU można znaleźć m.in. to, jak krok po kroku założyć własną firmę, dobierając jej optymalną formę prawną oraz rodzaj opodatkowania; jakie dokumenty są niezbędne do rejestracji działalności gospodarczej i jak je przygotować; jakie czekają przedsiębiorcę obowiązki rejestracyjne: w organie rejestrującym - ewidencja działalności w gminie lub Krajowym Rejestrze Sądowym (KRS) - na potrzeby ubezpieczeń społecznych, dla celów statystycznych i innych; jaki jest orientacyjny czas potrzebny na założenie firmy; jakie czekają opłaty związane z rejestracją firmy itp.; skąd i w jaki sposób pozyskać środki finansowe na założenie i rozwój firmy oraz jak pokonywać problemy pojawiające się w bieżącej działalności przedsiębiorstwa. Obok powyższych bezpłatnych ofert informacyjnych, KSU oferują płatną usługę doradczą w cenie 160 zł (90\% refunduje państwo) z zakresu konsultacji profilu planowanej działalności gospodarczej lub pomocy w przygotowaniu biznesplanu i zgromadzeniu niezbędnej dokumentacji. Można również skorzystać z płatnej asysty w prowadzeniu działalności gospodarczej (cena 240 zł) z zakresu formalno-prawnych obowiązków związanych z prowadzeniem firmy; marketingu przedsiębiorstwa; organizacji firmy lub korzystania ze źródeł finansowania dedykowanych przedsiębiorcom. Spośród oferowanych usług w $2012 \mathrm{r}$. oferty skierowane do start-upów stanowiły nie więcej niż $25 \%$ ogółu propozycji, przy czym najwięcej ofert było w Małopolsce i na Śląsku (ryc. 11B)

Następna poddana analizie usługa to Centralna Ewidencja i Informacja o Działalności Gospodarczej. Jest to działający od 2011 r. portal ułatwiający założenie działalności gospodarczej (oraz jej zawieszenie, zakończenie lub wznowienie) zdalnie przy pomocy komputera. Portal zawiera wszystkie potrzebne formularze i instrukcje oraz materiały szkoleniowe. Usługa ta nie wpływa bezpośrednio na proces zakładania firm, tak jak w przypadku dotacji i zachęt finansowych (choć te działania spotykają się z krytyką ze względu na ich nieetyczność, tj. przekazywanie publicznych pieniędzy; Dziewulski, 2009), jednakże usługa ta usprawnia sam proces biurokratyczny (Wach, 2005). 
Analizując liczbę zakładanych firm w latach 1992-2012 (wrzesień), widać ciągły wzrost z gwałtownym skokiem w 2001 r. oraz spadkiem w 2011 r. (ryc. 12A). Analizując z kolei wykorzystanie możliwości działań online, widać, że systematycznie wzrasta wykorzystanie portalu. Gwałtowny wzrost obserwujemy po roku 2012, od kiedy to portal nie jest wykorzystywany jedynie do zakładania firm, lecz również do działań mających na celu zakończenie lub zawieszenie działalności (ryc. 12B). Działania te przekładają się na większe możliwości reagowania na zmieniające się warunki gospodarcze oraz ułatwiają dostęp dla regionów peryferyjnych. W analizie rozkładu aktywności na portalu można zwrócić uwagę na cykliczne przerwy związane z brakiem lub obniżeniem działań na portalu. W przeważającej większości są to weekendy i święta. W ujęciu tym wydaje się ciekawe, że najdłuższy zastój obserwujemy w tzw. weekendzie majowym, kiedy to na prawie tydzień ustają wszelkie działania administracyjne.

Ryc. 12. Zgłoszenia działalności gospodarczej w latach 1992-2012 (A) oraz wnioski zgłaszane przez CEIDG w III i IV kwartale 2011 oraz I i II kwartale 2012

A.

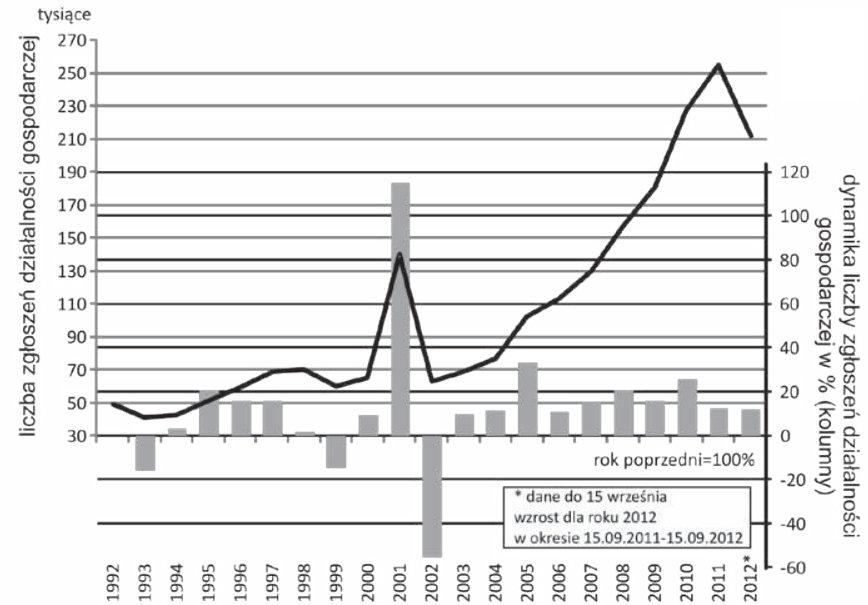

B.

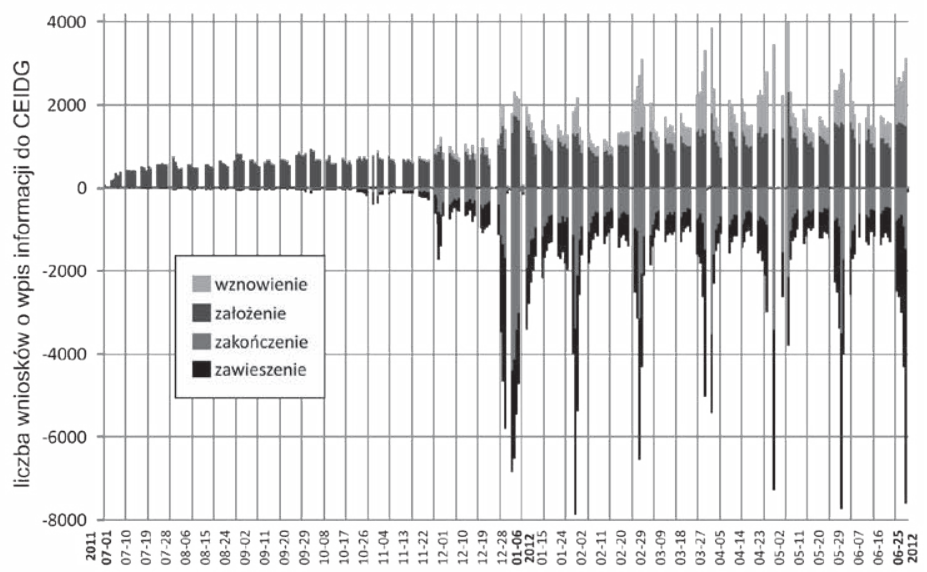

Źródło: opracowanie własne na podstawie GUS i CEIDG. 
Ostatnią analizowaną usługą jest Akademia PARP. Jest to portal edukacyjny dla małych i średnich przedsiębiorstw z systemem bezpłatnych szkoleń internetowych. Inauguracja portalu i projektu odbyła się w 2006 r szkoleniem e-learningowym nt. zarządzania strategicznego „Jak rozwijać firmę? Systemy zarządzania dla MMŚP”. Celem Akademii jest darmowe upowszechnienie dostępu do wiedzy biznesowej za pomocą metod zdalnej edukacji wśród: uczestników z mikro-, małych i średnich przedsiębiorstw, ograniczonej liczby uczestników z dużych przedsiębiorstw oraz osób planujących założenie własnej działalności gospodarczej. W ramach szkoleń uczestnicy mogą korzystać ze wsparcia infolinii z opiekunami kontaktującymi się telefonicznie lub przez e-mail, przez 12 godzin dziennie, przez 6 dni w tygodniu. Dodatkową możliwością jest dostęp do ekspertów merytorycznych - tutorów. Dokonując przeglądu oferowanych szkoleń pod kątem rozwijania własnej działalności gospodarczej, wyróżniono następujące szkolenie: „Jak założyć własną firmę” - składające się z 7 modułów omawiających nie tylko zagadnienia praktyczne, ale też teoretyczne. Godne uwagi są zamieszczone na stronach portalu testy, w tym test diagnozujący wiedzę.

Poza ciągłymi działaniami w PARP podejmowane są też specjalne działania na rzecz rozwoju własnej działalności. Przykładem mogą być uruchomione w zeszłym roku programy: start-up oraz techno starter, realizowane w ramach programu: „2011 - rokiem nowo powstałych firm”.

Start-up to nowy podmiot gospodarczy w początkowym okresie funkcjonowania lub przedsiębiorstwo, które rozpoczęło działalność i jest w pierwszej fazie rozwoju, niezależnie od jego wielkości. Najczęściej jednak jest to mikro- bądź małe przedsiębiorstwo, które nie sprzedaje jeszcze swoich produktów komercyjnie, lecz rozwija produkt i kompletuje dane marketingowe. Według badań PARP, corocznie publikowanych w Raporcie o stanie sektora MŚP, żywotność start-upów (firm działających poniżej 1 roku) wynosi 76,4\%. Natomiast technostarter (technology start-up) to przedsiębiorstwo założone przez pracownika lub pracowników środowisk naukowych wykorzystujących innowacyjne rozwiązania, do których posiadają prawa. Technostarterzy są najczęściej związani z uczelniami kapitałowo lub operacyjnie (spin-out) lub nie (spin-off). Instytucjami wspierającymi są parki oraz inkubatory technologiczne.

\section{Zakończenie}

Podsumowując przedstawione powyżej działania wybranych instytucji publicznych na rzecz wsparcia przedsiębiorczości w Polsce w dobie kryzysu gospodarczego, należy stwierdzić, że instytucje publiczne oferują szeroką gamę pomocy i usług związanych z założeniem własnej działalności gospodarczej. Jednakże to, co jest zauważalne, to małe wykorzystanie tych ofert, spowodowane bądź to brakiem informacji, bądź brakiem zainteresowania ze strony potencjalnych odbiorców tych usług. Inną zauważalną cechą w oferowanej pomocy publicznej jest ograniczony dostęp do niej. Ograniczenia te mają podłoże przestrzenne związane głównie z dyskryminacją peryferyjnych regionów Polski. Innym przejawem ograniczeń są uwarunkowania finansowe, które ograniczają możliwości pomocy wszystkim zainteresowanym. Dodatkowo uwidacznia się bardzo wyraźnie cenzus związany z wymogami stawianymi przed odbiorcami usług publicznych. Oferty kierowane są zazwyczaj do ludzi bezrobotnych, kobiet, osób młodych lub starszych. Również preferowane są różne branże zawodowe, np. wojskowi. Uwarunkowania te doprowadzają do patologii związanych np. z fałszowaniem swojej pozycji zawodowej (przejście na bezrobocie w związku z oczekiwaniem większej pomocy ze strony państwa). Wydaje się zatem właściwe podejmowanie większej liczby działań oraz ich promocji zwłaszcza wśród grup kreatywnych. Większa aktywizacja ludzi przedsiębiorczych może okazać się lepszym narzędziem walki z bezrobociem niż finansowanie wszystkich osób spełniających pewne odgórne kryteria. Zdaniem autorów, lepszymi adresatami omawianych usług oferowanych przez urzędy pracy i PARP byliby 
choćby mało doświadczeni, ale za to zdeterminowani do założenia własnej działalności gospodarczej (i przez to samozatrudnienia) absolwenci uczelni wyższych, lecz również szkół średnich.

Spośród wskazanych działań na pewno na uwagę zasługują działania innowacyjne, w tym głównie wykorzystanie technik ICT w procesie szkoleń i zakładania własnej działalności. $\mathrm{Z}$ jednej strony ułatwiają one pewne działania, a z drugiej strony je uatrakcyjniają, co również wydaje się godne pochwały. Pewien niedosyt można odczuć w związku z liczbą oferowanych szkoleń w terenie, gdzie większy nacisk powinien zostać położony na pomoc przy planowaniu i rozpoczęciu własnej działalności gospodarczej. To właśnie obawy związane z brakiem wiedzy z zakresu zakładania firmy oraz brak pomocy w tym temacie wydają się główną barierą rozwoju samozatrudnienia. Wzorem innych krajów wydaje się, że takie działania niekoniecznie muszą być realizowane przez urzędników państwowych, ale że właściwe jest wykorzystanie osób, które nabyły doświadczenie w praktyce.

\section{Literatura}

Batorska, U. (2005). Rodzaje i struktura bezrobocia w Polsce. Przedsiębiorczość - Edukacja, 1, 239-250.

Berger, S., Canning, R., Dolan, M., Kurek, S., Pilz, M., Rachwał, T. (2012). Curriculum-making in pre-vocational education in the lower secondary school: A regional comparative analysis within Europe. Journal of Curriculum Studies, 44(5), 679-701.

Dąbrowski, K. (2010). Przedsiębiorczość i edukacja jako strategie profesjonalistów na czas kryzysu. Przedsiębiorczość - Edukacja, 6, 493-498.

Dorocki, S. (2011). Wpływ kryzysu gospodarczego na przemiany struktur regionalnych Francji. Prace Komisji Geografii Przemystu Polskiego Towarzystwa Geograficznego, 17, 67-86.

Dziewulski, J. (2009). Liberalizm i keynesizm wobec kryzysu. Studia Ekonomiczne, 9, 2 (42), 25-50.

Kurek, S., Rachwał, T. (2011). Development of entrepreneurship in ageing populations of The European Union. Procedia - Social and Behavioral Sciences, 19, 397-405.

Makieła, Z. (2007). Przedsiębiorczość w Polsce w układzie regionalnym. Przedsiębiorczość - Edukacja, $3,18-23$.

MPiPS, (2011). Badanie ogólnopolskie nt. stosowanej formy aktywizacji zawodowej bezrobotnych, jaka jest przyznawanie środków Funduszu Pracy na podjęcie działalności gospodarczej. Gdańsk: EU-Consult Sp. z o.o.

Orłowski, W., Pasternak, R., Flaht, K., Szubert, D. (2010). Procesy inwestycyjne i strategie przedsiębiorstw w czasach kryzysu. Warszawa: Polska Agencja Rozwoju Przedsiębiorczości.

Osuch, W., Dwojak, A. (2009). Wspieranie przedsiębiorczości przez przeciwdziałanie marginalizacji społeczno-ekonomicznej grup nieprzystosowanych do konkurencji w gospodarce rynkowej jako dążenie do zrównoważonego rozwoju społeczeństwa informacyjnego (na przykładzie mniejszości ...). Przedsiębiorczość - Edukacja, 5, 244-253.

Piróg, D. (2012). Aspiracje i plany zawodowe młodzieży akademickiej w Polsce na przykładzie studentów geografii. W: A. Dudak, K. Klimkowska, A. Różański (red.), Przygotowanie zawodowe młodych pedagogów. Kraków: Oficyna Wydawnicza „Impuls”, 125-144.

Rachwał, T., (2010). Chapter 9. Entrepreneurship Education as a Growth Stimulus for Family Firms. W: A. Surdej, K. Wach (eds), Exploring the Dynamics of Entrepreneurship, Toruń: A. Marszałek Publishing House, 139-156.

Wach K., 2005, Wspótpraca matych i średnich przedsiębiorstw z ośrodkami naukowo-badawczymi na przykładzie Krakowskiego Parku Technologicznego. Zeszyty Naukowe Akademii Ekonomicznej w Krakowie, No. 671, s. 117-133.

Zioło, Z. (2007). Rola przedsiębiorczości w aktywizacji gospodarczej - zarys modelu. Przedsiębiorczość - Edukacja, 3, 10-17. 
Sławomir Dorocki, dr, Uniwersytet Pedagogiczny w Krakowie, Instytut Geografii, Zakład Przedsiębiorczości i Gospodarki Przestrzennej.

Absolwent studiów z zakresu geografii społeczno-ekonomicznej Uniwersytetu Pedagogicznego w Krakowie, doktor nauk humanistycznych w dyscyplinie historia (Instytut Europeistyki - Uniwersytet Jagielloński). Adiunkt w Instytucie Geografii Uniwersytetu Pedagogicznego w Krakowie. Jego zainteresowania badawcze skupiają się wokół problematyki regionów i procesów regionalizacji społeczno-gospodarczej, ze szczególnym uwzględnieniem zróżnicowania przestrzeni europejskiej oraz procesów integracji europejskiej i uwarunkowań historycznych.

Sławomir Dorocki, PhD, Pedagogical University of Cracow, Institute of Geography, Department of Entrepreneurship and Spatial Management.

Sławomir Dorocki, graduated from the Pedagogical University in Cracow, with an MA in geography, and a $\mathrm{PhD}$ in history at the Jagiellonian University (Institute of European Studies). Adiunkt (assoc. professor) at the Pedagogical University in Cracow, Institute of Geography. Research interests include regional problems and processes of socio-economic regionalization, with particular emphasis on the diversity of Europe, processes of European integration and historical conditions.

Agnieszka Świętek, mgr, Uniwersytet Pedagogiczny w Krakowie, Instytut Geografii, Zakład Przedsiębiorczości i Gospodarki Przestrzennej.

Absolwentka studiów z zakresu geografii, specjalności z przedsiębiorczością i gospodarką przestrzenną Uniwersytetu Pedagogicznego w Krakowie, gdzie pracuje jako asystent. Od 2010 r. prowadzi własną działalność gospodarczą. Jej zainteresowania badawcze skupiają się wokół zagadnień: edukacji (jako warunku poprawy poziomu życia grup zagrożonych wykluczeniem społecznym) oraz przedsiębiorczości (w szczególności przygotowania i sytuacji młodych ludzi w momencie wejścia na rynek pracy, wsparcia przedsiębiorców rozpoczynających działalność).

Agnieszka Świętek, MA, Pedagogical University of Cracow, Institute of Geography, Department of Entrepreneurship and Spatial Management.

Agnieszka Świętek, graduated from Pedagogical University in Cracow, with an MA in geography, specialized in Enterprise and land use. Asystent (assistant) at the Pedagogical University in Cracow, Institute of Geography. The author has also managed her own business since 2010. Her research interests are connected with education (as a condition of improving the standard of living of disadvantaged groups) and business (in particular, the preparation and situation of young people entering the labour market, and support to start-up companies).

Adres/Address: $\quad$ Uniwersytet Pedagogiczny w Krakowie Instytut Geografii, Zakład Przedsiębiorczości i Gospodarki Przestrzennej ul. Podchorążych 2, 30-084 Kraków, Polska e-mail: swietekaga@wp.pl,sdorocki@up.krakow.pl 


\title{
Wojciech Sadkowski
}

Uniwersytet Jagielloński

\section{Oferta sektora bankowego dla małych i średnich przedsiębiorstw w czasach kryzysu gospodarczego w Polsce}

\author{
The offer of the banking sector to small and medium-sized Polish enterprises \\ during a crisis
}

\begin{abstract}
Streszczenie
Podstawą sprawnego funkcjonowania gospodarki jest dobra współpraca przedsiębiorstw z bankami, przynosząca obustronne korzyści dla zainteresowanych podmiotów, mająca szczególnie istotne znaczenie w czasach kryzysu. Sektor MŚP stał się na tyle atrakcyjny, a banki w takim stopniu zainteresowały się obsługą firm z tego sektora, że współpraca na linii bank - przedsiębiorstwo zaczyna przynosić coraz lepsze rezultaty. Jednym z mierników tej współpracy jest wielkość akcji kredytowej banków dla przedsiębiorstw, która w 2011 r. znacząco wzrosła (o 14,2\%) w porównaniu z $2010 \mathrm{r}$. Poznanie specyfiki rynku międzybankowego (w czterech obszarach: prowadzenia rachunku bankowego, udzielania kredytów, wydawania i obsługi kart płatniczych oraz internetowej obsługi klienta) jest gwarancją zrozumienia istoty strategii banków i zależności występujących w polskiej gospodarce między podmiotami kredytującymi, które kreują podaż kredytów, a kredytobiorcami - małymi i średnimi podmiotami, które tworzą prawie $50 \%$ PKB oraz dają zatrudnienie dla ponad 2/3 zatrudnionych w Polsce.
\end{abstract}

\begin{abstract}
Fruitful cooperation between banks and businesses, which not only benefits stakeholders, but also provides aims particularly important in times of crisis, is the basis for efficient functioning of the economy. The SME sector has become so attractive, and banks are currently so interested in supporting companies from that sector, that co-operation between banks and businesses is beginning to yield much improved results. The amount of bank lending to businesses, which in 2011 increased significantly (by $14.2 \%$ ) compared to 2010, is one of the measures of this cooperation. Comprehension of the specifics of the interbank market (in four areas - maintaining a bank account, lending, issuing and processing of payment cards, and online customer services) creates understanding of the banks' strategies, and relationships that occur within the Polish economy, between funders, which create supply of credit, and borrowers - small and medium-sized entities that make up almost $50 \%$ of the GDP, and provide employment for more than two-thirds of employees in Poland.
\end{abstract}

Słowa kluczowe: bank; kredyt; małe i średnie przedsiębiorstwo; współpraca

Key words: bank; credit; small and medium-sized enterprises; cooperation

\section{Wprowadzenie}

Sektor małych i średnich przedsiębiorstw (MŚP) pełni w polskiej gospodarce bardzo ważną funkcję. Odpowiada za tworzenie prawie 50\% PKB, daje zatrudnienie $2 / 3$ wszystkich pracujących, przyczynia się do wzrostu przedsiębiorczości oraz konkurencyjności. Najpoważniejszą 
barierą rozwojową dla podmiotów tego sektora jest utrudniony dostęp do kapitału. Trudności w jego pozyskaniu wynikają z dużej niepewności, która wiąże się z dążeniem do technologicznego rozwoju, innowacji oraz niemożności dokładnego szacunku rozmiarów inwestycji tak, aby firma generowała zyski. Decydującym czynnikiem utrudniającym zdobycie kapitału jest więc związane z tym sektorem wysokie ryzyko.

W zdecydowanej większości przypadków $(64,8 \%)$ mikro-, małe i średnie podmioty są skazane tylko i wyłącznie na swoje fundusze (PARP, 2011). Niewystarczająca wielkość własnych nakładów inwestycyjnych powoduje, że firmy te sięgają po zewnętrzne strumienie kapitału, wśród których dużą popularnością cieszą się kredyty bankowe - udzielane na krótki, długi termin, zarówno w rachunku bieżącym, jak i kredytowym, inwestycyjne i obrotowe. Rozważania zawarte w niniejszym referacie oparte są na przekonaniu, że dobra współpraca banku z przedsiębiorstwem może przynieść korzyści obustronne i zapewnić długotrwałe relacje biznesowe, gwarantując dla podmiotu gospodarczego sprawdzone źródło kapitału i rozwój, a dla banku - pewny dochód i dobrą reklamę na rynku konkurującym o klienta korporacyjnego.

\section{Bank i jego współpraca z przedsiębiorstwem}

Działalność, którą prowadzi bank w zakresie obsługi klienta firmowego, można podzielić na kilka obszarów, takich jak:

- bieżąca obsługa przedsiębiorstwa (realizowana przez rachunek bieżący - należności wpływające od odbiorców za sprzedane towary, usługi, wypłata wynagrodzeń, pokrywanie zobowiązań, kredyt w rachunku bieżącym, lokowanie wolnych środków pieniężnych),

- lokowanie wolnych środków pieniężnych w różnych formach (lokata, papiery wartościowe),

- pozyskiwanie źródeł finansowania na działalność bieżącą i inwestycyjną (emisja bonów komercyjnych, pożyczki krótkoterminowe, kredyt bankowy, leasing, faktoring) (Grzywacz, 2006),

- obsługa w zakresie realizowania rozliczeń pieniężnych (realizowanie rozliczenia z zagranicą - akredytywa, inkaso dokumentowe, skup i sprzedaż waluty, gwarancja),

- doradztwo finansowe.

Dla banków małe i średnie przedsiębiorstwa są grupą podmiotów, która po ostatnim kryzysie z lat 2007-2009 okrzepła, posiada stabilną sytuację finansową oraz jest nastawiona na rozwój i ekspansję. Równie ważne jak stabilizacja finansowa jest otwarcie firm na nowoczesne usługi - bankowość online czy innowacyjne rozwiązania technologiczne. Coraz lepszy dostęp do firmowych baz danych ułatwia przyznawanie firmom kredytów. Rosnąca konkurencja na rynku w walce o klienta korporacyjnego powoduje wzrost jakości usług i obniżenie kosztów; banki w celu pozyskania małych i średnich podmiotów decydują się na wprowadzenie usług, które stają się wymogiem i koniecznością w XXI wieku (szybki kredyt - procesowany w ścieżce internetowej, obniżenie kosztów transakcji międzynarodowych, rozwijanie ofert firmowych kart kredytowych - obciążeniowych i przedpłaconych, rozwój trade finance, atrakcyjny kurs wymiany walut i zabezpieczenia się przed ryzykiem kursowym) (Styczek, 2012).

Pomimo rozwoju sektora usług bankowych dla firm, w dalszym ciągu spora grupa małych i średnich przedsiębiorstw nie jest zainteresowana ofertą bankową, co wynika:

- ze zbyt dużych żądań bankowych dotyczących zabezpieczeń,

- ze skomplikowanych i żmudnych procedur ubiegania się o kredyty,

- z niskiej zdolności kredytowej lub jej braku,

- za wysokich opłat i prowizji bankowych, a także wygórowanego oprocentowania,

- z długiego okresu oczekiwania na podjęcie decyzji przez bank,

- niekompetentnej obsługi bankowej (Korenik, 2006). 
Również banki mają zastrzeżenia do wiarygodności kredytowej swoich potencjalnych klientów, dotyczące:

- w wielu przypadkach niedostarczania kompletnych sprawozdań finansowych,

- niskiej rentowności i płynności w działaniu,

- słabej odporności na impulsy rynkowe,

- małych kapitałów własnych,

- niemożliwości zaoferowania przez MŚP zabezpieczenia adekwatnego do wielkości kredytu.

Przedstawienie problemów związanych ze współpracą banku z przedsiębiorstwem z punktu widzenia obu stron jest bardzo ważne dla pełnego zrozumienia się i nawiązania długotrwałej relacji, opartej na wzajemnym szacunku i partnerstwie biznesowym. Prawdziwe efekty takiego „związku” są widoczne i możliwe do oceny dopiero z perspektywy wielu lat. Budowanie wzajemnego zaufania jest tutaj sprawą kluczową - wiarygodność kredytowa i przejrzystość finansowa przedsiębiorstwa gwarantują również stabilność działalności banku, który ze sprawdzoną i solidną firmą może pójść na pewne ustępstwa cenowe (np. co do wysokości opłat ponoszonych przez danego klienta - opłat abonamentowych za bankowość elektroniczną, za prowadzenie rachunku walutowego, niższych kosztów przelewów międzybankowych). Bank przyjazny dla danego przedsiębiorstwa gwarantuje sobie tym sposobem znakomitą reklamę wśród potencjalnych klientów z tego obszaru.

\section{Polski rynek kredytów przeznaczonych dla firm}

Bardzo ważnym obszarem współpracy banku z podmiotem gospodarczym jest działalność kredytowa, dzięki której możliwy jest rozwój kredytobiorcy, przyczyniający się do wzrostu przedsiębiorczości oraz wprowadzania gospodarki na wyższy poziom. Sytuację na polskim rynku kredytowym prezentuje raport Narodowego Banku Polskiego o kondycji sektora przedsiębiorstw (NBP, kwiecień 2012). W raporcie tym wskazano odsetek podmiotów, które ubiegały się o kredyt, i rozpatrzonych pozytywnie wniosków w okresie pomiędzy 2008 r. a pierwszym kwartałem 2012 r. (ryc. 1). Widoczna jest tendencja spadkowa w liczbie firm, które ubiegały się o produkt kredytowy w badanym okresie czasu - odsetek ten spadł z poziomu 31\% w 2008 r. do ok. 21,5\% w czwartym kwartale 2011 r., przy czym ostateczna wielkość pozostała na podobnym poziomie od drugiego kwartału 2011 r. Takie zachowanie wynika z własnej oceny przedsiębiorstw na temat ich sytuacji finansowej - niepewne położenie powoduje zniechęcenie do zadłużania się.

Ryc. 1. Udział przedsiębiorstw ubiegających się o kredyt oraz odsetek pozytywnie rozpatrzonych wniosków kredytowych w latach 2008-2012
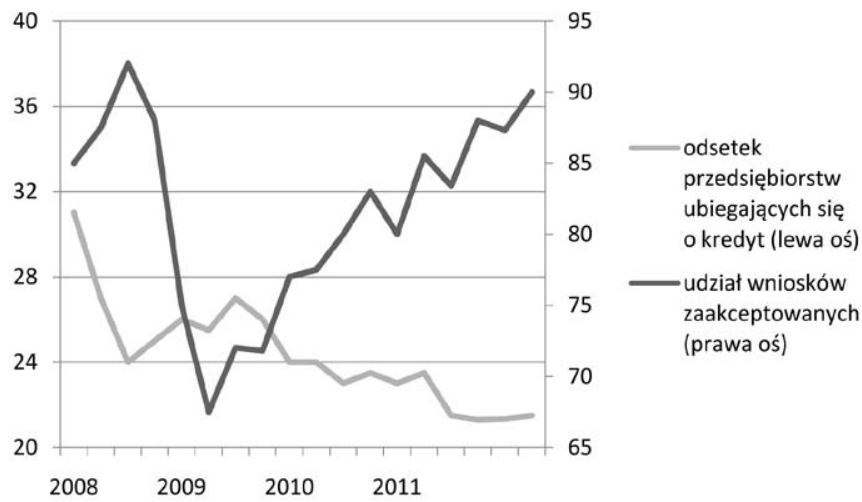

Źródło: NBP (kwiecień 2012). 
Również w przypadku, gdy przyszłość gospodarcza jest coraz większą niewiadomą, podmioty nie widzą szans dla siebie na uzyskanie kredytu.

Analizując wykres, można także zaobserwować silną korelację pomiędzy decyzją banku o przyznaniu kredytu a koniunkturą na światowych rynkach finansowych. Na przełomie 2008 i 2009 r., gdy kryzys osiągnął swoje apogeum, banki przestały ufać sobie nawzajem i potencjalnym klientom, ograniczając tym samym akcję kredytową. Późniejsza poprawa nastrojów na rynkach spowodowała stopniowy wzrost liczby przyznawanych kredytów. Tak więc w okresie ograniczenia akcji kredytowej bardzo cierpiały przedsiębiorstwa, dla których taka sytuacja stanowiła kluczowa barierę rozwojową. Sytuacja w 2010 i 2011 r. pokazuje, że zaufanie banków wraca do poziomu sprzed załamania, z czego korzysta również polska gospodarka. Niewielki spadek zaakceptowanych wniosków kredytowych w ostatnim kwartale 2011 r. nie był trwałą tendencją, co pokazał wzrost (o 1,5\%) odsetka przedsiębiorstw, które kredyt uzyskały w pierwszym kwartale $2012 \mathrm{r}$.

Najistotniejszym powodem odmów przyznania finansowania dla podmiotów gospodarczych w pierwszym kwartale 2012 r. był brak zdolności kredytowej. Spośród firm, których wniosek o kredyt został odrzucony, aż 55\% nie było zdolnych do przyszłego prawidłowego regulowania zobowiązań kredytowych, co stanowiło przyczynę odmowy rozpatrzenia wniosku. Jest to konsekwencja zaostrzenia polityki kredytowej przez banki wobec sektora MŚP w pierwszym kwartale 2012 r. w odpowiedzi na utrzymującą się niepewną sytuację gospodarczą (po raz pierwszy od początku 2010 r. banki podniosły marże na kredytach dla przedsiębiorstw, co ma związek z wyższym ryzykiem spadku koniunktury rynkowej).

Dla zobrazowania dostępności kredytów dla małych i średnich podmiotów została wykorzystana rycina $\mathrm{nr}$ 2. W latach 2010-2011 udział MŚP w ubieganiu się o finansowanie ze źródeł bankowych spadł z 24\% do poniżej 10\%. Równolegle zmniejszył się udział odrzuconych wniosków o kredyt, o który ubiegały się głównie podmioty będące w dobrej sytuacji ekonomicznej i optymistycznie oceniające przyszłą sytuację gospodarczą. Również wśród dużych spółek odnotować można tendencję spadkową odmowy udzielenia kredytu do poziomu 6-7\%.

Dostępność kredytów dla sektora MŚP w ostatnich latach uległa poprawie - banki akceptują coraz więcej wniosków. Równocześnie jednak systematycznie spada liczba jednostek, które ubiegają się o to źródło finansowania, co ma związek z samoistną selekcją podmiotów. Na staranie się o zasób potrzebnych środków pieniężnych decydują się firmy, które mają sta-

Ryc. 2. Odsetek firm sektora MŚP ubiegających się o kredyt oraz udział zaakceptowanych wniosków kredytowych w IV kwartale $2011 \mathrm{r}$.

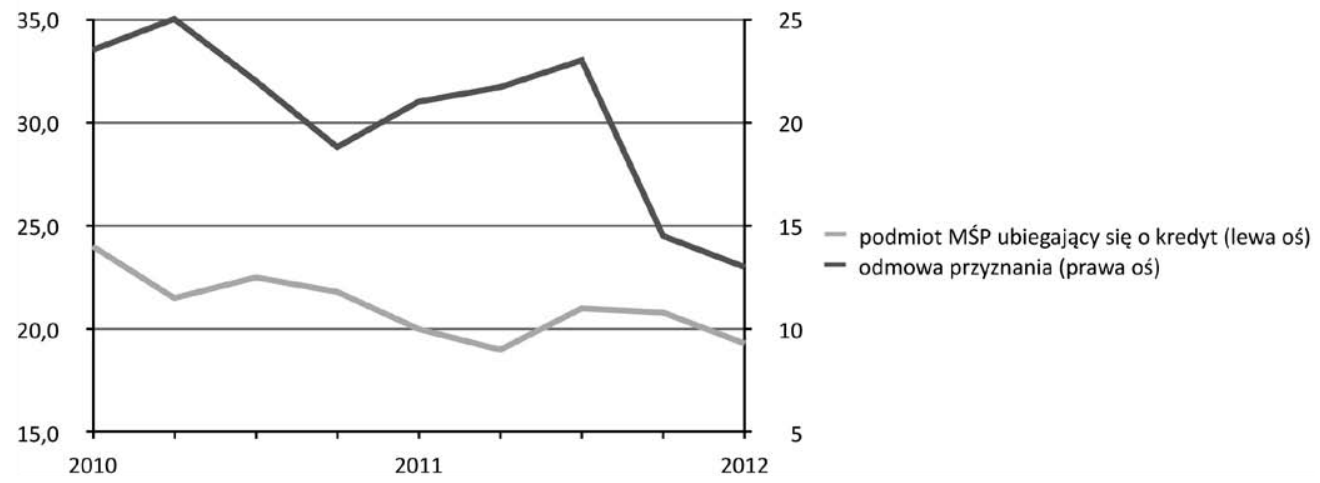

Źródło: opracowanie własne na podstawie NBP (2012, styczeń). 
bilną sytuację finansową, patrzą z optymizmem na rozwój swojej działalności, a także oczekują dobrych wyników z gospodarki.

W obliczu drugiej fali kryzysu, która dotknęła gospodarkę globalną, a ze szczególną siłą uderzyła w gospodarki krajów Unii Europejskiej, ważne jest przedstawienie reakcji polskiego rynku kredytowego dla przedsiębiorstw na zaistniałe wydarzenia. Dobrym zwierciadłem jest kształtowanie się popytu na kredyt, jaki wykazują podmioty gospodarcze (ryc. 3). Ankietowane banki nie wykazały istotnych zmian w popycie kredytów dla firm w czwartym kwartale 2011 r., natomiast w prognozie na pierwszy kwartał 2012 r. przewidywano wzrost popytu na kredyty krótkoterminowe, co jest pozytywną odpowiedzią w czasach narastającej niepewności. Pomimo zaostrzenia warunków kredytowych i kryzysu gospodarczego, który spowodował upadłość wielu podmiotów również w Polsce (sektor budowlany, branża turystyczna), widać, że wiara bankowców w siłę polskiej przedsiębiorczości i jej rozwój jest niezachwiana, a wręcz rośnie wraz z narastającymi zagrożeniami i niepewnością. Właśnie w czasach wysokiego ryzyka najłatwiej udowodnić jest, jak zdrowe są podstawy systemu gospodarczego i szkielet tworzący go w postaci małych i średnich przedsiębiorstw. Wzajemne zaufanie między bankami a kredytobiorcami z tego sektora jest gwarantem rozwoju przedsiębiorczości i świadczy o dużej dojrzałości i odporności na zewnętrzne wstrząsy.

Znając stopień dostępności kredytów udzielanych przez banki firmom i popyt na kredyty firmowe, niezbędne dla otrzymania pełnego obrazu tego rynku jest również zapoznanie się z różnymi rodzajami finansowania, które oferowane są dla zainteresowanych kredytobiorców. Różne formy produktów bankowych, z których korzystają MŚP, przedstawiono na rycinie 4.

Jak wynika z danych zaprezentowanych przez Ministerstwo Gospodarki, najczęściej firmy korzystają z kredytu na rachunku bieżącym (23\% firm), kredyt inwestycyjny uruchomiono dla $8 \%$ zainteresowanych podmiotów, a z kredytu obrotowego skorzystało 7\%. Udział firm starających się o kredyt obrotowy lub kredyt inwestycyjny w 2011 r. wyniósł 30\%, przy czym co drugi podmiot otrzymał wnioskowany kredyt - w grupie mikro- kredyt otrzymało 44\% firm, podmioty małe $-64 \%$, natomiast podmioty średnie - 73\% (Ministerstwo Gospodarki, 2012). Najwyższym udziałem zaakceptowanych wniosków kredytowych cieszą się średnie przedsiębiorstwa, a więc można stwierdzić, że są one jednostkami na tyle stabilnymi i perspektywicznymi, że nie mają problemów z uzyskaniem potrzebnej kwoty pieniężnej lub po prostu sięgają po kredyty o niewielkiej wartości, niewymagające dużych i bardzo solidnych zabezpieczeń transakcji.

Ryc. 3. Popyt na kredyt krótkoterminowy dla przedsiębiorstw

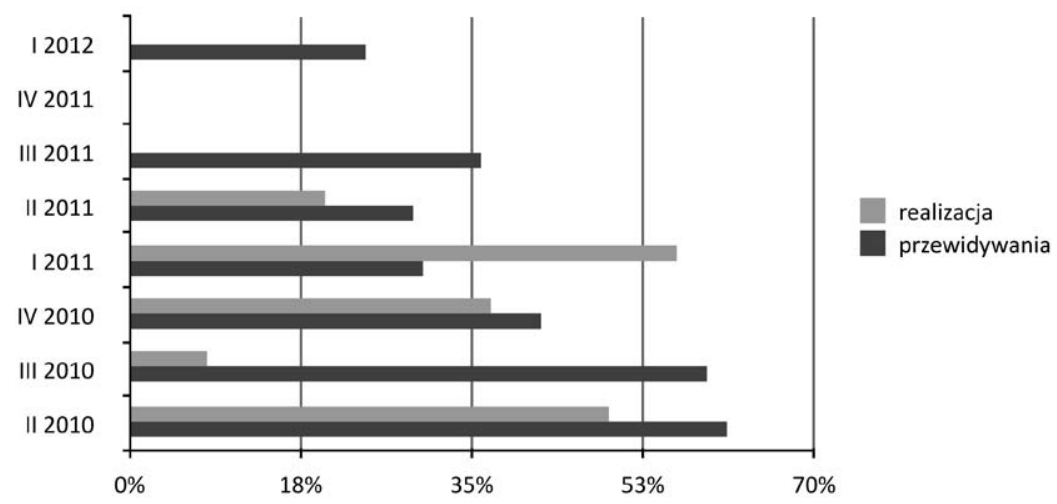

Źródło: opracowanie własne na podstawie NBP (2012, styczeń). 
Ryc. 4. Udział firm korzystających z różnych form kredytu w drugiej połowie $2011 \mathrm{r}$.

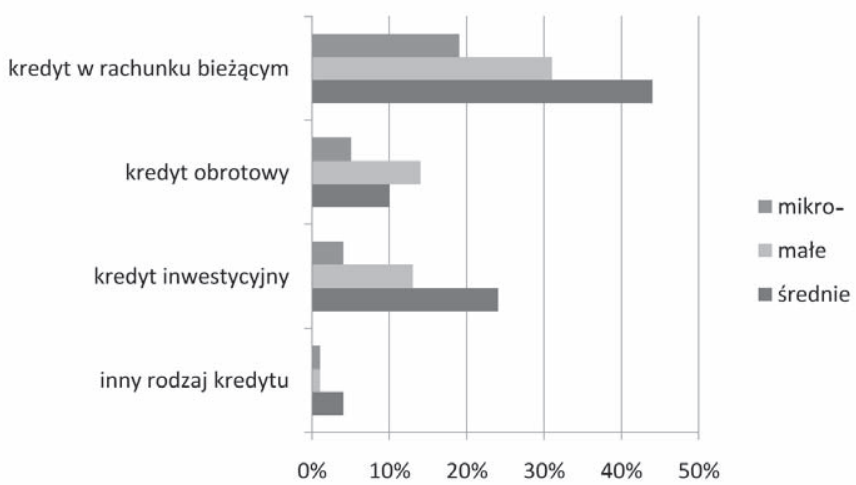

Źródło: Ministerstwo Gospodarki (2012, kwiecień).

Ryc. 5. Wielkość akcji kredytowej dla przedsiębiorstw

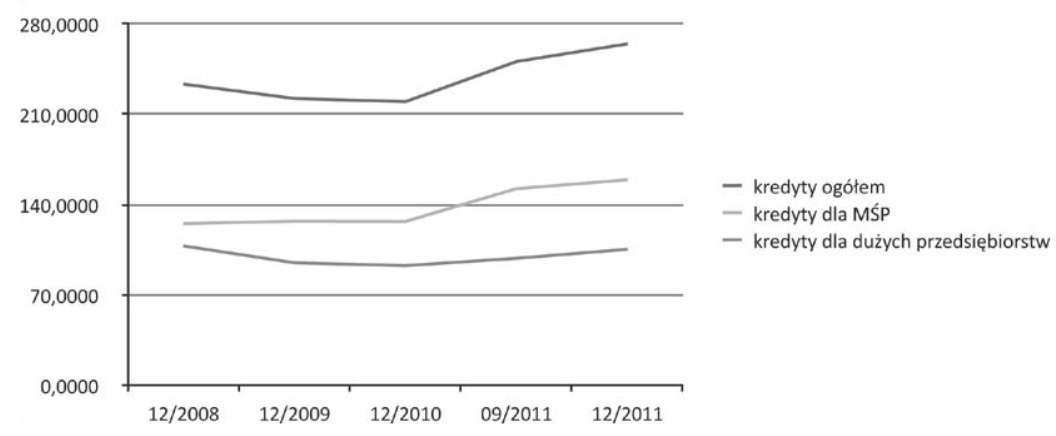

Źródło: opracowanie własne na podstawie: Urząd Komisji Nadzoru Finansowego (2012).

Ryc. 6. Wskaźnik bezpieczeństwa działalności gospodarczej

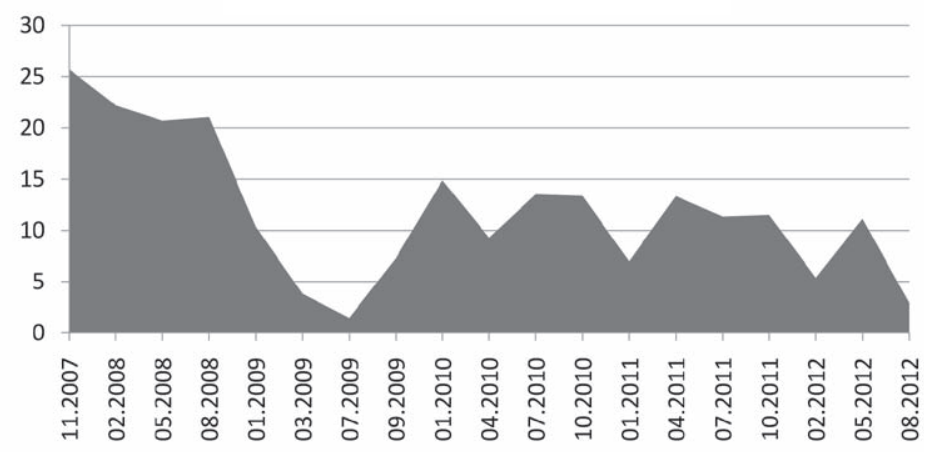

Źródło: BIG InfoMonitor (2012, wrzesień). 
Ważnym miernikiem obrazującym współpracę banków z przedsiębiorstwami jest wielkość akcji kredytowej dla podmiotów firmowych. W 2011 r. suma udzielonych kredytów wyniosła 264,5 mld zł, co w porównaniu z rokiem 2010 jest wzrostem o 44,8 mld zł (20,4\%). Świadczy to o silnym ożywieniu akcji kredytowej dla firm. Warto również zwrócić uwagę na wzrost udzielanych kredytów (o 13,8 mld zł, tj. 5,5\%) w czwartym kwartale $2011 \mathrm{r}$. w stosunku do wcześniejszego okresu, pomimo gorszego klimatu inwestycyjnego, w drugiej połowie $2011 \mathrm{r}$. Fakt ten potwierdza odporność sektora bankowego i całej gospodarki na rosnącą niepewność na rynkach światowych. Dane dotyczące struktury kredytów w Polsce zostały zestawione w tabeli 1 oraz zaprezentowane na rycinie 5 .

Istotny jest również zauważalny przyrost produktów operacyjnych (o $15 \mathrm{mld} \mathrm{zł}, \mathrm{tj} .16,5 \%$ ) i inwestycyjnych (o 18,7 mld zł; 28,7\%), co świadczy o wzroście aktywności w polskiej gospodarce, a także powinno wpłynąć korzystnie na tempo wzrostu w kolejnych okresach. W raporcie Komisji Nadzoru Finansowego dotyczącym banków podkreślono, że ,realizuje się zatem scenariusz, w którym utrzymujące się ożywienie w gospodarce przekłada się na wzrost popytu na kredyt ze strony przedsiębiorstw, a stabilizacja jakości portfela kredytowego na zwiększenie jego podaży ze strony banków" (Urząd Komisji Nadzoru Finansowego, 2012: 40-41). Zagrożeniem dla akcji kredytowej może być słabszy klimat inwestycyjny (wskaźnik bezpieczeństwa działalności gospodarczej - ryc. 6 - spadł o 8,19 pkt. do poziomu 2,93 pkt. w sierpniu 2012, co jest drugim najgorszym wynikiem w historii badania; gorszy wynik zanotowano tylko w lipcu 2009) (BIG InfoMonitor, 2012), pogorszenie koniunktury u głównych partnerów handlowych Polski, jak też oczekiwane słabsze tempo wzrostu polskiej gospodarki. Może to przyczynić się do ograniczenia popytu na kredyt oraz bardziej selektywnej podaży przez banki na tym rynku, a także spowodować kłopoty przedsiębiorców, którzy chcą rozwijać swoje firmy, a nie mają na to wystarczających nakładów.

Tab. 1. Struktura kredytów dla przedsiębiorstw (mld zł, \%)

\begin{tabular}{|l|r|r|r|r|r|r|r|r|}
\hline \multicolumn{2}{|c|}{} & \multicolumn{3}{c|}{ Wartość (mld zl) } & \multicolumn{3}{c|}{ Zmiana do (\%) } \\
\hline & & $\mathbf{1 2 / 2 0 0 8}$ & $\mathbf{1 2 / 2 0 0 9}$ & $\mathbf{1 2 / 2 0 1 0}$ & $\mathbf{1 2 / 2 0 1 1}$ & $\mathbf{1 2 / 2 0 0 9}$ & $\mathbf{1 2 / 2 0 1 0}$ & $\mathbf{1 2 / 2 0 1 1}$ \\
\hline $\begin{array}{l}\text { Kredyty ogółem, } \\
\text { w tym: }\end{array}$ & 233,3 & 222,1 & 219,7 & 250,8 & 264,5 & $19,1 \%$ & $20,4 \%$ & $5,5 \%$ \\
\hline 1. MŚP & 125,3 & 127,2 & 127,0 & 152,3 & 159,2 & $25,1 \%$ & $25,3 \%$ & $4,5 \%$ \\
\hline operacyjne & 47,2 & 46,0 & 46,2 & 57,9 & 57,6 & $25,1 \%$ & $24,6 \%$ & $-0,5 \%$ \\
\hline inwestycyjne & 32,2 & 34,1 & 35,2 & 42,8 & 47,5 & $39,1 \%$ & $35,1 \%$ & $10,9 \%$ \\
\hline na nieruchomości & 37,8 & 3,0 & 35,0 & 39,1 & 39,8 & $7,6 \%$ & $13,8 \%$ & $1,7 \%$ \\
\hline reszta & 8,0 & 10,0 & 10,6 & 12,5 & 14,3 & $41,9 \%$ & $34,1 \%$ & $14,2 \%$ \\
\hline $\begin{array}{l}\text { 2. Duże } \\
\text { przedsiębiorstwa }\end{array}$ & 108,0 & 94,9 & 92,7 & 98,4 & 105,4 & $11,1 \%$ & $13,7 \%$ & $7,1 \%$ \\
\hline operacyjne & 59,2 & 48,4 & 44,2 & 48,9 & 47,8 & $-1,2 \%$ & $8,1 \%$ & $-2,3 \%$ \\
\hline inwestycyjne & 33,2 & 30,3 & 30,1 & 32,7 & 36,5 & $20,3 \%$ & $21,3 \%$ & $11,5 \%$ \\
\hline na nieruchomości & 9,7 & 10,3 & 9,2 & 7,6 & 8,4 & $-18,4 \%$ & $-8,8 \%$ & $10,9 \%$ \\
\hline reszta & 6,0 & 5,8 & 9,2 & 9,2 & 12,7 & $117,1 \%$ & $38,5 \%$ & $37,8 \%$ \\
\hline Kredyty wg waluty & \multicolumn{7}{|c|}{} & \multicolumn{7}{|c|}{} & & & & & \\
\hline złotowe & 173,2 & 163,8 & 165,1 & 183,8 & 192,9 & $17,7 \%$ & $16,8 \%$ & $4,9 \%$ \\
\hline waluta & 60,1 & 58,3 & 54,6 & 67,0 & 71,7 & $23,0 \%$ & $31,3 \%$ & $7,0 \%$ \\
\hline
\end{tabular}

Źródło: Urząd Komisji Nadzoru Finansowego (2012). 
Ponadto, jak słusznie zauważa ekspert Business Centre Club Wojciech Warski „sektor małych i średnich przedsiębiorstw jest bardzo podatny na nastroje. Sama zapowiedź możliwego kryzysu powoduje zmniejszenie konsumpcji, co uderza w popyt na usługi tego sektora. Zachowawczo zaczynają się kształtować także relacje business to business, gdzie znajduje się większość odbiorców MŚP” (Przedsiębiorcy zawiedli się na Euro 2012. Nastroje najgorsze od trzech lat). Dlatego bardzo ważną rolę w rozwoju przedsiębiorczości w czasach kryzysu gospodarczego odgrywają banki, które zapewniają niezbędny kapitał. Bogata oferta kredytowa dla podmiotów firmowych, posiadających zróżnicowaną zdolność kredytową, daje większe możliwości zdobycia finansowania. Kompleksową analizę produktów kredytowych dla MŚP zaprezentowano w dalszej części artykułu.

\section{Analiza porównawcza oferty kredytowej dla MŚP}

Poznanie warunków dostępności, rodzajów oraz wielkości udzielanych kredytów daje obraz rzeczywistości, w której funkcjonują polscy przedsiębiorcy. W celu pełnego poznania specyfikacji rynku międzybankowego i zrozumienia istoty strategii banków oraz zależności występujących w gospodarce krajowej między podmiotami kredytującymi, które kreują podaż kredytów i dyktują kierunki rozwojowe, a kredytobiorcami, przeprowadzona została kompleksowa analiza porównawcza bankowej oferty kredytów dla przedsiębiorstw. Podmioty wykorzystane w badaniu znajdują się wśród największych polskich banków pod względem sumy bilansowej, jak również są wśród nich takie, które agresywną strategią chcą poprawić swoją pozycję i zwiększyć w znacznym stopniu swoje aktywa. Jako przeciwwagę dla przygotowanej analizy zaprezentowano wyniki rankingu Najlepszy Bank Miesięcznika „Forbes” dla małych i średnich przedsiębiorstw w 2011 r. W przeprowadzonym badaniu zostały wykorzystane tylko informacje dostępne publicznie wg stanu na 8 kwietnia $2012 \mathrm{r}$.

Prawdziwym polem twardej rywalizacji banków o przedsiębiorstwa jest obszar kredytów. Podmioty kredytujące prześcigają się tutaj w produktach udostępnianych klientom. Firmy mogą wybierać spośród kredytów w rachunku bieżącym, obrotowych odnawialnych i nieodnawialnych, przeznaczonych na finansowanie działalności inwestycyjnej, linii wieloproduktowych. Od momentu wejścia do UE dostępne dla polskich MŚP stały się kredyty technologiczne z premią Banku Gospodarstwa Krajowego oraz współfinansujące realizowane projekty unijne. Oferta kredytowa przebadanych podmiotów została zebrana i przedstawiona w tabeli 2.

Każdy z przebadanych podmiotów ma w swojej ofercie kredyt w rachunku bieżącym, który jest jednym z najpowszechniejszych sposobów finansowania. Czynnikiem wpływającym na potencjalnych kredytobiorców jest oprocentowanie takiego produktu naliczane jako stopa WIBOR plus marża, która jest ustalana indywidualnie przez bank. W celu określenia atrakcyjności dostępnych na rynku kredytów dla przedsiębiorstw wykorzystane zostały dostępne dane dotyczące prowizji od przyznania bankowego kapitału. Im niższa prowizja, tym mniejszy całkowity koszt kredytu. Należy jednak podkreślić, że porównywanie parametrów kredytowych jest w praktyce niemożliwe - banki indywidualnie rozpatrują zdolność kredytową podmiotu gospodarczego i negocjują z nim warunki kredytu.

Pod względem wysokości prowizji istnieje duże zróżnicowanie na rynku. Przedsiębiorcy mogą uzyskać potrzebny kapitał, płacąc minimum 200 zł w ING Banku Śląskim, 300 zł w Pekao i BGŻ, co najmniej 1000 zł w BRE Banku czy też minimum 1500 zł/2500 zł w Alior Banku. Interesującą propozycję przedstawia Idea Bank, zachęcający do wzięcia linii kredytowej z prowizją wynoszącą 0 zł. Konkurencyjną ofertą jest kredyt pod obroty w BNP Paribas z prowizją przygotowawczą wynoszącą $0 \%$, marżą przez 6 miesięcy wynoszącą $0 \%$ oraz prowizją od niewykorzystanej kwoty kredytu wynoszącą również $0 \%$, a także dostępny w banku Millennium kredyt dla klientów MAKRO do 30 tys. zł bez prowizji. 
Tab. 2. Kredyty oferowane przez banki dla firm z sektora MŚP (stan na 08.04.2012 r.)

\begin{tabular}{|c|c|c|c|}
\hline Bank & $\begin{array}{l}\text { Kredyt w rachunku } \\
\text { bieżącym }\end{array}$ & $\begin{array}{l}\text { Kredyt w rachunku } \\
\text { kredytowym }\end{array}$ & $\begin{array}{c}\text { Kredyty } \\
\text { inwestycyjne }\end{array}$ \\
\hline $\begin{array}{l}\text { PKO } \\
\text { Bank Polski }\end{array}$ & $\begin{array}{l}\cdot \text { od } 1,5 \% \text { do } 4 \% \text { prowizji } \\
\text { - udzielany na } 12-36 \\
\text { miesięcy }\end{array}$ & $\begin{array}{l}\text { - kredyt pomostowy - na } \\
\text { inwestycje z UE, do } 100 \% \\
\text { wartości dotacji } \\
\text { - kredyt technologiczny } \\
\text {-spłata części z premii tech., } \\
\text { wkład własny min. } 25 \%\end{array}$ & $\begin{array}{l}\text { - prowizja od 1,5\% maks. okres } \\
\text { kredytowania do } 25 \text { lat } \\
\text { - linia kredytowa Banku Rozwoju } \\
\text { Rady Europy - } \\
\text { dla rozpoczynających działal- } \\
\text { ność do } 2 \text { mln zł }\end{array}$ \\
\hline Bank Pekao & $\begin{array}{l}\text { - min. } 2 \% \text { (min. } 300 \mathrm{zl}) \\
\text { prowizji, do } 1 \text { roku, kwota } \\
\text { nie większa niż } 20 \% \text { sumy } \\
\text { przychodów ze sprzedaży } \\
\text { za ostatni rok obrotowy lub } \\
\text { za okres prowadzenia } \\
\text { działalności krótszy niż } 12 \\
\text { miesięcy }\end{array}$ & $\begin{array}{l}\text { - prowizja min. } 2 \% \text {, udzielany } \\
\text { w złotówkach, euro } \\
\text { i dolarach na } 12 \text { miesięcy } \\
\text { • kredyt obrotowy dla } \\
\text { młodych firm z poręczeniem } \\
\text { z EFI - do } 1 \text { roku, maks. } \\
\text { kwota } 20 \text { tys. zł, } 0 \text { zł } \\
\text { poręczenie EFI }\end{array}$ & $\begin{array}{l}\text { - prowizja min. } 2 \% \text {, do } 10 \text { lat, } \\
\text { linia kredytowa EBI - niższa } \\
\text { marża o } 0,25 \% \text {, bezpłatne } \\
\text { poręczenie EFI } \\
\text { - kredyt technologiczny z premią } \\
\text { BGK, } 25 \% \text { wkład własny, prosty } \\
\text { - SIL, AutoSIL do } 300 \text { tys. zł, } \\
5 \text { lat, min. } 20 \% \text { wkładu własnego }\end{array}$ \\
\hline BRE Bank & $\begin{array}{l}\text { - max } 5 \% \text { (min. } 1000 \mathrm{zł}) \\
\text { prowizji, do } 12 \text { miesięcy } \\
\text { - szybki kredyt do } 600 \text { tys. zł } \\
\text { lub równowartość } \\
\text { w walutach obcych, do } 12 \\
\text { miesięcy, uproszczona } \\
\text { i przyspieszona procedura } \\
\text { uzyskania }\end{array}$ & $\begin{array}{l}\text { - linia wieloprod. } \\
\text { do } 12 \text { miesięcy, maks. 5\% } \\
\text { (min. } 1000 \mathrm{zł} \text { ) prowizji } \\
\text { - kredyt odnawialny } \\
\text { w złotówkach lub walutach } \\
\text { obcych, na } 12 \text { miesięcy, } \\
\text { maks. okres spłaty } 90 \text { dni }\end{array}$ & $\begin{array}{l}\text { max. } 5 \%(\min .1000 \mathrm{zl})-\text { kredyt } \\
\text { na finansowanie nieruchomości } \\
\text { inwestycyjnych na okres } \\
\text { od } 1 \text { do } 20 \text { lat }\end{array}$ \\
\hline $\begin{array}{l}\text { ING } \\
\text { Bank Śląski }\end{array}$ & $\begin{array}{l}\text { - } \min .2 \%(\min .200 \mathrm{zl}) \\
\text { prowizja }\end{array}$ & \begin{tabular}{|l|} 
- um. wieloprod. na 6 lat \\
- kredyt obrotowy do 1 roku; \\
$1,8 \%$ prowizji w stosunku \\
rocznym, a $1 \%$, gdy wniosek \\
przez ING Direct Business \\
Credit
\end{tabular} & $\begin{array}{l}\text { - kredyt inwestycyjny do } 10 \text { lat } \\
\text { - kredyt technologiczny } \\
\text { z premią z BGK, dotacja maks. } \\
4 \text { mln zł, BGK poręcza do } 80 \% \\
\text { kwoty kredytu (od } 100 \text { tys. zł } \\
\text { do } 10 \text { mln euro) } \\
\text { - unijne obrotowe i inwestycyjne }\end{array}$ \\
\hline $\begin{array}{l}\text { Bank } \\
\text { Zachodni } \\
\text { WBK }\end{array}$ & $\begin{array}{l}\text { - do } 12 \text { miesięcy, przedłuże- } \\
\text { nie do } 3 \text { lat }\end{array}$ & \multicolumn{2}{|c|}{$\begin{array}{l}\text { - kredyt obrotowy i inwestycyjny: do } 50 \text { tys. zł prowizja min. } \\
3,5 \%, 50-200 \text { tys. zł, prowizja min. } 3 \%, 200-500 \text { tys. zł }-2 \% \text {, } \\
>500 \text { tys. zł }-1 \% \\
\text { - kredyt technologiczny z premią BGK }\end{array}$} \\
\hline $\begin{array}{l}\text { Millennium } \\
\text { Bank }\end{array}$ & $\begin{array}{l}\text { - } 1 \% \text { prowizji, do } 12 \text { miesięcy } \\
\text { - kredyt dla klientów } \\
\text { MAKRO, do } 30 \text { tys. zł, } \\
\text { bez prowizji } \\
\text { - } 2 \% \text { prowizja }\end{array}$ & \begin{tabular}{|l|} 
- obrotowy $2 \%$ prowizja \\
- linia wieloprod. prowizja $2 \%$
\end{tabular} & $\begin{array}{l}\text { - prowizja 2,6\% } \\
\text { - kredyt technologiczny } \\
\text { - Program Finansowania Rozwoju } \\
\text { Energii Zrównoważonej } \\
\text { (PolSEFF) z EBOiR, do } 1 \mathrm{mln} \\
\text { euro w formie kredytu inwesty- } \\
\text { cyjnego Eko Energia, 10\% lub } \\
15 \% \text { premii inwestycyjnej }\end{array}$ \\
\hline $\begin{array}{l}\text { Citi } \\
\text { Handlowy }\end{array}$ & - na 12 miesięcy & $\begin{array}{l}- \text { kredyt płatniczy do } 36 \\
\text { miesięcy na dowolny cel } \\
\text { - kredyt odnawialny na } 12 \\
\text { miesięcy }\end{array}$ & $\begin{array}{l}\text { - do } 3 \text { mln zł, na } 60 \text { miesięcy } \\
\text { - kredyt technologiczny z premią } \\
\text { nie większą niż } 4 \text { mln zł, min } \\
\text { 25\% wkładu własnego }\end{array}$ \\
\hline Kredyt Bank & $\begin{array}{l}\text { - limit w rachunku do } 50 \text { tys. } \\
\text { zł, na } 12 \text { miesięcy, } \\
\text { przedłużenie na } 10 \text { lat } \\
\text { - kredyt obrotowy odnawial- } \\
\text { ny i nieodnawialny }\end{array}$ & $\begin{array}{l}\text { - kredyt „Inwestycja z UE” } \\
\text { - pomostowy na okres do } \\
\text { wypłaty dotacji lub } \\
\text { standardowy na okres poza } \\
\text { terminem wypłaty dotacji, } \\
\text { zabezpieczony aktywami }\end{array}$ & $\begin{array}{l}\text { •,Szybki kredyt inwestycyjny” } \\
\text { dla firm z pełną księgowością } \\
\text { do } 5 \text { lat, min. wkład } 20 \% \\
\text { • dla firm z uproszczoną księgo- } \\
\text { wością rozłożenie spłaty na } 120 \\
\text { rat (10 lat), min. wkład }\end{array}$ \\
\hline
\end{tabular}




\begin{tabular}{|c|c|c|c|}
\hline Bank & $\begin{array}{c}\text { Kredyt w rachunku } \\
\text { bieżącym }\end{array}$ & $\begin{array}{c}\text { Kredyt w rachunku } \\
\text { kredytowym }\end{array}$ & $\begin{array}{c}\text { Kredyty } \\
\text { inwestycyjne }\end{array}$ \\
\hline & & $\begin{array}{l}\text { finansowymi wraz z cesją } \\
\text { praw z polisy ubezpiecze- } \\
\text { niowej }\end{array}$ & $\begin{array}{l}20 \% \text {, maks. kwota kredytu } \\
\text { równa do } 50 \% \text { przychodów za } \\
\text { poprzedni rok, nie więcej niż } \\
500 \text { tys. zł }\end{array}$ \\
\hline $\begin{array}{l}\text { Raiffeisen } \\
\text { Bank Polska }\end{array}$ & $\begin{array}{l}\text { • prowizja } 0,05 \% \text { kwoty } \\
\text { kredytu zabezpieczonego } \\
\text { na } 12 \text { miesięcy } \\
\bullet 0,06 \% \text { kwoty kredytu } \\
\text { na } 24 \text { miesięcy } \\
\text { • } 0,07 \% \text { kwoty kredytu } \\
\text { na } 36 \text { miesięcy, limit } \\
\text { do } 500 \text { tys. zł } \\
\text { - } 0,05 \% \text { prowizji dla kredytu } \\
\text { niezabezpieczonego }\end{array}$ & $\begin{array}{l}\text { - nieodn. fixed term } \\
\text { na finansowanie obrotowe } \\
\text { lub inw. } \\
\text { - nieodnawialny kredyt } \\
\text { obrotowy w RB } \\
\text { do } 250 \text { tys. zł do } 48 \text { miesięcy }\end{array}$ & $\begin{array}{l}\text { - kredyt technologiczny } \\
\text { - prowizja maks. } 4 \% \text { (min. } 2000 \text { zł), } \\
\text { na } 10 \text { lat, w złotówkach, min. } \\
50 \text { tys. zł, premia technol. może } \\
\text { stanowić } 40-70 \% \text { kwoty kredytu } \\
\text { (4 mln zł) } \\
\text { - RUnia (pomostowy) do } 10 \text { lat, } \\
\text { min. } 50 \text { tys. zł }\end{array}$ \\
\hline Bank BGŻ & $\begin{array}{l}\text { - kredytu obrotowego w RB, } \\
\text { prowizja min. } 2 \% \\
(\text { min. } 300 \mathrm{zl})\end{array}$ & \multicolumn{2}{|c|}{$\begin{array}{l}\text { - wielofunkcyjna linia kredytowa na } 12 \text { miesięcy } \\
\text { - prowizja od } 2 \% \text { (min. } 500 \text { zł) } \\
\text { - Kredyt Inwestycyjny „Zielona energia” - karencja w spłacie } \\
\text { do } 2 \text { lat, w złotówkach, euro, dolarach, udzielany na okres do } 15 \text { lat } \\
\text { - Kredyt Inwestycyjny „Czysta energia” - do } 1 \text { mln euro, na } 10 \text { lat, } \\
15 \% \text { udziału własnego, premia inwestycyjna ze środków } \\
\text { unijnych } 10 \% \text { lub } 15 \% \text { kwoty kredytu }\end{array}$} \\
\hline Getin Bank & $\begin{array}{l}\text { - od } 0,5 \%(\min .500 \mathrm{zł}) \\
\text { prowizji } \\
\text { • dofinansowany z EBI, } \\
\text { obrotowy do } 1 \mathrm{mln} \\
\text { na } 48 \text { miesięcy, do } 1 \mathrm{mln} \text { zł } \\
\text { bez zabezpieczeń }\end{array}$ & $\begin{array}{l}\text { - prowiza od 0,5\% (min. } 500 \mathrm{zl} \text { ) } \\
\text { - linia kredytowa na okres } \\
12 \text { miesięcy do trzykrotności } \\
\text { średniomiesięcznych } \\
\text { wpływów na rachunek } \\
\text { firmowy }\end{array}$ & $\begin{array}{l}\text { - prowiza od } 0,5 \% \\
\text { (min. } 500 \mathrm{z} \text { ), na okres } \\
\text { do } 15 \text { lat, dofinansowany z EBI } \\
\text { - kredyt z dofinansowaniem EBI } \\
\text { - maks. } 12,5 \text { mln euro na okres } \\
\text { od } 24 \text { miesięcy do } 60 \text { miesięcy }\end{array}$ \\
\hline BNP Paribas & $\begin{array}{l}\text { - na } 12 \text { miesięcy do } 10 \text { lat, } \\
\text { prowizja do negocjacji, } \\
\text { limit debetowy z prowizją } \\
\text { od } 3 \% \text { (min. } 500 \text { zł), kredyt } \\
\text { pod obroty (przychód netto } \\
\text { za ostatnie } 12 \text { miesięcy } \\
\text { min. } 2 \text { mln zł) do } 1 \text { mln zł } \\
\text { bez zabezpieczeń } \\
\text { rzeczowych, prowizja } \\
\text { przygotowawcza } \\
\text { - } 0 \text {, marża } 0 \% \text { przez } \\
\text { pierwsze } 6 \text { miesięcy od } \\
\text { zawarcia umowy, } 0 \% \\
\text { prowizji za niewykorzysta- } \\
\text { nie kredytu }\end{array}$ & $\begin{array}{l}\text { - energooszczędny na } \\
\text { finansowanie inwestycji } \\
\text { redukujących zużycie energii } \\
\text { w firmie, } 25 \text { tys. - } 1 \text { mln euro, } \\
\text { na } 7 \text { lat, premia inw. } 10 \% \\
\text { lub } 15 \% \text { od kredytu, } \\
\text { - Wielocelowa Linia } \\
\text { Kredytowa }\end{array}$ & $\begin{array}{l}\text { - prowizja min. } 3 \% \text { do negocjacji, } \\
\text { maks. na } 5 \text { lat } \\
\text { - kredyt inwestycyjny EBI od } 2 \\
\text { do } 10 \text { lat, wkład własny } 20 \% \text {, } \\
12,5 \text { mln euro, } \\
\text { - kredyt technologiczny do } 10 \text { lat, } \\
\text { wkład własny min. } 25 \% \text {, } \\
\text { z premią BGK (max } 4 \text { mln zł) } \\
\text { od } 40 \% \text { do } 70 \% \text { wartości kredytu } \\
\text { - kredyt pod dotacje UE maks. } \\
\text { na } 7 \text { lat }\end{array}$ \\
\hline Idea Bank & $\begin{array}{l}\text { - prowizja za przyznanie linii } \\
\text { kredytowej } 0 \text { zł } \\
\text { - kredyt obrotowy na } 3 \text { lata } \\
\text { do } 700 \text { tys. zł, staż firmy } \\
\text { co najmniej } 12 \text { miesięcy } \\
\text { - Kredyt Przedsiębiorczy na } \\
\text { cel operacyjny/inwestycyj- } \\
\text { ny do } 10 \text { lat, na cel } \\
\text { nieruchomościowy } \\
\text { do } 20 \text { lat }\end{array}$ & $\begin{array}{l}\text { - Kredyt na Start - zdolność } \\
\text { kredytowa na podstawie } \\
\text { oświadczenia klienta } \\
\text { o prognozowanym dochodzie, } \\
\text { staż firmy niewymagany, } \\
\text { do } 200 \text { tys. zł, na } 15 \text { lat } \\
\text { - Kredyt Gospodarczy bez } \\
\text { Zabezpieczenia dla firm } \\
\text { o krótkim stażu - } 6 \text { miesięcy } \\
\text { od rejestracji, nie jest } \\
\text { wymagane zabezpieczenie } \\
\text { hipoteczne, do } 5 \text { lat, kwota } \\
\text { do } 200 \text { tys. zł }\end{array}$ & $\begin{array}{l}\text { - Kredyt Deweloper dla inwestycji } \\
\text { realizowanej z myślą o sprzeda- } \\
\text { ży do } 5 \text { lat, w przypadku } \\
\text { inwestycji pod wynajem - mak- } \\
\text { symalnie do } 15 \text { lat, } 3 \text { mln zł, } \\
\text { do } 80 \% \text { wartości inwestycji } \\
\text { - prowizja } 1000 \text { zł, ale nie więcej } \\
\text { niż } 1 \% \text { wnioskowanej kwoty }\end{array}$ \\
\hline
\end{tabular}




\begin{tabular}{|c|c|c|c|}
\hline Bank & $\begin{array}{c}\text { Kredyt w rachunku } \\
\text { bieżącym }\end{array}$ & $\begin{array}{c}\text { Kredyt w rachunku } \\
\text { kredytowym }\end{array}$ & $\begin{array}{c}\text { Kredyty } \\
\text { inwestycyjne }\end{array}$ \\
\hline Nordea Bank & $\begin{array}{l}\text {-2,5\% do } 100 \text { tys. zł na } 12 \\
\text { miesięcy, odnawialny, brak } \\
\text { rzeczowych zabezpieczeń } \\
\text { (jedyne zab. do } 50000 \mathrm{zł} \text { to } \\
\text { oświadczenie o poddaniu } \\
\text { się egzekucji i pełnomoc- } \\
\text { nictwo) } \\
\text { - kredyt obrotowy w RB, } \\
\text { prowizja od } 1 \% \text {, działal- } \\
\text { ność przez } 24 \text { miesiące, } \\
\text { dwukrotność mediany } \\
\text { z miesięcznych. wpływów } \\
\text { na rachunek za okres } \\
\text { ostatnich } 6 \text { miesięcy, } \\
12 \text { miesięcy }\end{array}$ & $\begin{array}{l}\cdot 1 \% \text { prowizji } \\
\text { - kredyt obrotowy, do } 36 \\
\text { miesięcy, prowizja od } 1 \% \\
\text { - linia kredytowa }\end{array}$ & $\begin{array}{l}\text { - } 1 \% \text { prowizji } \\
\text { - kredyt inwestycyjny } \\
\text { - do } 90 \% \text { wartości inwestycji } \\
\text { (netto) udzielanych na } 5 \text { lat, do } \\
80 \% \text { wartości inwestycji (netto) } \\
\text { dla dłuższych niż } 5 \text { lat, karencja } \\
\text { w spłacie do } 12 \text { miesięcy, } \\
\text { w złotówkach i walutach obcych, } \\
\text { prowizja od 1\% } \\
\text { - Kredyt Nordea Europa dla } \\
\text { inwestycji dotowanych z UE }\end{array}$ \\
\hline Alior Bank & $\begin{array}{l}\text { • } 3 \% \text { prowizja } \\
\text { (min. } 1000 \mathrm{zl} \text { ) } \\
\text { • kredyt za wyciąg na } \\
\text { podstawie historii rachunku } \\
\text { firmowego z dowolnego } \\
\text { banku, dla firm funkcjonu- } \\
\text { jących min. } 1 \text { rok } \\
\text { • niewymagane zabezpiecze- } \\
\text { nia spłaty, w wysokości do } \\
20 \% \text { rocznych wpływów } \\
\text { (do } 200 \text { tys. zł) } \\
\text { • prowizja } 2 \% \text { (min. } 1500 \mathrm{zł} \text { ), } \\
\text { nieodnawialny, na } \\
\text { finansowanie działalności } \\
\text { bieżącej } 2 \% \text { (min. } 1500 \mathrm{zł} \text { ), } \\
\text { limit wierzytelności } 2,5 \% \\
\text { (min. } 2500 \mathrm{zł} \text { ) }\end{array}$ & $\begin{array}{l}\text { • kredyt nieodnawialny na } \\
\text { finansowanie działalności } \\
\text { bieżącej zabezpieczony } \\
\text { hipoteką na nieruchomości } \\
\text { z prowizją 2,5\% } \\
\text { (min. } 800 \text { zł), do } 300 \text { tys. zł } \\
\text { na } 36 \text { miesięcy } \\
\text { • kredyt odnawialny } \\
\text { w rachunku kred. na } \\
\text { finansowanie działalności } \\
\text { bieżącej 2\% (min. } 1000 \text { zł) } \\
\text { • kredyt nieodnawialny na } \\
\text { finansowanie działalności } \\
\text { bieżącej zabezpieczony } \\
\text { hipoteką na nieruchomości } \\
\text { 2,5\% (min. } 2000 \text { zł) }\end{array}$ & $\begin{array}{l}\text { - prowizja } 2 \% \text { (min. } 1000 \mathrm{zł}) \text {, } \\
\text { kredyt do } 80 \% \text { kwoty realizowa- } \\
\text { nej inwestycji } \\
\text { - na okres do } 20 \text { lat, dostępny } \\
\text { w } 5 \text { walutach } \\
\text { - kredyt technologiczny z premią } \\
\text { BGK } \\
\text { - prowizja } 2 \% \text { (min. } 2500 \mathrm{zl} \text { ) }\end{array}$ \\
\hline
\end{tabular}

Źródło: opracowanie własne na podstawie ofert banków dostępnych na stronach internetowych każdego z podmiotów: www.pkobp.pl, www.pekao.com.pl, www.brebank.pl, www.ingbank.pl, mim.firmy. bzwbk.pl, www.bankmillennium.pl, www.citibank.pl, www.kredytbank.pl, www.raiffeisen.pl, www.bgz.pl, www.getinbank.pl, www.bnpparibas.pl, www.ideabank.pl, www.nordea.pl, www.aliorbank.pl (stan na 08.04.2012 r.).

Ważnym elementem w bogatej ofercie kredytowej banków jest finansowanie w rachunku kredytowym. Każde przedsiębiorstwo ma szansę znaleźć produkt odpowiadający jego potrzebom. Dla firm rozpoczynających działalność, których okres funkcjonowania jest krótszy niż 12 miesięcy, z pomocą finansową przychodzi Idea Bank z Kredytem na Start do wysokości 200 tys. zł, oceniający zdolność kredytową na podstawie oświadczenia klienta o prognozowanym dochodzie oraz PKO BP z Linią Kredytową Banku Rozwoju Rady Europy do 2 mln zł. Podmioty gospodarcze szukające sfinansowania inwestycji ze środków UE mają do dyspozycji kredyt pomostowy w Raiffeisen Banku oraz Kredyt Banku. Coraz bardziej zyskującą na popularności wśród firm formą finansowania jest wieloproduktowa linia kredytowa z określonym limitem pieniężnym, która może być zrealizowana w formie kredytu w rachunku bieżącym, kredytu obrotowego, dyskonta weksli, akredytywy własnej i gwarancji. Znajduje się ona w ofercie m.in. BRE Banku, ING Banku Śląskiego, a także Getin Banku i Banku Nordea. 
Finansowanie działalności inwestycyjnej sektora MŚP jest bardzo ważnym elementem strategii kredytowej banków, pozwalającym na wprowadzanie na wyższy poziom rozwojowy całej gospodarki i zwiększenie jej konkurencyjności. Oferta bankowych kredytów inwestycyjnych jest dobrze rozbudowana i zawiera również produkty skierowane tylko i wyłącznie do tej grupy odbiorców. Oprócz standardowego finansowania inwestycji, zyskującym na znaczeniu w ostatnich latach jest kredyt technologiczny z premią technologiczną Banku Gospodarstwa Krajowego, wynoszącą maksymalnie $4 \mathrm{mln}$ zł oraz wymagający co najmniej 25\% wkładu własnego. Jest on dostępny w większości z poddanych analizie podmiotów. Specjalistyczne kredyty inwestycyjne - Zielona Energia (na finansowanie budowy elektrowni wiatrowych oraz instalacji wytwarzających energię z biomasy i biogazu) oraz Czysta Energia (z premią inwestycyjną na wsparcie projektów zakładających redukcję zużycia energii o minimum $20 \%$ lub instalacje mocy w ramach odnawialnych źródeł energii) są dostępne w BGŻ. Kredyt energooszczędny na zakup technologii ograniczających zużycie energii w firmie proponuje także BNP Paribas oraz Bank Millennium w ramach Programu Finansowania Rozwoju Energii Zrównoważonej w Polsce.

Jeżeli firma potrzebuje uzyskać szybko kapitał na inwestycje, może starać się o kredyt w Kredyt Banku (,Szybki kredyt inwestycyjny”) oraz Pekao S.A. (prosty kredyt inwestycyjny SIL lub AUTO SIL do 300 tys. zł). Godny uwagi jest też produkt Idea Banku - „Kredyt gospodarczy bez zabezpieczenia” do 200 tys. zł dla firm o krótkim stażu działalności oraz „Kredyt deweloper" na finansowanie inwestycji nieruchomościowej (pokazuje to, że ten podmiot chce oferować wyspecjalizowane produkty dla MŚP).

Oferta kredytowa banków jest bardzo rozbudowana, zdywersyfikowana oraz odpowiednio dopasowana do rynkowych potrzeb klientów. Konkurujące podmioty prześcigają się w stosowaniu różnych udogodnień i promocji dla przedsiębiorstw, takich jak brak zabezpieczeń rzeczowych, 0\% prowizji, 0\% marży, okres karencji w spłacie kapitału. Znaczący udział wśród MŚP chce zdobyć Idea Bank, prowadzący bardzo liberalną politykę kredytową - przyznając finansowanie na podstawie oświadczenia klienta o prognozowanym dochodzie oraz niewymaganiu stażu firmy, co jest dużą szansą dla firm nowo powstałych. Ramy możliwości podaży produktów kredytowych na polskim rynku wyznaczają najwięksi gracze - PKO BP, Pekao S.A., BRE Bank oraz ING Bank Śląski. Bardzo dobrą ofertą inwestycyjną mogą się pochwalić BGŻ oraz Kredyt Bank.

Ważną cechą obszaru kredytowego jest jego elastyczność (brak uzyskania kapitałów w jednym banku nie przekreśla możliwości zdobycia go w innym). Ponadto ważna jest coraz bardziej otwarta polityka finansowania prowadzona przez podmioty w stosunku do małych i średnich firm. Międzybankowy rynek kredytów pokazuje, że kredytodawcy dysponują dobrymi i różnorodnymi produktami także pod względem cenowym, co daje przedsiębiorcy możliwość wyboru najkorzystniejszej z jego punktu widzenia propozycji i prowadzenia skutecznych negocjacji.

Natomiast za najlepszego kredytodawcę w opublikowanym przez magazyn „Forbes” rankingu banków dla przedsiębiorcy uznane zostały ex aequo Kredyt Bank i BNP Paribas.

Poza kilkoma wyjątkami sytuacja kredytowa MŚP nadal jest jednak trudna i firmy mają duże problemy z otrzymaniem kredytu. Jak trafnie ocenia Krzysztof Pietraszkiewicz, prezes Związku Banków Polskich: „Firmy mają coraz lepsze programy biznesowe i solidniejsze zabezpieczenia, jednak nadal brakuje funduszy poręczeniowo-gwarancyjnych dla MŚP. Banki nie mają więc partnerów, z którymi mogłyby się podzielić ryzykiem” (Doliniak, 2012). 


\section{Oferta banków dla MŚP w zakresie obsługi rachunku bieżącego i bankowości elektronicznej} Oprócz działalności kredytowej banki specjalizują się również w obsłudze rachunków przedsiębiorstw, elektronicznej obsłudze klienta oraz dostarczaniu kart debetowych, kredytowych czy obciążeniowych.

Na przedsiębiorców, w tym na małe i średnie podmioty, jest nałożony formalny obowiązek posiadania rachunku bieżącego (zgodnie z art. 22 ustawy o swobodzie działalności gospodarczej). Nowoczesny rachunek bankowy oferowany jest obecnie w formie pakietów, w których jednostkowy koszt konkretnych usług jest niższy niż korzystanie z każdej z nich odrębnie.

Polityka analizowanych banków w prowadzeniu rachunku bieżącego i pozostałych rachunków jest zróżnicowana i nastawiona na różne grupy potencjalnych klientów korporacyjnych, niemniej jednak konto za 0 zł stało się już standardem w ofertach tych podmiotów finansowych. Zakres usług determinuje cenę za pakiet, ale widoczna jest tendencja do powiększania liczby darmowych kont dla firm, co na pewno zwiększy również zainteresowanie taką ofertą. Rosnąca konkurencja o klientów firmowych z sektora MŚP jest pozytywnym znakiem rozwoju tego rynku i na pewno wpłynie na obniżenie cen za poszczególne zestawy lub zwiększenie liczby produktów dostępnych w ramach każdego z nich za tę samą cenę.

W ciągu ostatnich lat częściej kontakt klienta korporacyjnego z bankiem odbywa się przez platformy elektroniczne z dostępem do Internetu niż przez tradycyjną formę spotkania. W XXI w. trudno sobie wyobrazić czynność bankową, która nie mogłaby zostać zrealizowana w systemie bankowości internetowej.

Najważniejszymi przyczynami rosnącej popularności takiej formy współpracy banku i przedsiębiorstwa są: bezpieczeństwo (gwarantowane podpisem elektronicznym), wygoda (systemy bankowe działające na telefonach komórkowych, netbookach, tabletach z dostępem do banku przez 24 godziny na dobę), szeroki wachlarz operacji (przelewy, polecenia zapłaty, pobieranie wyciągów, raportów, korzystanie z produktów kredytowych, lokacyjnych oraz kart bankowych). Systemy bankowości elektronicznej są również niezbędnymi narzędziami handlowymi do przeprowadzania transakcji na rynkach walutowych oraz rozliczania rozrachunków z dostawcami i odbiorcami z zagranicy (Rudnicka, 2012).

Przeprowadzona analiza opłat abonamentowych w poszczególnych pakietach oferowanych przez banki pokazuje, że bankowość elektroniczna jest dostępna w podstawowej wersji bez dodatkowych kosztów u każdego z podmiotów. Jest to rozwiązanie bardzo korzystne dla MŚP, które dzięki temu obniżają ponoszone koszty.

Wszystkie zbadane podmioty oferują darmowe przelewy wewnętrzne dla użytkowników swoich systemów. Przelewy do ZUS-u i urzędu skarbowego większość podmiotów udostępnia za darmo. Wszystkie przelewy internetowe za 0 zł znajdują się w pakietach oferowanych przez Citi Handlowy, Idea Bank oraz BRE Bank. Możliwość negocjowania cen przelewów przewiduje w ramach swojego pakietu dla MŚP BNP Paribas.

Obecna polityka banków w obszarze oferowania usług bankowości elektronicznej zachęca do korzystania z tej formy przez niskie koszty przelewów oraz brak dodatkowych opłat abonamentowych w pakietach dla małych i średnich podmiotów. Potencjał rozwojowy tego rynku jest bardzo duży i w przyszłości wszystkie operacje z rachunków klienta będą realizowane w formie elektronicznej, w tym również zamawianie kart depozytowych i obciążeniowych.

Wprowadzenie do polskiego systemu rozliczeń kart płatniczych było związane z ułatwieniem klientom korzystania ze środków zgromadzonych na rachunkach w banku oraz środków dostępnych w formie kredytu. Ze względu na umowę między posiadaczem karty a emitentem wyróżnia się karty: debetowe, kredytowe, obciążeniowe z odroczoną płatnością (charge) oraz 
przedpłacone. W sytuacji, gdy firma potrzebuje zastrzyku gotówki w krótkim czasie, najlepszym rozwiązaniem okazują się karty obciążeniowe i kredytowe.

Karty debetowe analizowanych podmiotów są udostępniane dla klientów w ramach poszczególnych pakietów. Najpowszechniejszą praktyką stosowną przez banki jest wydawanie tego środka płatniczego bez dodatkowych opłat. Również jego użytkowanie najczęściej odbywa się bezkosztowo. W zależności od ceny pakietu przedsiębiorcy mogą otrzymać jedną kartę debetową lub więcej kart debetowych (BGŻ, Pekao S.A. dają trzy karty w pakiecie za 99 zł, a Kredyt Bank udostępnia pięć kart debetowych bez dodatkowych opłat w cenie $240 \mathrm{zł} /$ miesiąc). W pełni darmowe „debetówki” dostępne są m.in. w Idea Banku, PKO BP, BZ WBK oraz Nordea Bank. Opłaty za użytkowanie w pozostałych podmiotach są dosyć zróżnicowane: od $15 \mathrm{zł} /$ rocznie do $10 \mathrm{zł} /$ miesięcznie. Wyraźnie widać, że banki dążą do popularyzacji takiej formy płatności i zwiększenia liczby jej użytkowników. W kontekście przyszłości i ery nośników elektronicznych jest to słuszny kierunek rozwojowy.

Szczegółowa analiza dostępności kart kredytowych w wybranych bankach pokazała, że nie znajdują się one w ofercie wszystkich podmiotów (brak ich m.in. w ofercie BRE Banku oraz BGŻ). Coraz popularniejsze stają się natomiast karty obciążeniowe typu charge z odroczoną płatnością (korzystanie z kredytu kupieckiego i nie ponoszenie kosztów odsetkowych, gdy środki pieniężne zwracane są w terminie, w przeciwnym razie płacenie wysokich odsetek). Wielkość kosztów za tego rodzaju karty sprowadza się do opłaty za wydanie (średnio 50 zł, aczkolwiek banki również kuszą zerowymi opłatami) i użytkowanie - w przedziale cenowym od 10 zł/miesiąc (Pekao S.A.) do nawet $500 \mathrm{zł} /$ rok w Raiffeisen Banku. Jest to bardzo wygodna forma krótkoterminowego pozyskiwania kapitału przez firmy, a wysokość limitów pieniężnych ustalana jest na podstawie zdolności kredytowej klienta. Szeroki wybór z dostępnych na rynku kart chargowych (MasterCard Business, MasterCard Business Gold Charge, Visa Business) świadczy o dużej konkurencji między bankami również w tym segmencie współpracy z przedsiębiorstwami.

Podobnie jak w przypadku kart typu charge sytuacja występuje z typowymi „kredytówkami” (kwota limitu, z której można korzystać w formie kredytu na karcie, spłacana na koniec okresu lub w formie rat) - są one szeroko dostępne i klienci mają duże możliwości wyboru najbardziej satysfakcjonującej z ich punktu widzenia. Przyznawane są przez pozytywną ocenę zdolności kredytowej potencjalnego podmiotu gospodarczego. Obsługa najprostszej karty kredytowej średnio-rocznie oscyluje w granicach $100 \mathrm{zł}$.

Rozwój oferty kart płatniczych jest tylko kwestią czasu - obecnie do obiegu wprowadzane są karty paypass umożliwiające płatności zbliżeniowe bez konieczności autoryzacji kodu PIN (do kwoty 50 zł). Zaletą takiego rozwiązania jest skrócenie czasu dokonywania transakcji, co w XXI w. jest bardzo ważną kwestią, zwłaszcza dla przedsiębiorców. Banki, podążając za postępem technicznym, na pewno przygotują ciekawe rozwiązania dla MŚP, by również na tym polu nawiązać owocną współpracę gwarantującą satysfakcję dla klientów i odpowiedni zarobek dla swojej organizacji.

Z przeprowadzonej analizy polskiego sektora bankowego należy wyciągnąć kilka ważnych wniosków. Pierwszym i najistotniejszym jest niewątpliwe zróżnicowanie w zakresie oferowanych produktów korporacyjnych. Ma to związek z możliwościami kapitałowymi podmiotów, jak i realizowanymi przez nie strategiami w tym obszarze. Najwięksi przedstawiciele sektora bankowego, świadomi nasycenia rynku, trzymają się strategii dywersyfikacyjnej, polegającej na pozyskiwaniu nowych klientów innymi usługami finansowymi. Zdobywanie rynku odbywa się na zasadzie świadczenia kompleksowych usług, również także pod względem technicznym. W ofercie bankowej znalazły swoje miejsce towarzystwa ubezpieczeniowe i inwestycyjne, spółki faktoringowe oraz leasingowe, domy maklerskie, doradcy inwestycyjni, banki inwestycyjne i hipo- 
teczne (np. Grupa ING). Drugą z wykorzystywanych strategii funkcjonowania jest rozwój produktu. Wiąże się on z połączeniem wybranych produktów, niebędących stricte bankowymi, z tradycyjnymi usługami i tworzeniem nowych, mających za cel zapełnienie jednej z występujących nisz rynkowych lub też stworzenie jej. Zdecydowanie bardziej pożądaną strategią jest jednak dywersyfikacja, która daje dużo lepsze efekty.

Bankowość dla małych i średnich przedsiębiorstw, choć we wcześniejszych latach nie była obszarem dużego zainteresowania instytucji kredytujących, teraz zyskuje bardzo na popularności. Stała się ona strategicznym celem tych instytucji kredytujących. W czasach niepewności gospodarczej oraz licznych afer finansowych to banki stają się najpewniejszym źródłem pozyskania finansowania czy lokowania zarobionego kapitału z zyskiem. Banki podchodzą do sektora MŚP z jak największą powagą, gdyż w obliczu praktycznie zacementowanego segmentu dużych przedsiębiorstw współpracujących z pewnymi partnerami kredytowymi, źródłem zysków stają się mniejsze firmy, które dzięki swojej innowacyjności i pomysłowości szturmują rynki Unii Europejskiej. Wzmocnienie pozycji kredytowej MŚP nastąpiło po wejściu do UE, która stara się jak tylko może przez różne pomysły ułatwić dostęp do kapitału, zapewniając gwarancje kredytowe oraz przeznaczając znaczne fundusze na działalność inwestycyjną podmiotów z tego sektora.

Oferty produktowe banków pod względem ceny są bardzo zróżnicowane. Dla przedsiębiorstw rozpoczynających działalność przygotowane są pakiety w jak największym stopniu minimalizujące koszty - darmowe założenie i prowadzenie rachunku bankowego, bankowość internetowa bez dodatkowych kosztów, wydanie i obsługa karty depozytowej, również bez opłat, oraz możliwość uzyskania kredytu na specjalnych warunkach lub bez zabezpieczeń. Tak dobrany koszyk produktów dostarcza Idea Bank, posiadający niewielkie aktywa i prowadząc tak „przyjazną” politykę, by zdobyć jak największą część zyskownego tortu, jaką niewątpliwie stanowią MŚP.

Najlepiej rozwinięte firmy z tego sektora również mają do dyspozycji bardzo atrakcyjne pakiety z różnymi grantami. Płacąc odpowiednio dużo, klient otrzymuje bardzo szeroki wachlarz produktów i usług. Jedną z najlepszych ofert udostępnia BRE Bank z 99 kontami oraz Citi Handlowy w pakiecie CitiGold dla biznesu z zerowymi opłatami. Bardzo dobrą ofertą kredytową dysponują najwięksi gracze - PKO BP, Pekao S.A, a także Millennium. Godna polecenia jest również perspektywa finansowania w Kredyt Banku, BGŻ oraz BNP Paribas. Na tak rozwiniętym i konkurencyjnym rynku międzybankowym każde przedsiębiorstwo na pewno znajdzie dla siebie najbardziej odpowiednią ofertę na miarę własnych potrzeb i możliwości.

Bogaty wachlarz produktów skierowanych dla klientów firmowych ze strony banków jest gwarancją dobrej kondycji polskich instytucji kredytujących oraz coraz lepszego rozwoju przedsiębiorstw. Szczególnie istotne w czasach kryzysu jest dodatkowe wsparcie dla wzrostu przedsiębiorczości, które powinno wyjść od podmiotów wykonujących czynności bankowe. Brak odpowiedniej reakcji spowoduje trwałe osłabienie w całej gospodarce, której silnikiem napędowym są małe i średnie przedsiębiorstwa.

Zawirowania na rynkach światowych w znaczącym stopniu odbijają się na sektorze MŚP w Polsce. Pewną stabilność gwarantuje duża konkurencyjność oferty bankowej dla firm oraz wysoki poziom rozwoju przedsiębiorczości. Posiadanie odpowiedniej zdolności kredytowej jest kluczowym kryterium w staraniach się o uzyskanie finansowania, dlatego niezbędne jest dbanie o osiąganie założonych celów biznesowych. Konsekwentne działania przedsiębiorców przyczyniają się do zwiększenia zaufania zarówno do polskiej gospodarki, jak i do zdrowego systemu bankowego. Brak banków i ich kapitałów byłby bardzo widoczny i bardzo bolesny - spowodowałby cofnięcie w rozwoju i zapaść gospodarczą, pogłębiającą się dodatkowo przez kryzysy gospodarcze. Nie do przecenienia jest rola instytucji finansujących podmioty firmowe 
- przedsiębiorczość nie rozkwitałaby w tak zawrotnym tempie, uodporniona siłą polskiej sfery bankowej. Na tej płaszczyźnie rysuje się silna korelacja między rozwojem przedsiębiorczości a różnorodną ofertą banków dla MŚP.

\section{Zakończenie}

Sektor bankowy w Polsce jest dla małych i średnich przedsiębiorstw bardzo ważnym partnerem biznesowym. Zapewnia im niezbędny kapitał rozwojowy, prowadząc ekspansywną politykę kredytową (w 2011 r. silny wzrost akcji kredytowej o 20\% w porównaniu z rokiem 2010). W czasach kryzysu gospodarczego, który w warunkach globalizacji rozprzestrzenia się i dotyka również kraje stabilne i odporne na wahania koniunktury, takie jak Polska, dostępność kredytów dla firm jest gwarantem rozwoju przedsiębiorczości. Pomimo zaostrzenia warunków kredytowych przez banki liczba odrzuconych wniosków o finansowanie systematycznie spada. Równocześnie zmniejsza się też liczba przedsiębiorców, którzy ubiegają się o kredyt, co ma związek z samoistną selekcją podmiotów, nie będących w stanie spełnić wymogów bankowych.

Przeprowadzona analiza oferty banków dedykowanej dla przedsiębiorców pokazała duże zróżnicowanie dostępnych produktów. Ma to związek z możliwościami kapitałowymi podmiotów jak i realizowanymi przez nie długofalowymi strategiami. Zdobywanie rynku polega na świadczeniu kompleksowych usług, również pod względem technicznym. Inną realizowaną strategią jest rozwój produktu. Dotyczy on podmiotów o niewielkich rozmiarach, które łączą wybrane produkty, niebędących sensu stricte bankowymi z tradycyjnymi usługami i tworzą nowe. Takie działanie sprzyja zapełnianiu występujących nisz rynkowych lub też ich tworzenie. Zdecydowanie bardziej pożądaną strategią jest dywersyfikacja, która daje dużo lepsze efekty.

Bankowość dla małych i średnich przedsiębiorstw w ostatnich latach bardzo zyskuje na popularności. Stała się ona ważnym strategicznym celem i dochodowym źródłem instytucji kredytujących. W czasach niepewności gospodarczej oraz licznych afer finansowych to banki stają się najpewniejszym źródłem pozyskania finansowania czy ulokowania zarobionego kapitału z zyskiem.

Bogaty wachlarz produktów bankowych dla firm stwarza szanse dla uzyskania dobrej kondycji przez polskie instytucje kredytujące oraz może przyczyniać się do rozwoju przedsiębiorstw. Szczególnie istotne w czasach kryzysu jest dodatkowe wsparcie dla wzrostu przedsiębiorczości, którego powinny udzielić podmioty wykonujące czynności bankowe (np. przez możliwość zdobycia kredytu na preferencyjnych warunkach dla przedsiębiorstw o ograniczonej zdolności kredytowej). Brak pomocy może przyczynić się do trwałego osłabienia w całej gospodarce, która napędzana jest przez małe i średnie przedsiębiorstwa.

Banki w rozwoju przedsiębiorczości w Polsce odgrywają kluczową rolę, dlatego też istnieje współzależność między ich ofertą skierowaną do sektora MŚP, a dynamicznym wzrostem gospodarki, która dzięki zdrowym podstawom potrafi w skuteczny sposób opierać się kryzysowi gospodarczemu, łagodząc jego negatywne skutki.

\section{Literatura}

BIG InfoMonitor. (2012, wrzesień). Wskaźnik bezpieczeństwa działalności gospodarczej-raport BIG. Chynał, H. (2008). Kredyty bankowe $i$ inne formy finansowania poradnik dla matych i średnich firm. Warszawa: Difin.

Doliniak K. (2012, 4 lipca). Ranking banków, czyli banki pewne na bank. Pozyskano z: http://www. forbes.pl/artykuly/sekcje/ranking-bankow-2011/ranking-bankow--czyli-banki-pewne-na-bank,19906,5 Forbes. 2011, 10.

Grzywacz, J. (2006). Wspótpraca przedsiębiorstwa z bankiem. Warszawa: Difin. 
Korenik, D. (2006). Innowacyjne ustugi banku. Warszawa: PWN.

Kwiatkowska, M. (2012, 20 marca). Parabanki kusza oferta kredytowa małe firmy. Pozyskano z: http:// serwisy.gazetaprawna.pl/msp/artykuly/602765,parabanki-kusza-oferta-kredytowa-male-firmy.html

Ministerstwo Gospodarki. (2012, kwiecień). Trendy rozwojowe sektora MŚP w ocenie przedsiębiorców $w$ drugiej połowie 2011 roku. Warszawa.

NBP. (2012, styczeń). Sytuacja na rynku kredytowym wyniki ankiety do przewodniczacych komitetów kredytowych I kw. 2012. Warszawa.

NBP. (2012, styczeń). Informacja o kondycji sektora przedsiębiorstw ze szczególnym uwzględnieniem stanu koniunktury w IV kw.2011 oraz prognoz koniunktury na I kw. 2012.

NBP. (2012, kwiecień). Informacja o kondycji sektora przedsiębiorstw ze szczególnym uwzględnieniem stanu koniunktury w I kw. 2012 oraz prognoz koniunktury na II kw. 2012.

Olczak, M.A. (2012, 3 lutego). Małe i średnie firmy biora kredyty z Europejskiego Banku Europejskiego. Pozyskano z: http://biznes.gazetaprawna.pl/artykuly/520584,male_i_srednie_firmy_biora_kredyty_z_europejskiego_banku_inwestycyjnego.html.

PARP. (2011). Raport o stanie sektora matych i średnich przedsiębiorstw w Polsce. Warszawa.

Przedsiębiorcy zawiedli się na Euro 2012. Nastroje najgorsze od trzech lat. Pozyskano z: http://wyborcza.biz/biznes/1,100896,12467102,Przedsiebiorcy_zawiedli_sie_na_Euro_2012_Nastroje.html.

Rudnicka, W. (2012, 1 kwietnia). Internet zmienia model wspótpracy przedsiębiorstw z bankami. Pozyskano z: http://edgp.gazetaprawna.pl/index.php?act=mprasa\&sub=article\&id=379345.

Styczek, D. (2012, 3 marzec). Mate i średnie firmy przyciagaja banki. Pozyskano z: http://biznes.gazetaprawna.pl/artykuly/513182,male_i_srednie_firmy_przyciagaja_banki.html.

Styczek, D. (2012, 12 stycznia). Prosty sposób na finansowanie. Pozyskano z: http://biznes.gazetaprawna.pl/artykuly/513183,prosty_sposob_na_finansowanie.html?utm_source=link\&utm_medium=referral\&utm_campaign=nastepny-artykul

Szelągowska, A. (2011). Dostępność kredytów bankowych dla polskich przedsiębiorstw w świetle badań literaturowych. W: A. Szelągowska (red.) Współczesna bankowość korporacyjna. Warszawa: CeDe$\mathrm{Wu}, 265-279$.

Uryniuk, J. (2012, 29 lipca). Tylko 4 proc. przedsiębiorstw korzysta z faktoringu. Pozyskano z: http:// serwisy.gazetaprawna.pl/msp/artykuly/605584,tylko-4-proc-przedsiebiorstw-korzysta-z-faktoringu. html.

Urząd Komisji Nadzoru Finansowego. (2012). Raport o sytuacji banków w 2011 r. Warszawa.

Wiatr, M.S. (2011). Zarzadzanie indywidualnym ryzykiem kredytowym. Elementy systemu. Warszawa: Oficyna Wydawnicza SGH w Warszawie.

\section{Źródla internetowe}

www.aliorbank.pl

www.bankmillennium.pl

www.bgz.pl

www.bnpparibas.pl

www.brebank.pl

www.citibank.pl

www.getinbank.pl

www.ideabank.pl

www.ingbank.pl

www.kredytbank.pl

www.mim.firmy.bzwbk.pl

www.nordea.pl

www.pekao.com.pl

www.pkobp.pl

www.raiffeisen.pl 
Wojciech Sadkowski, mgr, Uniwersytet Jagielloński, Instytut Ekonomii i Zarządzania.

Magister ekonomii międzynarodowej Uniwersytetu Jagiellońskiego (studia w latach 2007-2012). Jego zainteresowania badawcze to: bankowość korporacyjna, rachunkowość zarządcza, sektor małych i średnich przedsiębiorstw, upadłość przedsiębiorstw.

Wojciech Sadkowski, MA, Institute of Economics and Management of the Jagiellonian University. MA in International Economics at the Jagiellonian University (studied between 2007 and 2012). Research interests: corporate banking, management accounting, small and medium enterprises, company bankruptcy.

Adres/Address: $\quad$ Uniwersytet Jagielloński, Instytut Ekonomii i Zarządzania ul. prof. S. Łojasiewicza 4, 30-348 Kraków, Polska e-mail: wojciech.sadkowski@uj.edu.pl. 


\section{Funkcjonowanie firm, instytucji}

\section{i sektorów gospodarki w warunkach kryzysu}

The functioning of companies, institutions and sectors of economy within the conditions of a crisis 


\title{
Danuta Janczewska
}

Społeczna Akademia Nauk

w Łodzi

\section{Zachowania organizacyjne mikroprzedsiębiorstw w warunkach kryzysu}

\section{Organizational behaviour of micro enterprises in the conditions of a crisis}

\begin{abstract}
Streszczenie
Kryzys uważany jest obecnie za zjawisko ekonomiczne na trwałe wpisane w działalność przedsiębiorstw. Analiza zjawisk kryzysowych w zarządzaniu przedsiębiorstwem prowadzi do wskazania źródeł i przyczyn jego powstawania. Mogą one leżeć wewnątrz przedsiębiorstwa, jak również pochodzić z jego otoczenia. Teorie powstałe na gruncie zainteresowania badaczy dotyczą metod identyfikacji przyczyn oraz wpływu kryzysu na przedsiębiorstwo. Duże firmy i korporacje posiadają wypracowane modele analizowania sygnałów zbliżającego się kryzysu oraz procedury określające zasady postępowania w warunkach kryzysu. Mikroprzedsiębiorstwa nie mają wystarczającej wiedzy oraz menedżerów, którzy są w stanie dostrzec zbliżający się kryzys oraz sformułować zalecenia zapobiegające jego rozwojowi. Celem artykułu jest prezentacja zachowań organizacyjnych mikroprzedsiębiorstw w warunkach kryzysu. Przedstawione zostały w nim badania własne zachowań mikroprzedsiębiorstw na podstawie branży cukierniczej.
\end{abstract}

\begin{abstract}
Crisis, as an economic phenomenon, has always accompanied enterprises. The causes of crisis can be both internal, and external in relation to companies. Numerous theories exist, based on the interests of researchers, concerning the methods of identifying the reasons of crises, and measuring their influence on businesses. Examples of companies that failed to cope with a crisis confirm the thesis that a crisis may affect every enterprise. Large companies possess prepared models, for analysing the signals of an approaching recession. Micro enterprises are equipped with neither the knowledge, nor the managers, to formulate procedures of preventing the development of a crisis. The aim of this article is to present the organizational behaviours of micro enterprises in crisis situations. These are shown on the basis of the author's proprietary research of micro enterprises, on the example of the women-clothing branch.
\end{abstract}

Słowa kluczowe: analiza ryzyka; kryzys; mikroprzedsiębiorstwo; zarządzanie

Key words: analysis of risk; crisis; micro enterprises; management

\section{Wprowadzenie}

Kryzys jako zjawisko ekonomiczne jest na trwałe wpisany w gospodarki poszczególnych krajów oraz działalność przedsiębiorstw. Umiejętność radzenia sobie z nim może być uznana za jedną z umiejętności zarówno rządów państw, jak i menedżerów. Rozważania na temat kryzysu prowadzone są w skali makroekonomicznej (OECD, 2009: 10) i w skali mikroekonomicznej. 
Wskazuje się przy tym na przyczyny zjawisk kryzysowych, mogące pochodzić z wnętrza przedsiębiorstwa oraz z jego otoczeniu. Powstałe teorie dotyczą metod identyfikacji przyczyn oraz wpływu kryzysu na przedsiębiorstwo. Przykłady przedsiębiorstw, które nie poradziły sobie z kryzysem, potwierdzają tezę, że kryzys może pojawić się w każdym przedsiębiorstwie, bez względu na jego wielkość i zasoby. Jak wskazują badania, duże firmy i korporacje mają wypracowane modele rozpoznawania i diagnozowania sygnałów zbliżającego się kryzysu. Brak jest natomiast analiz dotyczących zachowań organizacyjnych w warunkach zagrożenia kryzysem w sektorze mikroprzedsiębiorstw.

Celem niniejszego artykułu jest prezentacja zachowań organizacyjnych mikroprzedsiębiorstw w warunkach kryzysu. Przedsiębiorstwa te, nie mając wystarczającej wiedzy oraz wykwalifikowanej kadry menedżerskiej, nie są w stanie dostrzec zbliżającego się kryzysu oraz sformułować zaleceń zapobiegających jego rozwojowi. W artykule została podjęta próba sformułowania modelu postępowania mikrofirmy na gruncie teorii zachowań organizacyjnych na podstawie badań własnych mikrofirm z branży cukierniczej. Autorka zaproponowała także procedury pożądanych zachowań organizacyjnych w warunkach kryzysu gospodarczego.

\section{Kryzys w zarządzaniu firmą XXI w. a zachowania organizacyjne}

Zarządzanie firmą w XXI w. jest skierowane na zewnątrz firmy (an outward directed management), zaś jego główne przejawy koncentrują się na definiowaniu celów w kontekście potrzeb rynku i klienta, a nie samej firmy. Współczesne wyzwania teorii i praktyki zarządzania ${ }^{1}$ obejmują zagadnienia:

- globalizacji działalności gospodarczej,

- zapewnienia jakości i wydajności,

- zmniejszenia rozmiarów produkcji i redukcji personelu,

- własności i etyki,

- odpowiedzialności społecznej,

- różnorodności siły roboczej.

Zagrożenie kryzysem polega na niespodziewanym pojawieniu się w funkcjonowaniu przedsiębiorstwa zdarzeń, które wiążą się z każdą dziedziną zarządzania w obszarach funkcjonowania przedsiębiorstwa. Podejmowanie decyzji w procesie zarządczym we wszystkich rodzajach i strukturach zarządzania przedsiębiorstwem może stać się źródłem ryzyka, w następstwie którego w przedsiębiorstwie może pojawić się kryzys. Każda decyzja związana z wyznaczaniem celów przedsiębiorstwa czy przewidywaniem określonego stanu w przyszłości obarczona jest dużym współczynnikiem niepewności i ryzyka - zatem oczekiwania w ekonomii formułuje się po to, by zmniejszyć ryzyko (Tarczyński, Mojsiewicz, 2001: 7). Główną trudnością jest rozpoznanie symptomów zbliżającego się kryzysu zarówno w sferze dotyczącej globalizacji rynków, jak i pozostałych wymienionych wyżej zagadnień. Identyfikacja zagrożeń kryzysem jest ważnym zadaniem menedżera zarządzającego przedsiębiorstwem i umożliwia podjęcie działań zapobiegających przekształceniu zagrożenia kryzysem w kryzys w pełnym tego słowa znaczeniu. W praktyce zarządzania zagrożenie kryzysem w przedsiębiorstwie jest zjawiskiem zakłócającym proces identyfikacji otoczenia, realizacji celów rynkowych i zaspokajania potrzeb klienta. Niedocenienie zapowiedzi przyszłych odstępstw jakościowych i ilościowych w zakresie obowiązujących parametrów procesowych, przyjętych procedur i kryteriów dotyczących efektywności przedsiębiorstwa może zagrażać dalszemu istnieniu firmy na rynku.

1 Wśród nowoczesnych koncepcji oraz kierunków teorii i praktyki zarządzania najbardziej znane zaprezentowane zostały przez następujących teoretyków: Friedman (2009); Drucker (2009); Breen, Hamel (2008). 
Zagrożenie kryzysem może wystąpić w niektórych obszarach działalności lub dotyczyć całości funkcjonowania przedsiębiorstwa (Janczewska, 2011). Przejawy zagrożenia kryzysem mogą mieć charakter:

- wymierny, wskaźnikowy - w tej kategorii można wyraźnie określić trend np. spadku sprzedaży czy utraty klientów,

- niewymierny, opisowy, intuicyjny - oparty na przypuszczeniach czy obserwacjach przejawów występujących w innych firmach.

O ile pierwsza grupa jest stosunkowo łatwa do identyfikacji przez monitorowanie i kontrolowanie danych charakteryzujących bieżącą działalność przedsiębiorstwa, o tyle druga grupa przejawów może być trudna do wyodrębnienia spośród nadmiaru informacji napływających zarówno z otoczenia przedsiębiorstwa, jak i z jego wnętrza. W ujęciu współczesnych koncepcji zarządzania przedsiębiorstwem należy przyjąć, iż rozpoznawanie i zarządzanie zagrożeniem kryzysem może mieć postać i strukturę procesową, wykorzystującą współczesne metody i narzędzia analizy procesu. Pojęcie to w polskich przedsiębiorstwach jest stosunkowo nowe i jest obiektem badań na gruncie interdyscyplinarnym. Nie zajmowano się też dotychczas analizą zachowań organizacyjnych w mikroprzedsiębiorstwie w kontekście zjawisk kryzysowych. Spośród mniej wykorzystywanych dziedzin nauki, które mogą służyć jako podstawa do prowadzenia działań rozpoznawczych samego zjawiska kryzysu w mikroprzedsiębiorstwie, jak i w procesie zarządzania kryzysem, można wskazać obszar zachowań organizacyjnych. Opisy wpływu kryzysu na przedsiębiorstwa duże oparte są na wiedzy z zakresu zarządzania, ekonomii, marketingu, zarządzania zasobami ludzkimi - nauk społecznych. Jedną z koncepcji i definicji ryzyka opracowała Komisja do spraw Terminologii Ubezpieczeniowej USA w roku 1996. Zaproponowała ona definicję ryzyka jako mierzalnej niepewności, dotyczącej tego, czy zamierzony cel działania zostanie osiągnięty.

Identyfikacja przyczyn kryzysu w mikroprzedsiębiorstwie może być prowadzona na podstawie typologii powiązanej z lokalizacją źródeł kryzysu (Iwanek, 2004: 85). Według tej typologii źródła kryzysu dzielą się na zewnętrzne i wewnętrzne. Do zewnętrznych źródeł przyczyn kryzysu należeć będą: tempo wzrostu gospodarczego kraju, polityka ekonomiczna względem mikroprzedsiębiorstw, polityka fiskalna, poziom dochodów ludności, dynamika zmian modelu konsumpcyjnego, skłonność do oszczędzania i konsumowania dochodów, kondycja przedsiębiorstw kooperujących, wielkość popytu na produkty przedsiębiorstwa, struktura popytu, natężenie konkurencji w sektorze, oddziaływanie dostawców, oczekiwania nabywców i siła ich oddziaływania, zmiany technologiczne rozumiane jako postęp techniczno-technologiczny, innowacje w sektorze.

Znacznie więcej przyczyn kryzysu można zidentyfikować w samym przedsiębiorstwie (Zaborowska, 2011: 20). Zalicza się do nich: brak misji i wizji przedsiębiorstwa, niejasne style zarządzania, utratę celu działalności, niedostosowanie działalności do warunków otoczenia. Przyczyny kryzysu mogą mieć źródło w metodach i stylu zarządzania oraz odnosić się do braku misji i wizji lub utraty celu działalności. Ponadto ich źródłem może być nieznajomość celów oraz brak utożsamiania się pracowników z przedsiębiorstwem, a także organizacja i zarządzanie w przedsiębiorstwie oparte na konserwatywnych metodach oraz niedostosowaniu stylu kierowania do warunków, w jakich działa przedsiębiorstwo. Wśród pozostałych symptomów zbliżającego się kryzysu można wymienić: stan samozadowolenia z osiągniętych rezultatów, błędy i konserwatywne metody w zarządzaniu finansami, brak strategii finansowej i kontrolowania, utratę płynności finansowej, dążenie do maksymalizacji zysku w przedsiębiorstwie, brak kontroli nad wydatkami, zapasami i należnościami, brak strategii marketingowej, 
niezrównoważony portfel produktów lub usług przedsiębiorstwa, brak nowych produktów i pomysłów innowacyjnych, słabą pozycję rynkową - jako efekt wewnętrznych słabości przedsiębiorstwa - wysokie koszty jednostkowe, przestarzałą bazę techniczną i technologiczną, niską produktywność, rozczarowania i frustracje pracowników, konflikty wewnątrz organizacji.

Wśród czynników stanowiących przyczyny wewnętrzne kryzysu można wskazać te, które tworzą i kształtują zachowania organizacyjne danego przedsiębiorstwa. Istotą zachowań organizacyjnych jest rozpoznanie oraz prezentacja przedsiębiorstwa jako zbioru wielu elementów, pośród których najważniejszy jest człowiek. Koncentrując rozważania na wskazaniu zależności pomiędzy zaobserwowaniem ryzyka oraz zagrożenia dla przedsiębiorstwa a zachowaniami organizacyjnymi, można zauważyć szereg czynników wpływających na wzrost zagrożenia kryzysem. Według C. Pritcharda (Pritchard, 2002: 53) do grupy ryzyka wewnętrznego pozatechnicznego należą: opóźnienia w realizacji procesów w przedsiębiorstwie, zmiany strukturalne i organizacyjne, zaburzenia przepływów wewnątrz przedsiębiorstwa. Natomiast źródłem tak sformułowanych kategorii ryzyka mogą stać się niedoświadczenie członków zespołu, błędy integracyjne, ograniczenie dostępu do informacji, błędy decyzyjne. Według Bizoń-Góreckiej istotne jest wyróżnianie kategorii ryzyka przez identyfikację kolejnych jego faz (Bizoń-Górecka, 2001: 51-93).

\section{Specyfika zjawisk kryzysowych z punktu widzenia mikroprzedsiębiorstwa}

Złożoność zjawisk kryzysowych utrudnia prowadzenie samych obserwacji przejawów zbliżającego się kryzysu, ich kwantyfikację oraz formułowanie wniosków i zaleceń mających uchronić przedsiębiorstwo przed ryzykiem nieprzetrwania firmy. Czynniki determinujące działalność przedsiębiorstwa i jego rozwój oraz zakłócenia w realizacji tychże czynników zdefinował Zelek (Zelek, 2003: 129). Z kolei badania Orłowskiego umożliwiły identyfikację czynników stymulujących zagrożenie kryzysem dla mikrofirm (Orłowski i in., 2010: 121). Są to czynniki powstałe w otoczeniu przedsiębiorstwa: system podatkowy, brak dopływu nowych klientów, nieprzewidywalność rynku, nieuczciwa konkurencja, nadmierna konkurencja, opóźnienia płatności lub ich brak, niestabilność regulacji prawnych, trudność w uzyskaniu kredytów, ustawione przetargi, brak pracowników o odpowiednich kwalifikacjach, niestabilne kursy walut, brak surowców lub wysokie koszty ich uzyskania, trudności w spłacie kredytów.

Graficzną postać zagrożenia dla funkcjonowania mikrofirm w odniesieniu do wymienionych powyżej czynników pokazano na rycinie 1. Badania prowadzone były przez PARP w sektorze MŚP na 1205 przedsiębiorstwach w branżach: przetwórstwo przemysłowe, budownictwo, transport i gospodarka magazynowa. Liczba mikroprzedsiębiorstw w badanej próbie wynosiła 57\%.

Według badań PARP najczęściej obserwowanym przez mikroprzedsiębiorców skutkiem sytuacji kryzysowej jest:

- spadek sprzedaży/obrotów oraz mniejsza liczba zleceń - 88\%,

- spadek rentowności firmy - 24\%,

- opóźnione płatności, czyli zjawiska typowe dla recesji - 30\%,

- trudności w uzyskaniu kredytu, pożyczki - 8\%.

Badania PARP określają, iż respondenci nie postrzegają obecnych zawirowań gospodarczych jako głównego zagrożenia dla funkcjonowania firmy (Orłowski i in., 2010). Co trzecia firma nie podjęła w związku z kryzysem żadnych działań, natomiast większość firm, które przedsięwzięły jakieś kroki, zaczęło przede wszystkim ograniczać koszty działalności i inwestycje. Niewiele firm przyjęło wobec kryzysu postawę aktywną, np. zaczęło szukać nowych rynków lub rozpoczęło restrukturyzację. $Z$ badań wynika, że przedsiębiorstwa nie są przygotowane 
na zawirowania rynkowe. Ponad dwie trzecie firm w sektorze MŚP nie ma zdefiniowanych procedur określających sposób postępowania w sytuacjach kryzysowych. Badania PARP w sektorze MŚP pozwoliły również na identyfikację działań podjętych w związku z kryzysem w badanej grupie przedsiębiorstw.

Ryc. 1. Zagrożenia zewnętrzne dla funkcjonowania mikroprzedsiębiorstwa

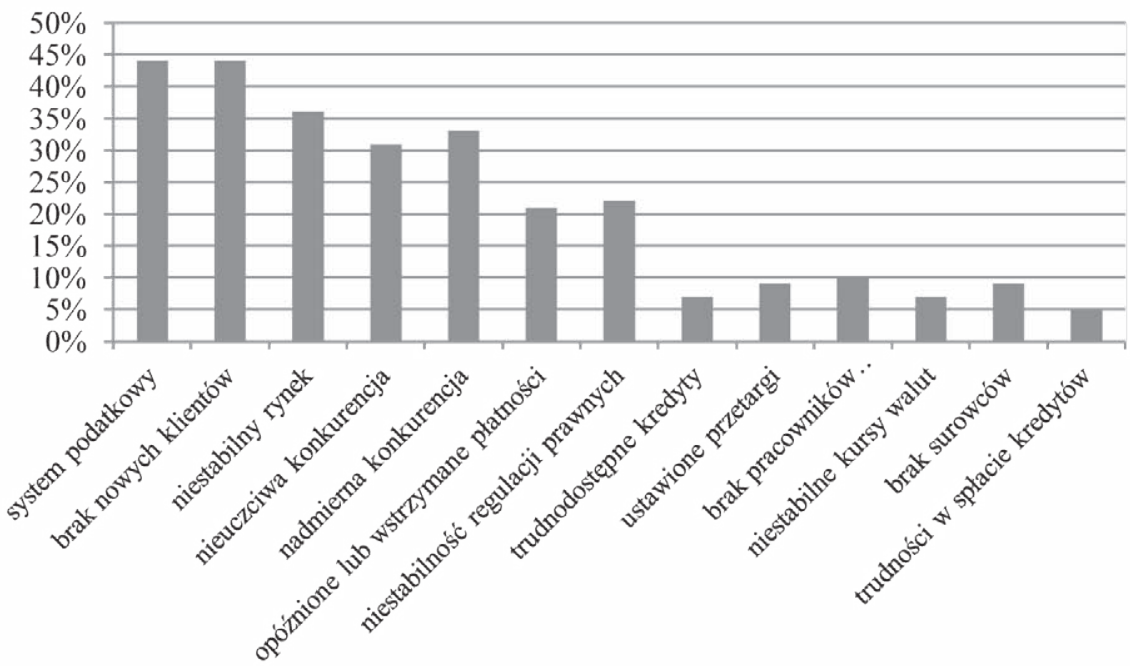

Źródło: opracowanie własne na podstawie: Orłowski i in. (2010: 121).

Ryc. 2. Działania podjęte w mikroprzedsiębiorstwach w związku z kryzysem

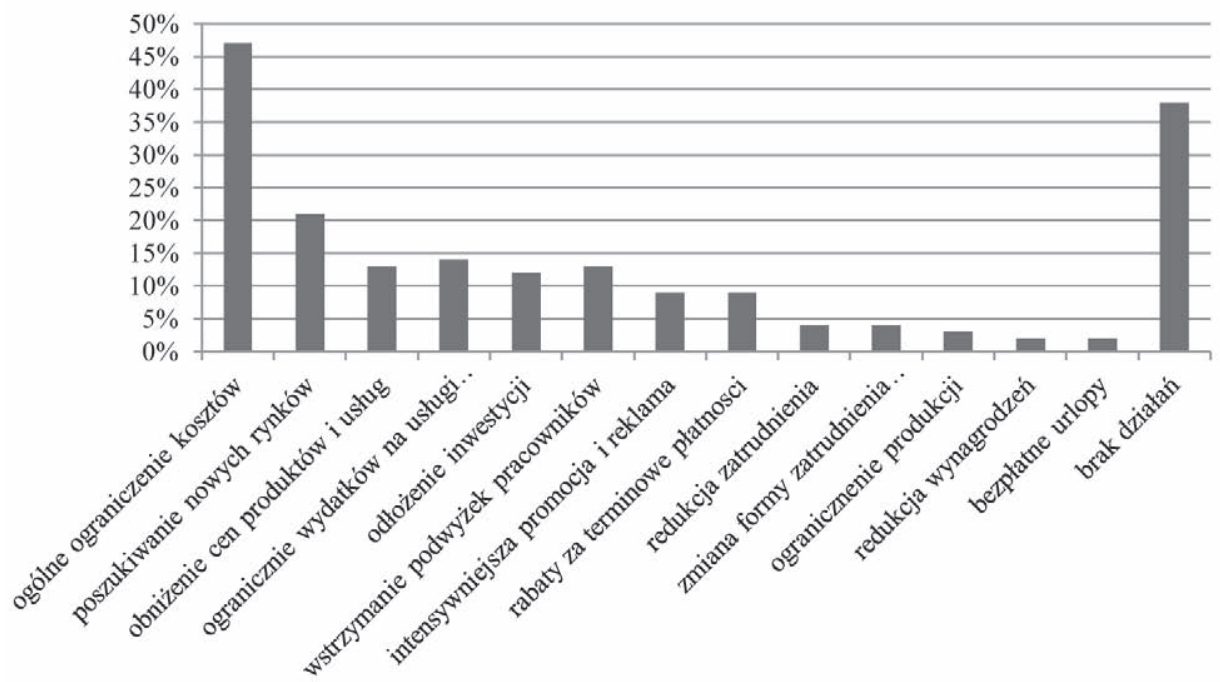

Źródło: opracowanie własne na podstawie: Orłowski i in. (2010: 122). 
Graficzną postać wyników badania PARP dla działań mikroprzedsiębiorstw w związku z kryzysem przedstawiono na ryc. 2. Z badań PARP wynikają następujące wnioski i uogólnienia:

- firmy z sektora MŚP przejawiają zróżnicowane postawy wobec kryzysu;

- ponad połowa to umiarkowani optymiści, dla których sytuacja kryzysowa stanowi wprawdzie zagrożenie, ale nie blokuje rozwoju ich działalności;

- jedynie nieliczni postrzegają sytuacje kryzysowe jako realne zagrożenie (firmy odczuwające bezsilność, niepotrafiące poradzić sobie z funkcjonowaniem w konkurencyjnych warunkach);

- większość przedsiębiorców nie dostrzega korzyści z precyzowania i określania celów, planów czy strategii działania, co stawia pod znakiem zapytania możliwości budowy długoterminowej przewagi konkurencyjnej w zmieniającym się otoczeniu.

\section{Zachowania organizacyjne mikroprzedsiębiorstw - nowy paradygmat zarządzania w warunkach kryzysu na podstawie badań własnych w branży cukierniczej}

W warunkach pojawiającego się kryzysu przedsiębiorstwo zazwyczaj poszukuje nowego celu funkcjonowania na rynku. Przesłanką do formułowania nowego celu jest zwykle poszukiwanie obniżenia kosztów. Często jednak przedsiębiorstwa dostrzegają konieczność zmiany asortymentów, poprawy jakości i wypełnienia norm i standardów. Głównym problemem staje się wówczas obniżenie kosztów produkcji przez poprawę zdolności produkcyjnych oraz zapewnienie elastyczności produkcji.

Przykładem tego typu zachowań organizacyjnych mogą być mikroprzedsiębiorstwa z branży cukierniczej. Autorka niniejszego artykułu w latach 2007-2010 prowadziła badania własne wśród 30 mikrofirm z województwa łódzkiego, mazowieckiego oraz kujawsko-pomorskiego. Celem badań było m.in. określenie zachowań organizacyjnych mikroprzedsiębiorstw w warunkach kryzysu, w tym zachowań wobec pojawiającego się zagrożenia kryzysem. Badane przedsiębiorstwa prowadziły działalność produkcyjną (70\%) oraz usługową (30\%). Dobór próby był celowy, zatem wyniki badań odnoszą się do badanej grupy mikroprzedsiębiorstw. Badania własne autorka prowadziła metodą wywiadów bezpośrednich, konsultacji z menedżerami i ekspertami oraz przez analizę źródeł wtórnych.

Wśród przyczyn kryzysu w firmach cukierniczych wskazywano następujące elementy: utrata płynności finansowej, obciążenia podatkowe, nieuczciwe działania konkurentów, utrata klientów i brak nowych klientów, zbyt wysokie ceny surowców, np. cukru, kakao, dodatków cukierniczych, brak interesującej oferty produktowej i usługowej, zbyt wysokie ceny na wyroby cukiernicze, brak strategii rynkowej mikroprzedsiębiorstwa, brak strategii logistycznych, brak wsparcia ze strony zrzeszeń rzemieślniczych. Na podstawie badań własnych mikroprzedsiębiorstw w branży cukierniczej można wskazać następujące kategorie zagrożeń kryzysem gospodarczym:

- kryzys strategiczny oznaczający starzenie się i dezaktualizację strategii, w tym strategii rynkowej przedsiębiorstwa w odniesieniu do jego działań w sferze produkcji, zarządzania, logistyki etc. - wskazania 60\% firm,

- kryzys wynikowy objawiający się znacznym pogorszeniem wyniku finansowego, będącego wynikiem utraty klientów, wolniejszym spływem należności, zmianą kursu walut, utratą zamówień, utratą partnerów i kooperantów, wstrzymaniem dotychczasowych kontraktów wskazania $80 \%$ firm,

- kryzys płynności, czyli sytuacja, w której brakuje gotówki na pokrycie bieżących wydatków. Na podstawie badań własnych określono pojęcie procesowy charakter kryzysu ze względu na ukierunkowanie, miejsce powstania, rozwój w czasie oraz umiejscowienie (lokalizację) efektów kryzysu. 
Procesowy model przekształcania zagrożenia kryzysem w kryzys w mikroprzedsiębiorstwie, sporządzony na podstawie badań własnych przedstawiono na ryc. 3. Istotne staje się zatem wskazanie lokalizacji źródeł powstawania zagrożenia oraz obserwacja rozwoju kryzysu. W przypadku powstania zagrożenia kryzysem wewnątrz organizacji jego źródłem mogą być:

- pracownicy przedsiębiorstwa (niezrozumienie polecenia, nieznajomość standardów i procedur, brak reakcji na odstępstwa od wymagań procedur postępowania, celowe działanie),

- komórki organizacyjne (brak przepływu informacji pomiędzy komórkami w strukturze organizacyjnej przedsiębiorstwa lub zbyt wolny przepływ informacji, niewłaściwe umiejscowienie komórki organizacyjnej w strukturze),

- procesy w organizacji (procesy strategiczne niedostosowane do strategii przedsiębiorstwa, niezapewniające osiągnięcia sukcesu rynkowego przedsiębiorstwa, w tym: procesy zarządzania w organizacji: planowanie i podejmowanie decyzji, organizowanie, kierowanie, kontrolowanie, procesy pomocnicze - jeżeli nie są podporządkowane procesom strategicznym i zarządczym),

- uwarunkowania międzykulturowe, wynikające z różnic w umiejętnościach międzykulturowych (np. używanie języka obcego w firmie, różnice w podejściu do biznesu, różnice w wiedzy specjalistycznej, sposób myślenia).

Ryc. 3. Etapy procesu przekształcenia zagrożenia w kryzys w mikroprzedsiębiorstwie

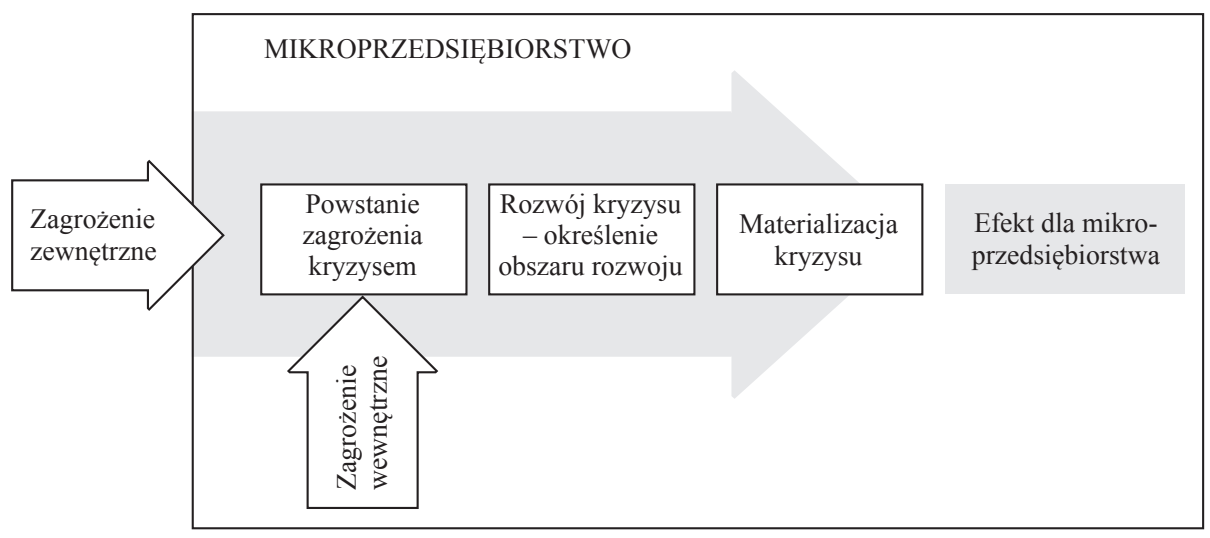

Źródło: na podstawie: Janczewska D., Zarządzanie ryzykiem w mikroprzedsiębiorstwie, referat wygłoszony na konferencji „Sytuacje trudne - przetrwanie emocjonalne” 15.03.2012 w Społecznej Akademii Nauk w Łodzi.

W tabeli 1 przedstawiono wybrane wyniki badań własnych wpływu zagrożeń kryzysowych wewnątrz organizacji na zachowania organizacyjne w mikroprzedsiębiorstwach na przykładzie branży cukierniczej.W przypadku zaistnienia kryzysu w przedsiębiorstwie mikro- w branży cukierniczej obserwowane były następujące zachowania organizacyjne:

- integracja pracowników - powołanie mieszanego zespołu zadaniowego (pracownicy firmy, eksperci i doradcy zewnętrzni) oraz właściciel mikrofirmy,

- wspólne poszukiwanie diagnozy i określenie przyczyn kryzysu,

- podejmowanie szybkich działań, tzw. quick wins, które przyniosą efekty oszczędnościowe i płynnościowe w krótkim okresie,

- implementacja działań, monitoring i modyfikacja,

- doskonalenie systemów wewnątrz przedsiębiorstwa. 
Tab. 1. Zachowania organizacyjne mikroprzedsiębiorstw wobec wewnętrznych źródeł zagrożeń kryzysem na przykładzie branży cukierniczej

\begin{tabular}{|c|c|c|c|c|c|}
\hline $\begin{array}{c}\text { Źródlo } \\
\text { zagrożenia } \\
\text { kryzysem }\end{array}$ & $\begin{array}{c}\text { Rodzaj } \\
\text { zagrożenia } \\
\text { i jego skutki }\end{array}$ & $\begin{array}{l}\text { Przewidywany } \\
\text { efekt o charakte- } \\
\text { rze kryzysowym }\end{array}$ & $\begin{array}{c}\text { Wybór działań } \\
\text { zapobiegających } \\
\text { rozwojowi } \\
\text { zagrożenia }\end{array}$ & $\begin{array}{c}\text { Zachowania } \\
\text { organizacyjne }\end{array}$ & $\begin{array}{c}\text { Ocena } \\
\text { poziomu } \\
\text { zagrożenia } \\
\text { kryzysem }\end{array}$ \\
\hline \multirow[t]{4}{*}{$\begin{array}{l}\text { Pracownicy } \\
\text { przedsiębior- } \\
\text { stwa }\end{array}$} & \begin{tabular}{|l|} 
niezrozumienie \\
polecenia \\
przełożonego, \\
wykonanie zadania \\
niedokładnie lub \\
niezgodnie \\
z wymaganiami \\
technicznymi \\
i zasadami \\
HACCP
\end{tabular} & $\begin{array}{l}\text { utrata przewidy- } \\
\text { wanych zysków } \\
\text { i rynków, } \\
\text { zniszczenie } \\
\text { surowców lub } \\
\text { maszyn, kryzys } \\
\text { finansowy, } \\
\text { zagrożenie } \\
\text { zdrowia i życia } \\
\text { nabywców }\end{array}$ & $\begin{array}{l}\text { analiza ryzyka, } \\
\text { przewidywanie } \\
\text { zagrożenia, } \\
\text { procedury } \\
\text { naprawcze } \\
\text { i korygujące }\end{array}$ & $\begin{array}{l}\text { integracja } \\
\text { pracowników, } \\
\text { wspólne } \\
\text { dyskusje }\end{array}$ & $\begin{array}{l}\text { wysoki poziom } \\
\text { zagrożenia }\end{array}$ \\
\hline & $\begin{array}{l}\text { nieznajomość } \\
\text { standardów } \\
\text { i procedur } \\
\text { oczekiwanych } \\
\text { przez odbiorców } \\
\text { wyrobów } \\
\text { cukierniczych - }\end{array}$ & $\begin{array}{l}\text { reklamacje, zwroty } \\
\text { wyrobów, wypłata } \\
\text { odszkodowań, } \\
\text { koszty naprawy } \\
\text { i powtórnej } \\
\text { produkcji }\end{array}$ & $\begin{array}{l}\text { szkolenia, } \\
\text { zapoznanie } \\
\text { z obowiązującymi } \\
\text { standardami, } \\
\text { monitorowanie } \\
\text { produkcji }\end{array}$ & $\begin{array}{l}\text { koncentracja sił } \\
\text { i działań na } \\
\text { szkoleniach }\end{array}$ & $\begin{array}{l}\text { wysoki poziom } \\
\text { zagrożenia }\end{array}$ \\
\hline & $\begin{array}{l}\text { brak reakcji } \\
\text { na odstępstwa } \\
\text { od wymagań } \\
\text { procedur, } \\
\text { niedokładność, } \\
\text { brak kontroli }\end{array}$ & $\begin{array}{l}\text { powtarzanie } \\
\text { błędów wykonaw- } \\
\text { czych grozi } \\
\text { zerwaniem } \\
\text { kontraktu przez } \\
\text { odbiorcę }\end{array}$ & $\begin{array}{l}\text { stosowanie } \\
\text { właściwej } \\
\text { motywacji, } \\
\text { monitorowanie, } \\
\text { kontrola jakości }\end{array}$ & $\begin{array}{l}\text { podejmowanie } \\
\text { szybkich działań }\end{array}$ & $\begin{array}{l}\text { wysoki poziom } \\
\text { zagrożenia }\end{array}$ \\
\hline & celowe działanie & $\begin{array}{l}\text { wzrost liczby } \\
\text { wadliwych } \\
\text { produktów, straty } \\
\text { materiałowe, } \\
\text { zagrożenie } \\
\text { zdrowia i życia } \\
\text { nabywców } \\
\text { wyrobów } \\
\text { cukierniczych }\end{array}$ & $\begin{array}{l}\text { zwolnienie } \\
\text { pracownika }\end{array}$ & $\begin{array}{l}\text { monitoring, } \\
\text { wzmożone } \\
\text { kontrole }\end{array}$ & $\begin{array}{l}\text { wysoki poziom } \\
\text { zagrożenia }\end{array}$ \\
\hline \multirow[t]{2}{*}{$\begin{array}{l}\text { Struktura } \\
\text { organizacji } \\
\text { komórki } \\
\text { organizacyjne }\end{array}$} & $\begin{array}{l}\text { niewłaściwa } \\
\text { struktura } \\
\text { organizacyjna } \\
\text { przedsiębiorstwa }\end{array}$ & $\begin{array}{l}\text { brak przepływu } \\
\text { informacji oraz } \\
\text { decyzji, nadmierne } \\
\text { przeciążenie } \\
\text { obowiązkami, } \\
\text { utrata efektywno- } \\
\text { ści przedsiębior- } \\
\text { stwa }\end{array}$ & $\begin{array}{l}\text { modyfikacja } \\
\text { struktury } \\
\text { organizacyjnej }\end{array}$ & $\begin{array}{l}\text { doskonalenie } \\
\text { struktur } \\
\text { wewnątrz firmy }\end{array}$ & $\begin{array}{l}\text { średni poziom } \\
\text { zagrożenia }\end{array}$ \\
\hline & $\begin{array}{l}\text { niewłaściwe } \\
\text { umiejscowienie } \\
\text { komórki } \\
\text { organizacyjnej } \\
\text { w strukturze } \\
\text { przedsiębiorstwa } \\
\text { cukierniczego }\end{array}$ & $\begin{array}{l}\text { niewłaściwy } \\
\text { przepływ } \\
\text { informacji, brak } \\
\text { współpracy } \\
\text { pomiędzy } \\
\text { komórkami } \\
\text { organizacyjnymi } \\
\text { lub poszczególny- } \\
\text { mi pracownikami }\end{array}$ & $\begin{array}{l}\text { zmiana lokalizacji } \\
\text { komórki } \\
\text { organizacyjnej, } \\
\text { budowa nowych } \\
\text { relacji pomiędzy } \\
\text { komórkami } \\
\text { organizacyjnymi } \\
\text { lub poszczególny- } \\
\text { mi pracownikami }\end{array}$ & $\begin{array}{l}\text { poszukiwanie } \\
\text { winnych, próby } \\
\text { eliminacji } \\
\text { winnych }\end{array}$ & $\begin{array}{l}\text { średni poziom } \\
\text { zagrożenia }\end{array}$ \\
\hline
\end{tabular}




\begin{tabular}{|c|c|c|c|c|c|}
\hline $\begin{array}{c}\text { Źródło } \\
\text { zagrożenia } \\
\text { kryzysem }\end{array}$ & $\begin{array}{c}\text { Rodzaj } \\
\text { zagrożenia } \\
\text { i jego skutki }\end{array}$ & $\begin{array}{l}\text { Przewidywany } \\
\text { efekt o charakte- } \\
\text { rze kryzysowym }\end{array}$ & $\begin{array}{c}\text { Wybór działań } \\
\text { zapobiegających } \\
\text { rozwojowi } \\
\text { zagrożenia }\end{array}$ & $\begin{array}{c}\text { Zachowania } \\
\text { organizacyjne }\end{array}$ & $\begin{array}{c}\text { Ocena } \\
\text { poziomu } \\
\text { zagrożenia } \\
\text { kryzysem }\end{array}$ \\
\hline & $\begin{array}{l}\text { niedopasowanie } \\
\text { zadań komórki } \\
\text { organizacyjnej } \\
\text { do realizacji } \\
\text { celów rynkowych } \\
\text { przedsiębiorstwa }\end{array}$ & \begin{tabular}{|l|} 
niewłaściwa \\
realizacja \\
produkcji lub \\
usługi, niewyko- \\
rzystanie \\
umiejętności \\
pracowników, \\
brak zadowolenia \\
z pracy, efekt \\
frustracji
\end{tabular} & $\begin{array}{l}\text { korekta zadań } \\
\text { i obowiązków } \\
\text { pracowników }\end{array}$ & $\begin{array}{l}\text { wspólne } \\
\text { poszukiwanie } \\
\text { właściwych } \\
\text { rozwiązań }\end{array}$ & $\begin{array}{l}\text { wysoki poziom } \\
\text { zagrożenia }\end{array}$ \\
\hline & $\begin{array}{l}\text { niedopasowanie } \\
\text { zadań komórki } \\
\text { organizacyjnej } \\
\text { do strategii } \\
\text { przedsiębiorstwa }\end{array}$ & $\begin{array}{l}\text { obniżenie } \\
\text { efektywności } \\
\text { przedsiębiorstwa, } \\
\text { opóźnianie zadań } \\
\text { planowych, } \\
\text { odstępstwo od } \\
\text { standardów }\end{array}$ & $\begin{array}{l}\text { korekta zadań } \\
\text { komórki } \\
\text { organizacyjnej }\end{array}$ & $\begin{array}{l}\text { wspólne } \\
\text { poszukiwanie } \\
\text { właściwego } \\
\text { rozwiązania }\end{array}$ & \\
\hline
\end{tabular}

Źródło: opracowanie własne.

Badani menedżerowie wskazywali na konieczność elastycznego i szybkiego reagowania na pojawiające się symptomy zagrożenia kryzysem, w tym konieczność właściwych zachowań organizacyjnych. Powinny one obejmować następujące kierunki działań:

- analiza źródeł powstawiania zagrożeń kryzysem,

- przygotowywanie scenariuszy wariantowych,

- analiza nowych wyzwań i szans wynikających z niespodziewanych incydentów i sygnałów rynkowych,

- rozwijanie zasobów gwarantujących długookresowy sukces, m.in. kapitału ludzkiego,

- unikanie bezpośrednich konfrontacji i ekspozycji na ryzyko,

- elastyczne kształtowanie bilansu firmy,

- dostosowywanie produkcji i usług do nowych wymagań konsumenta,

- formułowanie i wdrażanie przemyślanej strategii cenowej.

\section{Zakończenie}

Dynamiczne i nieprzewidywalne zmiany w otoczeniu firm staną się w nadchodzących latach najczęściej spotykanymi zjawiskami, co będzie wymagać od firm odpowiednich zmian strategii, a zwłaszcza poprawy w dziedzinie zarządzania ryzykiem. Badania własne prowadzone w mikroprzedsiębiorstwach w branży cukierniczej wskazały na istotne elementy zachowań organizacyjnych w warunkach kryzysu, umiejętności mikrofirm w kreowaniu zachowań sprzyjających wczesnemu sygnalizowaniu zagrożenia kryzysem oraz podejmowaniu działań wyprzedzających. 


\section{Literatura}

Antoszkiewicz, J.D. (1997). Firma wobec zagrożeń. Identyfikacja problemów. Warszawa: POLTEXT.

Baliś, M. (2012). Dobre i złe praktyki w zarządzaniu finansami mikro- i małych przedsiębiorstw w aspekcie zagrożenia kontynuacji działalności podmiotu. W: J. Buko (red.), Uwarunkowania rynkowe rozwoju mikro, małych i średnich przedsiębiorstw. Mikrofirma 2012. Szczecin: Wydawnictwo Uniwersytetu Szczecińskiego.

Białoń, L. Janczewska, D. (2006). Menedżer marketingu w firmie przyszłości. W: Białoń L. (red.), The Quality of Specialist Education in Terms of Managing Methods. Warszawa: Wydawnictwo Wyższej Szkoły Menedżerskiej.

Bizoń-Górecka, J., 2001. Inżynieria niezawodności i ryzyka w zarządzaniu przedsiębiorstwem. Bydgoszcz: Oficyna Wydawnicza OPO.

Breen, B., Hamel, G. (2008). Zarządzanie jutra. Jakie jest twoje miejsce w przyszłości. Warszawa: Wydawnictwo Red Horse.

Brussa, A., Tarnawa, A. (2010). Raport o stanie sektora matych i średnich przedsiębiorstw w Polsce, Warszawa: PARP.

Drucker, P. (2009). Zarządzanie XXI w. Wyzwania. Warszawa: Wydawnictwo MT Biznes.

Iwanek, T. (2003). Kryzys i jego odmiany. Wrocław: Wydawnictwo WSZ Edukacja.

Janczewska, D. (2011). Badanie powstawania źródet zagrożenia kryzysem podczas realizacji procesu innowacyjnego. W: Dembowska B., Gonicka J. (red.), Zarządzanie przedsiębiorstwem w kryzysie. Łódź: Wyd. AHE.

Kuchciak, I. (2012). Korzyści z wymiany informacji dla mikro i matych przedsiębiorstw podmiotu. W: J. Buko (red.), Uwarunkowania rynkowe rozwoju mikro- matych i średnich przedsiębiorstw. Mikrofirma 2012. Szczecin: Wydawnictwo Uniwersytetu Szczecińskiego.

Masłyk-Musiał, E. (2003). Organizacje w ruchu. Kraków: Oficyna Ekonomiczna.

Nęcki, Z. (2000). Negocjacje w biznesie. Kraków: Antykwa.

OECD. (2009). Strategic Response to the Financial and Economic Crisis. Contributions to the Global Effort. Paris: OECD.

Orłowski W., Pasternak R., Flaht K., Szubert D. (2010). Procesy inwestycyjne i strategie przedsiębiorstw w czasach kryzysu. Warszawa: PARP.

Pritchard, C. (2002). Zarzadzanie ryzykiem w projektach. Warszawa: WIG-Press.

Robbins, S.P. (2001). Zachowania organizacji. Warszawa: PWE.

Robbins, S.P., Judge, T.A. (2011). Zachowania w organizacji. Warszawa: PWE.

Sikorski, C. (2004). Zachowania ludzi w organizacjach. Warszawa: PWN.

Starczewska-Krzysztoszek, M. (2008). Kondycja sektora MSP 2008 - Ranking Najbardziej Innowacyjnych Firm $w$ Polsce. Warszawa: Lewiatan.

Tarczyński, W., Mojsiewicz, M. (2001). Zarządzanie ryzykiem. Warszawa: PWE.

Urbanowska-Sojkin, E. (1999). Zarządzanie przedsiębiorstwem. Od kryzysu do sukcesu. Poznań: Wydawnictwo Akademii Ekonomicznej.

Włodarczyk, M., Marjański, A. (2009). Bezpieczeństwo i zarządzanie kryzysowe - aktualne wyzwania. Zarzadzanie kryzysem w organizacjach gospodarczych. Łódź: Wyd. SWSPiZ, TomX, Zeszyt 7.

Wolański, R. (2012). Obciążenia poza podatkowe matych i średnich przedsiębiorstw. W: Buko J. (red.), Uwarunkowania rynkowe rozwoju mikro-, małych i średnich przedsiębiorstw. Mikrofirma 2012, Szczecin: Wydawnictwo Uniwersytetu Szczecińskiego.

Zelek, A. (2003). Zarzadzanie kryzysem w przedsiębiorstwie. Perspektywa strategiczna. Warszawa: Wydawnictwo IOiZwP „Orgmasz”.

Zaborowska, D. (2011). Zarządzanie w kryzysie. W: B. Dembowska, J. Gonicka (red.), Zarządzanie przedsiębiorstwem w kryzysie. Łódź: Wydawnictwo AHE. 
Danuta Janczewska, dr inż., adiunkt, Społeczna Akademia Nauk w Łodzi.

Adiunkt na Wydziale Zarządzania, w Katedrze Marketingu i Logistyki Społecznej Akademii Nauk w Łodzi. Jej zainteresowania naukowe i badawcze dotyczą sektora MŚP, w aspekcie rozwoju przedsiębiorczości oraz podnoszenia konkurencyjności mikroprzedsiębiorstw. Ma wieloletnią praktykę biznesową, współpracowała też z uczelniami menedżerskimi. Jest autorką ponad 60 publikacji związanych z przedsiębiorczością, innowacyjnością i podnoszeniem konkurencyjności MŚP.

Danuta Janczewska, ScD, Social Science Academy in Łódź.

The author is a senior lecturer at Faculty of Management, Chair of Marketing and Logistics of Social Science Academy in Łódź. Science and research interests: SME sector, development of enterpreneurship, growth of competitiveness of micro enterprises. Experience: long-term business practice in managing enterprises, co-operation with management academies, over 60 publications related to enterpreneurship, innovativeness, and growth of SME competitiveness.

Adres/Address: $\quad$ Społeczna Akademia Nauk w Łodzi ul. Sienkiewicza 9, 90-113 Łódź, Polska

e-mail: Janczewska@spoleczna.pl 


\author{
Sabina Sanetra-Pólgrabi \\ Uniwersytet Pedagogiczny \\ im. Komisji Edukacji Narodowej \\ w Krakowie
}

\title{
Instytucje ekonomii społecznej w warunkach kryzysu gospodarczego (na przykładzie podmiotów w województwie śląskim)
}

\author{
Social economy institutions in the conditions of an economic crisis \\ (on the example of the Silesia region)
}

\begin{abstract}
Streszczenie
W społecznościach lokalnych coraz częściej poszukuje się aktywnych i skutecznych sposobów wspierania zatrudniania osób wykluczonych. Obok instrumentów prawnych i finansowych ważne są też instytucje ekonomii społecznej. Okazuje się, że miasta, które mają tego typu instytucje, osiągają dużo lepsze wyniki gospodarcze, są atrakcyjniejsze dla inwestorów i cechują się mniejszym bezrobociem, niż miasta, które ich nie mają. Niniejszy tekst przedstawia znaczenie instytucji ekonomii społecznej w województwie śląskim. Analiza wykazała, że w regionie funkcjonuje 41 takich podmiotów, zwłaszcza spółdzielni socjalnych, towarzystw ubezpieczeń wzajemnych, fundacji rozwoju przedsiębiorczości, przedsiębiorstw społecznych, organizacji pozarządowych czy centrów aktywności społecznej. W artykule skupiono się na działalności wybranych instytucji, ukazano ich rolę w regionie, specyfikę funkcjonowania, główne osiągnięcia. Punktem wyjścia stało się zdefiniowanie podstawowych pojęć związanych w sposób bezpośredni z ekonomią społeczną, a także odniesienie się do roli tego sektora i znaczenia klimatu organizacyjnego oraz instytucjonalnego, korzystnego dla prawidłowego funkcjonowania tych podmiotów.
\end{abstract}

\begin{abstract}
Local communities are increasingly searching for active and effective ways to promote the employment of the excluded. Social economy institutions play an important part in that process, together with legal and financial institutions. It appears that cities, where social institutions are present, produce better economic results, are more attractive to investors, and have a lower unemployment rate. The following text presents the importance of these institutions in Silesia. The analysis indicates that there exist 41 such entities in the region, mostly social cooperatives, mutual insurance companies, enterprise development foundations, social enterprises, nongovernmental organizations and social activity centres. The article is focused on activities of selected institutions, their importance to the region, a specific character of functioning and main achievements. Definitions of basic concepts, connected directly with social economy, serve as a starting point. The article also discusses the importance of this sector, and the significance of organizations and institutions favourable to the proper functioning of the citizens.
\end{abstract}

Słowa kluczowe: instytucje ekonomii społecznej; organizacje pozarządowe; spółdzielnie socjalne; śląskie

Key words: social economy institutions; nongovernmental organizations; social cooperatives; Silesia 


\section{Wprowadzenie}

W społecznościach lokalnych coraz częściej poszukuje się aktywnych i skutecznych sposobów wspierania zatrudniania osób wykluczonych. W tym zakresie kluczowe okazały się instrumenty prawno-organizacyjne i finansowe (Kogut-Jaworska, 2008: 83; Filipiak, Ruszała, 2009: 82-105). W ramach pierwszego aspektu zwraca się uwagę na znaczenie określonych instytucji. Chodzi tu nie tylko o tzw. podmiotowe wspieranie biznesu, lokalnej przedsiębiorczości przez powstające inkubatory, ale też o popieranie funkcjonowania instytucji zaliczanych do ekonomii społecznej. Dostrzeżono, że miasta, które mają tego typu podmioty, osiągają dużo lepsze wyniki gospodarcze, są atrakcyjniejsze dla inwestorów i cechują się mniejszym bezrobociem. Najlepiej może o tym zaświadczyć pozycja Bielska-Białej jako subregionalnego bieguna wzrostu (Sobala-Gwosdz, 2010: 139). Wpływ na to miało również wiele innych czynników demograficznych i gospodarczych.

Niniejszy tekst przedstawia znaczenie zwłaszcza tych podmiotów, które zalicza się do sektora, czy też gałęzi ekonomii, określanej mianem gospodarki społecznej. Analiza wykazała, że w całym województwie śląskim funkcjonuje 41 instytucji, zwłaszcza spółdzielni socjalnych, towarzystw ubezpieczeń wzajemnych, fundacji rozwoju przedsiębiorczości, przedsiębiorstw społecznych, organizacji pozarządowych czy centrów aktywności społecznej. W artykule skupiono się na działalności wybranych instytucji, ukazano ich rolę w regionie, specyfikę funkcjonowania, główne osiągnięcia. Przyjęto następujące kryteria doboru instytucji do analizy: typ instytucji, okres działalności, lokalizacja. Zasadniczym celem jest ukazanie różnorodności tej gałęzi ekonomii oraz znaczenia instytucji ekonomii społecznej nie tylko dla miast, ale również dla społeczności lokalnych i osób wykluczonych.

Punktem wyjścia w artykule jest zdefiniowanie podstawowych pojęć związanych w sposób bezpośredni z ekonomią społeczną, a także odniesienie się do roli tego sektora i znaczenia klimatu organizacyjnego oraz instytucjonalnego, korzystnego dla prawidłowego funkcjonowania tych podmiotów.

\section{Cechy ekonomii spolecznej}

Od stosunkowo niedawna termin ekonomia społeczna jest niezwykle popularny. Złożyło się na to kilka przyczyn. Po pierwsze, nastąpił wzrost badań nad tym zjawiskiem, po drugie, wiele dyscyplin naukowych zaczęło się nim zajmować, a po trzecie, w związku z przeobrażeniami życia społecznego i gospodarczego tego typu podmioty zaczynają odgrywać coraz większą rolę, zwłaszcza w zakresie pomocy osobom niepełnosprawnym i wykluczonym oraz w zakresie rozwoju regionów (Głąbicka, 2011: 341-352). Jest to bowiem ten sektor, który może przyczyniać się do inkluzji społecznej, a przez to mieć wpływ na wzrost gospodarczy (Czemiel-Grzybowska, 2012; Narski, 2012). Poza wymienionymi wyżej czynnikami T. Kaźmierczak przyczyn wzrostu zainteresowania ekonomią społeczną dopatruje się w rozwoju technologicznym (zwłaszcza informatyki, telekomunikacji), prowadzącym do zmniejszania się ilości pracy, zmianie wzorów podziału pracy, zysków i kosztów w przekrojach społecznych, wyczerpaniu się możliwości popytowej polityki społeczno-gospodarczej, konieczności tworzenia nowego, instytucjonalnego ładu, który pozwoliłby zredukować nierozwiązywalne problemy i dał szanse zrównoważonego i trwałego rozwoju, zgodnie z aksjologią równości i sprawiedliwości społecznej (cyt. za: Gagacka, 2009: 458).

W najbardziej uproszczony sposób przez ekonomię społeczną można rozumieć każdą działalność ekonomiczną, w której zakłada się osiąganie zysku w sensie społecznym, a nie czysto ekonomicznym. Działalność gospodarcza służy wypracowywaniu nadrzędnych celów społecznych (Waszkiewicz, Podławiak, 2010: 6). Pomimo to do instytucji ekonomii społecznej zalicza się jedynie instytucje prowadzące działalność o charakterze gospodarczym. Zgodnie z defini- 
cją opracowaną przez europejską sieć badawczą EMES za podmiot ekonomii społecznej uznaje się taką aktywność, która prowadzona jest na podstawie zdefiniowanych celów społecznych, gdzie zyski w założeniu są reinwestowane w te cele lub we wspólnotę, a nie w celu maksymalizacji zysku lub zwiększenia dochodu udziałowców czy też właścicieli (Moroń, 2009: 420). Według EMES podmiot ekonomii społecznej ma spełniać kryteria zarówno ekonomiczne, jak i społeczne. Do pierwszej grupy zalicza się: prowadzenie działalności w sposób względnie ciągły i regularny, stosowanie instrumentów ekonomicznych, niezależność w stosunku do instytucji publicznych, ponoszenie ryzyka ekonomicznego oraz istnienie choćby nielicznego płatnego personelu. Pośród kryteriów społecznych pierwszorzędne znaczenie ma orientacja na społecznie użyteczny cel przedsięwzięcia, poza tym oddolny, obywatelski charakter inicjatywy, specyficzny, demokratyczny system zarządzania, możliwie wspólnotowy charakter aktywności oraz ograniczona repartycja osiąganych zysków (Gagacka, 2009: 461; Waszkiewicz, Podławiak, 2010: 7; Gagacka, Głąbicka, 2011: 16-17).

Biorąc pod uwagę podmioty ekonomii społecznej, najczęściej wskazuje się na przedsiębiorstwa społeczne. Ich zadaniem jest nie tylko wytwarzanie określonych dóbr i usług, ale także mobilizacja kapitału społecznego, generowanie innowacyjności oraz poszerzanie rynku przez włączanie do uczestnictwa w nim osób dotychczas wykluczonych. To specyficzna podgrupa ekonomii społecznej, ukierunkowana na rynek, stanowiąca część wspólną wszystkich sektorów (Frączek, Pokora, 2012: 7).

Przy badaniu i wyjaśnianiu roli podmiotów ekonomii społecznej ważne znaczenie ma autonomia gospodarcza tych instytucji. Są one bowiem praktycznie w całości odrębnymi organizacjami, niezależnymi zwłaszcza od władz publicznych. Jedynym punktem spornym jest działalność centrów integracji społecznej, czyli tzw. CIS-ów, tworzonych i nadzorowanych przez organy samorządu terytorialnego. Niejednokrotnie funkcjonują jako pewnego rodzaju nieformalne „części” składowe danego samorządu i tak też są traktowane. Poza tym należy się odnieść do działalności gospodarczej prowadzonej przez podmioty ekonomii społecznej, które powołane zostały jako wspólne przedsięwzięcia kilku organizacji i instytucji (zwłaszcza pozarządowych) (Waszkiewicz, Podławiak, 2010: 8). Inną kwestią jest właściwe ustalenie i rozumienie kryteriów społecznych. W każdym przypadku powinny być one bezwzględnie i w całości spełniane przez każdą instytucję, którą chcemy nazwać podmiotem ekonomii społecznej (Waszkiewicz, Podławiak, 2010: 9).

\section{Instytucje ekonomii społecznej}

W literaturze przedmiotu najczęściej do podmiotów ekonomii społecznej zalicza się zakłady aktywności zawodowej, spółdzielnie oraz centra integracji społecznej. Poza tym wymienia się prowadzące działalność gospodarczą organizacje pozarządowe - fundacje, stowarzyszenia, spółki z ograniczoną odpowiedzialnością niedziałające dla zysku i wioski tematyczne (Campion, 2012: 24; Moroń, 2012: 111; Gagacka, 2009: 459; Sobolewski i in., 2009). Z kolei K. Kietlińska do grona instytucji ekonomii społecznej zalicza: przedsiębiorstwa społeczne, spółdzielnie, organizacje wzajemnościowe, przedsiębiorstwa tworzące miejsca pracy dla osób niepełnosprawnych, instytucje, których celem jest przeciwdziałanie bezrobociu, instytucje działające na rzecz ograniczania wykluczania społecznego (Kietlińska, 2010: 128). W zdecydowanej większości przypadków podmioty te zatrudniają osoby niepełnosprawne w stopniu znacznym i umiarkowanym, kładąc przy tym nacisk na rehabilitację zawodową oraz bezrobotnych czy uzależnionych od alkoholu i narkotyków, po ukończonych programach terapeutycznych (Czemiel-Grzybowska, 2012: 67).

Z wyróżnionego grona podmiotów szczególną wagę przypisuje się spółdzielniom. Najczęściej wymienia się spółdzielnie inwalidów i niewidomych, spółdzielnie pracy i socjalne. Te ostatnie, 
Ustawą z dnia 27 kwietnia 2006 roku o spółdzielniach socjalnych (Dz.U. nr 94, poz. 651) określono jako przedsiębiorstwa społeczne. Ich celem jest prowadzenie wspólnej działalności, opierając się na osobistej pracy członków. Spółdzielnie socjalne działają na rzecz społecznej i zawodowej reintegracji swoich członków. Mogą je założyć: osoby bezrobotne, bezdomni realizujący indywidualny program wychodzenia z bezdomności, uzależnieni od alkoholu, po zakończeniu programu psychoterapii w zakładzie lecznictwa odwykowego, uzależnieni od narkotyków lub innych środków odurzających, po zakończeniu programu terapeutycznego w zakładzie opieki zdrowotnej, chorzy psychicznie, zwalniani z zakładów karnych, uchodźcy realizujący indywidualny program integracji, osoby niepełnosprawne (Piotrowski, 2009: 476-477; Głąbicka, 2011: 354-355). Spółdzielnię socjalną może założyć co najmniej pięć osób spełniających wymienione wyżej warunki, nie więcej jednak niż pięćdziesiąt (Sobolewski i in., 2009).

$\mathrm{Na}$ uwagę zasługują także centra integracji społecznej, które, obok klubów integracji społecznej i zakładów aktywności zawodowej, zaliczane są do tzw. podmiotów „,nowej ekonomii społecznej" (Czemiel-Grzybowska, 2012: 104-114). Ich działalność reguluje Ustawa z dnia 13 czerwca 2003 roku o zatrudnieniu socjalnym (Dz.U. nr 122, poz. 1143 z późn. zm.) Są one jednostkami organizacyjnymi utworzonymi przez organy samorządu terytorialnego (wójtów, burmistrzów, prezydentów miast) lub organizację pozarządową, realizujące reintegrację zawodową i społeczną przez prowadzenie dla osób zagrożonych wykluczeniem społecznym programów edukacyjnych, obejmujących m.in. nabywanie umiejętności zawodowych, przekwalifikowanie lub podwyższanie kwalifikacji zawodowych oraz nabywanie innych umiejętności niezbędnych do codziennego życia. Centra nie stanowią samodzielnych podmiotów prawnych, lecz są formą prawną adresowaną do instytucji oraz organizacji pozarządowych pracujących z osobami zagrożonymi wykluczeniem społecznym. W grupie beneficjentów są te same podmioty, które mogą założyć spółdzielnię socjalną. (Sobolewski i in., 2009).

Stosunkowo nowym rozwiązaniem są tzw. wioski tematyczne, czyli takie miejscowości, w których mieszkańcy decydują się na działalność zarobkową w wybranej dziedzinie gałęzi, czyniąc z niej lokalną specjalizację, np. pieczenie chleba. Ta kluczowa kompetencja zostaje następnie podzielona na nieskończenie wiele wątków i sposobów produkcji, sprzedaży czy usług informacyjnych, edukacyjnych i turystycznych. Specjalizacją wsi może być dosłownie wszystko, obok wypieku chleba może to być uprawa czy hodowla zachowawcza ginących gatunków i odmian, a nawet robienie najsmaczniejszych i najbardziej aromatycznych powideł śliwkowych w kraju i zgłębianie wiedzy na ich temat. W każdym przypadku specjalizacja zależy od samych mieszkańców, od ich decyzji i aktywności. Najlepiej jednak, gdy można opierać się na tym, co w danej miejscowości się znajduje - osobliwościach przyrody, unikatowej architekturze, historii bądź też na umiejętnościach samych mieszkańców. Poza tym wiele zależy od samych władz lokalnych i promocji danej miejscowości. Oferta, jaką wieś wspólnie tworzy, kierowana jest zwykle do mieszkańców miast, a także do określonej grupy docelowej: hobbistów, pasjonatów, turystów. Miejscowość oferuje daną usługę czy produkt, stając się pewnego rodzaju firmą z misją, główną linią produkcji, zaś mieszkańcy są jej pracownikami. W wyniku ich zaangażowania i pracy tworzy się łańcuch powiązań, w którym każdy ma określone zadania. Cały proces nie jest sformalizowany, nie wymaga rejestracji firmy, potrzebna jest jedynie lokalna umowa między mieszkańcami, która najczęściej przybiera prawną postać lokalnego stowarzyszenia (Sobolewski i in., 2009).

\section{Rola podmiotów ekonomii społecznej}

Podmiotom tradycyjnie zaliczanym do ekonomii społecznej, z uwagi na przedsiębiorczy i ekonomiczny wymiar działania, przypisuje się określone funkcje. Obok tradycyjnych zadań, 
zwłaszcza odnoszących się do integracji społecznej, pełnią one funkcje prorozwojowe, mogą przyczyniać się do modyfikacji zachowań rynkowych i politycznych (Surdej, 2008). Podmioty te odgrywają również komplementarną rolę w stosunku do zadań sektora publicznego. Ważne przy tym, aby szukać możliwości pogodzenia wzrostu gospodarczego na rzecz ograniczania nierówności społecznych. W czasie kryzysu na rynku pracy oraz masowego wyludniania się mniejszych miast i wsi jest to szczególnie ważne (Frączek, Pokora, 2012; Sobolewski, 2009).

Dotychczasowa praktyka działania instytucji ekonomii społecznej pokazuje, że w zakresie rozwoju gmin i rozwiązywania lokalnych problemów mogą one szczególnie wspomóc: aktywizację zawodową i społeczną osób niepełnosprawnych i wykluczonych, przedłużenie aktywności zawodowej, tworzenie dodatkowych możliwości zarobkowych, pozyskiwanie środków zewnętrznych, przeciwdziałanie ucieczce młodych, aktywizację (zawodową i społeczną) starszych mieszkańców, przeciwdziałanie alienacji i anonimowości nowych osiedli, oddłużanie mieszkań komunalnych i spółdzielczych, przeciwdziałanie uzależnieniu od pomocy społecznej, niezaradności życiowej, rosnące wydatki z budżetów. Ponadto działalność podmiotów ekonomii społecznej dla jednostki samorządu terytorialnego może przynieść zwiększenie bazy podatkowej, powstanie nowych miejsc pracy, zatrzymanie odpływu młodych ludzi, a także wydłużenie aktywności zawodowej mieszkańców, znalezienie nowych partnerów szczególnie zainteresowanych rozwojem społeczności lokalnej (Sobolewski, 2009).

Funkcjonując w środowiskach lokalnych, podmioty ekonomii społecznej są ważnymi dostarczycielami usług i produktów, którymi nie jest zainteresowany w sposób bezpośredni sektor komercyjny. Ich oferta jest zróżnicowana i obejmuje usługi opiekuńcze, edukacyjne, przemysł czasu wolnego. Poza tym sektor ekonomii społecznej realizuje ważne zadania w zakresie rozwijania i promowania lokalnych produktów, tzn. niszowych, tradycyjnych dóbr lub usług związanych ze specyfiką regionu (np. dobra i usługi związane z lokalnym dziedzictwem kulturowym, lokalne produkty spożywcze, rzemiosło ludowe itp.) oraz tzw. zielonym biznesem, przyczyniając się do wdrażania zasad zrównoważonego rozwoju. Niewątpliwie rola instytucji zaliczanych do ekonomii społecznej jest znacząca i uzupełniająca w stosunku do tradycyjnych podmiotów gospodarczych (Frączek, Pokora, 2012).

\section{Tworzenie korzystnego otoczenia dla sektora ekonomii społecznej}

Aby instytucje ekonomii społecznej w należyty sposób odgrywały swoją rolę, konieczne jest tworzenie dobrego klimatu organizacyjnego i instytucjonalnego. Po pierwsze, należy zwrócić uwagę na kompetencje pracowników samorządu, po drugie, niezbędne jest partnerskie traktowanie podmiotów ekonomii społecznej podobnie jak przedsiębiorców. Po trzecie, konieczne jest kreowanie zachęt infrastrukturalnych do uruchamiania i prowadzenia takich podmiotów, m.in. przez tworzenie lokalnych inkubatorów ekonomii społecznej, udostępnianie lokali podmiotom społecznym itd. Przykładowo podnoszenie kompetencji pracowników samorządu terytorialnego powinno odbywać się przez wspólne szkolenia z zakresu ogólnej wiedzy dotyczącej teoretycznego i praktycznego funkcjonowania instytucji ekonomii społecznej. Ważnym aspektem funkcjonowania tego typu podmiotów jest budowanie dialogu i zaufania, korzystając z narzędzi partnerstwa zawieranego zarówno w formie powoływanych paktów, jak i grup nieformalnych. Podstawą dla dialogu będzie zwłaszcza wymiana informacji, wspólne omawianie problemów i propozycji rozwiązań oraz otwartość na nowych członków. Niezmiernie ważne jest zaufanie społeczne do urzędu, wiedza, że wesprze on rozpoczętą działalność (kupi usługi, udostępni preferencyjnie lokal, będzie wspierał przez działania urzędu pracy), zaufanie do przedsiębiorców, że potraktują powstający podmiot ekonomii społecznej jako partnera 
do współpracy oraz pomoc ze strony innych podmiotów trzeciego sektora, aby chciały one zarówno wykorzystać potencjał tej instytucji, jak i traktować ją jako partnera (Sobolewski, 2009).

W obszarze wsparcia powstawania i działania podmiotów ekonomii społecznej należy podjąć następujące działania:

- tworzyć inkubatory ekonomii społecznej,

- kreować świadomą politykę wsparcia dla podmiotów ekonomii społecznej,

- kierować usługi i zakupy w stronę podmiotów ekonomii społecznej,

- tworzyć partnerstwa z podmiotami ekonomii, zarówno publiczno-prywatne do realizacji określonych zamierzeń lub inwestycji (np. prowadzenia przedszkoli, opieki nad osobami zależnymi, porządkowania terenów zielonych, promocji, prowadzenia informacji turystycznej), jak również dotyczące dostarczania określonych usług,

- prowadzić politykę promocyjną i informacyjną z zakresu ekonomii społecznej,

- wprowadzić aktywne formy reintegracji społecznej i zawodowej ośrodków pomocy społecznej i powiatowego urzędu pracy, ukierunkowane na powstawanie i wsparcie podmiotów ekonomii społecznej przez pracę socjalną ukierunkowaną na zakładanie podmiotów, włączanie się w ich działanie oraz kierowanie beneficjentów ośrodków pomocy społecznej i powiatowego urzędu pracy na odbycie praktyk w podmiotach ekonomii społecznej.

W obszarze wsparcia wykorzystania potencjału podmiotów w lokalnym rozwoju społecznym i gospodarczym należy uwzględnić:

- aktywizację osób do tej pory wykluczonych z rynku pracy lub mających trudności w dostępie do niego,

- wykorzystanie innowacyjności w działaniu i umiejętności łączenia potencjału osób i instytucji, a także pozyskiwania środków zewnętrznych,

- wytypowanie obszarów współpracy w ramach partnerstwa publiczno-prywatnego (Sobolewski, 2009).

\section{Ekonomia społeczna a kryzys gospodarczy}

W aktywnie rozwijającym się sektorze ekonomii społecznej upatruje się szans uelastycznienia rynku pracy zwłaszcza w odniesieniu do osób wykluczonych, którym znacznie trudniej jest się na nim utrzymać. Jest to tym istotniejsze, że kryzys gospodarczy panujący w Europie spowodował dramatyczne w skutkach konsekwencje na rynku pracy, wymagające coraz większej interwencji ze strony władz lokalnych i regionalnych (Zioło, 2011; Dorocki, 2011).

Również ze strony Unii Europejskiej podjęto przedsięwzięcia służące wsparciu tego sektora. Mają one przede wszystkim charakter instytucjonalny i finansowy. W ramach pierwszego aspektu Komisja Europejska zaleca państwom członkowskim wspieranie zwłaszcza przedsiębiorstw społecznych, które w czasie kryzysu mogą być ratunkiem dla wielu „oburzonych”. Działania te powinny obejmować zwłaszcza ułatwienia w zakresie dostępu do finansowania prywatnego, wprowadzenie mechanizmu pożyczkowego, tworzenie narzędzi pozwalających na dokładniejsze poznanie sektora i uwarunkowań jego działalności, wzmocnienie potencjału w sferze zarządzania oraz profesjonalizację i sieciowanie przedsiębiorstw społecznych (http:// www.ekonomiaspoleczna.pl/wiadomosc/760006.html).

\section{Charakterystyka wybranych instytucji ekonomii społecznej w województwie śląskim}

Rozwój sektora ekonomii społecznej w województwie śląskim jest w ścisły sposób powiązany z kilkoma tendencjami. Pierwszą z nich jest możliwość uzyskania określonych korzyści finansowych w związku z udziałem tego sektora w tworzeniu PKB oraz korzyści społecznych w postaci rozwoju formy integracji społeczno-zawodowej. Druga tendencja dotyczy inicjowa- 
nia różnych form aktywności w obszarze społecznym, co wpisuje się w cele strategiczne Unii Europejskiej, takie jak: spójność społeczna, pełne zatrudnienie, walka z ubóstwem i wykluczeniem społecznym, partycypacja obywateli, stały rozwój (Czemiel-Grzybowska, 2012). Trzecią kwestią jest możliwość finansowania różnych projektów środkami z Unii Europejskiej. Ważnym aspektem jest także wizerunek społeczny regionu, którego władze pomagają wykluczonym.

Na podstawie zebranych raportów można przyjąć, że liczba podmiotów ekonomii stopniowo ewoluowała. Przykładowo, według danych Ministerstwa Pracy i Polityki Społecznej, w 2009 r. funkcjonowało 9 zakładów aktywności zawodowej, z czego 2 zakłady o charakterze usługowym oraz 7 o charakterze wytwórczym i usługowym. Na terenie województwa funkcjonowały również 53 warsztaty terapii zajęciowej (Miżejewski, 2010: 11-12).

Według Bazy KLON/JAWOR oraz portalu www.ekonomiaspoleczna.pl, zajmujących się monitoringiem tych instytucji, w 2012 r. funkcjonowało ich 41. Zaliczono tutaj wszystkie typy podmiotów, czyli centra integracji społecznej, spółdzielnie socjalne, przedsiębiorstwa społeczne, zakłady aktywności zawodowej i towarzystwa ubezpieczeń wzajemnych. Wiele zmieniło się w zakresie liczby spółdzielni socjalnych. Przykładowo, według danych Ogólnopolskiego Związku Rewizyjnego Spółdzielni Socjalnych, w roku 2010 funkcjonowało 37 spółdzielni socjalnych, z kolei Baza KLON/JAWOR ich liczbę szacuje na 39, z czego 5 jest w stanie likwidacji. Najwięcej podmiotów tego typu zlokalizowanych jest w Bytomiu, Gliwicach, Chorzowie oraz Cieszynie. Dużą popularnością cieszą się także centra integracji społecznej, usytuowane w Jaworznie, Łazach, Mikołowie, Tychach i Zawierciu. W profilu działalności dominują usługi porządkowe, recykling oraz roboty budowlane i remonty.

Ponadto, jak podaje portal www.ekonomiaspoleczna.pl, występuje znaczące zróżnicowane przestrzenne koncentracji podmiotów ekonomii społecznej. Najwięcej z nich zlokalizowanych jest w miastach GOP-u, Gliwicach, a także w Częstochowie, Bielsku-Białej i Cieszynie (www.ekonomiaspoleczna.pl/mapstest?data=\&state_province[]=1311).

Do modelowych przykładów ekonomii społecznej można zaliczyć:

- Chrześcijańskie Stowarzyszenie Dobroczynne w Łazach,

- Stowarzyszenie Pomocy Wzajemnej „Być razem” w Cieszynie,

- Bielskie Stowarzyszenie Artystyczne „Teatr Grodzki”,

- Centrum Rozwoju Inicjatyw Społecznych „Cris” w Rybniku,

- Stowarzyszenie Współpracy Regionalnej w Chorzowie,

- Spółdzielnię Socjalną „Szansa i Wsparcie” w Chorzowie,

- Spółdzielnię Socjalną „Nowy Horyzont” w Cieszynie (Miżejewski, 2010).

Spośród wymienionych powyżej instytucji w sposób szerszy odniesiono się do wybranych, określonych na podstawie następujących kryteriów: typ podmiotu (pierwszy ma charakter warsztatu terapii zajęciowej, kolejne dwie są ważnymi dla miasta i regionu stowarzyszeniami, zaś ostatni jest spółdzielnią socjalną), okres działalności i lokalizacja. Wybór tych podmiotów podyktowany był ukazaniem kilku tendencji w zakresie rozwoju sektora ekonomii społecznej. Po pierwsze, różnorodnością podmiotów, po drugie, okazało się, że wiele instytucji może pochwalić się wieloma interesującymi inicjatywami, mającymi również cykliczny charakter. Po trzecie zaś, ich usytuowanie zwłaszcza w Bielsku-Białej i Cieszynie doborze wpisuje się w kreowanie polityki społecznej, a zwłaszcza przezwyciężanie problemu bezrobocia wśród osób wykluczonych.

Pierwsza z wybranych instytucji - Chrześcijańskie Stowarzyszenie Dobroczynne w Łazach - ma charakter warsztatów terapii zajęciowej i powstała w grudniu 2004 r. dzięki ścisłej współpracy lokalnych stowarzyszeń i samorządowi w Łazach. Warsztaty stały się dopełnieniem działań na rzecz osób niepełnosprawnych, bowiem tego typu placówka przeznaczona dla dorosłych była 
brakującym ogniwem działalności na rzecz integracji społecznej niepełnosprawnych z terenu gminy. Dzięki podejmowanym wysiłkom prowadzone są wszechstronne działania zmierzające do pomocy i edukacji osób niepełnosprawnych (http://www.chsd.pl/).

Stowarzyszenie Pomocy Wzajemnej „Być razem” zostało założone w 1996 r. przez ludzi młodych, pedagogów, psychologów, terapeutów, pracowników socjalnych, prawników, studentów, powodowanych przeświadczeniem o niewystarczającej skuteczności zinstytucjonalizowanego systemu pomocy społecznej. Od początku istnienia Stowarzyszenie stało się ważnym lokalnym partnerem kreującym politykę społeczną na terenie miasta i wpisało się w system pomocy jako jego integralny i wartościowy element. Przy współpracy z Gminą Cieszyn i holenderskimi fundacjami Stowarzyszenie „Być Razem” w 1997 r. uruchomiło swój pierwszy całodobowy ośrodek, działający z dużym powodzeniem do dzisiaj pod nazwą Centrum Profilaktyki Edukacji i Terapii „KONTAKT”. Stowarzyszenie oferuje wszechstronną pomoc psychologiczną i prawną, a także możliwość uczestniczenia w grupach terapii zajęciowej i grupach wsparcia. W 1999 r. w ramach rządowego programu Stowarzyszenie uruchomiło hostel dla kobiet i dzieci, ofiar przemocy i innych przestępstw, następnie młodzieżowy klub „Graciarnia” i Centrum Wolontariatu (http://bycrazem.com/).

Na Podbeskidziu zlokalizowane jest Bielskie Stowarzyszenie „Teatr Grodzki”, istniejące od 1999 r. Jego utworzenie było uwieńczeniem wysiłków artystów, pedagogów i animatorów kultury. Instytucja prowadzi działalność na rzecz grup zagrożonych wykluczeniem społecznym, ograniczonych w dostępie do świata kultury i sztuki. Adresatami inicjatyw Stowarzyszenia są zarówno dzieci i młodzież, jak i osoby w podeszłym wieku. Wśród nich znajdują się niepełnosprawni fizycznie i umysłowo, młodzież sprawiająca kłopoty wychowawcze i ze środowisk dysfunkcyjnych, osoby uzależnione, wychowankowie domów dziecka oraz placówek resocjalizacyjnych i opiekuńczych. Pośród głównych obszarów działania Stowarzyszenia znajdują się: warsztaty artystyczne, warsztaty terapii zajęciowej, zakład aktywności zawodowej, poradnictwo zawodowe oraz działalność wydawnicza. Jedną z inicjatyw Stowarzyszenia, wpisującą się w szeroko postrzegany nurt ekonomii społecznej, było utworzenie w 2004 r. Zakładu Aktywności Zawodowej „Zakład Introligatorsko-Drukarski. Teatr Grodzki”. Podmiot ten zatrudnia kilkadziesiąt osób niepełnosprawnych oraz kilkunastu pracowników kadry obsługowo-rehabilitacyjnej. Zakład jest przedsiębiorstwem całkowicie podporządkowanym potrzebom pracujących w nim niepełnosprawnych, a jednocześnie nastawionym na aktywizację i społeczną rehabilitację pracowników. Jego celem, tak jak każdego przedsiębiorstwa, jest przychód i zysk, który zależy od wydajności pracy, a więc również od procesu rehabilitacji społecznej pracowników (http://www.teatrgrodzki.pl/).

Kolejnymi podmiotami branymi pod uwagę w niniejszym artykule są spółdzielnie socjalne. Pierwsza z nich powstała w 2007 r. w wyniku współpracy kilku organizacji pozarządowych Spółdzielnia Socjalna „Szansa i Wsparcie”. Oferuje ona usługi opiekuńcze placówkom służby zdrowia (usługi pomocniczego personelu medycznego - sanitariuszek szpitalnych) oraz osobom starszym i niepełnosprawnym (usługi opiekuńcze). Nowatorskie działania podmiotu przejawiają się w organizacji marszów nordic walking. Inna spółdzielnia socjalna - „Nowy Horyzont” - została założona w 2008 r. w Cieszynie. Świadczy ona usługi zwłaszcza w zakresie: specjalistycznego i niespecjalistycznego sprzątania, zagospodarowania terenów zielonych, drobnych remontów i zimowego utrzymania chodników. W kompleksowy sposób współpracuje z podmiotami publicznymi i samorządowymi (Spółdzielnia Socjalna „Szansa i Wsparcie” (http://www.ekonomiaspoleczna.pl/files/ekonomiaspoleczna.pl/public/Atlas_dobrych_praktyk/ atlas_dobrych_praktyk_nowe/23atlas_Dobrych_Praktyk_Chorzow_ver052009.pdf:, http://www. fundacjabycrazem.pl/spoldzielnia-socjalna-nowy-horyzont-2.). 


\section{Wsparcie podmiotów ekonomii społecznej w województwie śląskim}

Podmioty ekonomii społecznej w województwie śląskim mogą liczyć na wsparcie instytucjonalne i finansowe. Świadczą o tym chociażby rozwinięte narzędzia promocyjne, np. opracowanie broszur i ulotek informacyjnych, zrealizowane projekty i zorganizowane konferencje. Celem tych przedsięwzięć jest propagowanie „dobrych praktyk” w zakresie ekonomii społecznej, zwiększanie wiedzy na ten temat wśród instytucji rynku pracy oraz ośrodków pomocy i integracji społecznej, ukazanie podmiotów ekonomii społecznej jako użytecznych sposobów aktywizacji zawodowej oraz zatrudniania osób wykluczonych. Poza tym zwraca się uwagę na popularyzowanie usług świadczonych przez te instytucje w województwie śląskim.

Egzemplifikacją wskazanych przedsięwzięć może być profesjonalne opracowanie strony internetowej poświęconej możliwościom dofinansowania środkami Unii Europejskiej wybranych projektów wspierających działalność podmiotów ekonomii społecznej. Poprzez stronę internetową udzielane jest poradnictwo na temat aspektów prawnych, księgowych i merytorycznych związanych z ich funkcjonowaniem. Działa również forum dyskusyjne służące wymianie informacji i doświadczeń z zakresu ekonomii społecznej. Innym przykładem może być broszura informacyjna Wizytówki śląskich podmiotów ekonomii społecznej, prezentująca rozwój omawianych instytucji w regionie, ze szczególnym uwzględnieniem danych teleadresowych, profilu działalności i opisu świadczonych usług. Podobną funkcję pełni także publikacja pt. Przewodnik po ekonomii społecznej, stanowiąca kompendium wiedzy na ten temat (czym jest ów sektor, jakie formy może przyjmować, skąd można pozyskać środki na działalność, zagadnienia prawne, biznesowe, przykłady dobrych praktyk). W zakresie seminariów i konferencji dobrym przykładem może być spotkanie pt. „Perspektywy rozwoju sektora ekonomii społecznej w województwie śląskim”, zorganizowane w ramach projektu systemowego Regionalnego Ośrodka Polityki Społecznej Województwa Śląskiego - „Kształcenie i doradztwo dla kadr pomocy i integracji społecznej województwa śląskiego", realizowanego w ramach Priorytetu VII „Promocja integracji społecznej” Programu Operacyjnego Kapitał Ludzki 2007-2013, współfinansowanego ze środków Europejskiego Funduszu Społecznego. Wzięli w niej udział członkowie zespołów zadaniowych przygotowujący wieloletni regionalny plan działań na rzecz promocji i upowszechnienia ekonomii społecznej oraz rozwoju instytucji sektora ekonomii społecznej i jej otoczenia w regionie, a także kadra zarządzająca instytucji pomocy i integracji społecznej województwa śląskiego, zainteresowana problematyką ekonomii społecznej (http://www.ekonomiaspoleczna.pl/x/485971, http://ropskatowice.pl/content/konferencja-ptperspektywy-rozwoju-sektora-ekonomii-spolecznej-w-wojewodztwie-slaskim, http://pl.scribd. com/doc/27832423/2010-02-Przewodnik-po-ekonomii-spo\%C5\%82ecznej).

Podmioty ekonomii społecznej mogą liczyć również na pomoc finansową. Od 2008 r. w ramach Programu Operacyjnego Kapitał Ludzki wdrażane jest poddziałanie 7.2.2. „Wsparcie ekonomii społecznej”. Efektem jest finansowanie projektów, których celem jest pomoc w utworzeniu i funkcjonowaniu (w tym wzmożenia potencjału) instytucji sektora ekonomii społecznej. Chodzi tu zwłaszcza o zapewnienie dostępu do usług prawnych, księgowych, marketingowych, doradztwo (indywidualne i grupowe), system szkoleń, ułatwienia w tworzeniu inkubatorów społecznych oraz wspieranie rozwoju partnerstw lokalnych na rzecz ekonomii społecznej. Projekty realizowane w ramach tego poddziałania powinny przyczyniać się do zapewnienia instytucjonalnego wsparcia ekonomii społecznej. Dla województwa śląskiego jako wskaźniki określono: co najmniej trzy instytucje wspierające ekonomię społeczną, które otrzymały wsparcie, 26 inicjatyw ekonomii społecznej wspartych z Europejskiego Funduszu Społecznego oraz 2191 osób, które otrzymają wsparcie w ramach podmiotów ekonomii społecznej. Efektem było zawarcie łącznie 31 umów z projektodawcami na realizację wsparcia ekonomii społecznej na łączną kwotę 15,7 mln zł. 
Poza działaniami czysto projektowymi lub wspieranymi ze źródeł budżetowych zaczęła funkcjonować infrastruktura wsparcia, czyli konkretne ośrodki, które wspierają w wymiarze doradczo-szkoleniowym podmioty ekonomii społecznej. Czasem oczywiście organizacje te są również beneficjentem projektowym. Do najważniejszych można zaliczyć m.in. Stowarzyszenie Wspierania Organizacji Pozarządowych Most z Katowic, Katowickie Forum Organizacji Socjalnych, Stowarzyszenie Współpracy Regionalnej z Chorzowa oraz Stowarzyszenie Centrum Rozwoju Inicjatyw Społecznych z Rybnika (http://www.funduszeeuropejskie.gov.pl/poradnikbeneficjenta/pokl/strony/7.2.2-wsparcie-ekonomii-spolecznej.aspx).

W zakresie organizacyjnym i szkoleniowym ważną rolę odgrywają tzw. inkubatory, często określane mianem inkubatorów społecznej przedsiębiorczości. Zwykle ich zadania sprowadzają się do organizowania doradztwa indywidualnego, szkoleń z zakresu podstaw ekonomii, elementów prawa pracy, prawa spółdzielczego, funkcjonowania firmy, coachingu indywidualnego i działań promocyjnych. Jako grupy docelowe tych usług najczęściej wskazuje się bezrobotnych, zarejestrowane na terenie regionu - podmioty ekonomii społecznej oraz instytucje rynku pracy i integracji społecznej (tab. 1).

Okazuje się zatem, że wsparcie podmiotów ekonomii społecznej w województwie śląskim przybiera kompleksową, złożoną postać i wymaga wielowymiarowego podejścia.

Tab. 1. Ośrodki wspierania ekonomii społecznej w województwie śląskim

\begin{tabular}{|c|c|c|c|c|}
\hline Lp. & Instytucja & Grupa docelowa & Oferta & $\begin{array}{c}\text { Podmiot } \\
\text { realizujący } \\
\text { projekt }\end{array}$ \\
\hline 1. & $\begin{array}{l}\text { Katowickie } \\
\text { Centrum Ekonomii } \\
\text { Społecznej } \\
\text { - wsparcie dla } \\
\text { sektora ekonomii } \\
\text { społecznej }\end{array}$ & $\begin{array}{l}\text { - osoby fizyczne w zakresie } \\
\text { doradztwa indywidual- } \\
\text { nego i szkoleń } \\
\text { • podmioty ekonomii } \\
\text { społecznej zarejestrowa- } \\
\text { ne na terenie woj. - } \\
\text { w zakresie doradztwa } \\
\text { i promocji } \\
\text { - instytucje rynku pracy } \\
\text { i integracji społecznej - } \\
\text { w zakresie promocji } \\
\text { i budowy lokalnego } \\
\text { partnerstwa na rzecz } \\
\text { rozwoju ekonomii } \\
\text { społecznej }\end{array}$ & $\begin{array}{l}\text { • doradztwo indywidualne } \\
\text { • szkolenia dla osób mających zamiar } \\
\text { utworzyć spółdzielnię socjalną } \\
\text { • coaching indywidualny inkubowanych } \\
\text { spółdzielni } \\
\text { • doradztwo dla działających podmiotów } \\
\text { ekonomii społecznej } \\
\text { • działania mające na celu powołanie } \\
\text { partnerstwa lokalnego na rzecz } \\
\text { rozwoju ekonomii społecznej - konfe- } \\
\text { rencje, artykuły, spotkania robocze } \\
\text { - promocję ekonomii społecznej } \\
\text { i zatrudnienia w sektorze ekonomii } \\
\text { społecznej }\end{array}$ & $\begin{array}{l}\text { Fundacja } \\
\text { Gaudete }\end{array}$ \\
\hline 2. & $\begin{array}{l}\text { Spółdzielnie } \\
\text { socjalne drugiej } \\
\text { generacji }\end{array}$ & $\begin{array}{l}\text { - osoby bezrobotne } \\
\text { (w tym długotrwale } \\
\text { bezrobotne) } \\
\text { - organizacje pozarządo- } \\
\text { we zainteresowane } \\
\text { zakładaniem spółdzielni } \\
\text { socjalnych }\end{array}$ & $\begin{array}{l}\text { • opracowywanie, wraz z zainteresowa- } \\
\text { nymi osobami, koncepcji działania } \\
\text { spółdzielni socjalnych, w tym pomoc } \\
\text { w przygotowaniu biznesplanu } \\
\text { • szkolenia w zakresie spółdzielczości } \\
\text { socjalnej } \\
\text { • szkolenie zawodowe przygotowane } \\
\text { pod kątem profilu działalności } \\
\text { konkretnej spółdzielni socjalnej } \\
\text { • wsparcie w pozyskaniu zleceń dla } \\
\text { spółdzielni socjalnych } \\
\text { • pomoc w montażu finansowym } \\
\text { przedsięwzięć } \\
\text { - doradztwo dla powstających } \\
\text { spółdzielni socjalnych i monitoring ich } \\
\text { działania po założeniu }\end{array}$ & $\begin{array}{l}\text { Stowarzy- } \\
\text { szenie } \\
\text { Współpracy } \\
\text { Regionalnej }\end{array}$ \\
\hline
\end{tabular}




\begin{tabular}{|c|c|c|c|c|}
\hline Lp. & Instytucja & Grupa docelowa & Oferta & $\begin{array}{c}\text { Podmiot } \\
\text { realizujący } \\
\text { projekt }\end{array}$ \\
\hline 3. & $\begin{array}{l}\text { Sieć inkubatorów } \\
\text { społecznej } \\
\text { przedsiębiorczości }\end{array}$ & $\begin{array}{l}\text { - osoby fizyczne } \\
\text { - funkcjonujące już } \\
\text { podmioty ekonomii } \\
\text { społecznej na terenie } \\
\text { województwa śląskiego }\end{array}$ & $\begin{array}{l}\text { - doradztwo ekspertów ds. księgowości, } \\
\text { prawnych i marketingu prowadzone } \\
\text { w ramach dyżurów, zarówno } \\
\text { stacjonarnie w poszczególnych } \\
\text { inkubatorach, jak również mobilne } \\
\text { (z dojazdem do beneficjenta ostatecz- } \\
\text { nego) } \\
\text { • szkolenia w ramach usług szkolenio- } \\
\text { wych w każdym podmiocie } \\
\text { - pomoc przy tworzeniu i wsparcie } \\
\text { działania stron WWW podmiotów } \\
\text { ekonomii społecznej } \\
\text { - promocja ekonomii społecznej }\end{array}$ & $\begin{array}{l}\text { Gliwickie } \\
\text { Centrum } \\
\text { Organizacji } \\
\text { Pozarządo- } \\
\text { wych, } \\
\text { z ramienia } \\
\text { Miasta } \\
\text { Gliwice }\end{array}$ \\
\hline 4. & $\begin{array}{l}\text { Inkubator } \\
\text { - Ośrodek } \\
\text { Wspierania } \\
\text { Instytucji Ekonomii } \\
\text { Społecznej }\end{array}$ & $\begin{array}{l}\text { - spółdzielnie socjalne; } \\
\text { - spółdzielnie pracy } \\
\text { - spółdzielnie inwalidów } \\
\text { i niewidomych } \\
\text { - organizacje pozarządo- } \\
\text { we zlokalizowane na } \\
\text { terenie województwa } \\
\text { śląskiego }\end{array}$ & $\begin{array}{l}\text { - inkubowanie podmiotów ekonomii } \\
\text { społecznej przez zapewnienie } \\
\text { infrastruktury technicznej } \\
\text { • Punkt Informacyjny - w nim można } \\
\text { uzyskać różne informacje dotyczące } \\
\text { zasad zakładania stowarzyszenia lub } \\
\text { fundacji, prawnych aspektów funkcjono- } \\
\text { wania organizacji pozarządowych } \\
\text { • szkolenia - zapewnienie kompleksowej } \\
\text { ścieżki wsparcia obejmującego tematy: } \\
\text { co to jest ekonomia społeczna, } \\
\text { podstawy prawne i finansowe } \\
\text { ekonomii społecznej, lobbing, } \\
\text { partnerstwo } \\
\text { - doradztwo i coaching z zakresu prawa, } \\
\text { księgowości, marketingu oraz } \\
\text { doradztwa finansowego }\end{array}$ & $\begin{array}{l}\text { Rudzka } \\
\text { Agencja } \\
\text { Rozwoju } \\
\text { INWESTOR } \\
\text { Sp. z o.o. }\end{array}$ \\
\hline
\end{tabular}

Źródło: opracowanie własne na podstawie: www.gaudete.katowice.opoka.org.pl, www.kces.pl, www.swr.pl, www.gcop.gliwice.pl; inkubatory.slask.pl, www.rarinwestor.pl, http://www.ekonomiaspoleczna.pl/x/485971.

\section{Zakończenie}

Niewątpliwie rozwój ekonomii społecznej w regionie śląskim przynosi zróżnicowane efekty. W każdym jednak przypadku jest dużym wyzwaniem i szansą. Jako zjawisko stosunkowo nowe w polskiej rzeczywistości rodzi wątpliwości, niejasności, wymaga udoskonaleń. Konieczne jest podjęcie szeroko zakrojonych działań promocyjnych przybliżających ideę ekonomii społecznej i związanych z nią korzyści.

Ekonomia społeczna, jak to wykazano w odniesieniu do praktyki funkcjonowania niektórych podmiotów, jest zwłaszcza szansą dla osób zagrożonych wykluczeniem społecznym. Tradycyjne instrumenty aktywizacji zawodowej i społecznej osób bezrobotnych, niepełnosprawnych, osób wykluczonych czy zagrożonych wykluczeniem społecznym często okazują się nieskuteczne. Ponadto system pomocy społecznej powoduje raczej uzależnienie podopiecznych od instytucji pomocowych i ugruntowanie pasywnych postaw na rynku pracy. Ekonomia społeczna przyczynia się do rozwoju samodzielności, przedsiębiorczości wśród grup defaworyzowanych, odwołując się do idei solidarności i pomocy wzajemnej. Podmioty ekonomii społecznej dają swym członkom nie tylko szansę (często jedyną) na uzyskanie zatrudnienia, ale też stanowią efektywną metodę integracji społecznej - realizacja misji społecznej i działalność na rzecz ludzi, nie zaś maksymalizacja zysków. 
W artykule odniesiono się także do kreowania lokalnego rynku pracy i szeroko pojętego rozwoju. W wielu przypadkach sektor ten aktywizuje całą społeczność, stając się przy tym dostarczycielem usług i produktów deficytowych lub nieopłacalnych z punktu widzenia prywatnego przedsiębiorcy, nastawionego wyłącznie na wysokie zyski finansowe.

Pomimo wielu zalet podmiotom ekonomii społecznej niezwykle trudno jest przetrwać zwłaszcza w warunkach kryzysu gospodarczego. Stąd niezwykle ważne jest tworzenie sprzyjającego otoczenia, klimatu, zarówno ze strony innych instytucji, jak i jednostek, władz lokalnych. Konieczna jest też partnerska współpraca, polegająca m.in. na zlecaniu usług podmiotom ekonomii społecznej przez instytucje i organizacje z sektora administracji i biznesu.

\section{Literatura}

Campion, M. (2012). Rola samorządu we wspieraniu lokalnej i regionalnej przedsiębiorczości. Kraków: Wydawnictwo Naukowe UP.

Czemiel-Grzybowska, W. (2012). Zarzadzanie przedsiębiorstwem społecznym w procesie konwergencji. Warszawa.

Dorocki, S. (2011). Wpływ kryzysu gospodarczego na przemiany struktur regionalnych Francji, Prace Komisji Geografii Przemystu Polskiego Towarzystwa Geograficznego, 17, 67-86.

Filipiak, B., Ruszała, J. (2009). Instytucje otoczenia biznesu. Rozwój, wsparcie, instrumenty. Warszawa: Centrum Doradztwa i Informacji Difin.

Frączek, M., Pokora, M. (red.), Ekonomia społeczna w Małopolsce - w stronę przedsiębiorczości społecznej. Kraków, 13-29.

Gagacka, M. (2009). Nierówności społeczne jako wyzwanie dla ekonomii społecznej. W: K. Głąbicka, M. Gagacka (red.), Wspótczesne wyzwania dla lokalnej polityki społecznej. Radom: PTPS i Politechnika Radomska, 458-467.

Gagacka, M., Głąbicka, K. (2011). Zarządzanie przedsiębiorstwem społecznym, Radom: Wydawnictwo Politechniki Radomskiej.

Głąbicka, K. (2011). Rola ekonomii społecznej integracji i aktywizacji zawodowej grup defaworyzowanych na rynku pracy. W: R.C. Horodeński, C. Sadowska-Snarska (red.), Integracja społeczna przez prace. Aspekty makroekonomiczne. Białystok: Wyższa Szkoła Ekonomiczna; Warszawa: Instytut Pracy i Spraw Socjalnych, 338-264.

Guz, H., Handzlik, A. (2012). Działania Urzędu Marszałkowskiego Województwa Małopolskiego na rzecz rozwoju ekonomii społecznej w Małopolsce. W: M. Frączek, M. Pokora (red.), Ekonomia społeczna w Małopolsce - w stronę przedsiębiorczości społecznej. Kraków: Fundacja Gospodarki i Administracji Publicznej, 13-29.

Gwosdz, K., Sobala-Gwosdz, A. (2010). Ośrodki wzrostu i obszary stagnacji w województwie śląskim oraz sposoby pobudzenia ich rozwoju. W: A. Sobala-Gwosdz (red.), Badanie trendów rozwojowych $w$ województwie ślaskim poprzez wyznaczenie ośrodków wzrostu i obszarów stagnacji. Bielsko-Biała: Strada Consultung Piotr Kurowski, 137-158.

Kietlińska, K. (2010). Rola trzeciego sektora w społeczeństwie obywatelskim, Warszawa: Difin.

Kogut-Jaworska, M. (2008). Instrumenty interwencjonizmu lokalnego w stymulowaniu rozwoju gospodarczego, Warszawa, CeDeWu.pl.

Miżejewski, C. (2010). Polityka rozwoju ekonomii społecznej w województwie ślaskim, Poznań: Stowarzyszenie na rzecz Spółdzielni Socjalnych.

Moroń, D. (2009). Współpraca samorządu terytorialnego i organizacji pozarządowych jako sposób realizacji zadań lokalnej polityki społecznej. W: K. Głąbicka, M. Gagacka (red.), Współczesne wyzwania dla lokalnej polityki społecznej. Radom: PTPS i Politechnika Radomska, 418-421. 
Moroń, D. (2012). Organizacje pozarządowe - fundament społeczeństwa obywatelskiego, Wrocław: Wydawnictwo Uniwersytetu Wrocławskiego.

Narski, Z. (2012). Ekonomia społeczna, Toruń: Wydawnictwo Adam Marszałek .

Piotrowski, M. (2009). Spółdzielnia socjalna jako instrument lokalnej strategii rozwiązywania problemów społecznych. W: K. Głąbicka, M. Gagacka (red.), Współczesne wyzwania dla lokalnej polityki spotecznej. Radom: PTPS i Politechnika Radomska, 469-480.

Sobolewski, A. i inni. (2009). Ekonomia społeczna w kreowaniu polityki lokalnej gmin i powiatów, Szczecin: Stowarzyszenie Czas Przestrzeń Tożsamość.

Surdej, A. (2008). Gospodarka - wspólnota - solidarność, Przedsiębiorczość - Edukacja, 4, 204-213.

Waszkiewicz, M., Podławiak, G. (2010). Ekonomia społeczna - popularne pojęcie. W: A. Waszkiewicz i inni (red.), Ekonomia społeczna kluczem do rozwoju regionu. Koszalin: Wojewódzki Urząd Pracy, 6-11.

Zioło, Z. (2011). Wpływ światowego kryzysu na tempo wzrostu gospodarki i światowych korporacji, Prace Komisji Geografii Przemystu Polskiego Towarzystwa Geograficznego, 17, 9-32.

\section{Źródla internetowe}

http://bycrazem.com/

www.chsd.pl/

www.ekonomiaspoleczna.pl

www.funduszeeuropejskie.gov.pl/poradnikbeneficjenta/pokl/strony/7.2.2-wsparcie-ekonomii-spolecznej.aspx www.gaudete.katowice.opoka.org.pl

www.gcop.gliwice.pl

www.inkubatory.slask.pl

www.kces.pl

www.ropskatowice.pl/content/konferencja-pt-perspektywy-rozwoju-sektora-ekonomii-spolecznej-wwojewodztwie-slaskim

www.swr.pl

www.teatrgrodzki.pl/

Sabina Sanetra-Pólgrabi, dr, Uniwersytet Pedagogiczny im. Komisji Edukacji Narodowej w Krakowie. Absolwentka politologii na Uniwersytecie Pedagogicznym im. KEN w Krakowie. Zajmuje się problematyką współpracy transgranicznej i zagadnieniem rozwoju regionalnego i lokalnego. Przygotowuje swoją pierwszą publikację książkową pt. Funkcjonowanie euroregionów na pograniczu poludniowym Polski po 1993 roku (analiza porównawcza trzech euroregionów: Śląsk Cieszyński, Beskidy i Tatry).

Sabina Sanetra-Pólgrabi, PhD, Pedagogical University of Cracow.

Sabina Sanetra-Półgrabi, a graduate of Political Science at the Pedagogical University of Cracow. Research interests include: cross-border cooperation, as well as issues related to regional and local governments. The author is in the course of preparing her first book, entitled Functioning of Euroregions in the southern Polish borderland after 1993 (a comparative analysis of three euroregions: Ślask Cieszyński (Cieszyn Silesia), Beskidy (the Beskid Mountains), Tatry (the Tatra Mountains).

Adres/Address: $\quad$ Uniwersytet Pedagogiczny im. Komisji Edukacji Narodowej w Krakowie Instytut Politologii ul. Podchorążych 2, 30-638 Kraków, Polska e-mail: sab_san@poczta.onet.pl 


\author{
Sławomir Dorocki, Paweł Brzegowy \\ Uniwersytet Pedagogiczny \\ im. Komisji Edukacji Narodowej \\ w Krakowie
}

\title{
Rozwój przemysłu turystycznego departamentów Francji zamorskiej w warunkach światowego kryzysu gospodarczego \\ Development of the tourism industry in overseas departments and collectivities of France in the conditions of a global economic crisis
}

\begin{abstract}
Streszczenie
Francuski sektor turystyczny stanowi jedną z najszybciej rozwijających się i dochodowych gałęzi narodowej gospodarki, a sama Francja należy do czołówki państw czerpiących największe korzyści z obsługi ruchu turystycznego. Z końcem ostatniego dziesięciolecia odwiedziło Republikę przeszło $81 \mathrm{mln}$ turystów, co pozwoliło wygenerować ponad 6\% PKB i dało zatrudnienie około 2 mln osób. Od lat 60. XX w. rozwój turystyki objął również ówczesne departamenty i terytoria zamorskie (DOM-TOM), które odznaczają się licznymi materialnymi świadectwami kolonialnej przeszłości i bogatym potencjałem przyrodniczym. Regiony te oferują szereg atrakcji i stanowią obecnie prestiżowy cel wypraw turystycznych.

Zamierzeniem prezentowanego studium jest zarys charakterystyki francuskiego przemysłu turystycznego w jej departamentach zamorskich w warunkach światowego kryzysu gospodarczego. Globalny spadek produktywności połączony ze wzrostem zadłużenia publicznego wielu państw wpłynął na regres branży turystycznej, tak w ruchu międzynarodowym, jak i wewnątrzkrajowym. Zgodnie z raportem UNWTO zaliczono Francję do grupy pięciu państw o najwyższej recepcji ruchu podróżnych $(-7,8 \%)$. Podczas analizowania przemysłu turystycznego Francji zamorskiej, wyrażonego przez produkcję dóbr i usług turystycznych, zbadano jego najważniejsze sektory, takie jak atrakcyjność wypoczynkowa, baza noclegowa wraz ze zmianami ruchu turystycznego oraz uśredniona długość pobytów. W artykule zawarto ocenę potencjału turystycznego oraz produktu turystycznego ze szczególnym uwzględnieniem alternatywnych form turystyki tradycyjnej, zwłaszcza popularnej w departamentach pozaeuropejskich ekoturystyki. Zważywszy na różnorodność form francuskiej turystyki kwalifikowanej i morskiej, dokonano ich zwięzłej charakterystyki. Wskutek przeanalizowania turystycznych strategii rozwoju, m.in. Schéma d'aménagement et de développement touristique (Schematu planowania przestrzennego i rozwoju turystyki) oraz Programme Sectoriel en Agritourisme (Sektorowego Programu Rozwoju Agroturystyki), podjęto próbę udzielenia odpowiedzi na pytanie o aktualność i efektywność tychże inicjatyw w świetle rosnącej konkurencyjności i spadku udziału turystów zagranicznych w ogólnej liczbie turystów.
\end{abstract}

\footnotetext{
Abstract

The French tourism sector is one of the fastest growing and profitable sectors of the country's national economy, and France itself should be at the forefront of deriving great benefits from tourist services. At the end of the last decade, the Republic was visited by over 81 million tourists, which generated more than $6 \%$ of the GDP, and provided employment to approximately 2 million individuals.
} 
Since the 60 s of the twentieth century, the development of tourism has covered also the departments and territories (DOM-TOM), endowed with numerous material evidence of the colonial past and rich natural potential. These regions offer a variety of activities, and are now prestigious tourist destinations. The aim of the present study is to outline the characteristics of the French tourism industry in communities and overseas departments of France, in the conditions of the global economic crisis. The global decline in productivity, coupled with an increase in public debt in numerous countries, contributed to the regression of the tourism industry, both in international traffic, as well as on the internal market. According to a UN report, the WTO includes France into a group of five countries with the highest reception of passenger traffic $(-7.8 \%)$.

When analysing the French overseas tourism industry, expressed by the production of goods and tourism services, attractive areas, a range of accommodation with the evolution of tourism, and the average length of stays have all been studied. The article describes and assesses the potential of the tourism product, with particular emphasis on the traditional alternative forms of tourism, especially in the departments where non-European ecotourism is popular. Taking into consideration the diversity of French qualified and maritime tourism, their brief characteristics have also been included. By analysing tourism development strategies, such as the Schémad'aménagement et de développementtouristique (Scheme Planning and Tourism Development) and the Programme Sectoriel en Agritourism (Agritourism Sector Development Programme), authors attempt to answer questions about the validity and effectiveness of these initiatives, in times of growing competition and decreasing share in the foreign tourist market.

Słowa kluczowe: DOM; kryzys gospodarczy; przemysł turystyczny

Key words: DOM; economic crisis; tourism industry

\section{Wprowadzenie}

Działalność turystyczna stanowi obecnie istotny czynnik dynamizujący rozwój społeczno-gospodarczy wielu krajów i regionów, pozostając jednocześnie jedną z najszybciej rozwijających się gałęzi światowej gospodarki ${ }^{1}$. Przemysł turystyczny rozumiany jest zazwyczaj jako wszystkie procesy komercyjne związane z turystyką. Przyjmuje się, iż obejmuje on zarówno branżową produkcję materialną, jak i sferę usług, zaś będący jego synonimem termin gospodarka turystyczna ma w dużej mierze charakter umowny (Łazarek, 1999). Rosnące znaczenie swobody przepływu osób i kapitału prowadzi do dalszej intensyfikacji usług turystycznych, co wzmaga współczesny rozwój państw i regionów. Korzystne geograficzne usytuowanie Francji niemetropolitalnej w globalnych obszarach celów podróży turystycznych, bogate zasoby środowiska przyrodniczego oraz przynależność departamentów zamorskich (départements d'outre-mer - DOM) do rynku wewnętrznego UE uczyniły z niej dogodne miejsce wypoczynku dla turystów krajowych i międzynarodowych.

Celem niniejszego opracowania jest przedstawienie przemysłu turystycznego Francji kontynentalnej i zamorskiej w perspektywie wyzwań i trudności związanych z postępującą regionalizacją i globalizacją w aspekcie światowego kryzysu gospodarczego. Rozwój turystyki ukazano poprzez charakterystykę walorów turystycznych DOM stanowiących połączenie elementów środowiska naturalnego i czynników pozaprzyrodniczych (Warszyńska, Jackowski, 1970). Ponieważ turystyka nie stanowi materii jednorodnej, lecz wykazuje charakter interdyscyplinarny, pochylono się również nad kwestiami ochrony środowiska w kontekście rozwoju ekoturystyki, uwarunkowaniami prawnymi oraz ogólną kondycją francuskich gospodarek pozaeuropejskich, a więc wszystkim tym, co synergią bezpośrednią bądź pośrednią z branżą turystyczną skutkuje.

\footnotetext{
${ }^{1}$ Oszacowano, iż udział globalnej gospodarki turystycznej w światowym produkcie brutto wynosił ponad 9\%, a w zatrudnieniu przeszło 7\% (Travel and Tourism Economic..., 2009: 8).
} 


\section{Turystyka Francji}

Republika Francuska należy nieprzerwanie od 1980 r. do czołówki państw czerpiących największe dochody z obsługi ruchu turystycznego w wymiarze globalnym (Rousseau, 2012). Zarówno Francja kontynentalna, jak i jej fragment zamorski, a w szczególności Indie Zachodnie i francuska Polinezja, pozostają popularnymi turystycznie miejscami. Rekordowy w tym względzie okazał się rok 2007, gdy część kontynentalną odwiedziło przeszło 81 mln turystów. Przemysł turystyczny wygenerował wówczas niemal 6\% PKB i dał zatrudnienie przeszło $2 \mathrm{mln}$ osób. W przypadku Francji europejskiej istotną podstawą ruchu turystycznego pozostaje dziedzictwo kulturowe o uniwersalnej, powszechnie znanej symbolice (Patin, Vincent, 1993). Początek rozwoju sektora turystycznego we Francji przypadł na połowę lat 30. XX w. i dotyczył głównie kurortów nadmorskich. Progresja gospodarcza lat 60., przejawiająca się wzrostem poziomu życia oraz dynamiczną modernizacją rynku lotniczego i jego rozbudową, wpłynęła na popularyzację turystyki krajowej i zagranicznej (Ardagh, Jones, 1998). Lata 60. stanowiły również zaczyn turystycznej intensyfikacji ówczesnych departamentów i terytoriów zamorskich (DOM-TOM). Kryzys finansowy zapoczątkowany jesienią 2008 r. doprowadził jednak do zahamowania, a następnie zmniejszenia światowego ruchu turystycznego (ryc. 1). Odnotowany w 2009 r. spadek liczby turystów zagranicznych (o ok. 3\%) zbilansowali Francuzi, którzy zdecydowali się na wypoczynek krajowy (ok. 10\%). Sytuacja polityczna oraz uwarunkowania gospodarcze spowodowały, że obecnie ok. 85\% mieszkańców tego państwa spędza urlop w części metropolitalnej. Niekorzystna sytuacja wystąpiła również w regionie Karaibów, gdzie nastąpił spadek obrotów o 130 mln euro wywołany głównie ubytkiem turystów w sezonie zimowym (o 60\%) - zaczęli oni wyjeżdżać do tańszych regionów śródziemnomorskich (Hiszpania). Ogólnie w 2012 r. we Francji nastąpiło zmniejszenie liczby turystów o ok. 1,6\% (niektóre regiony odnotowały spadek do 30\%) przy wzroście udziału wczasowiczów zagranicznych $(+2,2 \%)$, zwłaszcza z Brazylii, Chin i Rosji. Najbardziej zauważalne było skrócenie długości pobytu o ok. $9 \%$ oraz liczby udzielonych noclegów o $2,9 \%$ (rynek krajowy $-4,3 \%$ ) przy najmniejszym spadku w sektorze najtańszych noclegów $(-0,3 \%)$. Wydatki Francuzów na wczasy w kraju spadły o $4,8 \%$, a na wypoczynek za granicą - o $11,4 \%$.

Ryc. 1. Ruch turystyczny we Francji w latach 1994-2011

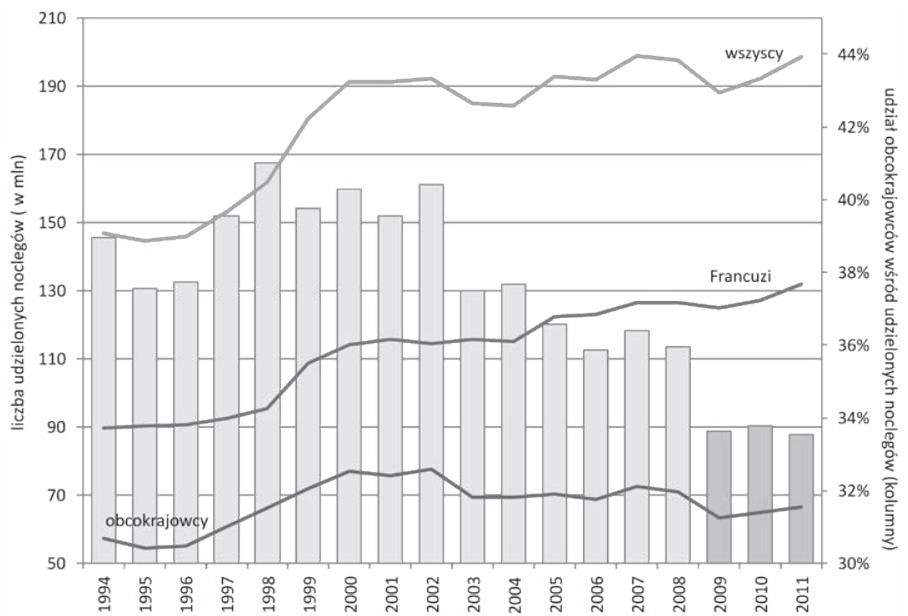

Źródło: opracowanie własne na podstawie danych EUROSTAT i Rousseau (2012). 
W związku z powyższymi problemami udział Francji w światowym rynku turystycznym od 2009 r. (1 miejsce na świecie - 74,2 mln turystów) wciąż się zmniejsza i wynosi obecnie ok. $15 \%$. Sytuacja ta może ulec pogorszeniu, ponieważ tylko $70 \%$ społeczeństwa planuje w najbliższych latach wyjechać na urlop, a 28\% zamierza skrócić swój pobyt w stosunku do lat ubiegłych. Sytuacja ta nie dotyczy wszystkich regionów Francji. Na przykład w Akwitanii udział pracowników sektora turystyki w strukturze zatrudnienia wzrósł o 5\%, a liczba miejsc pracy w sezonie zwiększyła się o 72 tys. Szacuje się, że w przyszłości nastąpi rozwój turystyki krajowej (ok. 2 mln osób), specjalistycznej oraz spersonalizowanej. Przykładem mogą być firmy Pierre \& Vacances Maeva lub Center Parcs, których obroty zwiększyły się o 653,2 mln euro, co w stosunku do poprzedniego roku stanowiło wzrost o ok. 14\%. Sytuację w sektorze turystyki ma poprawić misja „Vacances pour tous” rozpoczęta w połowie września 2012 r. i zaplanowana na lata 2013-2017.

Gospodarki DOM oparte głównie na rolnictwie bananów i trzciny cukrowej oraz systematycznie rozwijanym sektorze usług, w szczególności turystycznych, pozostają w znacznym stopniu uzależnione od funduszy unijnych przeznaczonych dla regionów peryferyjnych (Dorocki, Brzegowy, 2012). Departamenty i wspólnoty zamorskie znacznie wyraźniej odczuły wpływ kryzysu na koniunkturę turystyczną niż część metropolitalna. Ograniczeniu uległy podróże międzynarodowe, biznesowe oraz wydatki za granicą. Zmniejszyła się liczba cudzoziemców korzystających z bazy noclegowej, zmalał wskaźnik wykorzystania pokoi hotelowych i skrócił się średni czas pobytu. Nastąpiło też spowolnienie w zamorskim ruchu lotniczym. Głównymi odbiorcami rynku turystycznego DROM (przeszło 60\%) pozostawali mieszkańcy Francji kontynentalnej.

\section{Uwarunkowania rozwoju turystyki w departamentach zamorskich Francji}

Przed przystąpieniem do właściwej analizy rozwoju przemysłu turystycznego w departamentach zamorskich Francji w warunkach kryzysu gospodarczego, dokonano przeglądu ich atrakcyjności i uwarunkowań pod kątem rozwoju turystyki.

\section{Gwadelupa}

We wschodniej części Morza Karaibskiego, ok. 600 km od wybrzeża Ameryki Południowej, zlokalizowany jest jeden z dwóch departamentów antylskich Francji - Gwadelupa. Departament o powierzchni 1780 km² składa się z kilkudziesięciu wysp i wysepek, z których dwie największe to Grande-Terre i Basse-Terre (Jędrusik, 2002). Geologiczną podstawę pierwszej z nich tworzą głównie wapienie, a w łagodnym krajobrazie dominują niewielkie wzniesienia, pola uprawne i piaszczyste plaże. Korzystne ukształtowanie pionowe już w czasach kolonialnych uczyniło z Grande-Terre dogodne miejsce rozwoju rolnictwa plantacyjnego. Krajobrazowe walory wyspy zaczęto wykorzystywać pod rozwijającą się branżę turystyczną od lat 70. XX w. Do najważniejszych czynników sprzyjających miejscowemu rolnictwu należą również wulkaniczne gleby Basse-Terre, pożądane warunki klimatyczne oraz brak terenów górzystych (Gourou, 1963). Najwyższym wzniesieniem „,niskiej ziemi” jest czynny wulkan La Soufrière (1467 m n.p.m.), którego erupcje z lat 1976-1977 wymusiły ewakuację niemal 30 tys. mieszkańców (Renault, 1985). Antyle Francuskie są zlokalizowane w strefie klimatu zwrotnikowego morskiego. Średnia miesięczna temperatura powietrza wynosi $24-28^{\circ} \mathrm{C}$, a roczne opady, uzależnione częściowo od północno-wschodniego pasatu, zawieraja się w przedziale 800-2500 mm (Kubiatowicz, Ratajski, 1967). Przyrodnicze bogactwo Gwadelupy należy do największych w regionie Małych Antyli. Obfita w gatunki endemiczne flora tropikalnych lasów deszczowych obejmuje ok. 300 gatunków drzew i krzewów oraz niemal 100 gatunków storczyków. Niezwykła 
różnorodność jest także charakterystyczna dla środowiska morskiego archipelagu (ok. 300 gatunków ryb, 50 gatunków korali, przeszło 70 gatunków gąbek czy 570 gatunków mięczaków) (L'Association Guadeloupéenne d'Écotourisme, 2012). Aby propagować ekoturystykę, turystom dano możliwość zapoznania się z bogactwem lasów tropikalnych oraz przybrzeżnych lasów mangrowych i raf koralowych wchodzących w skład Gwadelupskiego Parku Narodowego o powierzchni $173 \mathrm{~km}^{2}$.

Uzupełnieniem walorów przyrodniczych departamentu pozostają liczne obiekty historyczne. Przykładem może być kanał wodny Le canal des Rotours z 1829 r. służący pierwotnie do transportowania trzciny cukrowej lub nekropolia symbolizująca kulturę europejską i afrykańską, z nagrobkami ułożonymi w formie czarno-białej szachownicy. Inną atrakcją jest zajmujący 90 ha kolonialny majątek plantacyjny La Domaine de l'Habitation la Grivelière. Odrestaurowane budynki gospodarcze i mieszkalne, a także zabytki techniki, takie jak młyny, piece chlebowe czy przyrządy do zbioru, suszenia oraz prażenia kawy i kakao, przyciągają rocznie ok. 20 tys. osób. Ślady kolonialnej rywalizacji francusko-angielskiej można odnaleźć w forcie Napoléon des Saintes na wyspie Terre-de-Haut. Fort ten, zniszczony przez Brytyjczyków w 1809 r., a następnie odbudowany w $1867 \mathrm{r}$. i wykorzystywany czasowo jako więzienie, został przekształcony w muzeum i uchodzi za najważniejszy historyczny zabytek archipelagu Les Saintes. W skład kompleksu wchodzi ponadto utworzony w 1984 r. Jardin exotique du Fort Napoléon - ogród botaniczny, zawierający bogatą kolekcję roślin przystosowanych do życia w wysokiej temperaturze (Heywood, Wyse Jackson, 1991). Spośród obiektów kolonialnych Grande-Terre wyróżnia się osiemnastowieczny Fort Fleur d'Épée, którego podziemia zaadaptowano współcześnie pod galerię sztuki. Z miejsc o przeznaczeniu sakralnym uwagę zwraca katedra Matki Boskiej z Gwadelupy z 1736 r. Interesująca pozostaje również architektura budynków użyteczności publicznej projektu A. Tur: Pałacu Sprawiedliwości, Palais du Conseil Général czy Pałacu Gubernatora. Departament Gwadelupy oferuje turystom ok. 200 restauracji wyspecjalizowanych głównie $\mathrm{w}$ daniach $\mathrm{z}$ owoców morza, będących mieszanką straw europejskich, afrykańskich, azjatyckich i karaibskich. Centrum gospodarcze Gwadelupy stanowi największy ośrodek miejski Pointe-à-Pitre z międzynarodowym portem lotniczym i morskim. Natomiast

Ryc. 2. Centra turystyczne Francji zamorskiej

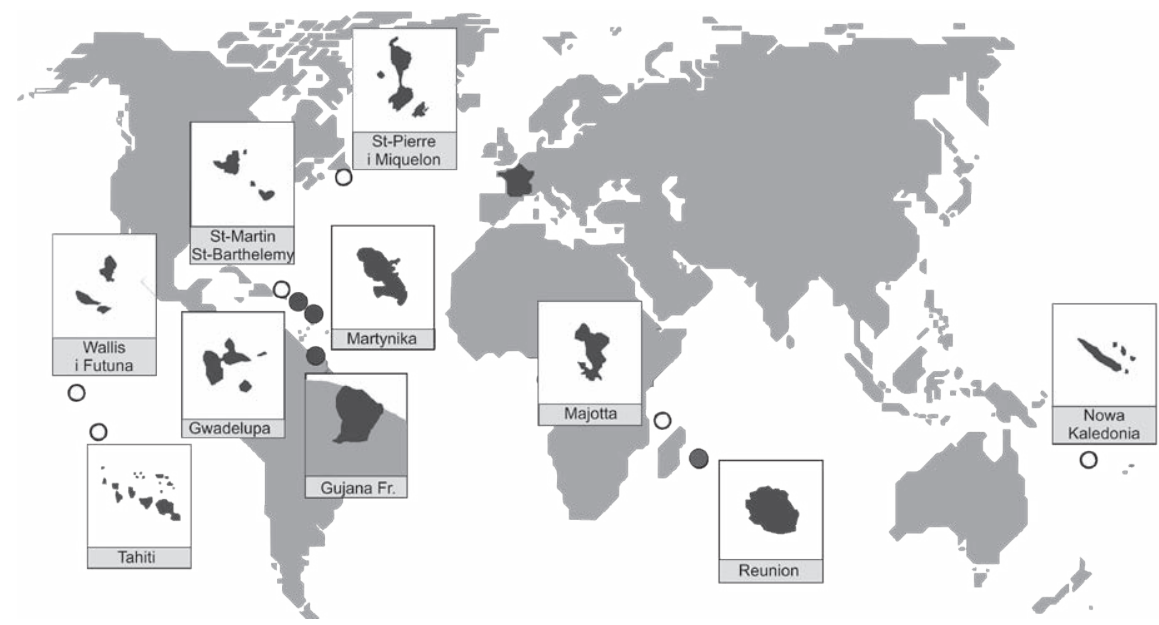

Źródło: opracowanie własne. 
centra turystyczne znajdują się na południowym wybrzeżu Grande-Terre z ośrodkami Barrote, Deshauteurs, Grand-Fonds, Louisiane, Le Helleux oraz Valletta.

Podstawowym narzędziem rozwoju i wdrażania idei ekoturystycznej jest powołane w $1996 \mathrm{r}$. L'Association Guadeloupéenne d'Écotourisme (AGÉ) - Ekoturystyczne Stowarzyszenie Gwadelupy. Inicjatywa ta zapobiega niebezpieczeństwom wynikającym z dynamicznego rozwoju turystyki tradycyjnej o charakterze masowym, upatrując w turystyce ekologicznej branżę przyszłościową i wartą zainwestowania. Wycieczki po departamencie promowanym hasłem Les îles de la Guadeloupe, source naturelle de sensations (Gwadelupa - naturalne źródło doznań) organizowano w niewielkich, kameralnych grupach - wszystko po to, by dokładniej zaprezentować charakter regionalnej kultury. Liczba uczestników zielonej turystyki w departamencie Gwadelupy corocznie wykazywała trend wzrostowy. W 2009 r. udział ekoturystów szacowano na $45 \%$, co w zestawieniu z rokiem uprzednim stanowiło dziesięcioprocentowy wzrost (Camus, 2010). Warto zauważyć, iż w 2006 r. uznano Gwadelupę za obszar o najlepszej bazie windsurfingowej ${ }^{2}$, a rok później, podczas World Travel Market w Londynie (największych na świecie targów w branży turystycznej), otrzymała ona tytuł najdogodniejszego miejsca do uprawiania turystyki ekologicznej (Lenoir, 2007).

Dobrym przykładem sprawnej organizacji tradycyjnego wypoczynku turystycznego i ekoturystycznego pozostawała położona w zachodniej części departamentu gmina Bouillante licząca nieco ponad 7,5 tys. mieszkańców (Population legalés 2009 de la commune...). Gmina ta, o pierwotnie rolniczym charakterze opierającym się na uprawie kawy i kakao, dynamicznie rozwinęła działalność turystyczną. Chroniony obszar morski w rezerwacie Cousteau wchodzącym w skład departamentalnego parku narodowego przyciąga głównie miłośników nurkowania. Okolice miejscowości Deshaies, będące ważnym źródłem produkcji energii geotermalnej, zaadaptowano pod atrakcyjny punkt widokowy i miejsce kąpieli wodnych. Z pozostałych znanych ośrodków wypoczynkowych Gwadelupy wspomnieć należy Amandiers, Gosier oraz Moule. Obecne na stokach wulkanu La Soufrière źródła termalne przyjmuje się za główną atrakcję uzdrowisk Ravine Chaude i Saint-Claude (Kruczek, 2008).

Z końcem lat 80. baza hotelowa Gwadelupy, skupiona głównie wokół Pointe-à-Pitre liczyła ok. 8,5 tys. miejsc. W 1989 r. departament odwiedziło 215 tys. turystów, przede wszystkim obywateli USA i Francji kontynentalnej, którzy pozostawili 95 mln USD (Koliba, 1997). W 2005 r. zyski z działalności turystycznej stanowiły 5\% departamentalnego PKB (Le tourisme en Guadeloupe: impact du tourisme sur l'activité et l'emploi, 2007).

\section{Martynika}

Drugim departamentem zlokalizowanym w regionie Karaibów jest Martynika. Położona w archipelagu Wysp Zawietrznych zajmuje powierzchnię $1128 \mathrm{~km}^{2}$ i jest trzecią co do wielkości wyspą Małych Antyli. Geograficznie departament dzieli się na trzy obszary: dziki i górzysty, północny na osi Fort-de-France - Le Robert, od Fort-de-France po Le Lamentin - centralny oraz turystyczny głównie, pagórkowaty - południowy (Auzias, Labourette, 2010). Na Martynice występują dwie pory roku: sucha, z maksymalną temperaturą powietrza $30^{\circ} \mathrm{C}$ (od lutego do kwietnia), i deszczowa, w której najwyższa odnotowana temperatura wyniosła $34,6^{\circ} \mathrm{C}$ (w 1999 r.).

Stolicą administracyjną i największym zurbanizowanym ośrodkiem departamentu jest Fort-de-France liczący 90 tys. mieszkańców. „Mały Paryż” pełni funkcję centrum gospodarczego.

\footnotetext{
${ }^{2}$ Według głosowania na portalu World Travel Awards.
} 
Znajduje się w nim też największy port morski. Do najważniejszych atrakcji historyczno-kulturowych należą trzy osiemnasto- i dziewiętnastowieczne porty: Desaix, Gerbault i Tartenson, jedna z największych w regionie karaibskim bibliotek - Biblioteka Schoelchera z 1887 r. (niemal 130 tys. woluminów), katedra Saint-Louis oraz słynny ogród botaniczny Jardin Botanique de Balata. Z oddalonym o ok. $10 \mathrm{~km}$ portem lotniczym łączy Fort-de-France autostrada A1.

Najważniejszym ośrodkiem przemysłowym wyspy i drugim co do wielkości miastem Martyniki jest Le Lamentin. Z pozostałych departamentalnych ośrodków zurbanizowanych wspomnieć warto: w części północnej: Basse-Pointe, Grand'Rivière, Le Prêcheur, Le Lorrain i Le Carbet, w części centralnej: Saint-Joseph, Le Robert, Schoelcher, Le François i Ducos oraz umiejscowione na południu: Sainte-Anne, Le Marin, Le Diamant, Sainte-Luce, Rivière-Pilote, Rivière-Salée i Le Vaculin.

Innymi atrakcjami departamentu są muzea: wulkanologiczne (Le Morne-Rouge), cesarzowej Józefiny i trzciny cukrowej (LesTrois-Îlets), ogrody d'Estripaut, kasyno Pointe du Bout oraz udostępniony w 2004 r. skansen kolonialnej wsi z przełomu XIX i XX w. - La Savane des Esclaves. Popularnością cieszy się również trzystuhektarowy obszar byłej plantacji Habitation Clément w Le François. W obiekcie zachowały się gorzelnia rumu, budynki mieszkalne oraz oryginalne piwnice. Przez zorganizowanie serii wystaw turystom dano sposobność zapoznania się z historią produkcji rumu oraz stylem i warunkami życia w kolonialnych tropikach. Z pozostałych plantacji wspomnieć trzeba nadal działającą La sucrerie Le Galion w La Trinité, gdzie w okresie od marca do czerwca oglądać można tradycyjne cukrowe żniwa.

Odznaczająca się bogatymi walorami środowiska przyrodniczego Martynika stwarza dogodne warunki do uprawiania systematycznie popularyzowanej w departamencie ekoturystyki. Turystyka ta, określana również mianem zielonej, przyrodniczej, miękkiej, czy ekologicznej, za priorytet przyjmuje zasadę maksymalnego ograniczenia ingerencji w ekosystem (Dudek, Kowalczyk, 2003). Ekoturystykę uznaje się też zwykle za rdzeń koncepcji turystyki zrównoważonej (Zaręba, 2000). Najczęstsze zastosowanie znajdują w niej obszary chronione, parki narodowe i rezerwaty. W przypadku Martyniki należały do nich rezerwaty la Réserve naturelle de la Caravelle i Sainte-Anne oraz zajmujący powierzchnię $700 \mathrm{~km}^{2}$ park Martyniki - Le Parc naturel ŕegional de la Martinique.

Wdrażaniem regionalnej strategii ekoturystycznej zajmuje się powołane w 1976 r. L'Association pour le tourisme en espace rural (AMATER) - Stowarzyszenie Turystyczne Obszarów Wiejskich - przyznające znak jakości Gîtes de France, które jest wspierane przez l'Agence régionale du tourisme martiniquais (ARDTM) - Regionalną Agencję Turystyki. W 1998 r. liczbę łóżek w kwaterach wiejskich szacowano na ok. 1000 i zakładano ich zwiększenie do 2800 w 2011 r. (Nosel, 2000). Uruchomiony z myślą o aktywnym wypoczynku szlak Route de la Trace prowadzi uczestników przez środek lasu tropikalnego na szczyt Montagne Pelée. Jest to jedna z przeszło 30 tras turystycznych, umożliwiających poznanie całego departamentu. Z pozostałych traktów wspomnieć należy Canal de Beauregard, Trace des Caps, Trace des Jésuites oraz La randonnée Grand Rivière. Oprócz pieszych wycieczek istnieje sposobność uprawiania jazdy konnej, kolarstwa górskiego, wędkarstwa, żeglarstwa, windsurfingu, kajakarstwa, kaytu, canyoningu czy przepraw górskimi strumieniami.

Stopniowe zmniejszanie supremacji rolnictwa na rzecz usług spowodowało trwającą od końca lat 80. widoczną redukcję użytków rolnych zajmujących w 2002 r. 32 tys. ha ziemi. Na popularyzację działalności agroturystycznej na obszarach wiejskich wpłynęła działalność Chambre d'Agriculture de Martinique - Izby Agroturystycznej Martyniki, prekursorki pierwszego programu poświęconego charakteryzowanej materii - Programme Sectoriel en Agritourisme (PSA) realizowanego w latach 2000-2006. Bastionem agrorolnictwa pozostaje głównie 
północna część departamentu. Według ekspertów agroturystyka stanowi ważny element aktywizacji gospodarczej obszarów wiejskich, ponieważ wymusza pośrednio ich ekonomiczne ożywienie (Dorocki, Szymańska, Zdon-Korzeniowska, 2012). Głównym celem prowadzenia takowej działalności jest pozyskiwanie przychodów finansowych (Feczko, 2010). Pod koniec 2002 r. agrousługi, obejmujące przede wszystkim zakwaterowanie i wypoczynek w gospodarstwie, oferowało niemal 30 obiektów na wyspie (Audit de la filière agritouristique en Martinique. Note de synthèse, 2002).

Przestrzenne zróżnicowanie zagospodarowania turystycznego, którego wyznacznikiem jest m.in. baza noclegowa, pozostaje istotnym czynnikiem wpływającym na intensyfikację ruchu turystycznego (Rettinger, 2010). Południowa część departamentu charakteryzuje się dużą koncentracją bazy hotelowej, dlatego podjęto działania mające na celu rozbudowę czterech obszarów turystycznych na północy: La Pointe du Bout, l'Anse à l'Ane (obydwa w gminie Les Trois-Îlets), Le Pointe Marin (w Sainte-Anne) oraz Le Pointe Cherry (w Le Diamant) (Taïlame, 2009: 4). W efekcie poczynionych działań zwiększyła się liczba rezydencji hotelowych wyposażonych w aneksy kuchenne. Obiekty hotelowe cechowało znaczne zróżnicowanie cenowe, determinowane przez sezony turystyczne i okresy świąteczne - przede wszystkim bożonarodzeniowy i wielkanocny. Popularnym rodzajem zakwaterowania pozostawały obecne na całej wyspie wille zaopatrzone zazwyczaj w baseny. Największą liczebność wykazywały jednak małometrażowe mieszkania jednopokojowe, czasami większe, nazywane apartamentami. Najemcy lokowali je we własnych domach bądź tworzyli oddzielne domki campingowe (Kwatery prywatne i hotele, Słoneczna Martynika). Łączną liczbę pokoi w 2006 r. szacowano na 8285 (207 $125 \mathrm{~m}^{2}$ powierzchni). Wielkość tę do 2015 r. planuje się zwiększyć do 18400 (Taïlame, 2009: 3).

\section{Gujana Francuska}

Zajmująca obszar $83846 \mathrm{~km}^{2}$ Gujana Francuska pozostaje największym departamentem i regionem zamorskim Republiki. Zlokalizowana w północno-wschodniej części Ameryki Południowej pomiędzy rzekami Maroni i Oyapock sąsiaduje z Gujaną i Brazylią. Gęsto zaludniony pas nabrzeża liczący $350 \mathrm{~km}$ długości jest połączony z rozciągającym się dalej na południe interiorem o powierzchni 80 tys. $\mathrm{km}^{2}$ (Bonasewicz, 1967). Gujana Francuska leży w strefie klimatu równikowego wilgotnego. Średnia roczna temperatura powietrza wynosi $26,4^{\circ} \mathrm{C}$, a średnie roczne opady na terenie zlewni kształtują się na poziomie 3,7 tys. mm (Le tourisme dans l'outre-mer français, 2008: 62). Dynamicznie rozwijające się ośrodki zurbanizowane: Kajenna, Kourou, Régina, Rémire-Montjoly, Saint-Laurent du Maroni oraz Matoury, poza nielicznym wyjątkami, znajdują się na obszarze przybrzeżnym. Stolicę administracyjną departamentu - Kajennę - zamieszkuje ok. 60 tys. ludzi. Pod względem planowania urbanistycznego stanowi ona interesujące połączenie architektury europejskiej i kolonialnej. W zestawieniu najważniejszych zabytków historycznych Gujany Francuskiej wyszczególniono 79 obiektów, z czego 39 znajdowało się w Kajennie, 14 w Rémire-Montjoly, zaś pozostałe rozproszone były w 14 departamentalnych gminach (Base Mérimée - Monuments historiques de Guyane).

Obdarzona bogactwem przyrodniczym Gujana Francuska stanowi dogodne miejsce do propagowania ekoturystyki (por. Braun, Collignon, 2008). W okresie jej upowszechniania (1996-1998) nocleg w tradycyjnych chatach wybrało 29,2\% wczasowiczów z łącznej liczby ok. 130 tys. (Baldy, Madeleine, Paulin, 2000). Przez wzgląd na liczbę odwiedzających (26 034 w 2007 r.) należy stwierdzić, iż najpopularniejszą turystyczną atrakcją departamentu pozostawało Centre Spatial Guyanais (CSG) - Gujańskie Centrum Kosmiczne w Kourou (Madeleine, 2008). Generowało ono w 2011 r. ok. 15\% regionalnego PKB, dając zatrudnienie ok. 1600 
pracownikom na miejscu i niemal 8 tys. w firmach powiązanych (Economie du spatial, 2012). Do najchętniej odwiedzanych miejsc należały również kolonialne obiekty penitencjarne na Wyspach Ratunku (46,6 tys. turystów), Muzeum Kultury Gujańskiej w Kajennie (9,1 tys.), Musée Franconie (5,0 tys.) oraz działające przy CSG Musée de l'Espace (19,3 tys.) i wyrzutnia rakietowa (14,2 tys.) (Madeleine, 2008).

Przypadający na połowę lat 90. rozwój departamentalnego sektora turystycznego warunkowała postępująca dywersyfikacja gospodarki i troska o ochronę dziedzictwa przyrodniczego. Na politykę turystyczną departamentu w znacznym stopniu wpłynęły decyzje podejmowane przez Le Comité du Tourisme de la Guyane (CTG) - Gujański Komitet Turystyki, odpowiedzialny za promocję branży z oddziałem w Paryżu, oraz Le Club des Hôteliers - Klub Hotelarski. Departamentalną bazę hotelową w 2008 r. ulokowaną w trzech regionach geograficznych: Ile de Cayenne, Kourou - Sinnamary oraz Saint Laurent - Saint Georges tworzyły 24 obiekty z 1169 pokojami ze wskaźnikiem wykorzystania 57,5\% (Jean, 2010). Zbudowany w 1943 r. Międzynarodowy Port Lotniczy Félix Eboué oddalony o 13,5 km od Kajenny obsłużył w 2011 r. 435440 pasażerów (Résultats d'activité des aéroports français 2011, 2012). Siatkę regularnych połączeń lotniczych zapewniały w pierwszej kolejności: Air France, Air Guyane oraz Air Caraïbes (Le tourisme dans l'outre-mer français, 2008: 70).

Tab. 1. Podstawowe wskaźniki makroekonomiczne departamentów Francji amerykańskiej (DFA) w 2010 r.

\begin{tabular}{|l|c|c|c|c|}
\hline \multicolumn{1}{|c|}{ DFA } & $\begin{array}{c}\text { PKB na 1 } \\
\text { mieszkańca }\end{array}$ & $\begin{array}{c}\text { Tempo } \\
\text { wzrostu PKB }\end{array}$ & $\begin{array}{c}\text { PKB per capita } \\
\text { (w tys. EUR) }\end{array}$ & Bezrobocie \\
\hline Gwadelupa & 21266,1 & $+2,7 \%$ & 21266 & $24,1 \%$ \\
\hline Martynika & 20268,4 & $+4,6 \%$ & 20268 & $21,2 \%$ \\
\hline Gujana Francuska & 14175,0 & $3,8 \%$ & 14028 & $21,0 \%$ \\
\hline
\end{tabular}

Źródło: Fédération des Entreprises d'Outre Mer (2012).

\section{Sektor turystyczny Reunion}

Podobnie jak DFA Reunion od 1946 r. stanowi integralną część Francji. Departament jest położony w południowo-zachodniej części Oceanu Indyjskiego, $700 \mathrm{~km}$ na wschód od Madagaskaru i $200 \mathrm{~km}$ w kierunku południowo-wschodnim od Mauritiusu. Ta największa wyspa wulkanicznego archipelagu Maskarenów zajmuje powierzchnię $2512 \mathrm{~km}^{2}$ (Géologie, relief et climat des enjeux humains et environnementaux forts, 2012). Departament ten leży w strefie klimatu zwrotnikowego. Na Reunionie znajdują się pasma wysokich gór (najwyższy szczyt Piton des Neiges - 3070,5 m n.p.m.), dlatego jego obszar cechuje obecność charakterystycznego mikroklimatu. Średnia roczna temperatura powietrza w części przybrzeżnej w zależności od pory roku zawiera się w przedziale $18-31^{\circ} \mathrm{C}$. W wyżej zlokalizowanych częściach wyspy rzadko przekracza $25^{\circ} \mathrm{C}$, zaś na wysokości $1800 \mathrm{~m}$ n.p.m. w lipcu i sierpniu możliwe są przymrozki. Pełniące funkcję stolicy administracyjnej departamentu Saint-Denis zamieszkuje 140 tys. osób (Population Saint-Denis). Miasto pozostaje wiodącym centrum politycznym, handlowym i kulturalno-naukowym.

Najważniejszym sektorem regionalnej gospodarki było w ostatniej dekadzie rolnictwo oparte na uprawie trzciny cukrowej, a kolejnym - turystyka. W okresie francuskiej kolonizacji eksportowano z Reunionu kawę, bawełnę, geranium i wanilię (Jędrusik, 2005: 121), a w XX w. - także rum i olejki eteryczne (Winid, 1967). Początki przemysłu turystycznego sięgają pierwszej połowy lat 60. Przyjmuje się, iż Air France i Air Madagascar, utrzymujące przez kolejnych 20 lat lotniczy monopol, hamowały rozwój działalności turystycznej dynamicznie upowszech- 
nianej po roku 1990. Z początkiem 2001 r. wybrane gminy przystąpiły do tworzenia tzw. villages créoles - wiejskich skansenów oferujących wczasowanie w atmosferze kreolskiej kultury (Villages creoles). W promowaniu departamentalnej turystyki pomocna okazała się uruchomiona w 2003 r. metropolitalna kampania la France des trois océans (Francja trzech oceanów) zachęcająca do wypoczynku w części pozaeuropejskiej.

Rada Regionalna w 2005 r. podjęła ambitną inicjatywę zwiększenia liczby turystów, którzy odwiedzą Reunion w 2020 r., do miliona. W opracowanej strategii szczególną uwagę zwrócono na seniorów i osoby niepełnosprawne. Podjęte działania odzwierciedlały ogólnoświatowy trend, jednak jak zauważyła Teresa Skalska (por. 2011), aktywność turystyczną w drugiej grupie przejawiały głównie osoby z lekkim i umiarkowanym stopniem niepełnosprawności oraz czynne zawodowo. Pakiet wypoczynkowy przeznaczony dla osób w wieku poprodukcyjnym podzielono na trzy kategorie. Dla seniorów pracujących (les seniors actifs) w przedziale wiekowym 50-59 lat, dla będących na emeryturze (les libérés) i uposażonych w odpowiednie środki finansowe (60-74 lata) oraz dla emerytów (les retirés) liczących 75 lat i więcej, i mających ograniczone możliwości podróżowania. Oszacowano, iż w 2020 r. we Francji kontynentalnej 29 mln osób przekroczy 50 lat, zaś w Europie liczba ta wyniesie ok. $220 \mathrm{mln}$ (Durand M.S., Fruteau M.C., 2004: 40). Z myślą o społeczności LGBT przyjęto w 2007 r. charte d'accueil - kartę zawierającą charakterystykę miast i kurortów przyjaznych mniejszościom seksualnym (La Réunion ,gay-friendly”, mais sans associations). Zapoczątkowany w 2005 r. kryzys przemysłu turystycznego powodowany był upadkiem Air Burbon, a w dalszej kolejności rzadką epidemią wirusa chikungunya (Chikungunya ou maladie de „l'homme courbé"). Ponowne ożywienie w ruchu turystycznym przypadło na rok 2009. Reunion odwiedziło wówczas niemal 422 tys. turystów, a zatem $6,4 \%$ więcej niż w roku uprzednim. W sezonie turystycznym wyróżnić można dwa szczyty: przypadający na czas wakacji szkolnych lipcowo-sierpniowy oraz październikowo-listopadowy. Sektor turystyczny zatrudniał w 2005 r. ponad 6 tys. osób. Z liczby tej przeszło 37\% mieszkańców pracowało w hotelarstwie, 18,6\% w gastronomii, 10,8\% $\mathrm{w}$ dziale sportu i rekreacji, a pozostali - w biurach turystycznych, transporcie oraz w rozrywce i kulturze (Bally i in., 2005).

Spośród atrakcji turystycznych o charakterze historyczno-kulturowym uwage zwracają muzea: sztuki Léon-Dierx w Saint-Denis, w którym zgromadzono zbiory Cézanne’a, Gauguina czy Renoira, Maison du Volcan w Le Tampon, oraz muzeum regionalnego rolnictwa Stella Matutina w Saint-Leu. Popularnością cieszyły się również departamentalne ogrody botaniczne: Jardin d'Éden, ogród egzotyczny w Pierrefonds, Jardin des parfums et des épices (Liste des monuments historiques de La Réunion, 2012). Przyrodnicze bogactwo departamentu objęto ochroną w ustanowionym w 2007 r. Parku Narodowym Reunionu, który zajmuje blisko 40\% powierzchni wyspy.

W przyjętym w 2004 r. Schéma d'Aménagementet de Développement Touristique de La Réunion (SADTR) - Schemacie planowania rozwoju turystycznego Reunionu - podkreślono konieczność systematycznego zwiększania rentowności przedsiębiorstw branżowych, dalszej rozbudowy oraz remontu zaplecza hotelowego i bazy okołoturystycznej (parkingów, przechowalni sprzętu i in.) przy jednoczesnej ochronie wrażliwego ekosystemu regionu oraz wprowadzeniu nowych bądź słabo spopularyzowanych w departamencie usług turystycznych, takich jak konferencje, seminaria, wellness i in. (Durand M.S., Fruteau M.C., 2004: 36). Następną inicjatywą była organizacja tematycznych ośrodków turystyczno-rekreacyjnych: zones d'aménagement lié à la mer, stref rozwoju związanych z morzem przede wszystkim w południowej części wyspy, oraz golfowego Bassin Bleu w Saint-Gilles-les-Hauts z widokiem na góry i ocean (Durand M.S., Fruteau M.C., 2004: 51, 55). 


\section{Baza turystyczna i ruch turystyczny DOM}

Kolejną część opracowania poświęcono ewolucji bazy turystycznej i ruchu turystycznego we Francji zamorskiej oraz - dla porównania - poszczególnych wskaźników obrazujących ruch turystyczny DROM z regionami metropolitalnymi.

Biorąc pod uwagę liczbę obiektów turystycznych we Francji w latach 2001-2011, można stwierdzić, że kryzys - w przeciwieństwie do innych krajów świata - nie miał wyraźnego wpływu na jej sektor turystyczny (Zdon-Korzeniowska, Rachwał, 2011). W badanym okresie następował ciągły wzrost nowo powstałych firm z sektora turystyki. Ogólnie zaobserwowano spadek liczby firm zlikwidowanych w stosunku do nowo powstałych - z 31 w 2001 do 21 w 2010 r. (ryc. 3A). Zauważalna jest natomiast tendencja wzrostu udziału firm z branży turystycznej w ogóle likwidowanych przedsiębiorstw przy równoczesnym zmniejszaniu się udziału w łącznej liczbie nowo powstałych. Warto podkreślić, że udział podmiotów gospodarczych

Ryc. 3. Liczba obiektów turystycznych we Francji w latach 2001-2010 (A) oraz liczba obiektów z sekcji hotele i restauracje w DOM w latach 1996-2009 (B)

A.

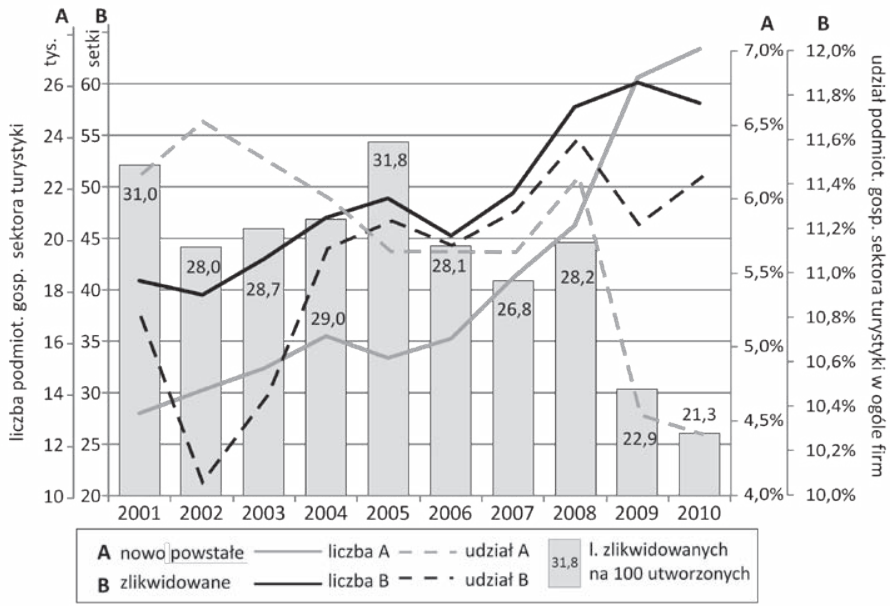

B.

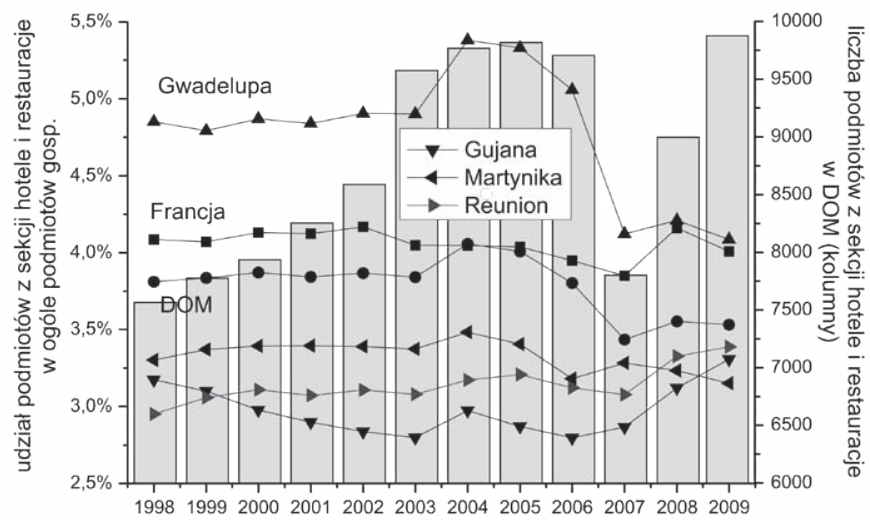

Źródło: opracowanie własne na podstawie danych INSEE, EUROSTAT i Rousseau (2012). 
z sekcji hotele i restauracje w ogóle przedsiębiorstw dla DOM wyraźnie zmalał z 4\% do 3,5\% i był niższy niż we Francji kontynentalnej. Wyższym wskaźnikiem niż Francja europejska odznaczała się tylko Gwadelupa, która odnotowała jednak największy spadek udziału, podczas gdy w pozostałych departamentach nie zaobserwowano większych jego wahań. Może to świadczyć o ogólnym wzroście gospodarczym w departamentach zamorskich; liczba podmiotów z sekcji hotelowej i restauracyjnej wzrosła z 750 w 1998 r. do 1000 w 2009 r. (ryc. 3B). Analiza obu wskaźników pozwala zauważyć wyraźny spadek udziału firm z branży turystycznej w 2008 r., co może sugerować wpływ kryzysu na branżę turystyczną DOM (ryc. 3AB). Innym miernikiem rozwoju usług turystycznych jest liczba zatrudnionych w tym sektorze. W departamentach zamorskich od 1996 r. obserwowano bardzo duży wzrost liczby zatrudnionych w sekcji hotele i restauracje przy równoczesnym spadku ich udziału w ogóle zatrudnionych (rys. 4A). Sytuacja ta była szczególnie widoczna w DOM na Karaibach i wynikała z rekordowej liczby turystów odwiedzających ten region w skali roku (przeszło 900 tys.). Zatrudnienie

Ryc. 4. Liczba zatrudnionych w sekcji hotele i restauracje w DOM w latach 1996-2009 (A) oraz liczba obiektów hotelowych w DOM w latach 2001-2011 (B)

A.

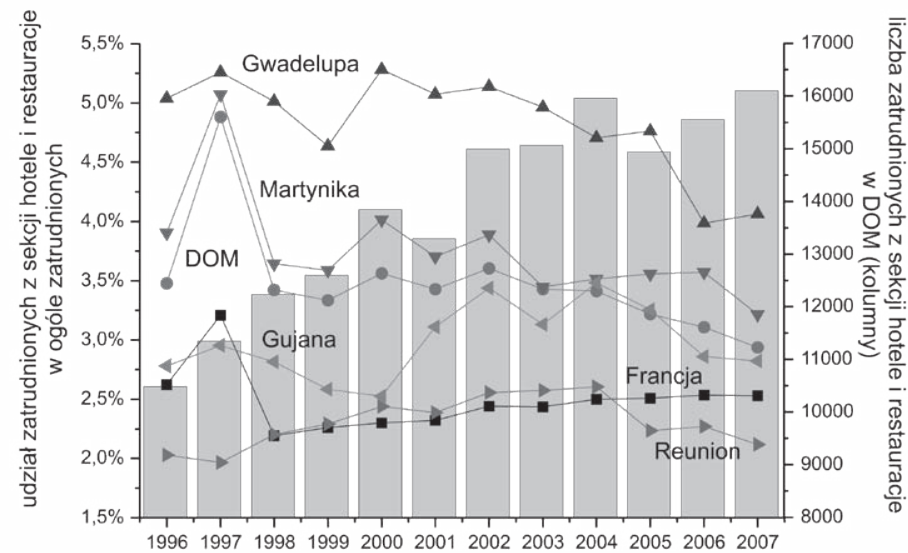

B.

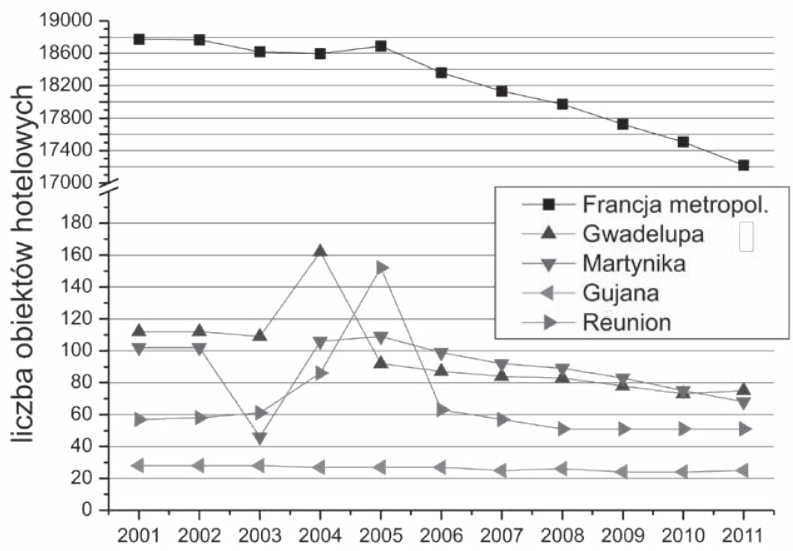

Źródło: opracowanie własne na podstawie danych INSEE, EUROSTAT i Rousseau (2012). 
w turystyce w DOM zbliżyło się do poziomu metropolitalnego $(2,5 \%)$, co może również świadczyć o różnicowaniu się gospodarek zamorskich.

W dalszej analizie skupiono się na bazie noclegowej. $\mathrm{Z}$ analizy dynamiki zmian liczby obiektów hotelowych w latach 2001-2011 wynika, że ok. 2005 r. we Francji nastąpił wyraźny spadek ich liczby utrzymujący się do 2011 r. (rys. 4B). Podobna sytuacja charakteryzowała również DOM, chociaż ubytki te nie były tak wyraźne, szczególnie w przypadku Reunionu. Najmniejsza zmiana w liczebności obiektów hotelowych wystąpiła w Gujanie Francuskiej, gdzie spadek po 2006 r. był minimalny.

Po 2005 r. wyraźnie zmalała liczba miejsc noclegowych w obiektach hotelowych DOM (ryc. 5A). Z kolei liczba miejsc noclegowych w przeliczeniu na jedną osobę w departamentach pozaeuropejskich znacząco się zwiększyła (z 50 do 85), przede wszystkim w Reunionie, podczas gdy w części kontynentalnej wartość ta była niezmienna i wynosiła ok. 50. W strukturze hotelowej przeważały pokoje gościnne $(56,06 \%)$ i obiekty typu bed \& breakfast $(23,40 \%)$,

Ryc. 5. Liczba miejsc noclegowych w obiektach hotelowych w DOM (A) oraz struktura bazy noclegowej DOM: liczba obiektów (B.1) i liczba miejsc (B.2)

A.

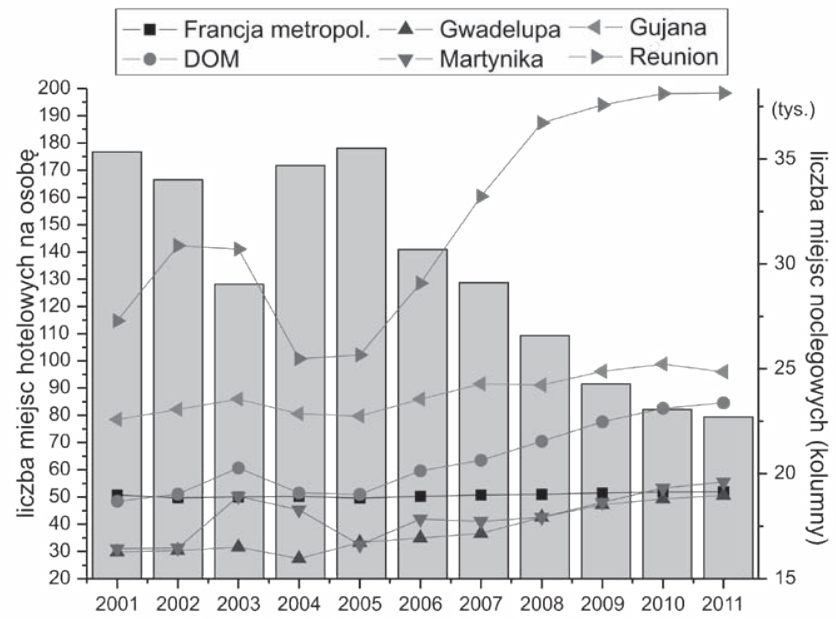

B.1.

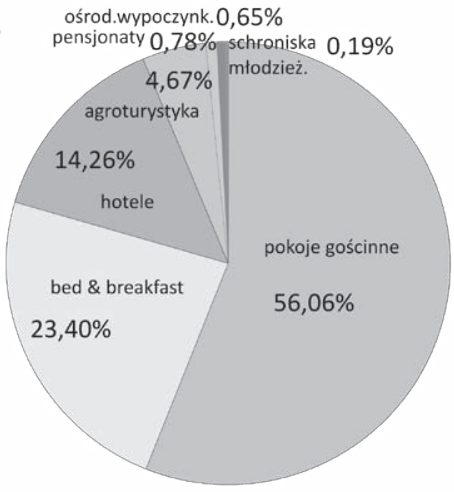

B.2. bed \& breakfast $3,69 \%$

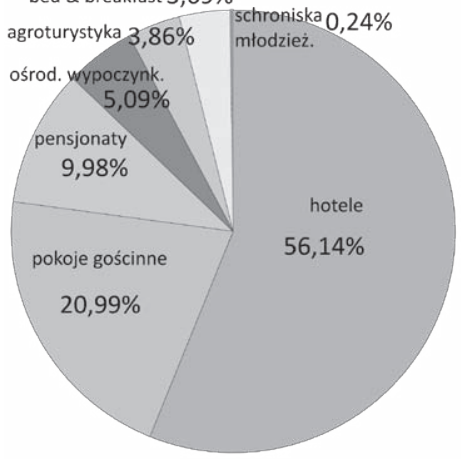

Źródło: opracowanie własne na podstawie danych INSEE, EUROSTAT i Rousseau (2012). 
natomiast pod względem miejsc noclegowych dominowały hotele $(56,14 \%)$, pokoje gościnne $(20,99 \%)$ oraz pensjonaty $(9,98 \%)$ (ryc. 5B.1 i 5B.2).

Innym przejawem rozwoju turystyki mogą być nakłady inwestycyjne. Jak można zauważyć na rycinie 6A, wartość inwestycji w sektorze hotele i restauracje po roku 1998 zmniejszyła się gwałtownie z ok. 160 do 80 mln euro. W 2004 r. nakłady wzrosły i od 2005 r. utrzymywały się na poziomie ok. $100 \mathrm{mln}$ euro. Według udziału w ogóle inwestycji nakłady w sektorze hoteli i restauracji w badanym okresie w departamentach zamorskich odnotowały spadek i zbliżyły się do poziomu metropolii. Największa deprecjacja cechowała Martynikę i Gwadelupę. Wartość inwestycji w przeliczeniu na jednego pracownika w sektorze turystycznym DOM w latach 1996-2007 dorównała Francji kontynentalnej, przy czym Martynika i Gwadelupa odnotowały spadek, a Gujana i Reunion - wzrost (ryc. 7A). Natomiast w analizie udziału inwestycji departamenty zamorskie (poza Reunionem) mają większy udział niż metropolia. Potwierdza to istotną rolę turystyki w gospodarce departamentów pozaeuropejskich oraz ciągły rozwój tej branży (ryc. 7B).

Atrakcyjność regionów zamorskich pod względem turystycznym można porównać za pomocą liczby gmin czerpiących dochody z opłaty klimatycznej oraz wielkości dochodów z tego tytułu. Najwięcej miejscowości kontynentalnych pobierających opłatę klimatyczną znajdowało się w regionach Prowansja-Alpy-Lazurowe Wybrzeże, Rodan-Alpy Owernia i Bretania (ryc. 8A).

Ryc. 6. Inwestycje brutto w dobra materialne w sektorze hotele i restauracje (A) oraz liczba turystów we Francji i w DOM w latach 2005-2010 (B)

A.

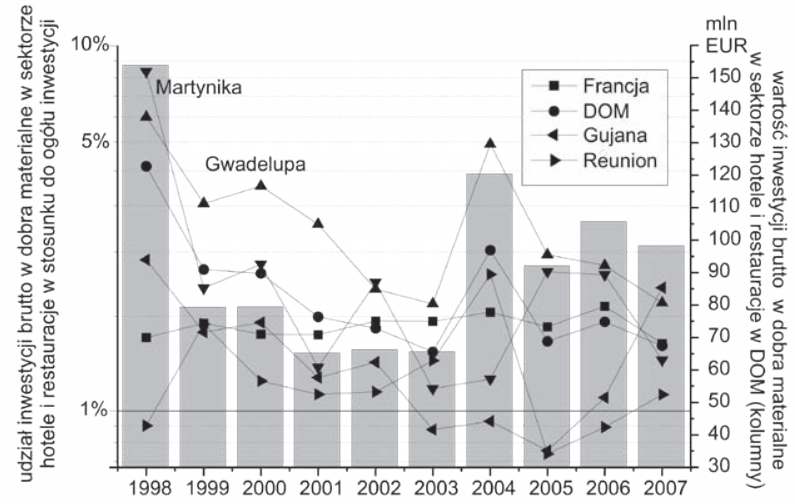

B.

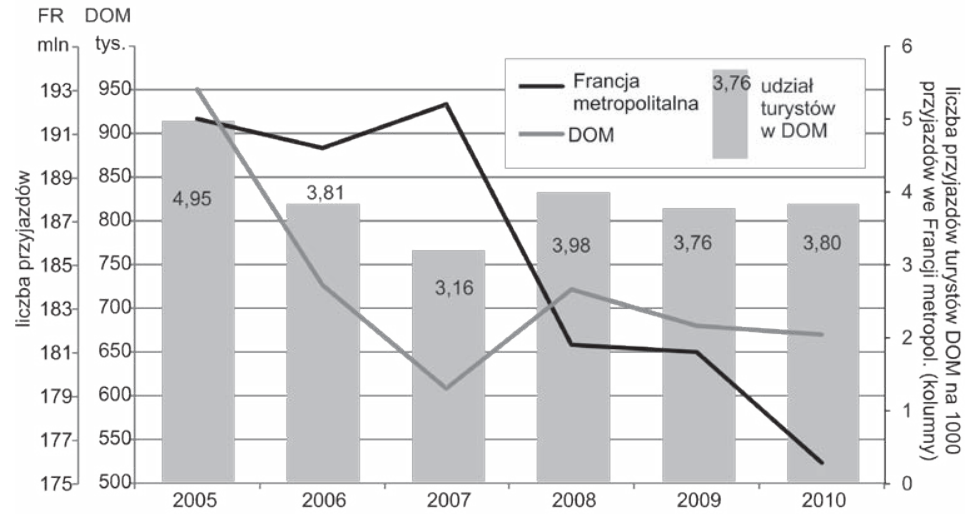

Źródło: opracowanie własne na podstawie danych INSEE, EUROSTAT i Rousseau (2012). 
Ryc. 7. Inwestycje w sektorze hotele i restauracje na jednego pracownika w DOM i we Francji kontynentalnej w latach 1996-2007

A.

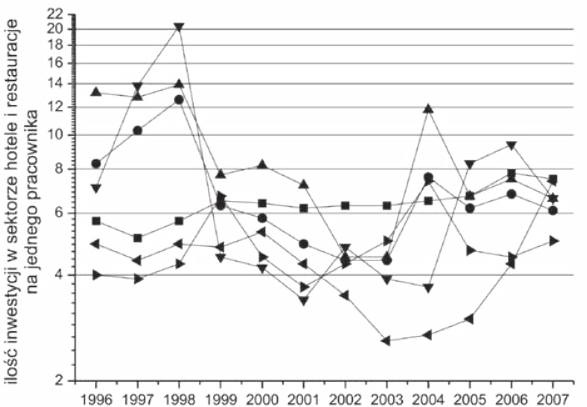

B.

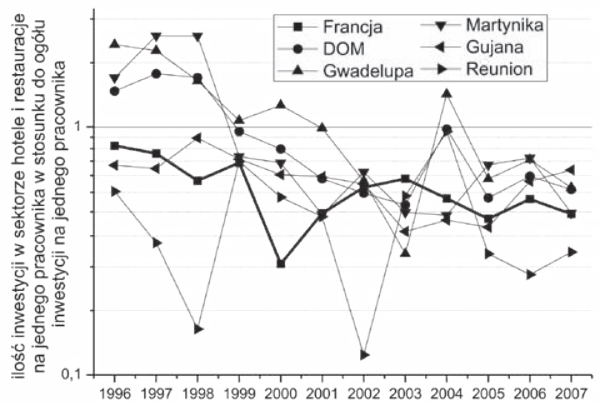

Źródło: opracowanie własne na podstawie danych EUROSTAT i Rousseau (2012).

Ryc. 8. Udział miejscowości pobierających opłatę klimatyczną (A) i średni dochód z opłaty klimatycznej na jedną gminę turystyczną (B)

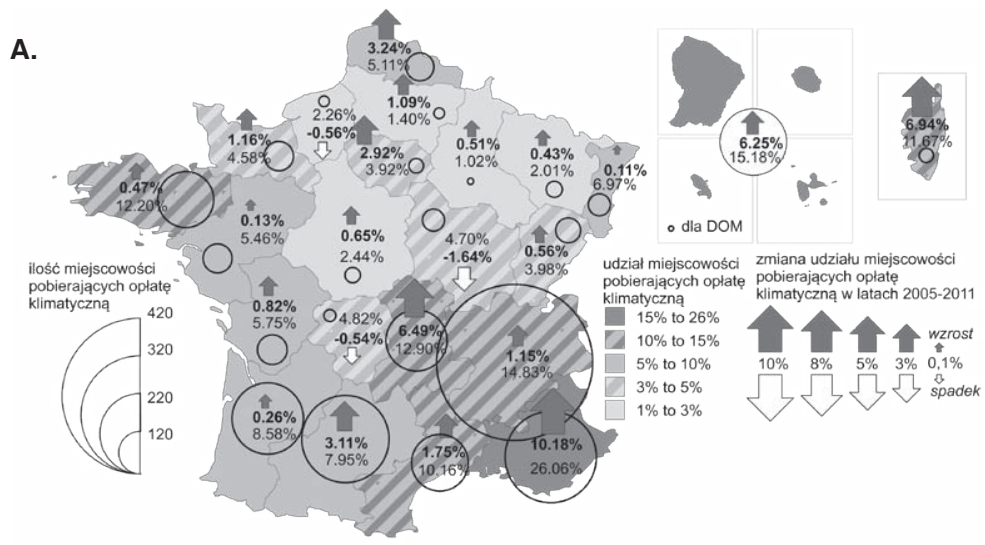

B.

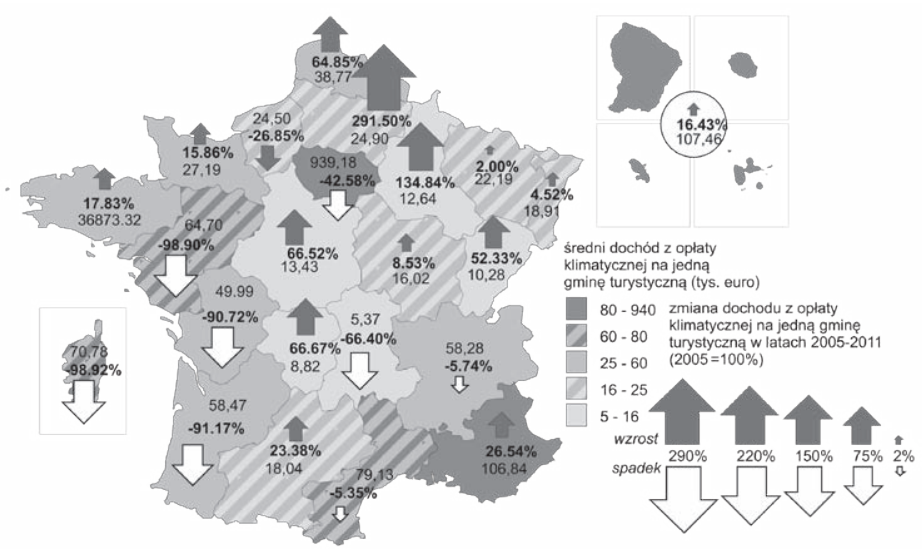

Źródło: opracowanie własne na podstawie danych EUROSTAT i Rousseau (2012). 
Wysokość średniego dochodu z opłaty klimatycznej w przeliczeniu na jedną gminę turystyczną była w DOM porównywalna z wartością metropolitalną, przy czym pierwsza z nich pozostawała nieco wyższa - przekraczała nieznacznie 107 euro (ryc. 8B). Biorąc pod uwagę natężenie ruchu turystycznego (rys. 6B) w poszczególnych regionach, należy zauważyć, iż po $2008 \mathrm{r}$. nastąpiło zahamowanie gwałtownego spadku w metropolii oraz łagodne zmniejszenie udziału turystów w DOM. Z analizy przyjazdów do obiektów hotelowych (rys. 9A) wynika, że po 2009 r. W części kontynentalnej nastąpił odczuwalny wzrost liczby turystów (po uprzednim spadku), a w DOM - bardzo mały, co było spowodowane głównie spadkiem liczby przyjazdów do Gwadelupy. Natomiast udział turystów zagranicznych w ogólnej liczbie przyjezdnych w badanym okresie w metropolii wyraźnie zmalał (z ok. 33\% do 28\%), podczas gdy w departamentach zamorskich nieznacznie wzrósł (do 14\%) (ryc. 9B). Było to głównie wynikiem wzrostu zainteresowania obcokrajowców Martyniką i Reunionem.

Analizując zmianę liczby udzielonych noclegów (rys. 10A), można zauważyć wyraźne załamanie w 2007 r. spowodowane głównie spadkiem liczby noclegów udzielonych turystom zagranicznym, zrekompensowane wzrostem udziału noclegów Francuzów. W znacznym stopniu wpłynęła na to kampania medialna Ministerstwa Turystyki propagująca wypoczynek w części europejskiej. Z proponowanego rozwiązania skorzystało wówczas ok. 10\% metropolitalnych wczasowiczów. Różnice te widoczne są wyraźnie w analizie tempa zmian liczby udzielonych noclegów (ryc. 10B). Natomiast w DOM liczba noclegów w okresie 2005-2011 wykazała niewielki spadek przejawiający się zmniejszeniem udziału noclegów w DOM z 16\% do $13 \%$. Uśredniony czas wypoczynku w DOM - ze względu na jego specyfikę i odległość geograficzną - był niemal czterokrotnie dłuższy niż we Francji kontynentalnej.

W analizie liczby udzielonych noclegów w obiektach hotelowych (ryc. 11A) należy odnotować, iż nastąpił ich krótkotrwały spadek, w tym akces noclegów udzielonych w DOM zmalał z ok. 2,9 w 2005 r. do 2,0 w 2009 r. Podczas badania regionalnych zmian liczby noclegów udzielonych we Francji i w DOM zauważono duże zróżnicowanie pomiędzy poszczególnymi regionami (ryc. 11B). W przypadku części kontynentalnej ubytek ten był nagły i krótkotrwały (ok. 10\%), zaś w DOM - długotrwały i wyraźnie zauważalny (ok. 30\%). Z analizy zmiany liczby noclegów w obiektach hotelowych wynika z kolei, że we Francji europejskiej dwa regiony: Île-de-France i Korsyka zanotowały przeszło dziesięcioprocentowy wzrost ich udziału,

Ryc. 9. Liczba przyjazdów (obiekty hotelowe) (A) i udział turystów zagranicznych w przyjazdach (B) we Francji i w DOM w latach 2005-2011

A.

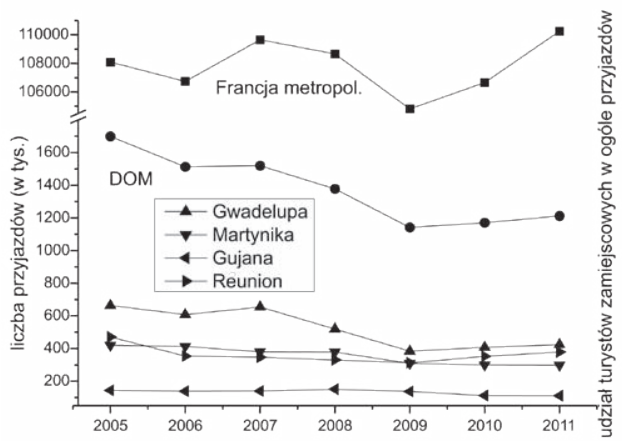

B.

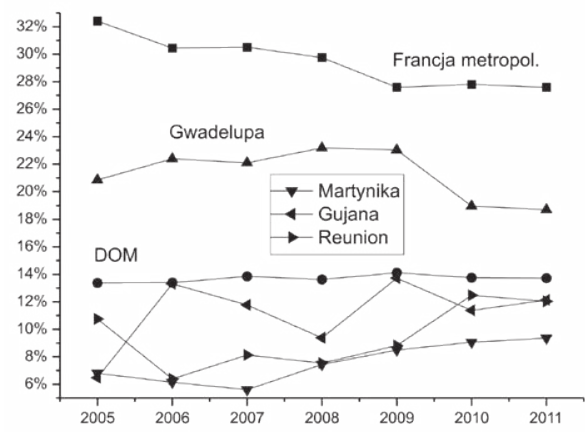

Źródło: opracowanie własne na podstawie danych EUROSTAT i Rousseau (2012). 
Ryc. 10. Liczba noclegów we Francji i w DOM w latach 2005-2011 (A) oraz dynamika zmian liczby noclegów we Francji (B)

A.

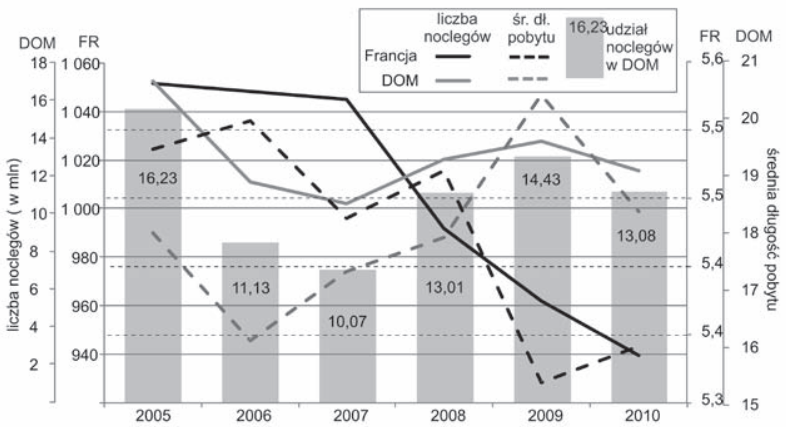

B.

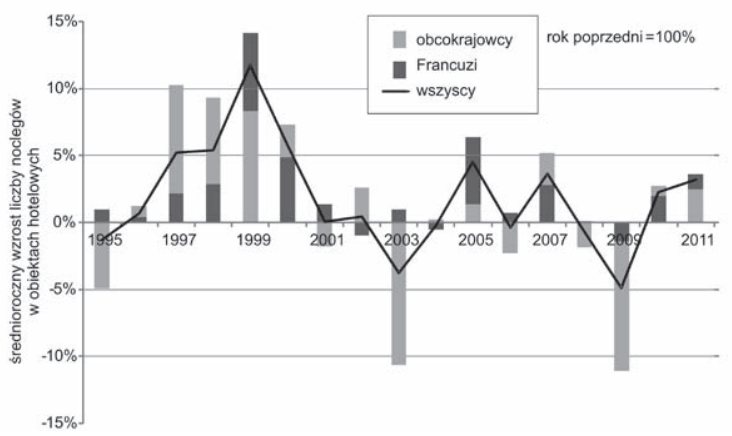

Źródło: opracowanie własne na podstawie danych EUROSTAT i Rousseau (2012).

Ryc. 11. Liczba noclegów w obiektach hotelowych we Francji i w DOM w latach 2005-2010 (A) oraz liczba noclegów ogółem w obiektach hotelowych w DOM (B)

A.

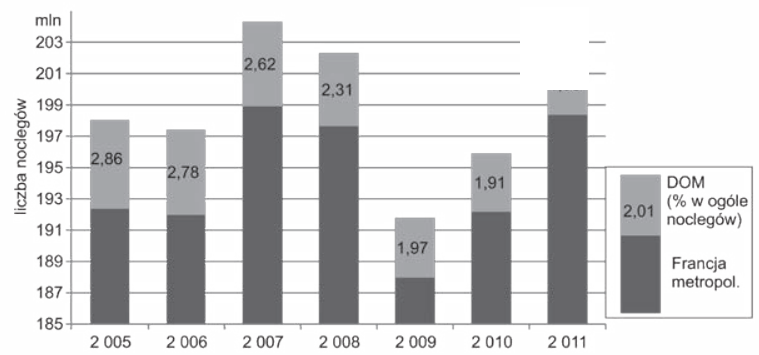

B.

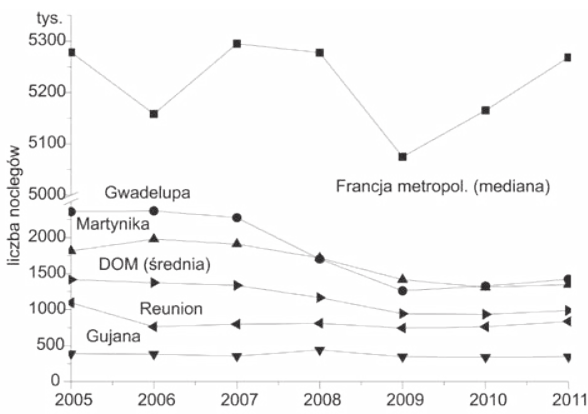

Źródło: opracowanie własne na podstawie danych EUROSTAT i Rousseau (2012). 
zaś wszystkie cztery DOM - spadek (ryc. 12A). Kolejne różnice między Francją a jej departamentami zamorskimi można dostrzec $\mathrm{w}$ trakcie porównywania liczby noclegów wg pochodzenia turystów (ryc. 13). Podczas gdy w metropolii wzrósł udział turystów krajowych, a udział wczasowiczów zagranicznych zmniejszył się do ok. 33\%, w DOM odsetek przybyłych obcokrajowców wzrósł z 13\% do 16\%. Badanie regionalnego zróżnicowania udziału turystów lokalnych w obiektach hotelowych części kontynentalnej (ryc. 12B) pozwala ponadto zauważyć, że w regionach Pikardii oraz Alzacji udział ten nieznacznie wzrósł, a w departamentach zamorskich wykazywał tendencję spadkową.

Ryc. 12. Zmiany liczby noclegów ogółem (A) oraz zmiana liczby noclegów Francuzów (B) w obiektach hotelowych w regionach Francji i DOM (2007-2011)

A.
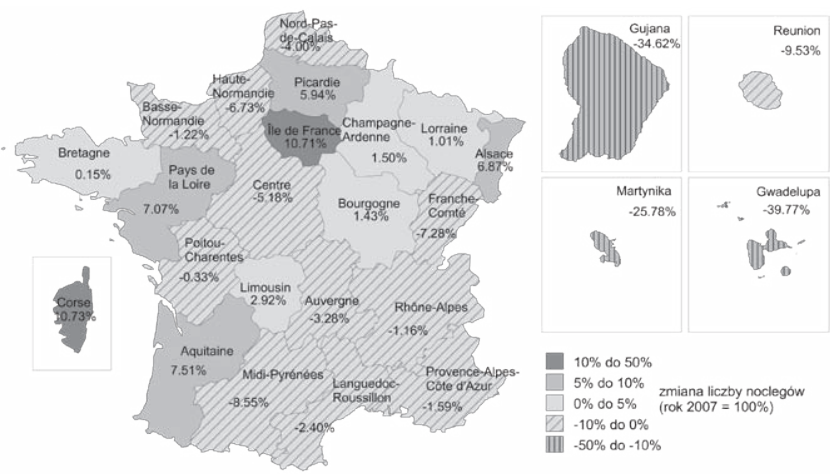

B.

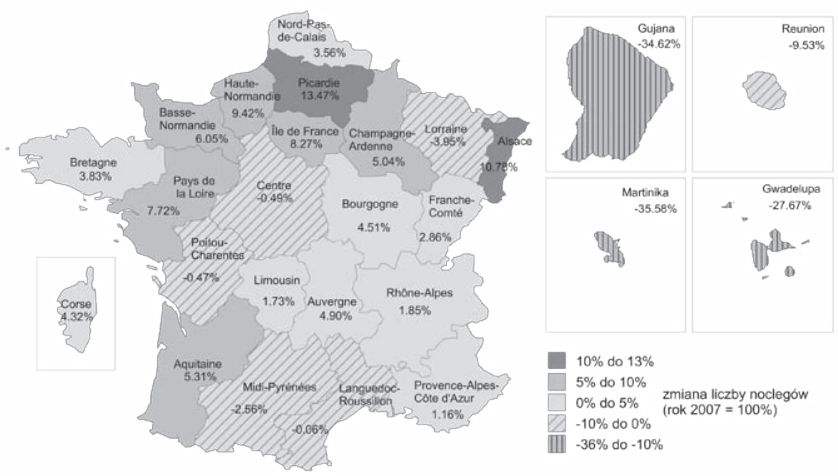

Źródło: opracowanie własne na podstawie danych EUROSTAT.

Odmiennie kształtowała się sytuacja noclegów udzielonych gościom zagranicznym (ryc. 15B). Ujemne wartości zanotowano we wszystkich regionach europejskich poza Korsyką, natomiast w DOM - tylko w Gwadelupie $(-44,13 \%)$. W trzech pozostałych departamentach nastąpił ponadczterdziestoprocentowy wzrost. Biorąc pod uwagę zmiany udziału liczby noclegów w obiektach hotelowych, można zauważyć także, że we Francji metropolitalnej nastąpił spadek udziału noclegów udzielonych turystom zagranicznym przy jednoczesnym wzroście udziału miejsc noclegowych, z których korzystali wczasowicze krajowi. Natomiast w DOM udział liczby noclegów udzielonych turystom krajowym zmniejszył się bardziej niż udział noclegów udzielonych turystom zagranicznym (ryc. 14).

Przyjmując za przedmiot analizy pochodzenie turystów w DOM w latach 2009-2010, można dostrzec, że wśród przyjezdnych i korzystających z noclegów przeważali Francuzi metro- 
Ryc. 13. Liczba noclegów (A) i udział klientów zagranicznych (B) we Francji i w DOM w latach 2005-2010

A.

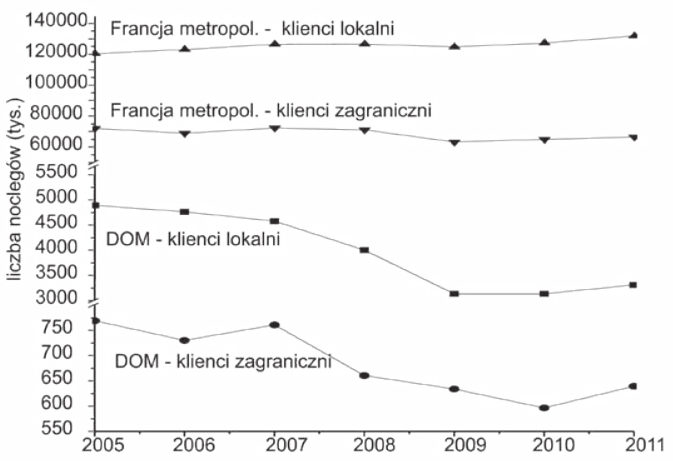

B.

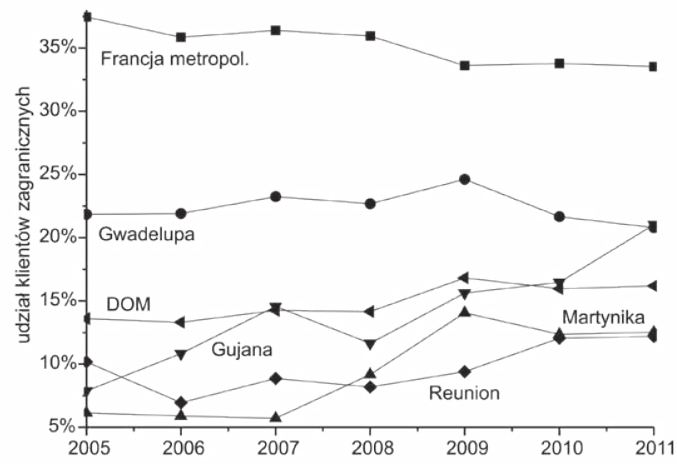

Źródło: opracowanie własne na podstawie danych EUROSTAT.

politalni (niemal 60\% i przeszło 60\%). Drugą grupę wczasowiczów stanowili obcokrajowcy pochodzący głównie z Ameryki Północnej i UE. Należy więc stwierdzić, że po roku 2008 w DOM nastąpił spadek udziału turystów metropolitalnych przy niewielkim wzroście udziału obcokrajowców - dokładnie odwrotnie niż we Francji kontynentalnej.

Światowy kryzys finansowy z 2008 r. trzeba uznać za jedną z determinant warunkujących spadek liczby turystów we Francji karaibskiej. W 2009 r. odwołano niemal 10 tys. uprzednio zarezerwowanych pobytów w departamentach Indii Zachodnich (Magras, 2011). W pierwszej dekadzie XXI w. wzrosła także konkurencja turystyczna ze strony innych państw wyspiarskich Karaibów. Największe natężenie wizyt turystycznych na Gwadelupie obserwowano w sezonach bożonarodzeniowym oraz wielkanocnym. W przeciwieństwie do Saint-Martin i Saint-Barthélemy departament przyciągał głównie klientelę metropolitalną, najczęściej z regionów: Île-de-France (33\%), Rodanu-Alp (7\%), Prowansji-Alp-Lazurowego Wybrzeża (5\%) oraz Akwitanii (5\%). Obywatele innych państw członkowskich UE stanowili łącznie 5,1\% wszystkich odwiedzających. Najczęściej byli to Włosi (32\%), Belgowie (19\%) oraz Niemcy (11\%). Przeszło połowa turystów wykupiła wycieczkę na Gwadelupę przez biuro podróży, a $16 \%$ z nich organizowało wyjazd we własnym zakresie i nabyło bilet bezpośrednio u przewoźnika lotniczego (Le tourisme dans l'outre-mer français, 2007). W okresie poprzedzającym kryzys ekonomiczny, w latach 2003-2008, tylko w departamencie Gwadelupy liczba miejsc noclegowych uległa zredukowaniu o 5 tys. (Atout France, Du diagnostic à la mise en oeuvre: priorités d'actions 
Ryc. 14. Liczba noclegów turystów krajowych (A) i zagranicznych (B) w obiektach hotelowych we Francji oraz w DOM w latach 2005-2010

A.

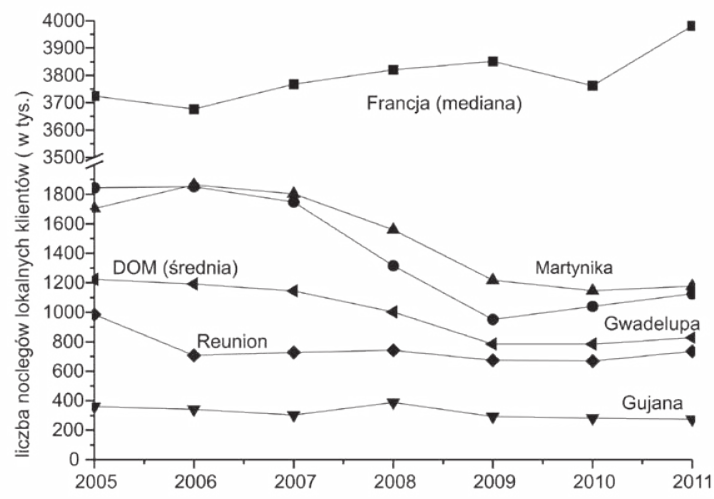

B.

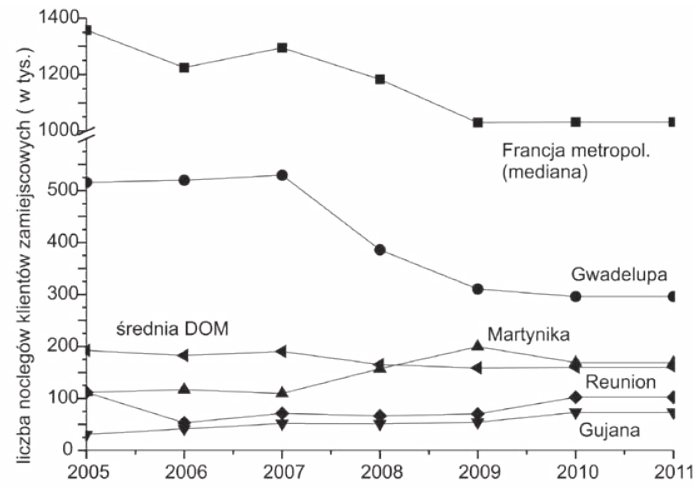

Źródło: opracowanie własne na podstawie danych EUROSTAT.

pour chaque destination. Synthèse finale, 2010). By skutecznie przeciwdziałać odpływowi turystów, proponowano m.in. zwiększenie połączeń lotniczych z Francji metropolitalnej do Pointe-à-Pitre i Fort-de-France, poprawę warunków hotelowych czy wydłużenie sezonu turystycznego (Philibert, 2011). W przypadku Francuskich Indii Zachodnich szczególnie ważną kwestią pozostaje dalsza rozbudowa transportu lotniczego spełniającego również funkcję rekreacyjno-rozrywkową. W przekonaniu Renaty Rettinger i Piotra Staszaka stanowi on również jedną z prymarnych przesłanek warunkujących rozwój podróży międzykontynentalnych (Rettinger, Staszak, 2010).

Przemysł hotelarski pozostaje obszarem najbardziej dotkniętym przez kryzys branży turystycznej. Odpowiedzialna za politykę turystyczną wspólnoty Saint-Martin Stéphanie Bessière (2010) zauważyła w swym raporcie, iż spadek liczby turystów zagranicznych wynikał pośrednio z przestarzałej infrastruktury hotelowej DOM, która obniżała ich atrakcyjność. W podobne wnioski obfitowało sprawozdanie Cécile Felzines (2007), w którym autorka stwierdziła, że obiekty hotelowe Gwadelupy i Martyniki cechuje niska komfortowość i unifikacja charakteru oferowanych usług. Bazę hotelową Martyniki tworzyły w 2007 r. 84 obiekty dysponujące 12144 miejscami noclegowymi. Największą liczbę łóżek (7294) posiadały hotele trzygwiazdkowe, najmniejszą zaś (130) - hotele o standardzie jednogwiazdkowym. Przeważającą część klientów 
Ryc. 15. Liczba noclegów turystów krajowych (A) i zagranicznych (B) w obiektach hotelowych we Francji oraz w DOM w latach 2005-2010

A.

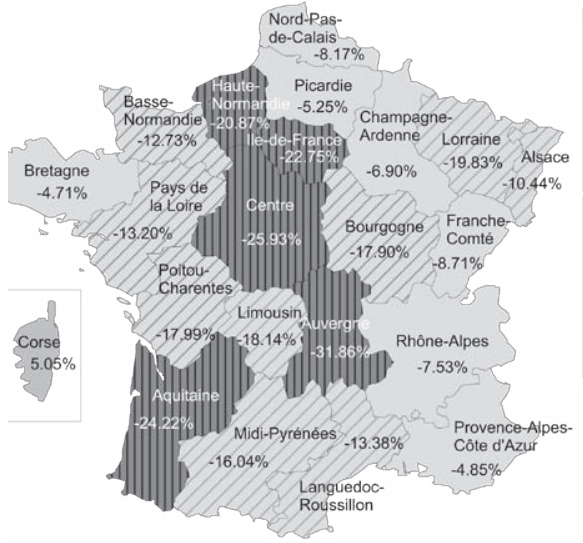

B.1.

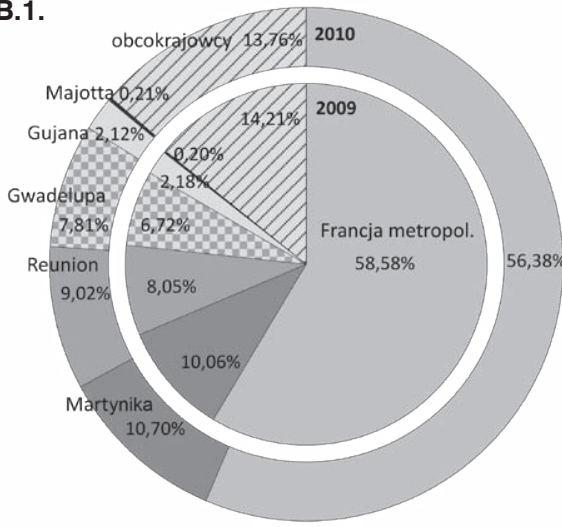

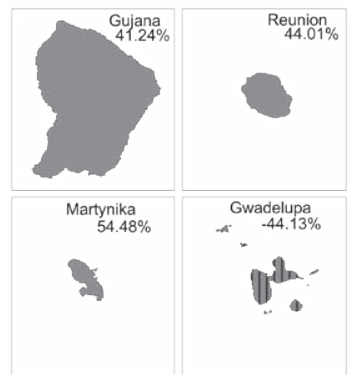

$10 \%$ do $54 \%$

$0 \%$ do $10 \%$ zmiana liczby noclegów

$-10 \%$ do $0 \%$ klientów zamiejscowych $-20 \%$ do $-10 \%$ (rok $2007=100 \%)$

$-44 \%$ do $-20 \%$

Żródło: opracowanie własne na podstawie danych EUROSTAT.

korzystających podczas wypoczynku z zaplecza hotelowego (aż 79\%) stanowili Francuzi metropolitalni. W dalszej kolejności byli to turyści z obydwu Ameryk i Europy (31\%) (Le tourisme dans l'outre-mer Francis, 2007: 30-31).

\section{Zakończenie}

Postępujący od lat 60. XX w. rozwój branży turystycznej w departamentach i wspólnotach zamorskich Francji pozostaje od lat 90. priorytetowym i nowoczesnym elementem aktywności społeczno-gospodarczej jednostek będących przedmiotem niniejszego opracowania. Stanowi to odzwierciedlenie postępującego procesu globalizacji i, jak stwierdził Dean MacCannell (2007), próbę uczynienia z turystyki największej gałęzi światowego przemysłu. Aby zwiększyć udział turystów, departamenty zamorskie zaczęły w większym stopniu eksponować dziedzictwo regionalne: historyczno-kulturowe oraz przyrodnicze. Powołując się na stwierdzenie Małgorzaty Zdon-Korzeniowskiej (2009), produkt turystyczny regionu nie musi być wcale regionalnym produktem turystycznym. W przypadku DOM pierwszy z produktów turystycznych stanowić będą kompleksy rekreacyjno-rozrywkowe, drugi zaś - oferty z zakresu agro- i ekoturystyki wykorzystujące elementy folkloru kreolskiego. 
Tab. 2. Analiza SWOT sektora turystycznego DOM

\begin{tabular}{|c|c|}
\hline Mocne strony & Slabe strony \\
\hline $\begin{array}{l}\text { - unikatowe walory przyrodnicze i kulturowe } \\
\text { (kompleksy leśne, rafy koralowe, zabytki } \\
\text { architektury kolonialnej) } \\
\text { - różnorodność krajobrazowa i ukształtowanie } \\
\text { terenu umożliwiające uprawianie zróżnico- } \\
\text { wanych form turystyki (pieszej, rowerowej, } \\
\text { samochodowej) } \\
\text { - bogate zasoby wodne sprzyjające turystyce } \\
\text { morskiej, żeglarstwu, kajakarstwu i in. } \\
\text { - zróżnicowanie kulturowe i narodowościowe } \\
\text { - brak gęstej zabudowy umożliwiający } \\
\text { tworzenie licznych tras turystycznych }\end{array}$ & $\begin{array}{l}\text { - niedostatecznie rozwinięta infrastruktura turystycz- } \\
\text { na, przede wszystkim w DFA i w Reunionie (baza } \\
\text { noclegowa, obiekty o przeznaczeniu sportowo- } \\
\text {-rekreacyjnym, usługi okołoturystyczne) } \\
\text { - zbyt słaba oferta turystyki posezonowej } \\
\text { - niewykorzystany potencjał turystyczny obszarów } \\
\text { wiejskich } \\
\text { - mała liczba regionalnych produktów turystycznych } \\
\text { - niezadawalający poziom bezpieczeństwa wewnętrz- } \\
\text { nego (Gwadelupa, Martynika) } \\
\text { - niedobory infrastrukturalne }\end{array}$ \\
\hline Szanse & Zagrożenia \\
\hline $\begin{array}{l}\text { - przynależność DROM do UE - możliwość } \\
\text { pozyskania nowych turystów } \\
\text { - nowe trendy społeczne i zmiany } \\
\text { w konsumpcji (ekokonsumpcja) } \\
\text { - wzrost zainteresowania ofertą } \\
\text { ekoturystyczną } \\
\text { - bliskość stref wolnocłowych (Saint- } \\
\text {-Barthélemy, Saint-Martin) }\end{array}$ & $\begin{array}{l}\text { - niebezpieczeństwo degradacji zasobów naturalnych } \\
\text { - wzrost konkurencji ze strony innych regionalnych } \\
\text { centrów turystycznych (m.in. państw wyspiarskich } \\
\text { Karaibów) } \\
\text { - brak równowagi pomiędzy źródłami finansowania } \\
\text { turystyki a potrzebami branży } \\
\text { - kryzysy gospodarcze } \\
\text { - wzrost cen paliw }\end{array}$ \\
\hline
\end{tabular}

Źródło: opracowanie własne.

Obszary zamorskie wyspecjalizowały się w turystyce krajoznawczej, kwalifikowanej (żeglarskiej, motorowodnej, kajakowej, pieszej, nurkowej), morskiej (wycieczki pełnomorskie, pasażerska żegluga przybrzeżna, minirejsy międzyportowe i rejsy inclusive), alternatywnej, kulturowej i aktywnej. Ma to związek z faktem, iż rekreacja ruchowa jest uznawana współcześnie za konieczną, a nie luksusową i dyktowana modą na zdrowy styl życia oraz zmianami demograficznymi (por. Nęcka, Żbikowski, 2005). W departamentach tych w ograniczonym lub znikomym wręcz stopniu rozwinęły się z kolei inne formy turystyki: biznesowa, kongresowa, uzdrowiskowa (Ravine Chaude i Saint-Claude w Gwadelupie) oraz socjalna. Działalność turystyczna we Francji zamorskiej ma wiele zalet, m.in. generuje jej wzrost gospodarczy, pozytywnie oddziałuje na bilans płatniczy poszczególnych terytoriów, a także sprzyja przedsiębiorczości i społecznej aktywności, ponieważ angażuje różne środowiska oraz wyzwala ekonomiczno-kulturową synergię. Prowadzi również do przekształcania infrastruktury i środowiska oraz pozostaje ważną determinantą rozwoju zrównoważonego, gdyż chroni dziedzictwo przyrodnicze przy jednoczesnym pielęgnowaniu tradycji regionalnych (villages créoles w Reunionie) oraz wdrażaniu nowych technologii (Gujana Francuska). Należy uznać, że przyjęte w strategiach rozwoju ruchu turystycznego (Schéma d'Aménagement et de Développement Touristique) rozwiązania sprzyjają budowaniu solidnych podstaw gospodarki turystycznej oraz prowadzą do nieobecnego dotychczas zaangażowania władz departamentalnych, regionalnych, a także przedstawicieli przedsiębiorców i organizacji branżowych. 
Podsumowując, po roku 2008 Francja znalazła się w grupie pięciu państw o najwyższej recepcji ruchu podróżnych, co wynikało z globalnego spowolnienia gospodarczego i niestabilności rynków finansowych. Departamenty i regiony zamorskie znacznie wyraźniej odczuły wpływ kryzysu na koniunkturę turystyczną niż część kontynentalna. Turystyka w UE stanowi trzeci pod względem znaczenia obszar działalności społeczno-gospodarczej, co w szczególności dotyczy regionów peryferyjnych (Europa - najpopularniejszy kierunek turystyczny na świecie - nowe ramy polityczne dla europejskiego sektora turystycznego, 2010). Dalsza intensyfikacja rozwoju przemysłu turystycznego DOM jest konieczna, gdyż warunkuje ich rozwój cywilizacyjno-infrastrukturalny, a zatem stanowi jeden z najważniejszych stymulatorów regionalnych gospodarek.

\section{Literatura}

Ardagh, J., Jones, C. (1998). Wielkie kultury świata. Francja. Warszawa: Świat Książki.

Atout France (2010), Du diagnostic à la mise en oeuvre: priorités d'actions pour chaque destination, Synthèse finale, 42.

Auzias, D., Labourette, J.P. (2010). Le Petit Fute Martinique 2011-2012 Paris: Petit Futé.

Baldy, S., Madeleine, É., Paulin, M.-H. (2000). Le challenge de l'écotourisme en Guyane. Antiane Éco, 46, 25-28.

Bally, B., Actif, N., Arnaud, J.-N. (2006). 6000 emplois salariés liés au tourisme à la fin 2005. Revue économie de La Réunion,131, 14-15.

Bessière, S. (2010). Le tourisme dans les Antilles françaises. Le défi de la concurrence caribéenn. Paris: L'Harmattan.

Bonasewicz, A. (1967). Region Gujana. W: A. Jahn (red.), Geografia powszechna. tom V: Arktyka, Ameryka, Australia i Oceania, Antarktyda, Ocean Światowy. Warszawa: PWN, 227-231.

Bonnabeau, D. (2002). Audit de la filière agritouristique en Martinique. Note de synthèse. Villeurbanne: Chambre d'Agriculture Martinique. Pozyskano z: http://www.odeadom.fr/wp-content/themes/odea$\mathrm{dom} /$ ressources/synthese-agrotourisme-martinique.pdf.

Braun, B., Collignon, F. (2008). La France en fiches. Paris: Bréal.

Chikungunya ou maladie de "l'homme courbé" (2012, 23 października). Pozyskano z: http://www.inserm.fr/thematiques/microbiologie-et-maladies-infectieuses/dossiers-d-information/chikungunya

Dorocki, S., Brzegowy, P. (2012). Regionalne zróżnicowanie kształcenia we Francji w aspekcie rozwoju przedsiębiorczości departamentów zamorskich. Przedsiębiorczość - Edukacja, 8, 229-258.

Dorocki, S., Szymańska, I.A., Zdon-Korzeniowska M. (2012) Polskie gospodarstwa agroturystyczne jako przedsiębiorstwa rodzinne. Przedsiębiorczość i Zarządzanie, XIII (8), 45-60.

Dudek, A., Kowalczyk, A. (2003). Turystyka na obszarach chronionych - szanse i zagrożenia. Prace i Studia Geograficzne, 32, 117-140.

Durand, M. S., Fruteau, M.C. (2004). Schéma d'Aménagement et de Développement Touristique de La Réunion. Île de la Réunion: SADTR - Orientations stratégiques. Pozyskano z: http://www.reunioneurope.org/DOCS/ 2014-2020/2014_2020_SDATR-Orientations\%20Strategiques\%202020.pdf.

Economie du spatial (2012, 10 października). Pozyskano z: http://www.cnes-csg.fr/web/CNES-CSG-fr/9759-economie-du-spatial.php.

Europa - najpopularniejszy kierunek turystyczny na świecie - nowe ramy polityczne dla europejskiego sektora turystycznego (2010). Bruksela: Komunikat Komisji do Parlamentu Europejskiego, Rady Europejskiego Komitetu Ekonomiczno-Społecznego i Komitetu Regionów.

Feczko, J. (2010). Gospodarka agroturystyczna - aspekty ekonomiczne i zarządcze. Przedsiębiorczość - Edukacja, 6, 422-430. 
Fédération des Entreprises d'Outre Mer (FEDOM) (2012, 3 października). Pozyskano z: http://www. fedom.org.

Felzines, C. (2007). Le tourisme, perspective d'avenir de l'outre-mer français. Sprawozdanie zaprezentowane w Radzie Ekonomicznej i Społecznej (Conseil économique et social).

Géologie, relief et climat des enjeux humains et environnementaux forts. (2012, 3 października). Pozyskano z: http://www.reunion.pref.gouv.fr.

Gourou, P. (1963). Un livre de géographie tropicale régionale sur la Guadeloupe de Guy Lasserre. Annales de Géographie, 72 (394), 731-733.

Heywood, V.H., Jackson Wyse, P.S. (1991). Tropical botanic gardens: their role in conservation and development, London: Academic Press, 72.

Jean, R. (2007). Le tourisme en Guadeloupe: impact du tourisme sur l'activité et l'emploi. Premiers Resultats, 9. Pozyskano z: http://www.insee.fr/fr/insee_regions/guadeloupe/themes/premiers_resultats/pr_eft/PR_tourisme2005_ga.pdf.

Jean, R. (red.). (2010). Tableaux Économiques Régionaux de la Guyane 2009-2010. Pozyskano z: http:// www.insee.fr/fr/insee regions/guyane/themes/ter/ter2010/ter2010 gy.pdf.

Jędrusik, M. (2002). Wyspy tropikalne i subtropikalne. W: M. Bogucka (red.), Geografia spojrzenie na Ziemię i środowisko. Warszawa: Wydawnictwo Naukowe PWN, Warszawa, 125-154.

Jędrusik, M. (2005). Wyspy tropikalne. W poszukiwaniu dobrobytu, Warszawa: Wydawnictwo Uniwersytetu Warszawskiego.

Koliba, A. (1997). Antyle. W: J. Warszyńska (red.), Geografia turystyczna świata. Część II, Warszawa: Wydawnictwo Naukowe PWN, 321-340.

Kwatery prywatne $i$ hotele, Słoneczna Martynika (2012, 10 października). Pozyskano z: http://www. slonecznamartynika. pl.

La Réunion ,gay-friendly”, mais sans associations (2012, 10 października). Pozyskano z: http://www. zinfos974.com/La-Reunion-gay-friendly--mais-sans-associations_a14522.html.

L'Association Guadeloupéenne d'Écotourisme (2012, 10 października). Pozyskano z: http://www.ecotourisme-guadeloupe.org/prestataires-11-milieux-naturels-preserves.html.

Le tourisme en Guadeloupe: impact du tourisme sur l'activité et l'emploi, INSEE Antilles-Guyane, ${ }^{\circ} 9$ mars 2007. Pozyskano z: http://www.insee.fr/fr/insee_regions/guadeloupe/themes/premiers_resultats/pr_eft/PR_tourisme2005 ga.pdf.

Le tourisme dans l'outre-mer français (2007). Direction du Turisme, Département de la Stratégie, de la Prospective, de l'Evaluation et des Statistiques. Pozyskano z: http://www.dgcis.gouv.fr/files/ files/directions_services/etudes-et-statistiques/etudes/tourisme/tourisme-outre-mer.pdf.

Le tourisme dans l'outre-mer français (2008) Direction du Turisme, Département de la Stratégie, de la Prospective, de l'Evaluation et des Statistiques. Pozyskano z: http://www.dgcis.gouv.fr/files/files/ directions_services/etudes-et-statistiques/etudes/tourisme/tourisme-outre-mer-2008.pdf.

Lenoir, D. (2007, 9 grudnia). Ecotourisme: la Guadeloupe récompensée. Newmedia. Pozyskano $\mathrm{z}$ : http://www.newmedia-fr.info.

Liste des monuments historiques de La Réunion (2012). Pozyskano z: http://www.reunion.pref.gouv.fr/ drac/livretMH974.pdf.

Łazarek, R. (1999). Ekonomika turystyki. Warszawa: Zakład Wydawniczy DrukTur.

MacCannell, D. (2007). Turysta. Nowa teoria klasy próżniaczej. Warszawa: Muza.

Madeleine, É. (2008). Des efforts sur «l'offre produit Guyane». Antiane-Guyane, 70, 22-23. Pozyskano z: http://www.insee.fr/fr/insee_regions/guyane/themes/ae_bilan/aes70gy/aes70gy_art12.pdf.

Magras, M. (2011). Rapport d'Information fait au nom de la commission de l'économie, du développement durable et del'aménagement du territoire sur «tourisme et environnement outre-mer». Sénat Session Ordinaire de 2010-2011. Pozyskano z: http:/www.senat.fr/rap/r10-547/r10-5471.pdf.

Magras, M.M. (2011). Guadeloupe et Martinique: d'un tourisme subi à un tourisme integer. Rapport d'information $\mathrm{n}^{\circ}$ 547. Pozyskano z: http://www.senat.fr/rap/r10-547/r10-547.html.

Monuments historiques de Guyane, (zestawienie zabytków architektonicznych Gujany Francuskiej) (2012, 23 października). Pozyskano z: http://www.culture.gouv.fr/public/mistral/merimee_fr?ACTION=CHERCHER\&FIELD_1=d\%e9partement\&VALUE_1=973\&FIELD_2=domaines\&VALUE _ $2=\% 27 \mathrm{MONUMENTS} \% 20 \mathrm{HISTORIQUES} \% 27$. 
Nęcka, D., Żbikowski, J. (2005). Tendencje organizacyjne i programowe w rekreacji ruchowej. W: Z. Kubińska, B. Bergier (red.) Rekreacja ruchowa w teorii i praktyce. Biała Podlaska: PWSZ, Biała Podlaska, 253-269.

Nosel, J. (2000). Quel écotourisme pour la Martinique. Antiane, 46, 21-24. Pozyskano z: http://www. insee.fr/fr/insee_regions/martinique/themes/antiane/ ae46/ae46_art06.pdf

Patin, V., Vincent, J.-M. (1993). Patrimoine culturel et tourisme en France. W: Economics of conservation, Sri Lanka: ICOMOS, 116-118, Pozyskano z: http://www.international.icomos.org/ publications/93sy_eco13.pdf.

Philibert, P. (2012, 10 kwietnia). Sauver le tourisme aux Antilles, FEDOM. Pozyskano z: http://www. fedom.org.

Population legalés 2009 de la commune. Pozyskano z: http:/www.insee.fr/fr/ ppp/bases-de-donnees/ recensement/populations-legales/commune.asp ?depcom=97106 (2012, 22 pażdziernika).

Population Saint-Denis. Pozyskano z: http://www.cartesfrance.fr/carte-france-departement/carte-departement-La-Reunion.html (2012, 2 października).

Renault, J.-M. (1985). La Guadeloupe: guide touristique et pratique, Paris: Éditions du Pelican, 84.

Résultats d'activité des aéroports français 2011. Statistiques de trafic. (2012) Paris: Union des Aéroports Français. Pozyskano z: http://www.aeroport.fr/fichiers/ UAF_rapport_d_activite_2011_des_aeroports_francais.pdf.

Rettinger, R. (2010). Turystyka jako czynnik aktywizacji gospodarki Chorwacji. Przedsiębiorczość Edukacja, 6, 450-461.

Rettinger, R., Staszak, P. (2010). Europejskie połączenia lotnicze głównych regionów turystycznych Azji Południowo-Wschodniej. Przedsiębiorczość - Edukacja, 6, 462-470.

Rousseau, L. (red.). (2012). Mémento du tourisme. Édition 2011. Pozyskano z: http://www.dgcis.gouv.fr/ files/files/archive/www.tourisme.gouv.fr/stat_etudes/memento/2011/memento-2011.pdf.

Skalska, T. (2011). Turystyka osób niepełnosprawnych. W: A. Dłużewska (red.), Nowe wyzwania edukacji turystycznej. Turystyka w obszarach odmiennych kulturowo i przyrodniczo cennych. Turystyka osób niepetnosprawnych. Warszawa: Wydział Turystyki i Rekreacji, Szkoła Wyższa Przymierza Rodzin w Warszawie.

Taïlame, J. (2009). Les avancées du tourisme face aux préconisations des politiques régionales. L'Observatoire, 6. Pozyskano z: http://www.aduam.com/aduam/etudes/publications/observ/observatoire-n6. pdf.pdf.

Travel and Tourism Economic. France. (2009). WTTC, London. Pozyskano z: http://torc.linkbc.ca/torc/ downs $1 /$ france $\% 20$ wttc.pdf.

Villages creoles. Pozyskano z: http://www.reunion.fr/preparer-son-voyage/choisir-son-label/villages-creoles.html (2012, 22 października).

Warszyńska, J., Jackowski A. (1970). Podstawy geografii turyzmu. Warszawa: PWN.

Winid, J. (1967). Wyspy afrykańskie Oceanu Indyjskiego. W: A. Zierhoffer (red.), Geografia Powszechna tom IV Zwiazek Socjalistycznych Republik Radzieckich, Azja, Afryka. Warszawa: PWN, 658-662.

Zaręba, D. (2000). Ekoturystyka. Wyzwania i nadzieje. Warszawa: PWN.

Zdon-Korzeniowska, M. (2009). Jak ksztaltować regionalne produkty turystyczne? Teoria i praktyka, Kraków: Wydawnictwo Uniwersytetu Jagiellońskiego.

Zdon-Korzeniowska, M., Rachwał, T. (2011). Turystyka w warunkach światowego kryzysu gospodarczego. Prace Komisji Geografii Przemystu Polskiego Towarzystwa Geograficznego, 18, 116-128.

Sławomir Dorocki, Uniwersytet Pedagogiczny im. Komisji Edukacji Narodowej w Krakowie, Instytut Geografii, Zakład Przedsiębiorczości i Gospodarki Przestrzennej.

Absolwent studiów z zakresu geografii społeczno-ekonomicznej Uniwersytetu Pedagogicznego im. Komisji Edukacji Narodowej w Krakowie, doktor nauk humanistycznych w dyscyplinie historia (Instytut Europeistyki - Uniwersytet Jagielloński). Adiunkt w Instytucie Geografii Uniwersytetu Pedagogicznego im. Komisji Edukacji Narodowej w Krakowie. Zainteresowania badawcze skupiają się wokół problema- 
tyki regionów i procesów regionalizacji społeczno-gospodarczej, ze szczególnym uwzględnieniem zróżnicowania przestrzeni europejskiej oraz procesów integracji europejskiej i uwarunkowań historycznych.

Sławomir Dorocki, PhD, Pedagogical University of Cracow, Institute of Geography, Department of Entrepreneurship and spatial Management.

Sławomir Dorocki graduated from the Pedagogical University in Krakow, with an MA in geography, and a PhD in history at the Jagiellonian University (Institute of European Studies). Adiunkt (assoc. professor) at the Pedagogical University in Cracow, Institute of Geography. Research interests include regional problems and processes of socio-economic regionalization, with particular emphasis on the diversity of Europe, processes of European integration and historical conditions.

Pawel Brzegowy, mgr, Uniwersytet Pedagogiczny im. Komisji Edukacji Narodowej w Krakowie, Instytut Geografii, Zakład Przedsiębiorczości i Gospodarki Przestrzennej.

Absolwent Uniwersytetu Jagiellońskiego (Instytut Nauk Politycznych i Stosunków Międzynarodowych), doktorant w Instytucie Geografii Uniwersytetu Pedagogicznego im. Komisji Edukacji Narodowej w Krakowie. Główne zainteresowania badawcze dotyczą historii społecznej i gospodarczej departamentów oraz wspólnot Francji pozaeuropejskiej oraz francuskiej i polskiej szkoły geografii politycznej.

Pawel Brzegowy, MA, Pedagogical University of Cracow, Institute of Geography, Department of Entrepreneurship and spatial Management.

Paweł Brzegowy, graduate of Faculty of International and Political Studies of the Jagiellonian University, doctoral student at Institute of Geography of the Pedagogical University of Cracow. Primary research interests focus on social and economic history of extra-European departments and communities of France, as well as the French and Polish schools of political geography.

Adres/Address: Uniwersytet Pedagogiczny im. Komisji Edukacji Narodowej w Krakowie Instytut Geografii, Zakład Przedsiębiorczości i Gospodarki Przestrzennej ul. Podchorążych 2, 30-084 Kraków, Polska e-mail: sdorocki@up.krakow.pl; pawel.brzegowy@uj.edu.pl 


\author{
Kamila Ziółkowska-Weiss \\ Uniwersytet Pedagogiczny \\ im. Komisji Edukacji Narodowej \\ w Krakowie
}

\title{
Ewolucja tradycyjnych funkcji muzeum w narracyjne muzea multimedialne na przykładzie muzeum Fabryka Emalia Oskara Schindlera
}

\author{
The evolution of museums from their traditional form into a narrative \\ multimedia experience on the example of Oskar Schindler's Factory
}

\begin{abstract}
Streszczenie
Kraków jest centrum turystycznym zarówno w skali regionalnej, jak i krajowej - rocznie przyjmuje kilka milionów turystów, a liczba ta z roku na rok rośnie. W 2010 r. liczba gości odwiedzających Kraków osiągnęła poziom ponad $8 \mathrm{mln}$. Miasto jest bardzo dobrze przygotowane na przyjmowanie znacznej liczby turystów krajowych i zagranicznych pod względem infrastruktury turystycznej. Baza gastronomiczna, noclegowa, rozrywkowa, a także wciąż rozwijająca się baza konferencyjna i kongresowa sprawiają, że Kraków jest miastem zaspokajającym potrzeby turystów o zróżnicowanych preferencjach i celach przyjazdu. Istotną kwestią jest zróżnicowanie usług turystycznych pod względem cenowym, co powoduje, iż miasto jest dostępne dla turystów o niższych dochodach.

Kraków jest wielkim centrum muzealnictwa. Liczne zabytki, szczególnie cenne pod względem historycznym i architektonicznym, przyciągają rzesze turystów, a utworzone na terenie Krakowa trasy turystyczne w znacznym stopniu ułatwiają ich zwiedzanie. Celem niniejszego artykułu jest przedstawienie oddziału Muzeum Historycznego Miasta Krakowa - Fabryka Emalia Oskara Schindlera. Zostanie w nim również omówione znaczenie muzeów w XXI w. oraz działalność promocyjno-informacyjna muzeów na terenie Polski. Ponadto znajdą się w nim wyniki ankiety przeprowadzonej wśród 100 osób zwiedzających muzeum. Celem ankiety było dowiedzenie się o główny motyw przybycia osób do muzeum i jak ich zdaniem miasto promuje i zachęca turystów do odwiedzenia muzeum.
\end{abstract}

\begin{abstract}
Cracow is a tourism centre both on a regional and national scale; it welcomes several million tourists annually, and the number increases each year. In 2010, the number of visitors to Cracow exceeded 8 million. The city is very well prepared to receive vast numbers of tourists, both national and foreign, from the perspective of the development of tourist infrastructure. The gastronomy, accommodation and entertainment base, as well as the ever - growing conference and congress facilities, make Cracow a city that satisfies the needs of tourists of varied preferences and motivations. A vital question is also the price diversity when it comes to tourist services, which makes the city available also to visitors with lower incomes.

Cracow is, furthermore, a great center of museums. Numerous monuments of magnificent historical and architectural value attract an immense number of tourists, and tourist routes that have been created in the city facilitate the visiting process. The goal of this article is to present Cracow's Historical Museum - Schindler's Factory. The article will describe the significance of the museum in the 21st
\end{abstract}


century, as well as its promotional and informative activities. The results of a survey carried out on a group of one hundred visitors to the museum will also be presented. The goal of the survey was to learn what the main reasons for their visit were, as well as their opinions, on how the city promotes and encourages tourists to visit this particular museum.

Słowa kluczowe: Kraków, muzeum; Oskar Schindler; turystyka, Żyd

Key words: Cracow; museum; Oskar Schindler; tourism; Jew

\section{Wprowadzenie}

Rynek usług turystycznych podlega ciągłym przemianom pod wpływem różnorodnych impulsów płynących z otoczenia międzynarodowego, a także czynników wynikających z uwarunkowań krajowych, regionalnych i lokalnych. Wpływ tych czynników uwidacznia się zarówno od strony podażowej, tj. funkcjonowania przedsiębiorstw tego sektora, jak i od strony popytowej, a więc klienta usług turystycznych.

Do czynników mających wpływ na kształtowanie się struktury i dynamiki rynku turystycznego zaliczyć należy m.in.:

- procesy koncentracji kapitału i procesy integracyjne przedsiębiorstw, prowadzące do wzrostu znaczenia działalności korporacji międzynarodowych, których rola w światowym rynku usług turystycznych jest coraz większa;

- szybki postęp technologiczny, w tym w środkach komunikacji, tj. łączności i transportu;

- kształtowanie się społeczeństwa informacyjnego związane ze swobodnym przepływem informacji dzięki dynamicznemu rozwojowi technologii informacyjnych. Dzięki temu podmioty gospodarcze mogą się szybciej kontaktować, a klient ma łatwiejszy i szybszy dostęp do oferty usług turystycznych, z możliwością sprawdzenia cen czy natychmiastowego dokonania rezerwacji i zakupu;

- wzrost znaczenia technologii informatycznych w zarządzaniu podmiotami gospodarczymi, w tym zastosowanie różnego typu systemów w turystyce;

- gospodarowanie oparte na wiedzy, prowadzące do wzrostu znaczenia zaawansowanych prac badawczo-rozwojowych i innowacji, umożliwiające uzyskanie przewagi konkurencyjnej przez innowacyjne przedsiębiorstwa tego sektora nad podmiotami, które nie dostrzegły wzrastającej roli wiedzy we współczesnej gospodarce;

- swobodniejsze przemieszczanie się ludzi dzięki liberalizacji przepisów dotyczących przekraczania granic oraz rozwój światowego systemu transportu lotniczego, kołowego, morskiego i krajowego (Zdon-Korzeniowska, Rachwał, 2011).

W przemianach sektora turystycznego nabiera znaczenia światowy kryzys gospodarczy i związane z nim działania rządów rożnych krajów, podejmowane w celu przeciwdziałania skutkom kryzysu, a także upadek wielu firm, w tym transportowych, i instytucji finansowych ściśle związanych z sektorem turystycznym. W związku z tym miasto Kraków podejmuje szereg innowacyjnych działań, które mają przyciągnąć turystów.

\section{Ruch turystyczny w Krakowie w 2011 r.}

Po okresie załamania się wielkości ruchu turystycznego w Krakowie w latach 2008-2009, rok 2011, pomimo kryzysu gospodarczego, zapisał się przyrostem liczby odwiedzających to miasto. W zakresie liczby turystów (gości nocujących) w Krakowie w 2011 r. odnotowano przyrost o 8,3\%. Odnosił się on tak do turystów krajowych, jak i zagranicznych, przy czym w tej pierwszej grupie okazał się znacznie większy (o 11,1\%, a turystów zagranicznych - o 2,5\%). Chociaż w 2011 r. ruch turystyczny zwiększył się, należy zauważyć, że turystów zagranicznych było tylko o 50 tys. więcej niż w roku 2010. 
Tab. 1. Szacunkowa liczba turystów w Krakowie w latach 2005-2011

\begin{tabular}{|l|c|c|c|c|c|c|c|}
\hline $\begin{array}{l}\text { Wyszcze- } \\
\text { gólnienie }\end{array}$ & $\mathbf{2 0 0 5}$ & $\mathbf{2 0 0 6}$ & $\mathbf{2 0 0 7}$ & $\mathbf{2 0 0 8}$ & $\mathbf{2 0 0 9}$ & $\mathbf{2 0 1 0}$ & $\mathbf{2 0 1 1}$ \\
\hline $\begin{array}{l}\text { Turyści } \\
\text { ogółem }\end{array}$ & 5500000 & 6200000 & 6800000 & 6000000 & 5850000 & 6050000 & 6550000 \\
\hline $\begin{array}{l}\text { Turyści } \\
\text { krajowi }\end{array}$ & 3400000 & 3900000 & 4340000 & 3900000 & 3900000 & 4050000 & 4500000 \\
\hline $\begin{array}{l}\text { Turyści } \\
\text { zagraniczni }\end{array}$ & 2100000 & 2300.000 & 2460000 & 2100000 & 1950000 & 2000000 & 2050000 \\
\hline
\end{tabular}

Źródło: opracowanie własne na podstawie Ruch turystyczny w Krakowie w 2011 roku - raport końcowy.

Trzeba jednocześnie zauważyć, że o ile w latach 2008-2009 miał miejsce spadek w zakresie zagranicznego ruchu turystycznego, a w 2010 r. - stabilizacja, o tyle w 2011 r. niekorzystna tendencja została przełamana. Liczba gości zagranicznych wróciła do wielkości z roku 2008, aczkolwiek była jeszcze i tak o 14\% mniejsza niż w rekordowym, jak dotychczas, pod tym względem roku 2007. W segmencie turystów zagranicznych nie osiągnięto jeszcze rekordowej wielkości z 2007 r. (o 16,7\% mniej). Turystów z Polski było natomiast o 3,7\% więcej. W sumie liczba turystów przybywających do Krakowa była w 2011 r. mniejsza od wielkości zaobserwowanych w 2007 r. o 3,7\% (ryc. 1).

Ryc. 1. Szacunkowa liczba turystów w Krakowie w latach 2003-2011

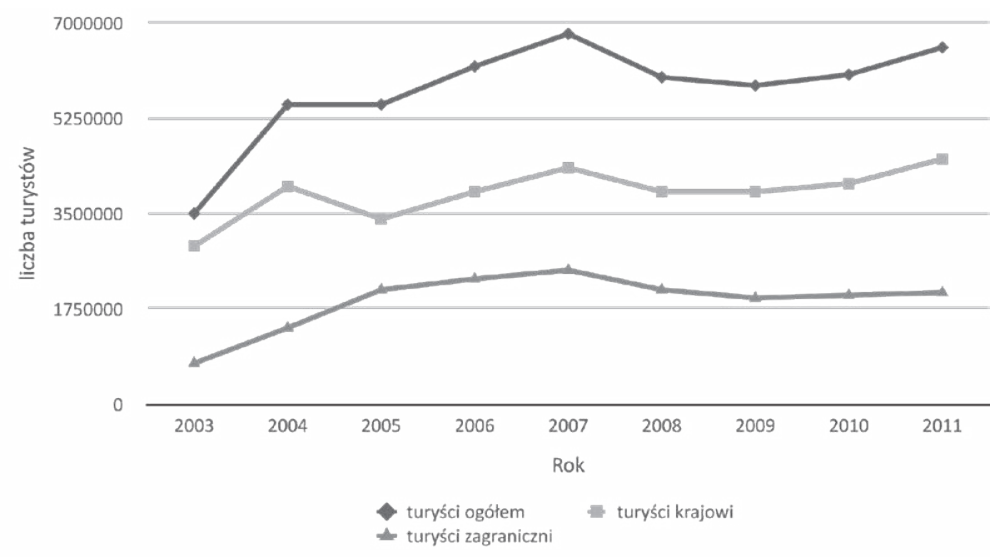

Źródło: Ruch turystyczny w Krakowie w 2011 - raport końcowy.

Warto w tym miejscu przedstawić główny cel przyjazdu ogółem odwiedzających do Krakowa. W dalszym ciągu głównym celem przyjazdu turystów do Krakowa jest chęć zwiedzania zabytków. W 2011 r. wskazało go 32,1\% turystów (tab. 2), niemniej jednak było to mniej o 4,1\% niż w roku 2010. Aby zachęcić turystów do większego i aktywniejszego zwiedzania zabytków, miasto Kraków zaczęło wprowadzać nowe, innowacyjne rozwiązania. 
Tab. 2. Główne cele przyjazdu ogółem odwiedzających do Krakowa w latach 2005-2006 i 2008-2011

\begin{tabular}{|l|c|c|c|c|c|c|}
\hline \multicolumn{1}{|c|}{ Glówny cel przyjazdu } & $\mathbf{2 0 0 5}$ & $\mathbf{2 0 0 6}$ & $\mathbf{2 0 0 8}$ & $\mathbf{2 0 0 9}$ & $\mathbf{2 0 1 0}$ & $\mathbf{2 0 1 1}$ \\
\hline Zwiedzanie zabytków & $34,9 \%$ & $35,1 \%$ & $19,4 \%$ & $34,76 \%$ & $36,23 \%$ & $32,10 \%$ \\
\hline Wypoczynek & $15,6 \%$ & $26,3 \%$ & $22,7 \%$ & $21,22 \%$ & $13,30 \%$ & $22 \%$ \\
\hline Rozrywka (kluby, dyskoteki, puby) & $4,0 \%$ & $3,9 \%$ & $8,9 \%$ & $5,34 \%$ & $10,09 \%$ & $7,30 \%$ \\
\hline Odwiedziny krewnych lub znajomych & $9,7 \%$ & $6,6 \%$ & $7,8 \%$ & $8,26 \%$ & $9,72 \%$ & $6,50 \%$ \\
\hline Odwiedziny znajomych & & & & $3,11 \%$ & $5,00 \%$ & $6,50 \%$ \\
\hline Odwiedziny krewnych & & & & $5,15 \%$ & $4,72 \%$ & $0 \%$ \\
\hline Cel religijny & $9,7 \%$ & $6,1 \%$ & $11,7 \%$ & $6,56 \%$ & $4,35 \%$ & $5,70 \%$ \\
\hline Odnowa duchowa & & & & $2,10 \%$ & $0,77 \%$ & $0,40 \%$ \\
\hline Sprawy służbowe (biznes) & $6,5 \%$ & $7,6 \%$ & $4,0 \%$ & $5,88 \%$ & $3,78 \%$ & $3,70 \%$ \\
\hline Zakupy & $1,8 \%$ & $1,1 \%$ & $1,8 \%$ & $1,11 \%$ & $3,70 \%$ & $2,90 \%$ \\
\hline Edukacja & $2,6 \%$ & $1,4 \%$ & $5,0 \%$ & $2,76 \%$ & $3,09 \%$ & $3,20 \%$ \\
\hline Cel zdrowotny & $0,7 \%$ & $0,4 \%$ & $3,2 \%$ & $1,3 \%$ & $2,56 \%$ & $1,40 \%$ \\
\hline $\begin{array}{l}\text { Udział w kongresie, konferencji, } \\
\text { szkoleniu }\end{array}$ & $2,7 \%$ & $2,4 \%$ & $3,8 \%$ & $2,56 \%$ & $2,52 \%$ & $1,00 \%$ \\
\hline Udział w konferencji & & & & & & \\
\hline Udział w szkoleniu & & & $2,2 \%$ & & $1,0 \%$ & $0,00 \%$ \\
\hline Udział w kongresie & $1,2 \%$ & $0,0 \%$ & $0,0 \%$ & $0,0 \%$ & $0,57 \%$ & $0 \%$ \\
\hline Tranzyt & $0,5 \%$ & $0,7 \%$ & $0,5 \%$ & $0,74 \%$ & $0,45 \%$ & $0,20 \%$ \\
\hline Udział w imprezie kulturalnej & $1,4 \%$ & $2,4 \%$ & $4,2 \%$ & $2,14 \%$ & $2,32 \%$ & $1,60 \%$ \\
\hline Udział w zawodach sportowych & $0,7 \%$ & $0,9 \%$ & $1,3 \%$ & $0,7 \%$ & $0,77 \%$ & $0,50 \%$ \\
\hline Odwiedziny miejsc rodzinnych & $11 \%$ & $1,0 \%$ & $1,6 \%$ & $1,12 \%$ & $0,61 \%$ & $0,30 \%$ \\
\hline Brak informacji & $4,2 \%$ & $2,2 \%$ & $1,3 \%$ & $1,3 \%$ & $2,41 \%$ & $2 \%$ \\
\hline Turystyka aktywna (kwalifikowana) & $100,00 \%$ & $100,00 \%$ & $100,00 \%$ & $100,00 \%$ & $100,00 \%$ & $100,00 \%$ \\
\hline Poznanie walorów przyrody & & $0,3 \%$ & & $0,52 \%$ & $0,30 \%$ \\
\hline Inny cel & & $1,8 \%$ & $2,7 \%$ & $2,06 \%$ & $2,52 \%$ & $5,20 \%$ \\
\hline Razem & & & & $1,0 \%$ & $0,70 \%$ \\
\hline Zrom $\%$ & & & & \\
\hline
\end{tabular}

Źródło: opracowanie własne na podstawie: Ruch turystyczny w Krakowie w 2011 - raport końcowy.

\section{Wdrażanie nowych technologii w turystyce}

W ostatnim czasie problematyka związków turystyki z technologią informacyjną jest efektem stosowania najnowszych możliwości, które daje technologia informacyjna, a które mogą wpłynąć na rozwój turystyki, zwłaszcza w środowisku młodzieżowym. Chodzi o to, aby propagować turystykę środkami i językiem technologii informacyjnej, tym językiem, którym porozumiewa się bardzo dużo młodzieży. Większość młodych turystów przygotowuje się do wyjazdu, korzystając z lokalizatorów internetowych. Oprócz produktów firmy Google: Google Maps i Google Earth, na rynku polskim polskim pomagają w tym takie programy, jak: Zumi, będący własnością portalu Onet, oraz Docelu, należący do Wirtualnej Polski. Każdy z tych serwisów umożliwia lokalizacje ogromnej liczby punktów użyteczności (POI - points of interest): hoteli, 
restauracji, dworców, lotnisk, szkół, szpitali, aptek, urzędów, obiektów kultury itp. Jest to też okazja do reklamy niektórych z tych punktów. Programy te i inne nowoczesne technologie stają się więc narzędziem promocji oraz zwiększania zainteresowania uczestnictwem w turystyce kulturowej.

Do głównych celów wdrażania nowych technologii w turystyce należą:

- nowoczesne zarządzanie ruchem turystycznym,

- udostępnienie turystom i zwiedzającym walorów turystycznych w nowej innowacyjnej i atrakcyjnej formie,

- promowanie walorów turystycznych i turystyki kulturowej,

- promowanie wizerunku atrakcyjnej destynacji turystycznej,

- wdrożenie nowego produktu turystycznego,

- stworzenie nowoczesnych kanałów dostępu do informacji turystycznej,

- przygotowanie i rozszerzenie atrakcyjnej oferty turystycznej, skierowanej do grup docelowych.

Powszechna akceptacja telefonów komórkowych stwarza szansę szerszego wykorzystania tych urządzeń, zwłaszcza do uzyskiwania informacji z sieci Internet. Od roku istnieje mobilna wersja serwisu Zumi pod nazwą ZumiLajt, która zawiera wszystkie najważniejsze funkcje oryginału. Dodatkowo za pomocą jednego przysłowiowego kliknięcia można połączyć się telefonicznie ze znalezioną firmą (hotelem, restauracją itp). Istnieją też serwisy mobilne baz noclegowych (Mobi. baza-noclegow.pl). Mobilne strony internetowe posiada również Kraków. Podążając za modą oraz innowacyjnością w turystyce, wprowadziło ono dla turystów odwiedzających to miasto dwie aplikacje mobilne dostępne w telefonach komórkowych. Jedna z nich to Treespot. Jest to system informacji miejskiej, w którym znaleźć można aktualne informacje o obiektach wartych odwiedzenia w Krakowie, najbliższych wydarzeniach oraz ciekawych trasach pieszych i rowerowych. Największymi atutami aplikacji Treespot Kraków są: przejrzysty interfejs, za pomocą którego użytkownik może w prosty sposób dotrzeć do interesujących go informacji, działanie aplikacji w trybie offline oraz aktualizowana na bieżąco baza obiektów i wydarzeń. Całość uzupełniają specjalnie przygotowane propozycje tras pieszych i rowerowych. Drugą aplikacją, którą proponuje Kraków, jest MobiTrip. Aplikacja ta jest w pełni darmowa dla użytkowników, przeznaczona na telefony i tablety wykorzystujące system operacyjny Android. MobiTrip podąża za najnowszymi trendami, jakimi są rozwiązania mobilne. Na podstawie geolokalizacji oraz interaktywnej mapy dostarcza informacji o obiektach i ciekawostkach znajdujących się w pobliżu. Oferuje szybki i bezpośredni dostęp do informacji w każdym miejscu i o każdej porze, również bez połączenia z Internetem, stając się przez to atrakcyjną formą promowania regionu i wygodnym narzędziem dla turysty w Krakowie. W MobiTrip znaleźć można: zabytki znane i mniej popularne, pałace, kościoły, cmentarze, forty, ruiny, miejsca, gdzie można smacznie zjeść (bary, pizzerie) i przenocować (restauracje, hotele, hostele, pensjonaty). Miejsca, gdzie można spotkać się z przyjaciółmi, pobawić, wypocząć - kluby, puby, dyskoteki, kina, teatry, parki. Miejsca niezbędne na co dzień - bankomaty, punkty medyczne, stacje benzynowe, przystanki oraz postoje taksówek.

Obok omówionych aplikacji mobilnych miasto Kraków proponuje również inne nowości technologiczne, które wykorzystywane są głównie w muzeach. Należą do nich m.in.:

- ekrany dotykowe, tablety, tablice interaktywne,

- prezentacje multimedialne,

- interaktywne quizy, zagadki i gry,

- pokazy i inscenizacje historyczne,

- tzw. projektory z funkcją wizualizacji trójwymiarowych - „Rzeczywistość rozszerzona”,

- hologramy, fotokody, projekcje laserowe,

- wirtualne spacery. 


\section{Nowe tendencje w polskim muzealnictwie}

$\mathrm{W}$ związku z rozwojem technologicznym na świecie potrzebna była rewolucja w sposobie myślenia o roli muzeum w społeczeństwie, metodzie działania promującego muzeum, sposobie docierania do odbiorców i rozbudzenia zainteresowania ekspozycją muzealną. Działalność muzeów uważana jest przez odbiorców za dobro czasu wolnego i to nie wyjątkowe, ale zaledwie jedno z wielu oferowanych na rynku. Aby skutecznie konkurować z innymi podmiotami i ich produktami, muzea muszą dokonać twórczej adaptacji podstawowych zasad i narzędzi marketingowych do działalności instytucji non profit. Pierwszorzędnym zadaniem w tym zakresie jest zdefiniowanie produktu danej placówki, a następnie stałe jego doskonalenie, rozwijanie, przygotowywanie wariantów dla różnych segmentów rynku (Stasiak, 2007)

Aby sprostać wymaganiom rynku i konkurencji, muzeum musi działać jak przedsiębiorstwo: traktować swoje zbiory jak produkt, który należy sprzedać, stosować różne zabiegi reklamowe, ułatwiające upowszechnienie zbiorów, organizować coraz atrakcyjniejsze formy zapoznania zwiedzających ze zgromadzonymi zbiorami, poszerzać tematykę oraz krąg zwiedzających (Białek, 2005).

Najnowsze tendencje w światowym muzealnictwie zalecają branie pod uwagę opinii odbiorców. Oni z reguły nie chcą naukowego wykładu, kolejnej lekcji na jakiś temat, chcą natomiast przeżycia niepowtarzalnej, wyjątkowej, nacechowanej emocjami wizyty w muzeum. Odpowiedzią na te oczekiwania rynku usług kulturowych jest strategia określana mianem Market Repositioning Toward Enterteinment. Zakłada ona poszerzenie oferty muzealnej przez wprowadzenie do niej elementów rozrywki (Rottermund, 2001). Kompromisem pomiędzy potrzebami a oczekiwaniami obu stron ma być edutainment (połączeniu słów: entertainment i education), a więc profesjonalnie skonstruowana oferta zawierająca elementy wiedzy i emocji. Współgra to z najnowszymi tendencjami na rynku turystycznym i rozwojem nowej turystyki typu 3 x E (entertainment, excitement, education). Świadome i celowe kreowanie przeżyć odbiorców ekspozycji nie jest łatwe. Pewne jest, że muzea „szklanych gablot” przeszły już do historii. Tradycyjne metody prezentacji eksponatów nie wzbudzają już większego zainteresowania. Przyszłość należy do placówek, które na podstawie zgromadzonych eksponatów zbudują jasny, czytelny i nacechowany emocjami przekaz informacji.

Nowoczesne muzeum to placówka interaktywna, niepozwalająca zwiedzającym pozostawać biernymi widzami, wciągająca ich do dialogu, pobudzająca do dociekań, zadawania pytań, a także samodzielnego poszukiwania odpowiedzi. Ekspozycja muzealna powinna oddziaływać nie tylko na wzrok, ale także na pozostałe zmysły: słuch (różnego rodzaju dźwięki powiązane z charakterem ekspozycji), węch, dotyk (możliwość dotknięcia, wzięcia do ręki eksponatu). Wykorzystanie takiej spójnej kompozycji wielu różnych bodźców tworzy niezwykle silne wrażenie i przeżycia wśród zwiedzających, buduje niepowtarzalną atmosferę wystawy.

Przyszłością muzeologii ma być narracyjne muzeum multimedialne. Sednem ekspozycji nadal jednak pozostanie autentyczny eksponat, ale nie jego prezentacja będzie najważniejsza. Eksponat jest tylko wstępem, pretekstem do opowiedzenia zajmującej historii, wykreowania określonych scen i obrazów, wieloaspektowego przybliżenia danego zagadnienia zwiedzającym. Narracja wokół zgromadzonych eksponatów ma charakter multimedialny i wykorzystuje najnowsze środki techniczne (m.in. komputerowe sterowane oświetlenie, lasery, trójwymiarowe filmy, tematyczne kioski multimedialne, a także wizualizację, reprodukcję i rekonstrukcję). Komputerowe elementy ekspozycji nie tylko budują nastrój, ale też współtworzą ją na różnych prawach z autentycznymi eksponatami. Pierwsze multimedialne placówki, które powstały w Polsce, to Muzeum Powstania Warszawskiego i Tyskie Muzeum Piwowarstwa. 
Omawiając innowacyjne rozwiązania w muzeach, należy wspomnieć również o działalności promocyjno-informacyjnej, która niewątpliwie wpływa na frekwencję w muzeach.

Bierna postawa w zakresie promocji może doprowadzić do porażki nawet najciekawsze wystawy. W dzisiejszych czasach nie można ograniczyć się tylko do wywieszenia plakatu reklamowego na budynku czy zamieszczenia informacji w prasie. Muzea wykorzystują coraz to nowsze formy i rodzaje reklam: ulotki, banery, reklamy radiowe, internetowe, a nawet telewizyjne, mailing, różnego rodzaju akcje reklamowe (happeningi) w przestrzeni publicznej. Aby te działania zostały zauważone, muszą być świeże, niekonwencjonalne, niebanalne oraz wyróżniające się. Dla największych wystaw organizuje się kampanie reklamowe, które przygotowują specjalnie wykwalifikowane do tego firmy. Przypuszcza się, że wkrótce standardem w strukturze organizacyjnej muzeum będzie odrębna komórka ds. reklamy, a muzealny budżet będzie musiał przewidywać znaczące wydatki na tego typu działania (Białek, 2005).

Potrzeba promocji pojedynczych, okazjonalnych wydarzeń muzealnych, nie może przesłaniać konieczności długofalowej, codziennej, żmudnej pracy nad kreowaniem pozytywnego wizerunku muzeum. Aby kreować swój pozytywny image (instytucji przyjaznej, interesującej, w której stale dzieje się coś ciekawego) i zdobywać społeczną akceptację dla swych poczynań, muzea powinny podejmować działania z zakresu public relations. Należą do nich m.in.: szeroka i wyczerpująca informacja o prowadzonej działalności, współpraca z dziennikarzami zapewniająca stałą obecność w mediach, otwartość i elastyczność w kontaktach z odbiorcami oferty, opracowanie i konsekwentne stosowanie systemu identyfikacji wizualnej (logo muzeum czy jednolitej stylistyki materiałów reklamowych). W erze informatycznej niezbędna jest obecność muzeum w świecie wirtualnym. Zwłaszcza dla młodych ludzi firma, instytucja czy muzeum istnieje tylko wtedy, gdy jest ona obecna w Internecie. Bez nowoczesnej strony internetowej niemożliwe jest dziś kreowanie pozytywnego wizerunku muzeum wśród młodzieży.

W polskich warunkach ciągle jeszcze nowością jest e-muzeum, czyli multimedialna prezentacja umożliwiająca wirtualne zwiedzanie placówki. Osoba siedząca przed komputerem ma możliwość odbycia wirtualnego spaceru po muzeum: odwiedza kolejne sale, ogląda wnętrza, eksponaty, może wysłuchać komentarza przewodnika lub dowiedzieć się więcej informacji na interesujący ją temat (Godlewski, 2004).

Chociaż e-muzea w naszym kraju są rzadkością, Małopolski Instytut Kultury wraz z miastem Kraków realizuje projekt „Wirtualne Muzea Małopolski”. Jego celem jest digitalizacja zbiorów muzealnych, utworzenie Regionalnej Pracowni Digitalizacji, a także portalu, na którym zaprezentowane zostaną obiekty wybrane przez Radę Ekspertów projektu z kolekcji 35 muzeów z terenu Małopolski. W wirutalnej przestrzeni zostanie umieszczonych 700 eksponatów z 35 muzeów, dla których do tej pory naturalnym środowiskiem były muzealne gabloty lub - ze względów bezpieczeństwa - muzealne magazyny, zostanie umieszczonych. Dzięki temu można będzie nie tylko poznać ich bogatą historię, ale także oglądać je, przybliżać i obracać, bez obawy o ich zniszczenie i naruszenie muzealnej etykiety. Dzięki interaktywnej i atrakcyjnej wizualnie formie ekspozycji obiekty muzealne znajdujące się w małopolskich muzeach będą miały szansę dotrzeć do szerokiego grona odbiorców. Znakiem rozpoznawczym portalu będą nieoczywiste powiązania i inspirujące konteksty, bogate materiały edukacyjne i dydaktyczne, dzięki którym czas spędzony w sieci będzie dawał możliwość nauki przez zabawę (http:// muzea.malopolska.pl/o-projekcie/). 


\section{Innowacyjne rozwiązania w muzeum Fabryka Emalia Oskara Schidlera}

Muzeum Fabryka Emalia Oskara Schidlera, działające pod patronatem Muzeum Historycznego Miasta Krakowa, powstało w miejscu założonej w 1937 r. fabryki wyrobów emaliowanych i blaszanych. Była ona wydzierżawiona, a potem przejęta przez niemieckiego przedsiębiorcę Oskara Schindlera w 1939 jako Niemiecka Fabryka Wyrobów Emaliowanych - Deutsche Emailwarenfabrik (DEF). Schindler zatrudniał w niej zagrożonych eksterminacją Żydów, wpisanych na tzw. listę Schindlera i uratowanych dzięki temu od zagłady. Od 2007 r. fabryka jest podzielona między dwie instytucje: Muzeum Historyczne Miasta Krakowa i Muzeum Sztuki Współczesnej (Chwalba, 2002).

Fabryka Emalia Oskara Schindlera to jeden z najnowocześniejszych w naszym kraju obiektów muzealnych. W muzeum zainstalowano m.in.: monitory LCD, monitory z nakładkami dotykowymi, ekrany projekcyjne, projektory multimedialne, odtwarzacze, konwertery sygnałów, wielostrefowy system nagłośnieniowy oraz system do zarządzania treścią i obrazem. Zostało ono wyposażone również przez TRIAS S.A. w salę kinową, systemy audiowizualne i sterowania. Fabryka Schindlera jest pierwszym w Polsce muzeum, w którym zastosowano instalację multimedialną opartą na infrastrukturze światłowodowej.

Od 11 czerwca 2010 r. w muzeum można zwiedzać wystawę „Kraków - czas okupacji 1939-1945”. Wystawa jest opowieścią o Krakowie i losach jego polskich i żydowskich mieszkańców w czasie II wojny światowej. Została ona zrealizowana przy użyciu środków wykraczających poza ramy tradycyjnej ekspozycji muzealnej. Autorzy aranżacji plastycznej: scenograf Michał Urban i reżyser Łukasz Czuj nadali ekspozycji charakter opowieści teatralno-filmowej. Scenograficzne rekonstrukcje autentycznych przestrzeni miejskich są zderzone z instalacjami rzeźbiarskimi, metaforycznie ujmującymi historię wojennego Krakowa.

Pięć kluczowych momentów dla historii miasta zostało oznaczonych przez „,maszyny pamięci” - stemplownice, w których każdy zwiedzający może odbić pieczęć związaną z danym wydarzeniem, zabierając ze sobą swoisty dokument czasu. Puentą wystawy jest instalacja rzeźbiarska - „Sala wyborów” - symbol etycznych dylematów i postaw w czasie wojny.

W 45 przestrzeniach wystawienniczych przeszłość Krakowa została wykreowana w taki sposób, by każdy ze zwiedzających mógł bezpośrednio dotknąć historii, poczuć emocje mieszkańców miasta okresu wojny. Nowoczesną i atrakcyjną dla widza formę przekazu muzealnego tworzą rozbudowane multimedia: 30 interaktywnych stanowisk z monitorami dotykowymi, 70 ścieżek dźwiękowych, 15 wideoprojektorów, 56 odtwarzaczy multimedialnych, 45 monitorów (w tym 32 dotykowe), 14 projektorów multimedialnych, ponad 100 głośników .

Warto podkreślić, że za wystawę „Kraków - czas okupacji 1939-1945” Gmina Miejska Kraków w konkursie Polish Digital Signage Association Awards 2011 została uhonorowana nagrodą w kategorii „Najlepsze rozwiązanie Digital Signage dla jednostek użyteczności publicznej".

Poniżej przedstawiono wyniki uzyskane z ankiety przeprowadzonej na 100-osobowej grupie zwiedzających muzeum. Badania przeprowadzone zostały w lipcu i sierpniu 2012 r. na osobach, które różniły się płcią, wykształceniem oraz rodzajem aktywności zawodowej. Ankieta dla osób odwiedzających muzeum Fabryka Emalia Oskara Schidlera składała się z 15 pytań. Celem ankiety było dowiedzenie się, jaki był głównych motyw przyjazdu do muzeum oraz jak miasto Kraków promuje i zachęca turystów do odwiedzenia tego muzeum. 
Na pytanie dotyczące źródła wiedzy o muzeum największa liczba osób odpowiedziało, że jest to Internet (32\%). Na pozostałych miejscach znalazła się promocja i reklama przez miasto $(21 \%)$ oraz ulotki $(14 \%)$.

Ryc. 2. Źródło wiedzy o muzeum

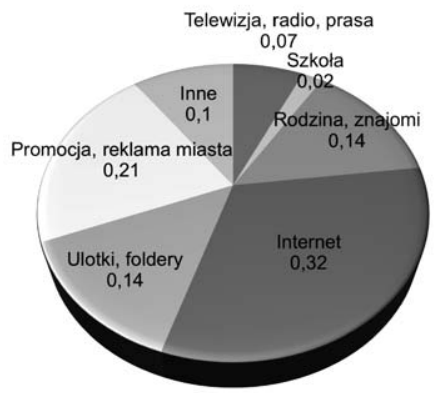

Źródło: opracowanie własne na podstawie wyników z ankiet.

Spośród ankietowanych 53\% uważa, że dostępność informacji dotyczących muzeum jest dobra, 11\% - że bardzo dobra. Nikt z ankietowanych nie zaznaczył, że dostępność ta jest niewystarczająca.

Ryc. 3. Dostępność informacji dotyczącej muzeum

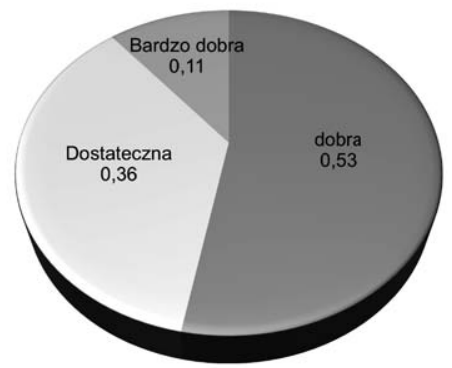

Źródło: opracowanie własne na podstawie wyników z ankiet.

Głównym motywem przyjazdu ankietowanych do muzeum była rekomendacja multimedialnej wystawy (41\%). Tylko 23\% odpowiedziało, że głównym motywem była chęć pogłębienia wiedzy na temat kultury żydowskiej.

Ryc. 4. Motywy przyjazdu do muzeum

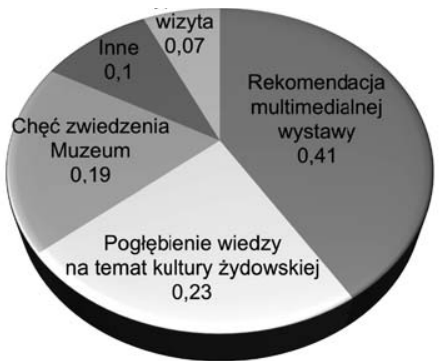

Źródło: opracowanie własne na podstawie wyników z ankiet. 
Na pytanie, co zachęciło Panią/Pana do odwiedzenia muzeum, najwięcej z nich (46\%) odpowiedziało, że była to multimedialna ekspozycja. Na kolejnych miejscach pojawiła się ciekawość $(22 \%)$ oraz edukacja (11\%).

Ryc. 5. Co zachęciło turystów do odwiedzenia muzeum

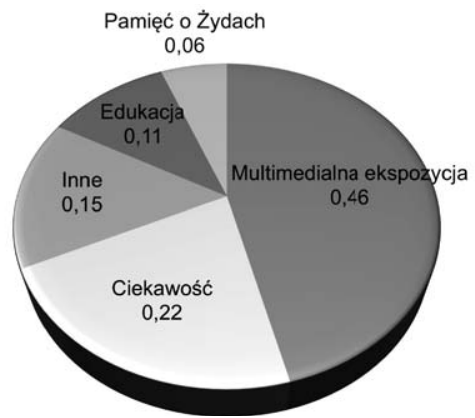

Źródło: opracowanie własne na podstawie wyników z ankiet.

Okazuje się, że wizyta w miejscu upamiętniającym historię Żydów dla prawie połowy z ankietowanych (47\%) jest zapoznaniem się z nowoczesnym zwiedzaniem muzeum. Tylko dla 7 $\mathrm{z}$ nich jest to lekcja historii.

Ryc. 6. Czym jest dla odwiedzających wizyta w miejscu upamiętniającym historię Żydów

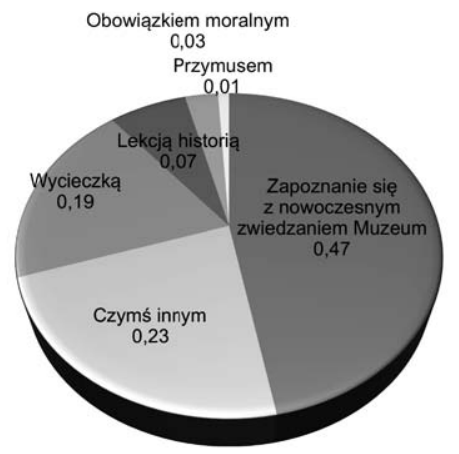

Źródło: opracowanie własne na podstawie wyników z ankiet.

31\% osób uważa, że muzeum powinno przekazywać wiedzę oraz historię w nowoczesny sposób. 18 osób (12\%) odpowiedziało, że muzeum powinno przekazywać informację, fakty o krakowskich Żydach oraz pielęgnować o nich pamięć.

Ryc. 7. Opinia ankietowanych dotycząca funkcji pełnionych przez muzeum

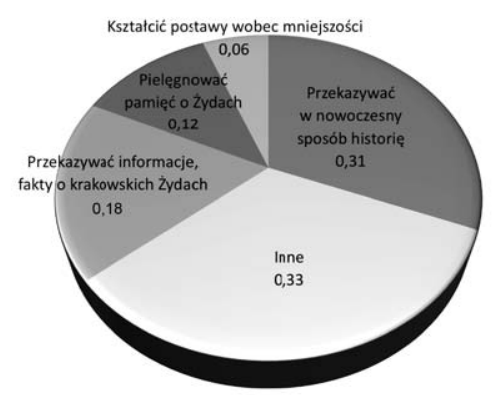

Źródło: opracowanie własne na podstawie wyników z ankiet. 
$53 \%$ respondentów odpowiedziało, że po obejrzeniu wystawy najbardziej zapamiętało nową wiedzę na temat środków multimedialnych. Niestety, 3\% osób odpowiedziało, że niczego nie wyniosło z wizyty w muzeum.

Ryc. 8. Co wynieśli ankietowani z wizyty w muzeum

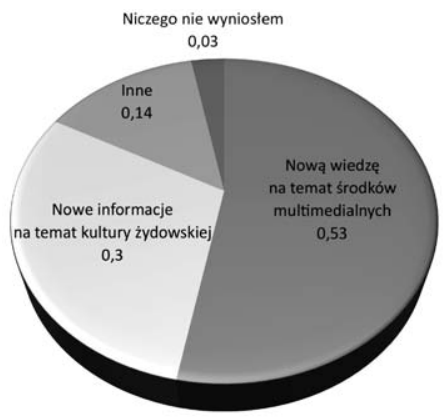

Źródło: opracowanie własne na podstawie wyników z ankiet.

Na pytanie, jak ocenia Pani/Pan wystawę: „Kraków - czas okupacji 1939-1945” 43\% odpowiedziało, że bardzo dobrze, 17\% - doskonale i tylko $8 \%$ oceniło ją jako średnią.

Ryc. 9. Ocena wystawy „Kraków - czas okupacji 1939-1945”

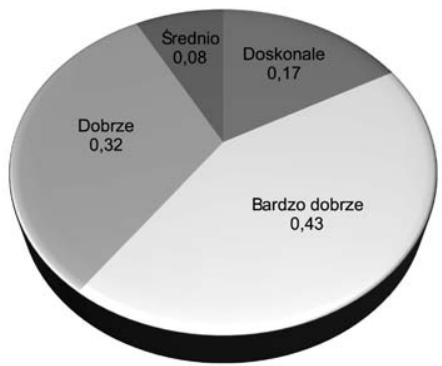

Źródło: opracowanie własne na podstawie wyników z ankiet.

Ostatnie pytanie dotyczyło tego, czy według ankietowanych wystawa „Kraków - czas okupacji 1939-1945" jest dobrze reklamowana i czy zachęca do odwiedzenia zdecydowana większość odpowiedziała, że tak (69\%).

Ryc. 10. Opinia ankietowanych, czy wystawa „Kraków - czas okupacji 1939-1945” jest dobrze reklamowana i zachęca do jej obejrzenia

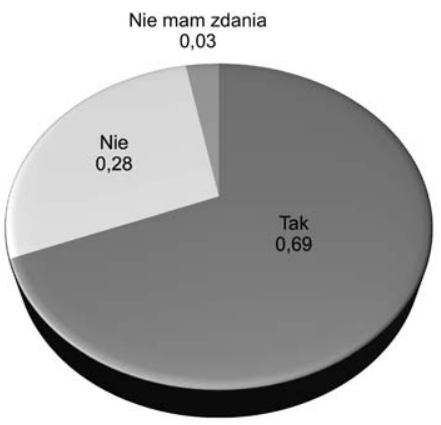

Źródło: opracowanie własne na podstawie wyników z ankiet. 
Na podstawie szczegółowej analizy odpowiedzi na pytania zawarte w ankiecie można dojść do następujących wniosków:

- głównym motywem odwiedzających muzeum Fabryka Emalia Oskara Schidlera na Zabłociu jest rekomendacja multimedialnej wystawy przez znajomych;

- dla respondentów wizyta w muzeum jest głównie zapoznaniem się ze sposobem nowoczesnego zwiedzania muzeum;

- według badanych muzeum przede wszystkim powinno przekazywać historię w nowoczesny, ciekawy i interaktywny sposób przy użyciu nowoczesnej technologii;

- po wizycie w muzeum ankietowani w większości zaznaczyli, że mają nową wiedzę na temat środków multimedialnych i nowego innowacyjnego zwiedzania obiektu;

- ankietowani uważają również, że miasto Kraków dobrze reklamuje i promuje nową, multimedialną wystawę zorganizowaną w muzeum.

\section{Zakończenie}

W XXI w. muzea polskie stanęły przed wyzwaniami. Po pomyślnym przejściu przez okres przemian ustrojowych i dostosowania się do wymagań wolnego rynku nastąpił szybki wzrost liczby placówek muzealnych. Obecnie nadszedł czas zmian jakościowych. Doskonałym tego przykładem jest muzeum Fabryka Emalia Oskara Schindlera w Krakowie, które z roku na rok odwiedza coraz większa liczba turystów. W 2011 r. odwiedziło je o 0,7\% więcej turystów krajowych niż w roku 2010. W opinii turystów krajowych i zagranicznych muzeum to znajduje się w pierwszej 15 największych atrakcji turystycznych Krakowa. W 2011 r. znalazło się ono na 14 pozycji. Niewątpliwie przyczyną tego sukcesu jest stosowanie nowych, multimedialnych rozwiązań, które miasto Kraków wprowadza i dzięki którym promuje aktywność turystyczną w warunkach kryzysu gospodarczego. W dzisiejszych czasach wiele osób podczas podróży używa nowoczesnych urządzeń technologii informacyjnej. Dziś, korzystając tylko z telefonu komórkowego, można dokładnie zaplanować swoją podróż, odnaleźć za pomocą odpowiednich aplikacji interesujące obiekty oraz bez kupowania przewodnika czy mapy dotrzeć do celu. Miasto Kraków proponuje swoim turystom nowe technologiczne rozwiązania turystyczne, co jest przydatne w dobie kryzysu gospodarczego.

\section{Literatura}

Bartoszewski, A. (2010). Najnowsze osiągnięcia technologii informacyjnej a turystyka - nowe wyzwania i możliwości. W: K. Denek, A. Kamińska A. Kojs (red.), Edukacja jutra. Proces wychowania w szkole i poza niq. Poznań: Wydawnictwo Naukowe UE, 301-315.

Bednarek, M. (2004). Deutsche Emailwarenfabrik Oskara Schindlera w Krakowie w latach 1939-1945. W: M. Bednarek (red.), Krzysztofory, 22, 127-143.

Białek, M. (2005). Muzeum jako firma stosująca marketing. W: Turystyka i Hotelartswo, 8.

Bąk, J., Stach P. (2001). Muzeum jako konkurujące przedsiębiorstwo - w poszukiwaniu dróg rozwoju. W: Zeszyt Naukowy WSDG. Warszawa: Wydawnictwo Naukowe WSDG, 8.

Chwalba, A. (2002). Dzieje Krakowa. Kraków w latach 1939-1945. Kraków: Wydawnictwo Naukowe PWN.

Kiedrowicz, G. (2009). Technologia informacyjna w turystyce i rekreacji. Radom: Wydawnictwo Naukowe Instytutu Technologii Eksploatacji - PIB.

Rottermund, A. (2001). Muzeum przyszłości. W: Spotkania z muzeami. Dwieście lat muzeów w Polsce, Warszawa: Spotkanie z zabytkami. 
Stasiak, A. (2007). O potrzebie rewolucji w polskim muzealnictwie XXI wieku. W: A. Stasiak (red.), Kultura i turystyka razem czy oddzielnie. Łódź: Wydawnictwo WSTH, 115-134.

Stasiak, A. (2006). Muzea wobec wyzwań współczesnej turystyki. W: A. Toczewski (red.), Rola muzeów w turystyce i krajoznawstwie, Zielona Góra: Wydawnictwo Naukowe UZ, 67-74.

Zdon-Korzeniowska, M., Rachwał, T. (2011). Turystyka w warunkach światowego kryzysu gospodarczego. Prace Komisji Geografii Przemystu Polskiego Towarzystwa Geograficznego, 18, 116-128.

Ruch turystyczny w Krakowie w 2011 roku-raport końcowy pod kierunkiem K. Borkowskiego.

\section{Źródła internetowe}

http://www.mhk.pl/oddzialy/fabryka_schindlera

http://krakow.treespot.pl/

http://mobitrip.pl/

http://muzea.malopolska.pl/o-projekcie/

Kamila Ziółkowska-Weiss, mgr, Uniwersytet Pedagogiczny im. Komisji Edukacji Narodowej w Krakowie, Instytut Geografii, Zakład Turystyki i Badań Regionalnych.

Absolwentka kulturoznawstwa na Uniwersytecie Jagiellońskim oraz geografii na Uniwersytecie Pedagogicznym w Krakowie. Ukończyła podyplomowe studia na Uniwersytecie Ekonomicznym w Krakowie na kierunku zarządzanie turystyką międzynarodową. Od 2011 doktorantka na Uniwersytecie Pedagogicznym na kierunku geografia. Od 2012 pracownik naukowy na stanowisku asystent w Zakładzie Turystyki i Badań Regionalnych Uniwersytetu Pedagogicznego w Krakowie. Czynny pilot wycieczek. Autorka kilku publikacji naukowych. Główne zainteresowania naukowe to turystyka kulturowa oraz mniejszości narodowe i grupy etniczne w Małopolsce.

Kamila Ziółkowska-Weiss, BA, Pedagogical University of Cracow, Institute of Geography, Department of Tourism and Regional Studies.

Graduate of Cultural Studies at the Jagiellonian University, Geography at the Pedagogical University in Cracow, and postgraduate studies in international tourism management at the Cracow University of Economics. Since 2011, the author has also been a doctoral student of Geography at the Pedagogical University of Cracow, and a research worker since 2012, acting as an assistant in Department of Tourism and Regional Studies at the Pedagogical University of Cracow. Active tourist guide, and author of several academic publications. Main academic interests include: cultural tourism, ethnic groups in Małopolska.

Adres/Address:

Uniwersytet Pedagogiczny im. Komisji Edukacji Narodowej w Krakowie Instytut Geografii, Zakład Turystyki i Badań Regionalnych

ul. Podchorążych 2, 30-084 Kraków, Polska

e-mail:kamilacamela@wp.pl 


\author{
Sławomir Dorocki, Anna Irena Szymańska, Małgorzata Zdon-Korzeniowska \\ Uniwersytet Pedagogiczny \\ im. Komisji Edukacji Narodowej \\ w Krakowie
}

\title{
Polskie gospodarstwa agroturystyczne w dobie kryzysu gospodarczego
}

\author{
Polish agritourism farms in times of an economic crisis
}

\begin{abstract}
Streszczenie
Kryzys gospodarczy ostatnich kilku lat dotknął w większym lub mniejszym stopniu każdej branży gospodarki światowej. W Polsce określone uwarunkowania oraz polityka państwa spowodowały, że gospodarka wykazała się znaczną, w stosunku do innych krajów, odpornością na kryzys (Sawicka, 2011). Jak podkreślają eksperci, znaczny wpływ na taki stan rzeczy mieli nasi rodzimi przedsiębiorcy, którzy nie poddali się pesymistycznym nastrojom. Okres spowolnienia gospodarczego dla przedsiębiorców jest czasem trudnym, ale i, jak zauważa A. Sawicka (2011), niezwykle mobilizującym, zmusza ich on bowiem do rewizji własnych celów oraz podjęcia zmian - zarówno w odniesieniu do zarządzania własnym przedsiębiorstwem, jak i w odniesieniu do rynku.

Przedmiotem analizy w niniejszym referacie jest działalność gospodarstw agroturystycznych, ze szczególnym uwzględnieniem ich zachowań rynkowych i przedsiębiorczych w dobie kryzysu gospodarczego. Analizy dokonano na podstawie wyników badań przeprowadzonych na grupie gospodarstw agroturystycznych z całej Polski. Badania miały m.in. na celu rozpoznanie, czy respondenci dostrzegają jakieś zmiany w funkcjonowaniu swojego gospodarstwa, a w efekcie, czy odczuwają w jakimś stopniu wpływ kryzysu gospodarczego na funkcjonowanie prowadzonych przez nich przedsiębiorstw agroturystycznych.
\end{abstract}

\begin{abstract}
The economic crisis of the last few years has affected each sector of the world economy in some way. Specific conditions and governmental policy introduced in Poland meant that, in comparison to other countries, the economy demonstrated considerable resistance to the crisis (Sawicka, 2011). As experts point out, a significant impact in this area was made by Polish entrepreneurs, who did not give in to the pessimistic mood. For businesses, the period of economic downturn is difficult, but also, as noted by A. Sawicka (2011), extremely mobilising. This is due to the fact that crises force the owners to review their goals and implement changes - both in relation to the management of their own company, as well as in relation to the market.

The subjects of the analysis in this paper are agritourism activities, with particular emphasis on the market and entrepreneurial behaviour in times of economic crisis. The analysis was based on the results of research, conducted on a group of agritourism farms from across Poland. These studies were to identify whether respondents notice any changes in the operation of their farms, and, as a result, whether they feel any impact of the economic crisis on the functioning of these agritourism enterprises.
\end{abstract}

Słowa kluczowe: agroturystyka; gospodarstwa agroturystyczne; innowacyjność; przedsiębiorczość; kryzys gospodarczy; rodzinność

Key words: agritourism; agritourism farms; innovation; entrepreneurship; economic crisis; family environment 


\section{Wprowadzenie}

Światowy kryzys gospodarczy, którego pierwsze skutki zaczęto dostrzegać w 2008 r., dotyczył w mniejszym lub większym stopniu każdej branży gospodarki światowej. Jak pokazują analizy wielkości charakteryzujących kondycję rynku turystycznego, najwyraźniej skutki dekoniunktury gospodarczej w branży turystycznej ujawniły się w 2009 r. (Zdon-Korzeniowska, Rachwał, 2010). W Polsce określone uwarunkowania oraz polityka państwa spowodowały, że gospodarka wykazała się znaczną, w stosunku do innych krajów, odpornością na kryzys (Sawicka, 2011). Jak podkreślają eksperci, znaczny wpływ na taki stan rzeczy mieli nasi rodzimi przedsiębiorcy, którzy nie poddali się pesymistycznym nastrojom.

Przedmiotem analizy w niniejszym referacie jest działalność gospodarstw agroturystycznych, ze szczególnym uwzględnieniem ich zachowań rynkowych i przedsiębiorczych w dobie kryzysu gospodarczego. Realizacja powyższych celów oparta została na analizie literatury przedmiotu, wyników badań obcych oraz własnych badań bezpośrednich z wykorzystaniem techniki bezpośredniego wywiadu kwestionariuszowego. Badania własne Autorów były przeprowadzone z wykorzystaniem techniki bezpośredniego wywiadu kwestionariuszowego w okresie od stycznia do marca 2012 r. na obszarze całej Polski. Ankiety rozesłano droga e-mailową do grupy 1330 gospodarstw agroturystycznych z całej Polski. Zwrot kształtował się na poziomie 46 kwestionariuszy ankiet (46 kwestionariuszy ankiet było kompletnie i poprawnie wypełnionych i tylko te zostały poddane dalszej analizie).

\section{Przedsiębiorstwa agroturystyczne w Polsce}

Aktywność agroturystyczna cieszy się rosnącym zainteresowaniem zarówno w naszym kraju, jak i w innych państwach Unii Europejskiej. Jej popularność widoczna jest nie tylko od strony popytowej, gdzie ceniona jest jako atrakcyjna forma spędzania czasu wolnego, ale również od strony podażowej - jako alternatywna forma działalności rolniczej obejmująca ofertę pobytu u rodzin wiejskich prowadzących gospodarstwa rolne oraz zróżnicowane formy rekreacji w oparciu o specyficzne walory obszarów wiejskich (Dorocki, Zdon-Korzeniowska, 2012). W Polsce po okresie transformacji i nastaniu gospodarki wolnorynkowej typowa działalność rolnicza napotkała znaczące trudności związane m.in. z możliwością zbytu płodów rolnych, niskimi cenami i rosnącymi kosztami produkcji rolnej, co doprowadziło do nieefektywności i likwidacji znacznej części gospodarstw rolnych. Naturalną konsekwencją tego stanu rzeczy było poszukiwanie przez rolników nowych, alternatywnych form działalności i zarobkowania. Jedną z nich stała się właśnie agroturystyka.

Obserwuje się systematyczny wzrost liczby gospodarstw agroturystycznych (tab. 1.). Według danych za 2011 r. w Polsce funkcjonują ok. 7852 gospodarstwa agroturystyczne dysponujące łącznie 82694 miejscami noclegowymi. Stanowi to niemal 20-procentowy wzrost liczby gospodarstw agroturystycznych oraz prawie 55-procentowy wzrost liczby miejsc noclegowych w stosunku do $2002 \mathrm{r}$.

Zdecydowanie najwięcej gospodarstw agroturystyczny znajduje się w gminach należących do województw: małopolskiego i podkarpackiego. Nieco mniej (choć nadal stosunkowo dużo) gospodarstw agroturystycznych zlokalizowanych jest w województwach: warmińsko-mazurskim, dolnośląskim, pomorskim i podlaskim. Największy, bo aż ponad 250-procentowy przyrost liczby tych gospodarstw w stosunku do 2002 r. odnotowano w województwie kujawsko-pomorskim, ponad 80-procentowe przyrosty nastąpiły również w województwach dolnośląskim, podkarpackim i śląskim. Niektóre z województw odnotowały jednak zmniejszenie się liczby gospodarstw agroturystycznych. Około 50-procentowe spadki widoczne są w województwach lubuskim i mazowieckim, o ok. 25\% spadła również liczba gospodarstw agroturystycznych w województwie warmińsko-mazurskim i o 2,4\% w województwie podlaskim. 
We wszystkich województwach z wyjątkiem dolnośląskiego procentowa zmiana liczby miejsc noclegowych była większa niż procentowa zmiana liczby gospodarstw agroturystycznych. Ponadto, również w tych w województwach, w których odnotowano spadek liczby gospodarstw agroturystycznych (z wyjątkiem lubuskiego) odnotowano przyrost liczby miejsc noclegowych. Fakty te świadczą o zwiększeniu przez poszczególne gospodarstwa agroturystyczne swojej pojemności, tj. liczby oferowanych miejsc noclegowych.

Ogólnie można przyjąć, że podmioty oferujące usługi agroturystyczne (gospodarstwa agroturystyczne) w Polsce funkcjonują (Dorocki, Szymańska, Zdon-Korzeniowska, 2012):

- w ramach gospodarstw rolnych lub też

- są indywidualną działalnością gospodarczą prowadzoną na własny rachunek, zgodnie z zapisami ustawy o swobodzie działalności gospodarczej oraz ustawy o podatku dochodowym i w różnych formach organizacyjno-prawnych.

W drugim wypadku bez wątpienia możemy mówić o przedsiębiorstwach. Działalność agroturystyczna prowadzona w ramach gospodarstwa rolnego zdaniem Autorów również może być uznana de facto za przedsiębiorstwo. W związku z działalnością turystyczną rolnicy są zmuszeni spojrzeć na swoją działalność bardziej rynkowo - uwzględniać potrzeby klientów, zidentyfikować i śledzić działania konkurentów i w tym aspekcie podjąć działania na rzecz przygotowania odpowiedniej oferty, jej promocji i skalkulowania ceny (Dorocki, Szymańska, Zdon-Korzeniowska, 2012). Podsumowując, działalność agroturystyczna (czy to zarejestrowana jako działalność gospodarcza czy też prowadzona w ramach gospodarstwa rolnego) jest działalnością gospodarczą, a jej podstawowym celem jest zysk (Sznajder, Przezbórska, 2009).

Badane przedsiębiorstwa agroturystyczne funkcjonowały w obydwu wymienionych wyżej formułach, a geneza ich powstania była różna. Część z nich powstała z przekształcenia gospodarstwa rolnego, część z nich prowadziła wcześniej inną działalność gospodarczą, a część od początku swego istnienia zaplanowana była jako działalność związana ze świadczeniem usług agroturystycznych. Szczegółowy rozkład wyników badań w tym zakresie zaprezentowano na rycinie 1 .

Jak wynika z badań, ponad $67 \%$ badanych przedsiębiorstw agroturystycznych powstało z przekształcenia gospodarstwa rolnego. W przypadku ponad 17\% wcześniej prowadzona była inna działalność pozarolnicza. Ponad 15\% podmiotów uczestniczących w badaniu od początku funkcjonowało jako gospodarstwa agroturystyczne (por. ryc. 1A). Pod względem

Ryc. 1. Geneza (A) oraz struktura działalności rolniczej (B) badanych gospodarstw agroturystycznych
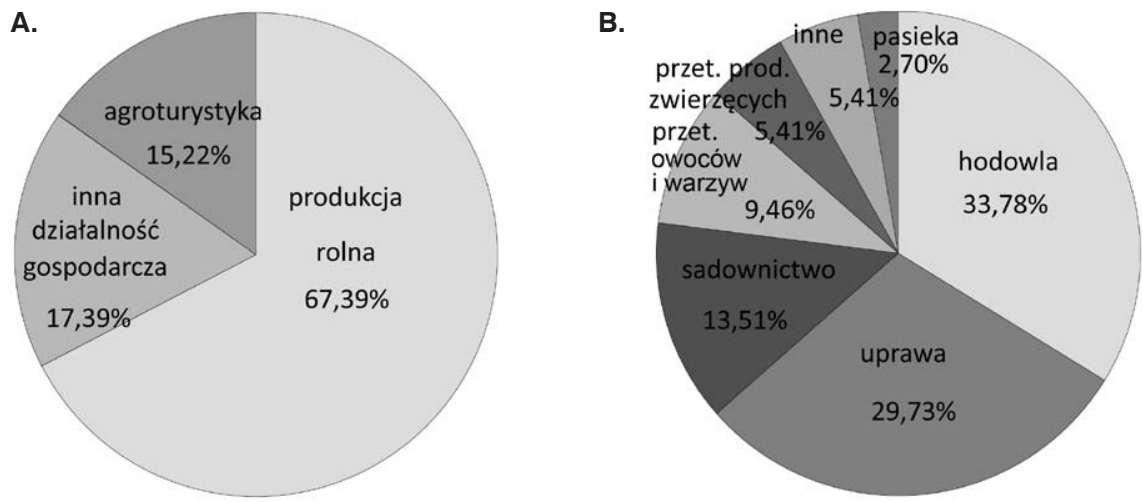

Źródło: opracowanie własne na podstawie wyników badań. 


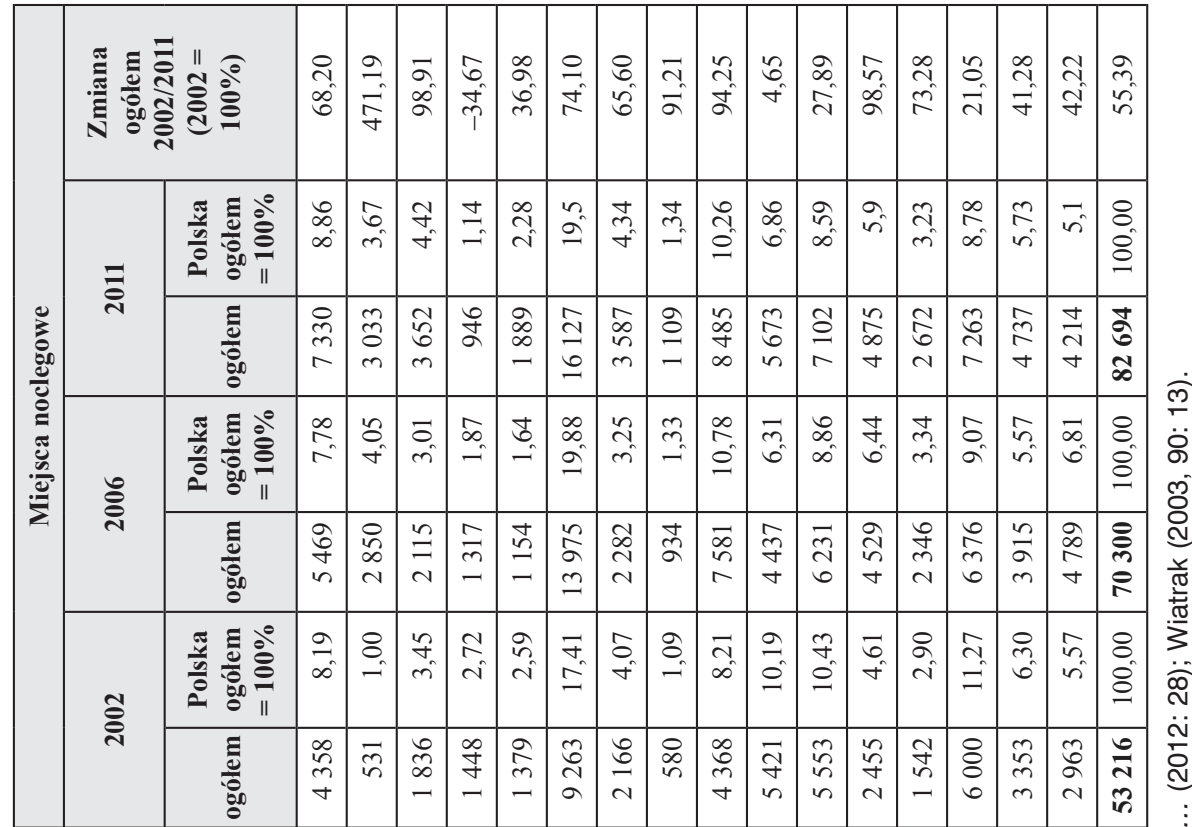

$\frac{\cdot \overline{2}}{\frac{2}{3}}$

3

包

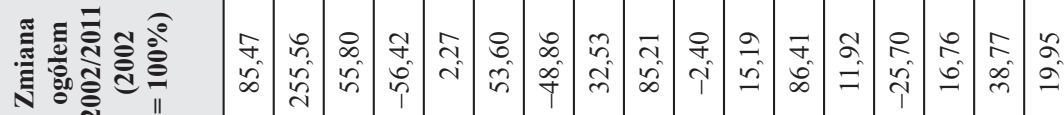

$\frac{1}{3}$

穴

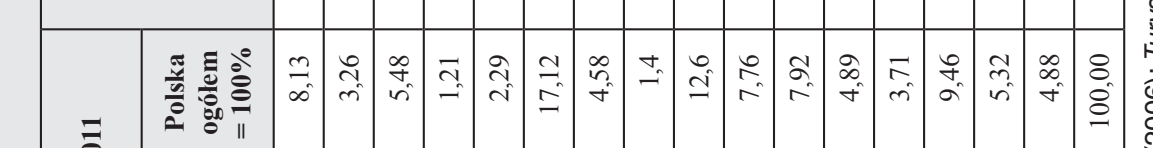

잉

¿

告

๘ ○ी

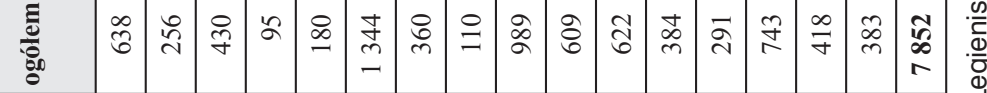

పे

들

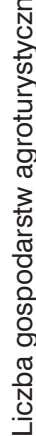

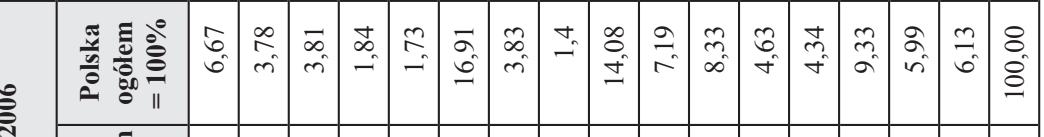

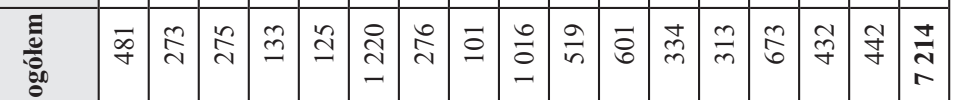

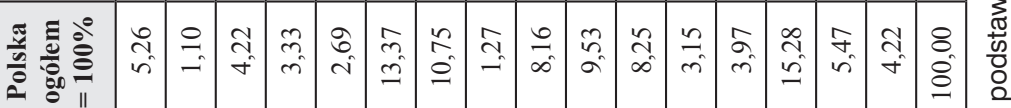

气ิ

\begin{tabular}{|c|c|c|c|c|c|c|c|c|c|c|c|c|c|c|c|c|c|}
\hline$\frac{\Xi}{0}$ & 寺 & $\mathbb{N}$ & $\stackrel{゚}{\sim}$ & $\frac{\infty}{\sim}$ & $\stackrel{゚}{\beth}$ & $\begin{array}{l}n \\
\infty \\
\infty\end{array}$ & $\stackrel{+}{?}$ & $\infty$ & 悫 & స్ర & 吕 & ֻั & $\stackrel{8}{\circ}$ & 8 & 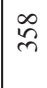 & $\stackrel{0}{\stackrel{0}{N}}$ & 先 \\
\hline
\end{tabular}

$\frac{2}{0}$

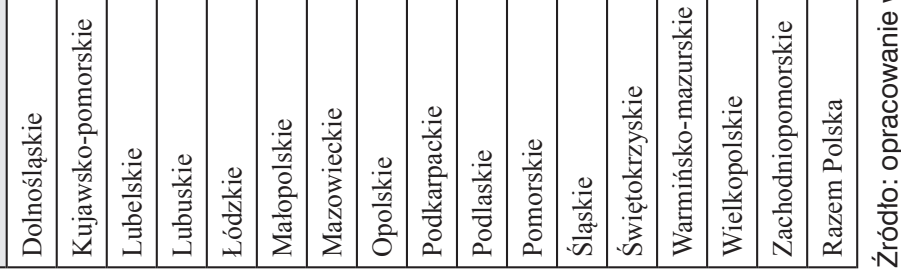


struktury działalności rolniczej w tych gospodarstwach, w których jest ona kontynuowana, to $\mathrm{w}$ przeważającej mierze wiąże się ona $\mathrm{z}$ hodowlą zwierząt $(33,78 \%)$ lub uprawą roślin (29,73\%). W ok. 13,5\% gospodarstw prowadzona jest działalność sadownicza, niespełna 10\% gospodarstw zajmuje się przetwórstwem owoców i warzyw, znacznie mniej przetwórstwem produktów zwierzęcych $(5,41 \%)$ i pszczelarstwem $(2,7 \%)$. W 5,41\% gospodarstw prowadzona jest inna niewymieniona wyżej działalność rolnicza (por. ryc. 1B).

\section{Skutki kryzysu w opinii gospodarstw agroturystycznych}

Okres spowolnienia gospodarczego dla przedsiębiorców jest czasem trudnym, ale i, jak zauważa A. Sawicka (2011), niezwykle mobilizującym. Zmusza on bowiem do rewizji celów oraz podjęcia zmian - zarówno w odniesieniu do zarządzania własnym przedsiębiorstwem, jak i w odniesieniu do rynku. Jak w czasie ostatnich kilku lat naznaczonych kryzysem gospodarczym poradziły sobie polskie gospodarstwa agroturystyczne? Czy dostrzegły, i w jakim zakresie, skutki dekoniunktury? Wspomniane we wstępie badania przeprowadzone na grupie gospodarstw agroturystycznych miały $\mathrm{m}$.in. na celu rozpoznanie, czy respondenci dostrzegają jakieś zmiany w funkcjonowaniu swojego gospodarstwa, a w efekcie, czy odczuwają w jakimś stopniu wpływ kryzysu gospodarczego na funkcjonowanie prowadzonych przez nich przedsiębiorstw agroturystycznych.

Jak wynika z przeprowadzonych badań, prawie 68\% respondentów dostrzegło zmiany w funkcjonowaniu swoich gospodarstw agroturystycznych w okresie ostatnich trzech lat, przy czym zdaniem 30,09\% były to zmiany pozytywnie wpływające na funkcjonowanie gospodarstwa, natomiast $31,74 \%$ dostrzegło zmiany negatywne (por. ryc. 2A i B).

Wśród pozytywnych zmian respondenci wymienili m.in. wzrost wysokości środków przeznaczonych na inwestycje (67\% badanych przedsiębiorstw - por. ryc. 3). W czasie kryzysu podmioty gospodarcze cechuje większa skłonność do oszczędzania niż inwestycji. Zwiększenie funduszy przeznaczonych przez gospodarstwa agroturystyczne na inwestycje może mieć dwojaką przyczynę: być może gospodarstwa te faktycznie nie poddały się pesymistycznym nastrojom i rzeczywiście inwestowały więcej lub pozyskiwały one na inwestycje fundusze unijne. Bez względu jednak na przyczynę tego stanu rzeczy zwiększone środki na inwestycje były zjawiskiem pozytywnym nie tylko dla badanych przedsiębiorstw agroturystycznych, ale i dla polskiej gospodarki.

Ryc. 2. Opinie gospodarstw agroturystycznych na temat dostrzegania zmian w ich funkcjonowaniu w okresie ostatnich trzech lat (A) i na temat charakteru tych zmian (B)

A.

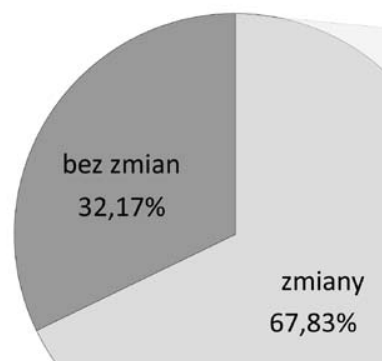

B.

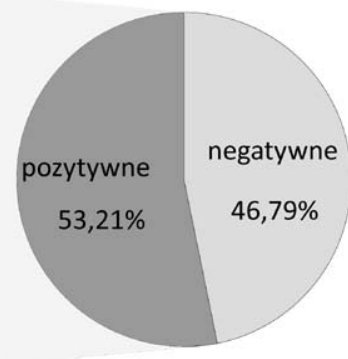

Źródło: wyniki badań własnych. 
Ryc. 3. Zmiany w funkcjonowaniu gospodarstw agroturystycznych zaobserwowane przez ich właścicieli w okresie ostatnich trzech lat
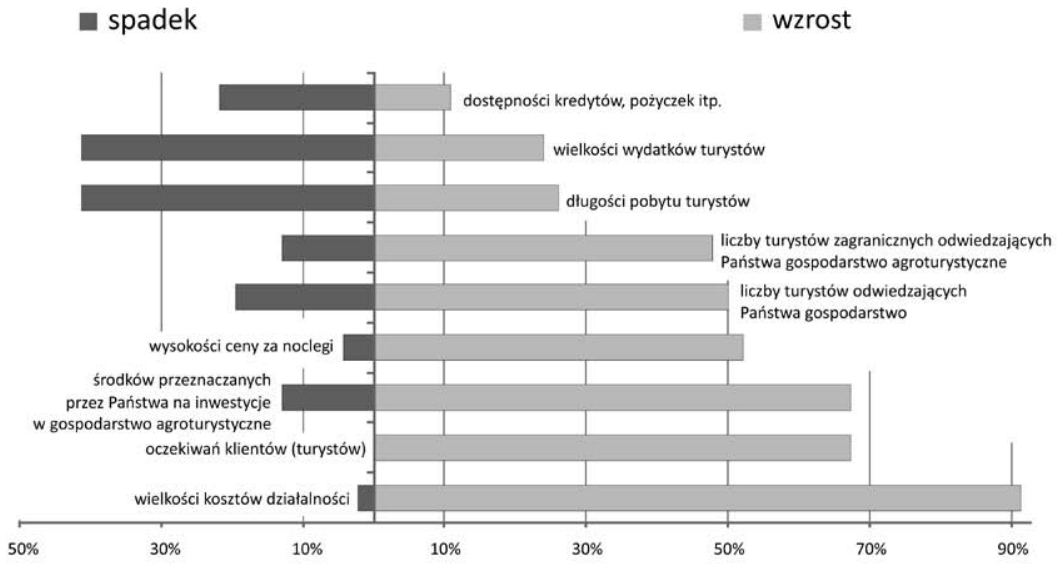

Źródło: wyniki badań własnych.

Wśród pozytywnych zmian zaobserwowanych przez badane podmioty był również wzrost liczby turystów odwiedzających gospodarstwa (50\% badanych), zwłaszcza turystów zagranicznych (47,8\% badanych). Choć jednocześnie odnotowano skrócenie czasu pobytu turystów w gospodarstwie (w 41,3\% przypadków) i wielkości ich wydatków (również w 41,3\% przypadków) oraz wzrost wymagań turystów (wg 67,4\% badanych gospodarstw) - co gospodarstwa odnotowały jako zjawiska dla nich niekorzystne. Najczęściej jednak wymienianym zjawiskiem niekorzystnym był wzrost kosztów działalności badanych przedsiębiorstw $(91,3 \%)$ oraz spadek dostępności kredytów i pożyczek (67\%). Pewną rekompensatą dla gospodarstw mógł być jednak zauważony przez ich właścicieli wzrost cen za oferowane usługi agroturystyczne $(52,2 \%$ gospodarstw).

Wśród innych pojedynczo podkreślanych zmian, jakie w ostatnich trzech latach zaszły w funkcjonowaniu gospodarstw agroturystycznych, wymieniano również następujące kwestie:

- nieprzeprowadzanie remontów,

- niepodnoszenie standardu tak jak w poprzednich latach,

- wzrost wydatków na promocję,

- wzrost opłat za wodę i ścieki,

- wzrost zainteresowania warsztatami i pokazami,

- zmiany w preferencjach żywieniowych (wzrost potrzeb klientów),

- wzrost cen żywności (wyżywienia).

Przeprowadzone badania pozwalają stwierdzić, że gospodarstwa agroturystyczne odczuły skutki dekoniunktury gospodarczej w swoim funkcjonowaniu w stosunkowo niedużym stopniu - de facto tylko nieco ponad 31\% gospodarstw dostrzegło negatywne zmiany. Najbardziej dotkliwymi były te związane ze wzrostem kosztów działalności. Większość gospodarstw nie zmniejszyła, a nawet zwiększyła swoje wydatki inwestycyjne, mimo dostrzeżonego spadku dostępności kredytów i pożyczek.

Jak się wydaje zatem, polskie gospodarstwa agroturystyczne nie uległy pesymistycznym nastrojom i dość dobrze poradziły sobie w okresie spadku koniunktury. Przyczyn tego stanu rzeczy możemy upatrywać w wielu czynnikach, m.in. w wielkości gospodarstw agroturystycznych, które najczęściej są mikro- lub co najwyżej małymi przedsiębiorstwami, odznaczającymi się przedsiębiorczością i elastycznością, tj. zdolnością dostosowywania się do zmieniających się 
warunków otoczenia (Zakrzewska-Bielawska, 2011a, 2011b). A, jak wskazuje A. Zakrzewska-Bielawska (2011b: 7), „umiejętność adaptacji jest niezwykle istotna w warunkach wahań cyklu koniunkturalnego, zwłaszcza w dobie kryzysu i spowolnienia gospodarczego".

Niebagatelne znaczenie w radzeniu sobie z kryzysem w przypadku gospodarstw agroturystycznych może mieć również ich rodzinny charakter. Owa rodzinność działalności gospodarczej wydaje się być, na podstawie uzyskanych wyników badań, dużym atutem i wsparciem dla funkcjonowania gospodarstw agroturystycznych w okresie dekoniunktury gospodarczej.

\section{Rodzinność i innowacyjność gospodarstw agroturystycznych a kryzys gospodarczy}

Działalność agroturystyczna ze względu na swoją specyfikę związaną ze świadczeniem usług turystycznych w oparciu o zasoby gospodarstwa rolnego lub równoważnego (często również domowego) jest od strony podażowej biznesem wybitnie rodzinnym. Niemal 100\% gospodarstw agroturystycznych możemy zakwalifikować do grona przedsiębiorstw o cechach „,rodzinności”. Nie wnikając w definicję pojęcia firma rodzinna, bez wątpienia należy stwierdzić, że przedsiębiorstwa tego typu ze względu na swój specyficzny charakter i związany z tym sposób funkcjonowania mogą liczyć na pewne, wynikające stąd „korzyści”, które wydają się być szczególnie istotne w czasach kryzysu gospodarczego. Pogląd ten potwierdzają gospodarstwa agroturystyczne uczestniczące w badaniach. Wypowiedź „W sytuacji kryzysowej bardziej można liczyć na wsparcie (również finansowe) członków rodziny niż osób do niej nienależących" uzyskała rangę 0,96 (tab. 2). Wsparcie to zdaniem badanych gospodarstw agroturystycznych wynika z wielu względów, m.in. z faktu, że:

- członkowie rodziny są bardziej zaangażowani w pracę gospodarstwa $(1,33)$,

- pracownicy będący członkami rodziny są bardziej lojalni $(1,56)$,

- członkowie rodziny bardziej angażują się w realizowane przedsięwzięcia $(1,54)$,

- członkowie rodziny bardziej dbają o zasoby majątkowe gospodarstwa $(1,48)$.

Niewątpliwie czynnikiem mobilizującym i sprzyjającym przetrwaniu w czasach kryzysu jest fakt, ,iż w przypadku przedsiębiorstw rodzinnych w znacznie większym stopniu niż w przypadku innych przedsiębiorstw ich właściciele patrzą w przyszłość, myśląc o sukcesji przedsiębiorstwa" (Dorocki, Szymańska, Zdon-Korzeniowska, 2012: 59). Perspektywa przejęcia przedsiębiorstwa w przyszłości przez następne pokolenia może wyzwalać w przedsiębiorcach dodatkowe siły mobilizujące podyktowane chęcią zapewnienia przyszłości swoim następcom.

Tab. 2. Opinie ankietowanych na temat wad i zalet płynących z prowadzenia działalności rodzinnej

\begin{tabular}{|c|c|c|}
\hline Lp. & Opinie ankietowanych & $\begin{array}{c}\text { Ocena } \\
\text { rangowa }\end{array}$ \\
\hline 1. & Członkowie rodziny są bardziej zaangażowani w pracę gospodarstwa. & 1,33 \\
\hline 2. & $\begin{array}{l}\text { Zarządzanie członkami rodziny jest znacznie łatwiejsze niż osobami } \\
\text { spoza niej. }\end{array}$ & 0,00 \\
\hline 3. & $\begin{array}{l}\text { Konflikty rodzinne/pokoleniowe przenoszone są na grunt zawodowy, } \\
\text { co utrudnia pracę. }\end{array}$ & $-0,52$ \\
\hline 4. & Członkowie rodziny bardziej dbają o zasoby majątkowe gospodarstwa. & 1,48 \\
\hline 5. & $\begin{array}{l}\text { W sytuacji kryzysowej bardziej można liczyć na wsparcie (również } \\
\text { finansowe) członków rodziny niż osób do niej nienależących. }\end{array}$ & 0,96 \\
\hline 6. & Członkowie rodziny bardziej angażują się w realizowane przedsięwzięcia. & 1,54 \\
\hline 7. & Pracownicy będący członkami rodziny są bardziej lojalni, godni zaufania. & 1,56 \\
\hline
\end{tabular}

Źródło: wyniki badań własnych. 
Poza elastycznością działania i potencjałem wynikającym z „rodzinności” niewielkich (mikroi małych) przedsiębiorstw do czynników sprzyjających walce i radzeniu sobie z kryzysem gospodarczym zaliczyć możemy również innowacyjność. Jak pokazują doświadczenia krajów wysoko rozwiniętych, „w zainicjowaniu innowacji i procesie ich rozpowszechniania dużą rolę odgrywają małe i średnie przedsiębiorstwa" (Lisowska, 2008: 35).

Zdaniem właścicieli gospodarstw agroturystycznych uczestniczących w badaniu starają się oni podejmować innowacyjne działania. Jednym z przejawów takiej postawy są innowacje produktowe. Aż $63 \%$ badanych przedsiębiorstw agroturystycznych zadeklarowało, że w ubiegłym roku wprowadziło jakąś nowość w ofercie. Pomysły w zakresie wprowadzanych zmian i nowości są zazwyczaj efektem sugestii gości (36,4\%), obserwacji działalności innych gospodarstw $(24,2 \%)$ lub stanowią pomysły własne albo członków rodziny (24,2\%). Najrzadziej inspiracją dla wprowadzanych nowości są pomysły zaczerpnięte ze szkoleń, w których uczestniczą pracownicy przedsiębiorstw agroturystycznych - stanowią one zaledwie 3,0\% ogółu wszystkich pomysłów na wprowadzane innowacje. Źródła innowacji produktowych w badanych gospodarstwach agroturystycznych zaprezentowano na rycinie 4 .

Ryc. 4. Źródła innowacji produktowych w gospodarstwach agroturystycznych

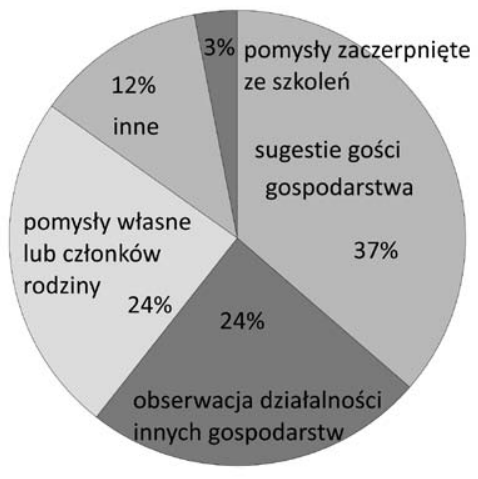

Źródło: wyniki badań własnych.

Podsumowując, należy podkreślić, że badane gospodarstwa agroturystyczne w stosunkowo niewielkim stopniu odczuły skutki dekoniunktury gospodarczej. Większość z nich w okresie trzech ostatnich lat nie odczuła żadnych zmian. Wśród wielu innych czynników taki stan rzeczy być może wynika również z faktu, że polska gospodarka w ogóle w niewielkim stopniu odczuła skutki ogólnoświatowego kryzysu gospodarczego. Najbardziej odczuwalną konsekwencją dekoniunktury gospodarczej w opinii właścicieli gospodarstw agroturystycznych, którzy w ogóle dostrzegli jakieś zmiany w okresie ostatnich trzech lat, był wzrost kosztów działalności - na fakt ten wskazało ponad $90 \%$ z nich.

Istotnym atutem gospodarstw agroturystycznych w walce z kryzysem gospodarczym wydaje się być ich rodzinny charakter. Bliskie więzi łączące współpracowników sprzyjają lepszej współpracy, efektywniejszej wymianie myśli i pomysłów, a w efekcie - większej innowacyjności podmiotów gospodarczych i większemu zaangażowaniu w działalność przedsiębiorstwa (związek emocjonalny, finansowy, poświęcony czas i wynikające stąd wsparcie emocjonalne czy finansowe, które uznać należy za szczególnie cenne w okresach dekoniunktury gospodarczej). 


\section{Literatura}

Dorocki, S., Rachwał, T., Szymańska, A.I., Zdon-Korzeniowska, M. (2012). Spatial Conditions for Agritourism Development on the Example of Poland and France. Current Issues of Tourism Research, 2(2), 20-29.

Dorocki, S., Szymańska, A.I., Zdon-Korzeniowska, M. (2012). Polskie gospodarstwa agroturystyczne jako przedsiębiorstwa rodzinne. Przedsiębiorczość i Zarządzanie, 8(8), 45-60.

Dorocki, S., Zdon-Korzeniowska, M. (2012). Agroturystyka jako alternatywna forma działalności rolniczej - przyktad Polski i Francji.

Lisowska, R. (2008). Bariery rozwoju działalności innowacyjnej małych i średnich przedsiębiorstw na terenach wiejskich na przykładzie województwa łódzkiego. W: N. Daszkiewicz (red.), Małe i średnie przedsiębiorstwa. Szanse i zagrożenia rozwoju, Warszawa: CeDeWu Sp. z o.o., 35-50.

Rachwał, T., Zdon-Korzeniowska, M. (2011). Turystyka w warunkach światowego kryzysu gospodarczego. Prace Komisji Geografii Przemystu Polskiego Towarzystwa Geograficznego, 18, 116-128.

Sawicka, A. (2011). Funkcjonowanie średnich firm w okresie spowolnienia gospodarczego. W: A. Zakrzewska-Bielawska, (red.), Wyzwania rozwojowe matych $i$ średnich przedsiębiorstw. Innowacje, technologie, kryzys, Warszawa: Difin, Warszawa, 255-269.

Sznajder, M., Przezbórska, L., (2006), Agroturystyka, PWE, Warszawa.

Zakrzewska-Bielawska, A. (2011a). Ocena innowacyjności małych i średnich przedsiębiorstw sektora ICT. W: A. Zakrzewska-Bielawska, (red.), Wyzwania rozwojowe matych i średnich przedsiębiorstw. Innowacje, technologie, kryzys, Warszawa: Difin, Warszawa, 37-53.

Zakrzewska-Bielawska, A. (2011b). Wprowadzenie. W: A. Zakrzewska-Bielawska, (red.), Wyzwania rozwojowe matych $i$ średnich przedsiębiorstw. Innowacje, technologie, kryzys, Warszawa: Difin, Warszawa, 7-8.

Sławomir Dorocki, dr, Uniwersytet Pedagogiczny im. Komisji Edukacji Narodowej w Krakowie, Instytut Geografii, Zakład Przedsiębiorczości i Gospodarki Przestrzennej

Absolwent studiów z zakresu geografii społeczno-ekonomicznej Uniwersytetu Pedagogicznego w Krakowie, doktor nauk humanistycznych w dyscyplinie historia (Instytut Europeistyki - Uniwersytet Jagielloński). Adiunkt w Instytucie Geografii Uniwersytetu Pedagogicznego w Krakowie. Zainteresowania badawcze skupiają się wokół problematyki regionów i procesów regionalizacji społeczno-gospodarczej, ze szczególnym uwzględnieniem zróżnicowania przestrzeni europejskiej oraz procesów integracji europejskiej i uwarunkowań historycznych.

Sławomir Dorocki, PhD, Pedagogical University of Cracow, Institute of Geography, Department of Entrepreneurship and Spatial Management.

Sławomir Dorocki graduated from the Pedagogical University in Cracow, with an MA in geography, and from the Jagiellonian University (Institute of European Studies), with a PhD in History. Adiunkt (assoc. professor) at the Pedagogical University in Cracow, Institute of Geography. Research interests include regional problems and processes of socio-economic regionalization, with particular emphasis on the diversity of Europe, processes of European integration and historical conditions.

Anna I. Szymańska, dr, Uniwersytet Pedagogiczny im. Komisji Edukacji Narodowej w Krakowie, Instytut Geografii, Zakład Przedsiębiorczości i Gospodarki Przestrzennej.

Absolwentka studiów magisterskich z zakresu zarządzania i marketingu Uniwersytetu Ekonomicznego w Krakowie, doktor nauk ekonomicznych w zakresie nauk o zarządzaniu (Katedra Analizy Rynku i Badań Rynkowych Uniwersytet Ekonomiczny w Krakowie). Adiunkt w Zakładzie Przedsiębiorczości i Gospodarki Przestrzennej Uniwersytetu Pedagogicznego w Krakowie. 
Jej zainteresowania naukowo-badawcze oscylują wokół problematyki potrzeb, preferencji i zachowań rynkowych konsumentów, jak również zagadnień z obszaru przedsiębiorczości i innowacyjności przedsiębiorstw ze szczególnym uwzględnieniem sektora MŚP.

Anna I. Szymańska, PhD, Pedagogical University of Cracow, Institute of Geography, Department of Entrepreneurship and Spatial Management.

Anna Irena Szymańska graduated from the University of Economics in Cracow, with a MA degree in Management and Marketing, a $\mathrm{PhD}$ degree in Economic Sciences in the field of management sciences (Department of Market Analysis and Marketing Research - University of Economics in Cracow). Adiunkt (assoc. professor) in Department of Entrepreneurship and Spatial Management at the Pedagogical University of Cracow. Research interests related to issues of consumer needs, preferences and market behaviour, as well as issues in areas of entrepreneurship and innovation, with particular emphasis on the SME sector.

Malgorzata Zdon-Korzeniowska

Malgorzata Zdon-Korzeniowska

Adres/Address: dr, Uniwersytet Pedagogiczny im. Komisji Edukacji Narodowej w Krakowie, Instytut Geografii, Zakład Przedsiębiorczości i Gospodarki Przestrzennej.

Absolwentka studiów magisterskich Uniwersytetu Ekonomicznego w Krakowie (kierunek: ekonomia, specjalność: przedsiębiorczość i innowacje), doktor nauk ekonomicznych w dyscyplinie nauk o zarządzaniu (Wydział Zarządzania i Komunikacji Społecznej Uniwersytetu Jagiellońskiego). Adiunkt w Zakładzie Przedsiębiorczości i Gospodarki Przestrzennej Instytutu Geografii Uniwersytetu Pedagogicznego w Krakowie. Jej zainteresowania naukowo-badawcze ogniskują się wokół problematyki zarządzania turystyką na poziomie lokalnym i regionalnym, ze szczególnym uwzględnieniem zrównoważonego rozwoju i budowy produktów turystycznych o charakterze lokalnym i regionalnym, a także integracji i koordynacji działań podmiotów zaangażowanych w ten proces, ze szczególnym uwzględnieniem roli samorządu terytorialnego.

MA in economy, $\mathrm{PhD}$ in economic sciences, Pedagogical University of Cracow, Institute of Geography, Department of Entrepreneurship and spatial Management. Małgorzata Zdon-Korzeniowska graduated from the Cracow University of Economics (Departament of Economics, specializing in Entrepreneurship and Innovation) with a MA degree in Economy, and from Faculty of Management and Social Communication, Jagiellonian University, Jagiellonian University, with a $\mathrm{PhD}$ in economic sciences in the discipline of management studies. Adiunkt (assoc. professor) at the Pedagogical University in Cracow, Institute of Geography, Department of Entrepreneurship and Spatial Management. Research interests center around the issues of tourism management at the local and regional level, with particular emphasis on sustainable development and the construction of local and regional tourist products, as well as the integration and coordination of the actors involved in this process, with particular emphasis on the role of local governments.

Uniwersytet Pedagogiczny im. Komisji Edukacji Narodowej w Krakowie ul. Podchorążych 2, 30-638 Kraków, Polska e-mail: sdorocki@up.krakow.pl; aszym@up.krakow.pl; mkorzen@up.krakow.pl 


\title{
Mirosław Włodarczyk
}

Społeczna Akademia Nauk

w Lodzi

Jerzy Janczewski

Akademia Humanistyczno-Ekonomiczna

w Lodzi

\section{Zarządzanie logistyką zwrotną w usługach motoryzacyjnych}

\section{Reverse logistics management in automotive services}

\begin{abstract}
Streszczenie
W przeszłości systemy logistyczne jedynie wspierały procesy przeprowadzane w sposób klasyczny przez przepływ materiałów od producentów i dystrybutorów do użytkownika końcowego. Producenci nie czuli się odpowiedzialni za swoje produkty po ich zużyciu. Zużyte produkty były wyrzucane lub spalane ze szkodą dla środowiska. Rosnąca świadomość ekologiczna konsumentów i ustawodawstwo zmusiły producentów do zainteresowania się powtórnym użyciem produktów i materiałów. Logistyka zwrotna różni się znacznie od logistyki tradycyjnej w podejściu do wszystkich operacji logistycznych w łańcuchu dostaw. W niniejszym artykule główne problemy logistyki zwrotnej przedstawiono dla zarządzania odzyskiem produktów w usługach motoryzacyjnych, łącznie z różnymi procesami recyklingu i sprzedaży odzyskanych towarów. Szczególną uwagę zwrócono na połączenie metod przynoszących maksimum zysków i mniej szkody dla środowiska.
\end{abstract}

\begin{abstract}
In the past, logistic systems supported only the processes carried out in the traditional manner of material flow from manufacturers and distribution to the end user. Manufacturers did not feel responsible for their products after consumer use. Used products were disposed of, or incinerated, with damage to the environment. The growing environmental consciousness of both consumers and legislators forced manufacturers to pay attention to the reuse of products and materials. Reverse logistics differs considerably from logistics, referring to all logistics operations within a supply chain. Main problems of reverse logistics have been presented on the example of product recovery management in automotive services, including various processes of recycling and selling of recovered goods. Special attention was given to the combination of methods, yielding maximum benefits and less damage to the environment.
\end{abstract}

Słowa kluczowe: logistyka; logistyka zwrotna; recykling; usługi motoryzacyjne Key words: logistics; reverse logistics; recycling; automotive services 


\section{Wprawadzenie}

Przyrost liczby samochodów na świecie oprócz wielu korzyści dla ich użytkowników i producentów stwarza liczne problemy logistyczne, które obejmują procesy zaopatrzenia, produkcji i dystrybucji samochodów, a przede wszystkim procesy posprzedażowe i procesy eksploatacji pojazdów - zwłaszcza ich obsługę i naprawę, ponowną sprzedaż używanych i likwidację w ostatnim stadium. W każdym z tych obszarów konieczne są sprawne i efektywne działania pod względem ekonomicznym, działania mające na celu jak najlepsze zaspokojenie potrzeb i wymagań klienta oraz działania zgodne z zasadami zrównoważonego rozwoju i poszanowania środowiska naturalnego. O ile zadania i działania logistyczne w kierunku przepływów materialnych i informacyjnych od producentów samochodów do ich użytkowników są dość dobrze rozpoznane i zbadane, o tyle działania logistyczne w obszarze procesów posprzedażowych, a także obsługi, naprawy, ponownej sprzedaży i likwidacji nie są dostatecznie rozpoznane i wymagają szczegółowych badań. Większość tych działań ma odwrotny charakter i jest domeną logistyki zwrotnej. Celem artykułu jest wskazanie roli i znaczenia logistyki zwrotnej w usługach motoryzacyjnych zwłaszcza w sektorach serwisowania, ponownej sprzedaży i likwidacji pojazdów, które są integralnym elementem zaplecza technicznego motoryzacji i mają decydujący wpływ na efektywność eksploatacji samochodów. Można tutaj postawić tezę, że poprawa efektywności eksploatacji samochodu i efektywności przedsiębiorstwa zajmującego się jego serwisowaniem, ponowną sprzedażą bądź likwidacją leży m.in. w obszarze zarządzania powrotnymi strumieniami towarów pozyskanymi w wyniku odzysku odpadów z procesów użytkowania bądź obsługi i naprawy oraz z likwidacji samochodu. Zatem skierowanie uwagi przedsiębiorstw z sektora usług motoryzacyjnych na procesy powrotne może być szansą dla rozwoju ich przedsiębiorczości, a tym samym łagodzenia skutków spowolnienia tempa gospodarki i sprawnego funkcjonowania w warunkach kryzysu gospodarczego.

\section{Logistyka zwrotna}

Działania i idee logistyczne są tak stare, jak gospodarowanie, i obejmują: obsługę klienta, prognozowanie popytu, przepływ informacji i przepływ pieniędzy, kontrolę zapasów, czynności manipulacyjne, realizowanie zamówień, naprawy i zaopatrzenie w części, lokalizację zakładów produkcyjnych i magazynów, procesy zaopatrzeniowe, transport i składowanie, obsługę zwrotów i gospodarowanie odpadami (Ciesielski, 2000: 2). W przypadku zwrotów dochodzą dodatkowe działania logistyczne, które nie występują w logistyce o tradycyjnym kierunku.

W literaturze logistyka zwrotna jest terminem stosunkowo młodym i być może dlatego nie ma jeszcze zgodności co do jej ostatecznej definicji, zwłaszcza że wiele kontrowersji wzbudza fakt, iż te same produkty mogą przepływać na przemian w różnych kierunkach (ryc. 1). Logistyka zwrotna znana jest również pod pojęciami logistyka odwrotna, logistyka odpadów, logistyka utylizacji, ekologistyka, logistyka odwrócona, logistyka recyrkulacji, logistyka powtórnego zagospodarowania, logistyka odzysku, logistyka posprzedażowa, downcycling lub logistyka wsteczna. Wybrane pokrewne pojęcia logistyki zwrotnej zaprezentowano w tabeli 1. Pod koniec lat 90. XX w. D.S. Rogers i R.S. Tibben-Lembke zdefiniowali logistykę zwrotną jako proces planowania, implementowania i kontrolowania efektywności przepływu surowców, zapasów w toku, dóbr finalnych i związanych z nimi informacji z punktu wykorzystania do punktu pochodzenia w celu odzyskania wartości lub właściwej utylizacji (Rogers, Tibben-Lembke, 1998: 2). Definicja ta nie uwzględniała opakowań i dlatego kilka lat później finansowana przez Unię Europejską Europejska Grupa Robocza ds. Logistyki Zwrotnej rozszerzyła ten pogląd i zdefiniowała logistykę zwrotną jako proces planowania, implementowania i kontrolowania zwrotnego przepływów surowców, zapasów, opakowań i gotowych wyrobów z punktu produkcji, dystrybucji lub wykorzystania do punktu odzysku lub właściwego usunięcia (Verstrepen i in., 2007: 304). 
Ryc. 1. Różne możliwości przepływów i zwrotów produktów

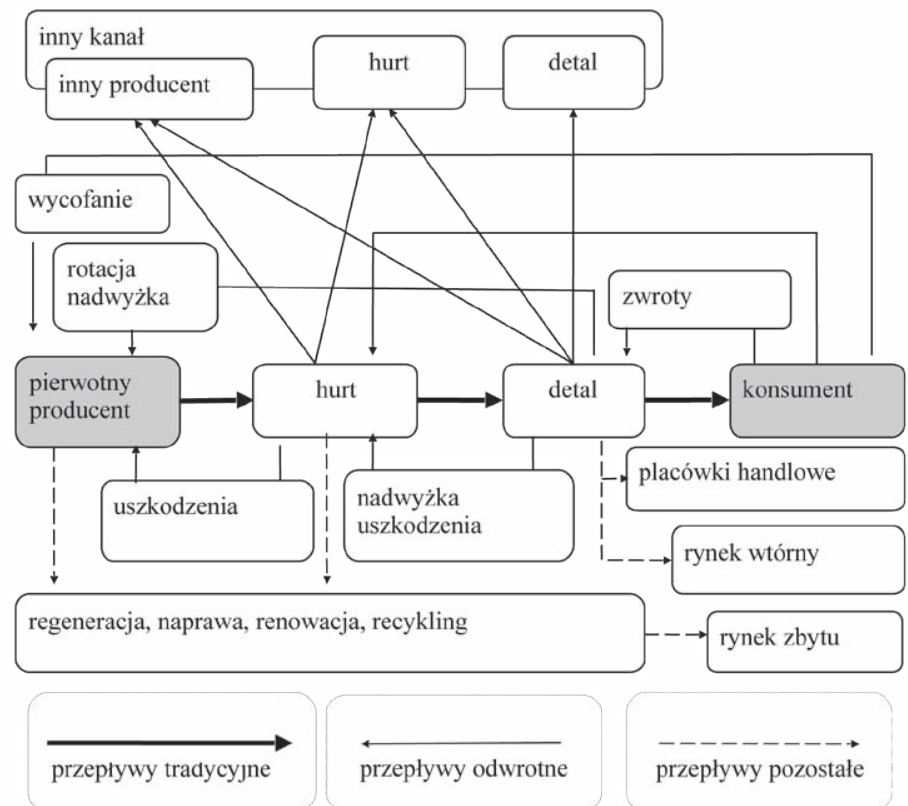

Źródło: opracowanie własne autorów na podstawie: Quesada (2003: 12).

Tab. 1. Wybrane pojęcia pokrewne z logistyką zwrotną

\begin{tabular}{|l|l|}
\hline \multicolumn{1}{|c|}{ Pojęcie } & \multicolumn{1}{c|}{ Definicja } \\
\hline Ekologistyka & $\begin{array}{l}\text { Zintegrowany system, który: opiera się na koncepcji zarządzania recyrkulacyjnymi } \\
\text { przepływami strumieni materiałów odpadowych w gospodarce oraz przepływami } \\
\text { sprzężonych z nimi informacji, zapewnia gotowość i zdolność efektywnego groma- } \\
\text { dzenia, segregacji, przetwarzania oraz ponownego wytwarzania odpadów według } \\
\text { przyjętych zasad technicznych i procesowych, spełniających wymogi normowe } \\
\text { i prawne ochrony środowiska, umożliwia podejmowanie technicznych i organizacyj- } \\
\text { nych decyzji w kierunku zmniejszania (minimalizacji) tych negatywnych skutków } \\
\text { oddziaływania na środowisko (Korzeń, 2001: 17). }\end{array}$ \\
\hline $\begin{array}{l}\text { Logistyka } \\
\text { utylizacji }\end{array}$ & $\begin{array}{l}\text { Zastosowanie koncepcji logistyki w odniesieniu do pozostałości, w celu wywołania } \\
\text { ekonomicznie i ekologicznie skutecznego ich przepływu, przy jednoczesnej transfor- } \\
\text { macji przestrzenno-czasowej, włącznie ze zmianą ilości i gatunku (Pfohl, 1998: 227). }\end{array}$ \\
\hline $\begin{array}{l}\text { Logistyka } \\
\text { recyrkulacji }\end{array}$ & $\begin{array}{l}\text { Sugeruje, że produkt, bądź opakowanie, krąży wielokrotnie w ramach zamkniętej } \\
\text { pętli łańcucha dostaw (Michniewska, 2006: 29). }\end{array}$ \\
\hline Downcycling & $\begin{array}{l}\text { Proces przetwarzania odpadów lub bezużytecznych produktów w nowe materiały } \\
\text { lub produkty o niższej jakości i funkcjonalności (Michniewska, 2006: 29). }\end{array}$ \\
\hline Odpady & $\begin{array}{l}\text { Wszystkie substancje stałe i ciekłe (z wyjątkiem ścieków), powstałe w wyniku dzia- } \\
\text { łalności gospodarczej lub bytowania człowieka, które są zgodnie z decyzją ich dyspo- } \\
\text { nenta nieprzydatne w miejscu i czasie, w którym powstały (Szołtysek, 2009: 81). }\end{array}$ \\
\hline $\begin{array}{l}\text { Logistyka } \\
\text { odwrotna }\end{array}$ & $\begin{array}{l}\text { Zastosowanie koncepcji logistyki w odniesieniu do pozostałości, aby w ten sposób } \\
\text { spowodować ekonomicznie i ekologicznie skuteczny przepływ pozostałości, przy jed- } \\
\text { noczesnej transformacji przestrzenno-czasowej, włącznie ze zmianą ilości i gatunku } \\
\text { (Bendkowski, Wengierek, 2002: 10). }\end{array}$ \\
\hline
\end{tabular}

Źródło: opracowanie własne autorów. 
W słowniku Reverse Logistics Executive Council (RLEC) sformułowanie terminu logistyka zwrotna jest podobne do definicji Rogersa i Tibben-Lembke'a i oznacza proces planowania, implementowania i kontrolowania przepływu surowców, zapasów w toku, dóbr finalnych oraz powiązanych $\mathrm{z}$ tymi strumieniami informacji z miejsca konsumpcji do punktu pochodzenia dobra, w celu odzyskania jego wartości lub przynajmniej części zainwestowanych uprzednio aktywów bądź właściwej utylizacji produktu. Również słownik Council of Supply Chain Management Profesiolnalss (CSCMP) podaje definicję logistyki zwrotnej, według której jest to wyspecjalizowany segment logistyki, koncentrujący się na przepływach, zarządzaniu produktami oraz zasobami po akcie sprzedaży i po ich dostawie do konsumenta.

Zdaniem D.F. Blumberga procesy logistyki zwrotnej występują zarówno w zamkniętych cyklach, jak i oddzielnie, i obejmują pełną koordynację i kontrolę fizycznego odbioru i dostarczania materiałów, części i produktów bezpośrednio do przetworzenia i recyklingu lub innego zadysponowania, jak i powrotu do obszaru stosowania (Blumberg, 2005: 22).

Precyzując przytoczone definicje, można stwierdzić, że logistyka zwrotna jest procesem odwrotnego przepływu produktów od ich typowego przeznaczenia do przeznaczenia końcowego w celu odzyskania ich wartości lub właściwej utylizacji, przy czym samo przeznaczenie końcowe może być w praktyce różnie rozumiane i interpretowane. Zatem koncepcja logistyki zwrotnej obejmuje przepływy odwrotne, które charakteryzują się przeciwnym kierunkiem i mniejszą wartością w stosunku do głównego strumienia towarów i usług oraz mniejszym natężeniem przepływu (Sadowski, 2009a).

J. Szołtysek na podstawie przeglądu rozmaitych definicji logistyki zwrotnej zarówno autorów polskich, jak i zagranicznych proponuje definicje, w której określa logistykę zwrotną jako ogół procesów zarządzania przepływami odpadów (w tym produktów uszkodzonych) i informacji (związanych z tymi przepływami), od miejsc ich powstawania (pojawiania się) do miejsc ich przeznaczenia, w celu odzyskania wartości (przez naprawę, recykling lub przetworzenie) lub właściwego ich unieszkodliwienia i długotrwałego składowania w taki sposób, by przepływy te były efektywne ekonomicznie i minimalizowały negatywny wpływ odpadów na środowisko naturalne człowieka (Szołtysek, 2009: 80). Autor ten również proponuje poszerzenie pojęcia odpad o pojęcie odpad tymczasowy - niespotykane dotychczas w logistyce - rozumiane jako dobro materialne nieprzydatne użytkownikowi ze względu na jakąś wadę czy też uszkodzenie, w stosunku do którego użytkownik wyraża chęć dalszego użytkowania po dokonaniu naprawy. Zatem do zakresu zainteresowania logistyki zwrotnej, jak słusznie zauważa Szołtysek, należy również włączyć przepływy materiałowe związane z procesem napraw - gwarancyjnych i pogwarancyjnych - z tzw. serwisem oraz czasowym wycofywaniem pełnowartościowych dóbr z systemu logistycznego np. w związku z ich starzeniem moralnym lub sezonowością popytu. Propozycja Szołtyska znacznie zmienia spojrzenie na odpady, które w tradycyjnym ujęciu traktowane są jako zużyte dobra fizyczne oraz substancje stałe, ciekłe i gazowe powstające w związku z bytowaniem człowieka lub jego działalnością gospodarczą, nieprzydatne w miejscu lub w czasie, w którym powstały, i uciążliwe dla środowiska (Korzeń, 2001: 15).

A. Sadowski, podobnie jak Szołtysek, zauważa, że logistyka zwrotna w sposób zasadniczy różni się od takich dziedzin, jak zarządzanie odpadami, które odnosi się głównie do skutecznego i efektywnego zbierania oraz przetwarzania odpadów. W zarządzaniu odpadami przyjmuje się, że pojęcie odpadów określa produkty, dla których nie istnieje nowe zastosowanie. Wypływa stąd wniosek, iż problemy z uściśleniem koncepcji logistyki zwrotnej oraz jej rozgraniczeniem w stosunku do innych, pokrewnych dziedzin nauki, sprowadzają się do rozumienia pojęcia odpady wraz ze wszystkimi wynikającymi z definicji konsekwencjami. Logistyka zwrotna 
dotyczy takich strumieni przepływów, w których istnieje możliwość odtworzenia wartości z wycofywanych produktów oraz sytuacji, gdy wyjście stanowi zasilenie dla nowego łańcucha dostaw (Sadowski, 2009b).

Mając na uwadze powyższe, należy stwierdzić, że logistyka zwrotna odgrywa zasadniczą rolę w działalności firm z branży usług motoryzacyjnych, gdyż wszystkie fazy eksploatacji pojazdu samochodowego, poczynając od obsługi posprzedażowej nowego pojazdu przez jego właściwe, obsługiwanie i naprawianie oraz zbycie na rzecz kolejnego właściciela, jak i wycofane z eksploatacji wymagają znacznego udziału logistyki zwrotnej. Zatem w usługach motoryzacyjnych logistyka zwrotna ma zastosowanie m.in. do przepracowanych materiałów eksploatacyjnych, w tym płynów i olejów, zużytych lub uszkodzonych części, elementów i zespołów, opakowań, pojazdów samochodowych nie tylko tych wycofanych z eksploatacji, które zgodnie z prawem stały się odpadem, ale i używanych, oczekujących na zmianę właściciela, powypadkowych, niesprawnych, a także i pojazdów zabytkowych oczekujących na odbudowę. Również budowanie systemów obsługi gwarancyjnej i pogwarancyjnej należy zaliczyć do obszaru logistyki zwrotnej oraz działania tzw. remarketingu. W remarketingu produkty są zwracane z różnych powodów, np. jako zwroty od klientów i anulowane zamówienia. Są to zatem całkowicie funkcjonalne produkty, które zalegały w magazynie i nie mogły być sprzedane w takim stanie jak z fabryki, produkty uszkodzone podczas transportu lub magazynowania, produkty, które zostały zwrócone przez sprzedawcę, aby zrobić miejsce na nowe lub które były przekazane w celach demonstracyjnych albo testowych.

\section{Produkty odpadowe i ich odzysk}

Produkty określane jako odpady podlegają uregulowaniom prawnym, które określają środki służące ochronie środowiska, życia i zdrowia ludzi. Środki te mają za zadanie zapobiegać i ograniczać negatywny wpływ na środowisko oraz zdrowie ludzi, wynikający z wytwarzania odpadów i gospodarowania nimi oraz zmniejszać ogólne skutki użytkowania zasobów i poprawiać efektywność tego użytkowania. Ustawa z dnia 27 kwietnia 2001 o odpadach (tekst ujednolicony z 1 maja 2012 r.), podobnie jak dyrektywa Parlamentu Europejskiego i Rady 2008/98WE z dnia 19 listopada 2008, definiuje odpady bardzo szeroko. Odpady oznaczają w niej każdą substancję lub przedmiot, którego posiadacz pozbywa się, zamierza się pozbyć lub do których pozbycia został zobowiązany. Równie szeroko definiowane jest pojęcie odzysk. Jest on rozumiany jako proces, którego głównym wynikiem jest to, że odpady służą użytecznemu zastosowaniu przez zastąpienie materiałów, które zostałyby zastosowane, lub w wyniku którego odpady są przygotowywane do takiego zastosowania - w danym zakładzie lub ogólnie w gospodarce. System prawa wciąż ewoluuje i obecnie (wrzesień 2012) dyskutuje się nad przyjętym w kwietniu 2012 r. przez rząd projekcie ustawy o odpadach z dnia 30 marca 2012.

Regulacje prawne o charakterze ramowym w gospodarce odpadami, tj. dyrektywy Rady Europy oraz ustawy krajowe, zobowiązują każdego przedsiębiorcę do zapobiegania powstawaniu odpadów, ograniczania ich ilości i zmniejszania ich szkodliwości. Regulacje te nakładają szereg zobowiązań na podmioty wytwarzające odpady i prowadzące działalność w zakresie zbierania, odzysku, unieszkodliwiania i transportu odpadów. W celu ustalenia adresata obowiązków wynikających z prawa zdefiniowano pojęcie wytwórca i posiadacz odpadów. Wytwórcą odpadów jest każdy, którego działalność lub bytowanie powoduje powstawanie odpadów (pierwotny wytwórca odpadów) oraz każdy, kto przeprowadza wstępną obróbkę, mieszanie lub inne działania powodujące zmianę charakteru lub składu tych odpadów. W wypadku odpadów powstających w wyniku świadczenia usług w zakresie budowy, rozbiórki, re- 
montu obiektów, czyszczenia zbiorników lub urządzeń oraz sprzątania, konserwacji i napraw wytwórcą jest podmiot, który świadczy usługę, chyba że umowa o świadczenie usługi stanowi inaczej. Wytwórca jest również posiadaczem odpadów i może to być osoba fizyczna, osoba prawna oraz jednostka organizacyjna nieposiadająca osobowości prawnej, będąca w posiadaniu odpadów.

Gospodarowanie przedmiotami lub substancjami uznanymi za odpady podlega odgórnie określonym regułom. Podstawową zasadą stosowaną w gospodarowaniu odpadami jest hierarchia postępowania z odpadami, która kładzie nacisk na zwiększenie ilości odpadów poddawanych procesom odzysku, a zmniejszenie ilości odpadów poddawanych unieszkodliwianiu, w szczególności przez składowanie, które jest najmniej pożądanym sposobem gospodarowania odpadami. Według hierarchii postępowania z odpadami priorytetem są działania, które prowadzą do zapobiegania powstawaniu odpadów, czyli takie działania, w wyniku których przedmioty lub substancje nie staną się odpadami.

Artykuł 18 przytoczonego wyżej projektu ustawy o odpadach wprowadza następującą hierarchię sposobów postępowania z odpadami:

1. zapobieganie powstawaniu odpadów,

2. przygotowywanie do ponownego użycia,

3. recykling,

4. inne procesy odzysku,

5. unieszkodliwianie.

Zapobieganie powstawaniu odpadów rozumiane jest przez środki zastosowane w odniesieniu do produktu, materiału lub substancji, zanim staną się one odpadami, zmniejszające ilość odpadów, w tym również przez ponowne użycie lub wydłużenie okresu dalszego używania produktu, a także zmniejszające negatywne oddziaływanie wytworzonych odpadów na środowisko i zdrowie ludzi lub zawartość substancji szkodliwych w produkcie i materiale. Zapobieganie powstawaniu odpadów ma już swój początek w fazie powstawania idei nowego produktu, opracowania i testowania jego koncepcji i prototypów, a w przypadku pojazdów samochodowych ma umożliwić przedsiębiorcy prowadzącemu stację demontażu pojazdów wycofanych z eksploatacji osiągnięcie poziomu odzysku i recyklingu odpadów w wysokości odpowiednio 95\% i 85\% masy pojazdów, przyjętych do jego stacji demontażu rocznie (ustawa o recyklingu pojazdów 2005, art. 28, poz. 1).

Przygotowanie do ponownego użycia rozumiane jest jako odzysk polegający na sprawdzeniu, czyszczeniu lub naprawie, w ramach którego produkty lub części produktów, które wcześniej stały się odpadami, są przygotowywane do tego, aby mogły być ponownie wykorzystywane bez jakichkolwiek innych czynności wstępnego przetwarzania. Posługując się tą definicją, można wnioskować, że do przygotowania do ponownego użycia należy zaliczać również produkty oferowane na tzw. rynku drugiej ręki jako produkty używane, zatem również i całe zespoły lub maszyny przeznaczone do dalszej odsprzedaży i wymagające zabiegów kosmetycznych, a niekiedy też naprawy. Produkty te, zgodnie z wcześniej przytaczaną propozycją Szołtyska, można zaliczyć do odpadów tymczasowych. W przypadku samochodów wycofanych z eksploatacji ponowne użycie rozumiane jest jako zastosowanie przedmiotów wyposażenia i części, wymontowanych z tych pojazdów, w tym samym celu, dla którego zostały pierwotnie zaprojektowane i wykonane (ustawa o recyklingu pojazdów 2005, art. 3, poz. 7).

Dopiero po tych dwóch preferowanych działaniach, na trzeciej pozycji jest promowany recykling, czyli jakikolwiek proces, w ramach którego odpady są ponownie przetwarzane w produkty, materiały lub substancje wykorzystywane w pierwotnym celu lub innych celach. Recykling obejmuje także ponowne przetwarzanie materiału organicznego (recykling organiczny), 
ale nie obejmuje odzysku energii oraz ponownego przetwarzania na materiały, które mają być wykorzystane jako paliwa lub do celów wypełniania wyrobisk. W usługach motoryzacyjnych dużego znaczenia nabiera recykling produktowy, polegający m.in. na regeneracji zespołów i podzespołów samochodu, pojedynczych elementów i części, opon, przepracowanych olejów i innych płynów eksploatacyjnych.

W następnej kolejności są inne metody odzysku, w tym odzysk energii zawartej w odpadzie. Najmniej preferowane, a właściwie niepożądane, jest unieszkodliwianie odpadów, czyli jakikolwiek proces, w wyniku którego nie dochodzi do odzysku ani substancji, ani energii. Samo umieszczanie odpadów na składowiskach odpadów jest procesem unieszkodliwiania, który powinno się eliminować lub maksymalnie ograniczać (O odpadach nieco więcej, 2010).

Na rycinie 2 pokazano pierwotne i wtórne przepływy produktów i odpadów, zaś w tabeli 2 porównano kluczowe czynniki, których znajomość jest niezbędna w efektywnym zarządzaniu tymi przepływami, a mianowicie: przewidywalność popytu i podaży, wartość produktu, identyfikacja potrzeb użytkownika, planowanie produkcji, znajomość kosztów, bezpieczeństwo dla środowiska, kontrola przepływów i pracochłonność produkcji.

Ryc. 2. Przepływy produktów i odpadów

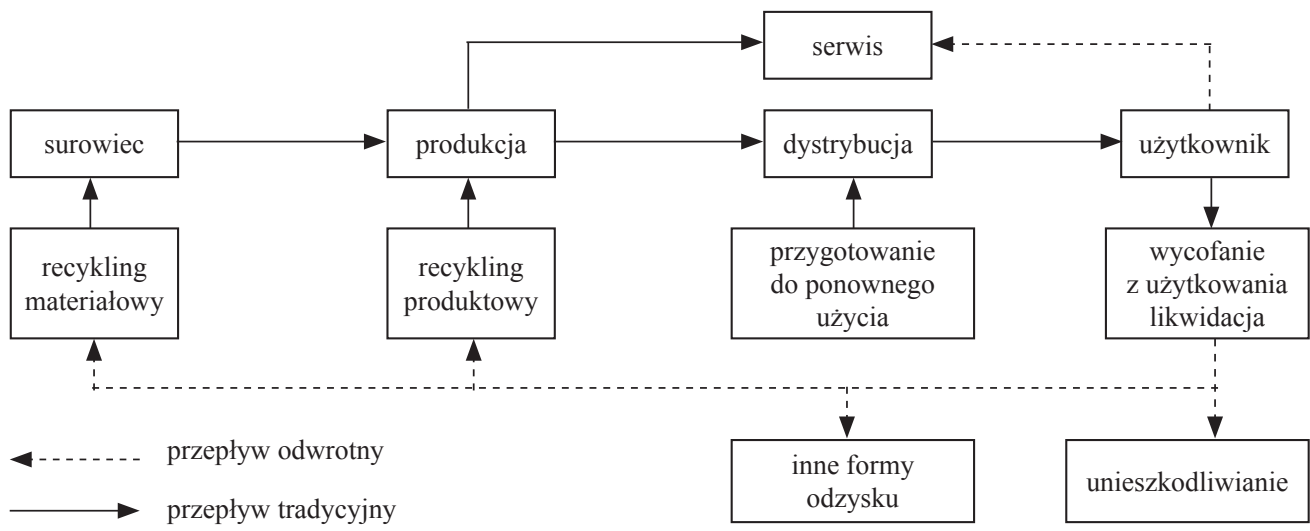

Źródło: opracowanie własne autorów na podstawie: Thierry i in. (1995: 118); Hensler, Buton (2003: 693).

Tab. 2. Porównanie przepływów pierwotnych z przepływami wtórnymi

\begin{tabular}{|l|c|c|}
\hline \multicolumn{1}{|c|}{ Kluczowe czynniki } & Przepływy pierwotne & Przepływy wtórne \\
\hline Przewidywalność popytu i podaży & łatwa & trudna \\
\hline Wartość produktu & duża & mała \\
\hline Identyfikacja potrzeb użytkownika & łatwa & trudna \\
\hline Planowanie produkcji & łatwa & trudna \\
\hline Znajomość kosztów & duża & mała \\
\hline Bezpieczeństwo dla środowiska & duże & małe \\
\hline Kontrola przepływów & łatwa & trudna \\
\hline Pracochłonność produkcji & mała & duża \\
\hline
\end{tabular}

Źródło: opracowanie własne na podstawie: Wąsowicz (2010: 366). 


\section{Logistyka zwrotna w systemach przygotowywania do ponownego użycia}

Ponowne użycie produktu może być realizowane na kilka sposobów, mianowicie jako:

1. ponowne bezpośrednie użycie,

2. odnowienie lub renowacja,

3. naprawa,

4. kanibalizacja.

Ponowne bezpośrednie użycie produktu jest najprostszą formą i występuje wtedy, kiedy produkt (bez dodatkowych zabiegów), jedynie po oględzinach lub weryfikacji i stwierdzeniu jego przydatności do funkcjonowania, zostaje ponownie wykorzystany w tym samym lub innym celu (ryc. 3).

Odnowa albo odświeżenie lub inaczej renowacja ma na celu doprowadzenie używanego produktu do określonego poziomu jakości, który jest mniej rygorystyczny w stosunku do nowych produktów. Zatem jest to przywracanie zwrotom odpowiedniej jakości przez demontaż, kontrolę i wymianę uszkodzonych części, a także technologiczną modernizację, polegającą na zastępowaniu przestarzałych modułów i komponentów technologicznie lepszymi i nowocześniejszymi.

Celem naprawy jest powrót sprawnego produktu z tym, że jakość naprawionych produktów jest prawdopodobne niższa niż jakość oryginału. Naprawa wymaga demontażu i usunięcia usterek i może być wykonana w dowolnym miejscu.

Kanibalizacja czasami nazywana jest selektywnym demontażem. Różni się ona od naprawy i renowacji tym, że tylko niewielka liczba zużytych produktów, które podlegają zwrotowi, pochodzi ze starego produktu i można je użyć ponownie. Części te mogą być używane w naprawach, remontach i regeneracji. Jakość części zależy od procesu, w którym będą one używane. Kanibalizacja może być również rozumiana jako proces polegający na pozyskiwaniu części zamiennych z uszkodzonych używanych maszyn. Celem tych sposobów zagospodarowania produktu jest zachowanie ich identyczności, natomiast w przypadku recyklingu tożsamość i funkcjonalność produktów i komponentów może być utracona. Materiały te mogą być ponownie wykorzystane do produkcji oryginalnych części, jeżeli jakość materiałów jest wysoka, albo też do produkcji innych elementów (Janczewski, 2012: 101).

Ryc. 3. Przygotowanie części do ponownego użycia

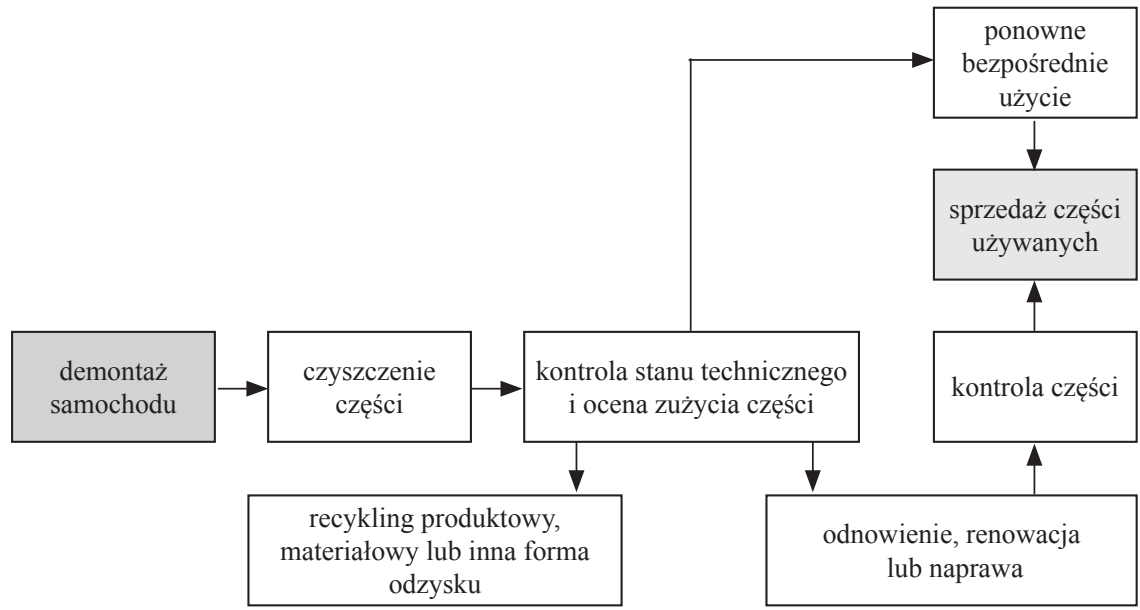

Źródło: opracowanie własne autorów. 
Samochody są niezwykle skomplikowanymi konstrukcjami, zawierającymi w sobie kilka tysięcy różnych części. Wiele z nich z powodzeniem może zostać wykorzystanych na rynku wtórnym. W usługach motoryzacyjnych klasycznym przykładem ponownego bezpośredniego użycia jest wykorzystanie całych zespołów, takich jak silniki, skrzynie biegów, różnego rodzaju przełączniki, urządzenia do pracy ciągłej, a mianowicie silniki wycieraczek, alternatory, rozruszniki, elementy często uszkadzane przy stłuczkach: zderzaki, chłodnice, maska silnika, klapa tylnia, szyby spełniające wymagania, kompletne drzwi z szybami i mechanicznym i elektrycznym podnoszeniem, elementy, które ze względu na zły stan dróg ulegają częstym uszkodzeniom, np. koła, elementy karoserii, fotele, lampy przednie, lampy tylne, lusterka zewnętrzne i inne. Części te najczęściej pochodzą z demontażu samochodów wycofanych z eksploatacji. Jednocześnie należy pamiętać, że istnieje grupa części, których ponowne bezpośrednie użycie zagraża bezpieczeństwu ruchu drogowego i ma negatywny wpływ na środowisko naturalne. Do takich części należ przede wszystkim: poduszki powietrzne z aktywatorami pirotechnicznymi, jednostkami kontroli elektronicznej i czujnikami, klocki, szczęki hamulcowe, przewody i uszczelnienia układu hamulcowego, tłumiki układu wydechowego, przeguby układu kierowniczego i zawieszenia, fotele zintegrowane z pasami bezpieczeństwa lub poduszkami powietrznymi, układy blokady kierownicy, immobilisery wraz z transponderami sterowania elektrycznego, elementy elektryczne i elektroniczne układów bezpieczeństwa jazdy, przewody paliwa, filtry jednorazowe i wkłady filtrów, zawory recyrkulacji spalin, instalacje zasilania gazem silników, automatyczne i nieautomatyczne zestawy pasów bezpieczeństwa, łącznie z częścią pasa wykonaną z materiału, klamrami, mechanizmem służącym do zwijania pasów, aktywatorami pirotechnicznymi i mechanicznymi, pióra wycieraczek szyb, katalizatory (Rozporzadzenie Ministra Infrastruktury...).

Stosowanie używanych części i zespołów (pochodzących z demontażu samochodów wycofanych z eksploatacji), które uzyskały zgodę na wprowadzenie ich do ponownego obrotu przez jednostki upoważnione do weryfikacji tych części, jest dopuszczalne w obsłudze serwisowej w okresie pogwarancyjnym wyłącznie na wyraźne życzenie klienta. Etapy przygotowania części do ponownego użycia pokazano na rycinie 3.

Ustawa o recyklingu pojazdów wycofanych z eksploatacji (SWE) narzuca trzystopniową organizację sieci recyklingu samochodów, w której występują punkty odbioru pojazdów wycofanych z eksploatacji, stacje demontażu i młyny przemysłowe. Odzysk zespołów, podzespołów i części zamiennych do ponownego użytku odbywa się w stacjach demontażu, one również wprowadzają te elementy na rynek wtórny jako tanie części zamienne, wykorzystując przy tym różne kanały dystrybucji.

W dystrybucji używanych części stacje demontażu wykorzystują kanały bezpośrednie i pośrednie. Najbardziej popularną sprzedażą jest sprzedaż na miejscu lub za pośrednictwem własnego sklepu, w którym klienci mogą zakupić części osobiście lub skorzystać z formy wysyłkowej, składając zamówienie przez telefon lub Internet. Stacje demontażu współpracują również z pobliskimi warsztatami samochodowymi, do których bezpośrednio dostarczają zamawiane części. Najczęściej są to zamówienia indywidualne, na konkretne części. Weekend dla niektórych firm jest możliwością pokazania się na innym rynku, nawiązania nowych kontaktów, pozyskania nowych odbiorców, a także sprzedaży. Zakłady demontażu posiadają stoiska na popularnych giełdach samochodowych, gdzie klienci mogą kupić lub odebrać wcześniej zamówione części.

W zależności od wybranego wariantu sprzedaży podmiotami w kanale dystrybucji używanych części są: sklepy, autoszroty, warsztaty, giełdy samochodowe, a także użytkownicy samochodów. W każdym z wariantów w inny sposób przekazywane są produkty, należności oraz informacje. 
Bardzo dogodną formą sprzedaży używanych części samochodowych są internetowe aukcje. Właściciele części wystawiają swoje produkty np. na stronach Giełda-Części, Motolokalizator lub Allegro, gdzie w wirtualnej przestrzeni można je obejrzeć, zapoznać się z ich opisem i z ceną oraz porównać całą ofertę z innymi ofertami. Ze względu na dużo zalet ta forma sprzedaży stała się bardzo popularna i opłacalna dla wszystkich uczestników transakcji. Firmy zajmujące się sprzedażą używanych części samochodowych od kilku lat notują znaczny wzrost sprzedaży wysyłkowej (zamówienia drogą elektroniczną) m.in. dzięki sieci ARES i internetowym aukcjom, co oznacza, że ta forma sprzedaży rozwija się bardzo dynamicznie. W skład sieci ARES wchodzą legalne stacje demontażu o ustalonym standardzie ochrony środowiska. Każda stacja tworzy w zależności od potrzeb własną sieć odbioru samochodów od klienta. Stacje te używają ujednoliconego oprogramowania wspierającego odbiór samochodów i tworzenie rejestru danych o przyjmowanych samochodach, dokumentującego kolejne etapy procesu demontażu, ułatwiającego zarządzanie magazynami i tworzącego bazę danych o zespołach, częściach, materiałach, uzyskiwanych z procesu. Bazy poszczególnych stacji demontażu połączone są łączami internetowymi, co zapewnia zainteresowanym częściami klientom dostęp do danych z całej sieci. System ARES obejmuje działalność ponad 30 stacji na całym terytorium naszego kraju. Baza części z demontażu dostępna w Internecie zawiera ich ponad 350 tys. i jest stale powiększana. Z każdym dniem przybywa ok. 200 nowych pozycji. System jest ciągle modernizowany i dzięki niemu Polska jest po Szwecji drugim krajem w Europie oferującym dostęp przez Internet do tanich części z demontażu, rozmieszczonych w wielu stacjach w Polsce (Ares..., 2010).

W prowadzeniu prawidłowej gospodarki częściami i zespołami pochodzącymi z demontażu samochodów wycofanych z eksploatacji pojawiają się także problemy. W Polsce nadal jest nierozwiązany problem nielegalnego demontażu pojazdów i tzw. szarej strefy w handlu używanymi częściami, można więc przypuszczać, że przydatne części z nielegalnie rozmontowanych samochodów np. przez giełdy samochodowe trafiają do ponownego użycia. Sytuacji takiej sprzyja fakt bezradności służb odpowiedzialnych za przeciwdziałanie wspomnianym praktykom oraz brak wiarygodnych i kompletnych danych w zakresie liczby samochodów zarejestrowanych i wyrejestrowanych oraz poddanych demontażowi.

\section{Logistyka zwrotna w systemach recyklingu produktowego}

Odpady powstałe w rezultacie użytkowania produktów (związane z wymianą uszkodzonych elementów bądź podzespołów) oraz poddane procesom regeneracji na etapie produkcji (części niespełniające norm jakościowych) stają się pełnowartościowymi produktami (Szołtysek, 2009: 104). Pod określeniem regeneracja (odnowienie, odtworzenie) rozumiane jest działanie polegające na przywróceniu za pomocą odpowiednich zabiegów zużytym lub uszkodzonym częściom lub zespołom ich pierwotnych właściwości użytkowych, takich jak kształt, wymiary, parametry i pozostałe cechy niezbędne do niezawodnej dalszej ich pracy. W procesie regeneracji wymontowana część bądź zespół (np. rozrusznik, alternator, przekładnia kierownicza) określane jako rdzeń muszą być całkowicie zdemontowane, oczyszczone i zbadane pod kątem zużycia i uszkodzenia. Zużyte, brakujące lub niefunkcjonujące składowe części są zamieniane na nowe lub odbudowane ${ }^{1}$. Prawidłowo regenerowane części mogą więc mieć jakość części nowych i mogą być nawet o $50 \%$ od nich tańsze.

\footnotetext{
${ }^{1}$ Odbudowa jest szczególnym przypadkiem ponownego użycia produktu i dotyczy obiektu, który przynajmniej częściowo nie istnieje; może się zdarzyć, że jakaś jego część uległa zużyciu lub uszkodzeniu i choć istnieje, to wymaga przeprowadzenia jej rozbiórki i odbudowy.
} 
W. Tomczyk (Tomczyk, 2005) przytacza szereg czynników mających bezpośredni wpływ na podjęcie właściwych (optymalnych) decyzji w zakresie regeneracji części wymiennych, co pokazano w tabeli 3. Typowy proces regeneracji części pokazano na rycinie 4.

Podejmowanie decyzji w zakresie regeneracji jest procesem bardzo złożonym ze względu na bardzo szeroki asortyment zespołów i części nadających się do regeneracji i różnorodność metod ich odnowy. Z uwagi na brak uniwersalnych metod regeneracji bardzo utrudniona jest typizacja regenerowanych części, co w konsekwencji może poważnie utrudnić osiągnięcie właściwych, pożądanych efektów technicznych i ekonomicznych (Tomczyk, 2005: 28).

W Stanach Zjednoczonych koncepcja regeneracji części samochodowych pojawiła się w 1920 r. Pierwsze stowarzyszenia na rzecz regeneracji, tj. Stowarzyszenie Regeneracji Silników Samochodowych (AERA) i Stowarzyszenie Regeneracji Części Samochodowych (APRA), powstały odpowiednio w 1922 i 1941 r. W latach kryzysu gospodarczego, gdy zasoby pieniędzy i tym samym nowych części stały się mniej dostępne, Henry Ford zobowiązał swoich dealerów do regeneracji części. Do rozwoju regeneracji w Stanach Zjednoczonych przyczyniła się również II wojna światowa. W tym czasie produkcja pojazdów do celów cywilnych została wstrzymana, a regeneracja części stała się podstawową metodą w naprawach samochodów (Timeline of industrial remanufacturing).

Ryc. 4. Typowy proces regeneracji części

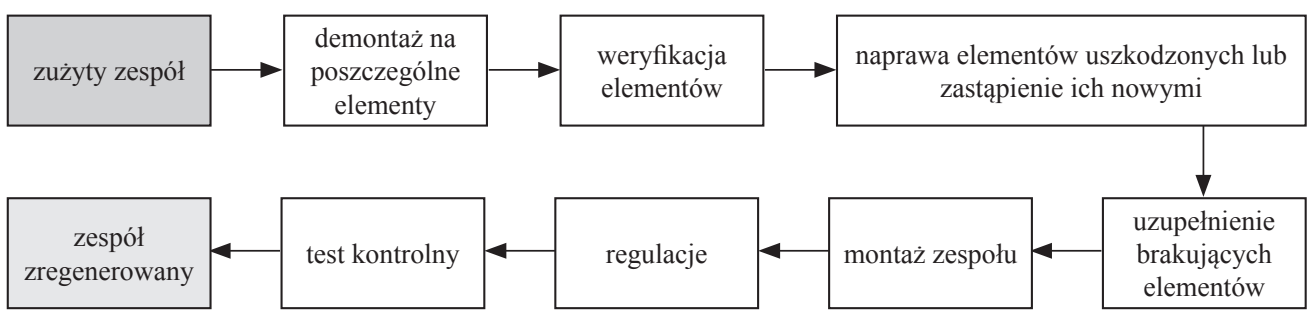

Źródło: opracowanie własne autorów.

Tab. 3. Kryteria regeneracji części maszyn

\begin{tabular}{|c|l|}
\hline Kryteria & \multicolumn{1}{c|}{ Cechy kryteriów } \\
\hline Eksploatacyjne & $\begin{array}{l}\text { funkcjonalność, zamienność części, wytrzymałość zmęczeniowa, odporność na } \\
\text { zużycie ścierne, krotność regeneracji danej części, współczynnik trwałości itp. }\end{array}$ \\
\hline Techniczne & $\begin{array}{l}\text { analiza zużyć części w czasie eksploatacji, wytypowanie części do regeneracji, } \\
\text { opracowanie technologii regeneracji, wybór metody regeneracji, wykonanie } \\
\text { wstępnych prób części zregenerowanych, dobór parametrów technicznych } \\
\text { regeneracji (obróbki materiałów), badania trwałości i niezawodności itp. }\end{array}$ \\
\hline Technologiczne & $\begin{array}{l}\text { dobór materiałów, dobór właściwych parametrów prowadzenia zabiegów } \\
\text { regeneracji, stan obróbki powierzchni, kształt elementu, wymiar i ciężar części, } \\
\text { liczba elementów itp. }\end{array}$ \\
\hline Ekonomiczne & $\begin{array}{l}\text { analiza rynku czéści, zapotrzebowanie na części regenerowane, analiza możliwo- } \\
\text { ści nabycia części nadających się do regeneracji, formy współpracy w zakresie } \\
\text { obrotu częściami, kalkulacja kosztów regeneracji, ustalenie cen części regenero- } \\
\text { wanych, działania marketingowe itp. }\end{array}$ \\
\hline Organizacyjne & $\begin{array}{l}\text { ustalenie sieci zakładów zajmujących się regeneracją, logistyka w zakresie } \\
\text { regeneracji (magazyny, transport, łączność) itp. }\end{array}$ \\
\hline
\end{tabular}

Źródło: Tomczyk (2005: 28). 
W ostatnich latach atrakcyjność regeneracji części w Polsce stopniowo wzrasta. Dla właścicieli dłużej eksploatowanych pojazdów istotna jest ich szybka naprawa z użyciem części o cenie zakupu adekwatnej do wartości posiadanego pojazdu (Włodarczyk, 2002: 84), zwłaszcza że obecne spowolnienie gospodarcze zmusza użytkowników samochodów do poszukiwania oszczędności, a największym atutem oprócz walorów ekologicznych są ceny i jakość regenerowanych części.

W Polsce przybywa firm zajmujących się regeneracją części samochodowych, a coraz częstsze i większe inwestycje zagraniczne dokonywane są przez zachodnie firmy regeneracyjne (Góra, 2012: 11). Również producenci samochodów coraz częściej decydują się na wprowadzenie do swojej oferty części regenerowanych m.in. z obawy o utratę klientów stacji serwisowych, po tym jak unijne przepisy zaczęły liberalizować rynek motoryzacyjny, a dyrektywa GVO umożliwiała serwisowanie samochodów w niezależnych warsztatach i ich naprawę za pomocą zamienników bez utraty gwarancji. Regenerowane podzespoły są zatem traktowane jako alternatywa dla stosowania tańszych zamienników.

\section{Logistyka zwrotna w systemach ponownej sprzedaży samochodów}

Samochód jest szczególnym przykładem produktu, którego pełen cykl użytkowania wymaga powtórnego lub nawet kilkakrotnego wprowadzenia na rynek i zaangażowania takich działań logistyki zwrotnej, jak:

- odbiór i transport,

- wycena i kontrola stanu technicznego,

- naprawa uszkodzeń i przygotowanie pojazdu do zbycia,

- wystawienie samochodu do ponownej sprzedaży.

Typowym przykładem mogą być działania firm zarządzających dużą liczbą samochodów, a więc firm leasingowych, firm CFM (Car Fleet Managment), banków, a także flot samochodowych. Zarządzanie flotą wiąże się z utrzymaniem pełnej mobilności firmowych samochodów przy optymalnych, czyli stosunkowo niskich kosztach. Jednym z kluczowych zadań logistyki zwrotnej, które wpływają na finansowy bilans korzystania z firmowej floty, jest ponowna sprzedaż samochodów, tzw. remarketing. Może ona dotyczyć następujących rodzajów pojazdów:

- pojazdów nowych z zerowym przebiegiem pochodzących z ekspozycji lub nadwyżek producentów,

- samochodów mających od 3 do 6 miesięcy, testowych, używanych przez dealerów,

- samochodów po wynajmie krótko- (od 6 do 12 miesięcy) lub długoterminowym (od 36 do 48 miesięcy),

- pojazdów używanych po krótkim, dwuletnim okresie leasingu,

- samochodów po normalnym okresie leasingu (od 2 do 4 lat),

- samochodów powypadkowych przeznaczonych do kasacji,

- pojazdów zabytkowych.

Najlepszym momentem na wymianę samochodów w firmie jest zakończenie okresu 3-4 lat użytkowania. Pojazdy są jeszcze stosunkowo młode i łatwiej znaleźć na nie nabywcę. Decyzja zależy jednak od polityki flotowej przedsiębiorstwa i innych czynników, np. rodzaju silnika, marki, klasy i przeznaczenia pojazdu. Serwisowanie samochodów liczących więcej niż 4 lata jest zazwyczaj droższe, podobnie jak ich bieżąca eksploatacja, a co za tym idzie - zwiększa się średni koszt przejazdu jednego kilometra (Romaldowski, 2012: 48). 
Proces powtórnego wprowadzania pojazdu na rynek rozpoczyna się w momencie zwrotu pojazdu przez klienta w dniu wygaśnięcia umowy o wynajem (ryc. 5). Samochód poddawany jest szczegółowej ekspertyzie przez niezależnego rzeczoznawcę. Wynikiem ekspertyzy jest raport oceny pojazdu zawierający dokładną specyfikację samochodu, mianowicie: markę, model, wyposażenie, przebieg, rodzaj paliwa itp., jego stan techniczny - uszkodzenia, stan opon, poprzednie naprawy blacharsko-lakiernicze oraz wycenę wartości pojazdu. Dodatkowo każdy raport zawiera również szczegółową dokumentację fotograficzną pojazdu. Skrupulatne przygotowanie opisu samochodu przed odsprzedażą jest bardzo ważne, gdyż specjalne przepisy w umowie konsumenckiej zakładają, że w przypadku złego opisu samochodu klient ma prawo np. po półrocznym użytkowaniu zgłosić niezgodność opisu ze stanem faktycznym i zwrócić pojazd bez kosztów, a nawet skierować sprawę do sądu. Po sporządzeniu takiego opisu pojazdy kierowane są na aukcje internetowe przeznaczone dla odbiorców hurtowych. Przed rozpoczęciem aukcji podawana jest cena wywoławcza pojazdu. Zainteresowani mają możliwość wglądu do dokumentacji samochodu oraz obejrzeć go fizycznie np. w Centrum Remarketingu albo na specjalnie przygotowanym parkingu. Sama licytacja trwa około 2-3 godzin, co pozwala z jednej strony osiągnąć maksymalne oferty cenowe, a z drugiej skrócić czas sprzedaży pojazdu. Udział w aukcji jest anonimowy, a każdy z licytujących widzi najwyższą złożoną ofertę, jednak nie ma dostępu do oferenta. Cenę można podbijać automatycznie lub manualnie. Platforma aukcyjna pozwala na śledzenie wybranych ofert, czyli konfigurowanie powiadomienia w taki sposób, aby otrzymywać informację tylko o interesujących modelach samochodów. Po zakończeniu licytacji najwyższe złożone oferty cenowe są potwierdzane nabywcom, co jest jednoznaczne z podjęciem decyzji o sprzedaży. Następnie pozostaje formalność wystawienia faktury VAT sprzedaży, odnotowania płatności oraz wydanie pojazdu kupującemu. Procesy transakcji na aukcjach wymagają również takich działań, jak reprezentowanie sprzedawcy, raportowanie transakcji, zarządzanie portfelem pojazdów flotowych, konsulting i doradztwo w zakresie sprzedaży, reklama prowadzonych sprzedaży, inspekcja, testowanie i arbitraż posprzedażowego, ubezpieczenie samochodów, finansowanie zakupu, windykacja należności i organizacja przechowania lub transportu.

Ryc. 5. Powrotne wprowadzenie na rynek pojazdu pokontraktowego

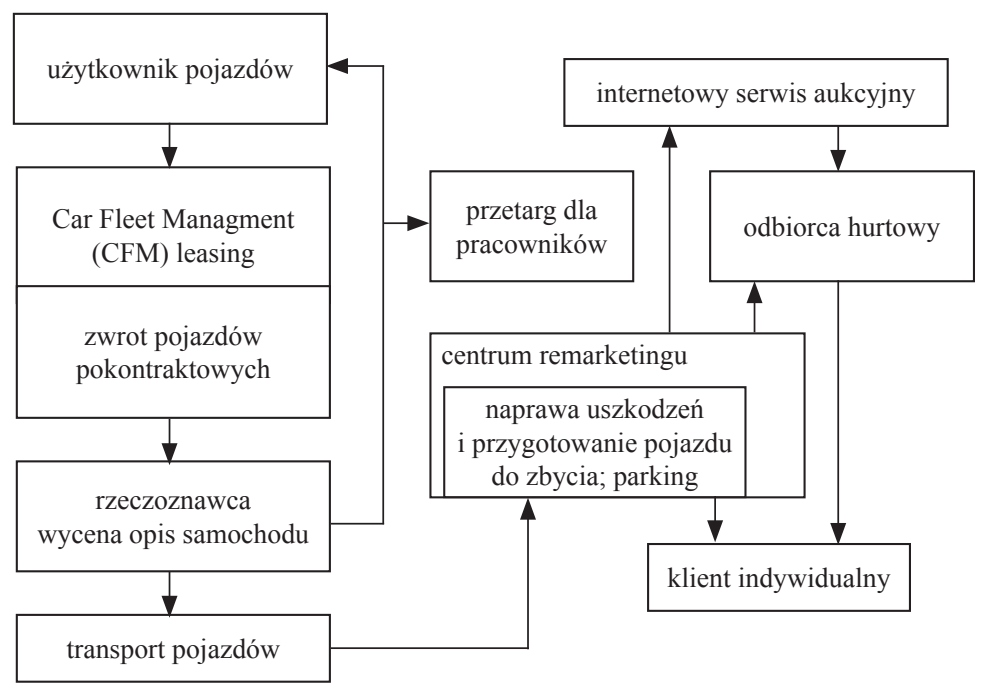

Źródło: opracowanie własne na podstawie: Romaldowski (2012); Chojnacki (2009). 
Innym kanałem jest sprzedaż samochodu dotychczasowemu użytkownikowi. Klient firmy CFM może odkupić samochód, z którego dotychczas korzystał. Po wyrażeniu takiej woli dotychczasowy użytkownik otrzymuje specjalną ofertę cenową skalkulowaną na podstawie wyceny rzeczoznawcy. Po jej zaakceptowaniu wystawiana jest faktura pro forma sprzedaży pojazdu, a odnotowanie płatności jest równoznaczne z przekazaniem pojazdu nabywcy wraz z kompletem dokumentów sprzedaży.

Kolejnym rozwiązaniem jest zorganizowanie wewnętrznego przetargu dla pracowników firmy klienta (Sosnowski, 2012: 103). Pracownicy, którzy do czasu zakończenia kontraktu korzystali z konkretnych samochodów, mają prawo pierwokupu na preferencyjnych warunkach. Zasady późniejszego nabycia pojazdu przez jego użytkownika stanowią często istotny element polityki motywacyjnej firmy. Przedsiębiorca powinien więc podać pracownikowi cenę wykupu już w ramach umowy o korzystaniu z pojazdu, regulującej zarówno zasady sprzedaży, jak i standardy eksploatacji. Zmotywowany wcześniej gwarancją atrakcyjnej ceny przy wykupie - zwykle niższej od rynkowej o marżę pośredników, czyli średnio o około 10-15\% - pracownik z pewnością będzie dbał o środek transportu, a dodatkowo dokładniej pozna jego historię serwisową. Pracodawca z kolei w ten sposób zyskuje niższe koszty użytkowania samochodu, które mogą zrekompensować mniejszy przychód przy odsprzedaży (Romaldowski, 2012: 48). Istotną rolę odgrywa także odpowiednie przygotowanie pojazdu do procesu powtórnego wprowadzenia na rynek. W przypadku dużej liczby pojazdów do zbycia usługi takie są zlecane wyspecjalizowanym firmom, które zajmują się kompleksową obsługą wymiany samochodów we flotach. Firmy te oferują przede wszystkim czyszczenie wnętrza, karoserii i silnika, naprawę karoserii od wewnątrz, wypolerowanie karoserii, techniczny check-up, który pozwoli na uniknięcie ewentualnych problemów podczas kolejnej konserwacji pojazdu. Naprawy te podnoszą standard samochodów, ich estetykę i co za tym idzie, cenę sprzedaży pojazdu używanego.

Złożoność i duża zmienność rynku używanych samochodów wymaga dywersyfikacji form ich sprzedaży. Im większa jest liczba sprzedawanych pojazdów, tym więcej form sprzedaży jest branych pod uwagę. Na wybór kanału sprzedaży pojazdu przede wszystkim wpływa czas sprzedaży samochodu. Pojazd po zakończeniu kontraktu jest biernym kapitałem, który stanowi balast dla firmy leasingującej, dlatego należy go jak najszybciej upłynnić. Sprzedaż aukcyjna samochodów zapewnia dobrą płynność, mogą brać w niej udział zaufani partnerzy, proces sprzedaży jest efektywny i sprawdzony, systemy online są bardzo wygodne dla sprzedawcy, gdyż nie wymagają kontaktu z klientem ostatecznym (brak kłopotliwych pytań i kontaktów, bez testowania i sprawdzania pojedynczego egzemplarza, bez programu gwarancji), sprzedawcy hurtowi odpowiedzialni są za transport i biorą końcowe ryzyko sprzedaży na siebie, ponieważ to oni odpowiadają za ostateczną dystrybucję samochodów, mogą działać na większą skalę i umożliwiać sprzedaż za granicę. W przypadku klientów indywidualnych proces sprzedaży samochodu jest bardziej skomplikowany, wzrasta odpowiedzialność posprzedażna, czas sprzedaży się wydłuża, lecz w zamian za te niedogodności można uzyskać wyższą marżę dla firmy.

\section{Zarządzanie logistyką zwrotną w usługach motoryzacyjnych - wybrane kwestie}

W ostatnich latach rośnie świadomość wielu przedsiębiorstw na temat istoty logistyki zwrotnej (Sadowski, 2008: 131), która stanowi ważny obszar zarządzania logistycznego zarówno w pojedynczych przedsiębiorstwach, jak i w łańcuchach dostaw, dostarczając firmom wiele możliwości dodatkowych przychodów ze sprzedaży.

W literaturze przedmiotu za podstawowe aspekty systemu logistyki zwrotnej przyjmuje się: zbieranie, sortowanie, przetwarzanie oraz projektowanie sieci logistycznej i dystrybucyj- 
nej dla zwrotów. Tym samym systemy logistyki zwrotnej nie są systemami funkcjonującymi „samodzielnie”, ale zostają włączone do istniejących struktur logistycznych przedsiębiorstw (Mesjasz-Lech, 2010: 448).

Zarządzanie przepływami w logistyce zwrotnej wymaga podejmowania takich działań, jak (Pokharel, Mutha, 2009) :

- prognozowanie zarówno podaży, jak i popytu na pozostałości nadające się do odzysku,

- planowanie lokalizacji punktów składowania zwrotów,

- określenie struktury systemu logistyki zwrotnej w odniesieniu do problemów lokalizacji punktów skupu zwrotów, ich dostępności dla realizacji procesów recyklingu i powtórnego wykorzystania,

- koordynacji w planowaniu i kontroli procesów realizowanych w ramach logistyki zwrotnej,

- wyceny dóbr wyprodukowanych z surowców wtórnych.

W firmach zajmujących się skupem i demontażem samochodów wycofanych z eksploatacji logistyka zwrotna stanowi podstawę ich funkcjonowania. Według dyrektywy europejskiej EU2000/53/EC co najmniej 85\% średniej masy samochodów obecnie produkowanych musi się nadawać do recyklingu, a w niedalekiej perspektywie wskaźnik ten będzie zbliżał się do 100\%. Stąd perspektywy rozwoju logistyki zwrotnej w usługach motoryzacyjnych są bardzo duże.

W przedsiębiorstwach, w których podstawową działalnością jest serwisowanie pojazdów samochodowych, logistyka zwrotna może być źródłem tworzenia dodatkowej wartości dodanej dla firmy. Przedsiębiorstwa te mogą czynnie uczestniczyć w łańcuchach pozyskania i sprzedaży używanych części, zespołów i pozostałych elementach samochodu zwłaszcza w procesach skupu i wymiany rdzeni na części fabrycznie regenerowane, a także w propagowaniu wśród klientów części regenerowanych.

W usługach motoryzacyjnych nadal niedostatecznie wykorzystanymi dziedzinami logistyki zwrotnej są takie sposoby ponownego użycia produktów, jak: odnowienie, renowacja, naprawa lub nawet kanibalizacja, a także pośrednictwo w sprzedaży i wymianie samochodów.

Jak wynika z obserwacji autorów, mechanicy unikają w serwisowaniu samochodów wspomnianych sposobów, natomiast najchętniej wymieniają wadliwe elementy na nowe. Dzieje się to przy aktywnym udziale klientów, którzy w większości preferują w naprawach nowe części samochodowe, zwłaszcza tanie zamienniki, odsuwając na drugi plan możliwości wykorzystania części używanych, naprawianych lub regenerowanych. Sytuacja taka powoli się zmienia, gdyż zarówno użytkownicy indywidualni jak i instytucjonalni z powodu rosnących kosztów eksploatacji samochodów zmuszani są do poszukiwania tańszych sposobów serwisowania pojazdów. Dodatkowo fakt ten potęguje ubożenie społeczeństwa, czego dowodem jest stale malejąca sprzedaż nowych samochodów w Polsce i duże zainteresowanie samochodami używanymi.

Dotychczas warsztaty samochodowe w Polsce, zwłaszcza te niezależne, cieszyły się rosnącym popytem na swoje usługi. Przyczyną tego był wzmożony import tanich używanych samochodów do Polski i tym samym wzrost zapotrzebowania na serwisowanie i naprawy takich samochodów. Używane samochody zazwyczaj mają niską wartość rezydualną, stąd można domniemywać, że zainteresowanie logistyką zwrotną w usługach motoryzacyjnych powinno stale wzrastać, chociaż motywacja pomiotów do prowadzenia działań logistyki zwrotnej może mieć różne podłoże, m.in. może być powodowana koniecznością oszczędności kosztów, dostosowania się do obowiązujących regulacji prawnych - póki co w warunkach Polski jest to chyba najczęstszy powód wdrażania logistyki zwrotnej, bądź skutkiem konieczności poprawy własnego wizerunku, jako jednej z dróg osiągania przewagi konkurencyjnej na rynku (Bril, Łukasik, 2012: 190). 
Meyer i Rosen podkreślają, iż procesy związane z logistyką odwrotną stają się coraz bardziej skomplikowane a wiele przedsiębiorstw nie jest w stanie samodzielnie podołać sprawnemu i efektywnemu zarządzaniu procesami logistycznymi związanymi z powrotnym przepływem odpadów pochodzących z działalności gospodarczej (Badanie świadomości..., 2011: 26). W wypadku odwrotnych przepływów konieczne jest wykonanie więcej działań niż w przepływach tradycyjnych. W przepływach odwrotnych dochodzą m.in. takie działania, jak demontaż, ocena i weryfikacja, naprawa i regeneracja, przepakowywanie, ponowne etykietowanie, magazynowanie i transport, sprzedaż oraz unieszkodliwianie. Działania te w skrajnych przypadkach mogą doprowadzić do kosztów logistyki zwrotnej, cztery do pięciu razy większych od kosztów działań logistyki tradycyjnej (Millar, 2012: 1), co może zniechęcać do zainteresowania powrotnymi przepływami produktów.

Rogers i Tibben-Lembke wyróżnili w przedsiębiorstwach osiem źródeł barier dla efektywnej logistyki zwrotnej (Rogers i Tibben-Lembke, 1998: 33). Są to:

- podrzędne znaczenie logistyki zwrotnej w stosunku do pozostałych problemów firmy, co oznacza przekładanie problemów zarządzania logistycznego na dalszy, bliżej nieokreślony plan,

- nieodpowiednia polityka przedsiębiorstwa,

- brak ujęcia systemowego,

- problemy z konkurencją,

- małe zainteresowanie menedżerów,

- bariery finansowe,

- bariery osobowe,

- bariery prawne.

W warunkach polskich barier tych jest jeszcze więcej, a najważniejsze z nich to: niski poziom świadomości menedżerów, pracowników usług motoryzacyjnych oraz ich klientów, istnienie szarej strefy i brak skutecznej kontroli oraz egzekwowania istniejącego prawa.

Dla usług motoryzacyjnych można wyróżnić następujące kluczowe kwestie mające wpływ na efektywne zarządzanie logistyka zwrotną:

- informacja o powrotnych przepływach,

- kontrolowanie towarów wchodzących do ponownego użycia,

- dystrybucja do centrów naprawczych i na rynek detaliczny,

- projektowanie sieci logistyki zwrotów,

- strategie logistyczne,

- szkolenia kierownictwa i pracowników,

- ścisła współpraca z rynkami wtórnymi,

- wchodzenie w relacje sieciowe z innymi firmami,

- wykorzystanie możliwości Internetu,

- standaryzacja i optymalizacja procesów wspomagających działania w obszarze powrotnych przepływów.

Narzędzia do zarządzania logistyką zwrotną to: weryfikacja, czyli sprawdzanie i testowanie części i zespołów przeznaczonych do ponownego użycia, analiza cyklu pracy części, zespołów i całych obiektów, systemy informacji, regenerację i naprawy, zarządzanie finansami oraz outsourcing.

\section{Zakończenie}

W krajach wysokorozwiniętych logistyka zwrotna stała się czynnikiem rozwoju gospodarczego, harmonijnie łącząc aspekty techniczno-ekonomiczne z ekologicznymi. W dobie kryzysu gospodarczego i dążenia do optymalizacji wydatków i kierowania strumienia pieniędzy w najbardziej potrzebne sektory działalności przedsiębiorstwa coraz wyraźniej zauważalna 
jest tendencja do szukania oszczędności. Menedżerowie coraz częściej dokonują analiz i kalkulacji, zauważając wymierne korzyści, jakie mogą przynosić procesy logistyki zwrotnej, stąd przybywa przedsiębiorstw, które są zainteresowane tym obszarem logistyki.

Przedsiębiorstwa, aby utrzymać się na rynku, muszą stawiać czoła coraz to nowszym problemom i wyzwaniom, a logistyka zwrotna, która obejmuje kluczowe procesy związane z odwrotnym przemieszczaniem się produktów w całym łańcuchu dostaw, daje możliwości strategicznej szansy i tworzenia dodatkowej wartości dla przedsiębiorstw nie tylko z sektora usług motoryzacyjnych. Skuteczne zarządzanie procesami logistyki zwrotnej może stać się wówczas źródłem przewagi konkurencyjnej podmiotu.

W Polsce logistyka zwrotna cieszy się rosnącym zainteresowaniem praktyków i teoretyków biznesu oraz poparciem społecznym, gdyż jej obszary dotyczą takich popularnych terminów jak społeczna odpowiedzialność oraz zrównoważony rozwój.

Aby zmniejszyć koszty logistyki zwrotnej, przedsiębiorstwa z sektora usług motoryzacyjnych będą musiały koncentrować się na kilku aspektach powrotnych przepływów. Należą do nich:

- implementowanie nowych technologii w serwisie i demontażu samochodów,

- wdrażanie technologii przyjaznych środowisku,

- stosowanie technik IT,

- podejmowanie ścisłej współpracy z innymi przedsiębiorstwami m.in. w relacjach sieciowych i obszarach outsourcingu,

- szkolenie menedżerów i pracowników,

- szeroko rozumiana współpraca z klientami - użytkownikami samochodów.

Samochody wycofane z eksploatacji określane są często mianem bomb ekologicznych. W Polsce ich liczba wynosi od 120 tys. do 150 tys. rocznie, a w wysoko rozwiniętych krajach UE już obecnie wynosi od $8 \mathrm{mln}$ do $9 \mathrm{mln}$ sztuk rocznie. Podkreślenia wymaga fakt, że część problemów związanych ze złomowaniem SWE jest przenoszona z tych krajów do Polski ze względu na znaczny import pojazdów używanych.

\section{Literatura}

Ares - opis systemu. (2010). Pozyskano z: http://www.ambit.pl/index.php?option=com_content\&ta$\mathrm{sk}=$ view\&id= $=51 \&$ Itemid $=45$.

Badanie świadomości i potrzeb informacyjno-edukacyjnych matych i średnich przedsiębiorstw w obszarze eko-zarządzania w województwie lubuskim. (2012, 15 sierpnia). Pozyskano z: http://www. mrr.gov.pl/aktualnosci/fundusze_europejskie_2007_2013/Documents/2Eko_zarz\%C4\%85dzanie_ monografia_24012011.pdf.

Bendkowski, J., Wengierek, M. (2002). Logistyka odpadów Procesy logistyczne w gospodarce odpadami. Gliwice: Wydawnictwo Politechniki Śląskiej.

Blumberg D.F. (2005). Reverse Logistics and Closed Loop Supply Chain Processes. New York: CRC Press.

Bril, J., Łukasik, Z. (2012). Logistyczny system gospodarki odpadami. Logistyka, (3).

Ciesielski, M. (2000). Logistyka. Pozyskano z: http://www.wszib.poznan.pl/wydawnictwo/dystrybucja/download/logistyka_ciesielski.pdf.

Did You Know that Cars Are the Most Recycled Product in America?. (2012). Pozyskano z: http://www. reuters.com/article/2008/01/14/idUS212526+14-Jan-2008+PRN20080114.

Dyrektywa 2000/53/EC Parlamentu Europejskiego i Rady Unii Europy z dnia 18 września 2000 dotycząca pojazdów o zakończonym życiu technicznym.

Góra, J. (2012). Regeneracja części zaczęła się w Ameryce. Rynek części, 10-11. 
Janczewski, J. (2011). Recykling produktowy w procesie zarządzania przedsiębiorstwem usługowym. W: J. Bakonyi, J. Dzieńdziora, O. Grabiec, M. Smolarek (red.), Zarządzanie w innowacyjnej gospodarce. Sosnowiec: Oficyna Wydawnicza Humanitas, 237-255.

Janczewski, J. (2012). Zarządzanie recyklingiem produktowym w usługach motoryzacyjnych. W: J. Cheda (red.), Ochrona środowiska jako kluczowy problem Polski XXI wieku. Warszawa: Fundacja Ius Medicinae, 93-113.

Janczewski, J. (2012). Zarządzanie procesem odzyskiwania produktów odpadowych w sektorze usług motoryzacyjnych, Logistyka, 2.

Korzeń, Z. (2001). Ekologistyka. Poznań: Instytut Logistyki i Magazynowania.

Mesjasz-Lech, A. (2010). Makroekonomiczne aspekty logistyki zwrotnej. Pozyskano z: http://www.czasopismologistyka.pl/czasopismo/index.php?option=com_docman\&task=doc_view\&gid=75\&tm$\mathrm{pl}=$ component $\&$ format $=$ raw\&Itemid $=79$.

Michniewska K. (2006). Nowe trendy w logistyce: Logistyka odzysku, a ekologistyka. Logistka, (1).

O odpadach nieco więcej. (2012, 19 lipca). Pozyskano z: http://www.ekorecykler.pl/index.php?optio$\mathrm{n}=$ com_content\&view $=$ category\&layout $=$ blog\&id $=6 \&$ Itemid $=4$.

Pfohl, H.-Ch. (1998). Systemy logistyczne, Poznań: ILiM.

Pokharel, S., Mutha, A. (2009). Perspectives in reverse logistics; A review. Resources Conservation and Recycling, 53.

Projekt Ustawy o odpadach z dnia 30.03.2012, Dziat I, Rozdziat 2, Art. 3.1, poz. 16, 2012, s. 8. (2012). Pozyskano z: http://mos.gov.pl/g2/big/2012_04/119d0010c269d27d303420458c29b3a0.pdf.

Quesada, I.F. (2012, 5 sierpnia), The koncept of reverse logistic. A review of literature, Paper presented at the Annual Conference for Nordic Researchers in Logistics NOFOMA'03 in Oulu (Finlandia) (2003, 12-13 czerwca). Pozyskano z: http://gio.uniovi.es/documentos/bel-li/nofoma.pdf.

Rogers, D.S., Tibben-Lembke R.S. (1998). Going Backwards: Reverse Logistics Trends and Practices. Nevada: University of Nevada, Reno Center for Logistics Management, Reverse Logistics Executive Council.

Romaldowski, R. (2012). Drugie życie. Metody remarketingu samochodów po wynajmie długoterminowym. Flota Auto Biznes (48).

Rozporzadzenie Komisji (WE) Nr 1400/2002 z dnia 31 lipca 2002 r. w sprawie stosowania art. 81 ust. 3 Traktatu do kategorii porozumień wertykalnych i praktyk uzgodnionych $w$ sektorze motoryzacyjnym.

Rozporządzenie Ministra Infrastruktury z 28 września 2005 w sprawie wykazu przedmiotów wyposażenia i części wymontowanych z pojazdów, których ponowne użycie zagraża bezpieczeństwu ruchu drogowego lub negatywnie wplywa na środowisko, Dz.U. 2005 nr 201, poz. 1666.

Sadowski, A. (2008). Zrównoważony rozwój z perspektywy logistyki zwrotnej. Problemy Ekorozwo$j u, 3(8)$.

Sadowski, A. (2009a). Czynniki determinujące rozwój logistyki zwrotnej w gospodarce (cz. II). Gospodarka Materiałowa i Logistyka, 4.

Sadowski, A. (2009b). Zarys rozwoju logistyki zwrotnej. Logistyka, 5.

Sosnowski, K. (2012). Metody remarketingu samochodów po wynajmie długoterminowym, Outsourcing \& More, $(7 / 8)$.

Sprawozdanie Rzeczypospolitej Polskiej na temat osiągniętych poziomów ponownego użycia i odzysku oraz ponownego użycia i recyklingu pojazdów wycofanych z eksploatacji za okres od dnia 1 stycznia 2010 r. do dnia 31 grudnia 2010 r. (2012, 5 sierpnia). Pozyskano z: http://www.mos.gov. pl/g2/big/2012_07/08344467b2cb93b46d381243d7f243cd.pdf.

Szołtysek, J. (2009). Logistyka zwrotna, Poznań: ILiM.

Timeline of industrial remanufacturing. (2012, 21 lipca). Pozyskano z: http://www.reman.rit.edu/about. html.

Thierry, M., Salomon, M., Nunen, J., Wassenhove, L. (1995), Strategic Issues in Product Recovery Management, California Management Review, 37(2).

Tomczyk, W. (2005). Aspekty ekologii w konstruowaniu i odnowie maszyn i urządzeń, Journal of Research and Applications in Agricultural Engineering, 50(4). 
Wąsowicz, A. (2010). Kierunki przepływów materialnych i informacyjnych w motoryzacji. Logitrans. W: Systemy Transportowe, Bezpieczeństwo w Transporcie, VII Konferencja Naukowo-Techniczna Logistyka.

Włodarczyk, M. (2002). Recykling jako czynnik rozwoju gospodarczego. W: M. Kozłowski (red.), Recykling tworzyw sztucznych R"2002". Wrocław: Oficyna Wydawnicza Politechniki Wrocławskiej, 81-85.

Verstrepen, S., Cruijssen, F., Brito, M.P., Dullaert, W. (2007). An Exploratory Analysis of Reverse Logistics in Flanders, European Journal of Transport and Infrastructure Research, 7(4).

Mirosław Włodarczyk, prof. dr hab. inż., prof. zw., Społeczna Akademia Nauk, Wydział Marketingu. Główne zainteresowania badawcze: zarządzanie wiedzą, ochrona wiedzy przedsiębiorstwa, ekologistyka.

Mirosław Włodarczyk, Prof, Social Academy of Science, Faculty of Marketing.

Professor at the Social Academy of Science, Faculty of Marketing; main research interests: knowledge management, protection of enterprise knowledge, ecologistics.

Adres/Address: $\quad$ Społeczna Akademia Nauk ul. Sienkiewicza 9, 90-113 Łódź, Polska

Jerzy Janczewski, $\quad$ dr inż., adiunkt, Akademia Humanistyczno-Ekonomiczna, Katedra Systemów Transportowych.

Inżynier mechanik, doktor nauk ekonomicznych w zakresie zarządzania. Zainteresowania badawcze koncentrują się na logistyce zwrotnej i problematyce zarządzania przedsiębiorstwami mikro- i małymi z branży usług motoryzacyjnych i transportu drogowego.

Jerzy Janczewski, MSc, PhD, University of Humanities and Economics in Lodz, Department of Transport Systems.

MSc Mechanical Engineering, $\mathrm{PhD}$ in economic sciences in management; research interests focus on reverse logistics and management issues of micro and small enterprises, in the automotive service industry and road transport.

Adres/Address: $\quad$ Akademia Humanistyczno-Ekonomiczna

Katedra Systemów Transportowych

ul. Rewolucji 1905, nr 64, 90-222 Łódź, Polska 


\title{
Jadwiga Gałka \\ Nina Grad
}

Uniwersytet Jagielloński

\section{Odnowa bielskiej starówki w opinii mieszkańców}

\section{Renovation of Bielsko-Biala's Old Town in the opinion of residents}

\begin{abstract}
Streszczenie
Bielsko-Biała podjęła się realizacji projektu „Rewitalizacja bielskiej starówki”, z którym równolegle były realizowane programy przeciwdziałania wykluczeniu społecznemu. Niestety, połączenie interesów mieszkańców z interesami przedsiębiorców czy samorządu jest niezwykle trudne i pomimo zakończenia 6 programów, w których wzięło udział ponad 450 osób, słyszy się wiele negatywnych opinii na temat rewitalizacji, która miała być reakcją na kryzys gospodarczy i zahamowanie rozwoju miasta. Wiele odnowionych kamienic nie znalazło do tej pory użytkowników, a część mieszkańców cały czas czeka na decyzję o przesiedleniu. Wyniki badań potwierdzają, że odnowa elewacji i wymiana stolarki okiennej jest niewystarczająca dla coraz bardziej wymagającego społeczeństwa obywatelskiego.
\end{abstract}

\begin{abstract}
Bielsko-Biala has pledged to carry out a project entitled 'Revitalization of Bielsko-Biała's Old Town', which was implemented in parallel programs, to combat social exclusion. Unfortunately, the discrepancy between the aims of the project and the needs and requirements of residents and local businesses is proving to be a source of immense difficulty. Despite finalizing six programs, which were attended by over 450 people, numerous negative reviews were noted, concerning revitalization. Many of the renovated buildings are still not inhabited, and some residents are expecting an eviction notice. This seems to confirm that renovating facades and replacing windows is not sufficient for an increasingly demanding society.
\end{abstract}

Słowa kluczowe: fundusze strukturalne; programy przeciwdziałania wykluczeniu społecznemu; rewitalizacja

Key words: structural funds; programs against social exclusion; revitalization

\section{Wprowadzenie}

Przystąpienie Polski w 2004 r. do struktur Unii Europejskiej budziło liczne obawy, ale jednocześnie dało nowe możliwości. Fundusze strukturalne wsparły działalność wielu beneficjentów, wśród których znalazły się również jednostki terytorialne próbujące otrzymać dotację na projekty wspomagające zrównoważony rozwój miast. Aby jednak mogła powstać harmonijna przestrzeń miejska, koniecznym stało się podjęcie przedsięwzięć przywracających ład przestrzenny i znaczenie obszarów zmarginalizowanych (Grad, 2010). Dobrym przykładem jest miasto Bielsko-Biała, które od kilkunastu lat skutecznie wykorzystuje środki europejskie, tak przedakcesyjne, jak i fundusze dostępne już po akcesji Polski do Unii Europejskiej. 
Pierwsze dotacje w wysokości $3 \mathrm{mln}$ zł miasto pozyskało na „Modernizację infrastruktury okołobiznesowej na Śląsku - Bielsko-Biała - uzbrojenie terenu Parku Przemysłowego i Usługowego" z programu PHARE 2000 - Spójność Społeczna i Gospodarcza. Z funduszy PHARE 1999 zrealizowano trzy projekty: „Renowacja kolektora CENTRUM”, „Modernizacja i budowa sieci kanalizacyjnej oraz wodociągowej dla miasta Bielsko-Biała”, „Modernizacja sieci uzdatniania wody dla Bielska-Białej” o wartości dofinansowania $20 \mathrm{mln}$ zł. W ramach Programu Współpracy Przygranicznej Phare CBC Polska-Słowacja - edycja 2002/2003 - i Phare CBC 2003 dofinansowanie w kwocie około 164 tys. zł otrzymały cztery tzw. miękkie projekty, które dotyczyły współpracy kulturalnej i sportowej z sąsiadami ze Słowacji. Były wśród nich projekty „Co jest grane? - nawiązanie transgranicznej współpracy sportowej” oraz „Poznajemy nasze góry - rozwój turystyki pieszo-rowerowej w Beskidach". Z kolei w ramach Phare 2002 miasto uzyskało dofinansowanie w kwocie 135 tys. zł na projekt „Przeciw bezradności lokalny system wsparcia aktywizacji zawodowej środowisk szczególnie zagrożonych wykluczeniem społecznym w mieście Bielsko-Biała”. W ramach Zintegrowanego Programu Operacyjnego Rozwoju Regionalnego miasto uzyskało około $102 \mathrm{mln}$ zł dofinansowania na projekty drogowe obejmujące modernizację bądź całkowitą przebudowę ulic. Wizytówką miasta stał się projekt „Nowa Starówka - Nowe Szanse. Rewitalizacja Bielskiej Starówki I etap”, który uzyskał 7 mln zł.

Ogółem przyznane dotacje na projekty twarde zrealizowane przez miasto Bielsko-Biała, realizowane i oczekujące na podpisanie umowy dotacji, wyniosły $214 \mathrm{mln}$ zł, a projekty miękkie - 24 mln zł. Ogółem dotacje przyznane dla miasta oraz spółek dają około $481 \mathrm{mln}$ zł (W Bielsku-Białej, 2009).

Niestety często względy ekonomiczne dominują w większości projektów nad problemami społecznymi, co w konsekwencji przekłada się na brak rzeczywistego ożywienia gospodarczego i rozwiązania problemów ubóstwa, bezrobocia czy przestępczości. Przesiedlanie najuboższych i wprowadzenie nowych mieszkańców i funkcji gospodarczych nie gwarantuje sukcesu, a wręcz przeciwnie, może przyczynić się do powstania tzw. miejskiej pustyni społecznej, z którą żaden mieszkaniec nie będzie chciał się utożsamiać.

Celem niniejszego artykułu jest zestawienie działań ujętych w Lokalnym Programie Rewitalizacji, analiza zrealizowanych do tej pory przedsięwzięć oraz przedstawienie oceny mieszkańców na temat aktualnych efektów rewitalizacji.

\section{Dokumenty strategiczne}

Bielsko-Biała jest jednym z niewielu miast, które może pochwalić się tak bogatym doświadczeniem rewitalizacyjnym (Grad, 2011). Miasto było bardzo dobrze przygotowane do tworzenia programu rewitalizacji ze względu na wcześniej przeprowadzone odpowiednie analizy, studia i ujęcia problematyki rewitalizacji w strategicznych dokumentach planistycznych. Już na początku lat 90. XX w. działania rewitalizacyjne zaczęły się od wypełniania luki remontowej. W latach 1991-1996 ze środków gminy wybudowano 263 lokale mieszkalne, co stanowiło 23,3\% ogólnej liczby wybudowanych mieszkań w Bielsku-Białej. Przez adaptacje budynków użytkowych i zmiany sposobu użytkowania lokali uzyskano 61 mieszkań, przez remonty pustych lokali w przejętych budynkach uzyskano 16 lokali, a przez adaptacje strychów uzyskano 25 mieszkań (Strategia rozwoju..., 1998).

W 1996 r. zostały opracowane założenia polityki mieszkaniowej, które miały przyczynić się do poprawy jakości życia w zasobach mieszkaniowych, wzrostu zasobów mieszkaniowych i pomocy mieszkaniowej najuboższym mieszkańcom. „W tymże roku liczba mieszkań na 1000 mieszkańców wynosiła 316 (Polska - 298, Niemcy - 430, Francja - 464, Wielka 
Brytania - 405) - jako minimalny standard europejski przyjmuje się dostępność 400 mieszka na 1000 mieszkańców, zatem dla Bielska-Białej niedobór wynosił ponad 15 tys. mieszkań" (Strategia rozwoju..., 1998).

W 1997 r. powołano urząd Pełnomocnika Prezydenta Miasta ds. Rewitalizacji Bielskiej Starówki oraz Zespół Koordynacyjny ds. rewitalizacji, który w latach 1997-1998 opracował Plan rewaloryzacji bielskiej starówki, przyjął Miejscowy plan zagospodarowania przestrzennego bielskiej starówki i Strategię rozwoju Bielska-Białej do 2010 roku.

Plan rewaloryzacji bielskiej starówki zakładał przeprowadzanie remontów z utrzymaniem zabytkowego charakteru obiektów, wykonanie prac konserwatorskich, poprawienie funkcjonalności układu pomieszczeń oraz zagospodarowanie istniejących podwórek. Miejscowy plan zagospodarowania przestrzennego bielskiej starówki zawiera szczegółowe wytyczne do przeprowadzenia remontów konserwatorskich, przebudowy infrastruktury technicznej, zagospodarowania przestrzeni publicznych na podstawie Planu rewaloryzacji bielskiej starówki. Strategia rozwoju Bielska-Białej do 2010 roku uwzględnia zachowanie tożsamości historyczno-kulturowej, poprawę funkcjonowania systemu transportowego, rozwój infrastruktury technicznej, rozwój budownictwa mieszkaniowego, zrównoważony rozwój miasta (Program rewitalizacji..., 2004)

W 2004 r. przyjęto Program rewitalizacji bielskiej starówki. Dokument poza ogólnymi zasadami gospodarowania mieniem, przeprowadzania remontów, nowych inwestycji, monitorowania i oceny określa planowane zadania inwestycyjne. Do najpilniejszych zadań z zakresu rewitalizacji zaliczono odbudowę budynku przy ul. Rynek 4, 5 wraz z odsłonięciem podcieni, remont konserwatorski kwartału A z rozbiórką zniszczonych i zbędnych przebudówek oraz oficyn, remont konserwatorski kwartału B, C, D z rozbiórką zniszczonych i zbędnych przebudówek oraz oficyn, rozbudowę i modernizację sieci uzbrojenia terenu, przebudowę płyty rynku, remont muru oporowego przy ul. Orkana i ul. Żwirki i Wigury. Poza tym gmina jest odpowiedzialna za uporządkowanie stanu formalno-prawnego nieruchomości, przygotowanie obiektów do sprzedaży, przygotowanie niezbędnej dokumentacji oraz rozbudowę i modernizację przestrzeni publicznych, naprawę i wzmocnienie skarp i murów oporowych Wzgórza Miejskiego, wprowadzenie i utrzymanie zieleni na terenach wolnych, przygotowanie mieszkań do przekwaterowania lokatorów. W Programie... równolegle założono przeciwdziałanie degradacji społecznej i wspieranie aktywizacji gospodarczej (Program rewitalizacji..., 2004).

W 2006 r. opracowano Strategię rozwoju Bielska-Białej do 2020 roku, która jest kontynuacją założeń ze Strategii rozwoju Bielska-Białej do 2010 roku. Przyjęta wizja brzmi: Bielsko-Biała miastem przedsiębiorczym, przyjaznym, uczącym się. Jako priorytety zakłada się rozwój przedsiębiorczości, usług i turystyki, odnowę miejsc zamieszkania i poprawę jakości przestrzeni publicznych, rozwój oparty na wiedzy i umiejętnościach, rozwój bielskiego obszaru metropolitalnego. Rezultatem w sferze społecznej ma być rozbudowa mieszkalnictwa, zahamowanie procesów wykluczenia społecznego, obniżenie środowiskowych kosztów funkcjonowania miasta oraz wzrost dostępności, bezpieczeństwa i sprawności funkcjonowania miejskiej infrastruktury transportowej (Strategia rozwoju..., 2006).

Rok 2007 to uchwalenie Programu rozwoju mieszkalnictwa miasta Bielska-Białej do 2020 roku, w którym dla realizacji celów przyjmuje się następujące kierunki działań: stworzenie warunków dla przyrostu nowych zasobów mieszkaniowych, rewitalizacja obszarów zabudowy mieszkaniowej, gospodarowanie mieszkaniowym zasobem gminy, przeciwdziałanie bezdomności. Wśród planowanych przedsięwzięć wyróżniono poprawę standardu technicznego, funkcjonalnego i ekologicznego osiedli, renowację historycznej zabudowy, przeciwdziałanie marginalizacji grup społecznych i ograniczenie zjawisk patologii społecznych, poprawę bez- 
pieczeństwa zamieszkania, pozyskiwanie powierzchni na lokale socjalne, pozyskiwanie lokali komunalnych, remont pustostanów.

Kolejnym krokiem w stronę rewitalizacji było uchwalenie w 2009 r. Programu rewitalizacji obszarów miejskich w Bielsku-Białej. W dokumencie tym przedstawiono charakterystykę obecnej sytuacji w mieście, ewaluacje rewitalizacji za okres 2004-2006, raport z konsultacji społecznych, założenia programu i plan działania, system wdrażania i monitoring. O wartościowej i spójnej konstrukcji PROM-u świadczy nawiązanie do licznych dokumentów strategicznych: Strategiczne wytyczne Wspólnoty dla spójności gospodarczej, społecznej i terytorialnej na lata 2007-2013, Narodowe Strategiczne Ramy Odniesienia 2007-2013 wspierajace wzrost gospodarczy i zatrudnienie, Narodowa strategia spójności, Strategia rozwoju województwa śląskiego na lata 2000-2020, Regionalny program operacyjny województwa śląskiego na lata 2007-2013, Strategia rozwoju Bielska-Białej do 2020 roku, Strategia rewitalizacji bielskiej starówki, Program rewitalizacji bielskiej starówki przyjęty uchwała nr XXXI/964/2004 Rady Miejskiej z dnia 6 lipca 2004 roku, Wieloletni plan inwestycyjny. Celem głównym Programu rewitalizacji obszarów miejskich w Bielsku-Białej jest ożywienie gospodarcze i społeczne oraz zwiększenie potencjału turystycznego i kulturalnego obszaru poddanego rewitalizacji. W dokumencie wyróżniono trzy cele strategiczne i kilka celów szczegółowych:

- Cel strategiczny 1: Rozwój infrastrukturalno-przestrzenny z zachowaniem dziedzictwa kulturowego.

- Cel szczegółowy: Renowacja historycznej zabudowy, poprawa ładu przestrzennego i estetyki miasta.

- Cel szczegółowy: Poprawa standardów mieszkaniowych w dzielnicach zabytkowych oraz z wielkiej płyty.

- Cel szczegółowy: Poprawa funkcjonalności struktury ruchu kołowego, pieszego oraz infrastruktury parkingowej.

- Cel szczegółowy: Modernizacja i poprawa estetyki terenów zieleni miejskiej.

- Cel szczegółowy: Rozwój infrastruktury turystycznej, rekreacyjnej i sportowej.

- Cel szczegółowy: Rozwój infrastruktury edukacyjnej i kulturalnej.

- Cel szczegółowy: Rozwój infrastruktury pomocy społecznej i zdrowia publicznego.

- Cel strategiczny 2: Aktywizacja gospodarcza obszarów rewitalizowanych.

- Cel szczegółowy: Tworzenie warunków i infrastruktury dla rozwoju przedsiębiorczości.

- Cel szczegółowy: Wspieranie aktywności i inicjatyw gospodarczych mieszkańców przez promocję, doradztwo i działania edukacyjne.

- Cel szczegółowy: Wzmocnienie funkcji usługowych i handlowych na obszarze rewitalizowanym.

- Cel strategiczny 3: Zapobieganie problemom społecznym i patologiom na obszarach objętych rewitalizacją.

- Cel szczegółowy: Poprawa bezpieczeństwa publicznego i zapobieganie przestępczości.

- Cel szczegółowy: Zwiększenie integracji społecznej osób wykluczonych społecznie oraz zagrożonych wykluczeniem, osób starszych i niepełnosprawnych.

- Cel szczegółowy: Dążenie do integracji na rynku pracy osób poszukujących pracy, nieaktywnych zawodowo oraz osób znajdujących się w niekorzystnym położeniu (osoby niepełnosprawne, zagrożone wykluczeniem społecznym), zapobieganie bezrobociu, zwłaszcza bezrobociu długotrwałemu i bezrobociu wśród młodzieży (Program rewitalizacji obszarów miejskich..., 2007). 


\section{Delimitacja obszaru rewitalizacji}

Obok pozyskania funduszy na rewitalizację bardzo ważny jest odpowiedni wybór obszaru objętego projektem. Tylko trafnie wskazany obszar kryzysowy i rzetelnie podjęte działania realnie mogą przyczynić się do przemiany sytuacji panującej na danym terenie i odnowy całej tkanki miejskiej. Zgodnie z kryteriami określonymi w art. 47 Rozporzadzenia Komisji WE nr 1828/2006 z dnia 8.12.2006 r. ustanawiajacego szczegółowe zasady wykonywania rozporzadzenia Rady (WE) nr 1083/2006 w procesie wyznaczania obszarów kryzysowych miast bierze się pod uwagę dla kategorii interwencji 61 - zintegrowane projekty odnowy miejskiej następujące kryteria, z czego co najmniej 2 muszą zostać spełnione:

- wysoki poziom ubóstwa i wykluczenia,

- wysoka stopa długotrwałego bezrobocia,

- niekorzystne trendy demograficzne,

- niski poziom wykształcenia,

- wysoki poziom przestępczości i wykroczeń,

- szczególnie wysoki stopień degradacji środowiska,

- niski wskaźnik prowadzenia działalności gospodarczej,

- wysoka liczba imigrantów, grup etnicznych i mniejszości lub uchodźców.

Dla interwencji 78 - infrastruktura mieszkalnictwa muszą być spełnione dwa kryteria z ww. oraz jedno z podanych poniżej:

- porównywalnie niski poziom wartości zasobu mieszkaniowego,

- niski poziom wydajności energetycznej budynków (rozporządzenia Komisji WE w procesie wyznaczania obszarów kryzysowych).

Obszary zdegradowane objęte rewitalizacją w Bielsku-Białej - starówka oraz centrum miasta - w znacznym stopniu są zamieszkiwane przez osoby długotrwale bezrobotne, niejednokrotnie borykające się z problemami patologii społecznej, które są zmuszone korzystać z systemu pomocy społecznej (ryc. 1). Stopa bezrobocia w mieście wynosi 4,8\%, przy czym bardzo negatywnym zjawiskiem jest fakt, że bez pracy dłużej niż 1 rok pozostaje $41 \%$ liczby ogółem bezrobotnych -4431 . Jest to poważny sygnał o potrzebie podejmowania nieustannych działań na rzecz społeczności lokalnych, mających na celu zapobieganie ich dalszemu wykluczeniu (Program rewitalizacji obszarów miejskich..., 2007; Rocznik demograficzny, 2010).

Ryc. 1. Rozmieszczenie bezrobocia w przestrzeni Bielska-Białej
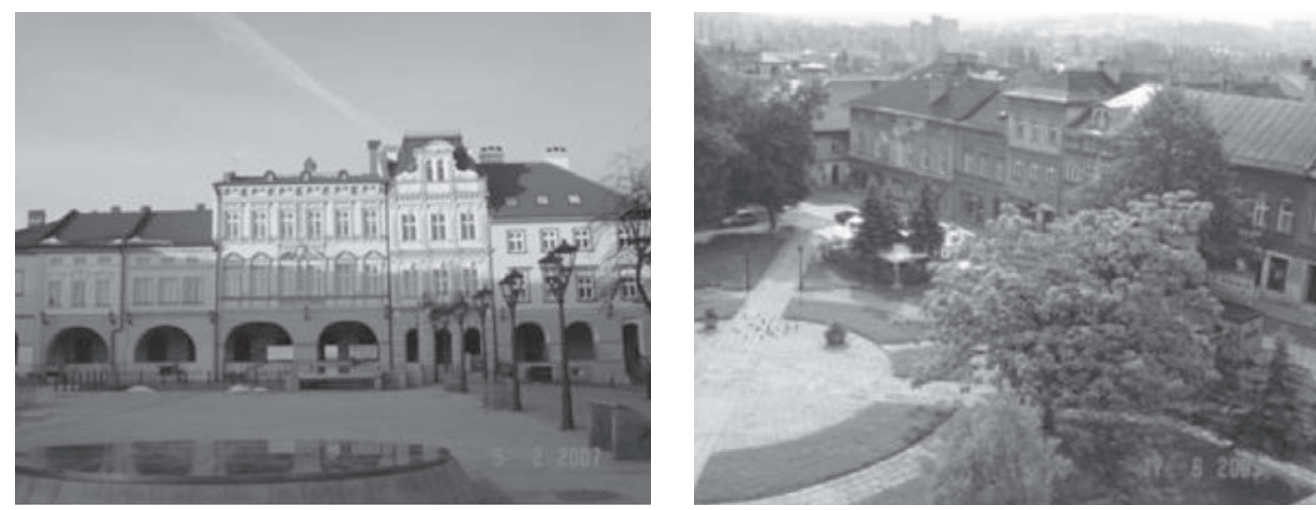

Źródło: Zborowski, Dej (2009). 


\section{Efekty rewitalizacji}

Spójny program rewitalizacji, konsekwencja w działaniu i zaangażowanie wielu podmiotów przyniosły efekty większe, niż się spodziewano. Przy I etapie odnowy rynku wskazano tylko 2 wskaźniki produktu: $200 \mathrm{~m}$ zmodernizowanych dróg i $5213 \mathrm{~m}^{2}$ zmodernizowanych obiektów dziedzictwa kulturowego, a także 1 wskaźnik rezultatu w postaci 5 nowych ofert programowych w zakresie kultury i turystyki. Ostatecznie nowa starówka to $750 \mathrm{~m}$ zmodernizowanej sieci wodociągowej, $726 \mathrm{~m}$ sieci sanitarnej, $360 \mathrm{~m}$ kanalizacji deszczowej, $550 \mathrm{~m}$ sieci gazowej i $700 \mathrm{~m}$ sieci energetycznej niskiego napięcia oraz sześć odnowionych historycznych obiektów tzw. małej architektury (np. pomniki) na płycie rynku. W latach 2003-2006 przeprowadzono remont konserwatorski budynku komunalnego przy ul. Cieszyńskiej, kamienicy przy ul. Rynek 4, 5, 6, katedry św. Mikołaja, przy ul. Rynek 13/15, przebudowano plac Św. Mikołaja, przeprowadzono remonty w budynkach prywatnych: ul. Cieszyńska 7, Piwowarska 3, Schodowa, pl. Św. Mikołaja 3, Podcienie 2 i 4, ul. Orkana 4, ul. Wzgórze 12, odsłonięto podcieni w zachodniej części Rynku, wykonano remont elewacji i dachów budynków przy ul. Rynek 1, 2, 3, wybudowano parking na około 30 stanowisk, rozpoczęto remont konserwatorski kamienicy przy ul. Rynek 15, przygotowano koncepcję 2 parkingów (w tym 1 parkingu wielopoziomowego na około 450 miejsc), wykonano I etap monitoringu bielskiej starówki, rozpoczęto remont konserwatorskich kolejnych kamienic prywatnych (ul. Rynek 7, Piwowarska 2, Cieszyńska 11 i 9, pl. św. Mikołaja 2, Celna 14, Rynek 28 i 29). Od 2007 r. zakończono remont konserwatorki kamienicy przy ul. Rynek 4, 15, 23, 30 oraz budowę parkingu przy ul. Orkana/pl. M. Lutra, wykonano remont konserwatorski muru oporowego przy budynku znajdującym się na pl. Żwirki i Wigury 1, kontynuowano remonty kamienic prywatnych (ul. Rynek 1, 2, 3, 7, Piwowarska 2, Cieszyńska 1, 3, 4, 9, 11, pl. Św. Mikołaja 2, ul. Celna 14), zakończono remont elewacji zamku Sułkowskich (Rewitalizacja bielskiej starówki, 2011).

Ciekawe wnioski pozwala wysunąć również analiza funkcjonalna obiektów. We wszystkich kapitalnie wyremontowanych prywatnych kamienicach mieszczą się już różnego rodzaju lokale usługowe lub nieruchomości te są przeznaczone do wynajęcia jako pomieszczenia użytkowe albo apartamenty. Ze względu na trwające lub niedawno zakończone prace w żadnej z tych kamienic nie rozwinęła się jeszcze funkcja mieszkaniowa. Widoczna jest natomiast wyraźnie sukcesja usług. Wywiad przeprowadzony wśród 20 firm potwierdził, że wprowadziły one swoje usługi do centrum dopiero po przeprowadzeniu remontów na terenie bielskiej starówki. Wyparły one też inne usługi i funkcje mieszkaniowe. Na tym terenie 3 firmy działają dłużej niż 5 lat, 2 firmy - 4 lata, a 15 firm krócej niż 2 lata, co świadczy o siedmiokrotnym zwiększeniu się ich liczby w ostatnich okresie. W kamienicach przy Rynku mieszczą się m.in.: hotel, bar, restauracja, fitness, apteka, cukiernia, antykwariat, wyposażenie wnętrz, oprawa obrazów, biuro podróży, centrum kreacji wizerunku, optyk, herbaciarnia. Przy ulicach odchodzących od Rynku swoją siedzibę znalazły: dwa salony fryzjersko-kosmetyczne, notariusz, winiarnia, księgarnia prawnicza, cztery biura nieruchomości, restauracja, cukiernia, komornik sądowy, kancelaria adwokacka, centrum promocji i reklamy, galeria włoskich sukien ślubnych, doradztwo finansowe. Choć ze względu na ciągle puste lokale mieszkalne za wcześnie tu mówić o procesie gentryfikacji, to napływ nowych, silniejszych ekonomicznie firm, wskazuje na zjawisko zwane gentryfikacją korporacyjną lub manhattanizacją (Majer, 1999).

\section{Badania ankietowe}

Uzyskane efekty rewitalizacji, obok przytoczonych zrealizowanych i planowanych działan, trzeba porównać z opinią mieszkańców Bielska-Białej. Opracowana przez Autorki ankieta została przeprowadzona wśród 3 grup respondentów: przedsiębiorców (w liczbie 21), którzy 
prowadzą swoją działalność przy Rynku, nielicznych mieszkańców (35), którzy jeszcze nie zostali przekwaterowani, oraz osób odwiedzających bielską starówkę (51), a zamieszkujących w innych dzielnicach bądź innych miastach.

Wśród przedsiębiorców 21 osób zgodziło się na udział w ankiecie. Wśród nich 47\% prowadzi swoją działalność w tym miejscu powyżej 10 lat, 29\% krócej niż 5 lat i 24\% 6-10 lat. Decydującymi czynnikami o lokalizacji był wolny lokal $-43 \%$, centrum miasta $-24 \%$, inne czynniki (np. sentyment, wcześniejsza lokalizacja) - 19\%; 14\% nie potrafiło wskazać głównego czynnika lokalizacji. 8 osób uznało, że przeprowadzone działania rewitalizacyjne nie wpłynęły na renomę firmy, 9 osób nie potrafiło jednoznacznie odpowiedzieć, a 4 osoby zauważyły wzrost renomy prowadzonej działalności, jednocześnie 47\% nie widzi wzrostu liczby klientów, 24\% trudno powiedzieć, a 28\% odnotowało większe obroty. Jeżeli chodzi o samo zainteresowanie odnowionym obszarem miasta, 52\% przedsiębiorców dostrzega większą liczbę odwiedzających, 33\% nie widzi większego ruchu, a 14\% nie obserwowało tego zjawiska. Plusy i minusy odnowy Starego Miasta w Bielsko-Białej wskazane przez badanych przedstawiono na rycinie 2 .

Ryc. 2. Plusy i minusy odnowy Starego Miasta w Bielsku-Białej

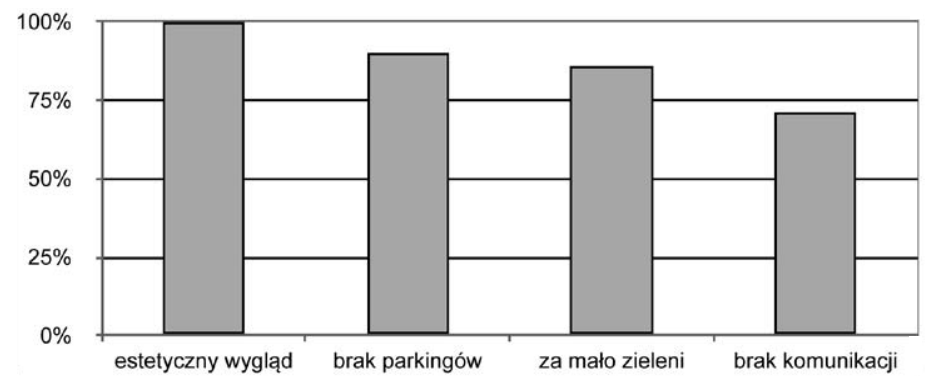

Źródło: badanie ankietowe przeprowadzone przez Autorki.

Godnym podkreślenie jest fakt, że 100\% ankietowanych przedsiębiorców uważa, że centrum miasta zostało słusznie wybrane do programu rewitalizacji. W badaniu wzięło udział 9 mężczyzn i 12 kobiet, wśród nich $29 \%$ to osoby do 25 roku życia, $38 \%$ to osoby w wieku 25-45 lat i 33\% to osoby powyżej 45 roku życia. 76\% osób posiada wykształcenie średnie, a $24 \%$ - wykształcenie wyższe.

Fot. 1, 2 - Bielski Rynek w 2005 i 2007 r.

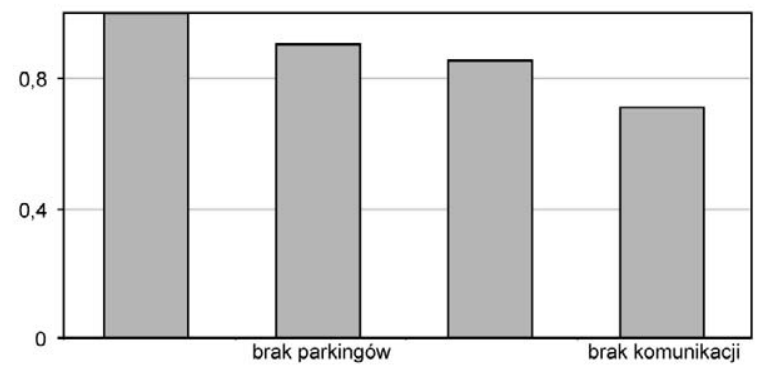

Źródło: www.um.bielsko.pl. 
Mieszkańcy jako plus odnowy wskazywali poprawę estetyki otoczenia i zwiększoną aktywność kulturalną, a do minusów zaliczyli hałas, odbywające się imprezy i działalność knajp. Badani nie podejmują jakiejkolwiek aktywności na rzecz miejsca zamieszkania, nie słyszeli i nie brali udziału w żadnych szkoleniach prowadzonych przez MOPS i konsultacjach organizowanych przez urząd miasta. Ankietowani nie mają kontaktów z sąsiadami. Mieszkańcy skarżą się na warunki mieszkaniowe (toalety w podwórku) oraz na przesiedlenia po tylu latach spędzonych w jednym miejscu. Respondenci to osoby z wykształceniem podstawowym bądź zawodowym, o średniej wieku 68 lat.

Osoby odwiedzające bielski Rynek to głównie ludzie młodzi: 30\% ma mniej niż 25 lat, a 52\% jest między 25 a 45 rokiem życia. 39\% badanych posiada wykształcenie wyższe, $35 \%$ wykształcenie średnie, 26\% wykształcenie podstawowe lub zawodowe. Wśród nich 70\% wie, że Stare Miasto w Bielsko-Białej zostało objęte programem rewitalizacji, a najczęstszymi skojarzeniami z pojęciem rewitalizacja były pojęcia odnowa, renowacja, przywrócenie dawnej świetności.

Respondenci doceniają poprawę estetyki otoczenia, dodatkowymi korzyściami jest dla nich stworzenie nowej wizytówki miasta, dokąd przyjeżdża więcej turystów. Jako wadę wskazali zbyt małą ilość zieleni (ryc. 3, fot. 1, 2).

Ryc. 3. Plusy i minusy odnowy Starego Miasta w Bielsku-Białej

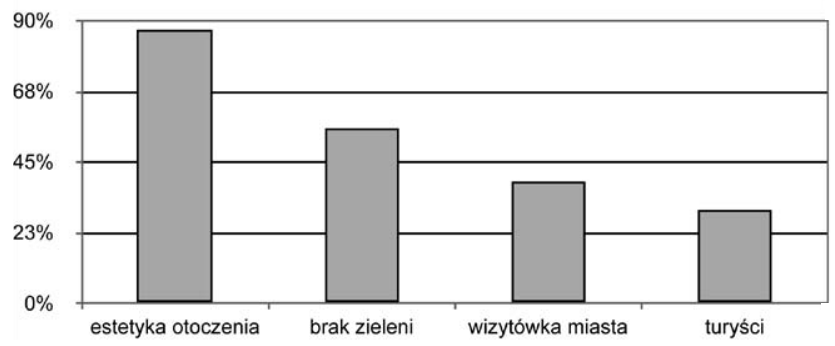

Źródło: badanie ankietowe przeprowadzone przez Autorki.

Osobiste korzyści, jakie odnieśli badani z przeprowadzonych działań rewitalizacyjnych, to przede wszystkim nowe miejsce spotkań i spacerów. 43\% badanych odwiedza centrum kilka razy w tygodniu, 35\% kilka razy w miesiącu, 12\% kilka razy w roku. Jednocześnie częstotliwość ta dla $65 \%$ badanych zwiększyła się po przeprowadzeniu programów odnowy. Podobnie jak w wypadku przedsiębiorców 100\% odwiedzających pochwala wybór Starego Miasta jako obszaru przeznaczonego do rewitalizacji.

\section{Zakończenie}

Bielsko-Biała jest przykładem miasta o bardzo bogatym doświadczeniu rewitalizacyjnym. Konsekwencja w działaniu, przemyślane i spójne programy przekładają się na ilość uzyskanych środków z funduszy europejskich oraz zrealizowanych i planowanych działań z zakresu przestrzennego, gospodarczego i społecznego. Ważnym elementem podejmowanych przedsięwzięć są liczne programy przeciwdziałania wykluczeniu społecznemu, które w wielu raportach otrzymują bardzo wysokie oceny. Nie zawsze jednak wizja podejmowanych działań pokrywa się z wyobrażeniami i oczekiwaniami samych mieszkańców. Choć badani jednomyślnie pochwalają wybór terenu do rewitalizacji i doceniają podjęte działania, to mają jednak wątpli- 
wości co do samych efektów. Bardzo wiele osób zwraca uwagę na nieprzemyślane i nieskoordynowane działania remontowo-budowlane i ubolewa nad betonowym obliczem obecnego, a kiedyś pełnego zieleni, rynku.

Pozostaje mieć nadzieję, że władze miasta dołożą jeszcze więcej starań nad lepszą komunikacją z mieszkańcami, a kolejne realizowane projekty będą dobrym przykładem dla innych polskich miast, które czeka jeszcze długa droga, aby być na takim etapie, na jakim jest dzisiaj Bielsko-Biała.

\section{Literatura}

Grad, N. (2010). Rola Zintegrowanego Programu Operacyjnego Rozwoju Regionalnego i regionalnych programów operacyjnych w realizacji procesów rewitalizacji, Przedsiębiorczość - Edukacja, 6, 379-390.

Grad, N. (2011). Przedsiębiorczość miejska - lokalne programy rewitalizacji instrumentami odnowy miast, Przedsiębiorczość - Edukacja, 7, 207-224.

Majer, A. (1999). Miasta Ameryki. Kryzys i polityka odnowy, Warszawa: PWN.

Program rewitalizacji bielskiej starówki 2004. (2004). Bielsko Biała.

Program rewitalizacji obszarów miejskich w Bielsku-Białej. (2007). Bielsko Biała.

Rewitalizacja bielskiej starówki (2011, 11 lipca). Pozyskano z: http://um.bielsko.pl/web/index.php?option $=$ com_content\&task $=$ view\&id=873\&Itemid $=64 . \mathrm{r}$

Rocznik demograficzny 2010 r. (2010). Pozyskano z: http://www.stat.gov.pl/cps/rde/xbcr/gus/PUBL_rs_ rocznik_demograficzny_2010.pdf.

Rozporządzenia Komisji WE w procesie wyznaczania obszarów kryzysowych (2011, 21 marca). Pozyskano z: http://www.mg.gov.pl/files/upload/10123/Sprostowanie_Rozp_Komisji_1828_8.12.2008 _EFRR_EFS_FS.pdf.

Strategia rozwoju Bielska-Białej do 2010 roku. (1998). Bielsko-Biała: Agencja Rozwoju Regionalnego. Strategia rozwoju Bielska-Białej do 2020 roku. (2006). Bielsko-Biała: Agencja Rozwoju Regionalnego. W Bielsku-Białej. (2009). Magazyn Samorządowy, Urząd Miejski w Bielsku-Białej.

Zborowski, A., Dej, M. (2009). Ocena stopnia zaawansowania zjawisk degradacji społecznej, procesy polaryzacji i segregacji, segmentacja rynku pracy w miastach Polski. W: A. Zborowski (red.), Demograficzne i społeczne uwarunkowania rewitalizacji miast w Polsce, Kraków: IRM, 100.

Jadwiga Gałka, dr, Uniwersytet Jagielloński, Instytut Geografii i Gospodarki Przestrzennej, Zakład Geografii Ludności, Osadnictwa i Rolnictwa.

Absolwentka Uniwersytetu Pedagogicznego w Krakowie, magister geografii, doktor nauk o Ziemi w dyscyplinie geografia (Instytut Geografii i Gospodarki Przestrzennej Uniwersytetu Jagiellońskiego). Asystent w Instytucie Geografii i Gospodarki Przestrzennej Uniwersytetu Jagiellońskiego. Zainteresowania badawcze związane są z postakcesyjnymi migracjami Polaków, skupiają się wokół przestrzennej i społecznej mobilności nowych polskich imigrantów w Londynie.

Jadwiga Galka, PhD, Jagiellonian University, Institute of Geography and Spatial Management, Department of Geography of Population, Settlement and Farming.

Jadwiga Gałka graduated from the Pedagogical University in Cracow, with an MA in geography, and from Institute of Geography and Spatial Management, Department of Geography of Population of the Jagiellonian University, with a PhD in geography. Assistant at Instytut Geografii i Gospodarki Przestrzennej of the Jagiellonian University. Research interests connected with the post-accession migration of Poles, focusing around spatial and social mobility of new Polish immigrants in London. 
Nina Grad, mgr, Uniwersytet Jagielloński, Instytut Geografii i Gospodarki Przestrzennej, Zakład Geografii Ludności, Osadnictwa i Rolnictwa.

Absolwentka Uniwersytetu Pedagogicznego w Krakowie, magister geografii i licencjat gospodarki przestrzennej (UEK). Obecnie w trakcie pisania rozprawy doktorskiej „Demograficzno-społeczne aspekty procesów gentryfikacji i rewitalizacji obszarów miejskich w Polsce" (w Instytucie Geografii i Gospodarki Przestrzennej Uniwersytetu Jagiellońskiego). Zainteresowania badawcze związane są z przestrzennych i demograficznych zmianami w miastach postsocjalistycznych, skupiają się wokół gentryfikacji, regeneracji, rewitalizacji w dużych i średnich miastach Polski.

Nina Grad, MA, Jagiellonian University, Institute of Geography and Spatial Management, Department of Geography of Population, Settlement and Farming.

Nina Grad graduated from the Pedagogical University in Cracow, with an MA in geography. Currently researching and writing her doctoral thesis, entitled 'Socio-demographical aspects of gentrification and revitalization processes of urban areas in Poland' (at Institute of Geography and Spatial Management, Department of Geography of Population, Settlement and Farming of the Jagiellonian University). Research interests connected with spatial and demographic changes in post-socialist cities, focusing on gentrification, revitalization and urban regeneration in large and medium-size Polish cities.

Adres/Address: Uniwersytet Jagielloński, Instytut Geografii i Gospodarki Przestrzennej Zakład Geografii Ludności, Osadnictwa i Rolnictwa ul. Gronostajowa 7, 30-387 Kraków, Polska 


\author{
Monika Plaziak \\ Uniewersytet Pedagogiczny \\ im. Komisji Edukacji Narodowej \\ w Krakowie
}

\title{
Technologia tanich domów energooszczędnych jako odpowiedź na kryzys w budownictwie mieszkaniowym
}

\author{
Technology of constructing cheap, energy-efficient house as an answer \\ to the housing ind ustry crisis
}

\begin{abstract}
Streszczenie
Na tle kryzysu gospodarczego, ujawniającego się m.in. w budownictwie mieszkaniowym oraz rosnących kosztach utrzymania mieszkań, zwłaszcza ze względu na rosnące ceny nośników energii oraz $\mathrm{w}$ aspekcie relatywnie niskiego standardu mieszkaniowego w Polsce, w artykule omówiono przykład innowacyjnych poszukiwań w zakresie taniego budownictwa. Technologia budowy domów ze spienionego polistyrenu (zwanego neoporem) jest próbą wyjścia naprzeciw zapotrzebowaniu deweloperów i użytkowników na domy tanie w budowie, a jednocześnie zgodne ze współczesnymi trendami, a więc odpowiadające wymogom energooszczędności i pasywności. Jest to przykład nowatorskiego myślenia, opierającego się nie na udoskonalaniu istniejących, lecz na wprowadzaniu nowych metod budowlanych, polegających na wykorzystywaniu materiału dotychczas używanego w celach izolacyjnych do celów odmiennych - konstrukcyjnych. Omówiona w artykule metoda nie pozostaje pomysłem na papierze, ale znajduje zastosowanie w praktyce; istnieją już budynki powstałe w tej technologii, których wzniesienie wygenerowało znaczne korzyści w porównaniu z budową domów tradycyjnych. W przyszłości należy spodziewać się większej liczby podobnych przedsięwzięć, zrodzonych z zapotrzebowania na oszczędności w dobie kryzysu, świadczących zarazem o potencjale innowacyjnym polskich środowisk inżynierskich. Oczywiście muszą zostać pokonane pewne bariery mentalne, zwłaszcza dotyczące oporów przed mieszkaniem „w styropianie”, a także wymagana jest pewna elastyczność przyszłych użytkowników domów z neoporu. Zaprezentowane w artykule korzyści płynące z potencjalnego zastosowania nowatorskiej technologii z pewnością zadecydują o jej wdrożeniu. Niebagatelne znaczenie w przyszłości będzie miało wspieranie tego rodzaju inicjatyw przedsiębiorców przez środowiska naukowe i badawczo-rozwojowe, polegające głównie na ocenie i testowaniu nowych materiałów oraz technologii.
\end{abstract}

\begin{abstract}
The following paper discusses research, connected with innovative solutions in the field of cheap housing construction, relating to the economic crisis, noticeable also in the housing industry, in the form of rising costs of dwelling usage, due mostly to increasing prices of energy, in the aspect of the relatively low standard of housing in Poland. The technology of design and construction of buildings from frothed polystyrene ('neopor'), presented in the following article, is an example of meeting the expectations of developers and dwelling users, by building houses which are less expensive to construct and maintain, in accordance with the requirements of energy-efficiency and passivity.
\end{abstract}


The above is an example of innovative thinking, based not on improvements to existing building methods, but on the implementation of new solutions, which take advantage of modern materials (neopor), heretofore used only for purposes of insulation, and now being employed as a construction material. The method described in this article is not only a theoretical idea, but one that is being currently realized, in the form of buildings constructed from prefabricated neopor elements in the Małopolska region. Erecting these buildings, using the above-mentioned method, was cheaper and faster, compared to the traditional manner. Similar undertakings should be expected in the future, due to demand for low-cost housing in the period of crisis, and as an expression of the innovative potential of Polish engineers. Of course, such innovative solutions require the breaking of certain barriers of stereotypical thinking, connected with 'living in polystyryne foam', as well as a dose of flexibility from users of future neopor houses. However, benefits of applying such an innovative technology, presented in the article, will certainly lead to its implementation. In the future, the most important issue seems to be the development of cooperation between scientists and entrepreneurs, especially in the areas of tests and evaluations of new materials and technologies.

Slowa kluczowe: domy energooszczędne i pasywne; kryzys gospodarczy

Key words: energy-efficient and passive houses; economic crisis

\section{Wprowadzenie}

W niniejszym opracowaniu zaprezentowano innowacyjną technologię budowy domów, które mogą być wznoszone w postaci budynków energooszczędnych i pasywnych. Jest to rozwiązanie unikatowe w skali światowej, zważywszy zwłaszcza na aspekt oszczędnościowy kosztów i czasu budowy. Zasadniczym celem artykułu jest zasygnalizowanie konieczności poszukiwania tego rodzaju rozwiązań w związku ze stwierdzonym kryzysem w branży budownictwa mieszkaniowego, a więc zakładanymi niższymi funduszami na inwestycje mieszkaniowe w przyszłości, jak również wymaganiami określonymi w dyrektywie unijnej dotyczącej obowiązku krajów członkowskich do wznoszenia nowych budynków do roku 2020 wyłącznie w standardzie „niemal zeroenergetycznym”, który aktualnie w warunkach polskich wymaga przynajmniej kilkunastoprocentowych suplementarnych kosztów budowy. Jak wskazują zamieszczone w niniejszym opracowaniu analizy kosztów budowy wzniesionych domów energooszczędnych i pasywnych na świecie i w Polsce, każdorazowa budowa dokonana w takim standardzie generowała dotychczas wyższe nakłady finansowe, w porównaniu z budową domu tradycyjnego. W związku ze wspomnianą dyrektywą unijną stosowanie popularnych technologii budowy do wznoszenia domów zgodnych z wymogami dyrektywy wiązać się będzie z wyższymi niż obecnie kosztami budowy, a co za tym idzie - z pogłębieniem kryzysu w zakresie budownictwa mieszkaniowego. Jedyną alternatywą uniknięcia takiego scenariusza staje się poszukiwanie nowych rozwiązań, odpowiadających wymogom budownictwa zgodnego z wytycznymi unijnymi przy jednoczesnym spadku kosztów budowy. Jednocześnie istotnym przedsięwzięciem winno być rozbudowywanie i upowszechnianie bazy laboratoriów testowania nowych rozwiązań. Utrudniona dostępność do tego rodzaju ośrodków i wysokie koszty badań stanowią, zdaniem konstruktorów i architektów, wyraźną barierę wdrażania nowych technologii w zakresie budownictwa niskoenergetycznego.

\section{Pytanie o kryzys w budownictwie}

Przyjmując za podstawę dane statystyczne GUS dotyczące produkcji montażowo-budowlanej w ostatnich latach, nie możemy jednoznacznie wnioskować o kryzysie w całości branży budowlanej. W latach 2005-2011 ogólna produkcja budowlano-montażowa w Polsce 
wykazywała charakter wzrostowy, co opisuje wskaźnik wartości sprzedaży tej produkcji na 1 mieszkańca (ryc. 1). W pierwszej połowie 2012 r. (I-V) produkcja ta była nieco wyższa niż dla roku poprzedniego. O ile okres VI-VIII 2012 r. przyniósł niższą produkcję niż analogiczny okres roku 2011, o tyle sytuacja w sierpniu 2012 r. poprawiła się w stosunku do wcześniejszego miesiąca (ryc. 2).

Ryc. 1. Sprzedaż produkcji budowlano-montażowej w Polsce w latach 2005-2011 przypadająca na 1 mieszkańca

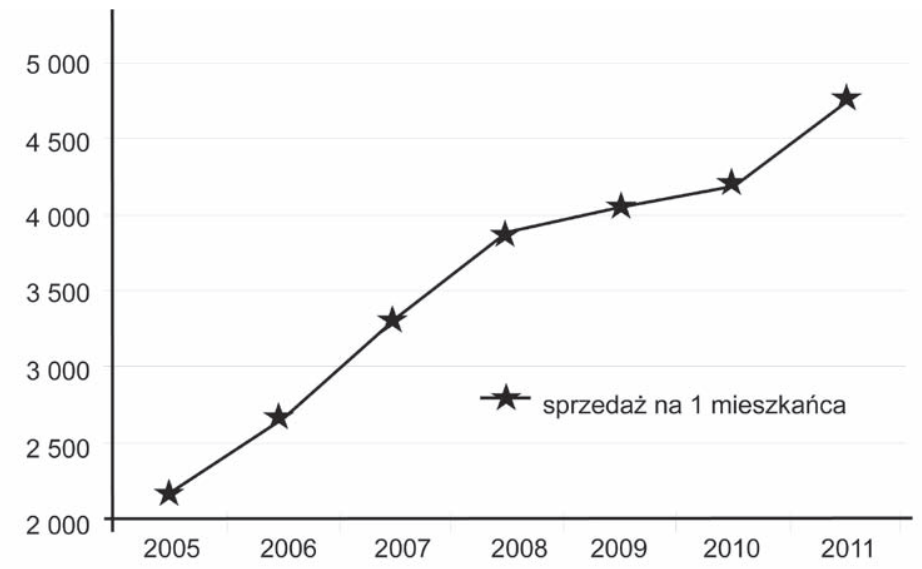

Źródło: opracowanie własne na podstawie danych GUS.

Ryc. 2. Miesięczna dynamika produkcji budowlano-montażowej w Polsce w latach 2008-2012

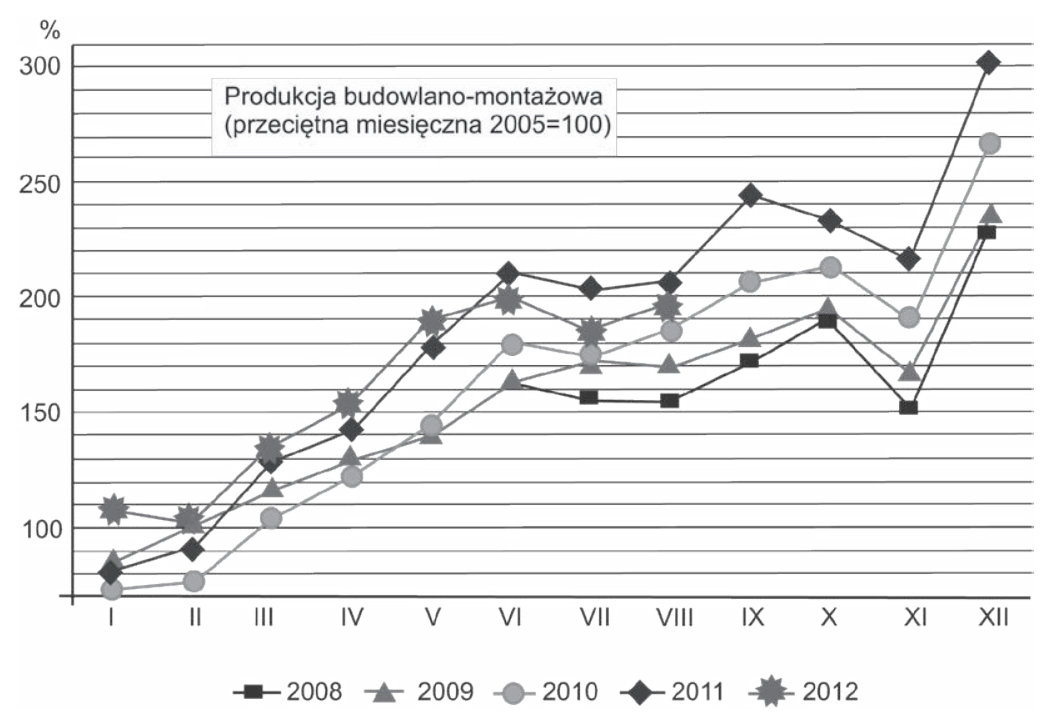

Źródło: GUS (2012). 
Biorąc jednak pod uwagę szczegółową produkcję budowlano-montażową za okres VIII 2011-VIII 2012, należy odnotować znaczny spadek produkcji w dwóch obszarach: produkcji firm budowlanych specjalizujących się we wznoszeniu budynków $(-13,2 \%)$ oraz produkcji firm wykonujących specjalistyczne roboty budowlane $(-6,3 \%)$. Natomiast firmy budowlane realizujące kontrakty w obszarze inżynierii lądowej i wodnej odnotowały wzrost produkcji $(+4,6 \%)$ (tab. 1). Ponadto, od 2005 r. notuje się systematyczny wzrost udziału zamówień publicznych w sferze budowlanej w ogólnej liczbie i wartości zamówień publicznych (Kozik, Starzyk, 2011).

Tab. 1. Dynamika produkcji budowlanej w okresie VIII 2011-VIII 2012

\begin{tabular}{|l|c|}
\hline Wznoszenie budynków & $-13,2 \%$ \\
\hline Specjalistyczne roboty budowlane & $-6,3 \%$ \\
\hline Kontrakty w obszarze inżynierii lądowej i wodnej & $+4,6 \%$ \\
\hline
\end{tabular}

Źródło: GUS (2012).

Całościowa produkcja budowlano-montażowa w okresie I-VIII 2012 r. była o 3,8\% wyższa niż w analogicznym okresie wcześniejszego roku. Jednakże należy pamiętać, że osiągnięte wyniki są konsekwencją wcześniej podpisanych kontraktów, w tym związanych z organizacją Mistrzostw Europy w Piłce Nożnej Euro 2012. Definiując kryzys ekonomiczny, za Encyklopedia $P W N$, jako ,gwałtowne zmniejszenie się aktywności gospodarczej (produkcji, zatrudnienia, inwestycji)", nie możemy wnioskować o kryzysie sięgającym całości produkcji budowlanej, ale z pewnością wspomniana powyżej ujemna dynamika produkcji dotycząca wznoszenia budynków oraz odnotowany po 2008 r. systematyczny spadek powierzchni mieszkań oddanych do użytkowania (ryc. 3), uzasadniają stwierdzenie kryzysu w budownictwie mieszkaniowym.

Kryzys gospodarczy do Polski dotarł z pewnym opóźnieniem w stosunku do jego obszaru źródłowego, czyli Stanów Zjednoczonych, a jego pierwsze przejawy uwidoczniły się w II kwartale 2008 r. (Rachwał, 2011). Budownictwo jest branżą niezwykle wrażliwą, dlatego ujawnienie się w niej znamion kryzysu w ramach niektórych rodzajów produkcji budowlanej nastąpiło relatywnie szybko (Gorzelak, 2009). Stąd też spadek w powierzchni mieszkań oddanych do użytkowania notowano już w 2009 r. (ryc. 3). Dobrym miernikiem kondycji budownictwa mieszkaniowego jest liczba wydawanych pozwoleń na budowę mieszkań. O ile w roku 2012 zanotowano, pierwszy po 2008 r., wzrost powierzchni mieszkań oddanej do użytkowania, o tyle w tym samym roku liczba pozwoleń na budowę mieszkań w nowych budynkach spadła (ryc. 4), co jest przejawem niepokojącym i potwierdzającym tendencję kryzysową w budownictwie mieszkaniowym Polski. Do tego faktu należy dołączyć kolejny - spadek liczby mieszkań sprzedanych, zachodzący pomimo obniżki cen mieszkań (źródło informacji: REAS). Mimo że na rynku oferta mieszkań nadal jest duża, deweloperzy przewidują jej uszczuplenie jako efekt obniżenia siły nabywczej potencjalnych klientów i spadku wolumenu kredytów udzielanych przez banki na zakup mieszkań. 
Ryc. 3. Powierzchnia mieszkań oddanych do użytkowania w Polsce w latach 2005-2011

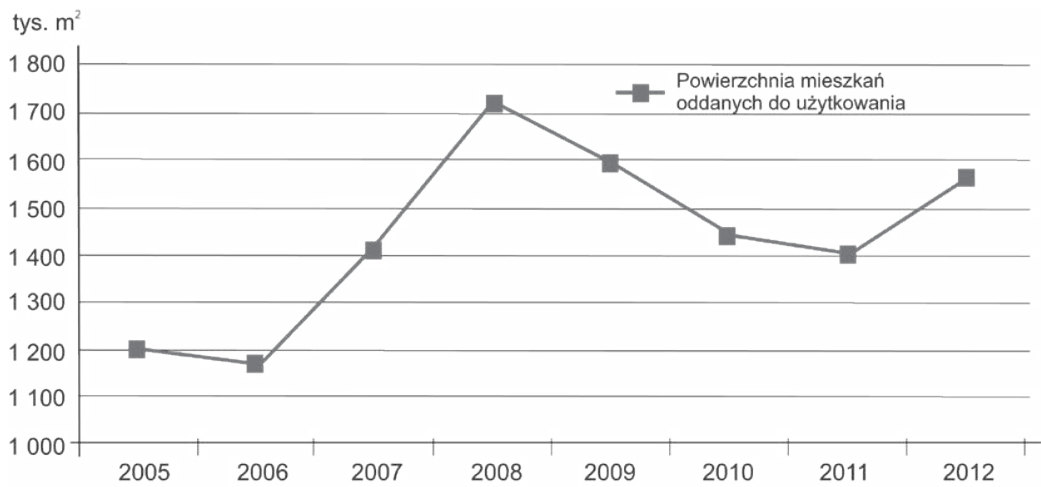

Źródło: opracowanie własne na podstawie danych GUS.

Ryc. 4. Liczba pozwoleń wydanych na budowę mieszkań w nowych budynkach mieszkalnych w Polsce w latach 2005-2012

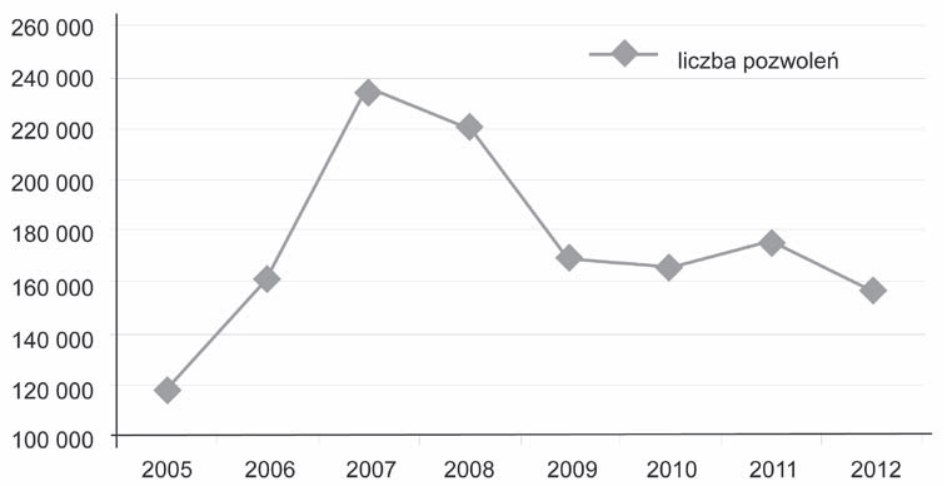

Źródło: opracowanie własne na podstawie danych GUS.

Na powyżej nakreśloną pogarszającą się sytuację produkcji i sprzedaży w budownictwie mieszkaniowym nakłada się relatywnie niski standard mieszkaniowy w Polsce, wyrażony przykładowo liczbą mieszkań przypadającą na 1000 osób. Wskaźnik ten dla Polski wynosi 348, podczas gdy dla większości krajów Europy Zachodniej ponad 500. Zbliżoną, a nawet wyższą wartość wskaźnika od tej aktualnej w Polsce, w krajach Europy Zachodniej stwierdzono już w latach 50. i 60. XX w. Polskie mieszkania są mniejsze i przeludnione, szacuje się, że w przeludnionych mieszkaniach żyje ponad 50\% ludności - gorszy wskaźnik spośród EU27 mają jedynie Węgry i Rumunia, przy średniej dla wszystkich państw unijnych wynoszącej niespełna 18\% (Housing Europe Review, 2011).

Kolejnym aspektem kryzysu w budownictwie mieszkaniowym są rosnące koszty utrzymania budynków, wyrażające się przede wszystkim rosnącymi kosztami energii służącej do ogrzewania mieszkań. Według danych GUS ceny użytkowania mieszkania i nośników energii tylko w okresie IX 2011-IX 2012 wzrosły o 5,5\%, w tym nośników energii o 6,4\%. 
Budownictwo mieszkaniowe stoi przed poważnym problemem wyjścia naprzeciw trudnościom związanym z malejącym popytem na mieszkania ze względu na ogólny kryzys gospodarczy, jak też z utrwalonymi, niższymi od unijnych, warunkami mieszkaniowymi w Polsce. W niniejszym opracowaniu autorka abstrahuje od rozwiązań politycznych, czyli na ile konieczna jest i jaką formę powinna przyjmować ingerencja państwa w rozwiązywanie problemów mieszkaniowych Polaków, ale podaje przykład skutecznej próby radzenia sobie z zaistniałą sytuacją i przetrwania na trudnym rynku mieszkaniowym przez firmy związane z branżą budowlaną. Wydaje się, że niebagatelnym sposobem radzenia sobie z kryzysem w budownictwie mieszkaniowym przez firmy budowlane powinno być poszukiwanie tańszych rozwiązań procesu budowlanego i niższych kosztów eksploatacji budynków.

\section{Czy dom energooszczędny może być tani w budowie?}

W krajach Europy Zachodniej coraz popularniejsza staje się technologia produkcji budynków energooszczędnych, dająca w dłuższej perspektywie czasowej użytkowania takich domów znaczne oszczędności w zakresie użytkowania energii elektrycznej oraz eksploatacji środowiska przyrodniczego. Przyjęło się, iż cena wybudowania takiego obiektu musi być wyższa niż cena obiektu powstającego w tradycyjnej technologii. Ponadto, cena ta rośnie wraz ze stopniem energooszczędności budynku. Jednakże po pewnym czasie dodatkowo poniesione koszty zwracają się, o czym szczegółowiej informuje dalsza część opracowania.

Również na gruncie polskim znane są już i popularyzowane budynki energooszczędne. Za budynek energooszczędny uznaje się zasadniczo taki, który zużywa 25-50\% mniej energii niż budynek tradycyjny, spełniający wymagania nowych warunków technicznych, obowiązujących od 1 stycznia 2009 r. (Rozporządzenie... Dz.U. nr 201, poz. 1238 z późn. zm.). Jak dotąd energooszczędność budynku nie jest prawnie określona, a wynika z zapotrzebowania i jest dynamiczna w związku z postępem techniki i coraz większymi wymaganiami użytkowników. Obecnie w Polsce wskaźnik zapotrzebowania ciepła na ogrzewanie budynku mieszkalnego wybudowanego zgodnie z aktualnymi przepisami budowlanymi wynosi ok. 65-125 kWh/m² powierzchni użytkowej na rok. Budynek energooszczędny powinien na cele ogrzewania, wentylacji i przygotowania ciepłej wody zużywać nie więcej niż 50-70 kWh/m² na rok (Kasperkiewicz, 2005).

Jak wcześniej wspomniano, wzniesienie budynku energooszczędnego od podstaw wymaga poniesienia dodatkowych kosztów w porównaniu z budową domu tradycyjnego, wynikających ze specjalnych wymogów i rozwiązań technicznych. Należą do nich:

- usytuowanie budynku z uwzględnieniem odpowiedniej rzeźby terenu, nasłonecznienia, kierunku wiatrów i osłony zielenią;

- forma budynku maksymalnie zwarta, bez występów i uskoków, pomieszczenia z dużymi oknami od strony południowej, małe okna lub ich brak od strony północnej, buforowe strefy ciepła (cieplarnie, przedsionki, okna słoneczne itp.);

- przegrody zewnętrzne (ściany, dach i stropodach) bardzo dobrze izolowane termicznie, z minimalną ilością mostków termicznych i szczelne;

- okna i drzwi zewnętrzne o wysokiej szczelności i izolacyjności termicznej;

- nocna izolacja okien (okiennice);

- konstrukcja budynku eliminująca większość mostków termicznych;

- balkony o specjalnej konstrukcji ograniczającej do minimum mostki termiczne;

- wentylacja automatycznie regulowana z odzyskiem ciepła;

- $\quad$ system grzewczy i system zaopatrzenia w wodę o bardzo dużej sprawności;

- zalecane wykorzystanie kolektorów słonecznych do przygotowania ciepłej wody użytkowej. 
Dom energooszczędny wymaga także pewnych obostrzeń na etapie projektowania i procesu budowy, czyli:

- dobrego projektu, w którym podane zostaną wszystkie szczegóły wykonania elementów, pozwalających na ograniczenie strat energetycznych;

- właściwej realizacji budowy, zgodnie z projektem, próby szczelności i badania rewizyjnego przegród zewnętrznych.

Powyżej wymieniono najważniejsze wymogi związane z budową domów energooszczędnych, w celu podkreślenia konieczności poniesienia dodatkowych, często wysokich kosztów, jak też zwrócenia uwagi na wynikające z energooszczędności ograniczenia w formie, usytuowaniu i użytkowaniu takich budynków, co może stanowić barierę w rozpowszechnianiu tego rodzaju budownictwa, który to problem poruszono w dalszych partiach niniejszego opracowania.

Wybitnym przykładem domu energooszczędnego jest dom pasywny, niemal całkowicie eliminujący zużycie energii do ogrzewania, zaledwie do $15 \mathrm{kWh} / \mathrm{m}^{2}$ na rok, w którym komfort cieplny zapewniony zostaje dzięki wykorzystaniu pasywnych źródeł ciepła, tj. pochodzących od mieszkańców, urządzeń elektrycznych i promieniowania słonecznego oraz dzięki radykalnemu zmniejszeniu strat ciepła związanego z przenikaniem przez ściany i na wentylację (odzysk ciepła w systemie rekuperacji). Budynek pasywny nie potrzebuje konwencjonalnych grzejników, a niezbędna ilość ciepła jest dostarczana przez dogrzewanie powietrza wentylacyjnego (Węglarz, Stępień, 2011).

Domy pasywne już od ponad 20 lat powstają w Niemczech, Austrii oraz innych krajach Europy Zachodniej. Budynek, aby mógł zostać uznany za pasywny, zwyczajowo w Europie musi uzyskać certyfikat niemieckiego Instytutu Domów Pasywnych w Darmstadt - instytucji sprawującej nadzór nad zachowaniem standardów pasywności, prowadzonej przez twórcę idei domu pasywnego, prof. Wolfganga Feista. Należy nadmienić, iż certyfikacja wiąże się z dodatkowymi kosztami, lecz daje gwarancję na określoną ilość energii, jaką dom będzie zużywał w przyszłości.

Z punktu widzenia korzyści ochrony środowiska domy energooszczędne, a zwłaszcza pasywne, przez ograniczone do minimum zapotrzebowanie na energię mają walor niezaprzeczalny. Korzyść ekonomiczna z punktu widzenia użytkownika także jest oczywista, jednakże odczuwalna dopiero po dłuższym czasie. Według informacji zasięgniętych w biurach projektowych oraz zawartych w literaturze przedmiotu (Węglarz, Stępień, 2011) budowa domu pasywnego kosztuje w Polsce o około 20\% więcej w porównaniu z budową domu tradycyjnego. Tak więc użytkownik może liczyć na zwrot dodatkowo poniesionych kosztów dopiero po kilkunastu latach najwcześniej. W wypadku domu energooszczędnego dodatkowe nakłady są niższe i ich zwrot następuje szybciej, lecz późniejsze zyski na oszczędzaniu energii są mniejsze niż w przypadku domu pasywnego. Dla porównania, w Danii koszt budowy domu pasywnego w stosunku do budowy domu tradycyjnego jest wyższy zaledwie o 4\% i taka inwestycja zwraca się po około 6 latach, a potem generuje już tylko oszczędności energetyczne, a co za tym idzie - ekonomiczne i środowiska naturalnego (tab. 2).

Tab. 2. Zestawienie kosztów i zysków dla domu energooszczędnego i domu pasywnego

\begin{tabular}{|l|c|c|}
\hline \multicolumn{1}{|c|}{ Koszty/zyski } & Dom energooszczędny & Dom pasywny \\
\hline Dodatkowe koszty budowy & kilka procent & $24 \%$ \\
\hline Zmniejszenie kosztów ogrzewania & trzykrotne & min. ośmiokrotne \\
\hline Zwrot dodatkowych kosztów budowy & kilka lat & kilkanaście lat \\
\hline
\end{tabular}

Źródło: informacje pochodzące z biur projektowych. 
W Polsce powszechnym błędem jest kalkulowanie ceny budynku tylko jako kosztów jego zbudowania, a przywiązywanie relatywnie niewielkiego znaczenia do kosztów eksploatacji. Wobec rosnących kosztów energii budownictwo energooszczędne i pasywne wydaje się jedyną alternatywą, która dostrzeżona została w krajach Europy Zachodniej już dawno temu. Przykładowo, w Austrii, w niektórych landach stosuje się tylko i wyłącznie budownictwo pasywne. Właśnie w tym państwie opracowano ogólnokrajowy program przebudowy obiektów zgodnie ze standardami pasywności, co wraz ze zwiększonym wykorzystaniem energii ze źródeł odnawialnych uczyni kraj niezależnym od paliw kopalnych oraz importu energii (Węglarz, Stępień, 2011).

Podsumowując, domy energooszczędne i pasywne mogą być tańsze, lecz tylko w dłuższej perspektywie czasowej, gdy dodatkowe koszty budowy zostaną zwrócone. Jest to od dawna możliwe w Europie Zachodniej. W warunkach polskich czas potrzebny na zwrot poniesionych kosztów jest ciągle długi, co wynika z wysokich kosztów budowy takich domów, będący następstwem ograniczonych możliwości technologicznych, warunków klimatycznych oraz niedostatecznych instrumentów dofinansowania, aby przeciętny inwestor czy użytkownik rozważał budowę takiego domu w aspekcie ekonomicznych oszczędności. Jak dotąd jest to modny wybór dla zamożniejszych klientów. Jednakże w obliczu rosnących kosztów uzyskania energii, a z drugiej strony - postępu technologicznego, stanowi on nieuniknioną drogę rozwoju budownictwa, śladem doświadczeń zachodnich. W Polsce, już od 1 stycznia 2009 r., niemal każdy, zarówno powstający, jak i remontowany budynek i lokal mieszkalny, budynek zamieszkania zbiorowego czy też budynek użyteczności publicznej, musi legitymować się świadectwem energetycznym (Rozporządzenie... Dz.U. z 2008 r. nr 201, poz. 1240). We wszystkich krajach unijnych do końca 2020 r. wszystkie nowe budynki będą musiały mieć niemal zerowe zużycie energetyczne (Dyrektywa 2002/91/UE; Dyrektywa 2010/31/UE).

Aby dom energooszczędny był naprawdę tani z punktu widzenia przeciętnego polskiego obywatela, musiałby spełnić nie tylko warunek ekonomicznej eksploatacji, ale także niższych od przeciętnych kosztów budowy. Takim oczekiwaniom wyjść może naprzeciw nowoczesna praktyka oparta na wiedzy, której towarzyszy odwaga przedsiębiorców i użytkowników w eksperymentowaniu z nowymi materiałami i technologiami. Temu zagadnieniu poświęcona jest poniższa część niniejszego artykułu.

\section{Innowacyjna technologia versus dom tradycyjny versus dotychczasowe budownictwo energooszczędne i pasywne}

W polskich realiach wysokich kosztów budowy, utrudnionego kredytowania zakupu mieszkań i rosnących kosztów eksploatacji mieszkań konieczne staje się poszukiwanie alternatywnych w stosunku do tradycyjnych, a uwzględniających nowoczesne, a więc energooszczędne lub wręcz pasywne technologie, nowych rozwiązań niosących ze sobą oszczędności finansowe na obu etapach: powstania i użytkowania budynków. Nowoczesną technologię budowania domów łączących oba aspekty: taniej budowy i taniej eksploatacji opracowała małopolska kadra architektów i konstruktorów we współpracy z przedsiębiorcami branży budowlanej. Innowacyjność przedsięwzięcia wyraża się w technologii wznoszenia ścian, w której konstrukcja budynku stanowi jednocześnie izolację termiczną. Ściany budynku wykonane są z neoporu (spienionego polistyrenu), czyli nowoczesnego materiału izolacyjnego, będącego kolejną fazą rozwoju styropianu. Jest to styropian o wyjątkowo dobrych warunkach termoizolacyjnych. Dotychczas spieniony polistyren wykorzystywany był jedynie jako materiał izolacyjny. Po dokonaniu odpowiednich obliczeń konstruktorskich okazało się, iż można go zastosować, przy specjalnym kształtowaniu, do celów konstrukcyjnych. Gotowe elementy 
ścian domów wycinane są z dużych bloków neoporu już w fabryce i następnie transportowane na teren budowy, gdzie są składane i klejone, tworząc sztywną bryłę domu (ryc. 5 i 6 ). Powiązanie budynku z fundamentem zapewnia zatopiona w tynku zewnętrznym siatka poliuretanowa, zakotwiczona w płycie fundamentowej. Siatka oplata cały budynek, tworząc bardzo wytrzymałą powłokę, która wspomaga ogólną stateczność budynku oraz wytrzymałość elementów prefabrykowanych na ściskanie, tworząc dodatkowy zapas nośności. W omawianej technologii charakterystyczne jest wykorzystanie łuków, które przez powielenie tworzą sklepienia kolebkowe, znane już sprzed XX w. p.n.e., a sprowadzające składowe sił powstające w konstrukcji przekrycia do sił ściskających działających na ściany. Podstawowe obciążenia wywołujące stany naprężenia zredukowane są do prostych sił ściskających (Repelewicz, 2011).

Ryc. 5. Schemat konstrukcji budynku z prefabrykowanych bloków ze spienionego polistyrenu (neoporu)
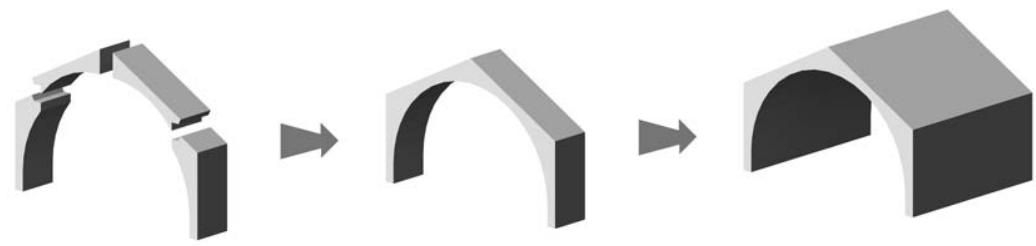

Źródło: M3-System.

Ryc. 6. Przykłady form budynków z prefabrykowanych bloków ze spienionego polistyrenu (neoporu)
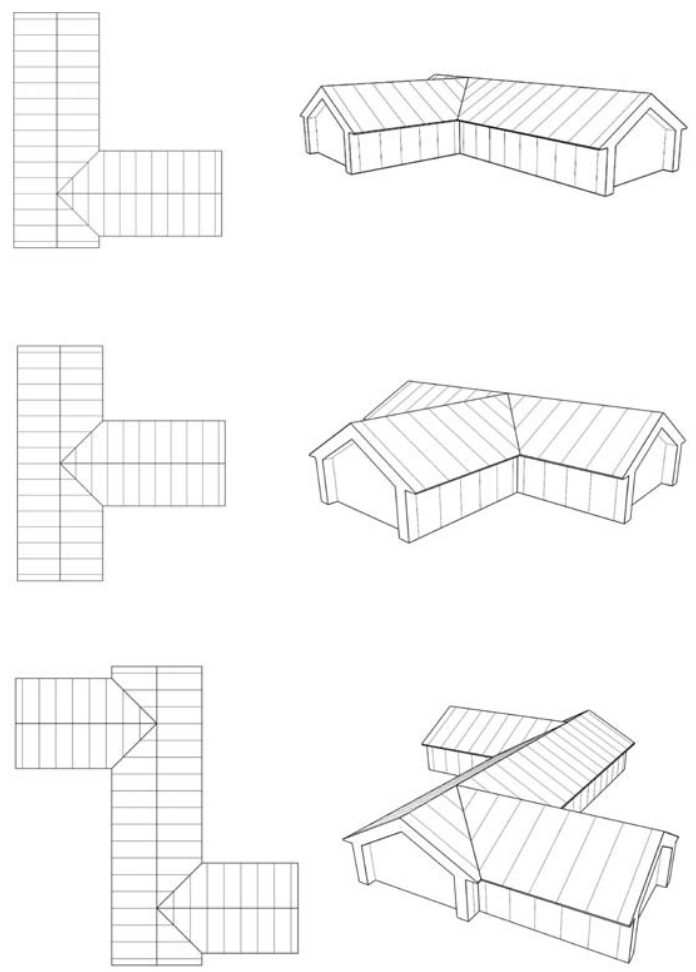

Źródło: M3-System. 
Oszczędności związane z budową obiektów z neoporu są wielorakie i wykraczają poza aspekt czysto ekonomiczny. Należą do nich:

1. oszczędności finansowe na etapie projektowania - projekty są proste, standardowe (oparte na możliwościach kształtowania neoporu), a więc cena projektu jest niższa od indywidualnego projektu domu tradycyjnego;

2. oszczędności finansowe (optymalizacja kosztów) na etapie wznoszenia budynku:

a) wykorzystanie jednego rodzaju materiału zarówno do konstrukcji, jak i izolacji wiąże się ze znacznie niższymi kosztami materiałów i robocizny,

b) zastosowanie formy monobloków eliminuje wykonanie niektórych elementów konstrukcyjnych, przede wszystkim więźby dachowej (monobloki od razu tworzą sklepienie),

c) ze względu na lekkość materiału konstrukcyjnego eliminuje się użycie dźwigów i drogiego transportu,

d) domy posadowione są na płycie fundamentowej, co eliminuje drogie roboty ziemne, a daje dodatkowe możliwości - domy z neoporu można stawiać nawet na gruntach o gorszych parametrach geotechnicznych, nieodpowiednich dla tradycyjnych technologii;

3. korzyści czasowe procesu budowy - ze względu na zastosowanie elementów wielkogabarytowych budowa domu trwa znacznie krócej niż zazwyczaj, zaledwie 2-3 miesiące do stanu ,pod klucz";

4. oszczędności finansowe na etapie użytkowania - małe straty energii służącej do ogrzania domu - wytworzone ciepło nie wnika w ściany, dom ogrzewa się szybko, dodatkowo można zastosować system rekuperacji powietrza, zamiast tradycyjnej wentylacji grawitacyjnej, który oszczędza energię;

5. korzyści dla środowiska naturalnego - przez ograniczone zużycie energii zmniejszona zostaje emisja gazów do otoczenia.

Według szacunków firmy wykonującej elementy konstrukcyjne z neoporu M3-System z Brzeska oraz pracowni projektowej Archisystem z Krakowa, budowa obiektu w tej technologii jest o połowę tańsza od budowy tradycyjnego domu. Ze względu na specjalne właściwości neoporu oraz opcjonalne zastosowanie rekuperacji powietrza, ilość energii zużytej do ogrzania domu może być niższa nawet do $85 \% \mathrm{w}$ porównaniu z tradycyjnym domem, co pozwala wykorzystać tę technologię do budowy domu energooszczędnego lub nawet pasywnego, w cenie nieprzekraczającej kosztów budowy domu tradycyjnego.

W omawianej technologii powstawać mogą nie tylko budynki mieszkalne, lecz również niewielkie obiekty użyteczności publicznej, np. biura, przedszkola, sklepy, kawiarnie. Dotychczas w tej nowatorskiej technologii powstało kilkanaście obiektów: budynek biurowy w Brzesku (całość budowy od momentu opuszczenia prefabrykatów z fabryki do zamknięcia obiektu trwała 6 tygodni) i Jarosławiu oraz domy jednorodzinne w Wieliczce, Niepołomicach i Michałowicach koło Krakowa (fot. 1, fot. 2). Aktualnie stawianych jest kilka domów jednorodzinnych w Małopolsce, na Śląsku oraz pod Warszawą. Innowacyjna technologia cieszy się zainteresowaniem w Austrii, Niemczech, w krajach arabskich oraz Meksyku i Brazylii, gdzie prowadzone są rozmowy odnośnie przyszłych realizacji.

System budowy obiektów z neoporu został opracowany przez konstruktorów i zgłoszony do urzędu patentowego. Materiał wykorzystywany do konstrukcji i zarazem izolacji jest produktem firmy „Basf” i posiada wszelkie atesty, m.in. świadectwo Instytutu Techniki Budowlanej. Jednakże pomysłodawcy opisanej nowatorskiej metody wznoszenia domów ze spienionego polistyrenu wskazują na niedostatek możliwości testowania tego rodzaju innowacji 
Fot. 1. Etap konstrukcji domu z prefabrykowanych bloków ze spienionego polistyrenu (neoporu)

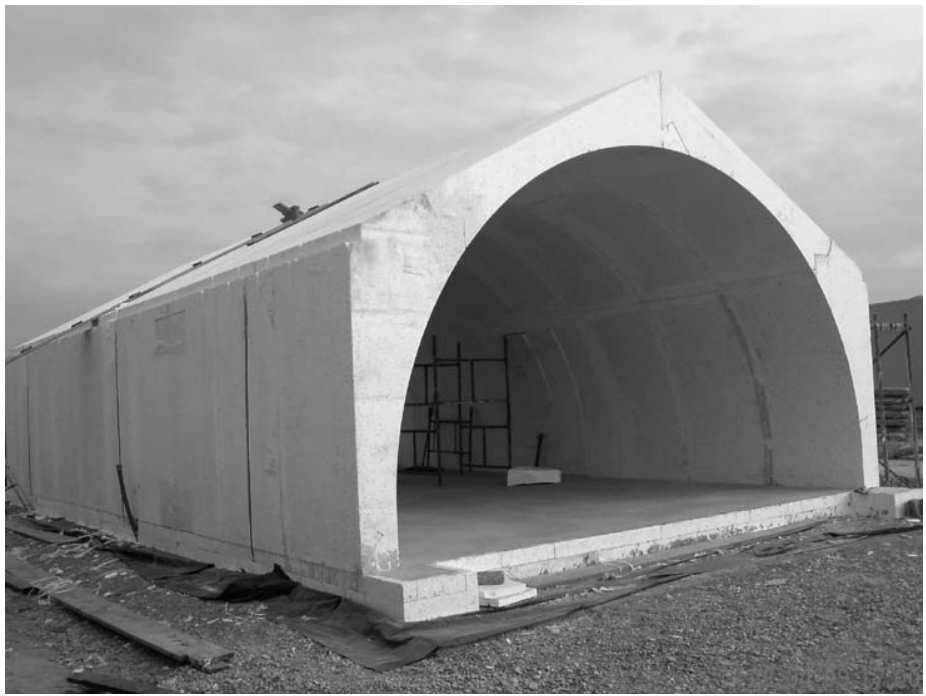

Źródło: M3-System.

Fot. 2. Przykład realizacji domu jednorodzinnego z prefabrykowanych bloków ze spienionego polistyrenu (neoporu), Wieliczka koło Krakowa

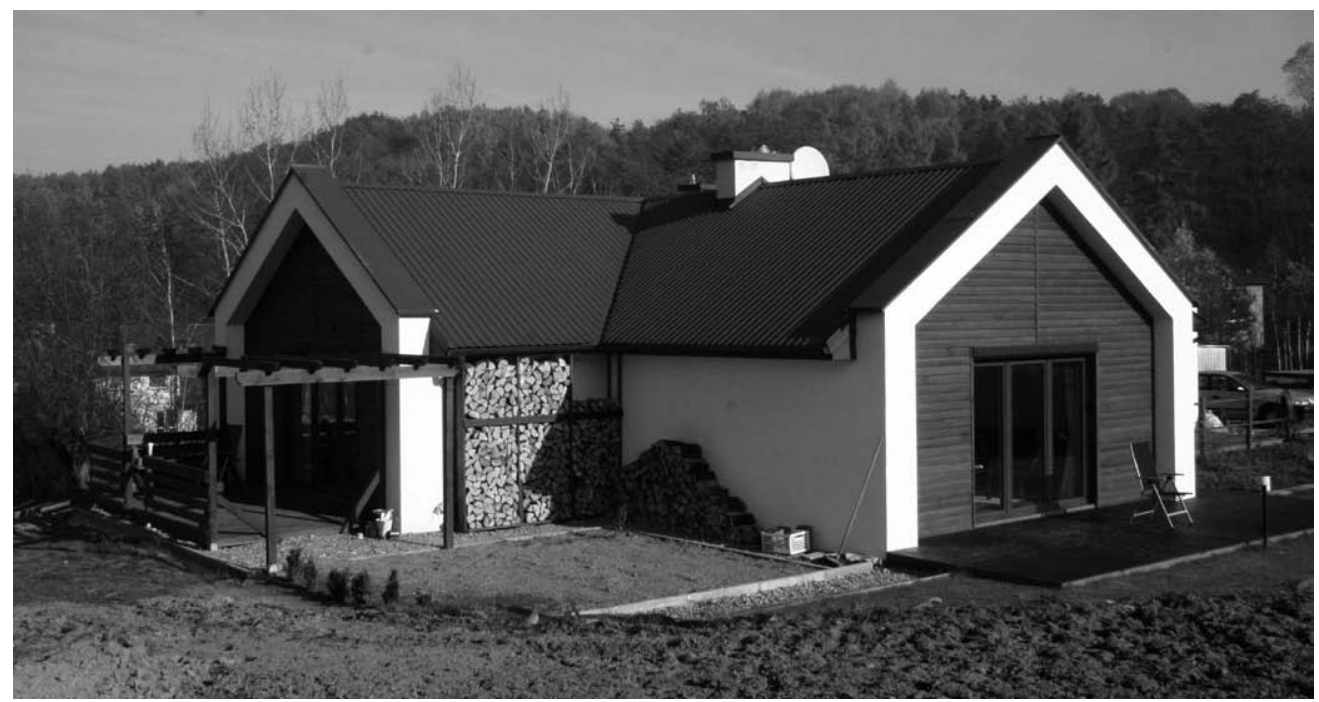

Źródło: M3-System.

w polskich realiach i postulują konieczność współpracy praktyków, tj. producentów, konstruktorów i projektantów ze środowiskiem naukowym w celach szerszego udostępnienia zaplecza naukowo-badawczego i pomocy przy weryfikacji oraz wdrażaniu nowatorskich pomysłów. W takie zapotrzebowanie wpisuje się doskonale inicjatywa powstania w naj- 
bliższej przyszłości Małopolskiego Laboratorium Budownictwa Pasywnego (MLBP) przy Politechnice Krakowskiej. Celem przedsięwzięcia jest m.in. stworzenie zaplecza badawczo-rozwojowego do badań, oceny oraz wdrażania nowoczesnych rozwiązań technologicznych, materiałowych, konstrukcyjnych i instalacyjnych dla tego rodzaju budownictwa. Samorząd województwa małopolskiego przeznaczył na projekt MLBP 3,5 mln euro (Fedorak-Cisak, Furtak, 2012). Laboratorium będzie prowadziło badania in situ, które w okresie początkowym będą miały charakter non profit. Staną się więc znaczącą pomocą dla przedsięwzięć takich, jak opisane w niniejszym opracowaniu. Firmy kreujące budowę domów z neoporu jako jedne z pierwszych wyraziły chęć współpracy z MLBP. Przyszła współpraca obu środowisk oraz przede wszystkim rozwój opisanego pomysłu budowy tanich domów z neooporu będzie przez Autorkę monitorowany, a spostrzeżenia znajdą swoje miejsce w przyszłych publikacjach.

\section{Zakończenie}

Nowatorska technologia wznoszenia domów ze spienionego polistyrenu, zwanego neoporem, jest doskonałą alternatywą dla drogich i nieekonomicznych domów tradycyjnych oraz jeszcze droższych w budowie, choć ekonomicznych w użytkowaniu, domów energooszczędnych lub pasywnych. Stanowi przykład owocnych poszukiwań nowych rozwiązań technologicznych, których celem jest uzyskanie oszczędności w procesie budowy. Oszczędności takie wymusza z jednej strony kryzys gospodarczy, a z drugiej strony - polityka unijna, wprowadzająca sukcesywnie w krajach członkowskich jako standard budownictwo niskoenergertyczne, związane ze specyficznymi wymogami materiałowymi i konstruktorskimi, generującymi jak dotąd dodatkowe koszty.

Wdrożenie na szerszą skalę omawianej technologii wymaga pokonania bariery mentalnej w postaci obaw przed nowością, uprzedzeń do mieszkania „w styropianie” oraz przyjęcia pewnych kompromisów, wynikających z ograniczeń dotyczących gabarytów i kształtowania formy - budynki powstające w tym systemie mogą być jednopoziomowe (lub ewentualnie dwupoziomowe, co podnosi jednak koszty budowy), a ich kształt podporządkowany jest elementom wielkogabarytowym, ograniczającym zróżnicowanie formy. Jednakże szala pozytywnych aspektów i barier do pokonania zdecydowanie przechyla się na korzyść tych pierwszych. Z pewnością w przyszłości coraz częściej będzie można napotkać w polskim krajobrazie budynki powstałe w omawianej technologii lub wykorzystujące podobne rozwiązania. W niniejszym opracowaniu zaprezentowano doskonały przykład próby przezwyciężania kryzysu w budownictwie mieszkaniowym od strony technologicznych rozwiązań - kryzys rodzi potrzebę działań innowacyjnych.

\section{Literatura}

Fedorak-Cisak, M., Furtak, M. (2012). Małopolskie laboratorium budownictwa pasywnego, Czasopismo Techniczne, Budownictwo, 3(109).

Gorzelak, G. (2009). Geografia polskiego kryzysu. Kryzys peryferii czy peryferia kryzysu? Warszawa: Regional Studies Association - Sekcja Polska.

Kasperkiewicz, K. (2005). Wybrane zagadnienia oceny i projektowania energooszczędnych budynków mieszkalnych, Prace Instytutu Techniki Budowlanej, 2 (134).

Kozik, R., Starzyk, E. (2011). Wpływ światowego kryzysu gospodarczego na polski rynek zamówień publicznych na roboty budowlane. Budownictwo i inżynieria środowiska, 2.

Rachwał, T. (2011). Wpływ kryzysu na zmiany produkcji przemysłowej w Polsce, Prace Komisji Geografii Przemystu Polskiego Towarzystwa Geograficznego, 17, 99-113. 
Repelewicz, M. (2011). Styropian jako materiał konstrukcyjny, Czasopismo Techniczne, Architektura, 11 (108).

Węglarz, A., Stępień, R. (2011). Dom pasywny. Warszawa: Instytut na rzecz Ekorozwoju, przy współpracy Krajowej Agencji Poszanowania Energii S.A.

\section{Źródla statystyczne i prawne}

Dyrektywa Parlamentu Europejskiego i Rady 2002/91/UE z dnia 16 grudnia 2002 r. w sprawie charakterystyki energetycznej budynków.

Dyrektywa Parlamentu Europejskiego i Rady 2010/31/UE z dnia 19 maja 2010 r. w sprawie charakterystyki energetycznej budynków.

GUS (2012, 15 października), Informacje bieżace, Warszawa.

Housing Europe Review, The Nuts and Bolts of European Social Housing Systems, 2012, 2011, CECODHAS Housing Europe's Observatory, Brussels.

Rozporzadzenie Ministra Infrastruktury z 6 listopada 2008 r. zmieniajace rozporzadzenie w sprawie warunków technicznych, jakim powinny odpowiadać budynki i ich usytuowanie (Dz.U. nr 201, poz. 1238 z późn. zm.).

Rozporządzenie Ministra Infrastruktury z 6 listopada 2008 r. w sprawie metodologii obliczania charakterystyki energetycznej budynku stanowiacej samodzielna całość techniczno-użytkowa oraz sposobu sporządzania świadectw i ich charakterystyki energetycznej (Dz.U. nr 201, poz. 1240).

\section{Źródła internetowe}

www.archisystem.pl, www.domy-pasywne.pl, www.m3system.pl, www.passiv.de, www.reas.pl

Monika Plaziak, dr, adiunkt, Uniwersytet Pedagogiczny, Instytut Geografii, Zakład Przedsiębiorczości i Gospodarki Przestrzennej.

Zainteresowania badawcze Autorki dotyczą zagadnień gospodarki przestrzennej w kontekście czynników lokalizacji przedsiębiorstw, szczególnie czynnika personalnego. Prace badawcze odnoszą się również do zagadnień współpracy jednostek naukowych i badawczo-rozwojowych z sektorem MŚP, zwłaszcza w zakresie wdrażania nowych technologii i materiałów, w tym dotyczących budownictwa energooszczędnego i pasywnego. Ponadto, autorka zajmuje się problematyką poziomu i jakości życia ludności, ze szczególnym uwzględnieniem małych i średnich miast Polski oraz miast postsocjalistycznych.

Monika Plaziak, PhD, Pedagogical University of Cracow, Institute of Geography, Department of Entrepreneurship and Spatial Management.

The author's research interests concern issues of spatial development in the context of location factors of enterprises, with special attention given to the personal factor. Research work also focuses on issues of cooperation between scientific and researchdevelopment organizations, within the sector of small and medium-sized enterprises, especially in the area of implementing new technologies and materials, related to energy-efficient and passive buildings. Additionally, the author analyses issues of the level and quality of life, with particular reference to small and medium-sized towns in Poland, as well as post-socialist towns.

Adres/Address: Uniwersytet Pedagogiczny, Instytut Geografii

Zakład Przedsiębiorczości i Gospodarki Przestrzennej

ul. Podchorążych 2, 30-084 Kraków

e-mail:mplaziak@up.krakow.pl 


\title{
Piotr L. Wilczyński
}

Uniwersytet Pedagogiczny

im. Komisji Edukacji Narodowej

w Krakowie

\section{Inwestycje w zbrojenia w czasach kryzysu gospodarczego}

\author{
Armaments in the period of an economic crisis
}

\begin{abstract}
Streszczenie
Skutki obecnego kryzysu finansowego często stają się przedmiotem dyskusji specjalistów w różnych dziedzinach, naukowców i publicystów. Głównym problemem badawczym w artykule jest określenie wpływu kryzysu na skalę i lokalizację inwestycji zbrojeniowych oraz obronność. Okazuje się, że kryzys finansowy nie wpływa znacząco na rozmiar wydatków, które w większości krajów są procentowo współmierne do dochodów osiąganych przed kryzysem. Istnieją jednak obszary o wzmożonych zbrojeniach, takie jak Rosja i kraje byłego Związku Radzieckiego, Chiny oraz sąsiadujące z nimi państwa, a także kraje Bliskiego Wschodu i Maghrebu. Kryzys w postaci redukcji zbrojeń jest zaś widoczny w Europie. W celu wyjaśnienia tego zjawiska zastosowano analizy porównawcze danych statystycznych. Ponieważ zmiany rozmieszczenia produkcji i konsumpcji broni wydają się ponadto niezbędną podstawą debaty geopolitycznej, wzbogacono artykuł o konieczne mapy. W zakończeniu problem jest rozpatrywany z perspektywy krajowej. Przedstawiono tam główne dylematy rozwoju polskiego przemysłu zbrojeniowego, polskiej obronności i zdolności bojowej Rzeczypospolitej Polskiej.
\end{abstract}

\begin{abstract}
Widespread discussions about crisis and its effects on military affairs are very popular among military scientists and journalists these days. Undertaken research focuses on question how crisis impacts military industry and defensiveness of states. It appears that financial problems didn't change military expenditures so much as expected. Those expenditures in most countries are proportional to GDP like before crisis. However there are some regional exceptions. Middle East and North African countries are now ones, which have much increased military expenditures. There are also notable increases in China and Russia with other post-soviet republics. On the other hand, the slight decrease is noticed in Western Europe. Accordingly, there are different views reasoning this situation presented in the paper. Statistical data analysis show also some changes in main military equipment producers and buyers. All those are presented on attached maps of weapon's international trade. Furthermore, at the end of paper there is local focus on discussed matter, concerning on polish military industry development dilemmas, challenges for polish defensiveness and military power of Republic of Poland.
\end{abstract}

Słowa kluczowe: broń; kryzys; obrona narodowa; przemysł zbrojeniowy; zbrojenia Key words: weapon; crisis; national defense; military industry; armament 


\section{Wprowadzenie}

Skutki obecnego kryzysu finansowego często stają się przedmiotem dyskusji specjalistów w różnych dziedzinach, naukowców i publicystów. Skłoniły one również geopolityków do rozważań na temat wpływu międzynarodowej sytuacji finansowej na przedmiot ich badań i wydarzenia na arenie międzynarodowej. Inspiracją dla autora podczas przygotowywania artykułu były publikacje dotyczące wpływu kryzysu finansowego na inwestycje zbrojeniowe, a także roli tych inwestycji w kształtowaniu polskiej racji stanu.

Głównym problemem badawczym jest określenie wpływu kryzysu na skalę i lokalizację inwestycji zbrojeniowych oraz obronność. Jego rozwiązanie wymaga sformułowania odpowiedzi na szereg pytań, przede wszystkim na to, czy w czasach kryzysu następuje wzrost wydatków na zbrojenia. Jeśli tak, to jakie mogą być tego przyczyny? Czy może jednak jest odwrotnie i kryzys prowadzi do redukcji wydatków na te cele? Jeśli tak, to które sektory tak zwanej zbrojeniówki będą musiały zredukować swe budżety? Czy okaże się, że kryzys finansowy nie wpływa znacząco na rozmiar wydatków i procentowo będą one współmierne do dochodów osiąganych przez ośrodki polityczne przed kryzysem?

W celu sformułowania odpowiedzi na powyższe pytania konieczne jest zastosowanie analizy porównawczej danych statystycznych. Uzyskano je z ośrodków badawczych, głównie ze Sztokholmskiego Międzynarodowego Instytutu Badań nad Pokojem (SIPRI), projektu „Correlates of War” (COW) czy Uppsalskiego Programu Zbierania Danych o Konfliktach $(\mathrm{UCDP})^{1}($ Eck, 2012). Szczególną rolę w badaniach dotyczących tej problematyki odgrywały także projekty ONZ. Dane te pochodzą już z 2011 r., a zatem są adekwatne do wybranego okresu - czasów kryzysu finansowego. Za początek kryzysu przyjęto pamiętny krach na giełdach w końcu 2007 r. (Konopczak, Sieradzki, Wiercicki, 2010). Zakresu przestrzennego nie ograniczono do wybranego regionu. Problem jest badany całościowo, choć należy sobie zdawać sprawę, że wiele jego aspektów zostało pominiętych ze względu na objętościowe ograniczenia niniejszej pracy.

Realizacja założonych celów wydaje się niezbędna dla stworzenia właściwych ram twórczej dyskusji na temat przyszłości przemysłu zbrojeniowego na świecie i powiązań najważniejszych ośrodków produkcyjnych z głównymi konsumentami. Analizy zmian rozmieszczenia produkcji i konsumpcji broni wydają się ponadto niezbędną podstawą debaty geopolitycznej. Podczas rozpatrywania problemu z perspektywy krajowej należałoby też odnieść się do jej lokalnego wymiaru i przedstawić główne dylematy rozwoju przemysłu zbrojeniowego, obronności i zdolności bojowej Rzeczypospolitej Polskiej. Wydaje się to uzasadnione wobec przewidywanych zagrożeń wynikających z możliwego kryzysu politycznego spowodowanego niestabilnością finansową na rynku światowym. Wnioski uzyskane dzięki przeprowadzonym analizom oraz zestawienie ich z bieżącymi koncepcjami geopolitycznymi stanowią niezbędny kontekst pozwalający na formułowanie założeń wstępnych do dalszych badań w geografii ekonomicznej, politycznej i geopolityce, zarówno w wymiarze światowym, jak i europejskim czy polskim.

Dla potrzeb niniejszej pracy przyjęto definicję inwestycji zbrojeniowych za SIPRI. Obejmuje ona następujące kategorie wydatków:

- koszty utrzymania sił zbrojnych, w tym sił pokojowych wysyłanych w ramach uczestnictwa w działaniach organizacji międzynarodowych,

\footnotetext{
${ }^{1}$ Zob. szerzej: www.sipri.org; www.correlatesofwar.org; www.ucdp.uu.se.
} 
- utrzymanie ministerstw obrony lub wojny oraz innych instytucji i urzędów państwowych biorących udział w podejmowaniu decyzji dotyczących działań zbrojnych,

- wydatki na utrzymanie jednostek paramilitarnych zdolnych do działań zbrojnych,

- finansowanie wojskowych operacji kosmicznych.

Wydatki te obejmują zarówno wynagrodzenia personelu, w tym świadczenia socjalne, jak i koszty bieżącej działalności i utrzymania wspomnianych instytucji. Do wydatków tych należą także o koszty badań naukowych na rzecz wojska, budowę potencjału wojennego (np. fortyfikacji) oraz zagraniczną pomoc na cele wojskowe. Poza tak zdefiniowanymi inwestycjami zbrojeniowymi pozostają wydatki na obronę cywilną (tj. wydatki na policję czy inne tego typu formacje) oraz wydatki na pokrycie kosztów dawnych operacji wojskowych, takich jak emerytury i renty dla weteranów, koszty demobilizacji czy utylizacji niepotrzebnej lub przestarzałej broni bądź innych przedmiotów własności wojska (Perlo-Freeman et al., 2012)².

Wydatki na zbrojenia oraz produkcja, handel i przepływy broni są obecnie przedmiotem zainteresowania nie tylko rządów państw. Jest to także niezwykle atrakcyjny temat z punktu widzenia dyplomatów, badaczy akademickich, organizacji pozarządowych oraz organizacji międzynarodowych, na przykład Banku Światowego czy Międzynarodowego Funduszu Walutowego. Nic więc dziwnego, że media, starając się zaspokajać zainteresowanie opinii publicznej, nie pozostają obojętne na tego typu problematykę. Coraz częściej prowadzone są badania mające na celu porównanie gospodarczego wysiłku, który podejmują rywalizujące państwa, aby zwiększyć swoją siłę militarną (obronność) (Pieroni, 2007; Skulski, 2011). Częste poruszanie tej tematyki w mediach i sposób jej prezentowania sprawiają, że przypomina ona specyficzny rodzaj rywalizacji sportowej. Psychologiczne oddziaływanie mediów na świadomość społeczną sprzyjające budowaniu poczucia rywalizacji międzynarodowej jest zapewne prowadzone na korzyść wielkich grup interesów (Silverman, 2011). Bardzo często badacze zestawiają wydatki zbrojeniowe państw z kosztami funkcjonowania innych sektorów (lub ich udziałami w budżetach), takich jak edukacja czy ochrona zdrowia. Ukazywanie zmian $\mathrm{w}$ tego typu proporcjach w czasie umożliwia im porównywanie i ocenianie polityki poszczególnych rządów. Wielkość wydatków zbrojeniowych zestawia się też z sytuacją państw w zakresie bezpieczeństwa (Sułek, 2008), co pozwala określić, jakich wyzwań najbardziej obawiają się te kraje: militarnych czy innych. Dzięki takim zestawieniom, szybki wzrost wydatków na zbrojenia często może być sygnałem zbliżania się wewnętrznego lub zewnętrznego konfliktu (Urbański i in., 1992). Ekonometryczne podejście umożliwia także kalkulowanie relatywnej potęgi militarnej państw. Użycie takich modeli jest jednak nadal dość problematyczne, i nawet najnowsze badania i pomiary potęgi militarnej nie mogą przewidzieć dokładnych rozstrzygnięć na polu walki (Sułek, 2001; Wilczyński, 2011).

\section{Kryzys a tendencje zmian w sektorze zbrojeniowym}

Dyskusję nad badanym zagadnieniem można rozpocząć od przedstawienia kilku faktów dotyczących kryzysu, a odnotowanych przez ekonomistów. Obecna sytuacja makroekonomiczna wymusza tendencję wzrostową cen produktów przemysłu zbrojeniowego. Nie jest to jednak jedyny czynnik kształtujący krzywe popytu i podaży. Według dostępnych danych można potwierdzić inflację w odniesieniu do dóbr produkowanych przez sektor zbrojeniowy. Ponadto należy podkreślić, że ceny tych produktów zależą w znacznej mierze od skali lokal-

\footnotetext{
${ }^{2}$ Wersja elektroniczna książki dostępna jest bezpłatnie pod adresem: http://www.sipri.org/research/armaments/milex.
} 
nych i regionalnych konfliktów zbrojnych. Wcześniejsze badania autora potwierdziły, że od początku XXI w. zmniejsza się zarówno liczba konfliktów na świecie, jak i ich intensywność. Powoduje to ograniczenie wpływu kryzysu na inflację w asortymencie produktów przemysłu zbrojeniowego. Z drugiej strony kryzys wymusza na niektórych krajach zwiększanie podaży broni używanej. Przykładem mogą być republiki postradzieckie, które w ostatnich latach wyprzedają swe arsenały starej broni konwencjonalnej, głównie do krajów Afryki i Azji. Oznacza to, że kryzys wywołuje dwie przeciwstawne tendencje: ograniczenie produkcji i zmniejszenie podaży nowego sprzętu wojskowego oraz wyprzedawanie arsenałów powodujące zwiększenie podaży starej broni (Perlo-Freeman i in., 2012).

Kryzys wpływa także na zmniejszenie różnorodności towaru dostępnego na międzynarodowym rynku. Jest to spowodowane bankructwami mniejszych i średnich przedsiębiorstw sektora zbrojeniowego w niektórych krajach, co w dłuższym okresie stwarza niebezpieczeństwo powstania karteli w poszczególnych wąskich branżach (Bauer, 2010). Świadczą o tym próby przeprowadzania fuzji podejmowane w ostatnich latach, na przykład w sektorze lotnictwa myśliwskiego. Luki w dostawach niektórych rodzajów produktów, między innymi czołgów, mogą zostać zapełnione dzięki uruchomieniu wyprzedaży sprzętu używanego, o której wspominano wyżej. Jednak w najbardziej innowacyjnych sektorach przemysłu zbrojeniowego nie można uzupełnić braków w dostawach wynikłych z bankructw. Wpływa to także na ceny niektórych towarów branży (Królikowski, 2010).

Czynniki ekonomiczne oddziałujące w czasach kryzysu wpływają także na zmiany w kierunkach handlu bronią i rozmieszczeniu jej produkcji (Gałganek, 2011; Wilczyński 2012). Dostępne dane pozwoliły na opracowanie szczegółowych map głównych kierunków importu i eksportu poszczególnych rodzajów broni ${ }^{3}$ w 2011 r. (ryc. 1 a-c). Widać na nich nie tylko, kto jaki sprzęt eksportował, lecz także kto we współczesnym świecie się zbroi. Na przedstawionych mapach zaznaczono również programy pomocy dla Iraku i Afganistanu zakładające transfer uzbrojenia dla odbudowujących się armii. W eksporcie ciężkiej broni dla wojsk lądowych dominują: USA (czołgi M1A1 i M1A2 Abrams, wozy Sand Cat, HMMWV, AMP-137 i ASV-150/M-1117), Chiny (czołgi T-59G, T-96G i T-90-2/MBT-2000 oraz wozy opancerzone WZ-501/T-86), Niemcy (czołgi Leopard-1A5 i Leopard-2A4 oraz wozy opancerzone Tpz-1 Fuchs i Fassmer-1850), a także Kanada (wozy opancerzone Piranha). W sprzedaży za granicę sprzętu lotniczego obecnie rywalizują jedynie USA (myśliwce F-16C, F-35A JSF i F/A-18E Super Hornet, samoloty transportowe King Air i KC-135 Stratotanker, helikoptery CH-47 Chinook, S-70B Seahawk, S-70 Blackhawk, AH-64D Apache, MacDonell-Douglas-500E, Bell-205 i 206) i Rosja (myśliwce Su-30MK/Flankier MiG-31M/Foxhound-B i MiG-29SMT/ Fulcrum, samoloty transportowe Ił-76M/Candid-B, helikoptery Mi-8MT/Mi-17/Hip-H, Mi-24VM/Hind-E). Zauważalny jest spadek eksportu z Europy. Z kolei w przemyśle stoczniowym zbrojenia wskazywałyby na wyjątkowy potencjał Francji jako głównego producenta okrętów wojennych. Jednakże statki dostarczone przez ten kraj do Algierii - 21 małych okrętów patrolowych - nie miały dużej wartości. Głównym producentem okrętów wojennych są zatem Chiny. W Europie Hiszpania i Francja dominują w produkcji małych jednostek nawodnych, zaś Niemcy w subkategorii okrętów podwodnych. Stany Zjednoczone nie sprzedają okrętów. Wszystkie statki dostarczone przez nie do innych krajów w 2011 r. stanowiły darowizny w postaci przestarzałych fregat i okrętów patrolowych.

\footnotetext{
${ }^{3}$ Ze względu na konieczność zachowania czytelności map uwzględniono jedynie najdroższy ciężki sprzęt (czołgi i wozy opancerzone, samoloty i helikoptery oraz okręty).
} 
Kolejnym zjawiskiem zauważalnym w czasach kryzysu jest konsolidacja kapitału w branży zbrojeniowej. W ostatnich latach głośno było o próbach przejmowania mniejszych przedsiębiorstw przez większe. Zjawisko to występuje również w przemyśle zbrojeniowym, szczególnie w przypadku upadłości spółek z udziałem Skarbu Państwa. Prywatni przedsiębiorcy uważają przejmowanie państwowych zakładów wojskowych w różnych krajach za dobry interes, co ma też szerokie implikacje gospodarcze. Coraz popularniejsze staje się także korzystanie z usług najemniczych. Najbardziej znanymi spółkami oferującymi najemników są Blackwater i Executive Outcomes. W dobie państw narodowych XX w. usługi tego rodzaju kojarzone były raczej ze średniowiecznymi lub renesansowymi wojskami zaciężnymi czy włoskimi kondotierami. Okazuje się jednak, że współczesny świat i toczące się obecnie konflikty zbrojne dają im wiele szans na rozwój. Prywatne korporacje najemnicze również dokonują zakupów broni i amunicji, lecz muszą to robić za pośrednictwem państw, które są ich klientami. W przeciwnym wypadku pozostaje im tylko korzystanie z operacji na czarnym rynku (Perlo-Freeman, Sköns, 2008).

Przykładów konsolidacji kapitału można podać kilka, zarówno w USA jak i Europie, choćby dotyczący producenta samolotów myśliwskich i ich komponentów, niedoszły, głośny koniec potężnej korporacji EADS ${ }^{4}$. Koncern ten, znany głównie z produkcji samolotów Airbus, miał zostać przejęty przez BAE Systems ${ }^{5}$, lecz transakcja nie doszła do skutku ze względu na interwencję kanclerza Niemiec Angeli Merkel. Wywołało to reperkusje na światowych giełdach w październiku 2012 r. (Milmo, 2012). Udanych fuzji jednak jest znacznie więcej niż nieudanych, a największe korporacje zbrojeniowe w ciągu ostatnich lat przejmowały nie po jednym przedsiębiorstwie, lecz zwykle po kilka mniejszych przedsiębiorstw. Struktura rankingu największych korporacji zbrojeniowych prowadzonego przez SIPRI zmieniła się przez lata, co świadczy o tym, że kryzys przyniósł konsolidację i skupienie kapitału. Konsolidacja zakładów zbrojeniowych w większe międzynarodowe korporacje, a także dokonane fuzje spowodowały, że produkcja została przemieszczona i dokonały się zmiany w podziale zadań produkcyjnych pomiędzy poszczególnymi zakładami znajdującymi się w posiadaniu danych korporacji ${ }^{6}$.

Kryzys finansowy wywarł wyraźny wpływ także na politykę większości producentów uzbrojenia. Na łamach prasy branżowej często pojawiają się informacje o zmianach polityki korporacyjnej danego producenta, których głównym wyznacznikiem jest coraz bardziej odważne inwestowanie w innowacje i badania naukowe (Wilczyński, 2012). Rezygnuje się też z przestarzałych i nieefektywnych technologii, które nie wytrzymują konkurencji. Doświadczyli tego producenci rosyjskich czołgów T-90, które zostały wyparte z rynków Azji Południowej i Bliskiego Wschodu przez chińską zmodernizowaną wersję T-90G. Proces ten jest widoczny również w polskim przemyśle zbrojeniowym - większość państwowych fabryk zbrojeniowych nie może znaleźć nabywców na swe produkty. Kryzys i konkurencja sprawiły, że wiele korporacji, aby utrzymać dochody, musiało zwiększyć nakłady na wprowadzanie innowacji. Tendencję tę obserwuje się szczególnie w Europie (Rachwał, 2011).

\footnotetext{
${ }^{4}$ The European Aeronautic Defence and Space Company N.V.

${ }_{6}^{5}$ Dawniej: British Aerospace.

${ }^{6} \mathrm{http}: / /$ www.sipri.org/research/armaments/production/Top100.
} 
Ryc. 1a. Handel międzynarodowy czołgami i wozami opancerzonymi w 2011 r.

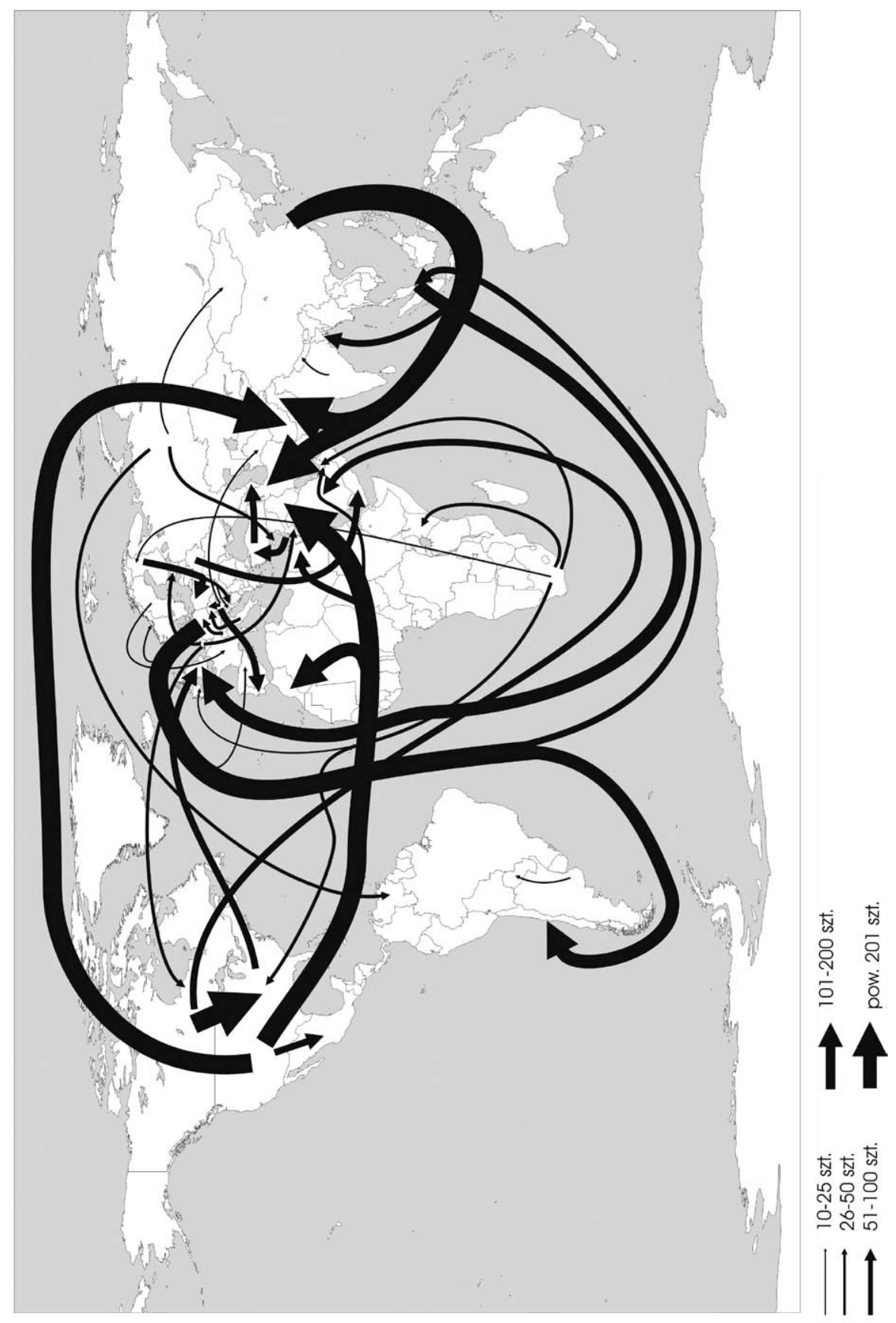

Źródło: opracowanie własne. 
Ryc. 1b. Handel międzynarodowy samolotami i helikopterami wojskowymi w $2011 \mathrm{r}$.

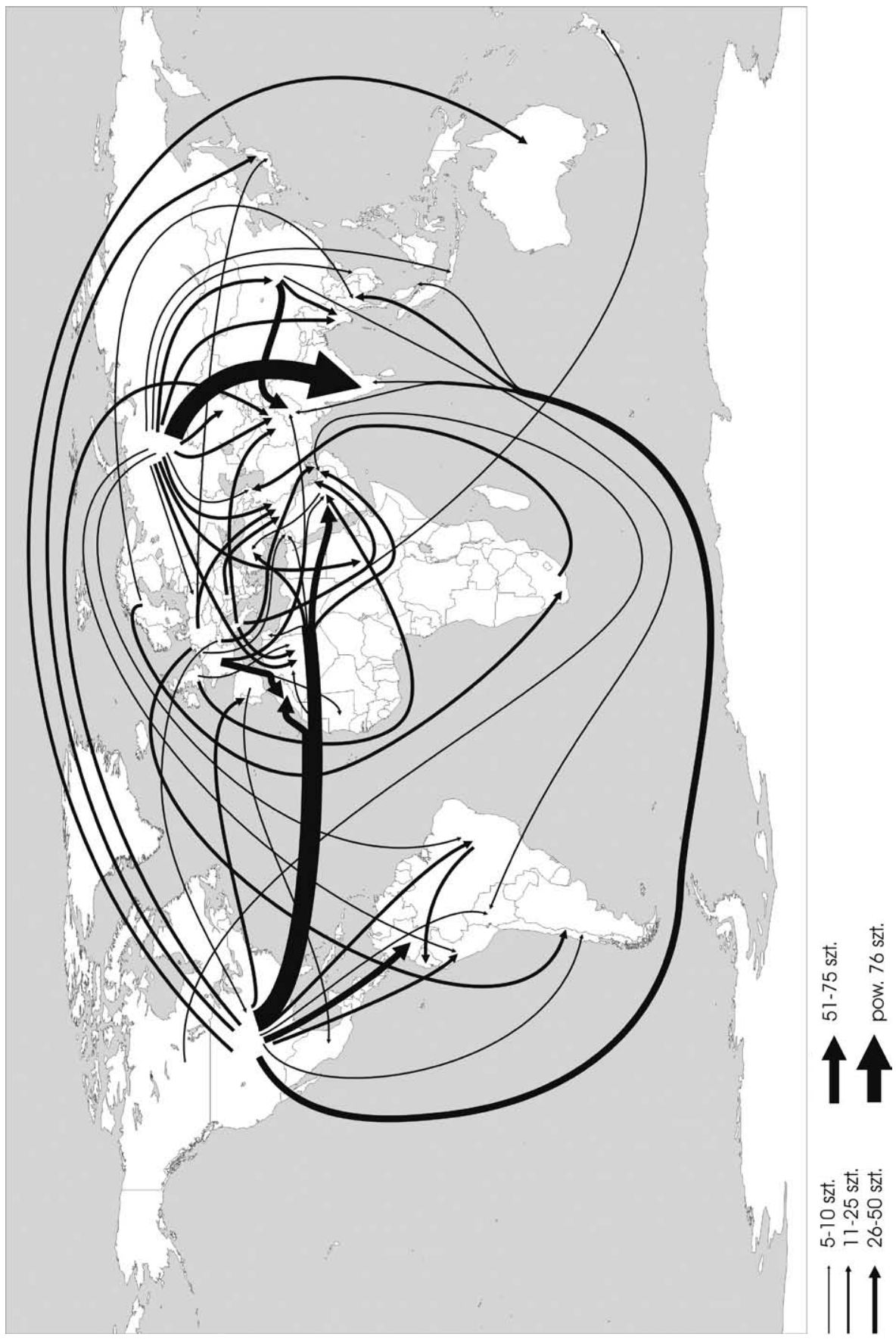

Źródło: opracowanie własne. 
Ryc. 1c. Handel międzynarodowy okrętami wojennymi w 2011 r.

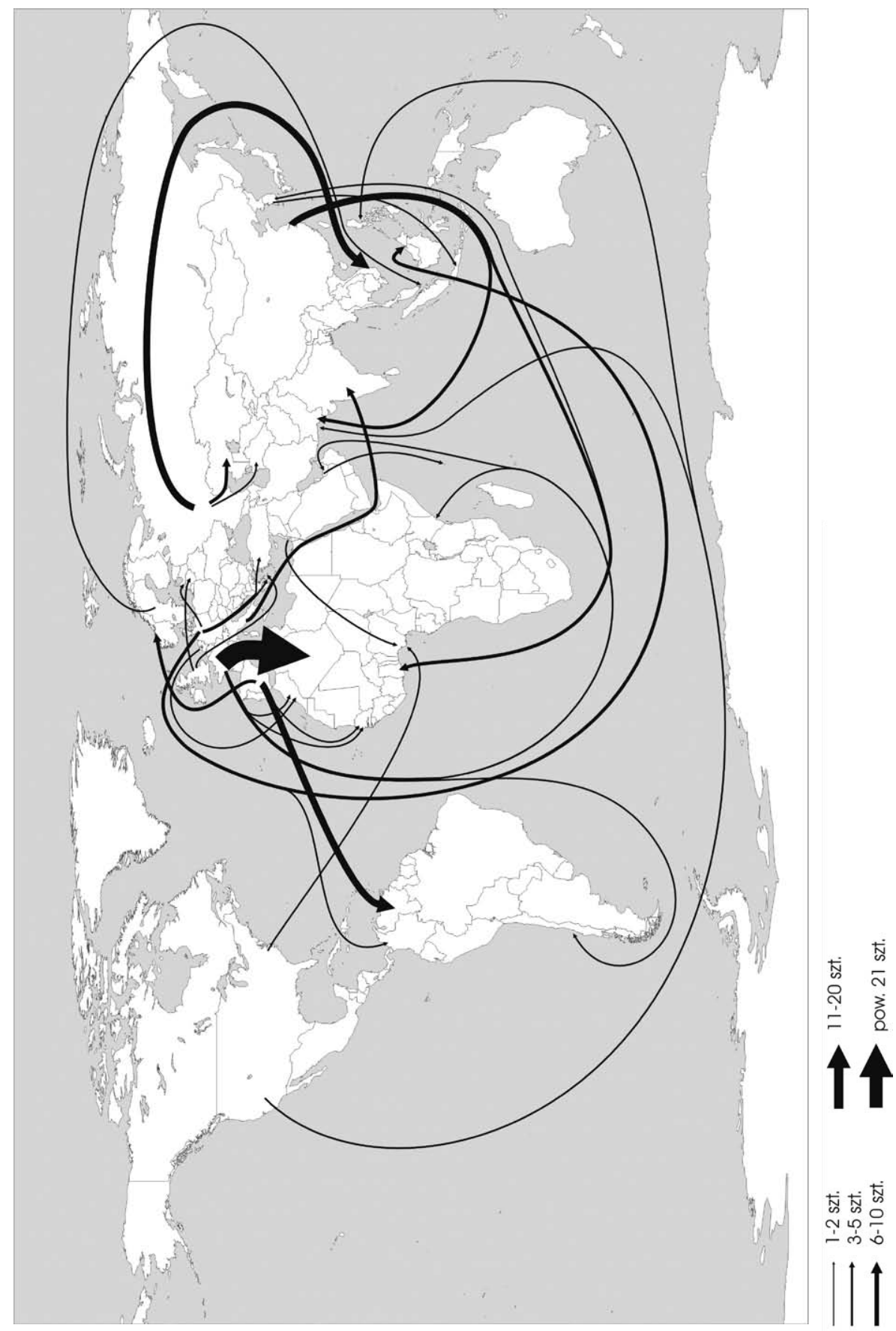

Źródło: opracowanie własne. 


\section{Wydatki na zbrojenia w 2011 r.}

Jak przedstawiają się dane ekonomiczne dotyczące wydatków na zbrojenia za ostatni rok? Jak duże były inwestycje w sektor zbrojeniowy? Czy branża rozwija się mimo kryzysu? Jak opisane wyżej tendencje wpłynęły na zbrojenia w ostatnich latach? Odpowiedzi na te pytania można uzyskać dzięki analizie danych zgromadzonych przez różne instytucje badawcze. Wynika z nich, że światowe inwestycje w zbrojenia rosną, ale wolniej niż PKB (jest to spore spowolnienie względem okresu 1998-2008). Ogólnie w 2011 r. na zbrojenia przeznaczono 1730 mld USD (249 USD na jednego człowieka na świecie) (Perlo-Freeman i in., 2012). W niektórych regionach (głównie w Europie) wartość inwestycji w zbrojenia znacznie się obniża, w innych zaś wyraźnie wzrasta (np. Syria +580\%). Największy wzrost nakładów na zbrojenia notują Afryka Północna i Bliski Wschód z największym zleceniem z Arabii Saudyjskiej na zakup rosyjskiej broni (głównie myśliwców). Na drugim miejscu są Rosja i inne kraje byłego ZSRR, a na trzecim - Azja Wschodnia z Chinami na czele. Oszczędza głównie Europa - na zbrojenia wydaje się tu mniej niż w 2000 r.

Najwięcej inwestycji zbrojeniowych, co nie dziwi, przeprowadzają zachowujące pozycję światowego hegemona od II wojny światowej Stany Zjednoczone. Jest to kraj, który nadal obawia się nowego rodzaju wojny, zupełnie prywatnej, gdzie po żadnej ze stron nie będą występować siły reprezentujące państwa, o których nie będą pisać czołowe gazety. Według analityków do takich konfliktów o małej skali będzie dochodzić coraz częściej (Drembkowski, 2010). W czasie tak zwanej zimnej wojny drugim mocarstwem był ZSRR, zaś Rosja już od dawna ustępuje Chinom, które inwestują w zbrojenia coraz więcej kapitału. Dynamika rozwoju chińskiego przemysłu zbrojeniowego jest od wielu lat najszybsza na świecie. Istotny wkład w rozwój przemysłu zbrojeniowego mają też potęgi regionalne: Japonia, Indie, Arabia Saudyjska i Brazylia, których wartość inwestycji w zbrojenia wciąż rośnie, a także Wielka Brytania, Niemcy i Francja w Europie. Udział poszczególnych państw w światowych wydatkach na zbrojenia w 2011 r. prezentuje ryc. 2.

Ciekawe przypadki stanowią kraje, które - jak się wydaje - są najbardziej pogrążone w kryzysie, np. Grecja. Z danych Unii Europejskiej (Official Journal of the EU, 2011) wynika, że już w 2010 r. państwo to, w trakcie negocjacji tzw. bail-out z krajami strefy euro, zakupiło od nich sprzęt wojskowy o wartości ponad 1 mld EUR. Według analityków oznacza to strach przed wciąż dobrze prosperującą Turcją, porównywalny do obaw Polski przed Rosją. W Grecji uważa się, że Turcja może zechcieć wrócić do nierozwikłanych sporów politycznych. Jak widać, niebezpieczeństwo bankructwa jest mniej groźne od niebezpieczeństwa utraty suwerenności. Nadal jednak głównym odbiorcą broni eksportowanej z Unii Europejskiej są kraje Bliskiego Wschodu, często te, w których panuje dyktatura (Rettman, 2012). Czy nie kłóci się to nieco z zasadami i założeniami przyznawania Pokojowej Nagrody Nobla? W niektórych krajach Unii produkcja uzbrojenia mimo kryzysu znacznie wzrosła (Nielsen, 2012). Kierunki eksportu sprzętu wojskowego zaprezentowano powyżej (ryc. 1 a-c).

Jedynym sektorem, na który wydatki zostały zmniejszone w wyniku kryzysu, jest sektor broni atomowej. Warto przy tym jednak zaznaczyć, że więcej wydatków związanych z tym rodzajem broni od kilku lat przeznacza się na utylizację starych ładunków niż na budowę nowych, ponieważ jest on ograniczony traktatami międzynarodowymi o nieproliferacji broni jądrowej. Obecnie 8 państw posiada 4400 głowic w stanie wysokiej gotowości bojowej, a 19000 ogółem. Są to: Rosja, USA, Francja, Chiny, Wielka Brytania, Pakistan, Indie i Izrael (w kolejności według największej liczby głowic). Posiadanie broni atomowej przez Koreę Północną nie jest pewne. Wydatki na budowę i utrzymanie broni atomowej są mniejsze niż na jej rozbrojenie, a zatem oszczędności, co może martwić, dotyczą przede wszystkim programów rozbrojeniowych Rosji, USA i innych państw (Kile, 2012). 
Ryc. 2. Udział państw w światowych wydatkach na zbrojenia w $2011 \mathrm{r}$.

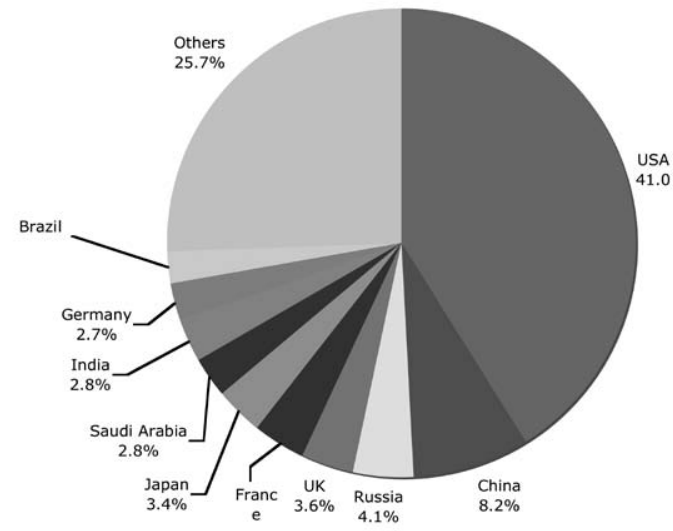

Źródło: Perlo-Freeman i in. (2012); http://www.sipri.org/research/armaments/milex.

\section{Wydatki na zbrojenia w perspektywie długookresowej}

Aby odpowiedzieć na postawione wcześniej pytania, należy porównać stan obecny do sytuacji sprzed kryzysu. Jak już wspomniano, inwestycje w zbrojenia zwiększają się mimo słabej koniunktury w gospodarce światowej, lecz tempo ich wzrostu jest dużo mniejsze - również w porównaniu ze spadkami PKB poszczególnych krajów i na świecie ogółem. Analiza porównawcza danych statystycznych ujawniła interesujące zjawisko, jakie wywołuje kryzys w przemyśle zbrojeniowym. W niektórych krajach branżę tę dotykają cięcia budżetowe, w innych zaś zagrożenia polityczne wynikające z kryzysu powodują wzrost nakładów na zbrojenia (przykład Grecji). Konsekwencje tej sytuacji mogą być interesujące, bowiem różnice między poszczególnymi regionami świata w nakładach są dość duże. Ponadto można pokusić się nie tylko o ocenę kondycji politycznej państw w świetle wydatków na zbrojenia, ale pójść dalej i śladem geopolityków próbować dokonywać predykcji przyszłych konfliktów (Sułek, 2001). Najszybciej względem okresu sprzed kryzysu rosną wydatki w krajach postsowieckich, a także na Bliskim Wschodzie. W żadnym z regionów nie zaniechano finansowania zbrojeń, jednak znacznie obniżono wydatki na obronność w Ameryce Łacińskiej, gdzie wygasły burzliwe niegdyś konflikty wewnętrzne, oraz w Europie, co zagraża jej bezpieczeństwu, gdyż najszybciej zbrojące się kraje to bliscy sąsiedzi - Rosja i kraje muzułmańskie (ryc. 3).

Dokładniejsza analiza budżetów poszczególnych państw może pokazać, w którym regionie świata najistotniejszym elementem jest obrona narodowa, a także które z państw najbardziej obawiają się konfliktów lub się do nich przygotowują - w zależności od doktryny wojskowej: ofensywnej bądź defensywnej. Dzięki zebranym danym można przypuszczać, że najbliższy konflikt zbrojny wystąpi na Bliskim Wschodzie, a jego ogniskiem zapalnym będzie prawdopodobnie trwający obecnie konflikt w Syrii. Ponad 5\% własnego PKB inwestują obecnie w zbrojenia wyłącznie kraje tego regionu (tab. 2).

Podczas porównywania danych w dłuższej perspektywie czasowej, sięgającej poza moment wystąpienia kryzysu finansowego, warto zwrócić uwagę na jeszcze jedną istotną tendencję. Otóż do krajów, gdzie wydatki na zbrojenia rosną najszybciej, należą trzy mocarstwa: USA, Chiny i Rosja, a zatem państwa ze światowej czołówki, oraz Indie i Arabia Saudyjska, które chcą umocnić swą pozycję i z mocarstw o zasięgu regionalnym stać się potęgami globalnymi (tab. 1). Upadek cywilizacji Zachodu, o którym często się mówi, mógłby zostać potwierdzony przez zmniejszenie potencjału bojowego krajów Unii Europejskiej wraz ze 
spadkiem finansowania. Jednak patrząc nie od strony inwestorów, lecz producentów, przemysł zbrojeniowy w Europie ma się dobrze i może konkurować z amerykańskim, a na pewno z rosyjskim czy krajów Azji (Kołodziej, 2008).

Ryc. 3. Zmiany w inwestycjach na zbrojenia w latach 2002-2011

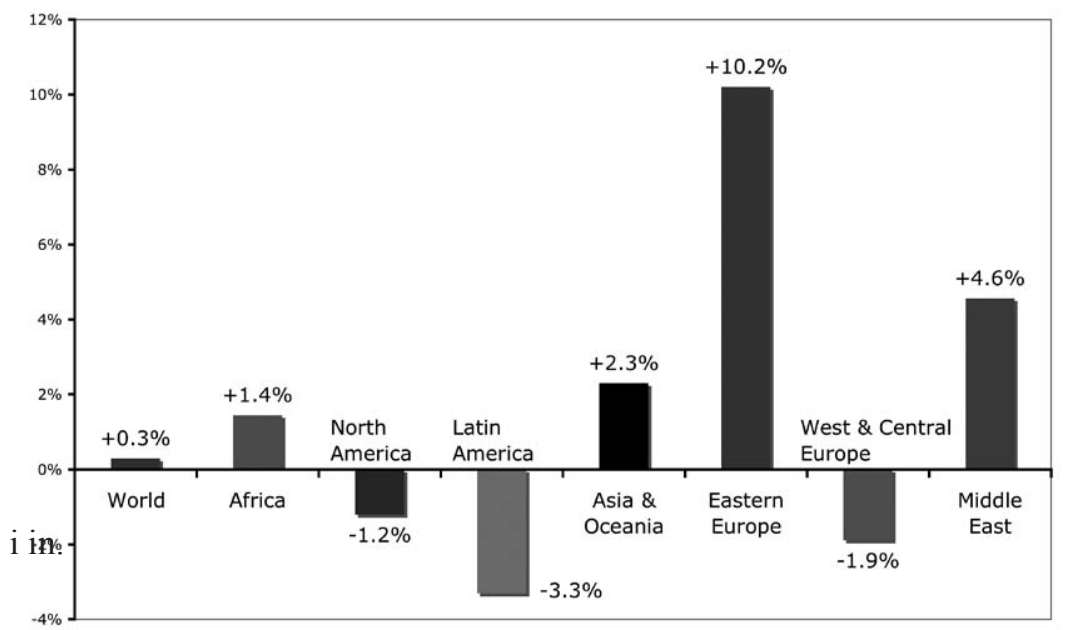

Źródło: Perlo-Freeman i in., (2012); http://www.sipri.org/research/armaments/milex.

Tab. 1. Państwa o największych inwestycjach w zbrojenia w 2011 r. oraz zmiana w wielkości tych inwestycji w latach 2001-2011

\begin{tabular}{|c|l|c|c|}
\hline Lp. & \multicolumn{1}{|c|}{ Państwo } & $\begin{array}{c}\text { Inwestycje w zbrojenia } \\
\text { w 2011 r. [mld USD] }\end{array}$ & $\begin{array}{c}\text { Zmiana w wielkości inwestycji } \\
\text { w latach 2001-2011 [\%] }\end{array}$ \\
\hline 1. & USA & 711 & +59 \\
\hline 2. & Chiny & 143 & +170 \\
\hline 3. & Rosja & 72 & +79 \\
\hline 4. & Wielka Brytania & 63 & +18 \\
\hline 5. & Francja & 62 & -1 \\
\hline 6. & Japonia & 59 & -2 \\
\hline 7. & Arabia Saudyjska & 48 & +90 \\
\hline 8. & India & 47 & +59 \\
\hline 9. & Niemcy & 47 & +19 \\
\hline 10. & Brazylia & 35 & -21 \\
\hline 11. & Włochy & 34 & +45 \\
\hline 12. & Korea Pd. & 31 & +37 \\
\hline 13. & Australia & 27 & +53 \\
\hline 14. & Kanada & 25 & -12 \\
\hline 15. & Turcja & 18 & +401102 \\
\hline
\end{tabular}

Źródło: IMF, Word Economic Outlook Database, http://www.imf.org/external/pubs/ft/weo/2011/02/ weodata/index.aspx. 
Podsumowując, kryzys wywołał istotne zmiany w wydatkach państw na zbrojenia. Pociąga to za sobą szereg przemian politycznych. Pojawiają się nowe konflikty, a stare tracą na znaczeniu. Część ekspertów spodziewa się rychłego rozpoczęcia kolejnego konfliktu obejmującego swym zasięgiem cały świat. Inni twierdzą, że system międzynarodowy istotnie czeka znaczne przemodelowanie, ale nie dojdzie do konfliktu na miarę II wojny światowej. Są też tacy, którzy bagatelizują dysproporcje zakłócające równowagę pomiędzy mocarstwami (Cooper, 2011). Dyskusja na ten temat toczy się również w Polsce - w kuluarach sejmowych i redakcjach mediów, w czasopismach branżowych, w takich instytucjach, jak Instytut Geopolityki czy inne organizacje badawcze typu think-tank, a także w opracowaniach akademickich lub na spotkaniach z ekspertami. Świadczy to o istotności poruszanego tematu, którego bagatelizowanie, jak pokazała historia, może stać się przyczyną ogromnych strat (Klin, 2011; Sułek, 2011).

Tab. 2. Państwa, w których udział środków na zbrojenia przekracza 5\% budżetów narodowych

\begin{tabular}{|l|c|c|}
\hline \multicolumn{1}{|c|}{ Państwo } & $\begin{array}{c}\text { Udzial w 2005 r. } \\
{[\text { \%] }}\end{array}$ & $\begin{array}{c}\text { Udział w 2010 r. } \\
{[\%]}\end{array}$ \\
\hline Arabia Saudyjska & 8,0 & 10,1 \\
\hline Oman & 11,8 & 8,5 \\
\hline Zjednoczone Emiraty Arabskie & 5,6 & 6,9 \\
\hline Izrael & 8,0 & 6,5 \\
\hline Jordania & 4,8 & 5,0 \\
\hline
\end{tabular}

Źródło: SIPRI, Military Expenditure Database, http://www.sipri.org/research/armaments/milex/resultoutput/milex_gdp.

\section{Produkcja uzbrojenia w czasach kryzysu}

Dotychczas w artykule analizowano temat z punktu widzenia państw jako głównych inwestorów i konsumentów produkcji przemysłu zbrojeniowego. Nie można jednak pominąć wpływu kryzysu na producentów broni oraz na rozmieszczenie jej produkcji na świecie. Jedną z najważniejszych informacji na temat produkcji uzbrojenia jest fakt, że nie wszystkie państwa wytwarzają nowoczesny sprzęt. Zasadniczo do producentów współczesnego sprzętu wojskowego zalicza się coraz mniej państw, co jest zdeterminowane przez bardzo szybki rozwój technologiczny. Coraz rzadziej broń jest eksportowana także przez Polskę i polskie zakłady zbrojeniowe (Rachwał, 2008). Nasz kraj częściej sprzedaje używany sprzęt po częściowym remoncie lub zmodernizowaniu do krajów Afryki i Azji (podobnie jak to robią republiki postsowieckie). W 2011 r. Polska nie sprzedała za granicę żadnego nowego, wyprodukowanego w kraju sprzętu wojskowego. Potwierdza to opisaną wcześniej tendencję do konsolidacji kapitału w przemyśle zbrojeniowym w ramach większych korporacji, do których polskie spółki się nie zaliczają.

Obecnie największym producentem, eksporterem i konsumentem uzbrojenia są Stany Zjednoczone. Jest to jedyne państwo, które w ostatnich 10 latach eksportowało każdego roku uzbrojenie o wartości przekraczającej 10 mld USD. Przed kryzysem eksport z USA systematycznie wzrastał, jednak skutki kryzysu dały o sobie znać już w 2007 r. Od tej pory eksport amerykański maleje, mimo że w pierwszej dziesiątce korporacji produkujących sprzęt wojskowy nadal znajduje się osiem firm z tego kraju. Obecnie na drugiej pozycji wśród eksporterów uzbrojenia jest Rosja, która wytwarza dobrej jakości sprzęt po dość konkurencyjnych cenach oraz wyprzedaje masowo stare używane czołgi, śmigłowce i samoloty do krajów Azji 
i Afryki. Mimo że Rosja traci stopniowo rynek na rzecz Chin, jej eksport w czasach kryzysu wyraźnie wzrósł i wyprzedziła ona trzeciego głównego eksportera broni - Wielką Brytanię. Spółki brytyjskie na początku kryzysu wyprzedziły znacznie konkurencję, lecz był to efekt jednorazowego zlecenia z krajów arabskich. Obecnie wartość brytyjskiego eksportu ponownie wynosi niespełna 10 mld USD rocznie. Przychody państw z eksportu uzbrojenia w pierwszej dekadzie XXI w. ukazuje tabela (tab. 3). Warto również zauważyć, że wśród głównych eksporterów brakuje największych odbiorców - Chin, Indii oraz Arabii Saudyjskiej. Kraje te nie zawsze eksportują produkowany przez siebie sprzęt, bowiem same gromadzą uzbrojenie (np. Chiny czy Indie) lub - ze względu na brak własnej produkcji - importują broń z zagranicy (np. Arabia Saudyjska, która może sobie na to pozwolić, gdyż dysponuje petrodolarami). W czasach kryzysu pojawili się też nowi eksporterzy broni, np. Holandia, Austria czy Bułgaria. Kraje te rozpoczęły promocję własnych produktów za granicą z powodu braku zapotrzebowania na rynku wewnętrznym. (Holtom i in., 2012). Polskich przedsiębiorców może martwić fakt, iż firmy z naszego kraju nie biorą udziału w tym eksporcie. Jak wynika bowiem z poniższego przykładu (tab. 3) na kryzysie mogłyby zarobić nie tylko polskie przedsiębiorstwa zbrojeniowe, lecz także nasz kraj.

Tab. 3. Przychody państw z eksportu uzbrojenia w mln USD w pierwszej dekadzie XXI w.

\begin{tabular}{|l|c|r|r|r|}
\hline \multicolumn{1}{|c|}{ Eksporter } & $\mathbf{2 0 0 1}$ & $\mathbf{2 0 0 4}$ & $\mathbf{2 0 0 7}$ & $\mathbf{2 0 1 0}$ \\
\hline USA & 11253 & 13408 & 12944 & 12189 \\
\hline Rosja & 4563 & 6673 & 7782 & 10000 \\
\hline Wielka Brytania & 7375 & 9609 & 20309 & 9007 \\
\hline Izrael & 3102 & 4271 & 5889 & 7200 \\
\hline Francja & 3489 & 10209 & 6535 & 5010 \\
\hline Niemcy & 404 & 1618 & 2173 & 2806 \\
\hline Szwecja & 365 & 1145 & 1494 & 1907 \\
\hline Hiszpania & 255 & 582 & 1344 & 1494 \\
\hline Korea Pd. & 246 & 485 & 888 & 190 \\
\hline Ukraina & 616 & brak danych & 736 & 957 \\
\hline Holandia & 0 & 0 & 1258 & 895 \\
\hline Włochy & 611 & 688 & 1824 & 816 \\
\hline Turcja & 165 & 226 & 442 & 634 \\
\hline Szwajcaria & 188 & 373 & 407 & 614 \\
\hline Norwegia & 219 & 345 & 574 & 592 \\
\hline Austria & 0 & 6 & 178 & 494 \\
\hline Kanada & 471 & 571 & 319 & 482 \\
\hline Bułgaria & 0 & 0 & 213 & 342 \\
\hline Czechy & 67 & 129 & 250 & 287 \\
\hline Rumunia & 31 & 48 & 88 & 163 \\
\hline Brazylia & 357 & 329 & 168 & 101 \\
\hline Finlandia & 44 & 60 & 108 & 78 \\
\hline Indie & brak danych & 51 & 87 & 72 \\
\hline Pozostali & 12 & $291-2010$ & 607 & \\
\hline
\end{tabular}

Źródło: SIPRI, The value of national arms exports, 2001-2010, in constant (2010) US\$, www.sipri.org/ research/armaments/transfers/measuring/financial_values/constant.xls. 
Monitoring światowego handlu uzbrojeniem stał się możliwy i bardziej doskonały po implementacji traktatu o handlu bronią (Arms Trade Treaty - ATT) pod egidą ONZ. Dzięki niemu rozpoczęto zbieranie danych dotyczących tego sektora handlu międzynarodowego oraz naprawiono szereg błędów w kontroli przepływu uzbrojenia praktykowanej dotychczas przez różne organizacje międzynarodowe (Holtom, Bromley, 2012). Jest to jeden z trendów wywołanych nie tylko kryzysem i zagrożeniami politycznymi z tego wynikającymi. Istotną rolę w tym traktacie odgrywały także największe korporacje zbrojeniowe. Przez lobbowanie za wprowadzeniem obostrzeń w produkcji broni i handlu nią mogą one zabezpieczać swe interesy przed konkurencją małych przedsiębiorstw, których nie stać na spełnianie zaostrzających się coraz bardziej wymogów licencyjnych. Monitoring ten stał się też wyznacznikiem tendencji zauważalnej w dobie narastających napięć międzynarodowych i domowych oraz kończącej się epoki triumfu demokracji (Fukuyama, 1996; Münkler, 1994; Miłoszowska, 2009).

\section{Zakończenie: wnioski w perspektywie polskiej racji stanu}

Nie da się zaprzeczyć, że najszybciej zbrojącym się sąsiadem Polski jest Rosja. Jej nakłady na zbrojenia mimo kryzysu finansowego dotykającego różne kraje świata stale rosną i to szybciej niż krajów NATO. Stanowi to przyczynę istotnego zachwiania równowagi w stosunkach międzynarodowych w regionie, o czym w 2008 r. przekonała się już Gruzja. Ambicje wyrażane przez władze rosyjskie często dotykają również Polskę. W artykule tym pominięto jednak popularne tematy katastrofy smoleńskiej, umowy paliwowej czy rurociągu północnego, gdyż jego celem nie jest zagłębianie się w politykę, lecz postawienie pewnych diagnoz wynikających z przeprowadzonej analizy.

Problematyką polską zajmują się nie tylko polskie organizacje typu think-tank, instytuty badawcze oraz organizacje zajmujące się konfliktami czy geopolityką. Ostatnio można było zapoznać się z analizą dokonaną przez George'a Friedmana z ośrodka analiz wywiadowczych Stratfor (Friedman, 2012). Badacz ten podjął kilka istotnych kwestii do dyskusji. Jako pierwsze wyraził mniemanie, że Polska, biorąc pod uwagę jej położenie i doświadczenia historyczne, za bardzo ufa swoim sojusznikom. Może to prowadzić do błędów w polityce, które zdecydowały o tragicznym losie naszego kraju w 1939 r. Wtedy też Polska miała sojuszników, ale żaden z nich nie nadszedł jej z pomocą. Co z tego wynika? Otóż w dobie rosnącego zagrożenia ze wschodu Polska powinna prawdopodobnie rozpatrzyć scenariusz, w którym sytuacja z 1939 r. się powtórzy. Rozważania na temat konsekwencji takich wydarzeń wykraczają poza temat tego opracowania. Redukowanie wydatków na zbrojenia przez państwa Europy Zachodniej świadczy o tym, iż nie widzą one zagrożenia ze strony Rosji. Pamiętać jednak należy, że w ewentualnym konflikcie, kraje te raczej nie zostaną zaangażowane jako pierwsze. Poza tym istnieje małe prawdopodobieństwo, aby państwa niegraniczące z Rosją pozostawały w kręgu zainteresowań potencjalnych ekspansjonistów znajdujących się we władzach tego mocarstwa. Z punktu widzenia geopolityki jako nauki warto byłoby policzyć prawdopodobieństwo wystąpienia rozmaitych scenariuszy wydarzeń wynikających z rosnącej potęgi militarnej Rosji.

George Friedman zwrócił także uwagę, co spowodowało wiele komentarzy w środowisku polskich geopolityków, że Stany Zjednoczone interweniują zbrojnie jedynie w krajach, które są istotne z punktu widzenia ich interesów (Kiwerska, 2000). Jeśli interwencja nie leży w interesie Waszyngtonu, to - jak przekonuje się Izrael w kwestii programu atomowego Iranu - nie można na nią liczyć. Warto rozważyć tę lekcję również przy przeprowadzaniu wyżej wspomnianych symulacji. Według doktryny wojennej USA sojusznik, jeśli zostanie zaatakowany, powinien móc bronić się przez cztery miesiące. Jest to czas, jakiego potrzebują Stany 
Zjednoczone, aby zmobilizować swe siły i zaangażować się w walkę. Przy obecnych nakładach na obronność, jak wykazano w głównej części artykułu, trudno byłoby konkurować Polsce z Rosją czy też z Niemcami i Ukrainą. Według danych podawanych przez analityków nakłady te pozwoliłyby nam utrzymać jedynie cztery dywizje, co pozwoliłoby na obsadzenie zaledwie $50 \mathrm{~km}$ frontu. To niestety za mało, abyśmy mogli obronić się przed agresją nie tylko ze strony mocarstw, lecz także średniej wielkości państw. Chyba, że zaatakuje nas Litwa...

Patrząc z kolei na sytuację geopolityczną zachodniej Europy, zauważyć można, że póki co Niemcy nie chcą tracić dobrych stosunków z Francją. Czy gdy relacje w Europie staną się bardziej skomplikowane i dalsza współpraca Niemiec z Francją się zakończy, możliwy byłby zwrot Niemiec w kierunku Rosji? Niektórzy uważają, że ten zwrot już następuje, a czy przyjaźń rosyjsko-niemiecka nie brzmi znajomo? Friedman zwraca uwagę, że Unia Europejska miała się stać supermocarstwem, na którego określenie publicyści często używali sformułowania Stany Zjednoczone Europy. Biorąc pod uwagę politykę bezpieczeństwa i politykę zagraniczną Unii Europejskiej, celem było to, co zapisano w traktacie lizbońskim - równoważenie siły USA i Rosji. Według George’a Friedmana i coraz większej liczby geopolityków tak się jednak nie stanie (Friedman, 2012). Co zatem będzie z Polską? Jak pokazały interwencja w Libii oraz obecne znikome wsparcie dla Turcji w konflikcie z Syrią NATO już prawie nie funkcjonuje. Większość geopolityków zgadza się w tej sytuacji, że w Polsce należy podnieść nakłady na zbrojenia i zmienić politykę bezpieczeństwa.

Pewne nadzieje na zmianę niekorzystnej sytuacji Polski pojawiły się w 2012 r., gdy rząd ogłosił program zbrojeń i wyraził wolę inwestowania w polski przemysł zbrojeniowy. Polskie stocznie i fabryki zbrojeniowe otrzymały pierwsze zlecenia. Niestety, z powodu wieloletnich zaniedbań zaległości w budowaniu potencjału obronnego naszego kraju są duże, co w sytuacji zagrożenia może przynieść fatalne konsekwencje. Takie zdanie wyraził niedawno analityk Fundacji Republikańskiej Tomasz Szatkowski (2012). Zwrócił on też uwagę, że mimo sporych obecnie wydatków zdolność bojowa naszego kraju nie ulega poprawie. Okazuje się, że najbardziej powiększa się zaplecze administracyjne, czego przykładem może być warszawski garnizon, gdzie jednostki bojowe stanowią jedynie 20\% personelu. Oznacza to, że w świetle analizy porównawczej wykonanej na podstawie danych dotyczących współczesnych zbrojeń w czasie kryzysu Polska nie byłaby w stanie stawić czoła zagrożeniom zewnętrznym ani nawet zapewnić sobie bezpieczeństwa w sytuacji konfliktów związanych z narastającymi podziałami społecznymi wewnątrz kraju, działalnością różnych grup interesów lub niezadowolonych z sytuacji obywateli. Potencjalne zagrożenia wewnętrzne dla polskiej racji stanu, wynikające z coraz częstszych przejawów zapaści państwa, jak i zewnętrzne, związane ze zdeterminowaną geopolitycznie postawą Rosji, nie stanowią niestety tematu badań naukowych, pozostając w sferze polemik politycznych o charakterze publicystycznym.

\section{Literatura}

Bauer, K. (2010). Kryzys finansowy a restrukturyzacja przedsiębiorstw w stanie upadłości, Prace Komisji Geografi Przemystu Polskiego Towarzystwa Geograficznego, 15, 209-218.

Cooper, L.F. (2011). A world without great-power war, International Studies Review, 13 (4), 684-686.

Drembkowski, P. (2010). Od symetrii do „teorii chaosu” - nowy typ konfliktu zbrojnego XXI wieku, Studia Polityczne, 25, 147-162.

Eck, K. (2012). In data we trust? A comparison of UCDP, GED and ACLED conflict events datasets, Cooperation and Conflict, 47, 124-141.

Friedman, G. (2012). Poland's Strategy, Stratfor Geopolitical Weekly, 4(8), 1-5. 
Fukuyama, F. (1996). Koniec historii. Poznań: Zysk i Spółka.

Gałganek, A. (2011). Maszyny wojny. Technologia militarna w społecznej historii stosunków międzynarodowych, Przeglad Strategiczny, 2, 15-41.

Holtom, P., Bromley, M. (2012). Implementing the Arms Trade Treaty: Mapping Assistance to Strenghten Arms Transfer Control. SIPRI Insights to Peace and Security, 2, 1-20.

Holtom, P., Wezeman, S.T., Wezeman, P.D., Bromley, M., Kelly, N., Buchhold, C. (2012). International Arms Transfers. Solna: SIPRI.

IMF, Word Economic Outlook Database, http://www.imf.org/external/pubs/ft/weo/2011/02/weodata/ index.aspx

Kile, S. N. (2012). World Nuclear Forces, SIPRI Yearbook 2012. Oxford: Oxford Univ. Press, 307-350.

Kiperska, J. (2000). Gra o Europę: bezpieczeństwo europejskie w polityce Stanów Zjednoczonych pod koniec XX wieku. Poznań: Instytut Zachodni.

Klin, T. (2011). Możliwości zastosowania zasad potęgometrii dla wybranych celów analizy geopolitycznej. Polityka i społeczeństwo, 8, 148-156.

Kołodziej, J. (2008). Europa w cieniu imperium. Euro-Facta, 1, 385-389.

Konopczak, M., Sieradzki, R., Wiercicki, M. (2010). Kryzys na światowych rynkach finansowych wpływ na rynek finansowy w Polsce oraz implikacje dla sektora realnego. Bank i Kredyt, 41 (6), 45-70.

Królikowski, H. (2010). Offset - mity i rzeczywistość. Politeja - Pismo Wydzialu Studiow Miedzynarodowych i Politycznych Uniwersytetu Jagiellońskiego, 13, 511-529.

Milmo, D. (2012). BAE/EADS merger off as Angela Merkel refuses to endorse a deal. The Guardian, 10, 10. Pozyskano z: http://www.guardian.co.uk/business/2012/oct/10/bae-eads-merger-off-political-concerns

Miłoszowska, D. (2009). Nowy porządek świata jako polityczna forma globalizacji, Geopolityka, 1 (2), 41-47.

Münkler, H. (1994). Wojny naszych czasów. Kraków: WAM.

Nielsen, N. (2012). EU arms trade booming despite crisis. EU-Observer, 27(2), 2-4.

Official Journal of the European Union (2011). Thirteenth Annual Report According to Article 8 (2) of Council Common Position 2008/944/CFSP Defining Common Rules Governing Control of Exports of Military Technology and Equipment. IV Notices from European Union Institutions, Bodies, Offices and Agencies, C 328, 1, aneks A 1.

Perlo-Freeman, S., Sköns, E. (2008). The private military services industry. SIPRI Insights on Peace and Security, 1, 1-20.

Perlo-Freeman, S., Solmirano, C., Kelly, N., Buchhold, C., Wilandh, H., Abdul-Shafi, W. (2012). Military Spending and Armament. Solna: SIPRI.

Pieroni, L. (2007). Military expenditure and economic growth. Defence and Peace Economics, 20 (4), 327-339.

Rachwał, T. (2008). Problematyka badawcza funkcjonowania przedsiębiorstw przemysłowych. Prace Komisji Geografii Przemystu Polskiego Towarzystwa Geograficznego, 11, 53-85.

Rachwał, T. (2011). Industrial restructuring in Poland and other European Union states in the era of economic globalization. Procedia. Social and Behavioral Sciences, 19, 1-10.

Rettman, A. (2012). EU figures show crisis-busting arms sales to Greece. EU-Observer, 7, 3, 2-3.

Silverman, H.I. (2011). Reuters: Principles of trust or propaganda. Journal Of Applied Business Research, 27 (6), 93-115.

SIPRI, Military Expenditure Database, http:/www.sipri.org/research/armaments/milex/resultoutput/ milex_gdp

SIPRI, The value of national arms exports, 2001-2010, in constant (2010) US\$, www.sipri.org/research/ armaments/transfers/measuring/financial_values/constant.xls

Skulski, P. (2011). Uwarunkowania marketingu na międzynarodowym rynku broni. Ekonomia, 1 (13), 192-206.

Sułek, M. (2001). Podstawy potęgonomii i potęgometrii. Kielce: WSEiA.

Sułek, M. (2008). Programowanie gospodarczo-obronne. Warszawa: Bellona. 
Sułek, M. (2011). Potęga jednostek politycznych w oczach polskich grup eksperckich 2003-2011. Geopolityka, 5. Pozyskano z: http://geopolityka.net/potega-jednostek-politycznych-w-oczach-polskichgrup-eksperckich-w-latach-2003-2011/

Szatkowski, T. (2012, 10 października). Kosztowna obronność. Forbes.

Urbański, J., Sułek, M., Płaczek, J. (1992). Potencjał obronno-ekonomiczny i wydatki wojskowe. Warszawa: AON.

Wilczyński, P.L. (2011). Uwarunkowania geograficzne i zróżnicowanie regionalne konfliktów zbrojnych na świecie po II wojnie światowej, Łódź: WNG UŁ (rozprawa doktorska).

Piotr L. Wilczyński, dr, Uniwersytet Pedagogiczny im. Komisji Edukacji Narodowej w Krakowie, Instytut Geografii, Zakład Geografii Społeczno-Ekonomicznej.

Adiunkt w Zakładzie Geografii Społeczno-Ekonomicznej UP. Prezes Geostrategic Consulting International Polska. Opiekun naukowy Krakowskiej Legii Akademickiej. Przewodniczący Oddziału Terenowego Polskiego Towarzystwa Geopolitycznego w Krakowie. Zainteresowania badawcze ukierunkowane na geografię wojenną, strategię i nauki wojskowe, geopolitykę, geografię regionalną, wyborczą i ekonomiczną.

Piotr L. Wilczyński, PhD, Pedagogical University of Cracow, Institute of Geography, Department of Entrepreneurship and Spatial Management.

Piotr Wilczyński is a lecturer at the Pedagogical University of Cracow. The author holds a PhD degree in geography, and specializes in geopolitical studies, economic, political and military geography, as well as national security and strategic studies. He also acts as Chairman of Geostrategic Consulting International, and is a member of the Polish Geopolitical Society. In 2013 he became a commander of Cracow Academic Legion.

Adres/Address: $\quad$ Uniwersytet Pedagogiczny im. Komisji Edukacji Narodowej w Krakowie Instytut Geografii, Zakład Geografii Społeczno-Ekonomicznej

ul. Podchorążych 2, 30-084 Kraków, Polska

e-mail: p.wilczynski@geostrategic.pl 



\section{Rola edukacji w zakresie \\ przedsiębiorczości w okresie \\ kryzysu gospodarczego}

The role of entrepreneurship education in times of an economic crisis 


\title{
Krzysztof Wach
}

Uniwersytet Ekonomiczny

w Krakowie

\section{Edukacja na rzecz przedsiębiorczości wobec współczesnych wyzwań cywilizacyjno-gospodarczych

\author{
Entrepreneurship education towards modern civilization and economic \\ challenges
}

\begin{abstract}
Streszczenie
Celem artykułu jest prezentacja edukacji na rzecz przedsiębiorczości w szerszym kontekście współczesnych wyzwań cywilizacyjnych i gospodarczych, zwłaszcza w aspekcie trwającego światowego kryzysu gospodarczego, identyfikacja tych wyzwań oraz próba nakreślenia pożądanych kierunków ewolucji edukacji dla przedsiębiorczości. W artykule omówiono problem nauczania przedsiębiorczości, dokonując rozróżnienia pomiędzy nauczaniem przedsiębiorczości ekonomicznej a nauczaniem przedsiębiorczości pozaekonomicznej, ponadto poruszono w nim kwestię wertykalnej oraz horyzontalnej edukacji na rzecz przedsiębiorczości. Artykuł zakończono próbą ustalenia rekomendacji dla dalszego kształtowania edukacji na rzecz przedsiębiorczości.
\end{abstract}

\begin{abstract}
The purpose of the article is to present entrepreneurship education in the wider context of contemporary civilizational and economic challenges, especially in the context of the ongoing global economic crisis, as well as its identification, and to attempt to outline the desired direction of education for entrepreneurship evolution. The article discusses the issue of entrepreneurship education by making a distinction between non-economic and economic entrepreneurship. The issue of vertical and horizontal entrepreneurship education is also presented. Furthermore, the article includes an attempt to draw recommendations for the further development of entrepreneurship education.
\end{abstract}

Słowa kluczowe: edukacja; edukacja ekonomiczna; postawy przedsiębiorcze; przedsiębiorczość Key words: education; business education; entrepreneurial attitudes; entrepreneurship

\section{Wprowadzenie}

Obecnie edukacja w zakresie przedsiębiorczości staje wobec wyzwań cywilizacyjnych, w tym wyzwań gospodarczych. Polski system edukacyjny wymaga intensyfikacji edukacji ekonomicznej, a kwestia ta jest podnoszona przez coraz szersze grono ekspertów. Doświadczenia ostatniego globalnego kryzysu finansowego i obecnie trwającego kryzysu zadłużeniowego w Unii Europejskiej jedynie potwierdzają zbyt niską świadomość ekonomiczną społeczeństwa europejskiego (w tym polskiego). Edukacja przedsiębiorcza, nie tylko w Pol- 
sce, jest zdominowana ekonomiczne, należy postrzegać to jednak pozytywnie. Ekonomiczne treści kształcenia nie powinny być w żadnej mierze eliminowane ani redukowane. Trwający kryzys oraz nagłaśniane w mediach liczne przypadki naiwności obywateli w stosunku do nieuczciwych przedsiębiorców i inwestorów jednoznacznie potwierdzają pilną potrzebę edukacji polskiego społeczeństwa właśnie w zakresie wiedzy ekonomicznej. Owszem, edukacja przedsiębiorcza pozaekonomiczna powinna być rozbudowana, ale nie kosztem edukacji ekonomicznej, której notabene jest za mało w polskim systemie kształcenia. Postawy przedsiębiorcze winny być kształtowane przez polską szkołę już od pierwszego roku edukacji wczesnoszkolnej i to na wszystkich zajęciach!

Celem niniejszego artykułu jest prezentacja edukacji na rzecz przedsiębiorczości w szerszym kontekście współczesnych wyzwań cywilizacyjnych i gospodarczych, zwłaszcza w aspekcie trwającego światowego kryzysu gospodarczego, a także identyfikacja oraz próba nakreślenia pożądanych kierunków ewolucji edukacji dla przedsiębiorczości.

\section{Przedsiębiorczość i jej nauczanie}

Przedsiębiorczość jest wielowątkowym tematem badawczym. Jak konkluduje A. Gaweł (2007: 13), „ekonomiści zajmujący się badaniem przedsiębiorczości uważają, że brakuje kompleksowej i jednolitej teorii przedsiębiorczości czy nawet jej definicji, co jest wynikiem wielowątkowości zagadnień poruszanych przy jej badaniu oraz interdyscyplinarnego charakteru tego fenomenu". Sytuacja taka ma swój przejaw również w podejściach do partykularnych wątków badawczych, w tym do analizy uwarunkowań rozwoju przedsiębiorczości. Można w bardzo dużym uogólnieniu przyjąć, że w piśmiennictwie naukowym przedsiębiorczość ujmowana jest w co najmniej dwóch głównych kategoriach (Davidsson, 2003: 317; Davidsson, 2008: 15):

- przedsiębiorczość jako fenomen społeczny,

- przedsiębiorczość jako dyscyplina naukowa.

W ramach pierwszej kategorii P. Davidsson (2008: 15-17) rozpatruje przedsiębiorczość na tle ogółu społeczeństwa oraz systemu gospodarczego, wyróżniając dwie jej funkcje:

- przedsiębiorczość jako funkcja konkurencyjnych zachowań kierujących rynkiem (Kirzner, 1973: 19-20),

- przedsiębiorczość jako funkcja wdrażania nowych przedsięwzięć gospodarczych prowadzących do zmian na rynku.

Z kolei H. Landström (2010: 11-13) w ramach przedsiębiorczości jako kategorii dyscypliny akademickiej wyróżnia trzy funkcje:

- przedsiębiorczość jako funkcja rynku,

- przedsiębiorczość jako funkcja indywidualnego przedsiębiorcy,

- przedsiębiorczość jako proces (rozróżniając dwa nurty, tj. proces powstawania nowych podmiotów oraz proces odkrywania okazji $)^{1}$.

Do tego katalogu warto dodać dwie kolejne funkcje, czyli (Wawrzyniak, 1988: 6-9; Gaweł, 2007: 23):

- przedsiębiorczość jako funkcja² osobowości,

- przedsiębiorczość jako funkcja mikro-, małych i średnich przedsiębiorstw.

\footnotetext{
${ }^{1}$ Procesowe ujęcie przedsiębiorczości można utożsamiać z przedsiębiorczością jako funkcją czynności menedżerskich (Wach, 2012: 199).

${ }^{2}$ Funkcja jest tutaj rozumiana w języku matematycznym, czyli jako przyporządkowanie elementom pewnego zbioru elementów innego lub tego samego zbioru.
} 
Każde z wymienionych podejść inaczej definiuje, analizuje i interpretuje fenomen przedsiębiorczości, a przytaczanie w tym miejscu wszystkich możliwych definicji nie jest uzasadnione. W kontekście edukacji i kształcenia najczęściej przytaczana jest definicja przedsiębiorczości opracowana przez grupę ekspercką powołaną przez instytucje unijne w celu opracowania, a następnie weryfikacji założeń edukacji w zakresie przedsiębiorczości. „Przedsiębiorczość oznacza zdolność osoby do wcielania pomysłów w czyn. Obejmuje ona twórczość, innowacyjność i podejmowanie ryzyka, a także zdolność do planowania przedsięwzięć i prowadzenia ich dla osiągnięcia zamierzonych celów. Stanowi ona wsparcie dla wszystkich w codziennym życiu prywatnym i społecznym, zaś pracownikom pomaga uzyskać świadomość kontekstu ich pracy i zdolność wykorzystywania szans; jest podstawą bardziej konkretnych umiejętności i wiedzy potrzebnych osobom podejmującym przedsięwzięcia o charakterze społecznym lub komercyjnym" (European Commission, 2005: 18; 2006: 4; 2008: 10).

Aż do początku lat 90 . XX w. w literaturze przedmiotu oraz codziennej praktyce toczyła się dysputa, czy przedsiębiorczość jest nauką, czy sztuką, innymi słowy - czy można jej nauczać i nauczyć się, czy przekazuje się ją w genach i tym samym jest magiczną umiejętnością. P. Drucker porównał przedsiębiorczość do medycyny, konstatując, że „przedsiębiorczość nie jest ani dyscypliną, ani sztuką, jest praktyką", ale podobnie jak medycyna może być przekazana i nauczana w podręcznikach (Drucker, 1985: VIII, 180). Jak na podstawie własnych badań zauważają G. Gorman, D. Hanlon oraz W. King (1997: 63), „większość badań empirycznych potwierdza, że przedsiębiorczość może być nauczana, a przynajmniej można do niej zachęcać w ramach edukacji w zakresie przedsiębiorczości”. Można zatem przyjąć za A. Fayollem (2006), że pytanie: Czy przedsiębiorczość może być nauczana? już nie jest odpowiednim pytaniem.

Edukacja per se, a w szczególności edukacja w zakresie przedsiębiorczości, ogrywa kluczową rolę w budowaniu przedsiębiorczego społeczeństwa i przedsiębiorczej gospodarki. Edukacja w zakresie przedsiębiorczości narodziła się w Stanach Zjednoczonych Ameryki, a jej początki sięgają przełomu lat 40. oraz 50. XX wieku. Pierwszy na świecie kurs akademicki z zakresu przedsiębiorczości uruchomiono w 1947 r. w Harvard Business School, natomiast w 1953 r. Peter Drucker na New York University rozpoczął prowadzenie zajęć z przedsiębiorczości i innowacji. W 2005 r. na 600 uczelniach na świecie można było studiować przedsiębiorczość jako kierunek studiów, a na kolejnych 400 jako specjalność, natomiast w ponad 1600 uczelniach oferowano przynajmniej 1 kurs akademicki z zakresu przedsiębiorczości (Kuratko, 2005: 577; Kuratko, 2009: XXIX). Co więcej, niektóre z najbardziej prestiżowych uczelni amerykańskich, takie jak Indiana University, University of Colorado, University of South Carolina, oferują studia doktoranckie z zakresu przedsiębiorczości, tym samym prowadząc badania naukowe w tej (sub)dyscyplinie naukowej.

\section{Edukacja dla oraz w zakresie przedsiębiorczości a edukacja ekonomiczna}

Polska literatura przedmiotu zawiera wiele pokrewnych, a z pozoru wręcz równoznacznych pojęć, takich jak nauczanie przedsiębiorczości, kształcenie $w$ zakresie przedsiębiorczości, edukacja dla przedsiębiorczości, edukacja w zakresie przedsiębiorczości, edukacja na rzecz przedsiębiorczości, edukacja przedsiębiorczości, przedsiębiorcza edukacja. Podobna sytuacja występuje również w języku angielskim, przy czym zdecydowanie dominującym i najszerszym pojęciem jest w nim entrepreneurship education, co zgodnie z założeniami translatyki można przetłumaczyć jako 'edukacja przedsiębiorczości’3, choć takie zwroty jak

\footnotetext{
${ }^{3}$ Tłumaczenie to jest dość rzadko stosowane w krajowej literaturze przedmiotu, choć przez analogię (economics education, economic education - 'edukacja ekonomiczna', business education - 'edukacja biznesowa') może być uważane za jedno z lepszych określeń.
} 
edukacja dla przedsiębiorczości czy edukacja na rzecz przedsiębiorczości też mają swoje merytoryczne uzasadnienie. Poszczególni autorzy czy poszczególne instytucje różnie kategoryzują edukację na rzecz przedsiębiorczości, dokonując odmiennej delimitacji pomiędzy współzależnymi, a wręcz interferencyjnymi obszarami kształcenia. Warto podać kilka przykładów, tych najbardziej popularnych w literaturze.

I. Jamieson (1984: 19-27) wprowadza trzykategoriowe ramy edukacji przedsiębiorczości, dokonując rozróżnienia pomiędzy edukacją o przedsiębiorczości (education about enterprises), edukacją dla przedsiębiorczości (education for enterprises) oraz edukacją przez przedsiębiorczość (education in enterprise). Edukacja o przedsiębiorczości przekazuje wiedzę teoretyczną na temat zakładania i prowadzenia własnej działalności gospodarczej. Edukacja dla przedsiębiorczości kształtuje umiejętności potrzebne przedsiębiorcom w prowadzeniu własnego biznesu, głównie umiejętności menedżerskie. Edukacja przez przedsiębiorczość dotyczy już działających przedsiębiorców i pomaga im rozwijać dalsze umiejętności biznesowe związane z rozwojem prowadzonej działalności gospodarczej (Raposo, do Paço, 2011: 455). Warto podkreślić, że jest to jedna z pierwszych typizacji, choć edukacja przedsiębiorczości jest tutaj traktowana głównie jako edukacja ekonomiczna czy biznesowa.

J. Guzmán oraz F. Liñán (2005: 6-7) wyróżniają cztery kategorie edukacji na rzecz przedsiębiorczości: edukację w zakresie promowania własnej działalności gospodarczej jako alternatywnej ścieżki kariery zawodowej, edukację w zakresie uruchamiania działalności gospodarczej w fazie start-up, edukację dokształcającą skierowaną dla dojrzałych przedsiębiorców oraz edukację w zakresie przedsiębiorczego dynamizmu promującą przedsiębiorcze postawy, takie jak kreatywność, innowacyjność, inwencyjność, własną inicjatywę w miejscu pracy oraz we własnym biznesie.

Interesujące rozróżnienie wprowadza brytyjska Agencja Zapewnienia Jakości w Szkolnictwie Wyższym QAA (2012: 2, 7). Edukacja w zakresie przedsiębiorczych przedsięwzięć (enterprises education) definiowana jest przez nią jako proces wyposażania uczniów i/lub studentów (względnie absolwentów) w bogate zdolności do generowania pomysłów, a także kształtowania umiejętności niezbędnych do realizacji tych pomysłów. Z kolei edukacja w zakresie przedsiębiorczości (entrepreneurship education) ma na celu przygotowanie uczniów i/ lub studentów w zakresie wiedzy, umiejętności i postaw wymaganych w kontekście tworzenia nowego przedsięwzięcia lub własnej działalności gospodarczej. Interesujące w tej koncepcji jest holistyczne ujęcie procesu nauczania - edukacji w zakresie kreatywności oraz przedsiębiorczości (enterprise and entrepreneurship education, EEE) ${ }^{4}$.

Wielu autorów postuluje wyraźne rozgraniczenie kształcenia w zakresie przedsiębiorczości od edukacji ekonomicznej (European Commission, 2008: 8; Volkmann i in., 2009: 19; Consortium for Entrepreneurship Education, 2008: 3), choć nie jest to łatwe zadanie. W naukach ekonomicznych, zwłaszcza w naukach o zarządzaniu, dominuje obecnie przedsiębiorczy model zarządzania (entrepreneurial management), natomiast w ekonomii na dobre zagościł paradygmat gospodarki przedsiębiorczej (entrepreneurial economy) (Wach, 2012: 200). Trudno jest obecnie oddzielić edukację ekonomiczną, czy uściślając - edukację biznesową - od edukacji przedsiębiorczości. Niewątpliwie edukacja ekonomiczna stanowi istotną część edukacji na rzecz przedsiębiorczości.

Dokonując próby pewnego uporządkowania terminologicznego, warto wprowadzić dość szerokie pojęcie edukacja na rzecz przedsiębiorczości (edukacja dla przedsiębiorczości),

\footnotetext{
${ }^{4}$ Analogiczne założenia przyjęła również irlandzka agencja HETAC (cop).
} 
które obejmuje zarówno edukację formalną, jak i edukację nieformalną, w tym kształcenie ustawiczne przez całe życie zgodnie z koncepcją lifelong learning (Najda-Janoszka, Wach, 2008). W tej drugiej kategorii mieszczą się przede wszystkim szkolenia i kursy dla przedsiębiorców, jak i samodoskonalenie. W ramach edukacji formalnej należy co najmniej wyróżnić trzy szczeble edukacji na rzecz przedsiębiorczości (Wach, 2007: 120; Wach, 2008: 36). Są to:

- edukacja elementarna (do 14 roku życia),

- edukacja średnia,

- edukacja akademicka (I, II oraz III stopień studiów).

Tak w ramach formalnej, jak i nieformalnej edukacji na rzecz przedsiębiorczości należy zidentyfikować co najmniej trzy komponenty edukacji w zakresie przedsiębiorczości (realizowanej w ramach danego przedmiotu szkolnego, kursu akademickiego, modułu kształcenia). Będą to ${ }^{5}$ :

- przedsiębiorczość indywidualna i organizacyjna,

- przedsiębiorczość biznesowa (edukacja biznesowa),

- edukacja ekonomiczna.

Pierwszy komponent dotyczy głównie komunikatywności, kreatywności, intraprzedsiębiorczości. Drugi komponent dostarcza wiedzę i kształtuje umiejętności potrzebne do podejmowania przedsięwzięć o charakterze biznesowym, komercyjnym i społecznym. Trzeci komponent, jako wspomagający, dostarcza wiedzy na temat otoczenia, w jakim funkcjonuje przedsiębiorstwo, przedsiębiorca czy dane przedsięwzięcie. Jego zadaniem jest promocja wiedzy ekonomicznej, niezbędnej we współczesnej rzeczywistości (por. ryc. 1).

W ramach edukacji formalnej stosowane są dwa rodzaje instrumentów - wertykalne oraz horyzontalne. Te pierwsze należą do klasycznych rozwiązań w zakresie systemu szkolnictwa, a nauczanie przedsiębiorczości odbywa się $\mathrm{w}$ ramach odrębnych przedmiotów, kursów czy modułów kształcenia. Mówi się wówczas o edukacji w zakresie przedsiębiorczości. Instrumenty wertykalne z kolei należy utożsamiać z koncepcją edukacji dla przedsiębiorczości, są holistycznie implementowane $\mathrm{w}$ całym procesie edukacyjnym (procesie nauczania - uczenia się) w danej instytucji. Ich zadaniem jest kształtowanie przedsiębiorczych postaw w szerokim rozumieniu.

Konkludując, można stwierdzić, że celem nauczania przedsiębiorczości (edukacji na rzecz przedsiębiorczości) jest promowanie kreatywności, innowacji i samozatrudnienia, a obejmuje ono w swoich założeniach m.in. (Kozlinska, 2011: 207; Raposo, do Paço, 2011: 454; European Commission, 2008: 8; Garavan, O'Cinneide, 1994: 5):

- rozwijanie osobistych cech i umiejętności, które stanowią podstawę ducha przedsiębiorczości i przedsiębiorczego zachowania (kreatywność, poczucie inicjatywy, podejmowania ryzyka, niezależności, pewności siebie, przywództwo, duch zespołu),

- podnoszenie świadomości uczniów i/lub studentów na temat samozatrudnienia i przedsiębiorczości, jak również możliwości dalszej kariery,

- praca na konkretnych projektach biznesowych lub w ramach działalności gospodarczej,

- zapewnienie szczególnych umiejętności biznesowych oraz wiedzy o tym, jak założyć własny biznes i pomyślnie go prowadzić.

\footnotetext{
${ }^{5}$ Podobną koncepcję zawarto również w pracy I. Hatak (2011: 27-28).
} 
Ryc. 1. Strukturalizacja edukacji na rzecz przedsiębiorczości

EDUKACJA NA RZECZ PRZEDSIEBBIORCZOSCI
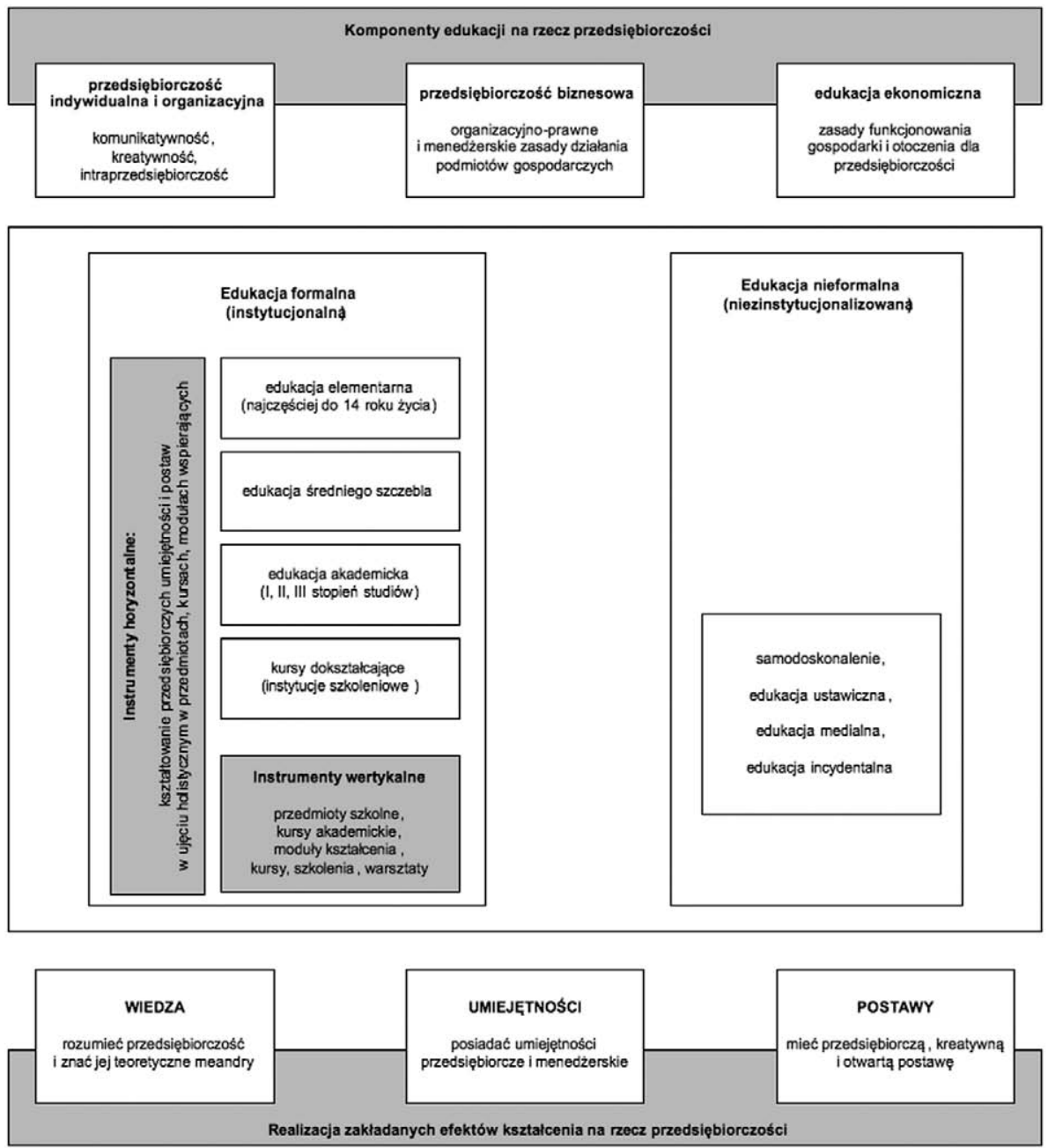

Źródło: opracowanie własne.

\section{Przedsiębiorcza edukacja na rzecz przedsiębiorczości}

Aby osiągnąć zamierzoną efektywność edukacji na rzecz przedsiębiorczości, musi zaistnieć swojego rodzaju synergizm programów kształcenia (edukacji formalnej) z nieformalnymi formami kształcenia pozaszkolnego czy pozakademickiego. Edukacja szkolna i uniwersytecka dla przedsiębiorczości musi zatem być wspierana przez otoczenie instytucjonalne, w tym zwłaszcza przez szeroko pojętą praktykę gospodarczą. Efektywność edukacji dla przedsiębiorczości jest realizowana przez trzy następujące po sobie etapy (QAA, 2012: 9-12):

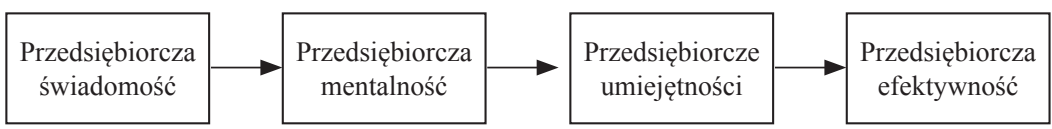


Przedsiębiorcza edukacja na rzecz przedsiębiorczości powinna obejmować trzy zintegrowane komponenty, czyli (Heinonen, Poikkijoki, 2006: 83):

- uczyć się, jak zrozumieć przedsiębiorczość (wiedza),

- uczyć się, jak być przedsiębiorczym (umiejętności),

- uczyć się, jak stać się przedsiębiorcą (postawy).

Celem edukacji dla przedsiębiorczości, obejmującej przekazywanie wiedzy, nabywanie umiejętności oraz kształtowanie postaw, jest krzewienie przedsiębiorczości (postaw przedsiębiorczych) w życiu osobistym, społecznym i zawodowym uczących się (ryc. 2). W praktyce pozwala to uczącym się odkryć, poznać i doświadczyć mechanizmy przedsiębiorczości procesowej, które warunkują osiągnięcie pożądanych celów edukacji dla przedsiębiorczości. W efekcie tak zaprogramowanego procesu kształcenia uczący się kształtują swoją przedsiębiorczość osobowościową, przejawiającą się w proaktywności i innowacyjności, gotowości na zmiany oraz działaniu, czyli aktywnej inicjatywności.

Ryc. 2. Przedsiębiorczy proces edukacji na rzecz przedsiębiorczości

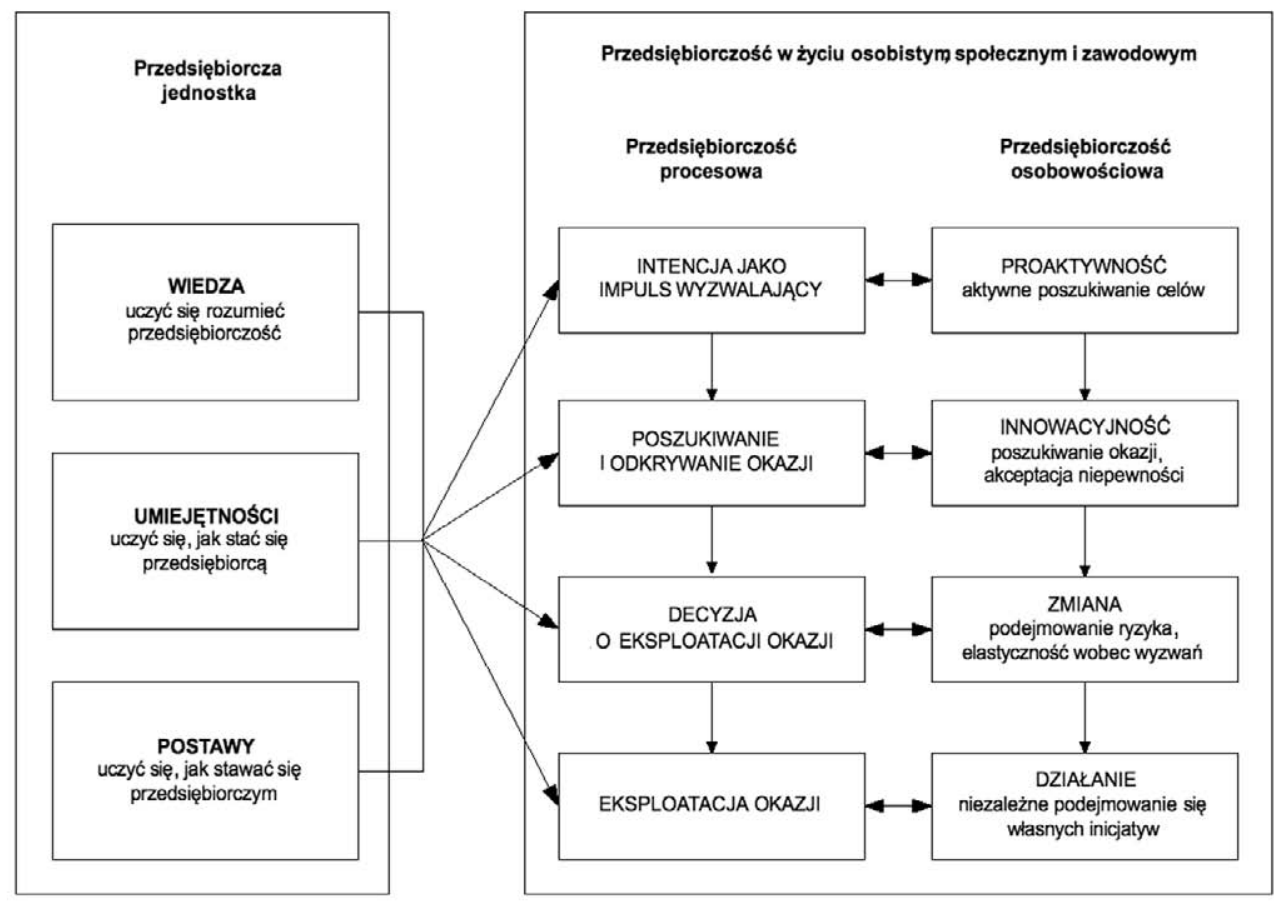

Źródło: opracowano na podstawie: Heinonen, Poikkijoki (2006: 84), Gibcus i in. (2012: 43).

L.G. Davies oraz A.A. Gibb (cyt. za: Marques, Albuquerque, 2012: 60) podkreślają, że używanie tradycyjnych metod nauczania do kształtowania kompetencji i postaw przedsiębiorczych jest niewystarczające, stąd proponowane jest przedsiębiorcze podejście do nauczania, określane w literaturze przedmiotu mianem przedsiębiorczej pedagogiki (entrepreneurial pedagogy) lub pedagogiki przedsiębiorczości (entrepreneurship pedagogy) (Kuratko, 2009: XXX). Kształcenie takie wymaga zatem stosowania szerokiego wachlarza metod aktywizujących, zwłaszcza aktywizujących metod problemowych wyzwalających w uczących się własną inicjatywność (tab. 1). 
Tab. 1. Charakterystyka porównawcza nauczania klasycznego i nauczania przedsiębiorczego

\begin{tabular}{|c|c|}
\hline Nauczanie klasyczne & Nauczanie przedsiębiorcze \\
\hline Uczenie się od nauczyciela & Uczenie się od siebie nawzajem \\
\hline Pasywna rola uczącego się jako słuchacza & Uczenie się przez działanie \\
\hline Uczenie się ze źródeł pisanych przez czytanie & $\begin{array}{l}\text { Uczenie się przez debaty i osobistą wymianę } \\
\text { informacji }\end{array}$ \\
\hline $\begin{array}{l}\text { Uczenie się w ramach nakreślonych przez nauc- } \\
\text { zyciela jako eksperta }\end{array}$ & $\begin{array}{l}\text { Uczenie się przez własne odkrywanie z wykor- } \\
\text { zystaniem porad nauczyciela }\end{array}$ \\
\hline $\begin{array}{l}\text { Uczenie się przez uzyskiwanie opinii zwrotnej } \\
\text { od nauczyciela }\end{array}$ & Uczenie się przez interakcje $\mathrm{z}$ wieloma osobami \\
\hline $\begin{array}{l}\text { Uczenie się w dobrze zorganizowanym } \\
\text { środowisku z wykorzystaniem planu zajęć }\end{array}$ & $\begin{array}{l}\text { Uczenie się w elastycznym, nieformalnym } \\
\text { środowisku }\end{array}$ \\
\hline $\begin{array}{l}\text { Uczenie się bez presji natychmiastowego } \\
\text { osiągnięcia celów }\end{array}$ & Uczenie się pod presją osiągnięcia celów \\
\hline $\begin{array}{l}\text { Uczeniu nie powinno towarzyszyć korzystanie } \\
\text { z cudzych wzorców }\end{array}$ & $\begin{array}{l}\text { Uczenie się przez obserwację działań innych, } \\
\text { odwzorowanie najlepszych praktyk }\end{array}$ \\
\hline $\begin{array}{l}\text { Uczeniu towarzyszy obawa związana } \\
\text { z popełnieniem błędów i porażką }\end{array}$ & $\begin{array}{l}\text { Uczenie się metodą prób i błędów, które służą } \\
\text { doskonaleniu }\end{array}$ \\
\hline Uczenie się przez robienie notatek & Uczenie się przez rozwiązywanie problemów \\
\hline
\end{tabular}

Źródło: adaptacja z: Gibb (1993: 24).

\section{Konkluzje i rekomendacje}

W raportach porównawczych (benchmarking reports) sporządzonych na zlecenie Komisji Europejskiej Polska jest do tej pory wysoko oceniania pod względem realizacji zaleceń w zakresie nauczania przedsiębiorczości w szkolnictwie powszechnym, głównie ze względu na wprowadzenie obowiązkowego przedmiotu podstawy przedsiębiorczości w szkołach ponadgimnazjalnych, ale także realizacji modułu ekonomiczno-przedsiębiorczego w ramach przedmiotu wiedza o społeczeństwie w gimnazjach (Rachwał, 2006: 427-434; Kurek, Rachwał, 2009: 127-142; Berger i in., 2012: 679-701). Wprowadzenie od 2012 r. w szkołach ponadgimnazjalnych uzupełniającego przedmiotu ekonomia w praktyce należy również odebrać in plus jako strategiczne działanie. Podkreślić jednak należy, że samo wprowadzenie obowiązkowego przedmiotu czy treści nauczania w zakresie przedsiębiorczości jest dopiero pierwszym etapem realizacji modelu przedsiębiorczej edukacji, o wiele bardziej istotna jest właściwa realizacja odpowiednich treści kształcenia w zakresie przedsiębiorczości. Inaczej niż w szkolnictwie gimnazjalnym i ponadgimnazjalnym wygląda realizacja kształcenia uniwersyteckiego dla przedsiębiorczości. Kształcenie na poziomie akademickim jest w Polsce, podobnie jak w innych krajach europejskich, zdecentralizowane, a nadal niewiele uczelni ekonomicznych, nie wspominając o nieekonomicznych, wprowadza obowiązkowe moduły kształcenia w zakresie przedsiębiorczości, choć bezsprzecznie elementy takiego kształcenia zawierają inne kursy akademickie, przynajmniej na kierunkach ekonomiczno-menedżerskich.

Nawet tylko pobieżna analiza zachowań indywidualnych inwestorów oraz konsumentów na światowych rynkach w warunkach trwającego globalnego kryzysu jednoznacznie potwierdza konieczność intensyfikacji ekonomicznej edukacji w zakresie przedsiębiorczości. Część problemów, zwłaszcza indywidualnych uczestników życia gospodarczego (czyli całego społeczeństwa) w pewnej mierze wynika z braku wiedzy ekonomicznej. Niedostatek 
tej wiedzy przejawia się w błędnych decyzjach ekonomicznych, zwłaszcza kapitałowych, ale także wyborczych, które to pośrednio wpływają na późniejszy stan gospodarki. Istnieje zatem pilna potrzeba intensyfikacji zarówno edukacji ekonomicznej, jak i edukacji na rzecz przedsiębiorczości.

W polskim szkolnictwie tak niższego szczebla, jak i szczebla uniwersyteckiego nadal dominuje klasyczny model nauczania. Współczesny model kształcenia przedsiębiorczego wymaga natychmiastowej implementacji i to na szeroką skalę, co z kolei wymaga odpowiedniego przeszkolenia nauczycieli, ale przede wszystkim sporych nakładów finansowych na wyposażenie szkół i uczelni publicznych. Niemniej jednak istnieje pilna potrzeba zapewnienia wsparcia metodycznego dla nauczycieli przedsiębiorczości w zakresie wykorzystania aktywnych metod nauczania (m.in. takich metod, jak moderacja wizualna, blended e-learning, edutainment). Aktywizujące metody nauczania powinny być szeroko stosowane w edukacji ekonomicznej zarówno w szkolnictwie ponadgimnazjalnym, jak i w szkolnictwie wyższym. Rekomendacja dla szkolnictwa wyższego w zakresie edukacji dla przedsiębiorczości obejmuje następujące zalecenia:

- studia pierwszego stopnia powinny mieć charakter bardziej praktyczny niż teoretyczny, a absolwenci kierunków ekonomicznych i menedżerskich powinni zdobyć praktyczne umiejętności menedżerskie, które będą mogli wykorzystać w pracy zawodowej. Środowisko akademickie powinno wprowadzić kształcenie w zakresie przedsiębiorczości stosowanej jako obligatoryjny kurs akademicki przynajmniej na wszystkich ekonomiczno-menedżerskich kierunkach studiów oraz co najmniej jako przedmiot fakultatywny na pozostałych kierunkach studiów. Pożądane jest również wprowadzenie fakultatywnego kształcenia w zakresie kreatywności i innowacji;

- studia drugiego stopnia powinny mieć charakter teoretyczny, przygotowywać absolwenta do pracy naukowej. Treści kształcenia na wszystkich kierunkach ekonomiczno-menedżerskich powinny obejmować kształcenie w zakresie teorii przedsiębiorczości (w zakresie przedsiębiorczości i innowacji). Pożądane jest również fakultatywne wprowadzenie kształcenia w zakresie zarządzania innowacjami, zwłaszcza na kierunkach technicznych, co przyczyni się do promowania transferu wiedzy i technologii;

- programy studiów powinny obejmować kształcenie praktyczne oparte na współpracy z przedsiębiorcami, w ramach którego studenci powinni realizować rzeczywiste projekty dla współpracujących z uczelnią przedsiębiorstw. Warsztaty takie powinny być oferowane jako fakultatywne kursy akademickie dla studentów wszystkich kierunków ekonomicznych;

- kształcenie akademickie w zakresie nauczania przedsiębiorczości powinno również wykorzystywać prowadzenie tzw. przedsiębiorstw studenckich (przedsiębiorstw treningowych), które w ramach zajęć fakultatywnych zakładaliby i prowadzili studenci pod nadzorem pracownika naukowo-dydaktycznego. Działania te powinny być wspierane przez intensyfikację realizacji koncepcji akademickich inkubatorów przedsiębiorczości;

- uczelnie ekonomiczne powinny włączyć się w międzynarodowe projekty edukacyjne związane z przedsiębiorczością. Pożądane jest tworzenie sieci współpracy z uczelniami krajowymi i zagranicznymi w zakresie nauczania przedsiębiorczości (np. CEEPUS, MINERVA). 


\section{Literatura}

Berger, S., Canning, R., Dolan, M., Kurek, S., Pilz, M., Rachwał, T. (2012). Curriculum-Making in PreVocational Education in the Lower Secondary School: A Regional Comparative Analysis within Europe, Journal of Curriculum Studies, 44, 5, 679-701.

Consortium for Entrepreneurship Education, (2008). Entrepreneurship Everywhere: The Case for Entrepreneurship Education, Columbus, $\mathrm{OH}$.

Davidsson, P. (2003). The Domain of Entrepreneurship Research: Some Suggestions, In: J. Katz, D. Shepherd (eds.), Advances in Entrepreneurship, Firm Emergence and Growth, vol. 6, JAI Press, Greenwich, CT, 315-372.

Davidsson, P. (2008). The Entrepreneurship Research Challenge, Chetenham - Northampton, MA: Edward Elgar Publishing Ltd.

Drucker, P.F. (1985). Innovation and Entrepreneurship. Practice and Principles, New York, NY: HarperCollins Publishers.

European Commission, (2005). Proposal for a Recommendation of the European Parliament and of the Council on key competences for lifelong learning, COM(2005)548 final, Brussels, 10.11.2005.

European Commission, (2006). Communication from the Commission to the Council, the European Parliament, the European Economic and Social Committee and the Committee of the Regions, Implementing the Community Lisbon Programme: Fostering entrepreneurial mindsets through education and learning, $\operatorname{COM}(2006) 33$ final, Brussels, 13.2.2006.

European Commission, (2008). Entrepreneurship in higher education, especially with non-business studies, Final report of the Expert Group, European Commission - Enterprise and Industry Directorate-General, Brussels - March 2008.

Fayolle, A. (2006). Essay on the Nature of Entrepreneurship Education, In: U. Fueglistaller, T. Volery (eds.), W. Weber, Understanding the Regulatory Climate for Entrepreneurship and SME., St. Gallen: KMU Verlag HSG.

Gaweł, A. (2007). Ekonomiczne determinanty przedsiębiorczości, Poznań: Wyd. Akademii Ekonomicznej w Poznaniu.

Garavan, T.N., O’Cinneide, B. (1994). Entrepreneurship Education and Training Programmes: A Review and Evaluation, Journal of European Industrial Training, 18, 8, 3-12.

Gibb, A.A. (1993). The Enterprise Culture and Education. Understanding Enterprise Education and Its Links with Small Business, Entrepreneurship and Wider Educational Goals, International Small Business Journal, 11, 3, 11-37.

Gibcus, P. i in. (2012). Effects and Impact of Entrepreneurship Programmes in Higher Education. Brussels: European Commission - Enterprise and Industry Directorate-General.

Gorman, G., Hanlon, D., King, W. (1997). Some Research Perspectives on Entrepreneurship Education, Enterprise Education, and Education for Small Business Management: A Ten-Year Literature Review, International Small Business Journal, 15, 3, 56-77.

Guzmán, J., Liñán, F. (2005). Perspectives on Entreprenerial Education: A US-Euope Comparison, Madrid: Universidad Antionio de Nebrija.

Hatak, I. (2011). Innovation in Entrepreneurship Education in Europe. An Analysis of New Initiatives, Implementation Processes and Associated Success Factors, Vienna University of Economics and Business - Research Institute for Co-Operation and Co- Operatives, RiCC Research Reports, 3.

Heinonen, J., Poikkijoki, S.-A. (2006). An Entrepreneurial-Directed Approach to Entrepreneurship Education: Mission Impossible?, Journal of Management Development, 25, 1, 80-94.

Henry, C., Hill, F., Leitch, C. (2005). Entrepreneurship Education and Training: Can Entrepreneurship be Taught? Part I, Education + Training, 47, 2, 98-111.

HETAC [cop]. Draft Guidelines and Key Criteria for the Review of Enterprise and Entrepreneurship Education (EEC). Higher Education and Training Awards Council.

Jamieson, I. (1984). Schools and Enterprise. W: Education for Enterprise, eds. A.G. Watts, P. Moran, Cambridge: Careers Research and Advisory Centre CRAC, 19-27.

Kirzner, I. (1973). Competition and Entrepreneurship, Chicago, IL: University of Chicago Press. 
Kozlinska, I. (2011). Contemporary Approaches to Entrepreneurship Education, Journal of Business Management, 4, 205-220.

Kuratko, D.F. (2005). The Emergence of Entrepreneurship Education: Development, Trends, and Challenges, Entrepreneurship Theory and Practice, 29, 5, 577-598.

Kuratko, D.F. (2009). Entrepreneurship. Theory, Process, Practice, 8th edition, Masson, OH: SouthWestern Cengage Learning.

Kurek, S., Rachwał T. (2009). The Role of Business Education in the Development of Entrepreneurship in the Member States of the European Union, Europa XXI, 19, 127142.

Landström, H. (2010). Pioneers in Entrepreneurship and Small Business Research, New York, NY: Springer.

Marques, L.A., Albuquerque, C. (2012). Entrepreneurship Education and the Development ogf Young People Life Competences and Skills, Journal of Entrepreneurship Perspectives, 1, 2, 55-68.

Najda-Janoszka, M., Wach, K. (2008). Lifelong Learning in the Fields of Tourism in the European Union taking Poland into Special Consideration. W: M. Bednarczyk (red.), Entrepreneurship in Tourism and Sport Business, Kraków: Fundacja dla Uniwersytetu Jagiellońskiego, 45-58.

QAA, (2012). Enterprise and Entrepreneurship Education. Guidance for UK Higher Education Providers, Draft for Consultations, The Quality Assurance Agency for Higher Education, February 2012, mimeo.

Rachwał, T. (2006). Kształtowanie postaw przedsiębiorczych w edukacji szkolnej. W: B. Muchacka (red.), Szkoła w nauce i praktyce edukacyjnej, t. II, Kraków: Oficyna Wydawnicza „Impuls”, 427-434.

Raposo, M., do Paço A. (2011). Entrepreneurship Education: Relationship between Education and Entrepreneurial Activity, Psicothema, 23, 3, 453-457.

Volkmann, Ch. i in. (2009). Educating the Next Wave of Entrepreneurs. Unlocking Entrepreneurial Capabilities to Meet the Global Challenges of the 21st Century. A Report of the Global Education Initiative, Geneva: World Economic Forum.

Wach, K. (2007). Kształtowanie postaw przedsiębiorczych w programach nauczania. Stan obecny i proponowane kierunki zmian. W: P. Wachowiak, M. Dąbrowski, B. Majewski (red.), Kształtowanie postaw przedsiębiorczych a edukacja ekonomiczna, Warszawa: Fundacja Promocji i Akredytacji Kierunków Ekonomicznych, 120-127.

Wach, K. (2008). Entrepreneurship Education in Poland, ERENET Profile, III, 3 (11), 36-44.

Wach. K. (2012). Europeizacja małych i średnich przedsiębiorstw. Rozwój przez umiędzynarodowienie, Warszawa: Wydawnictwo Naukowe PWN.

Wai Mui Yu, Ch., Wing Yan Man, Th., (2007). The Sustainability of Enterprise Education: A Case Study in Hong Kong. Education + Training, 49, 2, 138-152.

Wawrzyniak, B. (1988). Przedsiębiorczość - legitymacja do przyszłości, Przegląd Organizacji, 7 (582), 6-9.

Krzysztof Wach, dr hab., Uniwersytet Ekonomiczny w Krakowie, Katedra Przedsiębiorczości i Innowacji.

Doktor habilitowany nauk ekonomicznych w zakresie ekonomii, doktor nauk ekonomicznych w zakresie nauk o zarządzaniu, absolwent, a następnie pracownik Uniwersytetu Ekonomicznego w Krakowie, specjalista z zakresu przedsiębiorczości międzynarodowej, autor kilkunastu książek, w tym monografii naukowych i podręczników akademickich oraz poradników z zakresu przedsiębiorczości oraz internacjonalizacji małych i średnich przedsiębiorstw. Członek komitetów redakcyjnych kilku czasopism naukowych, w tym rocznika „Przedsiębiorczość - Edukacja”, redaktor naczelny kwartalnika naukowego 'Entrepreneurial Business and Economics Review'. Od 2012 r. pełni funkcję krajowego eksperta OECD oraz Komisji Europejskiej ds. Przedsiębiorczości, jest uczestnikiem międzynarodowych projektów edukacyjnych i badawczych (m.in. Jean Monnet, Atlantis, International Visegrad 
Fund, Central European Initiative), odbył gościnne wykłady m.in. w Grand Valley State University (Grand Rapids, USA), Roosevelt University (Chicago, USA), University of Detroit Mercy (Detroit, USA), Loyola University Chicago (Chicago, USA), Northumbria University (Newcastle, UK), Universidad Politecnica e Cartagena (Kartagena, Hiszpania).

Krzysztof Wach, DEcon, PhD, Cracow University of Economics, Department of Entrepreneurhsip and Innovation.

Habilitated doctor of economics (DEcon), PhD in management, graduate and then associate professor at the Cracow University of Economics, specialist in international entrepreneurship, author of several books, including monographs and scholarly books, as well as practical guides for entrepreneurs in the field of entrepreneurship and the internationalization of small and medium-sized enterprises, member of editorial boards of several scientific journals, including the annual 'Entrepreneurship - Education'; editor-in-chief of the scientific quarterly 'Entrepreneurial Business and Economics Review', an OECD national expert for entrepreneurship since 2012, participant of various international education and research projects (e.g. Jean Monnet, Atlantis, International Visegrad Fund IVF, Central European Initiative CEI), visiting professor in various American and European universities, including Grand Valley State University (Grand Rapids, USA), Roosevelt University (Chicago, USA), University of Detroit Mercy (Detroit, USA), Loyola University Chicago (Chicago, USA), Northumbria University (Newcastle, UK), Technical University of Cartagena (Cartagena, Spain).

Adres/Address: Uniwersytet Ekonomiczny w Krakowie, Katedra Przedsiębiorczości i Innowacji ul. Rakowicka 27, 31-510 Kraków, Polska e-mail:wachk@uek.krakow.pl 


\author{
Tomasz Tadeusz Brzozowski \\ Uniwersytet Wrocławski \\ Wyższa Szkoła Bankowa we Wrocławiu \\ Wyższa Szkoła Techniczno-Ekonomiczna w Świdnicy
}

\title{
Status przedsiębiorczości w warunkach kryzysu edukacji \\ Status of entrepreneurship in the conditions of an educational crisis
}

\begin{abstract}
Streszczenie
Autor treścią niniejszego artykułu uczynił problem kryzysu systemu edukacji w Polsce. Ów kryzys jest wynikiem wielu czynników, które z czasem ujawiły się z większa siłą, przyczyniając się do odczuwanego stanu zapaści polskiej oświaty na wszystkich jej szczeblach. Trudno wskazać jeden główny element odpowiedzialny za aktualny stan polskiego systemu edukacji. Autor skupia swą uwage na, jego zdaniem, sześciu najważniejszych elementach, poddając każdy z nich analizie.

Szczególną rolę do odegrania w programach nauczania ma przedmiot podstawy przedsiębiorczości, którego wprowadzenie miało na celu reorientację postaw młodego pokolenia i otwarcie go na zmiany rynkowe oraz na to, co wolny rynek aktualnie oferuje. Z perspektywy czasu można odnieść wrażenie, że przedmiot ten znacząco zmarginalizowano, czego dowodem jest choćby znikoma liczba godzin w tygodniowym rozkładzie zajęć szkoły ponadgimnazjalnej. Autor zwraca uwagę na korelację zubożenia liczby godzin i treści programowych tego przedmiotu z niepokojącymi wynikami badań, dotyczących stopnia przedsiębiorczości młodych Polaków oraz ich kompetencji w odczytywaniu nowych szans i wyzwań wolnego rynku na tle zjednoczonej Europy.

Mimo konstatowanej przez wielu badaczy erozji systemu edukacji w Polsce można dostrzec ambitne próby tworzenia nowych wartości w obrębie przestarzałego systemu. Autor wymienia inicjatywy, które przy wsparciu władz oświatowych mają szansę odegrać znaczącą rolę w przełamywaniu barier i niechęci, stając się tym samym poważną alternatywą dla skostniałych i nieprzydatnych dziś form kształcenia postaw przedsiębiorczych w społeczeństwie.
\end{abstract}

\footnotetext{
Abstract

The author discusses the problem of a crisis of the contemporary Polish education. He attempts to explain the causes of its poor condition. The crisis of the educational system in Poland relates to different levels (primary school, secondary school, higher education). In the author's opinion, the lack of a long-term and concrete aim of education constitutes the most significant issue. The second source of difficulty is a continuous state of reform. These two factors, among others, have led to the present, negative condition of Polish schools.

This article indicated numerous problems, which the Polish educational system is forced to cope with, in order to achieve better results. The subject entitled "basics of entrepreneurship" is a particular subject of discussions taking place presently. The level of knowledge of young individuals in this area is unsatisfactory. This is confirmed by the results of public research. Although various public initiatives have appeared, aiming at improving and raising the condition of Polish education, their scale is too small, and without comprehensive aid of from the Ministry of Education, they will not change the current reality.
} 
Słowa kluczowe: edukacja; kryzys; poziom kształcenia; przedsiębiorczość

Key words: education; crisis; level of education; entrepreneurship

\section{Wprowadzenie}

Przedmiot podstawy przedsiębiorczości na dobre zagościł w programach nauczania szkół ponadgimnazjalnych. Przedsiębiorczość - w jej różnych odcieniach znaczeniowo-przedmiotowych - jest także wykładana na różnych kierunkach szkół wyższych. Problem w tym, że choć jest ona przedmiotem przez większość uznawanym za podstawowy, którego znajomość wpływa bezpośrednio na większą świadomość zachodzących procesów ekonomicznych w otoczeniu rynkowym i może znacząco polepszyć warunki bytowe każdego podmiotu chcącego aktywnie funkcjonować w rzeczywistości wolnorynkowej, podstawowa wiedza na jego temat jest w obecnym społeczeństwie znikoma (Saskia-Sassen, 2007: 135). Potwierdzają to wyniki badań, do których się odwołamy, próbując wskazać źródła tak niskiego stanu wiedzy oraz nakreślić inicjatywy wraz z oceną ich skuteczności, które mają te niekorzystne tendencje w edukacji odwrócić.

W punkcie wyjścia analizy należy się zastanowić, w jakiej kondycji znajduje się aktualnie polska oświata. Konstatacja dotycząca stanu kryzysu edukacji w Polsce jest na ogół czymś oczywistym, ale warto zwrócić uwagę na czynniki, które w znacznej mierze się do niego przyczyniły. Jak w większości przypadków, również w tej kwestii mamy do czynienia z wielozjawiskowością. W sferze edukacji stan rozkładu jest następstwem wielu wcześniejszych błędów i zaniedbań. Najważniejsze z nich postaram się wskazać i pokusić o próbę odpowiedzi na pytanie dlaczego wystąpiły. Artykuł nie jest jedynie próbą diagnozy aktualnego stanu edukacji w Polsce, ale obok analizy niepokojących zjawisk, pragnę wskazać na działania, których celem jest zahamowanie dążeń destruujących szkolnictwo w Polsce na szczeblu ponadgimnazjalnym i wyższym, które, mimo niesprzyjającej sytuacji, idą ,pod prąd” aktualnym trendom systemowym. Istotnym elementem, wspomagającym niniejsze rozważania i poniekąd uprawomocniającym artykułowane tezy jest materiał empiryczny, czerpany z różnych źródeł, który, jak sądzę, przyda treści artykułu waloru obiektywizacji.

\section{Glówne składowe kryzysu edukacji}

Wniosek z raportu Banku Światowego z 2004 r., zatem sprzed ośmiu lat, mówił, że podstawowym zagrożeniem dla rozwoju gospodarki opartej na wiedzy w Polsce jest ułomny system edukacji. Autorzy raportu, konkretyzując swe obawy wynikające z badań, wskazują przede wszystkim na:

- brak powiązań między środowiskiem akademickim a przedsiębiorstwami,

- zbyt niskie nakłady firm prywatnych na badania i rozwój,

- brak stabilizacji w sektorze edukacji (system edukacji w stanie permanentnej reformy),

- zgubny w skutkach nacisk na kształcenie teoretyczne zamiast orientacji na pozyskiwanie umiejętności praktycznych, co zresztą było pierwotnym założeniem reformy.

Po ośmiu latach ów raport zadziwia swą aktualnością: nakłady na edukację w naszym kraju należą do najniższych w Europie, zaś poziom współpracy biznesu z ośrodkami akademickimi należy do rzadkości, pozostawiając wiele do życzenia. Pod względem deregulacji systemu edukacji (szczególnie na poziomie gimnazjalnym i ponadgimnazjalnym) stanowimy państwo-ewenement. Cele przyświecające wdrożeniu kolejnych programów poszczególnych ministrów edukacji nie zadowalają ich samych, nie mówiąc o rodzicach i uczniach. Rodzi się więc pytanie: Dlaczego kolejne pomysły na usprawnienie systemu edukacji okazują się niewiele warte i z góry skazane są na porażkę? Udzielenie odpowiedzi nie jest łatwe, ale, jak sądzę, i nie niemożliwe. 
Oto wnioski, które można znaleźć na stronie podsumowującej obrady XIII Międzynarodowej Konferencji „Filozofia i pedagogika twórczości - główne problemy, podstawowe rozstrzygnięcia”, która została zorganizowana przez Polskie Towarzystwo Uniwersalizmu w Warszawie w dniach 12-13 maja 2011 r. Wynika z nich, że brakuje właściwej reakcji ze strony realizatorów reformy szkolnictwa, która by była adekwatną odpowiedzią na dane specjalistów i wyniki badań dotyczących potrzeb rynkowych. To, co najbardziej niepokoi, to rozłożone w czasie obniżanie standardów nauczania oraz wymagań. Ponadto, problemem jest wciąż rosnąca liczba uruchamianych przez uczelnie kierunków humanistycznych, czego powodem jest niska atrakcyjność kierunków ścisłych (choć ta tendencja ostatnio nieco się zmienia, ale wiele danych wskazuje na to, że to trend wyraźnie koniunkturalny; http://rydygier. blog.onet.p1/Kryzys-polskiej-szkoly-skutkie,2,ID427227148,n).

Przyglądając się głównym celom stawianym przez gremia kierujące się misją unowocześnienia rodzimego szkolnictwa, należy zauważyć, że z jednej strony jest to postulat zapewnienia odpowiedniego poziomu edukacji, z drugiej zaś strony stworzenie z miejsca edukacji przyjaznej szkoły. Oba cele, jak słusznie zauważa prof. A. Nowak (Szkoła miernoty, 2008) są ze sobą sprzeczne. Dysjunkcja zachodzi tu nie tylko na poziomie treści, ale i sensu. Jako przyjazna szkoła musi pełnić funkcję placówki o charakterze inkluzywnym, tzn. nie może być miejscem wykluczenia kogokolwiek. Jednak utrzymanie wysokich standardów nauki i egzekwowania wiedzy będzie siłą rzeczy skutkowało wyłączeniem jakiejś części populacji uczących się, którzy nie będą w stanie sprostać takim wymogom. Jedynym lekarstwem na ten problem okazuje się obniżanie standardów. Odbywa się to kosztem uśrednienia treści programowych i wymagań, by dostosować je do możliwości intelektualnych tzw. średnio zdolnego ucznia. Powstaje więc pytanie: Co z uczniem zdolnym? Czyż w sytuacji obniżenia poziomu nauczania i wymagań nie jest on wyłączony i odcięty od dostępu do głębszej wiedzy, kosztem ratowania średnio zdolnej lub mało zdolnej reszty?

Dzisiejsza szkoła powinna być miejscem, w którym uczeń odkrywa swój potencjał, jasno określa swe cele i potrafi wykształcić w sobie metody ich zdobywania. W rodzimej szkole zostaje mu przekazana określona wiedza z przedmiotów, które składają się na model polskiego szkolnictwa. Rodzą się więc wątpliwości: Czy, i w jakiej mierze, współczesna szkoła wychowuje? W jaki sposób włącza młodego człowieka w proces socjalizacji? Czy przygotowuje do świadomego i odpowiedzialnego uczestnictwa w społeczeństwie obywatelskim? Są to, jak się wydaje, podstawowe pytania, za którymi kryje się zwykła troska obywatelska każdego dorosłego, zastanawiającego się nad światem wartości młodej generacji oraz kształtem ideowym przyszłego społeczeństwa.

Spośród wielu problemów składających się na fatalny obraz polskiej edukacji warto wymienić sześć podstawowych: Pierwszym jest rozbudowany na przestrzeni ostatnich kilkunastu lat system wdrażania korekt i reform w stosunku do zastanego stanu. Każdy kolejny krok jest niekoherentnym z całością elementem, którego nie da się wpasować w dziedzictwo poprzedników. Przy obecnym kursie edukacyjne puzzle nie mają szans na połączenie, które by dało obraz logicznej i spójnej całości. Powód? Każda z ciągnących się od 1989 r. reform polskiego szkolnictwa nie wypracowała podstawowego celu i misji. Jeśli wiemy, co chcemy osiągnąć i po co, wówczas kroki, nawet błędne, które po okresie niepowodzeń można korygować, w końcu do tego celu doprowadzą. Współcześni architekci polskiej edukacji wyraźnie upodobali sobie dialektyczny model dziejów historii Hegla albo pozostają pod uwodzicielskim przekazem pism Marksa. Sytuacja wprowadzania kolejnych detalicznych posunięć ze strony MEN jest, jak sądzę, próbą wywołania wrażenia, że ministerstwo coś robi. Wdrażanie kolejnych programów nie ma, moim zdaniem, szans na osiągnięcie zamierzonego celu, bo wyraźny i skonkretyzowany cel 
nie istnieje. Spotykając się z jakimkolwiek skutkiem kolejnej reformy, pozostanie stwierdzić, że się powiodła, bowiem nikt nie wie, co było rzeczywistym jej zamiarem (w ciemnym pokoju wszystkie koty są czarne).

Trwały stan dezinformacji wraz z wykorzystywaną z uporem funkcją dystorsyjną języka są stałym sposobem komunikacji społecznej środowisk decyzyjnych. Toteż każdy zaistniały stan u schyłku żywotności którejś kolejnej poprawki edukacyjnej staje się powodem do radości jej pomysłodawców. Jak zwykle najgorzej na tym wychodzą sami zainteresowani - uczniowie i ich rodzice, są bowiem błędnie przekonani, że ich dzieci są wreszcie uczone lepiej. Ponadto, każdy krótkotrwały sukces (będący np. splotem okoliczności przypadkowych, dotyczących choćby bardziej zdolnego rocznika jakiejś generacji) służy za dowód, że idziemy w dobrym kierunku i staje się powodem do publicznego obwieszczenia sukcesu. I tak do kolejnych wyników matur, które jeśli okazują się słabsze od poprzednich, stanowią podstawę do kolejnego wdrożenia nowych treści edukacyjnych lub dodatkowych godzin w ramach pensum nauczyciela, np. dla tzw. ucznia mniej zdolnego, bo do tych ruchów, w istocie, sprowadza się aktywność MEN. Warto przypomnieć, że wspomniana już dialektyka jako narzędzie, służyła w koncepcji Hegla do realizacji postępu i choć dzieje zawierały w sobie błędy, były one wpisane w heglowski panlogizm i racjonalność, której podlegał cały systemu. Dzieje zmierzały do konkretnego celu, do stanu samo-rozpoznania ducha absolutnego. Tego skonkretyzowanego celu w polskiej edukacji wciąż brakuje.

Drugi czynnik to ruchy i inicjatywy markujące prawdziwą reformę edukacji, mające charakter wyłącznie programowy. Wszelkie zmiany, jakich dokonuje się w imię poprawy komfortu edukacji oraz celem dostosowania standardów nauczania do zmieniającej się rzeczywistości społecznej, nie są niczym innym jak zmianą treści programowych. I tak z języka polskiego, wedle nowej podstawy programowej, dowiadujemy się, że podobnie jak dzieła literackie, równie ważne są tzw. teksty kultury. To prawda, ale przy ograniczonej liczbie godzin przewidzianych dla tego podstawowego w naszym systemie edukacji przedmiotu, teraz miast koncentrować się na poznawaniu dziedzictwa literatury polskiej oraz pokazywania jej wartości i miejsca na tle dorobku cywilizacji europejskiej, należy dodatkowo włączać treści kulturowe.

By zrealizować pozornie „odchudzony” program literacki, do tych ekwilibrystycznych puzzli dodano treści kulturowe, których waga i wymowa nie są młodemu człowiekowi w ogóle znane, bo gdzie i skąd mógł o nich słyszeć? Znamy alarmujące dane na temat liczby osób regularnie uczęszczających do teatru, opery, filharmonii, odwiedzających wernisaże, czytających książki, wiemy, jaki jest stan kultury muzycznej młodego pokolenia. Kto zetknął się ze współczesną polską szkołą od strony katedry doskonale wie, że większość tekstów kultury jest nieczytelna i, jak mówią sami uczniowie (nie mówię, że wszyscy, wszak nie o wyjątki tu chodzi), nieatrakcyjna. Brak atrakcyjności bierze się z lenistwa i chęci wysiłku na rzecz poznania tła ideowo-intelektualnego epok lub ich podłoża historyczno-kulturowego. Zasoby semantyczne i semiotyczne przeciętnego młodego Polaka ograniczają się do umiejętności dekodowania prostych i „uśrednionych” przekazów medialnych i teleinformatycznych. Brak możliwości zaistnienia podstawowego kontaktu intelektualnego między nauczycielem a młodzieżą dotyczy nie tylko uczniów szkół ponadgimnazjalnych, ale też ich starszych kolegów. Są to absolwenci tych samych szkół. Można odnieść wrażenie, że priorytetem kolejnych reform wciąż pozostają kwestie zmian minimów programowych i przesunięcia wieku początku edukacji.

Trzeci, w moim przekonaniu, najbardziej niebezpieczny element przyczyniający się do stanu kryzysu edukacji to izolacja lub zanik systemu wychowania na rzecz programu edukacji jako sposobu li tylko przekazywania wiedzy merytorycznej (http://wiadomosci.onet.pl/kraj/ legutko-wychowania-w-szkole-juz-nie-ma,1,5024732,wiadomosc.html). Zaakcentować nale- 
ży tu słowo przekazywanie. Każdemu aktowi komunikacji, by spełniał on swoje podstawowe funkcje, musi towarzyszyć właściwy, tj. zgodny z zamysłem nadawcy, odbiór. Nadawców jest wielu, ale kompetentnych (uzbrojonych w jakąś przed-wiedzę) odbiorców coraz mniej. Zadowalająca weryfikacja przyswojenia określonych treści sięga dziś poziomu 30\%, zatem ze 100\% przekazywanej wiedzy wystarczy przyswoić jedynie 30\%, by czuć się, że proces dydaktyczny odniósł sukces. Poczucie sukcesu dotyczy niestety obu stron, zarówno nauczyciela, jak i ucznia. W tym wypadku mówimy o poziomie zaliczenia, który dla wielu stanowi maksimum nie tyle możliwości (w to nie wierzę), ile chęci. Niewykluczone, że w niedługim czasie uzna się 30\% za zbyt wiele, wszak idzie tu o komfort ucznia spędzającego czas w przyjaznej szkole.

Etos pracy na rzecz przyrostu wiedzy dotyczy przede wszystkim sfery wychowania. Można odnieść wrażenie, że szkoła wychowuje jak chce, bo rodzina, nie mając czasu na ten wyjątkowo interesujący, ale i odpowiedzialny przywilej wynikający z kwalifikacji bycia rodzicem, całkowicie scedowała go na szkoły, kupując tym samym dla siebie trochę czasu. Spora część rodziców najbardziej zainteresowana jest tym, jakie wyniki dziecko osiąga, gubiąc po drodze coś znacznie ważniejszego, mianowicie troskę o to, na jakiego człowieka zostanie wychowany ich syn lub córka. Programy wychowawcze oczywiście w szkołach istnieją, formalnie też im niczego zarzucić nie można. Ale możliwość dotarcia do indywidualnego przypadku ucznia w 30-osobowej klasie przez jednego wychowawcę, mającego do dyspozycji jedną tzw. godzinę wychowawczą, jego działania skazuje na porażkę. Taka forma pracy sprawia, że żaden nauczyciel nie jest w stanie wejść w głębsze relacje i nawiązać więź emocjonalną nawet z kilkoma podopiecznymi.

Czwarty problem odnosi się do faktu, że nauczyciel to pracownik budżetowy, który mimo śladowych podwyżek, bardzo szumnie artykułowanych w mediach jest słabo wynagradzany, często nie najlepiej przygotowany do wykonywania zawodu i słabo zmotywowany. Oczywiście opinia taka nie dotyczy wszystkich nauczycieli, ale wziąwszy pod uwagę średnie zarobki nauczyciela np. w Niemczech lub w którymś z krajów skandynawskich, polski nauczyciel może mu co najwyżej pozazdrościć. System kształcenia kadr dydaktycznych pozostawia sporo do życzenia. Poza szkołami ściśle pedagogicznymi, tzw. studium przygotowania pedagogicznego, wybieranych przez studentów jako dodatkowa szansa na ewentualną pracę szkole, nie jest w stanie przygotować rzetelnie do zawodu.

Praktyki zawodowe odbywane w szkołach podstawowych, gimnazjach lub liceach są prowadzone krótkoterminowo. Jedynym wyznacznikiem przydatności do zawodu jest opinia opiekuna praktyk, tj. nauczyciela, u którego student takie praktyki odbywa. Dobór miejsca praktyk oraz weryfikacja predyspozycji do zawodu to często kwestia przypadku. Brakuje egzaminu z wiedzy teoretycznej, podstaw prawa oświatowego, merytorycznej oceny prowadzenia zajęć oraz sposobu zachowania nauczyciela w klasie z tzw. trudną młodzieżą. Powyższe obserwacje stanowią efekt osobistych doświadczeń w wieloletnim sprawowaniu opieki nad studentami humanistycznych kierunków uniwersyteckich. Młodzi adepci zawodu wprost deklarują, że ich taka praca i za takie pieniądze nie interesuje, a ,papier” warto zdobyć, tym bardziej, że nie wiąże się to z jakimś trudem. Dokument może okazać się jednak przydatny jako asekuracja, gdyby się okazało, że innej pracy nie ma. Młodzi studenci z charyzmą i zacięciem do tego zawodu to przypadki mi znane, ale na tle większości - zdecydowanie incydentalne.

Co do motywacji grupy nauczycielskiej duże nadzieje pokładano w ,zreformowanym” systemie awansu zawodowego. Po krótkim czasie zorientowano się, że zbyt duża liczba nauczycieli i zbyt łatwo uzyskała kolejne stopnie, co wymuszało wypłatę wyższych uposażeń na mocy ustawy. Toteż w niedługim czasie znacznie wydłużono ten okres, nie spiesząc z merytorycznymi zmianami w zakresie podniesienia poziomu i trudności w ich zdobyciu. Organizatorzy 
reformy znów poszli na skróty. Chcąc zostać nauczycielem mianowanym lub dyplomowanym, należy przede wszystkim gromadzić certyfikaty o często wątpliwej wartości. Dokumenty tego typu z merytorycznego punktu widzenia są bezwartościowe. Trudno za taki stan winić tylko nauczycieli. $\mathrm{Ci}$, w takich realiach, poza obowiązkiem uczenia, są zmuszani do wypełniania rubryk, statystyk i tworzenia tzw. diagnoz i ewaluacji.

Kolejny element odpowiedzialny za opłakany stan naszej edukacji wiąże się z powyższymi. Nauczyciel źle zmotywowany to nauczyciel źle opłacany. Wniosek: jego prestiż jako osoby pracującej jest w społeczeństwie bardzo niski.

Piąty czynnik to upadek prestiżu, selekcja negatywna i nadmierna feminizacja zawodu. W tym punkcie dotykamy kilku kwestii, ale na tyle ważnych, choć bardzo znanych, że należy poświęcić im nieco uwagi. Zacznijmy od końca: praca w szkolnictwie na poziomie elementarnym i gimnazjalnym coraz bardziej staje się domeną kobiet. Nie ma w tym nic nadzwyczajnego, chyba że odwołamy się do ogólnego odczucia społecznego.

W codziennych rozmowach na ten temat padają różne odpowiedzi. Od takich, które sugerują, że kobiety bardziej się do tego nadają, mają większą cierpliwość, są bardziej wrażliwe na potrzeby i problemy dziecka, po takie, że kobieta w szkole, chcąc być wśród ludzi, dba także o swoje świadczenia emerytalne lub że chce być niezależna finansowo. W mimo wszystko patriarchalnym wzorcu kultury europejskiej praca mężczyzny z dziećmi traktowana jest przez środowisko jako uwstecznienie, nie bardzo wpisujące się w szorstki i twardy wizerunek kreowany dziś przez media. Dodatkowo to praca słabo opłacana. I tu dotykamy kolejnego elementu - płacy. To głównie ona wpływa na obniżenie wizerunku i rangi społecznej nauczyciela w obecnym społeczeństwie. Cywilizacja dostatku i redundancji środków finansowych, budująca mocny wizerunek społeczny na bazie wysokiego cenzusu majątkowego wyklucza z tego obrazu ludzi pracujących w budżetowej oświacie. Pracują oni głównie na opłacenie rachunków i zabezpieczenie podstawowych warunków egzystencji. Poza tym, wysokość zarobków nauczycielskich jest dziś powszechnie znana. Mężczyzna-nauczyciel postrzegany bywa jako zniewieściały i ,zakręcony” w swej pasji przekazywania wiedzy nieudacznik. Taki przykład nie jest w stanie pociągnąć współczesnego ucznia. Praca nauczyciela daje małe szanse na to, by zainspirować podopiecznych do wyboru podobnej drogi.

Selekcja negatywna bierze się stąd, że młodzi i ambitni absolwenci, którym jakimś cudem udało się znaleźć pracę zaraz po studiach, bardzo szybko mają jej dosyć. Pierwszym odkryciem młodych adeptów sztuki nauczania jest prawda, że, wbrew temu, o czym marzyli, szkoła wcale nie jest miejscem wykorzystywania ich potencjału intelektualno-dydaktycznego, ale biurem, w którym są zmuszeni do potwierdzenia swej przydatności do wykonywania zawodu. Ciążą na nich zgoła niedydaktyczne obowiązki (sprawozdania, pomiary tzw. przyrostu wiedzy, diagnozy, nieustanne dokumentowanie swego wkładu w edukację innych). Innymi słowy, rzeczywistość szkolna to dziś statystyki, słupki, wykresy. Na szarym końcu znajduje się uczeń i jego problem, nie zawsze tylko intelektualny, często o wiele głębszy i poważniejszy (emocjonalny, rodzinny, psychiczny). To rzeczywisty obraz współczesnej polskiej szkoły, jakże odmienny od tego $z$ oficjalnych stron internetowych wydziałów oświaty lub komisji egzaminacyjnych.

Ostatnim z sześciu problemów jest nadmierna „produkcja” absolwentów. Dość powiedzieć, że jeszcze kilkadziesiąt lat temu maturzyści stanowili 10-15\% populacji uczących się. Ktoś powie, jest lepiej, bo ten odsetek jest dziś wyraźnie wyższy. Odpowiedzią na tak postawioną tezę może być pytanie: Jakim kosztem? Obniżanie standardów i wymagań w stosunku do beneficjentów edukacji to najkrótsza, ale i najskuteczniejsza droga do tego, by towarzyszyło nam poczucie dobrze wykonanego zadania. Ale to pozór. 
W starym systemie edukacji nikt na przykład nie pytał o status błędów językowych, czy są to błędy pierwszorzędne, drugorzędne czy może błędy jedynie w zapisie, nie zawężano treści prac pisemnych do minimum 250 wyrazów. Uczeń mógł dać upust swej fantazji i inwencji twórczej, mógł się intelektualnie wyżyć w tym, co go interesowało. Dziś musi się wpasować w sztywne ramy tzw. klucza odpowiedzi, o poprawności którego decyduje komisja ekspertów. Do aktualnych dylematów nauczyciela próbującego przekazać wiedzę uczniom o trudniejszym profilu (uczniowie z dysfunkcjami, osadzeni w zakładach karnych) należy taki oto: czy, w skądinąd ciekawych pracach pisemnych, 10-15 błędów ortograficznych (nowa kwalifikacja oznacza, że jest to błąd w zapisie) to dający się jeszcze zaakceptować próg zaliczenia czy nie?

Coraz częściej słychać głosy na temat zasadności utrzymywania egzaminu dojrzałości w obecnym kształcie. Status matury znacząco podupadł i, w moim przekonaniu, stracił swe dawne znaczenie. Może warto powrócić do formuły egzaminów wstępnych na poszczególne kierunki studiów? Uczelnie o wiele sprawniej weryfikowałyby merytoryczną przydatność kandydatów, którzy chcąc podjąć studia na danym kierunku, musieliby wykazać się niezbędnym kompendium wiedzy. Ograniczyłoby to, jak sądzę, rzeszę niezdecydowanych, zasilających dość pokaźnie tzw. nabór negatywny. Sytuacja na uczelniach, szczególnie technicznych, wygląda dziś tak, że dla pierwszego roku prowadzi się równoległe zajęcia, mające na celu wyrównanie poziomu. Kursy te, w zamyśle, mają dostosować studentów do poziomu szkoły wyższej. Przeskok poziomu przekazywania wiedzy jest dla niektórych zbyt duży, by mogli oni z pożytkiem korzystać z zajęć przewidzianych programem akademickim. Problem tranzycji z poziomu ponadgimnazjalnego do poziomu akademickiego to osobna kwestia, ale warto nań tu także zwrócić uwagę, bo moim zdaniem, będzie się on z całą mocą coraz bardziej ujawniał: „Dzisiejsi studenci zostali poddani bardzo szkodliwej reformie w szkolnictwie średnim. Są często bardzo słabo przygotowani albo wcale. Efektem studiów o masowym charakterze są młodzi ludzie, którzy niejednokrotnie studiować nie powinni - twierdzi wykładowca" (http://blog.onet. pl/42203,3,archiwum_goracy.html).

Podsumujmy: Polska edukacja cierpi na chroniczny brak wizji przyszłości. Obraz współczesnej edukacji ujawnia kompletną amorficzność. Wizja edukacji jest tak krótkotrwała, jak krótkotrwałe są układy polityczne oraz indywidualne predylekcje poszczególnych ministrów edukacji. Wciąż brak konkretnie określonego celu. W zaistniałej sytuacji warto zadać serię pytań: Po co kształcimy? Kogo kształcimy? Jak kształcimy? Czego się po takim modelu kształcenia spodziewamy? I czy w ogóle mamy moralne prawo czegoś się spodziewać? Na dramatyzm tego typu pytań nakładają się inne, raczej niezależne (choć to kwestia interpretacji) czynniki. Zaliczam do nich niż demograficzny, a także coraz widoczniej przekładający się na kondycję gminnych budżetów - kryzys finansowy. To, z punktu widzenia rozwiązań systemowych, kwestie peryferyjne, ale równie ważne, szczególnie że dziś, w trakcie pertyfikowania się struktur społeczeństwa informacyjnego i modelu gospodarki opartej na wiedzy - to sprawy zasadnicze. Nie ma jakości bez nakładów! Problem w tym, że nakłady na naukę są postrzegane jedynie w kategoriach obciążenia. Trudno dziś o zgoła odmienną interpretację, mianowicie taką, że problem nakładów to inwestycja, inwestycja w zasoby ludzkie, której stopa zwrotu jest w naturalny dla siebie sposób rozłożona w czasie, ale ma za to dużą szansę na zwielokrotnienie zysków. Trzeba tylko stworzyć temu przedsięwzięciu dogodne warunki, dać mu szansę.

W kontekście problemów finansowych polskiego systemu szkolnictwa wyższego warto zwrócić uwagę na instytucję Narodowego Centrum Nauki. W zamyśle jest ono agencją wykonawczą, której głównym zadaniem, o czym można przeczytać na stronie internetowej, jest wspieranie działalności naukowej w zakresie badań podstawowych ,prac eksperymentalnych, 
teoretycznych podejmowanych przede wszystkim w celu zdobycia nowej wiedzy o podstawach zjawisk i obserwowalnych faktów, bez nastawienia na praktyczne zastosowania ani użytkowanie" (http://www.ncn.gov.pl/o-ncn/zadania-ncn). Narodowe Centrum Nauki finansuje m.in. badania realizowane w formie projektów badawczych, stypendia doktorskie i staże po uzyskaniu stopnia naukowego doktora, projekty badawcze ważne dla rozwoju nauki i pionierskie badania naukowe. Zajmuje się też nadzorem realizacji tychże badań. Inne z zadań to zlecone przez Ministra Nauki i Szkolnictwa Wyższego opracowywanie programów badawczych ważnych dla kultury narodowej. Narodowe Centrum Nauki wspiera także młodych naukowców, przeznaczając nie mniej niż 20\% środków pozostających w jego dyspozycji na wsparcie rozwoju osób rozpoczynających karierę naukową.

Poza oficjalnymi danymi na temat wysokości nakładów przeznaczanych na naukę, tak naprawdę nie wiemy, ile pieniędzy realnie jest na ten cel przeznaczonych. Wcześniej można to było obliczyć. Było wiadomo, ile środków jest przyznawanych poszczególnym placówkom naukowym. Wystarczyło zsumować oficjalne dane, by w przybliżeniu określić realną kwotę, będącą w obiegu. Dziś trudno ustalić ich rzeczywistą wartość, tj. ile realnie jest dziś środków w obiegu, by mieć przybliżony obraz stanu aktualnego finansowania nauki. Rodzą się więc pytania takie jak to: Co w sytuacji, jeśli oficjalne dane nie pokrywają się z sumą środków będących w aktualnym obiegu? Zapewne NCN wie, ile ich posiada, ale ustalenie tego z zewnątrz jest dziś niezmiernie trudne. Możliwym jest, że deklarowana suma środków jest w rzeczywistości znacznie mniejsza, bo np. przesunięto je do innego sektora gospodarki. To przykład nie do końca jasnej zasady funkcjonowania systemu. Jedno jest pewne - jeśli jest się czym chwalić, nie ma potrzeby utrzymywania tak zmąconej formy przekazu, rodzącej wątpliwości co do obrazu stanu faktycznego.

\section{Miejsce podstaw przedsiębiorczości w edukacji}

Przedmiot podstawy przedsiębiorczości jest wciąż obecny w polskich szkołach. Jednak jego wymiar godzinowy już nie wszystkich do końca zadowala. Jeśli uznamy za prawdę, że wiedza o charakterze ekonomicznym stanowi klucz do świadomego i praktycznego, tj. takiego, który poprawi w sposób konkretny poziom życia przyszłego absolwenta, to obecny wymiar na pewno jest minimalny. Trudno spodziewać się, że przekazana w czasie dwóch godzin tygodniowo wiedza nie tylko ma szansę na utrwalenie, ale i wykorzystanie jej w praktyce życia codziennego. To stanowczo zbyt mało w stosunku do ambitnego celu, jaki przed tym przedmiotem postawiono. Tu cele były bardziej skonkretyzowane, mianowicie chodziło o to, by zmienić dotychczasowe postawy młodzieży, która po zdobyciu wiedzy ekonomicznej lepiej rozpozna swoje szanse na rynku i będzie potrafiła ją praktycznie wykorzystać, zakładając np. własną działalność gospodarczą. ,[...] kształtowanie postaw przedsiębiorczych, przejawiających się w dążeniu do rozwijania aktywności gospodarczej, społecznej, kulturowej czy politycznej, jest niezbędne na wszystkich szczeblach edukacji instytucjonalnej, począwszy od poziomu wczesnoszkolnego poprzez poziom podstawowy, gimnazjalny, ponadgimnazjalny do kształcenia na poziomie akademickim, a następnie w procesie dokształcania i doskonalenia zawodowego w całym okresie aktywności człowieka na rynku pracy i działalności społecznej" (Zioło, 2012: 11).

Kilka lat obecności tego przedmiotu w szkołach rewolucji nie zrobiło i nie wzrosły jakoś wyraźnie wskaźniki zaangażowania ekonomicznego młodzieży kończącej szkoły. Za to przybyła nam nowa rzesza poszukujących pracy lub bezrobotnych. Jednym z najbardziej mierzalnych wskaźników przedsiębiorczości, jako postawy dążącej do niezależności, są działania mające na celu osiągnięcie stanu samodzielności. Uznając samodzielność za przejaw przedsiębiorczo- 
ści, należy wskazać na badania, z których wynika, że 41\% młodych Polaków wciąż mieszka z rodzicami. Jest to populacja rzędu $2,5 \mathrm{mln}$ osób w przedziale wiekowym 25 lat - 34 lata. Wskazują na to dane Eurostatu. W Europie problem ten dotyczy 28\% ludzi rozpoczynających aktywność zawodową, ale są kraje, w których z rodzicami mieszka tylko kilka procent osób w wieku 25 lat - 34 lata.

Warto zastanowić się, czy rozbudowane partie materiału w podręcznikach podstaw przedsiębiorczości, dotyczące m.in. uwarunkowań psychologicznych przedsiębiorcy, faktycznie sprawią, że młodzi ludzie od razu się usamodzielnią lub zamienią w inwestorów? Wydawnictwa, podążając za duchem czasów, dodają do podręczników płyty CD z filmami, których poziom merytoryczny oraz poziom naiwności występujących w nich aktorów budzą często śmiech odbiorców. Młodzi doskonale się orientują, w jakich realiach żyją. Pokazywanie założonego z góry sukcesu ich rówieśników, którzy zakładają firmę informatyczną, sytuuje taki film w gatunku kiepskich komedii lub niezbyt wyszukanego żartu z odbiorcy. Ich rodzice i starsze rodzeństwo nazbyt dobrze wiedzą, czym są niepowodzenia na rynku, co to jest bezrobocie i kryzys finansowy. Niejedna ich firma zdążyła już upaść. Należy więc uczniom zaproponować nie gry strategiczne, ale rzetelne narzędzia przewidywania tendencji na rynku, rozpoznawania trendów giełdowych, zaznajomić ich z zasadami inwestowania, kreatywności w zakresie wyszukiwaniu nisz rynkowych etc.

Od przyszłego roku w etap edukacyjny włączono nowy przedmiot do wyboru. Jest to ekonomia w praktyce. W jednym z podręczników do tego przedmiotu we wstępie czytamy, że przedmiot może być traktowany jako wstęp lub kontynuacja obowiązkowego przedmiotu postawy przedsiębiorczości. To kolejna niedorzeczność. Zważywszy na stopień zaawansowania nauki podstaw przedsiębiorczości, nie bardzo wiem, jak ten nowy przedmiot miałby być wstępem do czegoś, skoro to coś albo jest w trakcie realizacji, albo już się zakończyło. Zrozumiałbym jeszcze słowo uzupetnienie, choć i tu rodzą się wątpliwości, szczególnie wtedy, gdy zagłębimy się w treść proponowanej książki. Merytorycznie jest jej niewiele. Sporą część wypełniają różnej jakości ilustracje. Poza zbyt ogólną eksplikacją modnej ostatnio, ale zupełnie niedostosowanej do naszego systemu edukacji, metody projektu (to kosztowna metoda), pozostałe treści się powtarzają. Powielają tematy inherentnie zawarte $\mathrm{w}$ treściach programowych podstaw przedsiębiorczości. Czytamy tu o pomyśle na biznes, o planowaniu działalności gospodarczej, jej rozpoczęciu, kierowaniu zespołem itd. Pojawiają się zatem pytania: Czy stać nas na to, by marnować czas przeznaczony na rzetelne przygotowanie młodego pokolenia do przytomnego udziału w rzeczywistości gospodarczej, na którą siłą rzeczy będą zdani? Czy wiedza ekonomiczna jest dziś w ogóle potrzebna?

Okazuje się, że co trzeci młody Polak nie ma podstawowej wiedzy z dziedziny gospodarki, a jeśli już, to czerpie ją z mediów. Według „Rzeczpospolitej” ponad 30\% uczniów szkół ponadgimnazjalnych uznało swoją wiedzę na temat zagadnień finansowych za małą lub bardzo małą. Wyniki badań PZU i Fundacji Młodzieżowej Przedsiębiorczości (przebadano ponad 3 tysiące uczniów) pokazują, że 70\% uczniów uważa, iż umiejętności ekonomiczne są w ich wieku potrzebne. Zdaniem prezesa PZU Andrzeja Klesyka 1/3 młodych ludzi nie zdaje sobie sprawy z tego, jak ważna jest edukacja finansowa (http://www.forbes.pl/artykuly/sekcje/kariera/ mlodzi-polacy-nie-maja-podstawowej-wiedzy-z-ekonomii,2). Taki wynik ukazuje, że aktualne metody nauczania są nieskuteczne. Kogo za taki stan winić? Według Józefa Kuźmy „Kryzys oświaty jest zjawiskiem permanentnym [...] W Polsce, ma ponadto charakter polityczny, ekonomiczny, strukturalny i programowy. Spowodowany został przez złą politykę społeczną i oświatową" (Kuźma, 2000). Warto więc zastanowić się nad skutkami tej patologii. 
Badania wykonane przez OBOP wskazują, że do 2013 r. w Polsce zabraknie ponad 46 tys. inżynierów. Jeśli nic się nie zmieni, grozić nam będzie analfabetyzm funkcjonalny, ograniczający percepcję ludzi ze średnim wykształceniem (prof. Mikołaj Rudolf z Wydziału Chemii Uniwersytetu Wrocławskiego za: Wysoki, 2009). Kwestia jest paląca, bowiem z szacunków Urzędu Pracy w Warszawie wynika, że najwięcej ofert zatrudnienia skierowanych jest do inżynierów, informatyków i ekonomistów (Nowak, 2009.). Zanim przejdziemy do odpowiedzi rynku, warto zwrócić uwagę na dane ukazujące potrzebę powrotu do wychowawczej roli szkoły, jako jej podstawowej funkcji. Z badań socjolog Hanny Palskiej wynika, że 60\% polskiej młodzieży nie ma żadnego autorytetu w sensie personalnym ani spójnego systemu wartości (Szczęśliwi Polacy, 2003). Konkluzje wynikające z tego pesymistycznego obrazu nie tylko kondycji obecnej edukacji, ale nade wszystko młodzieży można zamknąć w kilku zdaniach:

- Brak pragmatycznego sensu nauki (wizja bezrobocia).

- Deklarowana chęć wyjazdu za granicę.

- Mglista wizja przyszłości.

- Neutralizacja marzeń (problem tzw. oszukanego pokolenia).

Ostatnie określenie dotyczy m.in. wzmożonej aktywności młodych ludzi, prowadzących ostatnio ożywioną debatę na stronach internetowych. Mianem oszukanego pokolenia nazwano populację obecnych 20-30-latków. To pokolenie z wyżu demograficznego, które dostało od niegdysiejszych architektów życia społecznego w momencie swojej młodości jasny przekaz, że najważniejsza rzecz, to nauka języka angielskiego, ukończenie studiów wyższych ze stopniem magistra. Potem już tylko dostatnie i rozwojowe w sensie kariery życie zawodowe, ponieważ praca będzie na nich czekać. Problem w tym, że dziś bardzo duży odsetek tych osób, mimo wywiązania się z obietnic, zasila rzeszę bezrobotnych. Oszukano je, czy same się oszukały, naiwnie wierząc, że odległe w czasie obietnice mają szanse na urzeczywistnienie? (http://info.elblag. pl/31,27383, Oszukane-pokolenie-czyli-bajka-o-tym-ze-wyzsze-wyksztalcenie-zapewnia-prace. html\#ixzz28FPzZtvV).

Problemem związanym z edukacją wyższego szczebla jest często przypadkowy dobór kadr dydaktycznych na uczelniach (http://wroclaw.gazeta.pl/wroclaw/1,35771,10395094,Bachmann_Nepotyzm_na_uczelniach_zabije_konkurencja.html). Najgorsze recenzje wystawiają sami zawiedzeni: „Fatalnie przygotowani wykładowcy, przymykanie oczu na ściąganie, banalnie proste zaliczenia, pytania egzaminacyjne powtarzające się z roku na rok. Brzmi znajomo? To jeszcze nic! O absurdach nauki w szkołach wyższych mówią sami zainteresowani. Nikt lepiej nie wie, co dzieje się w murach uczelni niż studenci”. „[...] efektem dzisiejszego systemu szkolnictwa wyższego jest brak występowania selekcji wśród wykładowców, którzy lekceważą swoją pracę i nie rozwijają się..." (http://blog.onet.pl/42203,archiwum_goracy.tml). Osobnym problemem, który przeradza się w niemal powszechną praktykę, jest kwestia nieuprawnionego kopiowania cudzego dorobku intelektualnego. Okazuje się, że takiemu procederowi podlegają w równym stopniu studenci, jak i niektórzy wykładowcy (http://wiadomosci.onet.pl/kraj/ hartman-kraina-plagiatu-obszerne-ma-granice, 1,5289384, wiadomosc.html).

Na powyższe wątpliwości, rodzące się w trakcie analizy aktualnych uwarunkowań i wyników polskiej edukacji, odpowiada rynek. Jest to jednak reakcja o charakterze wyraźnie koniunkturalnym. Uczelnie uruchomiły program tzw. kierunków zamawianych. Dodatkiem do wyboru tego typu studiów jest stypendium, najczęściej w wysokości 1000 złotych. Jaka jest reakcja? Obserwuje się np. zwiększenie naboru na do tej pory niepopularnych kierunkach, takich jak np. mechatronika (na Politechnice Wrocławskiej jest to około siedmiu kandydatów na jedno miejsce), mechanika i budowa maszyn (czterech kandydatów na jedno miejsce, infor- 
matyka - trzech kandydatów na jedno miejsce; dane za rok akademicki 2009/2010). Tendencje się utrzymują. Kwestią do rozstrzygnięcia wciąż pozostaje problem motywacji, jeśli jest nią zdecydowanie większa szansa na znalezienie zatrudnienia po ukończeniu studiów, stan taki da się zaakceptować, ale niektórych „długodystansowych studentów” przyciągają pieniądze lub np. wizja korzystania z ulg komunikacyjnych. Bywa, że ów stan trwa do pierwszej weryfikacji, tj. sesji egzaminacyjnej, ale, w przypadku nieudanej próby, można korzystać z tzw. warunków lub ostatecznie przenieść się na inny kierunek, znacząco wydłużając czas ,ulgowego życia”. Z innych danych wynika, że Politechnika Warszawska notuje stały wzrost zainteresowania budownictwem, geodezją, kartografią i mechatroniką. W 2009 na Uniwersytecie Warszawskim ośmiu kandydatów na jedno miejsce zgłosiło akces do studiowania nowego kierunku: zastosowanie fizyki w biologii i medycynie.

W sprawozdaniu Rektora UW za 2011 r. w zakresie danych rekrutacyjnych można przeczytać, że według kryterium liczby kandydatów na jedno miejsce, najwięcej osób, bo aż 32, zgłosiło się na międzykierunkowe studia ekonomiczno-menedżerskie, dalej uplasowały się: dziennikarstwo i komunikacja społeczna (specjalność: public relation i marketing medialny (24 kandydatów na jedno miejsce), orientalistyka (tu dominowała sinologia), japonistyka i filologia angielska (16 kandydatów na jedno miejsce). W 2011 r. na UW studiowało 51803 studentów (tu tendencja jest zdecydowanie malejąca), w 2010 liczba ta wynosiła 53 696, w 2009 - 55 387, w 2008 - 55 973, w 2007 - 55 515, w 2006 - 56 633, rekordowy okazał się roku 2005 - 56 858, zaś w 2004 była to liczba 55736 (http://www.uw.edu.pl/strony/o_uw/dok/spraw2011/spraw2011.pdf).

\section{Inicjatywy na rzecz zmian i nowych sposobów kształcenia}

Należy zauważyć, że mimo niekorzystnej sytuacji w edukacji podejmuje się różne inicjatywy oddolne, mające na celu wzbudzenie zainteresowania tym, co dzieje się w polskiej szkole. Aktywność różnych grup i zrzeszeń, której źródłem jest niepokój wywołany nasilaniem się zjawisk ograniczających poziom przekazywanej wiedzy, ograniczeń godzin przewidzianych na realizację programów z różnych przedmiotów (historia), ale również minimalizujących poziom wymagań stawianych uczniom — ma na celu ich zahamowanie i przywrócenie polskiej szkole odpowiedniego poziomu. Do takich spektakularnych wystąpień należała akcja „Przejdź do historii”. Według Obywatelskiej Komisji Edukacji Narodowej rok szkolny 2012/2013 jest kolejnym przykładem wprowadzania obniżonych standardów, bowiem kolejny raz wdraża się reformę szkolnictwa ponadgimnazjalnego. Akcję „Przejdź do historii” zorganizowały Dolnośląski Instytut Korfantego, Inicjatywa Historyczna, Obywatelska Komisja Edukacji Narodowej, Ruch Edukacji Narodowej, Sekcja Oświaty i Wychowania NSZZ ,Solidarność” oraz Stowarzyszenie Odra - Niemen. Działacze postulowali przywrócenie liceum charakteru ogólnokształcącego. Według rzeczników tych organizacji, polska szkoła musi mieć silnie zaznaczony element wychowania, bowiem w życiu publicznym potrzebni są ludzie wrażliwi na sprawy społeczne, mający szacunek dla tradycji, wartości i patriotyzmu, przygotowani do odbioru wyższej kultury (http://wpolityce.pl/artykuly/35582-akcja-przejdz-do-historii-polska-szkola-musi-miec-silniezaznaczony-element-wychowania).

Innym przykładem nawołującym do zmiany kursu w polskiej edukacji, nastawionym na zmiany w sposobie prowadzenia zajęć z podstaw przedsiębiorczości, jest projekt pt. „Być przedsiębiorczym - nauka przez działanie”. To innowacyjny program nauczania przedsiębiorczości w szkołach ponadgimnazjalnych, realizowany od 1 lipca 2010 do 31 października 2013 przez pwn.pl Sp. z o.o. przy udziale Uniwersytetu Ekonomicznego we Wrocławiu oraz Uniwersytetu Ekonomicznego z Wiednia. Nadrzędny cel projektu ma zostać osiągnięty przy pomocy trzech celów szczegółowych: 1. Dostosowania programów nauczania podstaw przedsiębiorczości 
do trendów europejskich przez opracowanie diagnozy potrzeb uwzględniającej m.in. analizę SWOT dotychczasowych rozwiązań z punktu widzenia różnych grup docelowych (uczniów, nauczycieli, rodziców, kuratorium), przegląd europejskich programów nauczania przedsiębiorczości, by wykorzystać najlepsze europejskie praktyki. Ma nimi być tzw. komponent ponadnarodowy; 2. Uatrakcyjnienia zajęć z podstaw przedsiębiorczości przez wprowadzanie nowych instrumentów opartych na nowoczesnych technologiach i aktywnych formach nauczania; 3. Wypracowania i testowania implementacji nowatorskiego i innowacyjnego programu nauczania przedmiotu podstawy przedsiębiorczości (www.bycprzedsiebiorczym.pl).

Projekt obejmuje dwa etapy. Etap I trwał od 1 lipca 2010 do 31 marca 2011 r. i koncentrował się na nawiązaniu współpracy z partnerem zagranicznym - w tym przypadku współpraca dotyczyła Uniwersytetu Ekonomicznego w Wiedniu. Przygotowano także analizę wykorzystania skutecznych europejskich praktyk w zakresie nauczania podstaw przedsiębiorczości. Przy pomocy analiz i badań sporządzono diagnozę potrzeb w zakresie uczenia przedmiotu w polskich szkołach. Rekrutacja dla potrzeb projektu objęła 30 szkół z województwa dolnośląskiego. Pomysłodawcy, chcąc zachęcić potencjalnych uczestników, organizowali lekcje pokazowe dla nauczycieli, seminaria oraz konferencję informacyjną. Opracowano również innowacyjny program nauczania podstaw przedsiębiorczości i gotowy pakiet złożono do kuratorium, celem wydania opinii i ostatecznej akceptacji. Kolejne działania dotyczyły stworzenia strategii wdrażania programu opartego na innowacyjnych metodach pracy z uczniem, w zakresie nauczania przedmiotu. Na tym zakończono pierwszy etap pracy nad projektem.

Etap II obejmuje okres od 1 kwietnia 2011 do 31 października 2013, zatem jest obecnie realizowany. Działania koncentrują się na przygotowaniu do wdrożenia innowacyjnego programu w wytypowanych i zgłoszonych do udziału szkołach ponadgimnazjalnych w województwie dolnośląskim i obejmują tworzenie prezentacji multimedialnych, gier kierowniczych, symulacji biznesowych, e-podręczników, portalu wiedzy. Organizowane są tzw. wizyty studyjne uczestniczących w projekcie nauczycieli w Uniwersytecie Ekonomicznym w Wiedniu. Autorzy pomysłu zorganizowali Otwarte Dni Przedsiębiorczości, konkursy wiedzy z zakresu przedmiotu, zajęcia w szkołach, zgodnie z nowym programem i nowatorskimi metodami pracy oraz seminaria dla dyrektorów szkół i nauczycieli. Próbą zachęty do pracy na podstawie metod wypracowanych w ramach projektu są lekcje pokazowe dla uczniów i nauczycieli niebiorących bezpośrednio udziału w projekcie. Autorzy zapowiadają organizację konferencji o zasięgu międzynarodowym, której tematem przewodnim ma być problem: Jak skutecznie uczyć przedsiębiorczości?

Przedstawiona inicjatywa, jak sądzę, nie jest jedyną w kraju, bowiem na szczeblach regionów i województw różne gremia, mimo trudności, o których była już mowa, starają się podejmować działania na rzecz udoskonalenia metod nauczania, co wpisuje się w obywatelską troskę o lepszą jakość polskiej edukacji. Wspomnieć tu należy choćby o inicjatywie „Krok w przedsiębiorczość”. Jej nadrzędnym celem, jak deklarują pomysłodawcy, jest projekt i pilotażowe wdrożenie sprawdzające, obejmujące obszar województwa małopolskiego i podkarpackiego, innowacyjnego w doborze metod i przekazywaniu treści - programu. Inicjatywa ma na celu, skuteczniejsze od tradycyjnych sposobów, kształtowanie postaw przedsiębiorczych wśród młodzieży wraz z rozwojem ich kompetencji matematycznych i umiejętności komputerowych. Działania dotyczą poziomu szkoły ponadgimnazjalnej. Program kształcenia opiera się na pomyśle tworzenia wirtualnej firmy (umiejscowionej na otwartej platformie edukacyjnej) i konkurowaniu w cyberprzestrzeni. Program został stworzony dla powszechnego wykorzystania w szkołach ponadgimnizjalnych. Może być wsparciem nie tylko jako metoda kształcenia w ramach podstaw przedsiębiorczości, ale także dla wprowadzanego przez MEN przedmiotu do wyboru ekonomia w praktyce (http://www.krokwprzedsiebiorczosc.pl/). 


\section{Zakończenie}

$\mathrm{Na}$ tle nienajlepszej sytuacji w polskiej oświacie, co potwierdzają wyniki badań, najbardziej groźnymi są: brak skonkretyzowanych i rozłożonych w czasie celów, które powinny zostać osiągnięte na końcu procesu edukacji, tkwiące w dotychczasowych przesłankach sprzeczne cele pośrednie, nienajlepszy dobór, wychowanie i kształcenie kadr pedagogicznych, brak jasnych i wyraźnych motywatorów, choćby przez osiąganie realnych sprawności nauczycielskich popartych rzeczywistymi osiągnięciami w pracy zawodowej, akcentowania faktycznego dorobku nauczycieli (finansowo znacząca waloryzacja ich aktywności w dziedzinach podejmowania samokształcenia, studiowania innych kierunków na pełnych studiach, studiów doktoranckich, publikacji naukowych w dziedzinie pedagogiki i osobistych zainteresowan, faktycznych osiągnięć ich uczniów, mających bezpośredni związek z metodami pracy nauczyciela i ich realnym wpływem na podopiecznych itd.). Polski system edukacji na poziomie szkoły ponadgimnazjalnej, np. w ogóle nie gratyfikuje nauczycieli ze stopniem doktora. To ważny sygnał dla ministerstwa, bo nauczycieli z takim stopniem przybywa i, poza tym, że jest to zwykle wynikiem ich zainteresowań badawczych i siłą rzeczy wnosi do szkół nową jakość, powinni być oni finansowo znacząco docenieni.

Nie tylko wyniki matur, ale i stopień przygotowania potencjalnych studentów, jak pokazują powyższe badania i opinie, pozostawia sporo do życzenia. Prawda brzmi może nazbyt szczerze, ale w obecnej sytuacji nie każdy absolwent szkoły średniej nadaje się na studenta. W perspektywie naszych rozważań warto zastanowić się na konstruktywną alternatywą dla tych, którzy nie mają (bo i nie muszą mieć) ambicji ukończenia studiów wyższych i zadbać o rynek w kierunku zebrania rzetelnych danych dotyczących realnego zapotrzebowania na rozmaite zawody, do których wykonywania wystarczy dobry fachowiec. Może nim być absolwent szkoły zasadniczej lub technikum, który przeszedł okres solidnej praktyki zawodowej lub stażu. Technika, to potencjalne inkubatory przyszłych kadr inżynieryjnych, a w świetle badań tych najwięcej brakuje. Rodzime uczelnie wyższe również bardzo odstają od realnego poziomu konkurencyjności z europejskimi ośrodkami akademickimi. Zamiast prowadzić badania i koncentrować się na poszerzeniu ofert edukacyjnych zgodnych z oczekiwaniami rynku, szkoły wyższe, coraz bardziej się komercjalizując, gorączkowo poszukują rozwiązań umożliwiających pozyskanie dodatkowych środków, wprowadzając do swej oferty zajęcia podyplomowe, organizując uniwersytety trzeciego wieku i różne kursy: „W obliczu mizernej kondycji finansowej polskich uczelni i w ogóle - nauki, przedsiębiorczość w poszukiwaniu sposobów poprawy sytuacji wydaje się ze wszech miar wskazana. Bez dochodów z tytułu sprzedaży usług edukacyjnych i wszelkich innych budżety wielu uczelni wyższych załamałyby się. Również nasze uniwersytety z wolna przekształcają się w instytucje po części komercyjne” (Dylus, 2005: 104).

Zaprezentowane badania i ich interpretacja wskazują na mimo wszystko niski poziom przedsiębiorczości wśród Polaków. Choć w potocznym odbiorze wcale nienajgorzej radzimy sobie w trudnych czasach, to inicjatywy na szerszą skalę, oparte na profesjonalnej wiedzy ekonomicznej i regułach, jakim podlega gospodarka wolnorynkowa, pozostawiają wiele do życzenia. Tym bardziej wartościowymi okazują się inicjatywy, które próbują zmienić niekorzystny wizerunek, do których zaliczam wymienione w ostatnim podrozdziale. Takich przedsięwzięć jest o wiele więcej i, jak sądzę, przy zaniedbywaniu tej gałęzi wiedzy ze strony systemowych ośrodków decyzyjnych, stają się one nie tylko poważną alternatywą, ale i szansą na odwrócenie niekorzystnych tendencji. Podejmowanie partykularnych działań na rzecz podniesienia poziomu wiedzy w zakresie ekonomii i zmian w postawach przedsiębiorczych ma realną szansę na pozytywną zmianę w opisanych obszarach wiedzy i w praktycznej działalności człowieka. 


\section{Literatura}

Akcja przejdź do historii. Polska szkoła musi mieć silnie zaznaczony element wychowania (2012, 21 października). Pozyskano z: http://wpolityce.pl/artykuly/35582-akcja-przejdz-do-historii-polska-szk ola-musi-miec-silnie-zaznaczony-element-wychowania.

Bachman, K. (2013, 30 maja). Nepotyzm na uczelniach zabije konkurencja. Gazeta.pl. Wrocław. Pozyskano z: http://wroclaw.gazeta.pl/wroclaw/1,35771,10395094,Bachmann_Nepotyzm_na_uczelniach_zabije_konkurencja.html.

Być przedsiębiorczym (2013, 30 maja). Pozyskano z: www.bycprzedsiebiorczym.pl.

Hartman, J. (2013, 30 maja). Kraina plagiatu obszerne ma granice. Pozyskano z: http://wiadomosci.onet. $\mathrm{pl} / \mathrm{kraj} /$ hartman-kraina-plagiatu-obszerne-ma-granice, 1,5289384,wiadomosc.html.

Brzozowski, T.T. (2012). Przedsiębiorczość jako postawa wobec innych i świata w kontekście procesu budowania płaszczyzny dla dialogu interpersonalnego. Perspektywa pedagogiczno-kulturowa. Przedsiębiorczość - Edukacja, 8, 115-126.

Dylus, A. (2005). Globalizacja. Refleksje etyczne. Wrocław: Wydawnictwo OSSOLINEUM.

Klesyk, A. (2012, 8 października). Młodzi Polscy nie mają podstawowej wiedzy z ekonomii, Forbes. Pozyskano z: http://www.forbes.pl/artykuly/sekcje/kariera/mlodzi-polacy-nie-maja-podstawowejwiedzy-z-ekonomii,2.

Krok w przedsiębiorczość. Cele projektu (2013, 30 maja). Pozyskano z: http://www.krokwprzedsiebiorczosc.p1/.

Kuźma, J. (2000). Nauczyciele przyszłej szkoły. Kraków: Wydawnictwo Naukowe AP.

Legutko, R. (2013, 30 maja). Wychowania w szkole już nie ma. Pozyskano z: http://wiadomosci.onet.pl/ kraj/legutko-wychowania-w-szkole-juz-nie-ma,1,5024732,wiadomosc.html.

Legutko, R. (2013, 30 maja). 3 kroki do uzdrowienia edukacji. Pozyskano z: http://www.radiownet.pl/ publikacje/legutko-3-kroki-do-uzdrowienia-edukacji.

Narodowe Centrum Nauki. (2013, 07 maja). Pozyskano z: http://www.ncn.gov.pl/o-ncn/zadania-nen.

Nowak, A. (2008, 18 maja). Szkoła miernoty, Wprost.

Nowak, J. (2009, 2 lutego). Kierunek do niczego. Metro.

Olejniczak, A. (2012, 22 października). Absurdy ze studiów. Pozyskano z: http://blog.onet.pl/42203,archiwum_goracy.html.

Palska, H. (2003, październik). Szczęśliwi Polacy? Impresje socjologa o sensie życia. Więź.

Sprawozdanie roczne rektora Uniwersytetu Warszawskiego za rok 2011 (2013, 30 maja). Pozyskano z: http://www.uw.edu.pl/strony/o_uw/dok/spraw2011/spraw2011.pdf.

Rydygier, E. (2013, 30 maja). Kryzys polskiej szkoły skutkiem ciagłego jej reformowania. Pozyskano z: http://rydygier.blog.onet.pl/Kryzys-polskiej-szkoly-skutkie,2,ID427227148,n.

Sassen, S., (2007). Globalizacja. Eseje o nowej mobilności ludzi i pieniędzy. Kraków: Wydawnictwo UJ. Wysoki, T. (2009, 29 czerwca). Na uczelnie trafiają niedouczeni kandydaci. Gazeta Wyborcza.

Zioło, Z. (2012). Miejsce przedsiębiorczości w edukacji. Przedsiębiorczość - Edukacja, 8, 10-24.

Żyła, A. (2013, 30 maja). Oszukane pokolenie, czyli bajka o tym, że wyższe wyksztatcenie zapewnia pracę. Pozyskano z: http://info.elblag.pl/31,27383, Oszukane-pokolenie-czyli-bajka-o-tym-ze-wyzszewyksztalcenie-zapewnia-prace.html\#ixzz2UnnUsiWW.

Tomasz Tadeusz Brzozowski, dr, Uniwersytet Wrocławski, Instytut Kulturoznawstwa.

Absolwent filologii polskiej i filozofii Uniwersytetu Wrocławskiego we Wrocławiu. Studia podyplomowe z przedsiębiorczości w WSH we Wrocławiu oraz historii Uniwersytetu Wrocławskiego. Rozprawa doktorska napisana w Instytucie Filozofii na Wydziale Nauk Społecznych UWr. Nauczyciel dyplomowany, aktualnie doktorant Instytutu Kulturoznawstwa UWr. Zajmuje się filozofią wartości, bada przestrzeń aksjologiczną i jej wpływ na kształt polskiej myśli filozoficznej XIX i XX w. Ponadto interesuje go dziedzina ontologii i miejsce, jakie wyznaczają jej różne odmiany filozofii transcendentalnej. Zajmują go także zagadnienia etyki biznesu 
oraz procesy globalne i ich wpływ na jakość międzypodmiotowych relacji dialogicznych. Jest wykładowcą Wyższej Szkoły Bankowej we Wrocławiu oraz WSTE w Świdnicy, pracuje jako tutor w ALA we Wrocławiu.

Tomasz Tadeusz Brzozowski, PhD, University of Wroclaw, Institute For Cultural Studies.

The author graduated from Polish Philology and Philosophy at the University of Wroclaw. Furthermore, he completed postgraduate study programmes in entrepreneurship and history. Employed as a certified teacher, the author is currently a doctoral candidate at Wydział Nauk Historycznych i Pedagogicznych at the University of Wrocław. Cultural studies have provided the author with tools and competencies to analyse and understand value systems, as well as identity strategies in the modern world. The author's areas of interest in this regard encompass ethics, ontology, and transcendental philosophy, as well as polish philosophy of the XIX and $\mathrm{XX}$ centuries. He is further interested in business ethics (Corporate Social Responsibility). The author is currently preparing a second dissertation, concerning global processes and their influence on the quality of interpersonal and dialogical relationships. Employed as a lecturer at the Wroclaw School of Banking, and the School of Technology and Economics in Świdnica. Also works as a tutor in the Authorial Artistic High School in Wroclaw.

Adres/Address:

University of Wroclaw, Institute For Cultural Studies

e-mail: tomasz.brzozowski@wsb.wroclaw.pl 
Wioletta Kilar, Sławomir Kurek, Tomasz Rachwal

Uniwersytet Pedagogiczny

im. Komisji Edukacji Narodowej

w Krakowie

\title{
Kształtowanie kompetencji osobistych i społecznych w szkolnictwie zawodowym dla sektora handlu detalicznego w świetle opinii partnerów społecznych
}

\author{
Developing personal and social competencies in vocational training \\ for the retail sector in the opinions of social partners
}

\begin{abstract}
Streszczenie
Celem artykułu jest przedstawienie roli kompetencji osobistych i społecznych jako składowych postawy przedsiębiorczej w warunkach kryzysu gospodarczego, którego jednym z przejawów jest wzrastające, głównie wśród ludzi młodych, bezrobocie. Szczególna uwaga zostanie skierowana na kształcenie tych kompetencji w szkolnictwie zawodowym, przygotowującym do pracy w sektorze handlu detalicznego na podstawie celów i założeń międzynarodowego projektu badawczo-edukacyjnego „Kompetencje Sektora Handlu Detalicznego - kształtowanie kompetencji osobistych i społecznych w szkolnictwie zawodowym dla sektora handlu detalicznego (ReSeCo)". W artykule przedstawiono także ważniejsze wnioski z analizy opinii partnerów społecznych odnośnie potrzeb i wymagań w sektorze sprzedaży detalicznej w zakresie rozwijania kompetencji osobistych i społecznych oraz przydatności proponowanych materiałów dydaktycznych.
\end{abstract}

\begin{abstract}
This article aims to present the role of social and self-competencies, as a part of entrepreneurial attitudes in the conditions of economic crisis, which is one of the symptoms of rising unemployment, especially among young people. Particular attention will be paid to the training of these competencies in the course of vocational education, preparing for work in the retail sector, based on the goals and objectives of international research and the educational project: 'Retail Sector Competencies: Developing self- and social competencies in vocational training for the retail sector (ReSeCo)'. This article presents major findings from the analysis of the social partner opinions, concerning the needs and requirements in the retail sector, to develop social and self-competencies and suitability of the proposed teaching materials.
\end{abstract}

Słowa kluczowe: kompetencje osobiste i społeczne; partnerzy społeczni; sektor handlu detalicznego; szkolnictwo zawodowe

Key words: personal and social competencies; social partners; retail sector; vocational education 


\section{Wprowadzenie}

Choć współczesny okres dekoniunktury gospodarczej, określany powszechnie mianem światowego kryzysu, dotyka w różnym stopniu poszczególne działy gospodarki w sektorze rolniczym, przemysłowym oraz usługowym, to jednak wbrew powszechnym, nagłośnionym medialnie opiniom o depresji gospodarczej porównywalnej z Wielkim Kryzysem przełomu lat 20. i 30. XX w. jego wpływ na przemiany struktur gospodarczych, funkcjonowanie wielu rodzajów działalności, stref ekonomicznych, jak i poszczególnych korporacji jest ograniczony (m.in. Czapliński, 2011; Dorocki, 2011; Kitowski, 2009; 2011; Rachwał, 2011; Rachwał, Zdon-Korzeniowska, 2011; Rettinger, Staszak, 2011; Uliszak, 2011; Wójtowicz, 2011; Zioło, 2011). Nie zmienia to faktu, że - jak stwierdzili T. Rachwał i M. Zdon-Korzeniowska (2011) na podstawie badań własnych i prac innych autorów - gospodarka światowa wkroczyła w erę turbulencji, gdzie sytuacja społeczno-ekonomiczna staje się nie tylko niestabilna, ale także trudno przewidywalna. Te turbulencje i ograniczone możliwości skutecznego przewidywania dalszych tendencji przemian stają się nową rzeczywistością. W tej sytuacji w szczególnie trudnym położeniu znajduje się pojedynczy człowiek, dla którego te burzliwe fluktuacje społeczno-gospodarcze oznaczają niepewność w zakresie możliwości dalszego zatrudnienia bądź znalezienia pracy w przypadku jej braku, utrzymania dobrego poziomu życia, budowania skutecznych strategii finansowych zarówno w odniesieniu do budżetu domowego, jak i firmy, której jest właścicielem lub w której pracuje. Niezwykle istotne w tej sytuacji są jego kompetencje osobiste i społeczne, związane z postawą przedsiębiorczą, dzięki którym łatwiej będzie się mu odnaleźć w warunkach niepewnej, nieprzewidywalnej i trudnej sytuacji gospodarczej.

W nawiązaniu do zarysowanych przesłanek celem artykułu jest więc przedstawienie roli kompetencji osobistych i społecznych jako składowych postawy przedsiębiorczej w warunkach dekoniunktury gospodarczej. Szczególna uwaga została zwrócona na kształcenie tych kompetencji w szkolnictwie zawodowym, przygotowującym do pracy w sektorze handlu detalicznego na podstawie celów i założeń międzynarodowego projektu badawczo-edukacyjnego „Kompetencje Sektora Handlu Detalicznego - kształtowanie kompetencji osobistych i społecznych w szkolnictwie zawodowym dla sektora handlu detalicznego (ReSeCo)". Projekt ten, wspólfinansowany ze środków UE w ramach Lifelong Learning Programme (subprogram: Leonardo da Vinci, kategoria działania: Projekty wielostronne, działanie: Transfer innowacji), był realizowany w okresie 1.10.2011-30.09.2013 przez zespół naukowców reprezentujących uniwersytety z czterech krajów partnerskich: Niemiec (Uniwersytet w Kolonii, lider projektu), Polski (Uniwersytet Pedagogiczny w Krakowie), Wielkiej Brytanii (Uniwersytet w Southampton, w pierwszym roku realizacji Uniwersytet Westminster w Londynie) oraz Włoch (Uniwersytet w Bergamo). W projekcie więli też udział nauczyciele i uczniowie szkół ponadgimnazjalnych (zawodowych) z południowo-wschodniej Polski, w których zostały pilotażowo wdrożone materiały edukacyjne, będące przedmiotem transferu innowacji.

Projekt ReSeCo nawiązywał do europejskich priorytetów w zakresie edukacji i rozwoju społeczno-gospodarczego, $\mathrm{tj}$. wspierania kompetencji kluczowych w przygotowaniu zawodowym i kształceniu przez całe życie. Praktycznym efektem jego realizacji jest transfer innowacji - opracowanych materiałów dydaktycznych, powstałych w wyniku realizacji wcześniejszego projektu unijnego (SeSoKo-fit1), przez zaadaptowanie ich do potrzeb kształcenia dla sektora handlu detalicznego oraz przystosowanie do krajowych wymagań specyficznych dla danego systemu oświaty. Opracowane materiały dydaktyczne dla nauczycieli przedsiębiorczości i in-

\footnotetext{
${ }^{1}$ Informacja (w języku niemieckim) nt. projektu SeSoKo-Fit: http://www.lehrstuhlwipaed.uni-koeln.de/ fileadmin/wiso_fak/wipaed_pilz/Literatur/Projektbeschreibung_SeSoko-Fit.pdf.
} 
nych przedmiotów ekonomicznych zostały wydane w języku angielskim i innych językach narodowych (polski, niemiecki, włoski) w celu upowszechnienia ich w zainteresowanych tymi materiałami placówkach oświatowych. Ponadto w jego ramach dokonano analizy literatury przedmiotu i przeprowadzono wstępne wywiady w zakresie wymagań zainteresowanych stron (partnerów społecznych, szkół) w sektorze detalicznym co do rozwijania kompetencji osobistych i społecznych. W wyniku nawiązania kontaktu z partnerami społecznymi (pracodawcami, organizacjami pracodawców i związkami zawodowymi) przeprowadzono następnie pogłębione wywiady z ich przedstawicielami w odniesieniu do potrzeb i wymagań w sektorze sprzedaży detalicznej w zakresie rozwijania kompetencji osobistych i społecznych oraz przydatności proponowanych materiałów dydaktycznych. W sumie przeprowadzono cztery wywiady pogłębione (2012 r.) z przedstawicielem kadry zarządzającej w międzynarodowej sieci handlowej, z właścicielem sklepu spożywczego, z przedstawicielem Małopolskiej Izby Rzemiosła i Przedsiębiorczości oraz reprezentantem Małopolskiego Stowarzyszenia Kupców i Przedsiębiorców. W artykule przedstawiono więc także ważniejsze wnioski z analizy opinii wymienionych partnerów społecznych.

\section{Przesłanki, cele i przewidywane efekty realizacji projektu ReSeCo}

Podstawową przesłanką realizacji projektu ReSeCo były obserwowane w wielu krajach europejskich problemy z przechodzeniem z kształcenia zawodowego do systemu zatrudnienia (rynku pracy), które wynikają z deficytu kompetencji osobistych i społecznych. Szczególnie dotyczy to niżej wykwalifikowanych młodych ludzi, którzy stoją tuż przed wejściem w życie zawodowe. Głównym celem realizacji projektu była poprawa jakości edukacji w sektorze handlu detalicznego przez rozwój kompetencji osobistych i społecznych. Rozwijanie kompetencji osobistych i społecznych odbywało się w ramach godzin lekcyjnych przedmiotu podstawy przedsiębiorczości i innych przedmiotów zawodowych za pomocą materiałów dydaktycznych dostarczonych nauczycielom. W wyniku wcześniejszej analizy literatury przedmiotu i badań zapotrzebowania środowiska szkolnego w ramach realizacji projektu SeSoKo-fit szczególna uwaga została zwrócona na cztery zagadnienia w ramach szkolenia zawodowego. Było to rozwijanie kompetencji związanych z umiejętnością: pracy zespołowej, świadomego przyjmowania krytyki, zarządzania czasem oraz analizy własnych słabych i mocnych stron w celu lepszej autoprezentacji.

Dobór krajów partnerskich do projektu (Niemcy, Polska, Wielka Brytania i Włochy) pozwolił uzyskać kombinację krajów o odmiennych uwarunkowaniach rozwoju społeczno-gospodarczego i różnych systemach kształcenia zawodowego. Na szczególną uwagę zasługuje tu system polskiego szkolnictwa zawodowego, który w warunkach transformacji gospodarczej ulega głębokim przemianom w wyniku reform organizacyjnych i programowych systemu oświaty, co było przedmiotem szczególnego zainteresowania S. Kurka i T. Rachwała (2012). Transfer innowacji od lidera projektu (Niemcy) odbywał się na trzech różnych poziomach: różnego przedziału wiekowego uczniów, określonej grupy zawodowej i pomiędzy krajami (różne państwa europejskie). Przedmiotem badań i transferu innowacji był sektor detaliczny, który charakteryzuje się różnymi aspektami komunikacji i kontaktu z klientem. Wymagania zawodowe w sektorze handlu są coraz wyższe, szczególnie w związku z kluczowymi kompetencjami społecznymi i osobistymi, co wynika z charakteru tej pracy, wymagającej wysokich umiejętności w zakresie obsługi klienta. Do tych umiejętności należy zaliczyć, za M. Rachwał i T. Rachwałem (2005), m.in. tworzenie kultury organizacyjnej (przedsiębiorstwa lub zespołu obsługi klientów - pracowników tzw. pierwszej linii), która na pierwszym miejscu stawia troskę o klienta, biegłość w kontaktach międzyludzkich, czyli grzeczność, uprzejmość, uczciwość 
opartą na fachowości, umiejętność aktywnego słuchania i tym samym zdobywania informacji, jakie są potrzeby klienta i w jaki sposób można je zaspokoić, analizowanie informacji zwrotnej od klienta, nastawienie na pomoc klientowi, a nie na inne zadania, elastyczny sposób zaspokajania potrzeb klientów, szybkie i sprawne rozpatrywanie reklamacji i umiejętność rozwiązywania konfliktów, który w tym zakresie mogą wystąpić oraz budowanie relacji opartych na partnerstwie, czyli współpracy. Zawód sprzedawcy (handlowca) jest odpowiedni dla transferu innowacji w zakresie edukacji w obrębie krajów Unii Europejskiej, ponieważ wymagania odnośnie tego zawodu są podobne w krajach europejskich, a jego znaczenie jest coraz większe w związku z dynamicznym rozwojem sektora handlu oraz europeizacją, czy wręcz - globalizacją działalności firm tego sektora, czego skutkiem jest wprowadzanie w wielu krajach jednolitych standardów pracy i obsługi klienta.

Efektem długoterminowym realizacji projektu powinno być, przez powszechne zastosowanie w szkole wypracowanych materiałów dydaktycznych, osiągnięcie przez uczniów sukcesu w życiu zawodowym, a przez firmy handlowe - korzyści dzięki lepszemu przygotowaniu potencjalnych pracowników. Nawiązuje to do stanowiska M. Rachwał i T. Rachwała (2005), którzy zauważyli, że w celu utrzymania wysokiego poziomu obsługi klienta w sektorze handlu niezbędne jest kształtowanie tych kluczowych umiejętności już na etapie szkoły ponadgimnazjalnej w ramach edukacji w zakresie przedsiębiorczości, a także w ramach kształcenia ustawicznego w formach pozaszkolnych oraz w rozbudowanym systemie szkoleń pracowników w firmach, jednorazowe szkolenie w tym zakresie nie przynosi bowiem pożądanych efektów. Szkolenia te muszą być systematycznie powtarzane i utrwalane w miejscu pracy w systemie coachingowym i dotyczyć przede wszystkim tzw. miękkich kompetencji, takich jak umiejętność słuchania, rozwiązywania konfliktów, opanowania w kontaktach z klientem, szczególnie w przypadku tzw. trudnych (roszczeniowych) klientów, i empatii. W efekcie, zdaniem tych autorów, budowanie doskonałych relacji z klientem może w istotnym stopniu przyczynić się do podniesienia konkurencyjności przedsiębiorstw oraz konkurencyjności samych uczniów szkół ponadgimnazjalnych, którym ta umiejętność będzie bardzo przydatna w życiu zawodowym. Dlatego też rola tych umiejętności jest nieoceniona w kształceniu w zakresie przedsiębiorczości.

Dla realizacji przyjętych celów określono szczegółowy harmonogram i poszczególne zadania partnerów projektu, które obejmowały, oprócz wspomnianego wyżej przeprowadzenia pogłębionych wywiadów z przedstawicielami partnerów społecznych, także:

- dostosowanie materiałów dydaktycznych (dla czterech modułów kształcenia) do potrzeb krajowego systemu szkolnictwa zawodowego i systemu szkoleń w zakresie handlu detalicznego,

- wdrożenie testujące opracowanych modułów kształcenia w co najmniej trzech szkołach zawodowych lub placówkach szkoleniowych w każdym kraju,

- przeprowadzanie wywiadów z nauczycielami i uczniami w celu oceny procesu wdrażania testującego i przydatności proponowanych materiałów dydaktycznych,

- optymalizację materiałów dydaktycznych na podstawie procesu ewaluacji w fazie wdrożeniowej,

- opracowanie raportów dotyczących procesu realizacji projektu w zakresie uzyskanych wyników na szczeblu krajowym i międzynarodowym,

- upowszechnienie wyników krajowych i międzynarodowych przez raporty i publikacje w języku angielskim oraz językach narodowych, informowanie kluczowych osób w systemie oświaty (m.in. nauczyciele i dyrektorzy szkół oraz centrów kształcenia ustawicznego, przedstawiciele tzw. organów prowadzących, kuratoriów oświaty, ośrodków doskonalenia nauczycieli) dzięki rozpowszechnianiu informacji oraz organizowaniu warsztatów, wspieranie procesów innowacyjnych w systemie szkolnictwa i kształcenia zawodowego. 
Odpowiednie zaplanowanie zadań i pakietów roboczych pozwoliło na efektywną realizację całego projektu ${ }^{2}$.

\section{Rola kompetencji osobistych i społecznych jako składowych postawy przedsiębiorczej w warunkach dekoniunktury gospodarczej}

Kompetencje osobiste i społeczne, takie jak umiejętność analizy własnych słabych i mocnych stron, umiejętność autoprezentacji, umiejętności w zakresie komunikacji interpersonalnej, świadomego przyjmowania krytyki ze strony innych osób, w tym przełożonych i wyciągania z niej wniosków, oraz umiejętność pracy w zespole, zaliczane są do grupy kompetencji podstawowych warunkujących funkcjonowanie każdego człowieka w społeczeństwie i jego efektywne uczestnictwo w życiu społeczno-gospodarczym. Mieszczą się one w obszarze tzw. kompetencji kluczowych europejskiego systemu edukacji (Zalecenie..., 2006; Kompetencje..., 2007). Realizacja projektu i wdrożenie materiałów dydaktycznych do praktyki szkolnej pozwoli na kształtowanie dwóch z nich: inicjatywności i przedsiębiorczości oraz kompetencji społecznych i obywatelskich, a także będzie wspierać osiąganie kompetencji takich jak umiejętność uczenia się i porozumiewania się w języku ojczystym (ryc. 1).

Ryc. 1. Kompetencje kluczowe w europejskim obszarze edukacyjnym w odniesieniu do projektu ReSeCo

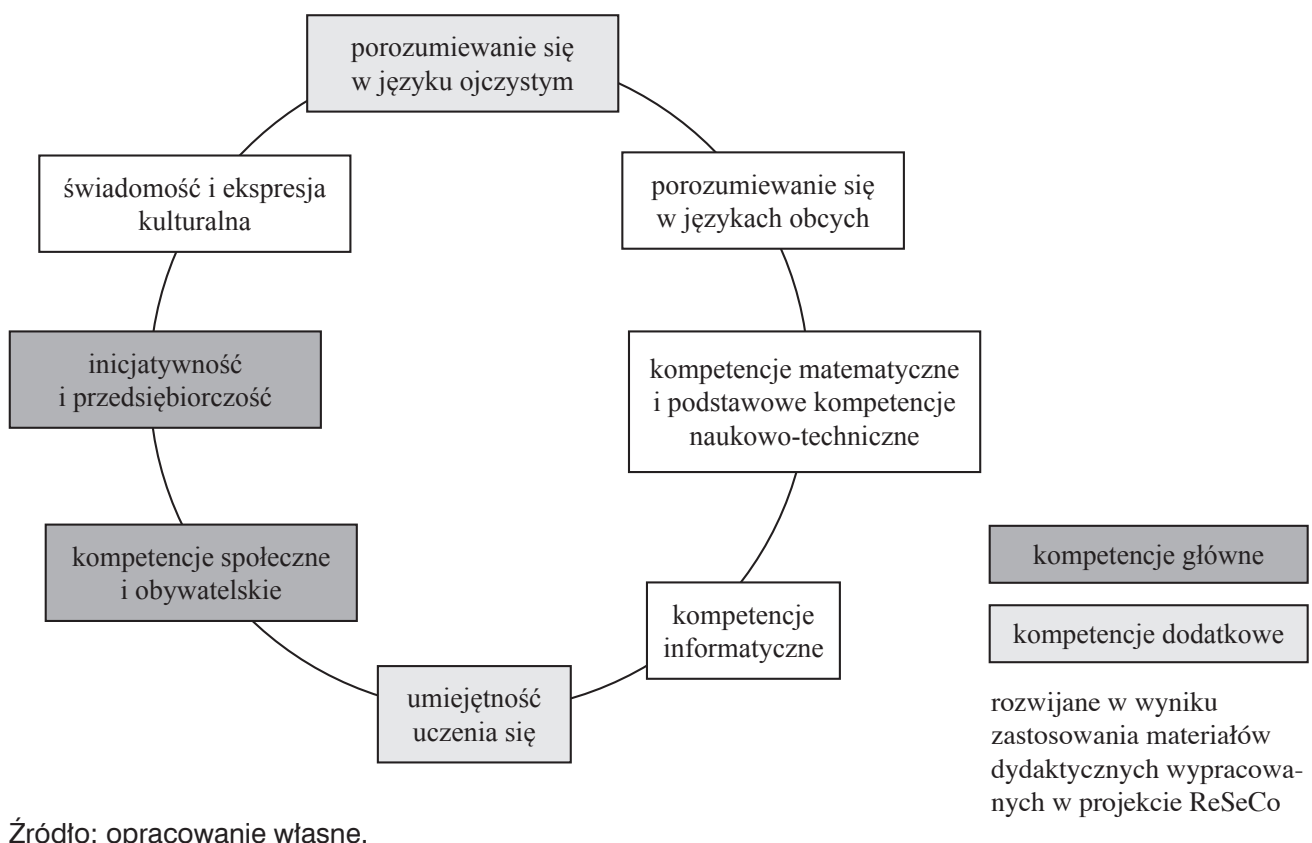

Źródło: opracowanie własne.

\footnotetext{
${ }^{2}$ Więcej o realizacji projektu, w tym informacje o pakietach roboczych, na stronach internetowych UE i partnerów projektu: http://www.adam-europe.eu/adam/project/view.htm?prj=8530\&page=FILES\#. UXzTBbWeN8H; http://www.up.krakow.pl/geo/reseco.html ; http://www.great.uni-koeln.de/16372.html?\&L=1; http://www.southampton.ac.uk/education/research/projects/retail_sector_competencies.page; http://www.unibg.it/struttura/struttura.asp?cerca=dsfc_reseco.
} 
Zgodnie z definicją przyjętą w Unii Europejskiej (Zalecenie..., 2006: 16-17) grupa kompetencji społecznych i obywatelskich to ,kompetencje osobowe, interpersonalne i międzykulturowe obejmujące pełny zakres zachowań przygotowujących osoby do skutecznego i konstruktywnego uczestnictwa w życiu społecznym i zawodowym, szczególnie w społeczeństwach charakteryzujących się coraz większą różnorodnością, a także rozwiązywania konfliktów w razie potrzeby. [...] Kompetencje społeczne są związane z dobrem osobistym i społecznym, które wymaga świadomości, w jaki sposób można zapewnić sobie optymalny poziom zdrowia fizycznego i psychicznego, rozumianego również jako zasób danej osoby i jej rodziny oraz bezpośredniego otoczenia społecznego, a także wiedzy, w jaki sposób może się do tego przyczynić odpowiedni styl życia. Dla powodzenia w kontaktach interpersonalnych i uczestnictwie społecznym niezbędne jest rozumienie zasad postępowania i reguł zachowania ogólnie przyjętych w różnych społeczeństwach i środowiskach (np. w pracy). Równie istotna jest świadomość podstawowych pojęć dotyczących osób, grup, organizacji zawodowych, równości płci i niedyskryminacji, społeczeństwa i kultury. Konieczne jest rozumienie wielokulturowych i społeczno-ekonomicznych wymiarów społeczeństw europejskich, a także wzajemnej interakcji narodowej tożsamości kulturowej i tożsamości europejskiej. Podstawowe umiejętności w zakresie tej kompetencji obejmują zdolność do konstruktywnego porozumiewania się w różnych środowiskach, wykazywania się tolerancją, wyrażania i rozumienia różnych punktów widzenia, negocjowania połączonego ze zdolnością tworzenia klimatu zaufania, a także zdolność do empatii. Osoby powinny być zdolne do radzenia sobie ze stresem i frustracją oraz do wyrażania ich w konstruktywny sposób, a także powinny dokonywać rozróżnienia sfery osobistej i zawodowej. Kompetencja ta opiera się na współpracy, asertywności i prawości. Osoby powinny interesować się rozwojem społeczno-gospodarczym, komunikacją międzykulturową, cenić różnorodność i szanować innych ludzi, a także być przygotowane na pokonywanie uprzedzeń i osiąganie kompromisu".

Natomiast kompetencje określane jako inicjatywność i przedsiębiorczość oznaczają ( $\mathrm{Za}$ lecenie..., 2006: 17-18), ,zdolność osoby do wcielania pomysłów w czyn. Obejmują one kreatywność, innowacyjność i podejmowanie ryzyka, a także zdolność do planowania przedsięwzięć i prowadzenia ich dla osiągnięcia zamierzonych celów. Stanowią one wsparcie dla indywidualnych osób nie tylko w ich codziennym życiu prywatnym i społecznym, ale także w ich miejscu pracy, pomagając im uzyskać świadomość kontekstu ich pracy i zdolność wykorzystywania szans; są podstawą bardziej konkretnych umiejętności i wiedzy potrzebnych tym, którzy podejmują przedsięwzięcia o charakterze społecznym lub handlowym albo w nich uczestniczą. Powinny one obejmować świadomość wartości etycznych i promować dobre zarządzanie. Konieczna wiedza obejmuje zdolność identyfikowania dostępnych możliwości działalności osobistej, zawodowej lub gospodarczej, w tym szerszych zagadnień stanowiących kontekst pracy i życia ludzi, takich jak ogólne rozumienie zasad działania gospodarki, a także szanse i wyzwania stojące przed pracodawcami i organizacjami. Osoby powinny również być świadome zagadnień etycznych związanych z przedsiębiorstwami oraz tego, w jaki sposób mogą one wywoływać pozytywne zmiany, np. przez sprawiedliwy handel lub przedsięwzięcia społeczne. Umiejętności odnoszą się do proaktywnego zarządzania projektami (co obejmuje np. planowanie, organizowanie, zarządzanie, kierowanie i zlecanie zadań, analizowanie, komunikowanie, sporządzanie raportów, ocenę i sprawozdawczość), skutecznej reprezentacji i negocjacji oraz zdolności zarówno pracy indywidualnej, jak i współpracy w zespołach. Niezbędna jest umiejętność oceny i identyfikacji własnych mocnych i słabych stron, a także oceny ryzyka i podejmowania go w uzasadnionych przypadkach. Postawa przedsiębiorcza 
charakteryzuje się inicjatywnością, aktywnością, niezależnością i innowacyjnością zarówno w życiu osobistym i społecznym, jak i w pracy. Obejmuje również motywację i determinację w kierunku realizowania celów, czy to osobistych, czy wspólnych, zarówno prywatnych, jak i w pracy".

Warto również podkreślić, że w niektórych podejściach umiejętności społeczne i w zakresie komunikacji interpersonalnej łączone są ściśle z postawą przedsiębiorczą (Borowiec, Rachwał, 2011; Choinkowska, 2012; Gabała, 2005, Rachwał, 2004a, 2004b, 2006; Osuch, 2011; Wach, 2007) bądź są zaliczane do tzw. kompetencji biznesowych (Berger i in., 2012; Kurek, Rachwał, 2010; Kurek, Rachwał, Szubert, 2012a, 2012b). Są one także przedmiotem głębokiego zainteresowania twórców innych innowacyjnych projektów edukacyjnych w Polsce, takich jak „Krok w przedsiębiorczość" (Rachwał, Ratajski, Zając, 2012; Kilar, Rachwał, Zając, 2012; Dorocki i in., 2012) i ,Jestem przedsiębiorczy” (Świłło, 2012) jako element edukacji w zakresie przedsiębiorczości. Przykładowo, w tym drugim projekcie zakłada się rozwój 11 podstawowych, wyróżnionych na podstawie badań i literatury przedmiotu kompetencji: komunikacja, współpraca, przedsiębiorczość (w węższym rozumieniu, jako zdolność do realizacji wyznaczanych celów biznesowych), elastyczność związana ze zdolnością do reagowania na zmieniającą się rzeczywistość gospodarczą, analiza potrzeb klientów, efektywność (rozumiana jako skuteczność w podejmowanych działaniach), niezależność, związana ze świadomością swoich mocnych i słabych stron, rozwiązywanie problemów, planowanie i organizowanie własnej pracy, kształcenie ustawiczne oraz panowanie nad stresem. Zdaniem I. Świłło (2012: 72) „kompetencje te wzajemnie się uzupełniają i tworzą profil osoby przedsiębiorczej w szerokim rozumieniu tego pojęcia". Analiza definicji kompetencji kluczowych będących przedmiotem projektu ReSeCo zawarta w dokumentach unijnych oraz podejściach różnych autorów wskazuje, że w największym stopniu opracowane materiały dydaktyczne wspierają kompetencje związane z szeroko rozumianą przedsiębiorczością.

Należy w tym miejscu zwrócić uwagę na ogromną rolę przedsiębiorczości w systemie edukacji; roli tej w dużej mierze poświęcono poprzedni, 8 tom czasopisma „Przedsiębiorczość Edukacja”. W artykule wprowadzającym, wskazując na znaczące miejsce przedsiębiorczości w systemie edukacji, Z. Zioło (2012: 11) zwrócił uwagę, że „kształtowanie postaw przedsiębiorczych, przejawiających się w dążeniu do rozwijania aktywności gospodarczej, społecznej, kulturowej czy politycznej, jest niezbędne na wszystkich szczeblach edukacji instytucjonalnej, począwszy od poziomu wczesnoszkolnego przez poziom podstawowy, gimnazjalny, ponadgimnazjalny do kształcenia na poziomie akademickim, a następnie w procesie dokształcania i doskonalenia zawodowego w całym okresie aktywności człowieka na rynku pracy i działalności społecznej”. Jego zdaniem proces ten winien być wspierany przez różnorodne podmioty gospodarcze i instytucje funkcjonujące w otoczeniu społeczno-gospodarczym każdego człowieka. Na potrzebę kształtowania postaw przedsiębiorczych na różnych poziomach edukacji, a także na dużą rolę przedsiębiorczości w rozwoju społeczno-gospodarczym oraz wejściu młodzieży na rynek pracy zwracali uwagę także inni autorzy (por. Cieślik, 2007; Jankowska, Pietrzykowski, 2012; 2013; Juchnowicz, 2005; 2007; Kurek, Rachwał, 2010; 2011; Osuch, 2012; Pietrzykowski, 2011; Piróg, 2012a; 2012b; Surdej, Wach, 2007; Świętek, 2012; Wach, 2007, 2008). Jest to szczególnie ważne w okresie kryzysu gospodarczego, kiedy ograniczenie produkcji wpływa na coraz większe trudności w zakresie znalezienia pracy. Okres dekoniunktury gospodarczej znajduje bowiem swoje odbicie w wysokiej stopie bezrobocia w Polsce i innych krajach Unii Europejskiej, szczególnie wśród młodych ludzi (ryc. 2). 
Ryc. 2. Stopa bezrobocia ogółem oraz wśród ludzi młodych w Unii Europejskiej i wybranych krajach na przełomie 2012 i 2013 r.*

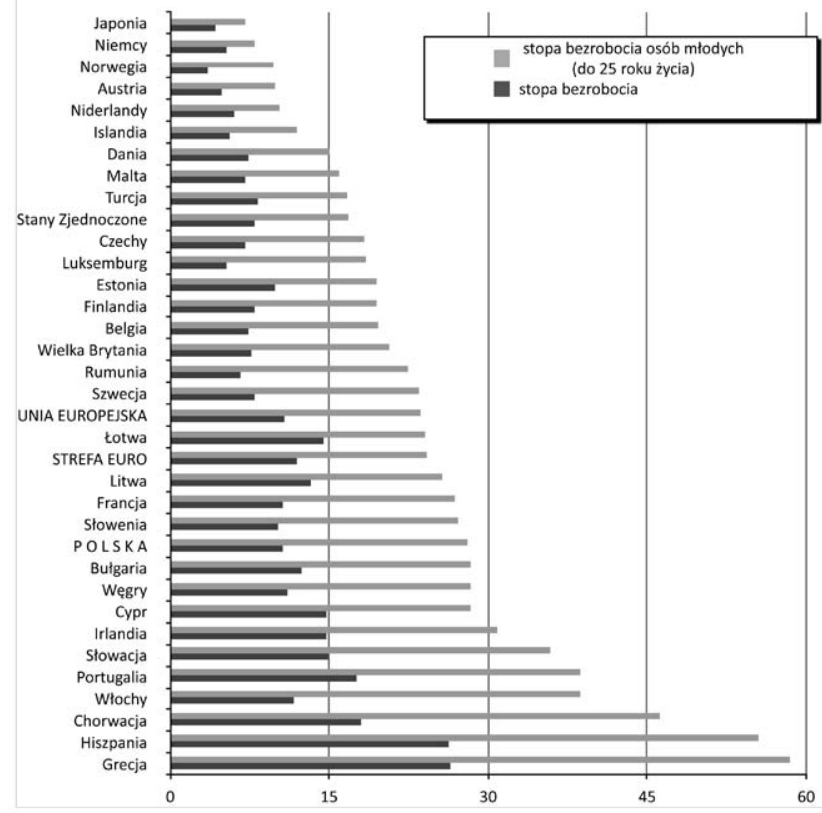

* w zależności od dostępności dane wg stanu na styczeń 2013 lub grudzień 2012 r.

Źródło: opracowanie własne na podstawie danych Eurostatu.

Ryc. 3. Stopa bezrobocia wg wykształcenia w Unii Europejskiej i innych wybranych krajach w 2012 r.

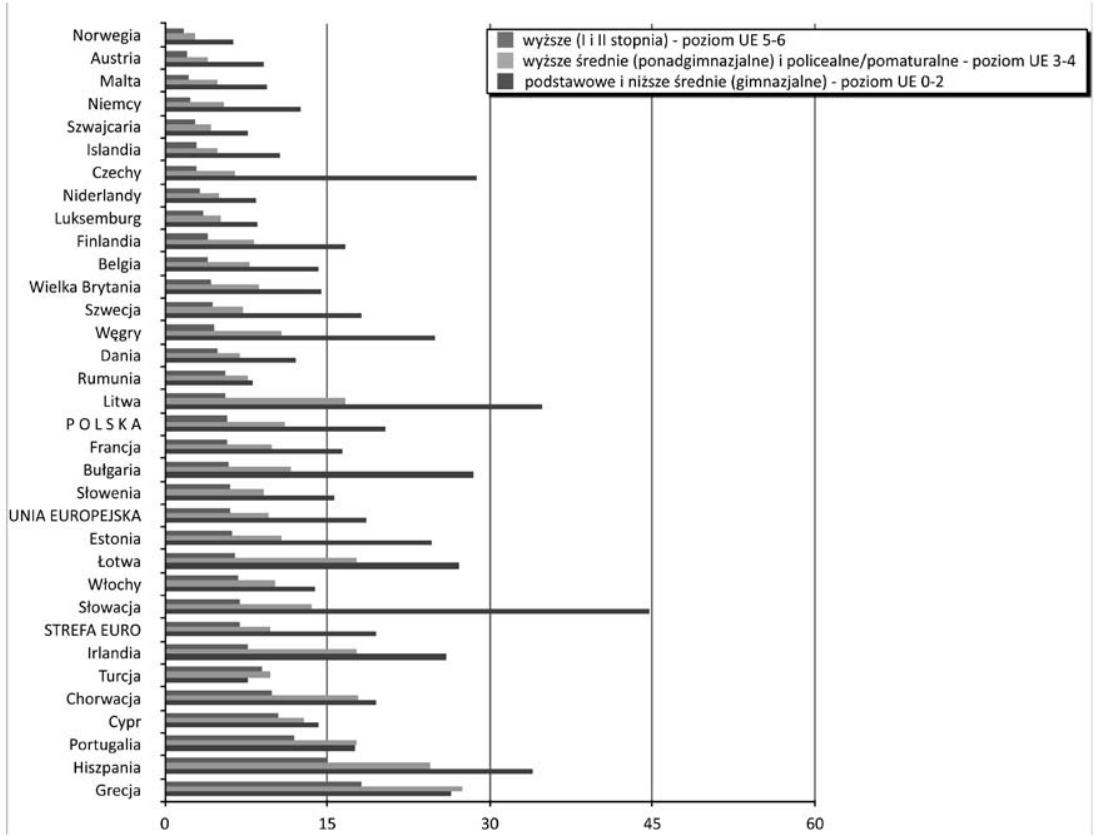

Źródło: opracowanie własne na podstawie danych Eurostatu. 
Warto przy tym zauważyć za D. Piróg (2011a; 2011b; 2012b), że problem trudności w zakresie tranzycji ze systemu szkolnictwa do rynku pracy dotyczy także absolwentów szkół wyższych, choć nadal, mimo tendencji wzrostowej, stopa bezrobocia w Polsce i innych krajach europejskich wśród osób z wyższym wykształceniem jest niższa niż wśród osób z wykształceniem średnim i podstawowym/gimnazjalnym (ryc. 3). Autorka zwraca więc szczególną uwagę na konieczność kształtowania ich kompetencji, nie tylko merytorycznych związanych z wykonywanym w przyszłości zawodem, ale także miękkich, związanych z przedsiębiorczością. Ze stanowiskiem tym zgadzają się inni autorzy, m.in. W. Osuch (2011), podkreślający ogromne znaczenie kompetencji związanych z komunikacją interpersonalną, czy E. Choinkowska (2012), akcentująca rolę pasji, umiejętności podejmowania decyzji, pozytywnego nastawienia i współpracy jako ważnych składowych przedsiębiorczości, odgrywających doniosłą rolę w systemie edukacji.

Należy zwrócić uwagę na fakt, że wychodząc naprzeciw wyzwaniom związanym z dynamicznymi przemianami gospodarczymi oraz problemami rynku pracy w warunkach dekoniunktury gospodarczej, w nawiązaniu do Zalecenia Parlamentu i Rady UE (Zalecenie ..., 2006) w wielu krajach europejskich opracowano specjalne strategie implementacji bądź rozwoju kształcenia w zakresie przedsiębiorczości w kształceniu ogólnym na różnych szczeblach edukacji. Działania takie podjęto w sześciu krajach (Dania, Estonia, Litwa, Niderlandy, Szwecja, Norwegia) i dwóch regionach (część flamandzka Belgii, Walia w Wielkiej Brytanii). Są to najbardziej innowacyjne kraje i regiony północnej Europy. W pozostałych krajach, podobnie jak w Polsce, działania na rzecz szerszego włączenia przedsiębiorczości w system edukacji są z reguły podejmowane jako elementy szerszej strategii rozwoju edukacji lub strategii gospodarczych. Jak bowiem zauważono w raporcie Entrepreneurship Education at School in Europe (Entrepreneurship..., 2012), Europa stoi przed wieloma wyzwaniami, na które może odpowiedzieć, jeśli ma innowacyjnych, dobrze wykształconych i przedsiębiorczych obywateli, którzy mają ducha i ciekawość do myślenia w nowy sposób, a także odwagę, by sprostać i dostosować się do wyzwań stojących przed nimi. Ponadto, dynamicznie zmieniająca się gospodarka, aby być innowacyjna i zdolna do tworzenia nowych miejsc pracy, wymaga większej liczby młodych ludzi, którzy są gotowi i zdolni do podjęcia działalności gospodarczej. A ponieważ edukacja jest kluczem do kształtowania postaw młodych ludzi, ich umiejętności i kultury, ważne jest, żeby nauczanie przedsiębiorczości rozpoczynało się od najmłodszych lat. Kształcenie w zakresie przedsiębiorczości ma kluczowe znaczenie dla kształtowania postaw młodych ludzi, a także zapewnia wiedzę i umiejętności, które są najważniejsze dla rozwoju kultury przedsiębiorczości, będącej podstawą każdej innowacyjnej współczesnej gospodarki.

\section{Opinie partnerów społecznych o roli kompetencji osobistych i społecznych w handlu de- talicznym i edukacji}

W wyniku podjętych działań w pierwszym etapie realizacji projektu - nawiązania kontaktu z partnerami społecznymi (pracodawcami, organizacjami pracodawców i związkami zawodowymi) i przeprowadzenia pogłębionych wywiadów z ich przedstawicielami - uzyskano wyniki pozwalające określić potrzeby i wymagania w sektorze handlu detalicznego w zakresie rozwijania kompetencji osobistych i społecznych. Opinie te dotyczyły czterech kompetencji i zarazem modułów kształcenia, dla których przygotowane zostały materiały dydaktyczne. Były to: umiejętność przyjmowania krytyki, pracy w zespole, zarządzania czasem oraz samooceny mocnych i słabych stron.

W odniesieniu do znaczenia umiejętności świadomego przyjmowania krytyki partnerzy społeczni zwracali uwagę, że bardzo trudno jest nie tylko pracować, ale żyć z ludźmi, którzy 
nie przyjmują konstruktywnej krytyki. Są oni trudni we współpracy i ciężko jest rozwiązywać z nimi problemy pojawiające się w pracy. Partnerzy zwracali uwagę na fakt, że przyjmowanie krytyki jest bardzo ważne, gdyż brak tej umiejętności przenosi się na postawy wobec klientów. Pracownik, który nie jest w stanie przyjąć krytyki swojego szefa, najczęściej obraża klienta i źle go traktuje. Jeden z pracodawców zwracał również uwagę, że w pracy często spotyka się z sytuacjami, w których pracownik się obraża, kiedy - jako właściciel i kierownik - zwraca mu grzecznie uwagę, aby coś wykonał inaczej lub że nie wykonał niektórych zadań. To sprawia, że trudno jest rozwijać relacje między przełożonymi a podwładnymi. Pracownicy przenoszą to zachowanie później na klientów, którzy np. domagają się reklamacji towaru, traktując to jako niesłuszną krytykę ze strony klienta. Rozmówcy podkreślali, iż niestety rozwój tej kompetencji jest bardzo trudny, ponieważ większość ludzi nie chce i nie będzie przyjmować krytyki. Wynika to z psychologii człowieka: nikt nie lubi, gdy ktoś zwraca mu uwagę. Pracodawcy podkreślali również, że kompetencja ta jest bardzo ważna w każdym sektorze gospodarki, nie tylko w handlu. Nie można współpracować z innymi osobami, w tym z przełożonymi, bez tej kompetencji. Trzeba być w stanie przyjmować konstruktywną krytykę w każdej pracy. Krytyka jest niezbędna, zwłaszcza w relacji szef - podwładny lub pomiędzy pracownikami tego samego poziomu. W rozmowach najczęściej przewijał się pogląd, że kompetencja ta jest bardzo ważna, ale trudna do opanowania.

W zakresie umiejętności pracy w zespole partnerzy wskazywali, że w dzisiejszym świecie jest to jedna z kluczowych kompetencji, gdyż, jak powszechnie wiadomo, razem możemy osiągnąć więcej niż osobno. Pracodawcy są więc świadomi ogromnej roli synergii w pracy zespołowej. Zwracał na to też uwagę m.in. S. Covey $(2003,2004)$, który umiejętność tę opisywał jako jedną z podstawowych zasad skutecznego działania i przewodzenia ludziom. Właściciele sklepów detalicznych twierdzili, że w zarządzaniu sklepem praca zespołowa jest najważniejsza. Prowadzenie sklepów składa się z różnorodnych zadań, na sali sprzedaży i w biurze, od rozpakowania dostawy do finalizowania transakcji z klientem przy kasie. Aby te zadania były wykonywane płynnie, potrzeba doskonałej współpracy między sprzedawcami, jak również między sprzedawcami a zespołem zarządzającym. Jest to szczególnie ważne w małych przedsiębiorstwach w sektorze usług i handlu - zwłaszcza w małym sklepie, gdzie kilka osób pracuje na małej powierzchni. Czasami osoby te mają wspólne zadania, a czasami po prostu pracują obok siebie. Ponieważ są w różnych grupach wiekowych i posiadają różne doświadczenia oraz nawyki, mogą pojawić się różne problemy, szczególnie przy pracy na małej przestrzeni. Dlatego współdziałanie w grupie jest bardzo ważne. Jeden z respondentów zwrócił jednak uwagę, że zależy to od organizacji handlu w danym sklepie. Osoba, która pełne osiem godzin siedzi przy biurku/kasie w sklepach wielkopowierzchniowych (hipermarketach), zwykle nie jest w stanie wykazywać tych kompetencji, a jej przełożeni pewnie nie przywiązują do tej kompetencji dużej wagi. Pracodawcy podkreślali też, że kompetencja ta jest bardzo ważna podczas pracy w różnych firmach, nie tylko w sektorze handlu detalicznego, a współcześnie istnieje coraz mniej zawodów, w którym nie trzeba pracować w zespole.

Jeżeli chodzi o umiejętność zarządzania czasem, partnerzy społeczni podkreślali, że jest ona nie tylko potrzebna w pracy, ale też w naszym życiu zawodowym i osobistym. Dobre planowanie sprawia, że życie nie będzie zbyt chaotyczne i można je będzie zaplanować zgodnie z własnymi celami i wartościami. Zaznaczali oni, że w każdym biznesie czas to pieniądz. Bez dobrego zarządzania czasem marnuje się więc zasoby, które są zawsze ograniczone. Dzięki dobrej organizacji czasu można alokować swoje zasoby w sposób najbardziej efektywny i osiągnąć najlepsze możliwe wyniki. Partnerzy zwrócili też uwagę na fakt, że handel detaliczny, zwłaszcza w bezpośredniej obsłudze klienta, jest specyficzny. Kiedy klient pojawia się w sklepie, nie moż- 
na odroczyć jego sprawy na później. Trzeba więc zatrzymać wykonywanie innych czynności, takie jak odbieranie lub układanie towarów, a następnie wrócić do ich wykonywania. Dlatego ważne jest, aby zaplanować czas i mieć zdolność do wykonywania wielu rzeczy na raz. Jeden z pracodawców podkreślał praktyczne aspekty posiadania tej umiejętności przez pracowników dla właściciela firmy. Dla niego jest to bardzo ważna kompetencja, bo jeśli pracownicy jej nie mają, to oznacza, że będzie musiał być jako szef (właściciel) ciągle obecny w miejscu pracy, nakazując im, co mają zrobić w danej chwili. Taka organizacja pracy z punktu widzenia efektywności funkcjonowania przedsiębiorstwa nie ma sensu. Dlatego uważa on, że pracownicy powinni mieć dużą samodzielność, gdyż najlepiej wiedzą, co należy robić w danym momencie, nawet gdy nie ma właściciela w firmie, bo załatwia inne sprawy biznesowe. Ponadto podkreślał on, że ma to znaczenie w zakresie motywowania do pracy: narzucanie pracownikom planu dnia byłoby bardzo złe, bo ludzie poczuliby, że szef nie ma do nich zaufania. Potwierdził to stanowisko inny pracodawca, który podkreślał, że przecież pracownicy w sklepie muszą sami wiedzieć, co i kiedy mają robić, a nie czekać na szefa, który przyjdzie i dokładnie wyznaczy zadania oraz czas ich realizacji. W świetle wypowiedzi partnerów można wnosić, że to jest ważna kompetencja w każdej pracy, nie tylko w handlu detalicznym. Jej znaczenie zależy jednak od charakteru pracy, jak jest ona zorganizowana, np. w sklepach wielkopowierzchniowych (hipermarketach), gdy ktoś pracuje przy kasie, nie ma możliwości wykazać się dobrą organizacją swojego czasu pracy, a więc występuje podobna sytuacja jak w przypadku umiejętności pracy w zespole.

Również czwarta kompetencja uznana została przez partnerów społecznych jako bardzo ważna. Pracodawcy oczekują bowiem od pracowników oceny swoich kompetencji: mocnych i słabych stron. Jest dla nich istotne, jak pracownik ocenia swoje kompetencje, gdyż przyczynia się to do rozwoju pracownika. Bez tych umiejętności pracownicy nie są zwykle bardzo efektywni, nie potrafią ocenić siebie, jak również środowiska, w którym funkcjonują. Ich zdaniem ważne jest, aby dowiedzieć się, jakie są własne możliwości i jak można je wykorzystać w firmie, takiej jak sklep. Jeden z respondentów zwracał uwagę na fakt, że przyjmowanie krytyki i samoocena mają bardzo wiele wspólnego. Osoba, która nie jest w stanie przyjąć konstruktywnej krytyki, z reguły nie jest w stanie przyznać przed sobą, że ma pewne słabości. Dlatego ta ważna kompetencja powinna być rozwijana już od szkoły podstawowej. W szkole zawodowej jest na to trochę za późno, gdyż uczeń przed wyborem profilu szkoły ponadgimnazjalnej (szkoła zawodowa, technikum lub liceum) musi poznać swoje mocne i słabe strony. Zdaniem respondentów jest to kompetencja bardzo przydatna także w życiu codziennym, a zrozumienie własnego potencjału i umiejętność przekazania informacji o swoich własnych mocnych i słabych stronach jest bardzo ważna dla udanej współpracy w grupie. Kompetencja ta może być więc traktowana jako podstawa umiejętności synergicznej pracy zespołowej. Warto jednak podkreślić, że proszeni o hierarchizację wszystkich czterech kompetencji rozmówcy wskazywali, że z punktu widzenia funkcjonowania przedsiębiorstwa samoocena może być uznana za istotną, ale mniej ważną kompetencję w porównaniu z innymi. Jest natomiast niezwykle przydatna w życiu każdego człowieka, w jego osobistym rozwoju, dlatego nie można jej pominąć w toku edukacji szkolnej.

W trakcie wywiadów zebrano także opinie o liczących po kilkadziesiąt stron przygotowywanych materiałach dydaktycznych, obejmujących oprócz szczegółowego scenariusza zajęć także materiały dodatkowe i karty pracy dla uczniów. Zdaniem jednego z rozmówców problematyka ta jest tak ważna, że powinien być nawet odrębny obowiązkowy dla wszystkich przedmiot w szkole mający na celu przygotowanie do życia w społeczeństwie i rozwijanie kompetencji społecznych. Wszyscy partnerzy podkreślali, że proponowane narzędzia dydaktyczne są ciekawe i niosą jasne przesłanie. Zastanawiali się jednak, czy z tych bardzo ciekawych materiałów nauczyciele będą chcieli korzystać i czy będą to robili odpowiednio. Szczególnie spodobały 
się ćwiczenia z zakresu dobrej współpracy w zespole, polegające na wspólnym projektowaniu i budowaniu mostu między ławkami szkolnymi. Budowa mostu jest bardzo odpowiedzialnym i dość skomplikowanym zadaniem, więc rozwija kompetencje zespołu, ponadto most jest także symboliczny: teamwork to budowanie mostów między ludźmi - pozwala lepiej się komunikować, ufać sobie nawzajem. Należy jednak zwrócić uwagę na fakt, że partnerzy społeczni z zagranicy (w wyniku badań partnerów zagranicznych projektu) zaproponowali zamianę mostu na coś bardziej kojarzącego się z handlem (projektowanie i konstruowanie z tektury pudełka do pakowania towaru z zamknięciem). W przypadku materiałów dotyczących samooceny zwrócono uwagę na fakt, że uczniowie mogą się wstydzić pokazywać swoje mocne i słabe strony przy całej klasie. Ponadto, jeden z pracodawców zauważył, że największym problemem współcześnie w Polsce jest brak konieczności posiadania formalnych kwalifikacji do określonego zawodu. Jeśli zostałby przywrócony taki system jak wcześniej, to uczniowie byliby bardziej zmotywowani i bardziej troszczyli się o to, aby rozpoznać swoje mocne i słabe strony oraz wybrać odpowiednią szkołę, przygotowującą do zawodu, który jest zgodny z ich potencjałem i możliwościami. W przeciwnym razie bardzo często wybór profilu szkoły i zawodu jest przypadkowy.

\section{Zakończenie}

Badania przeprowadzone wśród partnerów społecznych wykazały dużą rolę analizowanych kompetencji. Partnerzy wskazali też na wysoką przydatność proponowanych materiałów dydaktycznych w procesie kształcenia z punktu widzenia kształtowania kompetencji społecznych i osobistych przyszłych sprzedawców (handlowców). Ich zdaniem materiały te obejmują cztery, najważniejsze, umiejętności (kompetencje) przydatne nie tylko w sektorze handlu, ale także w każdej innej pracy i życiu osobistym. Dlatego można je wykorzystywać także w szkołach o innym profilu, a nawet na lekcjach przedsiębiorczości w liceach ogólnokształcących. Respondenci przedstawili propozycje niewielkich zmian w materiałach dydaktycznych, niezmieniających istotnych założeń każdego z czterech modułów kształcenia.

Faza wdrożeniowa (testowa) w szkołach, której zakończenie planowane było na początek II kwartału 2013 r. pozwoliła na dalszą optymalizację materiałów pod kątem potrzeb szkół zawodowych kształcących dla sektora handlu detalicznego. Już jednak pierwszy etap realizacji projektu wskazał na wysoką aktualność i potrzebę realizacji tego typu działań w polskiej szkole.

\section{Literatura}

Berger, S., Canning, R., Dolan, M., Kurek, S., Pilz, M., Rachwał, T. (2012). Curriculum-making in prevocational education in the lower secondary school: A regional comparative analysis within Europe. Journal of Curriculum Studies, 44 (5), 679-701.

Borowiec, M., Rachwał, T. (2011). Kształtowanie postaw przedsiębiorczych na lekcjach geografii wyzwaniem edukacyjnym w procesach globalizacji. Przedsiębiorczość - Edukacja, 7, 321-332.

Choinkowska, E. (2012). Budowanie postaw przedsiębiorczych w pracy pedagogicznej przez oddziaływanie psychologiczne. Przedsiębiorczość - Edukacja, 8, 127-136.

Cieślik, J. (2007). Kształcenie w zakresie przedsiębiorczości na poziomie akademickim. W: P. Wachowiak, M. Dabrowski, B. Majewski (red.), Kształtowanie postaw przedsiębiorczych a edukacja ekonomiczna. Warszawa: Fundacja Promocji i Akredytacji Kierunków Ekonomicznych, 71-80.

Covey, S.R. (2003). 7 nawyków skutecznego działania. Poznań: Rebis.

Covey, S.R. (2004). Zasady skutecznego przywództwa, Poznań: Rebis. 
Czapliński, P. (2011). Funkcjonowanie przemysłu przetwórstwa rybnego w Polsce w okresie kryzysu gospodarczego. Prace Komisji Geografii Przemystu Polskiego Towarzystwa Geograficznego, 17, 114-128.

Dorocki, S. (2011). Wpływ kryzysu gospodarczego na przemiany struktur regionalnych Francji. Prace Komisji Geografii Przemystu Polskiego Towarzystwa Geograficznego, 17, 67-86.

Dorocki, S., Kilar, W., Rachwał, T., Świętek, A., Zdon-Korzeniowska, M. (2012). Biznesplan krok po kroku. Poradnik dla uczniów i uczennic. III część produktu finalnego. Warszawa: wydawnictwo Nowa Era.

Entrepreneurship Education at School in Europe. National Strategies, Curricula and Learning Outcomes (2012). Education, Audiovisual and Culture Executive Agency. Brussels: Eurydice.

Gabała, J. (2005). Kształtowanie postaw przedsiębiorczych uczniów. Przedsiębiorczość - Edukacja, 1, $145-152$.

Jankowska, B., Pietrzykowski, M. (2012). Postawy proprzedsiębiorcze studentów a profil kształcenia Polska na tle innych krajów. Przegląd Organizacji, 8, 28-32.

Jankowska, B., Pietrzykowski, M. (2013). Pro-entrepreneurial attitudes of students in relation to their educational profile: Poland against the background of other countries. Interdisciplinary Studies Journal, 2 (4), 83-102.

Juchnowicz, K. (2007). Polityka edukacyjna wobec potrzeb rynku pracy. W: P. Wachowiak, M. Dabrowski, B. Majewski (red.), Kształtowanie postaw przedsiębiorczych a edukacja ekonomiczna. Warszawa: Fundacja Promocji i Akredytacji Kierunków Ekonomicznych, 40-46.

Juchnowicz, M. (2005). Uwagi dotyczące realizacji przedmiotu podstawy przedsiębiorczości. Przedsiębiorczość - Edukacja, 1, 189-193.

Kilar, W. (2011). Wpływ kryzysu na funkcjonowanie korporacji Panasonic. Prace Komisji Geografii Przemystu Polskiego Towarzystwa Geograficznego, 17, 187-196.

Kilar, W., Rachwał, T., Zając, M. (2012). Poradnik metodyczny dla nauczycieli i nauczycielek. II część produktu finalnego. Warszawa: wydawnictwo Nowa Era.

Kitowski, J. (2009). Influence of Global Economic Crisis on Operation of Special Economic Zones in Poland. Geopolitical Studies, 15, 241-267.

Kitowski, J. (2011). Wpływ kryzysu finansowego i gospodarczego na efekty funkcjonowania specjalnych stref ekonomicznych w Polsce. W: B. Namyślak (red.), Przeksztatcenia regionalnych struktur funkcjonalno-przestrzennych. Współczesne kierunki przemian społeczno-ekonomicznych, Rozprawy Naukowe Instytutu Geografii i Rozwoju Regionalnego, 19, Wrocław, 23-39.

Kompetencje kluczowe w uczeniu się przez całe życie. Europejskie Ramy Odniesienia. (2007). Luxembourg: Urząd Oficjalnych Publikacji Wspólnot Europejskich.

Kurek, S., Rachwał, T. (2010). The Role of Business Education in the Development of Entrepreneurship in the Member States of the European Union, Europa XXI, 19, 127-142.

Kurek, S., Rachwał, T. (2011). Development of entrepreneurship in ageing populations of The European Union, Procedia. Social and Behavioral Sciences, 19 (2011), 397-405.

Kurek, S., Rachwał, T. (2012). Vocational Education and Training in Poland During Economic Transition. In: M. Pilz (ed.), The Future of Vocational Education and Training in a Changing World. Wiesbaden: Springer, 321-340.

Kurek, S., Rachwał, T., Szubert, M. (2012a). Business Competencies in Polish School Curricula: Opinions of Teachers and Social Partners. In: M. Pilz, S. Berger, R. Canning (eds), Fit for Business. PreVocational Education in European Schools, Wiesbaden: Springer, 61-88.

Kurek, S., Rachwał, T., Szubert, M. (2012b). Kształtowanie kompetencji biznesowych uczniów gimnazjum w świetle opinii nauczycieli na podstawie wyników badań prowadzonych w ramach europejskiego projektu FIFOBI. Przedsiębiorczość - Edukacja, 8, 24-36.

Nowak, P. (2011). Funkcjonowanie sektora motoryzacyjnego w okresie kryzysu w latach 2008-2009. Prace Komisji Geografii Przemystu Polskiego Towarzystwa Geograficznego, 17, 177-186.

Osuch, W. (2011). Kompetencje w zakresie komunikacji interpersonalnej w dobie postępujących procesów globalizacji. Przedsiębiorczość - Edukacja, 7, 177-186.

Osuch, W. (2012). Ocena wykształcenia kompetencji przedmiotowych z geografii społeczno-gospodarczej a wybrane aspekty innowacyjności w edukacji i kształceniu nauczycieli. Annales Universitatis Paedagogicae Cracoviensis Studia Geographica, 3, 122-137. 
Pietrzykowski, M. (2011). Entrepreneurship in Higher Education - the case of Poland. In: M. Dabić, M. Pietrzykowski (eds), Fostering Education in Entrepreneurship, Poznań: Bogucki Wydawnictwo Naukowe, 113-128.

Piróg, D. (2011a). Usługi edukacyjne na poziomie akademickim w kontekście wymagań rynku pracy, Prace Komisji Geografii Przemystu Polskiego Towarzystwa Geograficznego, 18, 23-36.

Piróg, D. (2011b). Graduates of geographical studies on the labour market in the process of transformation in higher education. Prace i Studia Geograficzne, 48, Prace Instytutu Geografii UJK, 18, 161-172.

Piróg, D. (2012a). Changes to the conception of geography curricula within university education in Poland in the 21 st century in the face of labour market challenges. European Journal of Geography, $3(2), 24-41$.

Piróg, D. (2012b). Methods for efficiency improvement of geographical studies within the scope of procurement of work by graduates exemplified by solutions applied in Great Britain and in Germany. In: B. Wójtowicz (ed), Natural sciences in educational systems of European countries in the 21 st century. Kraków: Wydawnictwo DEHON, 129-141.

Rachwał, M., Rachwał, T. (2005), Rola kształcenia umiejętności obsługi klienta na lekcjach podstaw przedsiębiorczości. Przedsiębiorczość - Edukacja, 1, 221-226.

Rachwał, T. (2004a). Podstawy przedsiębiorczości. Słownik, Warszawa: wydawnictwo Nowa Era.

Rachwał, T. (2004b). Cele i treści kształcenia przedsiębiorczości w szkołach ponadgimnazjalnych. W: J. Brdulak, M. Kulikowski (red.), Przedsiębiorczość stymulatorem rozwoju gospodarczego, Warszawa: Instytut Wiedzy, 263-270.

Rachwał, T. (2006). Kształtowanie postaw przedsiębiorczych w edukacji szkolnej. W: B. Muchacka (red.), Szkoła w nauce i praktyce edukacyjnej, t. II, Kraków: Oficyna Wydawnicza „Impuls”, Akademia Pedagogiczna w Krakowie, 427-434.

Rachwał, T., (2011). Wpływ kryzysu na zmiany produkcji przemysłowej w Polsce. Prace Komisji Geografii Przemystu Polskiego Towarzystwa Geograficznego, 17, 99-113.

Rachwał, T., Zdon-Korzeniowska, M. (2011). Turystyka w warunkach światowego kryzysu gospodarczego. Prace Komisji Geografii Przemystu Polskiego Towarzystwa Geograficznego, 18, 116-128.

Rachwał, T., Ratajski, P., Zając M. (2012). Innowacyjna Strategia Kształcenia „Krok w przedsiębiorczość”. I część produktu finalnego. Warszawa: wydawnictwo Nowa Era.

Rettinger, R., Staszak, P. (2011), Wpływ kryzysu na wielkość pasażerskiego ruchu lotniczego na świecie na podstawie wybranych przykładów. Prace Komisji Geografii Przemysłu Polskiego Towarzystwa Geograficznego, 18, 129-138.

Šerý, O. (2011). The impact of economic crisis on regions dominated by motor vehicles industry (the case of Vysočina Region). Prace Komisji Geografii Przemystu Polskiego Towarzystwa Geograficznego, $17,155-163$.

Surdej, A., Wach, K. (2007). Entrepreneurship as the Challenge for Polish Economy in the 21st Century. Miskolc University - Faculty of Economics Conference Proceedings. Pozyskane z: http://dx.doi. org/10.2139/ssrn.1113531.

Świętek, A. (2012). Oczekiwania a realia wejścia ludzi młodych na rynek pracy jako wyzwanie dla edukacji z przedsiębiorczości. Przedsiębiorczość - Edukacja, 8, 137-154.

Świłło, I. (2012), „Jestem przedsiębiorczy - kształtowanie postaw przedsiębiorczych wśród młodzieży z wykorzystaniem innowacyjnych technik i narzędzi”. Prezentacja projektu, Przedsiębiorczość Edukacja, 7, 64-70.

Uliszak, R. (2011). Przejawy kryzysu we współczesnym rolnictwie. Prace Komisji Geografii Przemystu Polskiego Towarzystwa Geograficznego, 18, 101-115.

Wach, K. (2007). Kształtowanie postaw przedsiębiorczych w programach nauczania. Stan obecny i proponowane kierunki zmian. W: P. Wachowiak, M. Dabrowski, B. Majewski (red.), Kształtowanie postaw przedsiębiorczych a edukacja ekonomiczna. Warszawa: Fundacja Promocji i Akredytacji Kierunków Ekonomicznych, 120-127.

Wach, K. (2008). Entrepreneurship Education in Poland. ERENET Profile, vol. III, no. 3 (11), 36-44.

Wójtowicz, M. (2011). Wpływ światowego kryzysu gospodarczego na brazylijski i meksykański przemysł samochodowy. Prace Komisji Geografii Przemystu Polskiego Towarzystwa Geograficznego, 17, 
Zalecenie Parlamentu Europejskiego i Rady z dnia 18 grudnia 2006 r. w sprawie kompetencji kluczowych w procesie uczenia się przez całe życie (2006/962/WE).

Zioło, Z. (2011). Wpływ światowego kryzysu na tempo wzrostu gospodarki i światowych korporacji. Prace Komisji Geografii Przemystu Polskiego Towarzystwa Geograficznego, 17, 9-32.

Zioło, Z. (2012). Miejsce przedsiębiorczości w edukacji. Przedsiębiorczość - Edukacja, 8, 10-23.

Wioletta Kilar, dr, Uniwersytet Pedagogiczny im. Komisji Edukacji Narodowej w Krakowie, Instytut Geografii, Zakład Przedsiębiorczości i Gospodarki Przestrzennej.

Geograf ekonomiczny. Adiunkt w Zakładzie Przedsiębiorczości i Gospodarki Przestrzennej Instytutu Geografii Uniwersytetu Pedagogicznego w Krakowie, Sekretarz Rady Redakcyjnej czasopisma „Prace Komisji Geografii Przemysłu Polskiego Towarzystwa Geograficznego". Posiada znaczne doświadczenie jako nauczyciel geografii i podstaw przedsiębiorczości, które zdobyła pracując w kilku ponadgimnazjalnych szkołach krakowskich. Jej zainteresowania badawcze ukierunkowane są przede wszystkim na procesy kształtowania się i funkcjonowania ponadnarodowych korporacji, globalizacji, przemian struktur przestrzennych przemysłu oraz problematykę nauczania przedsiębiorczości i geografii w szkole. Jest autorem i współautorem licznych publikacji z zakresu geografii społeczno-ekonomicznej i przedsiębiorczości oraz wielu materiałów dydaktycznych, edukacyjnych i ekspertyz.

Wioletta Kilar, PhD, Pedagogical University of Cracow, Institute of Geography, Department of Entrepreneurship and Spatial Management.

An economic geographer. Lecturer at Department of Entrepreneurship and Spatial Management of Institute of Geography of the Pedagogical University of Cracow. Secretary of the Editorial Board of the Studies of the Industrial Geography Commission of the Polish Geographical Society. Possesses considerable experience as a teacher of geography and basics of entrepreneurship, having been employed at several secondary schools in Krakow. Research interests focus primarily on the processes of formation and operation of multinational corporations, globalization, transformation of spatial structures of industry, and issues of entrepreneurship and geography education at school. Author of numerous publications in the area of socio-economic geography and entrepreneurship, and various teaching and educational materials and expertise.

Sławomir Kurek, dr hab., profesor Uniwersytetu Pedagogicznego, Uniwersytet Pedagogiczny im. Komisji Edukacji Narodowej w Krakowie, Instytut Geografii, Zakład Geografii Społeczno-Ekonomicznej.

Geograf społeczno-ekonomiczny. Członek Komitetu Nauk Demograficznych PAN. Pełni m.in. funkcję zastępcy dyrektora Instytutu Geografii ds. Nauki i Współpracy Zagranicznej, kierownika Studiów Doktoranckich z Geografii oraz redaktora naczelnego czasopisma „Annales Universitatis Paedagogicae Cracoviensis, Studia Geographica”. Jego zainteresowania badawcze skupiają się przede wszystkim na problematyce przemian struktur społeczno-demograficznych Polski i Europy, procesów suburbanizacji w obszarach metropolitalnych oraz edukacji w zakresie przedsiębiorczości.

Stawomir Kurek, associate professor at the Pedagogical University of Cracow, Institute of Geography, Department of Socio-Economic Geography.

A socio-economic geographer. Member of the Committee on Demographic Studies of the Polish Academy of Sciences. He is, among other activities, the Deputy Head for Research and International Relations of Institute of Geography, Head of Doctoral Studies in geography at the Pedagogical University, and Editor in Chief of Annales Universitatis Paedagogicae Cracoviensis, Studia Geographica. Research interests focus primarily on the issue of changes of the socio-demographic structures in Poland and Europe, suburbanisation processes in metropolitan areas, as well as entrepreneurship education. 
Tomasz Rachwal, dr, Uniwersytet Pedagogiczny im. Komisji Edukacji Narodowej w Krakowie, Instytut Geografii, Zakład Przedsiębiorczości i Gospodarki Przestrzennej.

Geograf ekonomiczny, członek Krajowej Rady Przedsiębiorczości. Pełni m.in. funkcję Kierownika Zakładu Przedsiębiorczości i Gospodarki Przestrzennej Instytutu Geografii Uniwersytetu Pedagogicznego w Krakowie, Sekretarza Naukowego Komisji Geografii Przemysłu Polskiego Towarzystwa Geograficznego, Zastępcy Redaktora Naczelnego czasopism „Prace Komisji Geografii Przemysłu Polskiego Towarzystwa Geograficznego”, „Przedsiębiorczość - Edukacja” oraz „Annales Universitatis Paedagogicae Cracoviensis Studia Geographica". Jego zainteresowania badawcze skupiają się przede wszystkim na problematyce przemian struktur przestrzennych przemysłu, funkcjonowania różnych branż działalności gospodarczej, restrukturyzacji przedsiębiorstw oraz roli przedsiębiorczości w rozwoju układów przestrzennych oraz edukacji w zakresie przedsiębiorczości.

Tomasz Rachwal, PhD, Pedagogical University of Cracow, Institute of Geography, Department of Entrepreneurship and Spatial Management.

An economic geographer. Member of the National Council for Entrepreneurship. Head of Department of Entrepreneurship and Spatial Management of Institute of Geography of the Pedagogical University of Cracow, Scientific Secretary of the Industrial Geography Committee of the Polish Geographical Society, Deputy Editor in Chief of the following journals: Studies of the Industrial Geography Commission of the Polish Geographical Society, Entrepreneurship -Education and Annales Universitatis Paedagogicae Cracoviensis Studies Geographica. Research interests focus primarily on the issue of change of spatial structures of industry, the functioning of various branches of industrial activity, corporate restructuring and the role of entrepreneurship in the development of spatial systems and entrepreneurship education.

Adres/Address: Uniwersytet Pedagogiczny

Instytut Geografii, Zakład Przedsiębiorczości i Gospodarki Przestrzennej

ul. Podchorążych 2, 30-084 Kraków, Polska

e-mail: W.Kilar@up.krakow.pl, T.Rachwal@up.krakow.pl, sgkurek@up.krakow.pl

Publikacja powstała w ramach projektu „Retail Sector Competencies: Developing self and social competencies in vocational training for the retail sector (ReSeCo) / Kompetencje Sektora Handlu Detalicznego - kształtowanie kompetencji osobistych i społecznych w szkolnictwie zawodowym dla sektora handlu detalicznego" realizowanego przy wsparciu finansowym Komisji Europejskiej w ramach Programu „Uczenie się przez całe życie” (Lifelong Learning Programme), numer projektu DE/11/LLP-LdV/ TOI/147405. Publikacja odzwierciedla jedynie stanowisko ich autorów i Komisja Europejska nie ponosi odpowiedzialności za umieszczoną w nich zawartość merytoryczną.
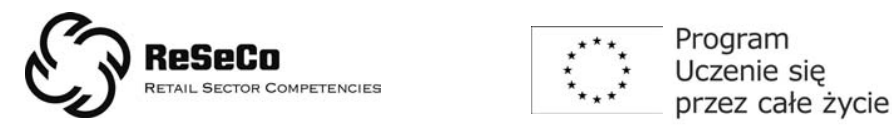


\title{
Agata Pradela
}

Politechnika Śląska

\section{Rola systemu poradnictwa zawodowego w edukacji i tworzeniu inicjatyw klastrowych w systemie oświaty na przykładzie miast: Zabrza, Gliwic i Rybnika}

\author{
The role of vocational advisory services in the creation of cluster initiatives \\ in the educational systems in Zabrze, Gliwice and Rybnik
}

\begin{abstract}
Streszczenie
Procesy podejmowania decyzji przez abiturientów szkół różnych szczebli są kluczowe dla dalszej kariery edukacyjnej i zawodowej młodzieży. W warunkach dynamicznych zmian gospodarczych coraz większą rolę odgrywa system orientacji i poradnictwa zawodowego, którego nadrzędną rolą jest udzielanie wsparcia uczniom w planowaniu dalszej ścieżki kariery, zgodnie z ich potrzebami, predyspozycjami, ale też wymaganiami rynku. Artykuł przedstawia wyniki badań dotyczących systemu orientacji i poradnictwa zawodowego, przeprowadzonych na terenie województwa śląskiego. W pierwszej części artykułu przedstawiono modelową strukturę systemu doradztwa zawodowego w Zabrzu oraz działania władz miasta zmierzające w kierunku rozwoju tego systemu. W drugiej części przedstawiono wyniki badań systemu doradztwa zawodowego w Gliwicach i Rybniku w następujących aspektach: sposoby poszukiwania informacji nt. dalszej ścieżki edukacji i kariery, znajomość doradców zawodowych i oceny ich kompetencji, efektywność lekcji z przedmiotu podstawy przedsiębiorczości, potrzeby informacji nt. perspektyw na rynku pracy.
\end{abstract}

\begin{abstract}
Decision making processes of graduates of all educational levels are essential to the creation of their educational and career paths. In the conditions of dynamic economical changes, the systems of vocational advisory services play a very important role. Their main task is to provide professional consulting on career planning for pupils and graduates in accordance with their needs, attitudes and requirements of the labour market. This article presents research on the vocational advisory system, carried out in the Silesia region. The first part highlights the well-organised structure of the vocational advice system in Zabrze. The second part presents research on vocational advisory systems, carried out in Gliwice and Rybnik, in the following aspects: ways of researching information about career paths among respondents, effectiveness of the work of vocational advisors, effectiveness of lessons on 'basics of entrepreneurship', the need for information on labour market perspectives.
\end{abstract}

Slowa kluczowe: potrzeby edukacyjne; system doradztwa zawodowego; ścieżka kariery edukacyjnej i zawodowej; zarządzanie oświatą

Key words: educational needs; vocational advisory system; career paths of graduates; educational management. 


\section{Wprowadzenie}

Z przeciwdziałaniem bezrobociu wśród absolwentów są związane podmioty dwóch resortów: Ministerstwa Edukacji Narodowej oraz Ministerstwa Pracy i Polityki Społecznej. Ich działania przebiegają w dwóch etapach:

- etap pierwszy obejmuje proces poradnictwa zawodowego, realizowany w strukturach systemu oświaty,

- etap drugi obejmuje działania skierowane do absolwentów, prowadzone głównie przez powiatowe urzędy pracy.

Wymienione działania uzupełniają proces kształcenia, wspomagają ucznia w wyborze szkoły zgodnie z predyspozycjami i potrzebami rynku pracy oraz w poszukiwaniu pracy. Kształtowanie postaw przedsiębiorczych jest elementem edukacji na wszystkich przedmiotach, przez wszystkich nauczycieli i, jak zauważył Z. Zioło (2011), wymaga przyjaznych sytuacji w otoczeniu lokalnym, regionalnym oraz krajowym, w szczególności:

- dbania o podnoszenie jakości instytucji edukacyjnych na każdym poziomie,

- tworzenia klimatu innowacyjności i rozwijania kultury innowacyjnej,

- przyjaznego stosunku i jakości władz samorządowych do podnoszenia konkurencyjności obszaru,

- kształtowania sprawnie działającego otoczenia finansowego.

Istotne znaczenie w przygotowaniu młodzieży do aktywnego udziału w rynku pracy ma lokalny system doradztwa zawodowego w danej jednostce samorządowej. Jego działania uzupełniają edukację w ramach poszczególnych przedmiotów. Skuteczny system doradztwa zawodowego jest pomostem między edukacją a rynkiem pracy i powinien dostarczać wiedzy na temat potrzeb tego rynku i wspierać współpracę szkół z osobami przedsiębiorczymi (potencjalnymi pracodawcami i miejscami praktyk zawodowych). Teza postawiona przez M. Borowiec (2011), iż głównym wyzwaniem dla edukacji jest kształtowanie umiejętności współpracy, budowania warsztatu naukowego, który będzie umożliwiał podejmowanie działań w zakresie doskonalenia zawodowego, umiejętności wykorzystania wiedzy, rozumienia dynamicznych zmian w gospodarce, kształtowania postaw przedsiębiorczych, etycznych i odpowiedzialności jest weryfikowana w praktyce przedsiębiorstw. Pracodawcy w badaniach autorki wielokrotnie wskazują na braki w kompetencjach wskazanych przez M. Borowiec, a system doradztwa zawodowego, badając rynek pracy, powinien aktywnie reagować na procesy edukacji i działania doradztwa zawodowego.

Niniejszy artykuł przedstawia wyniki badań nad skutecznością działań systemu doradztwa zawodowego w Gliwicach i Rybniku. Jest to fragment badań realizowanych w ramach własnego projektu badawczego pt. „Tworzenie inicjatyw klastrowych w systemie oświaty”, finansowanego ze środków Ministerstwa Nauki i Szkolnictwa Wyższego (nr umowy 0193/B/ H03/2010/39).

\section{Struktura lokalnego systemu doradztwa zawodowego}

Podmioty i instytucje szczebla krajowego są odpowiedzialne za tworzenie ogólnych wytycznych i zarysów działań doradców zawodowych, służą im wsparciem i pomocą ekspertów, niemniej dopiero działania i procesy realizowane na szczeblu szkół przekładają się bezpośrednio na efektywne przygotowania młodzieży do wejścia na rynek pracy.

Modelowa struktura lokalnego systemu doradztwa zawodowego obejmuje:

- doradców zawodowych,

- pedagogów szkolnych,

- wychowawców klas, 
- nauczycieli przedmiotów zawodowych,

- opiekunów praktyk zawodowych,

- nauczycieli praktycznej nauki zawodu,

- nauczycieli przedsiębiorczości,

- dyrektorów szkół,

- poradnie psychologiczno-pedagogiczne,

- szkolne ośrodki kariery,

- organ prowadzący szkoły i placówki,

- pracodawców.

Struktura lokalnego systemu doradztwa zawodowego zależy od uwarunkowań danej jednostki samorządowej i polityki oświatowej prowadzonej w jednostce. Zaś działania systemu bądź niechęć władz do podejmowania tematu tworzenia i funkcjonowania systemu doradztwa rzutuje na decyzje uczniów dotyczące wyboru dalszej ścieżki kariery i na ich kompetencje na rynku pracy.

Stopień przygotowania do pracy w określonym zawodzie w dużej mierze zależy od umiejętności, jakie uczeń nabył w szkole na zajęciach z praktycznej nauki zawodu.

Wykształcenie, umiejętności, także wiedza o tym, jak poruszać się na rynku pracy, często nie wystarczają, aby znaleźć pracę. Wśród problemów, które napotyka młodzież w procesie wejścia na rynek pracy, dominują: niedopasowanie wiedzy i kwalifikacji oferowanych przez młodych kandydatów do wymagań pracodawców, powszechna niechęć pracodawców do zatrudniania osób bez doświadczenia zawodowego, konieczność ponoszenia kosztów szkoleń zawodowych oraz utrzymywania niedoświadczonych pracowników w okresie dochodzenia do pełnej wydajności pracy.

Działania systemu doradztwa zawodowego są integralną częścią edukacji. W szkole, na lekcjach wychowawczych i zajęciach z podstaw przedsiębiorczości uczeń powinien uzyskać pomoc w nabywaniu umiejętności wyboru zawodu i kierunku kształcenia. Zajęcia z przedmiotu podstawy przedsiębiorczości mają na celu uświadomienie uczniowi potrzeby kształtowania kariery zawodowej uwzględniającej jego zainteresowania i predyspozycje. Na nich uczeń powinien zdobyć wiedzę na temat ogólnych zasad poruszania się po rynku pracy, poznać prawne podstawy zatrudnienia, zdobyć wiedzę na temat prawidłowego przygotowania dokumentów niezbędnych przy ubieganiu się o pracę. Są to działania realizowane bez dodatkowego wsparcia finansowego i organizacyjnego ze strony szkoły i jednostki samorządowej. Konieczność ciągłej modyfikacji programów nauczania przedsiębiorczości podkreślają H. Wąsik (2010), a T. Rachwał w (2009) podsumował kilkuletni dorobek pracowników naukowych i praktyków oraz wskazał szczegółowe rekomendacje dla autorów podstawy programowej.

Przed reformą systemu oświaty w 1999 r. w każdej szkole jeden z nauczycieli pełnił funkcję koordynatora do spraw preorientacji zawodowej, ściśle współpracując z pełnomocnikiem ds. preorientacji zawodowej w poradni wychowawczo-zawodowej (obecnie jest to poradnia psychologiczno-pedagogiczna). Jego zadaniem była pomoc uczniom w wyborze szkoły i zawodu przez m.in.: ułatwienie kontaktu z pełnomocnikiem ds. preorientacji zawodowej w tej poradni, organizowanie spotkań uczniów z przedstawicielami różnych zawodów, organizowanie wycieczek do zakładów pracy. Bezpośrednio po reformie w 1999 r. system był krytykowany i nie przywiązywano wagi do doradztwa zawodowego. Popularyzowało się kształcenie ogólne, młodzież coraz rzadziej wybierała szkoły zawodowe i doradztwo zawodowe zostało zepchnięte na margines. Obecnie rośnie świadomość konieczności realizacji doradztwa zawodowego, rozwiązania sprzed reformy w 1999 r. uznaje się w wielu aspektach za użyteczne (Pradela, 2010). 
Współcześnie w każdej szkole jest zatrudniony pedagog szkolny, pełniący funkcję m.in. doradcy zawodowego. Istnieje także możliwość zatrudnienia doradcy zawodowego, lecz ze względów finansowych nie jest to korzystne dla budżetu organu prowadzącego. W dobie gospodarki rynkowej pedagog szkolny odgrywa dużą rolę, jest osobą, z którą kontaktuje się uczeń w sprawach wyboru kariery szkolnej i zawodowej - pod warunkiem, że uczeń wie o możliwości skorzystania z porady u pedagoga. Gdy jego pomoc jest niewystarczająca, kieruje on ucznia do poradni psychologiczno-pedagogicznej. Wielu nauczycieli ukończyło studia podyplomowe z zakresu doradztwa zawodowego i wykonuje tę pracę dodatkowo. Dobrym przykładem sprawnie funkcjonującego, modernizowanego i dostosowanego do potrzeb mieszkańców jest system doradztwa zawodowego w Zabrzu1.

Analizując system doradztwa w Zabrzu, należy wziąć po uwagę rozbudowaną strukturę szkół znajdujących się w tym mieście (tab. 1). Strukturę systemu poradnictwa zawodowego w Zabrzu tworzy Poradnia Psychologiczno-Pedagogiczna i zespół 21 doradców zawodowych, w tym 18 pełnozatrudnionych w szkołach ${ }^{2}$. Doradcy zawodowi są zatrudnieni w 15 szkołach i placówkach, w większości szkół ponadgimnazjalnych i w 10 gimnazjach. Zadania z zakresu szkolnego doradztwa zawodowego realizowane są również przez pedagogów szkolnych, nauczycieli (m.in. nauczycieli przedsiębiorczości) i wychowawców.

Tab. 1. Struktura szkół dla młodzieży w Zabrzu

\begin{tabular}{|l|c|c|c|}
\hline \multicolumn{1}{|c|}{ Typy szkól } & $\begin{array}{c}\text { Szkoły } \\
\text { i przedszkola } \\
\text { publiczne }\end{array}$ & $\begin{array}{c}\text { Szkoły i przedszkola } \\
\text { publiczne, prowadzone } \\
\text { przez inny organ niż } \\
\text { miasto Zabrze }\end{array}$ & $\begin{array}{c}\text { Szkoły } \\
\text { i przedszkola } \\
\text { niepubliczne }\end{array}$ \\
\hline Przedszkola & 38 & 1 & 5 \\
\hline Szkoły podstawowe & 37 & 1 & 2 \\
\hline Gimnazja & 28 & 2 & 2 \\
\hline Licea ogólnokształcące & 11 & 1 & 0 \\
\hline Licea profilowane & 8 & 0 & 0 \\
\hline Technika & 8 & 0 & 0 \\
\hline Zasadnicze szkoły zawodowe & 10 & 0 & 0 \\
\hline Szkoły policealne & 7 & 1 & 0 \\
\hline Uzupełniające licea & 3 & 0 & 0 \\
\hline ogólnokształcące & 3 & 1 & 25 \\
\hline Technika uzupełniające & 2 & 7 & \\
\hline Szkoły artystyczne & 155 & & 0 \\
\hline Szkoły dla młodzieży razem & & 0 & 0 \\
\hline
\end{tabular}

Źródło: opracowanie własne.

Co roku w Zabrzu jest wydawany (dostępny także w wersji elektronicznej) informator o szkołach i kształconych zawodach dla uczniów gimnazjów i ich rodziców, zwierający oprócz charakterystyki szkół, zawodów i profili kształcenia informacje ułatwiające podjęcie decyzji na temat dalszej ścieżki edukacyjnej (informacje o kwalifikacjach uzyskiwanych po zakończeniu szkoły, przedmiotach kierunkowych, sposobach realizacji praktyk zawodowych,

\footnotetext{
${ }^{1}$ Strategia edukacji Miasta Zabrze na lata 2011-2021. Załacznik do Uchwaty RM z dn. 17.10.2011.

2 Analiza strategiczna dla ,Strategii edukacji Miasta Zabrze na lata 2011-2021”, Urząd Miejski, Zabrze, sierpień 2011, raport niepublikowany.
} 
możliwościach podjęcia pracy). Wzrasta także zainteresowanie przedsiębiorców współpracą z zabrzańskimi szkołami zawodowymi. Podpisywane są umowy, na mocy których najlepsi uczniowie mają zagwarantowaną pracę.

Podstawową placówką tworzącą zabrzański system doradztwa zawodowego jest Poradnia Psychologiczno-Pedagogiczna (jej działalność szeroko została opisana w części dotyczącej placówek oświatowych). W roku szkolnym 2010/2011 w zajęciach grupowych aktywizujących do wyboru kierunku kształcenia i zawodu organizowanych przez tę placówkę wzięło udział 336 uczniów. W poradni jest zatrudnionych 2 nauczycieli pełniących obowiązki doradcy zawodowego.

Działania systemu doradztwa zawodowego w Zabrzu będą wspierane i rozwijane, co ma swoje potwierdzenie w zapisach Strategii edukacji miasta Zabrze na lata 2011-2021. Planowana jest realizacja następujących celów w obszarze rozwoju doradztwa zawodowego:

- zatrudnienie doradcy zawodowego w każdym gimnazjum i w każdej szkole ponadgimnazjalnej (wymiar etatu zależny od wielkości szkoły),

- rozwój współpracy ze środowiskiem lokalnego rynku pracy,

- publikowanie informatora nt. szkół ponadgimnazjalnych dla uczniów ostatnich klas gimnazjów,

- utrzymanie centralizacji kształcenia praktycznego,

- doradztwo indywidualne w zakresie określania predyspozycji zawodowych (zadanie Poradni Psychologiczno-Pedagogicznej),

- dalszy rozwój Szkolnych Ośrodków Kariery.

Zmodernizowana zostanie także struktura Centrum Kształcenia Praktycznego

i Ustawicznego. Władze Miasta uznały, iż najlepszym rozwiązaniem jest zatrudnienie doradcy w każdej szkole, bez tworzenia osobnego podmiotu czy jednostki. Przez utworzenie Lokalnego Centrum Rozwoju Edukacji (wynik udziału w realizacji projektu systemowego Ministerstwa Edukacji Narodowej) istotnie wzmocniona zostanie rola Poradni PsychologicznoPedagogicznej ${ }^{3}$.

\section{Ocena procesu doradztwa zawodowego w powiecie gliwickim i rybnickim}

Metodyka i przygotowanie badań obejmowały następujące elementy: dobór próby, wybór form i metod pomiaru, skonstruowanie narzędzi badawczych, przeprowadzenie pilotażu.

W celu doboru próby do badań wyznaczono:

- populację badania: abiturienci wybranych gimnazjów i szkół ponadgimnazjalnych na podstawie wykazów uczniów w szkołach;

- jednostkę próby: abiturient danej szkoły;

- wielkość próby: próba została dobrana w sposób celowy wg przekonań badającego. Plan badania zakładał przeprowadzenie badań wśród abiturientów trzech gimnazjów, trzech liceów ogólnokształcących, trzech techników oraz trzech szkół zawodowych. Ze względu na stopniową likwidację liceów profilowanych badania przeprowadzono w jednej szkole tego typu. Wybór szkół ponadgimnazjalnych zależał od przynależności szkoły do zespołu szkół (im więcej typów szkół wchodzi w skład zespołu, tym krócej trwa przeprowadzanie badań) oraz popularności szkoły. Wybór gimnazjów zależał od formy funkcjonowania (gimnazjum samodzielne lub w zespole szkół z liceum ogólnokształcącym) oraz środowiska wychowawczego (w opinii nauczycieli). Zakładana liczebność próby wynikała z liczby oddziałów (klas);

\footnotetext{
3 „System doskonalenia nauczycieli oparty na ogólnodostępnym kompleksowym wspomaganiu szkół”. Projekt systemowy realizowany na podstawie decyzji Ministra Edukacji Narodowej z dnia 27 lipca 2010 r. nr UDA-POKL.03.03.01-00-002/10-00, w ramach poddziałania 3.3.1
} 
- miejsce przeprowadzania badań: wybrane szkoły w Gliwicach i powiecie rybnickim;

- czas przeprowadzenia badań: marzec - maj 2011;

- wykorzystana metoda zbierania danych pierwotnych to ankieta rozdawana.

Instrumentami pomiarowymi były odpowiednio skonstruowane kwestionariusze ankiety dla abiturientów każdego typu szkoły oddzielnie - czyli zbiory celowo zaprojektowanych i odpowiednio ułożonych pytań, które miały być zadane badanym osobom. Na początku kwestionariuszy umieszczono krótką informację dotyczącą celu badań oraz sposobu zaznaczania odpowiedzi. Kwestionariusze składały się z pytań zamkniętych i półotwartych. Ułożono pytania w logicznej, celowej kolejności - począwszy od pytań ogólnych, aby zainteresować ucznia tematem ankiety i zachęcić do dalszego wypełniania, skończywszy na pytaniach problemowych. Przy każdym pytaniu umieszczono informację o liczbie możliwych odpowiedzi. Część pytań miała charakter filtrujący. Za ich pomocą została wydzielona podgrupa badanych, do których skierowane były oddzielne pytania.

Badaniom pilotażowym poddano 20 uczniów: 11 abiturientów gimnazjów i 9 abiturientów szkół ponadgimnazjalnych. Po dokonaniu koniecznych zmian w kwestionariuszach badawczych, podyktowanych wynikami pilotażu, przystąpiono do realizacji właściwych badań.

Podstawowe informacje na temat badanej populacji zawarto tabelach 2 i 3 .

Tab. 2. Liczba i odsetek ankietowanych w poszczególnych typach szkół

\begin{tabular}{|c|c|c|c|c|c|}
\hline G & LO & LP & T & ZSZ & Lącznie \\
\hline 159 & 123 & 25 & 132 & 210 & 649 \\
\hline $24,4 \%$ & $19 \%$ & $3,9 \%$ & $20,3 \%$ & $32,4 \%$ & $100,00 \%$ \\
\hline
\end{tabular}

Źródło: opracowanie własne.

Tab. 3. Struktura płci ankietowanych

\begin{tabular}{|c|c|c|c|c|c|c|c|c|c|c|c|c|}
\hline & \multicolumn{2}{|c|}{ G } & \multicolumn{2}{|c|}{ LO } & \multicolumn{2}{|c|}{ LP } & \multicolumn{2}{|c|}{$T$} & \multicolumn{2}{|c|}{ ZSZ } & \multicolumn{2}{|c|}{ Lącznie } \\
\hline & 1. & $\%$ & 1. & $\%$ & 1. & $\%$ & 1. & $\%$ & 1. & $\%$ & I. & $\%$ \\
\hline $\mathrm{K}$ & 76 & 47,8 & 67 & 54,4 & 5 & 20,0 & 71 & 53,8 & 41 & 19,5 & 260 & 40,0 \\
\hline $\mathrm{M}$ & 82 & 51,6 & 45 & 36,6 & 20 & 80,0 & 59 & 44,7 & 161 & 76,7 & 367 & 56,6 \\
\hline $\begin{array}{c}\text { Brak } \\
\text { odpowiedzi }\end{array}$ & 1 & 0,6 & 11 & 9,0 & 0 & 0,0 & 2 & 1,5 & 8 & 3,8 & 22 & 3,4 \\
\hline
\end{tabular}

Źródło: opracowanie własne.

Analiza procesu podejmowania decyzji przez abiturientów gimnazjów skłoniła do poszukiwań nt. źródeł informacji, z których korzystają uczniowie przy wyborze szkoły (tab. 4). Najczęściej informacje były poszukiwane przez Internet, na stronach urzędów miast i szkół. Umieszczanie oferty edukacyjnej na stronach internetowych szkół i placówek oraz organów prowadzących jest pośrednim działaniem systemu poradnictwa zawodowego. Te informacje stanowią pierwsze przesłanki do podjęcia decyzji o wyborze szkoły. Blisko połowa ankietowanych czerpie informacje od kolegów i ponad 30\% korzysta z informatora o szkołach ponadgimnazjalnych. Istotna jest także rola szkoły - wychowawców klas i pedagogów szkolnych. System oświaty wykorzystuje w tym obszarze z powodzeniem media elektroniczne, a podejmowane działania w przekazywaniu oferty edukacyjnej są skuteczne.

Zadaniem ankietowanych było także wskazanie rozwiązań dla niezdecydowanych kolegów (tab. 5). Nie było ankietowanego, który nie podałby swojej propozycji. Ponad $72 \%$ badanych 
sugerowało sięgnięcie do zasobów Internetu, głównego i podstawowego narzędzia komunikacji. $72,3 \%$ badanych sugerowało, aby wybrać szkołę zgodnie z zainteresowaniami. Uczniowie wskazywali też na kontakt z pedagogiem lub doradcą zawodowym $(34,6 \%)$, wychowawcą $(31,4 \%)$, poradnią psychologiczno-pedagogiczną $(23,9 \%)$, inną osobą w szkole $(10,7 \%)$. To wskazuje, iż uczniowie wiedzą, że w szkole można uzyskać wsparcie z zakresu doradztwa zawodowego i że porada może być pomocna kolegom.

Tab. 4. Źródła informacji na temat szkół ponadgimnazjalnych w opinii abiturientów gimnazjów

\begin{tabular}{|l|c|c|}
\hline & Liczba (N = 159) & Odsetek* \\
\hline Internet, strony urzędów miast, strony szkół & 87 & 54,7 \\
\hline Koledzy & 78 & 49,0 \\
\hline Informator o szkołach ponadgimnazjalnych & 49 & 30,9 \\
\hline Wychowawcy klas & 36 & 22,6 \\
\hline $\begin{array}{l}\text { Odpowiedź: „Od dawna wiem, do jakiej pójdę szkoły i nie } \\
\text { potrzebuję takich informacji” }\end{array}$ & 28 & 17,6 \\
\hline Pedagog szkolny & 26 & 16,4 \\
\hline Internet: portal NK & 16 & 10,0 \\
\hline Internet: portal Facebook & 10 & 6,3 \\
\hline Rodzina & 2 & 1,3 \\
\hline Targi edukacyjne & 2 & 1,3 \\
\hline Inna osoba w szkole & 1 & 0,6 \\
\hline Forum dyskusyjne (tematyka ogólna) & 1 & 0,6 \\
\hline
\end{tabular}

* Respondenci mogli zaznaczyć więcej niż jedną odpowiedź, stąd łączna liczba odpowiedzi przekracza 100\%.

Źródło: opracowanie własne.

Tab. 5. Propozycje działań dla niezdecydowanych abiturientów gimnazjów dotyczące wyboru szkoły w opinii (kolegów) abiturientów gimnazjów

\begin{tabular}{|l|c|c|}
\hline & Liczba (N = 159) & Odsetek* \\
\hline Poszukać informacji w Internecie & 116 & 73,0 \\
\hline Wybrać szkołę zgodną z zainteresowaniami & 115 & 72,3 \\
\hline Porozmawiać ze starszymi kolegami lub rodziną & 76 & 47,8 \\
\hline Porozmawiać z pedagogiem lub doradcą zawodowym & 55 & 34,6 \\
\hline Porozmawiać w wychowawcą & 50 & 31,4 \\
\hline Pójść do Poradni Psychologiczno-Pedagogicznej & 38 & 23,9 \\
\hline $\begin{array}{l}\text { Wybrać szkołę, po której można zdobyć zawód: szkoła zawo- } \\
\text { dowa lub technikum }\end{array}$ & 36 & 22,6 \\
\hline Wybrać jakieś liceum & 20 & 12,6 \\
\hline Porozmawiać z inną osobą w szkole & 17 & 10,7 \\
\hline $\begin{array}{l}\text { Odpowiedź: „Nic, jak ktoś nie chce, to nie musi chodzić dalej do } \\
\text { szkoły” }\end{array}$ & 5 & 3,1 \\
\hline $\begin{array}{l}\text { Odpowiedź: „Nic, jak się nie wybierze szkoły, to i tak zostanie } \\
\text { się do jakiejś przydzielonym” }\end{array}$ & 4 & 2,5 \\
\hline $\begin{array}{l}\text { Inne (wybrać szkołę w pobliżu - 1 odpowiedź; udział w targach } \\
\text { edukacyjnych - 2 odpowiedzi) }\end{array}$ & 3 & 1,9 \\
\hline
\end{tabular}

* Respondenci mogli zaznaczyć więcej niż jedną odpowiedź, stąd łączna liczba odpowiedzi przekracza 100\%.

Źródło: opracowanie własne. 
Uczniowie byli pytani o znajomość doradców zawodowych w swoich szkołach (tab. 6). W szkołach, w których jest zatrudniony doradca (lub uczniowie mieli z nim kontakt), uczniowie mieli tego świadomość.

Tab. 6. Obecność doradców zawodowych w gimnazjach i szkołach ponadgimnazjalnych w opinii abiturientów

\begin{tabular}{|l|c|c|c|c|c|c|c|c|c|c|c|c|}
\hline & \multicolumn{2}{|c|}{$\begin{array}{c}\text { G } \\
(\mathbf{N}=\mathbf{1 5 9})\end{array}$} & \multicolumn{2}{c|}{$\begin{array}{c}\text { LO } \\
(\mathbf{N}=\mathbf{1 2 1})\end{array}$} & \multicolumn{2}{c|}{$\begin{array}{c}\text { LP } \\
(\mathbf{N}=\mathbf{2 5})\end{array}$} & \multicolumn{2}{c|}{$\begin{array}{c}\text { T } \\
(\mathbf{N}=\mathbf{1 3 0})\end{array}$} & \multicolumn{2}{c|}{$\begin{array}{c}\text { ZSZ } \\
(\mathbf{N}=\mathbf{2 1 0})\end{array}$} & \multicolumn{2}{c|}{$\begin{array}{c}\text { Lącznie } \\
(\mathbf{N = 6 4 5})\end{array}$} \\
\hline & 1. & $\%$ & 1. & $\%$ & 1. & $\%$ & 1. & $\%$ & 1. & $\%$ & 1. & $\%$ \\
\hline Tak & 21 & 13,2 & 5 & 4,0 & 10 & 40,0 & 18 & 13,9 & 90 & 42,9 & 144 & 22,3 \\
\hline Nie & 94 & 59,2 & 40 & 33,0 & 12 & 48,0 & 71 & 54,7 & 48 & 22,9 & 265 & 41,0 \\
\hline Nie wiem & 44 & 27,6 & 76 & 63,0 & 3 & 12,0 & 41 & 31,4 & 72 & 34,2 & 236 & 36,7 \\
\hline
\end{tabular}

Źródło: opracowanie własne.

Ocena doradców zawodowych została ujęta w stosunku do ankietowanych, którzy mieli kontakt z doradcą zawodowym (tab. 7 i 8). Największą liczbę uczniów, którzy w szkole mieli możliwość kontaktu z doradcą zawodowym, stanowili uczniowie zasadniczych szkół zawodowych. Uczniowie mają ograniczony dostęp do pomocy doradców, ale ci, którzy z ich pomocy korzystają, oceniają tę pomoc dobrze. Na ile ta pomoc jest skuteczna wykażą dopiero badania losów absolwentów, które będą prowadzone w okresie od 1 roku do 2 lat po ukończeniu przez nich szkoły ponadgimnazjalnej.

Opinie o lekcjach dotyczących wyboru ścieżki kariery zawarto w tabeli 9 i 10. W gimnazjach w tych lekcjach uczestniczyło 93\% uczniów, w szkołach ponadgimnazjalnych blisko 39\%, z czego największy odsetek stanowili uczniowie z zasadniczych szkół zawodowych.

Tab. 7. Doradcy zawodowi w opinii abiturientów gimnazjów, w których był zatrudniony doradca zawodowy

\begin{tabular}{|l|c|c|}
\hline \multicolumn{1}{|c|}{ Doradca zawodowy: } & $\begin{array}{c}\text { Liczba } \\
(\mathbf{N = 2 1})^{*}\end{array}$ & Odsetek* \\
\hline $\begin{array}{l}\text { udziela informacji, do jakiej szkoły można pójść po ukończeniu gim- } \\
\text { nazjum }\end{array}$ & 18 & 85,7 \\
\hline pomaga wybrać szkołę, jeśli ktoś potrzebuje & 11 & 52,4 \\
\hline robi testy i na tej podstawie pomaga wybrać szkołę & 10 & 47,6 \\
\hline dużo wie o szkołach ponadgnminazjalnych & 10 & 47,6 \\
\hline organizuje spotkania, prelekcje nt. wyboru szkoły, zawodu & 10 & 47,6 \\
\hline wysyła do poradni psychologiczno-pedagogicznej & 1 & 4,8 \\
\hline nie wiem, czym się zajmuje & 2 & 9,5 \\
\hline
\end{tabular}

* Respondenci mogli zaznaczyć więcej niż jedną odpowiedź, stąd łączna liczba odpowiedzi przekracza 100\%, w badanej próbie było 21 respondentów, uczących się w szkołach, w których był zatrudniony doradca zawodowy.

Źródło: opracowanie własne. 
Tab. 8. Doradcy zawodowi w opinii abiturientów szkół ponadgimnazjalnych, w których był zatrudniony doradca zawodowy

\begin{tabular}{|c|c|c|c|c|c|c|c|c|c|c|}
\hline \multirow[t]{2}{*}{ Doradca zawodowy: } & \multicolumn{2}{|c|}{$\begin{array}{c}\text { LO } \\
(N=3)\end{array}$} & \multicolumn{2}{|c|}{$\begin{array}{c}\text { LP } \\
(\mathrm{N}=10)\end{array}$} & \multicolumn{2}{|c|}{$\begin{array}{c}T \\
(N=18)\end{array}$} & \multicolumn{2}{|c|}{$\begin{array}{c}\text { ZSZ } \\
(\mathbf{N}=90) \\
\end{array}$} & \multicolumn{2}{|c|}{$\begin{array}{c}\text { Lącznie } \\
(\mathrm{N}=121)\end{array}$} \\
\hline & 1. & $\% *$ & I. & $\%{ }^{*}$ & I. & $\% *$ & I. & $\% *$ & I. & $\% *$ \\
\hline $\begin{array}{l}\text { udziela informacji o tym, jak } \\
\text { szukać pracy }\end{array}$ & 1 & 20,0 & 0 & 0,0 & 1 & 5,5 & 63 & 70,0 & 65 & 53,72 \\
\hline $\begin{array}{l}\text { pomaga zdecydować, gdzie } \\
\text { pracować lub gdzie się uczyć }\end{array}$ & 3 & 60,0 & 1 & 10,0 & 3 & 16,7 & 51 & 56,7 & 58 & 0,48 \\
\hline $\begin{array}{l}\text { dużo wie o szkołach, w których } \\
\text { możemy kontynuować naukę }\end{array}$ & 3 & 60,0 & 0 & 0,0 & 3 & 16,7 & 41 & 45,6 & 47 & 0,39 \\
\hline $\begin{array}{l}\text { organizuje spotkania, przycho- } \\
\text { dzi na lekcje }\end{array}$ & 0 & 0,0 & 1 & 10,0 & 0 & 0,0 & 21 & 23,3 & 22 & 0,18 \\
\hline $\begin{array}{l}\text { wysyła do Poradni Psycholo- } \\
\text { giczno-Pedagogicznej }\end{array}$ & 0 & 0,0 & 0 & 0,0 & 0 & 0,0 & 4 & 4,4 & 4 & 0,03 \\
\hline nie wiem, czym się zajmuje & 0 & 0,0 & 7 & 70,0 & 10 & 55,6 & 20 & 22,2 & 37 & 0,31 \\
\hline $\begin{array}{l}\text { Inne (niekompetentne doradz- } \\
\text { two) }\end{array}$ & 0 & 0,0 & 0 & 0,0 & 0 & 0,0 & 1 & 1,1 & 1 & 0,01 \\
\hline
\end{tabular}

* Respondenci mogli zaznaczyć więcej niż jedną odpowiedź, stąd łączna liczba odpowiedzi przekracza 100\%, w badanej próbie było łącznie 121 respondentów (w tab. 8 podano te liczby także wg typów szkół), uczących się w szkołach, w których był zatrudniony doradca zawodowy.

Źródło: opracowanie własne.

Tab. 9. Podejmowanie tematu wyboru ścieżki kariery na dodatkowych lekcjach w opinii uczniów gimnazjów

\begin{tabular}{|l|c|c|}
\hline & $\begin{array}{c}\text { Liczba } \\
(\mathbf{N}=\mathbf{1 5 9})\end{array}$ & Odsetek* \\
\hline Nie, nikt z nami o tym nie rozmawia & 13 & 8,2 \\
\hline Tak, rozmawiamy o tym z wychowawcą & 30 & 18,9 \\
\hline Tak, rozmawiamy o tym z pedagogiem & 11 & 7,0 \\
\hline $\begin{array}{l}\text { Tak, rozmawiamy o tym z doradcą z Poradni Psychologiczno- } \\
\text {-Pedagogicznej }\end{array}$ & 47 & 29,6 \\
\hline Tak, rozmawiamy o tym z doradcą zawodowym & 78 & 49,1 \\
\hline Tak, rozmawiamy o tym z gośćmi ze szkół ponadgimnazjalnych & 8 & 5,0 \\
\hline
\end{tabular}

* Respondenci mogli zaznaczyć więcej niż jedną odpowiedź, stąd łączna liczba odpowiedzi przekracza $100 \%$.

Źródło: opracowanie własne.

Ocena lekcji dotyczących wyboru szkoły i dalszej ścieżki kariery wypadła przeciętnie. Najwięcej, bo 36\% uczniów liceów deklarowało, iż takie lekcje nie są potrzebne, ponieważ ankietowani mają sprecyzowaną ścieżkę dalszej kariery. Ponad połowa ankietowanych z zasadniczych szkół zawodowych pozytywnie odebrała lekcje. Nie jest prowadzony monitoring potrzeb rynku pracy (badań trudnych ze względu na opór pracodawców, brak czasu na badania, brak świadomości potrzeby ich realizacji). Uczniowie i rodzice skorzystaliby z takich danych w kształtowaniu ścieżki kariery. Niezależnie od trendów na rynku pracy, konieczności ciągłego doskonalenia zawodowego i przekwalifikowania takie informacje 
są pożądane przez uczniów i byłyby cennym materiałem w pracy doradców zawodowych i nauczycieli przedmiotu przedsiębiorczość.

Tab. 10. Podejmowanie tematu wyboru ścieżki kariery w opinii uczniów szkół ponadgimnazjalnych

\begin{tabular}{|c|c|c|c|c|c|c|c|c|c|c|}
\hline & \multicolumn{2}{|c|}{$\begin{array}{c}\text { LO } \\
(\mathrm{N}=123)^{*}\end{array}$} & \multicolumn{2}{|c|}{$\begin{array}{c}\text { LP } \\
(\mathrm{N}=\mathbf{2 5})^{*}\end{array}$} & \multicolumn{2}{|c|}{$\begin{array}{c}T \\
(N=132)^{*}\end{array}$} & \multicolumn{2}{|c|}{$\begin{array}{c}\text { ZSZ } \\
(\mathrm{N}=132)^{*}\end{array}$} & \multicolumn{2}{|c|}{$\begin{array}{l}\text { LACCZNIE } \\
(\mathrm{N}=490)^{*}\end{array}$} \\
\hline & 1. & $\% *$ & 1. & $\% *$ & 1. & $\% *$ & 1. & $\% *$ & 1. & $\% *$ \\
\hline Nie & 69 & 56,1 & 5 & 20,0 & 36 & 27,3 & 77 & 36,7 & 187 & 38,2 \\
\hline $\begin{array}{l}\text { Nie, nikt z nami o tym nie } \\
\text { rozmawia }\end{array}$ & 23 & 18,7 & 0 & 0,0 & 18 & 13,6 & 24 & 11,4 & 65 & 13,3 \\
\hline Z doradcą zawodowym & 4 & 3,3 & 9 & 36,0 & 31 & 23,5 & 55 & 26,2 & 99 & 20,2 \\
\hline $\begin{array}{l}\text { Z doradcą z Poradni } \\
\text { Psychologiczno-Pedagogicznej }\end{array}$ & 0 & 0,0 & 0 & 0,0 & 18 & 13,6 & 4 & 1,9 & 22 & 4,5 \\
\hline Tak, z inną osobą & 3 & 2,4 & 5 & 20,0 & 17 & 12,9 & 12 & 5,7 & 37 & 7,6 \\
\hline $\begin{array}{l}\text { Dodatkowych lekcji nie było, ale } \\
\text { rozmawialiśmy o tym na godzi- } \\
\text { nie wychowawczej }\end{array}$ & 24 & 19,5 & 2 & 8,0 & 20 & 15,2 & 36 & 17,1 & 82 & 16,7 \\
\hline $\begin{array}{l}\text { Lekcje nie było obowiązkowe } \\
\text { i nie chodziłem }\end{array}$ & 2 & 1,6 & 3 & 12,0 & 4 & 3,0 & 3 & 1,4 & 12 & 2,4 \\
\hline
\end{tabular}

* Respondenci mogli zaznaczyć więcej niż jedną odpowiedź, stąd łączna liczba odpowiedzi przekracza 100\%. Źródło: opracowanie własne.

Tab. 11. Opinie abiturientów na temat lekcji dotyczących wyboru dalszej ścieżki kariery

\begin{tabular}{|c|c|c|c|c|c|c|c|c|c|c|c|c|}
\hline \multirow{2}{*}{$\begin{array}{l}\text { Opinie na temat lekcji } \\
\text { dotyczących wyboru } \\
\text { dalszej ścieżki kariery }\end{array}$} & \multicolumn{2}{|c|}{$\begin{array}{c}\mathbf{G} \\
(\mathrm{N}=\mathbf{1 7 4})^{*}\end{array}$} & \multicolumn{2}{|c|}{$\begin{array}{c}\text { LO } \\
(\mathbf{N}=33)^{*}\end{array}$} & \multicolumn{2}{|c|}{$\begin{array}{c}\text { LP } \\
(\mathrm{N}=19)^{*}\end{array}$} & \multicolumn{2}{|c|}{$\begin{array}{c}\mathbf{T} \\
(\mathbf{N}=\mathbf{9 0})^{*}\end{array}$} & \multicolumn{2}{|c|}{$\begin{array}{c}\text { ZSZ } \\
(\mathbf{N}=\mathbf{1 1 0})^{*}\end{array}$} & \multicolumn{2}{|c|}{$\begin{array}{c}\text { Lącznie } \\
(\mathrm{N}=426)^{*}\end{array}$} \\
\hline & 1. & $\%$ \%* & l. & $\% *$ & I. & $\%$ \%* & l. & \%* & I. & \%* & 1. & $\% *$ \\
\hline $\begin{array}{l}\text { Te lekcje ułatwiły mi } \\
\text { wybór szkoły/ścieżki edu- } \\
\text { kacyjnej i zawodowej }\end{array}$ & 51 & 29,3 & 5 & 15,1 & 8 & 42,1 & 22 & 24,4 & 57 & 51,8 & 143 & 33,6 \\
\hline $\begin{array}{l}\text { Te lekcje nie ułatwiły mi } \\
\text { wyboru szkoły ścieżki } \\
\text { edukacyjnej i zawodowej }\end{array}$ & 28 & 16,1 & 7 & 21,2 & 1 & 5,3 & 16 & 17,8 & 17 & 15,4 & 69 & 16,2 \\
\hline $\begin{array}{l}\text { Po tych lekcjach } \\
\text { jeszcze bardziej nie } \\
\text { wiedziałem(am), jaką } \\
\text { szkołę wybrać lub co mam } \\
\text { robić po skończeniu szkoły }\end{array}$ & 27 & 15,5 & 9 & 27,3 & 4 & 21,1 & 16 & 17,8 & 18 & 16,3 & 74 & 17,4 \\
\hline $\begin{array}{l}\text { Nie interesowały } \\
\text { mnie te lekcje, bo i tak } \\
\text { wiedziałem(am), co będę } \\
\text { robić po zakończeniu szkoły }\end{array}$ & 44 & 25,3 & 12 & 36,3 & 5 & 26,3 & 21 & 23,3 & 29 & 26,3 & 111 & 26,1 \\
\hline Inne & 3 & 1,7 & 1 & 3,0 & 0 & 0,0 & 3 & 3,3 & 0 & 0,0 & 7 & 1,6 \\
\hline
\end{tabular}

* Respondenci mogli zaznaczyć więcej niż jedną odpowiedź, stąd łączna liczba odpowiedzi przekracza 100\%, $\mathrm{N}$ - liczba uczniów, którzy brali udział w tych lekcjach.

Źródło: opracowanie własne. 
Tab. 12. Oceny wystawione lekcjom na temat wyboru dalszej ścieżki kariery

\begin{tabular}{|c|c|c|c|c|c|c|c|c|c|c|}
\hline & \multicolumn{2}{|c|}{$\begin{array}{c}\text { LO } \\
(\mathrm{N}=123)^{*}\end{array}$} & \multicolumn{2}{|c|}{$\begin{array}{c}\text { LP } \\
(\mathrm{N}=\mathbf{2 5})^{*}\end{array}$} & \multicolumn{2}{|c|}{$\begin{array}{c}T \\
(N=132) *\end{array}$} & \multicolumn{2}{|c|}{$\begin{array}{c}\text { ZSZ } \\
(\mathrm{N}=132)^{*}\end{array}$} & \multicolumn{2}{|c|}{$\begin{array}{c}\text { Lącznie } \\
(\mathrm{N}=490)^{*}\end{array}$} \\
\hline & l. & $\%$ & 1. & $\%$ & I. & $\%$ & 1. & $\%$ & 1. & $\%$ \\
\hline ndst & 6 & 4,2 & 3 & 9,4 & 1 & 5,9 & 7 & 9,1 & 14 & 12,1 \\
\hline dop. & 19 & 13,3 & 6 & 18,8 & 3 & 17,6 & 13 & 16,9 & 10 & 8,6 \\
\hline dst & 55 & 38,5 & 12 & 37,5 & 2 & 11,8 & 32 & 41,6 & 37 & 31,9 \\
\hline $\mathrm{db}$ & 43 & 30,1 & 9 & 28,1 & 4 & 23,5 & 14 & 18,2 & 43 & 37,1 \\
\hline $\mathrm{bdb}$ & 20 & 14,0 & 2 & 6,3 & 7 & 41,2 & 11 & 14,3 & 12 & 10,3 \\
\hline $\begin{array}{l}\text { Brak } \\
\text { odpowiedzi }\end{array}$ & 16 & 0,1 & 91 & 0,7 & 8 & 0,3 & 55 & 0,4 & 94 & 0,4 \\
\hline Średnia & 3,36 & & 3,03 & & 3,76 & & 3,11 & & 3,25 & \\
\hline
\end{tabular}

Źródło: opracowanie własne.

Tab. 13. Odpowiedzi abiturientów gimnazjów na pytanie: „Czy potrzebna jest informacja, w jakich zawodach można znaleźć dobrą pracę" ( $\mathrm{N}=159)$

\begin{tabular}{|l|r|r|}
\hline Nie, lepiej iść do liceum & 19 & $12,0 \%$ \\
\hline Tak, to pomogłoby mi w wyborze szkoły & 134 & $84,8 \%$ \\
\hline Inne & 5 & $3,2 \%$ \\
\hline Lącznie & 158 & $100,0 \%$ \\
\hline
\end{tabular}

Źródło: opracowanie własne.

Tab. 14. Odpowiedzi abiturientów szkół ponadgimnazjalnych na pytanie: „Czy potrzebna jest informacja, w jakich zawodach i po jakich szkołach można dostać dobrą pracę?"

\begin{tabular}{|c|c|c|c|c|c|c|c|c|c|c|}
\hline & \multicolumn{2}{|c|}{$\begin{array}{c}\text { LO } \\
(N=123)\end{array}$} & \multicolumn{2}{|c|}{$\begin{array}{c}\text { LP } \\
(\mathrm{N}=\mathbf{2 5})\end{array}$} & \multicolumn{2}{|c|}{$\begin{array}{c}T \\
(N=132)\end{array}$} & \multicolumn{2}{|c|}{$\begin{array}{c}\text { ZSZ } \\
(\mathbf{N}=\mathbf{2 1 0})\end{array}$} & \multicolumn{2}{|c|}{$\begin{array}{c}\text { Lącznie } \\
(\mathrm{N}=490)\end{array}$} \\
\hline & I. & $\%$ & I. & $\%$ & I. & $\%$ & 1. & $\%$ & 1. & $\%$ \\
\hline Tak, potrzebna jest taka informacja & 106 & 86,2 & 19 & 76,0 & 98 & 74,2 & 138 & 65,7 & 361 & 73,7 \\
\hline $\begin{array}{l}\text { Nie, bo nie wiadomo, gdzie będę } \\
\text { pracować; myślę, że będę zmieniać } \\
\text { pracę }\end{array}$ & 8 & 6,5 & 4 & 16,0 & 19 & 14,4 & 27 & 12,9 & 58 & 11,8 \\
\hline $\begin{array}{l}\text { Gdybym takie informacje miał(ła) pod } \\
\text { koniec gimnazjum, to pomogłoby mi } \\
\text { to w wyborze szkoły }\end{array}$ & 5 & 4,0 & 0 & 0,0 & 13 & 9,9 & 43 & 20,5 & 61 & 12,5 \\
\hline Inne & 2 & 1,6 & 2 & 8,0 & 0 & 0,0 & 0 & 0,0 & 4 & 0,8 \\
\hline Brak odpowiedzi & 2 & 1,7 & 0 & 0,0 & 2 & 1,5 & 2 & 0,9 & 6 & 1,2 \\
\hline
\end{tabular}

Źródło: opracowanie własne.

\section{Zakończenie}

System doradztwa zawodowego powinien być pomostem pomiędzy szkołami i placówkami a rynkiem pracy. Działania systemu są realizowane przez wiele osób i podmiotów nie zawsze współpracujących ze sobą. Doradcy zawodowi, którzy są zatrudnieni w szkołach, są znani uczniom i znany jest ich zakres działań. Ważną, lecz nieformalną rolę odgrywają w tym obszarze wychowawcy i wszyscy nauczyciele przedmiotowi, którzy podczas swoich lekcji 
nawiązują do konieczności świadomego wyboru dalszej ścieżki kariery. Lekcje prowadzone przez doradców były ocenione przeciętnie, a dla ponad $30 \%$ badanych były użyteczne.

System doradztwa zawodowego zależy od polityki oświatowej jednostki samorządowej. W gminach, które decydują się na zapewnienie stałego dostępu do doradców zawodowych (m.in. Rybnik, Zabrze), ocena systemu doradztwa zawodowego jest wyższa. Gminy, które nie budują silnego systemu doradztwa, opierają się na dotychczasowej pracy pedagogów szkolnych (już bardzo obciążonych obowiązkami) i na działaniach poradni psychologiczno-pedagogicznych, które z mocy praca nie są podmiotami związanymi z rynkiem pracy. Doradztwo w zakresie predyspozycji zawodowych odgrywa istotną funkcję, ale nie rekompensuje braków nt. potrzeb rynku pracy, tak bardzo potrzebnych.

W środowisku akademickim ważną rolę pełnią Biura Karier Studenckich. Aktywnie współpracują one ze sobą i z rynkiem pracy. Ich działalność dotyczy przede wszystkim: pośrednictwa pracy, organizacji praktyk studenckich, nawiązywania kontaktów z pracodawcami i utrzymywania istniejących, doradztwo zawodowe, realizacja projektów ukierunkowanych na rozwój zawodowy studentów i szeroko pojęta aktywizacja zawodowa studentów, w tym badania losów absolwentów. Te działania mogą być wskazówką dla Szkolnych Ośrodków Kariery.

Dzięki wsparciu finansowemu z Unii Europejskiej realizowane są projekty badawcze i aplikacyjne w zakresie promocji przedsiębiorczości w edukacji i wsparcie dla systemów doradztwa zawodowego. Warto wspomnieć o projekcie „Krok w przedsiębiorczość” (Dorocki, Kilar, Rachwał, 2011), dostarczającym narzędzi pracy dla nauczycieli przedsiębiorczości (może także wspomagać pracę doradców zawodowych. Projekt FIFOBI - Kurek, Rachwał, 2010) i interesujących wyników badań na temat młodzieży gimnazjalnej w Europie i ich przedsiębiorczych kompetencji - taka wiedza również jest niezbędna w pracy doradców zawodowych. Te przykłady wskazują na silną potrzebę badań w zakresie różnych aspektów przedsiębiorczości i tworzenia narzędzi wspomagających pracę nauczycieli, doradców, pedagogów dla skutecznego przygotowania młodzieży do wejścia na rynek pracy.

\section{Literatura}

Borowiec, M. (2011). Role edukacji w procesach globalizacji. Przedsiębiorczość - Edukacja, 7, 296-307. Dorocki, S., Kilar, W., Rachwał, T. (2011). Założenia i cele projektu „Krok w przedsiębiorczość”. Przedsiębiorczość - Edukacja, 7, 308-320.

Kurek, S., Rachwał, T. (2010). Założenia i wstępne wyniki europejskiego projektu badawczego FIFOBI w zakresie kształtowania kompetencji uczniów gimnazjum do prowadzenia działalności gospodarczej. Przedsiębiorczość - Edukacja, 6, 472-485.

Pradela, A. (2010, kwiecień). Diagnoza potrzeb edukacyjnych szkolnictwa zawodowego w Gliwicach. Niepublikowany raport z eksperckiego panelu dyskusyjnego. Gliwice.

Rachwał, T. (2009). Ocena projektu zmiany podstawy programowej podstaw przedsiębiorczości (przedstawionej przez MEN w 2008 r. w ramach reformy systemu edukacji). Przedsiębiorczość Edukacja, 5, 349-372.

Wąsik, H. (2010). Nauczanie przedsiębiorczości w kontekście integracji europejskiej. Przedsiębiorczość - Edukacja, 6, 486-492.

Zioło, Z. (2011). Rola przedsiębiorczości w warunkach nasilających się procesów globalizacji. Przedsiębiorczość - Edukacja, 7, 10-23. 
Agata Pradela, dr inż., Politechnika Śląska, Wydział Organizacji i Zarządzania, Instytut Inżynierii Produkcji.

Obszary zainteresowań badawczych autorki: badania systemów oświaty w aspektach potrzeb i wymagań rynku pracy; badania strategii edukacji w jednostkach samorządu terytorialnego, analizy efektywności systemu oświaty w aspekcie zmian gospodarczych, analizy procesów przedsiębiorczości, ocena jakości edukacji i zarządzania oświatą.

Agata Pradela, PhD, Eng, Silesian University of Technology, Faculty of Organisation and Management, Institute of Production Engineering.

Author's research interests include: research on educational systems in conjunction with labour market needs and requirements; research on educational strategies in local governments; analysis of educational system effectiveness in the aspects of economical changes, entrepreneurship process analysis, evaluation of quality of education and educational management.

Adres/Address: Politechnika Śląska, Instytut Inżynierii Produkcji

Wydział Organizacji i Zarządzania

ul. Roosevelta 26, 43-800 Zabrze, Polska

e-mail: Agata.Pradela@polsl.pl 


\author{
Danuta Piróg \\ Uniwersytet Pedagogiczny \\ im. Komisji Edukacji Narodowej \\ w Krakowie
}

\title{
Absolwenci szkół wyższych na rynku pracy w warunkach kryzysu ${ }^{1}$
}

\section{Higher education graduates on the labour market in times of an economic crisis ${ }^{2}$}

\begin{abstract}
Streszczenie
Przechodzenie nowo promowanych absolwentów szkół wyższych z etapu edukacji do etapu zatrudnienia wydaje się być jednym z bardziej złożonych mechanizmów zachodzących obecnie na rynku pracy. Procesy transformacji zaowocowały tendencją do wzrostu korelacji między ukończonym szczeblem edukacji a pozycją na rynku pracy, co ukształtowało w społeczeństwie trwałe przekonanie, że legitymowanie się posiadaniem studiów wyższych jest gwarancją zatrudnienia zgodnego z poziomem wykształcenia i na korzystnych warunkach płacowych. Tymczasem w Polsce i w wielu innych krajach Europy obserwuje się stały wzrost odsetka osób bezrobotnych z wyższym wykształceniem. Celem opracowania jest przedstawienie dynamiki zmian liczby i struktury kierunkowej absolwentów szkół wyższych w latach 1990-2010, ukazanie konsekwencji tych przemian w zakresie pozyskiwania zatrudnienia przez absolwentów oraz próba nakreślenia możliwości optymalizowania ich pomyślnej tranzycji na rynek pracy. Przeprowadzone badania pozwoliły ustalić, że pozycja absolwentów szkół wyższych w Polsce na rynku pracy stopniowo się pogarsza. Podstawowymi drogami optymalizacji ich sytuacji są prowadzenie ilościowych i jakościowych badań tranzycji absolwenckich, reorientacja celów i metod kształcenia akademickiego i realizowanie koncepcji uniwersytetu przedsiębiorczego, uwzględniającej wnioski z przeprowadzonych badań tranzycyjnych.
\end{abstract}

\begin{abstract}
The transition of university graduates from the stage of education to employment seems to be one of the most complex and difficult processes taking place on the labour market. Economic transformation resulted in the tendency to have a correlation between the level of education and ones position on the labour market. This formed the strong belief in society that higher education graduating can guarantee profitable employment relevant to ones level of education. Meanwhile in Poland and in other European countries there has been a constant increase in the percentage of unemployed people with higher education The purpose of the research firstly is to present the dynamic of the number and specialisation of higher education graduates between the years 1990-2010; secondly to show the consequences of these changes regarding the procurement of jobs by the graduates and thirdly attempts at pin-pointing the possibilities of optimising their successful transition into the labour market. The conducted research has proven that the situation of higher education graduates on the labour market in Poland is steadily worsening. The afore-mentioned ways of optimising their situation is conducting qualitative and quantitative surveys of the transition process and implementing the results of these surveys into the conception of an entrepreneurial university.
\end{abstract}

Słowa kluczowe: absolwent; bezrobocie; studia wyższe; rynek pracy; tranzycja

Key words: graduate; higher education; labour market; transition; unemployment

\footnotetext{
${ }^{1}$ Praca naukowa finansowana ze środków budżetowych na naukę w latach 2010-2012 jako projekt badawczy nr N N114 076739.

${ }^{2}$ Study financed from budget funds for science between 2010 and 2012 as research project No. N N114 076739 .
} 


\section{Wprowadzenie}

Zmiany związane z powstawaniem gospodarki opartej na wiedzy zdeterminowały powszechne przekonanie, że w warunkach globalizacji i integracji nakłady na wykształcenie są jedną z najefektywniejszych form inwestycji. Zarówno w teorii ekonomii, jak i w rzeczywistości gospodarczej paradygmat budowania kapitału edukacyjnego jako stymulatora rozwoju regionów oraz państw staje się czynnikiem determinującym tempo i poziom rozwoju gospodarczego, a także jest zasadniczym narzędziem w walce z kryzysem (Borowiec, 2008; Kukliński, 2003; Jakubowska, Rosa, 2011; Zioło, 2008). Ujawniona w okresie transformacji ogólna tendencja do wzrostu korelacji między wykształceniem a pozycją na rynku pracy, charakterystyczna dla gospodarek rynkowych, oraz popularność koncepcji gospodarki opartej na wiedzy ukształtowały w społeczeństwie bardzo mocne przekonanie, że ukończenie studiów wyższych jest niezbędnym warunkiem pozyskania atrakcyjnej pracy, a w skrajnych okolicznościach przynajmniej stanowi gwarancję jakiegokolwiek zatrudnienia (Domański, 2004). Nadto, jak zakłada teoria sygnalizacji, wykształcenie potwierdzone dyplomem ukończenia studiów pełni funkcję jednego z głównych kryteriów rekrutacji i selekcji kandydatów do pracy, bowiem informuje o prawdopodobnie wysokim poziomie posiadanych przez nich kompetencji (Gębski, 2009). Dynamiczny wzrost zainteresowania młodzieży podejmowaniem studiów wyższych był również wynikiem oczekiwania szeregu innych potencjalnych korzyści ekonomicznych, społecznych i podmiotowych, tak w sferze prywatnej, jak w sferze publicznej, płynących z tytułu posiadania dyplomu. Wśród nich kluczową grupę profitów stanowią te, które zwiększają prawdopodobieństwo pozyskania zatrudnienia na korzystnych warunkach płacowych, co w efekcie sprzyja zgromadzeniu większych oszczędności, osiągnięciu wyższej stopy życiowej i statusu społecznego, a także osobistej oraz zawodowej mobilności (ryc. 1).

Ryc. 1. Wybrane potencjalne korzyści płynące z posiadania wyższego wykształcenia
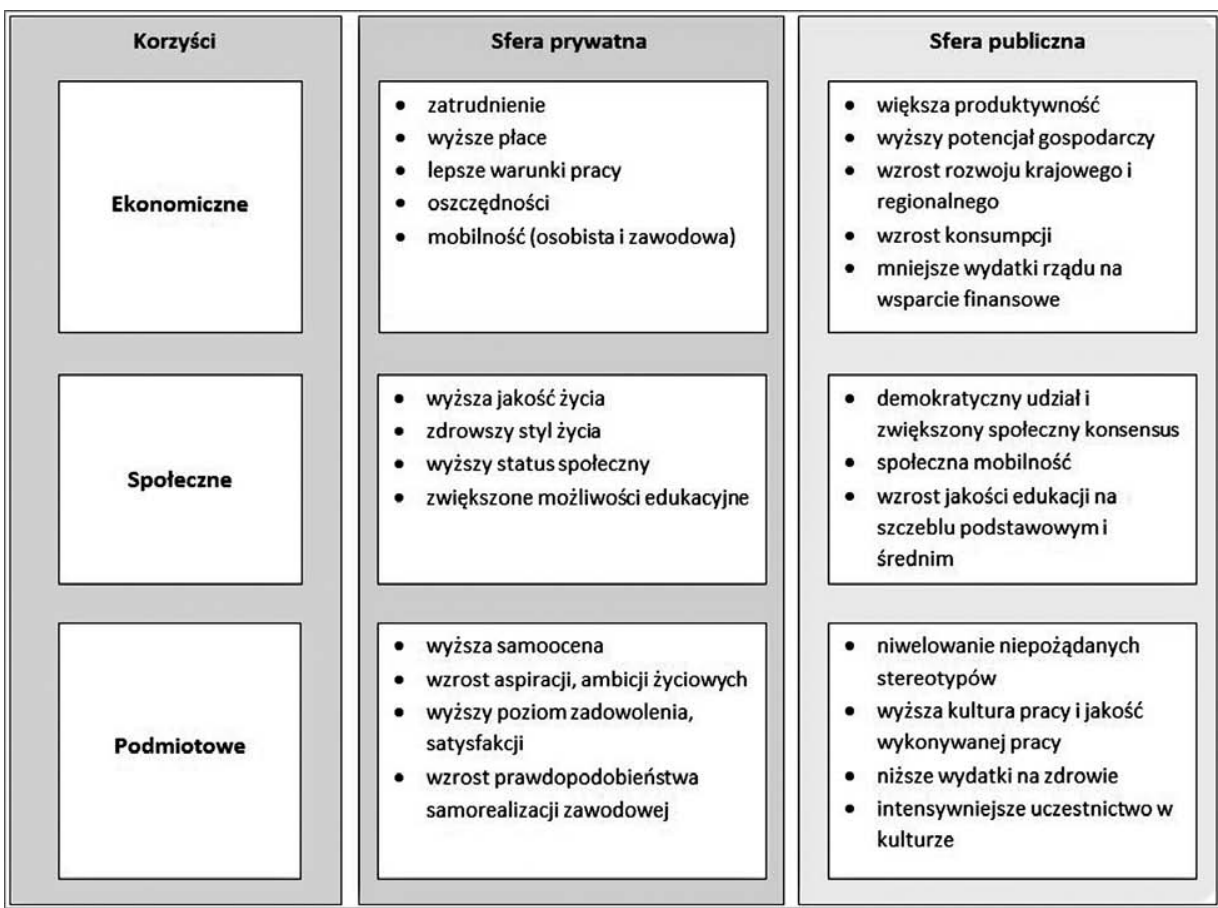

Źródło: opracowanie własne na podstawie Buchner-Jeziorska (2011); Zarycki (2009). 
Należy także mieć na względzie, że w Polsce przez wiele lat ukończenie uczelni wyższej miało wysoką wartość kulturową, było przepustką do kręgu inteligencji i w zdecydowany sposób podnosiło możliwości wykonywania pracy o dużym prestiżu społecznym (Kobylarek 2004). Tym rozlicznym oczekiwaniom i wyzwaniom powinny starać się sprostać uczelnie wyższe (zwłaszcza publiczne), będące szczególnym przypadkiem instytucji, w których ważną rolę odgrywają wartości wyższe i misja społeczna. Model, rola, zasady funkcjonowania uniwersytetu zmieniały się w czasie. Obecnie zachodzi proces kolejnej transformacji wizji uniwersytetu po to, by odpowiadał on wymogom współczesnych realiów, w tym przygotowywał studentów do pomyślnego wejścia na rynek pracy i nie tracił swojego akademickiego charakteru (Leja, 2008). Jednak kształcenie wyższe pojmowane jako inwestycja w kapitał ludzki z poczynioną nadzieją określonych korzyści materialnych i pozamaterialnych jest obarczone ryzykiem (Kryńska, 2011). Zakładanie, że strategia ta musi być efektywna, jest absolutyzowaniem i upraszczaniem. Mimo to społeczeństwo polskie nadal uważa, że warto się kształcić a motywem determinującym podejmowanie trudu edukacji na poziomie wyższym jest oczekiwanie pozyskania atrakcyjnego zatrudnienia po jej zakończeniu. Jak wynika z badań CBOS z 2009 r., średnio 85\% Polaków pragnie wyższego wykształcenia dla swoich dzieci (86\% dla córki i $84 \%$ dla syna, co stanowi wzrost odpowiednio o $22 \%$ i $19 \%$ w porównaniu z badaniami z roku 1993). Głównym motywem dążenia do zdobywania wyższego wykształcenia są spodziewane wysokie zarobki (64\%), ciekawy zawód (39\%) i łatwiejsze życie (35\%) (CBOS, 2009). Tymczasem w Polsce i w wielu innych krajach Europy obserwuje się wzrost odsetka osób bezrobotnych z wyższym wykształceniem.

Sytuacja absolwentów szkół wyższych na rynku pracy, szczególnie trudności związane z pozyskaniem przez nich zatrudnienia po zakończeniu edukacji akademickiej to problem złożony i mający wielorakie uwarunkowania, będące w sferze zainteresowań naukowych specjalistów z różnych dyscyplin (por. m.in.: Buchner-Jeziorska, 2008; 2011; Kabaj, Jeruszka, 2009; Korpysa, 2003; Mikuła-Bączek, 2009; Kiersztyn, 2011, Orczykowska, 2006; Kryńska, 2002, 2008, 2011; Knapińska, 2008; 2009; Jeruszka, 2011; Jakubowska, Rosa, 2011; Sztanderska, Minkiewicz, Bąba, 2005, Piróg, 2011a; 2012a).

Niniejsze opracowanie ma na celu przedstawienie dynamiki zmian liczby i struktury kierunkowej absolwentów szkół wyższych w latach 1990-2010, ukazanie konsekwencji tych przemian w zakresie pozyskiwania zatrudnienia, zwłaszcza przez nowo promowanych absolwentów, i próba nakreślenia możliwości optymalizowania ich pomyślnego przejścia z etapu studiowania do etapu zatrudnienia.

\section{Dynamika liczby absolwentów szkół wyższych}

W okresie 1990-2010 obserwuje się w Polsce stały i dynamiczny wzrost liczby studentów, a zatem i absolwentów szkół wyższych (por. ryc. 2). W roku akademickim 1990/1991 edukację na poziomie wyższym ukończyło 56078 osób. W interwale 6 lat nastąpiło podwojenie liczby absolwentów do 115868 osób (1996/1997), a kolejne podwojenie zajęło już tylko 3 lata (1999/2000; 215423 absolwentów). Do zaspokajania rosnących aspiracji edukacyjnych i przyspieszenia tempa wzrostu liczby absolwentów w znacznej mierze przyczyniło się umożliwienie przez ustawę o szkolnictwie wyższym tworzenia szkół niepublicznych, co zintensyfikowało rozwój sieci instytucji w ramach sektora edukacji wyższej. Działalność uczelni niepublicznych zaowocowała jeszcze szybszym wzrostem liczby studentów, a tym samym i absolwentów. W roku akademickim 1997/1998 wypromowały one swoich pierwszych absolwentów w liczbie 22 625, a w roku 2001/2002 odnotowano już 103712 absolwentów tych szkół, co stanowiło pięciokrotny wzrost w okresie zaledwie trzech lat. W roku 2010/2011 uczelnie niepubliczne ukończyło 169039 studentów. Na przełomie wieków odnotowano naj- 
większy w całym omawianym okresie wzrost liczby absolwentów studiów wyższych (liczba absolwentów w roku akademickim 2000/2001 wyniosła 303966 osób, tj. o 41\% więcej niż w roku poprzedzającym). Istotną przyczyną najpierw tak dynamicznego wzrostu liczby studentów, a potem absolwentów studiów wyższych było także wejście na rynek edukacji akademickiej osób urodzonych w okresie wyżu demograficznego lat 70. XX w. Trend stałego wzrostu liczby absolwentów w XXI w. utrzymał się, a przekroczenie czterystu tysięcy nastąpiło w roku 2006/2007 (410 107 osób). Obecnie liczba ta wynosi 478916 (rok 2009/2010) (GUS, 1990-2010; GUS, 2004-2010).

Ryc. 2. Absolwenci szkół wyższych w latach 1990-2010 (w tys.)

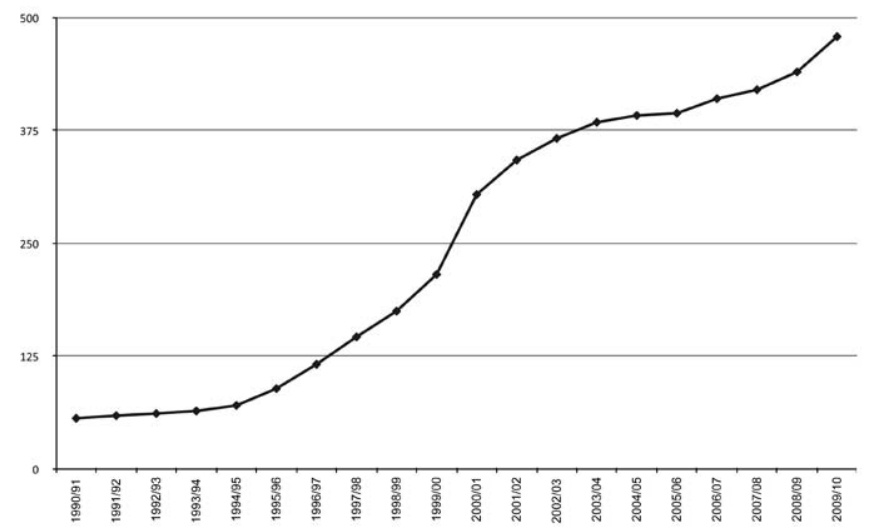

Źródło: opracowanie własne na podstawie: GUS (1990-2003); Szkoły (2004-2010).

Wyrazem rozbudzonych aspiracji edukacyjnych Polaków połączonym z urynkowieniem szkolnictwa wyższego, zwiększaniem limitów rekrutacyjnych i rozpowszechnieniem studiów niestacjonarnych, był gwałtowny wzrost współczynnika skolaryzacji. W latach 1990-2010 współczynniki skolaryzacji wzrosły ponad czterokrotnie, w tym współczynnik skolaryzacji brutto wzrósł z 12,9\% w roku akademickim 1990/1991 do 53,8\% (2010/2011), a netto - odpowiednio z $9,8 \%$ do $40,8 \%$ (por. ryc. 3 ).

Ryc. 3. Współczynnik skolaryzacji brutto w szkolnictwie wyższym w Polsce w latach 1990-2010 (w \%)

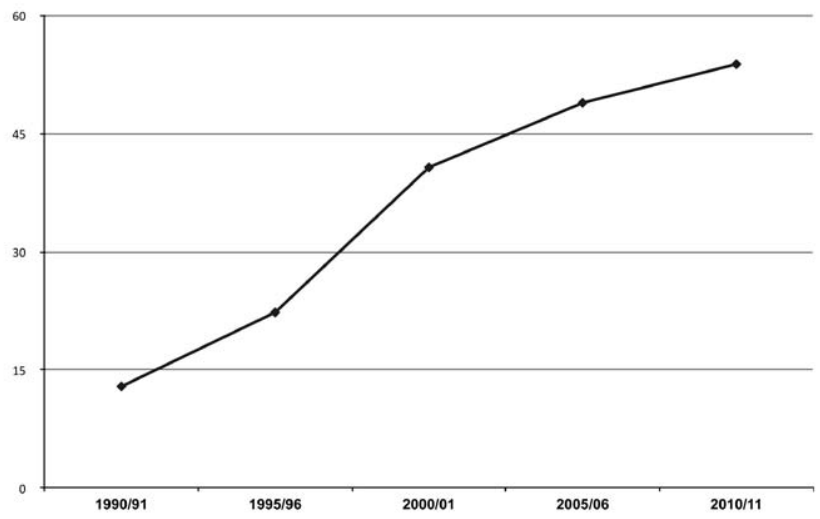

Źródło: opracowanie własne na podstawie: GUS (1990-2000; 2004-2010). 
Obecnie Polska należy do grupy tych państw Unii Europejskiej, w których notuje się jedną z najwyższych liczb studentów na 10 tys. mieszkańców (zajmuje piąte miejsce ze wskaźnikiem 568). Wyższe wskaźniki są tylko na Litwie, w Finlandii, Słowenii oraz na Łotwie (GUS, 2010). Kształcenie stało się sposobem dostosowania się młodzieży do obserwowanych zmian na rynku pracy. Podnoszenie poziomu wykształcenia było też inspirowane przez działania podmiotów polityki edukacyjnej w dziedzinie szkolnictwa publicznego, stałe podnoszenie dostępności i poszerzanie oferty edukacyjnej (kierunkowej i specjalnościowej).

\section{Zmiany kierunkowe}

Wpływ na sytuację absolwentów wchodzących na rynek pracy, oprócz zaprezentowanego dynamicznego wzrostu ich liczby, ma również tryb, kierunek i stopnień ukończonych studiów. W omawianym okresie zwiększyła się liczba uczelni wyższych, a w ich obrębie gama kierunków i specjalności do wyboru, zatem i struktura kierunkowa absolwentów wykazywała wyraźne trendy zmian.

W roku akademickim 1990/1991 najliczniejszą zbiorowość stanowili absolwenci kierunków technicznych (19,4\% ogółu absolwentów szkół wyższych), wyprzedzając absolwentów kierunków pedagogicznych (17,5\%), kierunków medycznych (10,1\%), kierunków związanych z biznesem i zarządzaniem $(9,8 \%)$ oraz kierunków humanistycznych $(9,6 \%)$. Odsetek osób $\mathrm{z}$ dyplomem ukończenia studiów technicznych był jednak stosunkowo niski w porównaniu z rokiem 1980/1981, kiedy stanowili oni około 32\% ogółu. Od początku lat 90. XX w. rosnącą popularnością cieszyły się kierunki z zakresu biznesu, finansów, bankowości, zarządzania oraz nauki społeczne i prawo. W następnej dekadzie, od w roku akademickiego 2000/2001, w strukturze absolwentów dominowali już ekonomiści $(33,7 \%)$. Na drugiej pozycji niezmiennie plasowały się osoby kończące kierunki pedagogiczne (16,2\%), a trzecie miejsce w hierarchii (14,3\%) należało do absolwentów kierunków społecznych. W roku 2005/2006 także dominowali absolwenci kierunków ekonomicznych i administracyjnych $(27,1 \%)$, a tuż za nimi najliczniejszą, choć nieco mniejszą niż pięć lat wcześniej, zbiorowość stanowili absolwenci uczelni pedagogicznych (15,6\%). Trzecie miejsce zajęli absolwenci kierunków społecznych $(14,7 \%)$, a za nimi uplasowali się absolwenci kierunków humanistycznych $(8,4 \%)$ oraz inżynieryjno-technicznych $(5,4 \%)$. W XXI w. zmiany struktury kierunkowej wiodących grup absolwentów były znacznie mniejsze. Utrzymywała się przewaga (choć z malejącym odsetkiem) absolwentów profilów ekonomicznych i administracyjnych (z 31,5 \% w roku 2000 do 25,7\% w roku 2010). Drugie miejsce nadal należało do kierunków pedagogicznych, natomiast trzecie zajęli absolwenci kierunków społecznych. Tuż za nimi znaleźli się absolwenci kierunków humanistycznych. W ostatnim dziesięcioleciu największy, bo trzykrotny wzrost, zarejestrowano wśród absolwentów kierunków medycznych (z 2,3\% w 2000 do 6,9\% w roku 2010) (GUS, 2004-2010).

Obecnie w Polsce przypada średnio 11,1 absolwenta kierunków przyrodniczych i technicznych na 1000 mieszkańców, przy średniej dla krajów UE na poziomie 12,9. Szczególnie niepokojący jest obserwowany trend spadkowy zainteresowania studiami na kierunkach inżynieryjno-technicznych.

Różnice w proporcjach absolwentów poszczególnych kierunków były i są efektem oddziaływania wielu czynników. Do ważniejszych zaliczyć należy zmiany popytu na rynku pracy, wynikające m.in. z ograniczenia produkcji przemysłowej, restrukturyzacji przemysłu, pojawienia się nowych typów przedsiębiorstw korporacyjnych, rozwoju instytucji finansowych, banków i giełdy. Spadek zainteresowania studiami technicznymi jest także pokłosiem likwidacji obligatoryjnego egzaminu maturalnego z matematyki (Buchner-Jeziorska, 2011: 25). 
Duży popyt ze strony kandydatów na studia ekonomiczne miał swoje korzenie w latach 90 . XX w., kiedy w Polsce rodziła się gospodarka rynkowa, która generowała zapotrzebowanie na specjalistów z tych dziedzin i zapewniała im intratne posady. Na zainteresowanie przyszłych studentów szybko odpowiedział rynek usług edukacyjnych i właśnie uczelni ekonomicznych dotyczył najwyższy dziewiętnastokrotny wzrost ich liczby (z 5 w roku 1990 do 95 w roku 2006/2007) (Mikuła-Bączek, 2009). Drugim, poza popytem na studia ekonomiczne, powodem tak spektakularnego zwiększenia liczby szkół wyższych, oferujących studia ekonomiczne i humanistyczne, był aspekt kosztów. Prowadzenie tych kierunków nie wymagało tak wysokich nakładów finansowych, jak prowadzenie studiów z grupy nauk eksperymentalnych, technicznych, które wiążą się z koniecznością posiadania specjalistycznej aparatury i zaplecza laboratoryjnego. Powodowało to wyraźnie mniejszą aktywność w zakresie uruchomiania takich kierunków przez uczelnie niepubliczne (Borowiec, 2011). Tymczasem kierunki ekonomiczne były i nadal są prowadzone na niemal wszystkich typach uczelni, w tym na uczelniach rolniczych, technicznych, a nawet na wychowania fizycznego.

Wyrazem działań ministerialnych, mających na celu korygowanie zanotowanej dysproporcji pomiędzy absolwentami kierunków humanistycznych a osobami kończącymi studia techniczne i matematyczno-przyrodnicze, było rozpoczęcie przez Ministerstwo Nauki i Szkolnictwa Wyższego dotowania tzw. kierunków zamawianych. Uczelnie, które prowadzą te kierunki studiów, mogą otrzymywać dodatkowe fundusze celem podnoszenia atrakcyjności kształcenia m.in. przez organizowanie dla studentów np. kursów wyrównawczych z matematyki i fizyki, rozbudowanych lektoratów z języka angielskiego, obozów naukowych, zajęć dydaktycznych prowadzonych przez wybitnych specjalistów z różnych dziedzin, kursów dających dodatkowe kwalifikacje i uprawnienia zawodowe, wyjazdów studyjnych do przedsiębiorstw oferujących zatrudnienie absolwentom. Na kierunkach tych wypłacane są dość wysokie motywacyjne stypendia dla studentów. W roku akademickim 2011/12 do kierunków zamawianych zaliczono: analitykę gospodarczą, automatykę i robotykę, elektronikę, i telekomunikację, informatykę, biotechnologię, budownictwo, chemię, energetykę, energetykę jądrową, fizykę i fizykę techniczną, informatykę, informatykę stosowaną z komputerową nauką o materiałach, inżynierię gospodarczą i wodną, inżynierię materiałową, inżynierię środowiska, nanotechnologię i technologię procesów materiałowych, matematykę, mechanikę i budowę maszyn, mechatronikę, ochronę środowiska, studia matematyczno-przyrodnicze, technologie ochrony środowiska, wzornictwo oraz zaawansowane materiały i nanotechnologie (Ministerstwo Pracy i Polityki Społecznej, 2012). Trudno ocenić, czy kwalifikacje nabywane przez studentów na kierunkach zamawianych, są tymi, które znacznie podnoszą konkurencyjność w procesie pozyskiwania zatrudnienia, bowiem nie ma opublikowanych badań sytuacji absolwentów - przedstawicieli tych kierunków na rynku pracy.

W rozpatrywanym okresie nastąpiły także duże zmiany w systemie organizacji studiów. Od 1991 r. wiele wyższych uczelni zaczęło różnicować jednolity, magisterski system studiów. Działania te zostały zintensyfikowane w roku 2005, kiedy ustawowo wprowadzono podział studiów na trzystopniowe. Jak podkreślają U. Sztanderska, B. Minkiewicz i M. Bąba, to właśnie zmiany charakterystyk (tak indywidualnych, jak i zbiorowych) osób z wyższym wykształceniem są czynnikiem mającym istotny wpływ na trudności w pozyskaniu pracy przez absolwentów uczelni wyższych. Ich zdaniem, istnieje duże prawdopodobieństwo, że dzisiejszy absolwent odbył krótszą edukację akademicką niż jego kolega sprzed kilkunastu lat, często w trybie niestacjonarnym, co łączy się z przede wszystkim ze skromniejszym wymiarem godzin dydaktycznych. W tych warunkach kapitał edukacyjny absolwentów jest obecnie znacznie mniejszy i stawia ich w trudniejszym położeniu w procesie konkurowania o pracę (Sztanderska i in. 2005a, b). 
Obecnie zbiorowość absolwencką szkół wyższych tworzą osoby posiadające tytuł doktora, magistra, licencjata, inżyniera, absolwenci studiów stacjonarnych i niestacjonarnych, odbytych tak w dużych ośrodkach akademickich i na renomowanych uczelniach, jak i w szkołach nowo powstałych, często z ubogim doświadczeniem naukowo-dydaktycznym i utrudnionym kontaktem z najlepszymi specjalistami czy bibliotekami (Orczykowska, 2006). Co istotne, w przeciwieństwie do innych krajów, w Polsce tytuł licencjata nie jest ciągle powszechnie uznany za dowód pełnowartościowego wyższego wykształcenia (Teichler, 2011). Ta heterogeniczność zbiorowości absolwentów, połączona z brakiem ogólnopolskich badań ich rzeczywistej sytuacji na rynku pracy, poważnie utrudnia, a niekiedy wręcz uniemożliwia wykonanie jednoznacznej oceny, czy, a jeżeli tak, to który tryb i stopnień ukończonych studiów w obrębie danego kierunku, ułatwia uzyskanie pracy po ich zakończeniu.

\section{Absolwent w dobie kryzysu gospodarczego}

Scharakteryzowany we wcześniejszej części opracowania dynamiczny wzrost liczby absolwentów szkół wyższych zachodził w okresie powiększającego się w Polsce bezrobocia. Na początku badanego okresu bezrobocie w Polsce wynosiło 6,5\% i bardzo szybko zaczęło wzrastać, by osiągnąć swoje maksymalne wartości w latach 2002-2004 (stopa bezrobocia wyższa niż 20\%). Ten niekorzystny trend nie pozostawał bez wpływu na absolwentów uczelni wyższych i chociaż wykształcenie akademickie stanowiło niewątpliwy atut na rynku pracy, to można stwierdzić, że sytuacja tej zbiorowości osób ulegała powolnemu pogorszeniu, a odsetek osób bezrobotnych posiadających wyższe wykształcenie wzrósł z 2,6\% w roku 2000 do 10,5\% w roku 2011 (por. ryc. 4). Na końcu sierpnia roku 2012 różnica między stopą bezrobocia ogółem a stopą bezrobocia wśród osób z wyższym wykształceniem wynosiła zaledwie 1,1 punktu procentowego na korzyść tej zbiorowości osób.

Ryc. 4. Stopa bezrobocia w latach 1999-2012 (w \%)

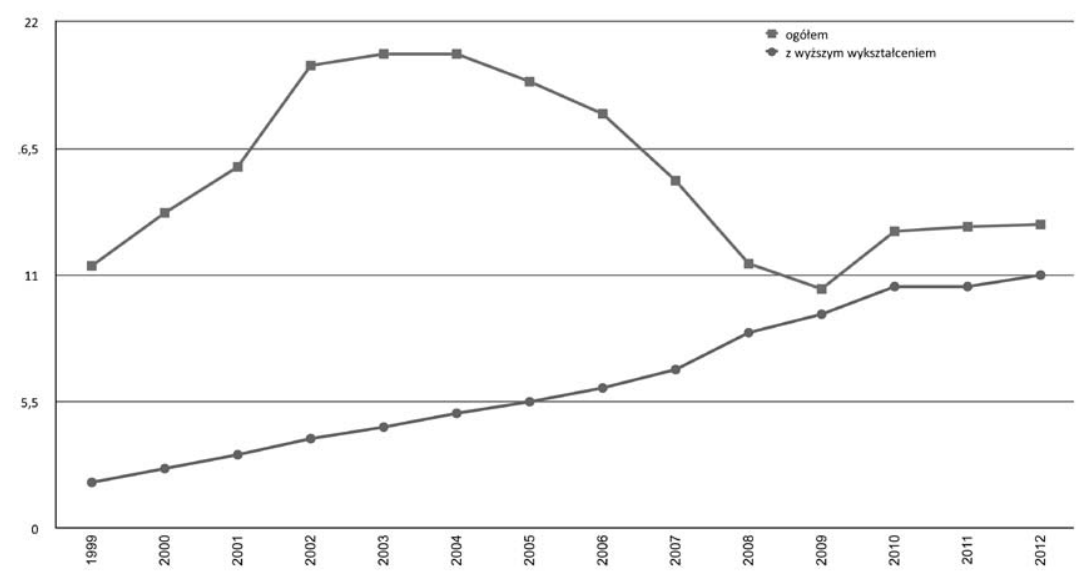

Źródło: opracowanie własne na podstawie GUS (2012).

Podobnie niepokojąco nasilają się trudności z płynnym przejściem na rynek pracy nowo promowanych absolwentów szkół wyższych, które coraz częściej jest obarczone ryzykiem niepowodzenia. W IV kwartale 2010 r. absolwenci studiów wyższych stanowili 36,3\% ogółu absolwentów i 16,3\% wszystkich bezrobotnych absolwentów. W ostatnim dziesięcioleciu 
odsetek bezrobotnych absolwentów z wyższym wykształceniem był niższy niż średnia stopa bezrobocia dla absolwentów ogółem, niemniej około $20 \%$ z nich pozostawało bez pracy (por. ryc. 5).

Ryc. 5. Bezrobotni absolwenci w latach 2003-2012 (w \%)

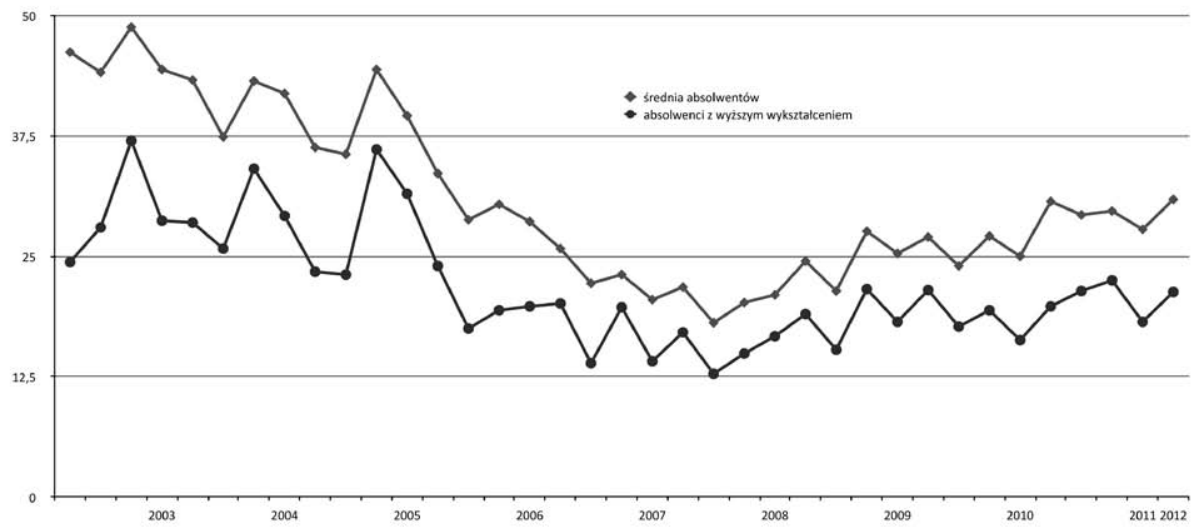

Źródło: opracowanie własne na podstawie GUS (2003-2012).

Z drugiej strony utrzymanie wskaźnika zatrudnienia osób z wyższym wykształceniem na prawie tym samym poziomie około $76,6 \%$ przez dwadzieścia lat przy tak dynamicznym wzroście liczby absolwentów szkół wyższych należy uznać za sukces w realizacji funkcji zaspokajania potrzeb rynku pracy (por. ryc. 6). Jednak trzeba pamiętać, że wskaźnik ten nie uwzględnia czy absolwent pracuje na stanowisku zgodnym z poziomem wykształcenia, czy poniżej swoich kwalifikacji. W latach 1999-2008 tylko około połowa (54\%) absolwentów szkół wyższych znalazła zatrudnienie na stanowiskach wymagających wyższego wykształcenia (Jeruszka, 2011: 2).

Ryc. 6. Wskaźnik zatrudnienia osób z wyższym wykształceniem 1992-2011 (w \%)

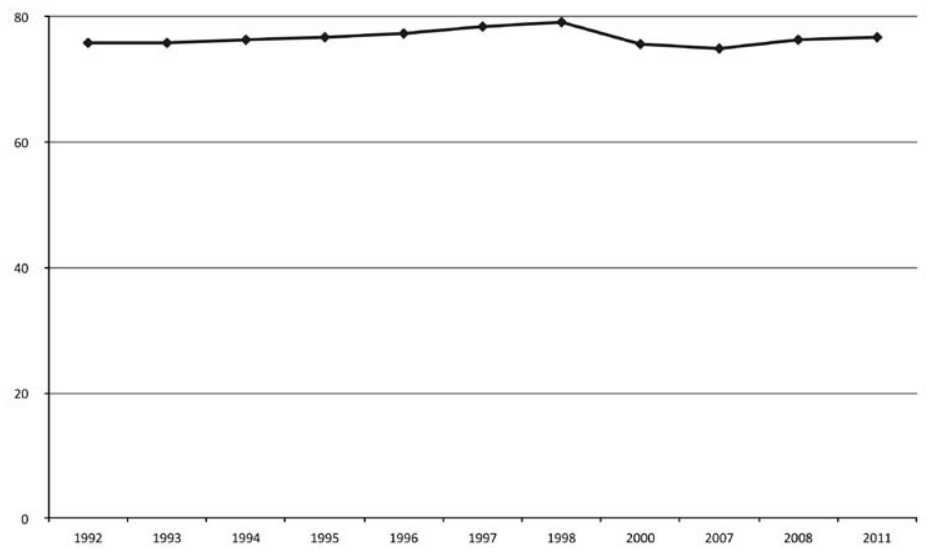

Źródło: opracowanie własne na podstawie Buchner-Jeziorska (2011). 
Obserwowane problemy z pozyskaniem pracy przez absolwentów szkół wyższych były nowym i sprzecznym z powszechnym przekonaniem społeczeństwa procesem. Posiadanie dyplomu ukończenia wyższej uczelni przestało być kluczem do zdobycia atrakcyjnej pracy i skuteczną ochroną przed problemem bezrobocia. Paradoksalnie wskazane zjawiska indukowały dalszy intensywny wzrost liczby studentów i absolwentów, który bywa nazywany nawet swoistą próbą ucieczki młodzieży przed zderzeniem się z wyzwaniami rynku pracy (przynajmniej na okres kształcenia), motywowanej nie tyle nadzieją na zdobycie konkurencyjnych kompetencji w toku studiów na prestiżowej uczelni, co spodziewaną ogólną poprawą sytuacji na rynku pracy i wyciszeniem skutków kryzysu gospodarczego. To z kolei, przez powszechną dostępność szkolnictwa wyższego, przyjmowanie bardzo dużej rzeszy kandydatów na studia niestacjonarne czy na uczelnie niepubliczne, pogorszyło sytuację wszystkich nowych absolwentów studiów wyższych na rynku pracy (Ernst, Young, 2009). Urynkowienie edukacji wyższej spowodowało, że studia mogą podejmować nie tylko osoby o dużych zdolnościach intelektualnych, ale też o walorach przeciętnych i poniżej przeciętnej. Systemy zarządzania uczelnią, głównie w obszarze zapewnienia odpowiedniej jakości, okazały się nieprzygotowane na tak duże zmiany. Efektem tego niekorzystnego trendu jest duża liczba osób legitymujących się dyplomem ukończenia studiów wyższych przy nierzadko jednoczesnym braku realnej zgodności poziomu kompetencji specjalistycznych, psycho-społecznych ze stopniem wykształcenia zapisanym na dyplomie. Niezależnie od chęci i deklaracji werbalnych, uczelnie w znacznym stopniu dopasowały wymagania dydaktyczne do możliwości percepcji odbiorców. Proces ten zdewaluował wartość wyższego wykształcenia i nadszarpnął zaufanie pracodawców wobec kształcenia na tym poziomie (Kryńska, 2011).

Liczba miejsc pracy dla pracowników o wysokich kwalifikacjach i kompetencjach jest znacznie mniejsza niż podaż potencjalnych pracowników. Istnieje duży popyt na pracowników z wyższym wykształceniem, ale głównie na inżynierów i menadżerów projektów. Jednym z dowodów na występowanie nadwyżki, oprócz wzrastającego odsetka bezrobotnych absolwentów szkół wyższych, jest duże i utrzymujące się zapotrzebowanie rynku pracy na pracowników w zawodach nie wymagających ukończenia studiów (pierwsze miejsce i największa liczba wakujących miejsc pracy, tj.: 32,6\% należy do pracowników z wykształceniem zawodowym). Jak podaje raport Ministerstwa Pracy i Polityki Społecznej, najbardziej deficytowe zawody/stanowiska pracy (na podstawie wskaźnika intensywności nadwyżki) w pierwszym półroczu 2011 r. to: ,pozostali praktykujący niekonwencjonalne lub komplementarne metody terapii, czyściciel dywanów, lekarz - rehabilitacja medyczna, pielęgniarka specjalista pielęgniarstwa opieki długoterminowej, pozostali pracownicy domowej opieki osobistej, urzędnik podatkowy ,sprzedawca reklam internetowych, dekorator wyrobów cukierniczych, robotnik osuszania i odgrzybiania budowli, spawacz metodą MIG”. W grupie zawodów o najniższym poziomie wskaźnika intensywności nadwyżki uplasowały się kolejno: ,politolog, technik agrobiznesu, filolog - filologia polska, technik żywienia i gospodarstwa domowego, technik transportu kolejowego, filolog - filologia obcojęzyczna, pozostali pracownicy usług domowych, elektromechanik elektrycznych przyrządów pomiarowych, technik technologii żywności - przetwórstwo mleczarskie, właściciel małego sklepu" (Ministerstwo Pracy i Polityki Społecznej, 2012). W tej sytuacji pracodawca może stawiać absolwentowi nierealne wymagania, bo ma świadomość wysokiej nadwyżki podaży osób z wysokimi kwalifikacjami i nierzadko proponuje niską płacę zasadniczą, mówiąc, że zależy ona od wyników pracy, a mechanizm ich oceny nie jest transparenty (Korpysa, 2003: 126-127).

Ukazane fakty mogą być potwierdzeniem wystąpienia problemu nadwyżki osób z wyższym wykształceniem i nasycenia potrzeb kształcenia na poziomie akademickim w poszczególnych 
kategoriach zawodowych. Wielu absolwentów uczelni wyższych staje zatem przed koniecznością podjęcia zatrudnienia niedopasowanego do poziomu wykształcenia, co niesie ze sobą niepożądane społeczne i indywidualne koszty. Zaliczają się do nich: nakłady finansowe jakie społeczeństwo poniosło na edukację, które w takiej sytuacji są inwestycją przynoszącą straty. Badania wykazały nadto, iż praca poniżej swoich kwalifikacji zmniejsza wydajność pracownika (Kiersztyn, 2011). Kolejnym niekorzystnym następstwem tej nadwyżki jest wypieranie osób z niższym, ale w pełni właściwym w odniesieniu do zadań przewidzianych do realizowania na danym stanowisku, poziomem wykształcenia przez osoby z wyższym wykształceniem, dla których oznacza to pracę na stanowiskach poniżej ich kompetencji i kwalifikacji - tzw brain draining (Jakubowska, Rosa, 2011). Jednym z dowodów na występowanie tego zjawiska, jak wskazują badania POLPAN z lat 1998-2008, jest wzrost odsetka osób z nadwyżką wykształcenia wśród osób pracujących z 7,5\% do 19,1\% (Kiersztyn, 2011: 11).

Przyczyny rosnących trudności wchodzenia na rynek pracy osób kończących studia wyższe są wielorakie. Jedną z nich jest niewątpliwie spadek koniunktury gospodarczej, wynikający z obniżenia popytu globalnego warunkującego popyt na pracę oraz spowolnienie tempa wzrostu gospodarczego (Kryńska, 2000: 7-10). Nadto, trudności te mogą wynikać z odmiennych postaw i oczekiwań tak wśród pracodawców, jak i wśród osób poszukujących zatrudnienia. Do podstawowych czynników zmniejszających szanse zatrudnienia po ukończeniu studiów, a stawianych przez pracodawców zaliczyć można wymagania dotyczące posiadania stażu pracy i znacznego doświadczenia zawodowego. Absolwenci zaś mogą osłabiać swoje szanse na pomyślną tranzycję przez niechęć podejmowania pracy w zawodzie innym niż wyuczony, małą mobilność i brak klarownego planu rozwoju swojej kariery zawodowej.

\section{Kierunki optymalizacji wchodzenia nowo promowanych absolwentów na rynek pracy}

Zarysowany obraz sytuacji absolwentów szkół wyższych na rynku pracy, pokazujący stopniowe osłabienie ich pozycji, wydaje się jasno wskazywać zarówno na potrzebę dyskusji skupiającej się na roli i aktualnych funkcjach szkolnictwa wyższego, jak i na rozpoczęcie konkretnych przedsięwzięć, mających na celu optymalizowanie przechodzenia młodzieży z etapu edukacji do zatrudnienia, określanego jako proces tranzycji (Allen, Van der Velden, 2007) w warunkach kryzysu gospodarczego.

Pierwszym koniecznym krokiem w tym zakresie jest kompleksowe rozpoznanie realnej sytuacji absolwentów szkół wyższych na rynku pracy, zwłaszcza skuteczności procesu ich tranzycji z etapu edukacji do zatrudnienia. Częściowo ten niedoeksplorowany obszar badań powinien być podejmowany przez poszczególne uczelnie, bowiem od października $2011 \mathrm{r}$. Ministerstwo Nauki i Szkolnictwa Wyższego wprowadziło obowiązek monitoringu losów zawodowych absolwentów przez poszczególne uczelnie: art. 13a „uczelnia monitoruje kariery zawodowe swoich absolwentów w celu dostosowania kierunków studiów do potrzeb rynku pracy, w szczególności po trzech i pięciu latach od dnia ukończenia studiów”.

Rodzi się jednak pytanie, czy możliwy będzie dostęp do wszystkich uczelnianych raportów przez osoby i instytucje zainteresowane wynikami takich badań? Jeśli tak, to czy wykonalne będzie porównywanie opracowań, które zrealizowanych z zastosowaniem różnej metodologii i narzędzi badawczych? Wreszcie, czy badanie sytuacji absolwentów na rynku pracy aż po trzech i pięciu latach będzie przydatne uczelniom wyższym do modyfikacji koncepcji programów studiów w czasach, gdy przemiany rynku pracy są niezwykle dynamiczne i indukują potrzebę szybkiego adaptowania się do nowych uwarunkowań? Jeśli celem takich badań ma być dostarczanie uczelniom informacji, które mają służyć im do trafniejszych wprowadzania zmian programowych i metodycznych, wskazane wydaje się być, wzorem rozwiązań przyję- 
tych w większości krajów europejskich, monitorowanie sytuacji nowo promowanych absolwentów krótko po zakończeniu studiów (najczęściej po sześciu miesiącach) i ewentualne ich kontynuowanie po dłuższym czasie (np.: kilku lat).

Drugim obszarem działań powinien być pogłębiony namysł nad współczesnymi koncepcjami kształcenia akademickiego, które służyłyby równie skutecznie realizowaniu swojej tradycyjnej misji i usatysfakcjonowaniu jak najliczniejszej rzeczy interesariuszy. Zasadne wydaje się najpierw przeprowadzenie rzetelnego audytu programu studiów, obejmującego ofertę programową kursów danego kierunku studiów; charakter i intensywność współpracy kierunku studiów z biurem karier uczelni; kontakty z potencjalnymi pracodawcami oraz badanie losów absolwentów na rynku pracy i wykorzystywanie wyników tych badań do korekt programowych (Piróg, 2011b). Następnie wyniki przeprowadzonej oceny należy wykorzystać do reorientacji celów i metod kształcenia akademickiego w obrębie danego kierunku studiów. Jedną z dróg takiej modernizacji jest wkomponowanie w proces dydaktyczny praktycznych metod kształcenia. Szczególną uwagę należy poświęcić metodzie projektów, która na poziomie akademickim powinna być stosowana przede wszystkim jako filozofia konstrukcji całej oferty programowej (Hennemann, Liefner, 2010; Pawson i in., 2006). Wówczas program ma składać się z precyzyjnie wybranych i gruntowanie przemyślanych kursów skupionych na takich problemach do przestudiowania, by umożliwiły doskonalenie krytycznego myślenia, efektywnego rozwiązywania problemów, umiejętności pracy zespołowej i samokształcenia. Sposób postępowania powinien być możliwie najbliższy realnym ścieżkom działań w podobnej sytuacji występującej w życiu i karierze zawodowej przyszłych absolwentów, a prowadzenie niektórych modułów w obrębie kursów tematycznych należy powierzyć praktykom i pracodawcom (Piróg, 2012c).

Ważne wydaje się także posiadanie gruntownej wiedzy studenta każdego kierunku o rynku pracy i umiejętność planowania swojej kariery zawodowej. Znajomość oczekiwań pracodawców, instytucji, które mogą wspierać absolwenta w poszukiwaniu zatrudnienia, podstaw prawa pracy, nabycie umiejętności wyartykułowania swoich zalet, postawienia celów i zaplanowania obszarów dalszego rozwoju zawodowego, może przyczynić się do podjęcia wieloaspektowych działań studentów już w toku studiów, które mogą optymalizować ich szanse na pomyślną tranzycję. Kolejnym niezbędnym etapem jest doskonalenie technik komunikowania się bezpośredniego, pisemnego, elektronicznego i telefonicznego oraz autoreklamy rozumianej jako umiejętność zdefiniowania i promowania własnego potencjału (Piróg, 2012b, c).

Niezwykle istotne jest także wypracowanie dobrego wizerunku danego kierunku studiów oraz marki uczelni. Trwale wysoki poziom kształcenia, wiodące pozycje w rankingach, bogata i ciekawa oferta edukacyjna, której odzwierciedleniem jest poziom kompetencji absolwentów i ich konkurencyjność na rynku pracy, sprzyja większemu zainteresowaniu pracodawców potencjalnymi pracownikami, rekrutującymi się z takich uczelni i kierunków (Dworak, 2011). Na wizerunek znacząco wpływa kadra akademicka, która powinna posiadać zarówno rozległą wiedzę teoretyczną, jak i bogate doświadczenia empiryczne z zakresu prowadzonych zajęć (Kowalska, 2011).

Wszystkie wymienione działania są odpowiedzią na potrzebę kreowania koncepcji uniwersytetu przedsiębiorczego, która zakłada, że szkoła wyższa będzie: „organizacją racjonalnie (twórczo, efektywnie) zarządzającą posiadanym kapitałem społecznym i intelektualnym przez procesy działania specyficzne dla uczelni, to znaczy: badania, kształcenie i kulturotwórcze relacje ze środowiskiem" (Czerepaniak-Walczak, 2010: 58). Celem uczelni jest wówczas pomnażanie kapitału społecznego i intelektualnego, które stanowią zasadniczy czynnik wielowymiarowego rozwoju osobowego. Realizacja tak sformułowanych celów jest możliwa wów- 
czas, gdy dokonana zostanie innowacja metod, form i treści kształcenia akademickiego, które omówiono powyżej. Taka wizja wydaje się również godzić zarówno w niezbywalną potrzebę kontynuowania na jak najwyższym poziomie idei kształtowania elity intelektualnej, jak i prowadzenia nowatorskich, rzetelnych badań naukowych z równoczesnym podjęciem wyzwań wynikających z przemian społeczno-gospodarczych.

Wreszcie, doniosłym kierunkiem optymalizowania szans absolwentów na rynku pracy w warunkach kryzysu jest kształcenie (na wszystkich szczeblach edukacji), mające na celu wypracowanie u młodzieży postaw przedsiębiorczych (Borowiec, Rachwał, 2011; Osuch, 2012; Kurek, Rachwał, 2011; Rachwał, 2006; Tracz, 2006). W kontekście przygotowania do wejścia na rynek pracy przedsiębiorczość należy rozumieć jako podstawę efektywnego zarządzania obszarami życia osobistego, zawodowego i społecznego. Tak postawa w warunkach kryzysu umożliwia zdolność adaptacji do nowych warunków, zwiększa skłonności do zmiany kwalifikacji, miejsca zamieszkania, miejsca zatrudnienia, adaptacji niestandardowych form zatrudnienia, atypowych miejsc pracy, które w zasadniczy sposób podnoszą szanse na płynne przejście na rynek pracy (Kryńska, 2008). Za istotny czynnik wpływający na powodzenie na rynku pracy uznaje się także samoocenę podmiotu jako osoby przedsiębiorczej, która jest kluczem do skutecznej rywalizacji w aktualnych realiach rynkowych (Bernat, Kunasz, 2005).

Można zatem stwierdzić, że działania mające na celu optymalizowanie szans absolwentów na rynku pracy powinny opierać się na trzech filarach: prorynkowych strategiach kształcenia szkół wyższych, proedukacyjnych strategiach pracodawców oraz racjonalnych działaniach studentów.

\section{Zakończenie}

Rozpatrując sytuację absolwentów szkół wyższych na rynku pracy, należy stwierdzić, że jest ona pochodną wielu czynników, do których należy zaliczyć:

- kryzys gospodarczy, który char akteryzuje się zmniejszeniem produkcji, realnych dochodów i wzrostem bezrobocia we wszystkich grupach społecznych,

- ograniczoną zdolność gospodarki do wchłaniania zasobów pracy,

- sytuację demograficzną, zwłaszcza wkraczanie na rynek pracy pokoleń wyżu demograficznego,

- niedostosowanie rozmiarów kształcenia i struktury kierunkowej wybieranych przez młodzież profilów kształcenia do realnych potrzeb rynku pracy,

- malejące wymagania stawiane kandydatom w toku rekrutacji na studia wyższe i w ciągu studiów, umożliwiające zdobycie nominalnie wyższego wykształcenia, ale realnie znacznie odbiegającego od przyjętych standardów,

- dyskryminacyjne rekrutacyjne praktyki pracodawców,

- niedobory w wypracowaniu u przyszłych absolwentów pożądanych postaw sprzyjających skutecznemu poszukiwaniu pracy (Giermanowska, Racław-Markowska, 2003; Skórska, 2004; Sztanderska, 2007).

W świetle przeprowadzonych badań stwierdza się, że ukończenie studiów jest wciąż cennym składnikiem kapitału intelektualnego i stwarza większe szanse na pozyskanie zatrudnienia niż legitymowanie się dyplomami niższych etapów kształcenia. Ze względu na nadwyżkę podaży nad popytem absolwentów większości kierunków studiów muszą się oni jednak wykazywać się coraz wyższą konkurencyjnością, a pracodawcy mogą stosować niemal nieograniczoną selekcję w naborze kandydatów i proponować znacznie mniej korzystne dla pracowników warunki pracy, wyrażone niższym wynagrodzeniem i zatrudnianiem na stanowiskach nie wymagających posiadania dyplomu szkoły wyższej. 
Sytuacja demograficzna Polski, a w konsekwencji - malejący popyt na usługi edukacyjne na poziomie wyższym - powoduje, że zarówno uczelnie o mniejszym prestiżu i krótszych doświadczeniach akademickich, jak i renomowane uniwersytety z tradycjami już zaczynają zabiegać lub w niedalekiej przyszłości będą musiały w sposób szczególny zatroszczyć się o własną pozycję, a niekiedy wręcz dalszą egzystencję na rynku usług edukacyjnych. Należy się spodziewać, że wskaźniki zatrudnialności (podobnie jak w wielu krajach Europy Zachodniej) staną się jedną z miar jakości pracy uczelni i będą współdecydować o jej pozycji na rynku usług edukacyjnych.

Zdecydowana większość szkół wyższych podejmie intensywne działania wykraczające poza dotychczasowe rozwiązania, polegające głównie na tworzeniu nowych kierunków lub specjalności w obrębie tych kierunków. Należy mieć nadzieję, że wiele uczelni będzie intensywnie dążyć do jak najwyższej jakości kształcenia skupionej na wyedukowaniu absolwentów wyposażonych w szeroki zakres kompetencji, które zapewnią im sukces na rynku pracy.

\section{Literatura}

Allen, J., Van der Velden, R. (2007). Transitions from higher education. W: U. Teichler (red.), Careers of University Graduates. Springer, 55-78.

Bernat, T., Kunasz, M. (2005), Realia gospodarcze a postawy przedsiębiorcze studentów. Wyniki badań. Zeszyty Naukowe Uniwersytetu Szczecińskiego, 408, Prace Katedry Mikroekonomii, 10, 95-109.

Borowiec, M. (2008). Rola szkolnictwa wyższego w procesie kształtowania gospodarki opartej na wiedzy. Przedsiębiorczość - Edukacja, 4, 24-36.

Borowiec, M. (2011). Zmiany kierunków kształcenia akademickiego w Polsce. Prace Komisji Geografii Przemystu Polskiego Towarzystwa Geograficznego, 18, 9-22.

Borowiec, M., Rachwał T. (2011). Kształtowanie postaw przedsiębiorczych na lekcjach geografii wyzwaniem edukacyjnym w procesach globalizacji. Przedsiębiorczość - Edukacja, 7, 321-332.

Buchner-Jeziorska, A. (2008). Absolwenci szkół wyższych na rynku pracy (lata 1990-2006). W: B. Minkiewicz, P. Błędowski (red.), Absolwenci SGH na rynku pracy, Warszawa: Wyd. SGH, 11-23.

Buchner-Jeziorska, A., (2011). Studia wyższe - bez szans na sukces?! Acta Universitatis. Folia Sociologica, 39, 17-31.

CBOS. (2009). Aspiracje i motywacje edukacyjne Polaków w latach 1993-2009. Warszawa: CBOS. Pozyskano z: http://www.cbos.pl/SPISKOM.POL/2009/K_070 09.PDF.

Czerepaniak-Walczak, M. (2010). Uniwersytet - instytucja naukowo-edukacyjna czy przedsiębiorstwo? Szkoła wyższa w procesie zmiany. W: J. Piekarski, D. Urbaniak-Zając (red.), Innowacje w edukacji akademickiej. Szkolnictwo wyższe w procesie zmiany, Łódź: Wyd. UŁ, 53-64.

Domański, H. (2004). Między komunizmem a rynkiem. Wpływ wykształcenia na zarobki w 27 krajach. W: H. Domański, A. Ostrowska, A. Rychter (red.), Niepokoje polskie, Warszawa: Wyd. IFiS PAN.

Dworak, J. (2011). Wizerunek szkoły wyższej. Zarządzanie szkoła wyższą. Dylematy $i$ wyzwania, Gdańsk: Zeszyty Naukowe WSB, 14, 107-119.

Ernst \& Young Business Advisory, Instytut Badań nad Gospodarką Rynkową. (2009). Diagnoza stanu szkolnictwa wyższego w Polsce. Pozyskano z http://ptbk.mol.uj.edu.pl/download/aktualnosci/akt.diagnoza.pdf.

Gębski, M. (2009). Wybrane teorie rynku pracy. Miscellanea Oeconomicae, 13 (2), 11.

Giermanowska, E., Racław-Markowska, M. (2003). Społeczności lokalne wobec problemu bezrobocia młodzieży. Warszawa: ISP.

GUS. (1990-2010). Roczniki Statystyczne Rzeczpospolitej Polskiej 1990-2010. Warszawa.

GUS. (2000-2011). Bezrobocie rejestrowane w Polsce z lat 1999-2010, Warszawa.

GUS. (2003-2011). Kwartalna informacja o aktywności ekonomicznej ludności 2003-2012, Warszawa.

GUS. (2004-2010). Szkoty wyższe i ich finanse 2004-2010, Warszawa.

GUS. (2012). Bezrobocie rejestrowane I kwartat 2012 rok, Warszawa. 
Hennemann, S., Liefner I. (2010). German university education in geography and development: the mismatch between knowledge and competencies required. Journal of Geography in Higher Education, 34 (2), 215-230.

Jakubowska, A., Rosa, A. (2011). Problemy dopasowania oferty kształcenia szkół wyższych do potrzeb rynku pracy w Polsce. Zarządzanie szkoła wyższa. Dylematy $i$ wyzwania, Gdańsk: Zeszyty Naukowe WSB, 14, $29-43$

Jeruszka, U. (2011). Efektywność kształcenia w szkołach wyższych. Polityka Społeczna, 1, 1-7.

Kabaj, M., Jeruszka, U. (2009). Lepsze przygotowanie absolwentów szkół wyższych do potrzeb gospodarki i funkcjonowania na rynku pracy. Warszawa: IPiSS,

Kiersztyn, A. (2011). Racjonalne inwestycje czy złudne nadzieje: nadwyżka wykształcenia na polskim rynku pracy. Polityka Społeczna, 1, 7-14.

Knapińska, M. (2008). Transformacja zasobów pracy w Polsce w latach 1990-2006, Polityka Społeczna, 2, 6-10.

Knapińska, M. (2009). Sytuacja na rynku pracy w Polsce w latach 2000-2007. W: J. Sokołowski (red.), Problemy ekonomii, polityki ekonomicznej i finansów publicznych, Prace Naukowe Uniwersytetu Wrocławskiego, 143-155.

Kobylarek, A. (2004). Sytuacja społeczno-zawodowa absolwentów uniwersytetu na przykładzie Uniwersytetu Wrocławskiego. Toruń: Wyd. A. Marszałek.

Korpysa, J. (2003). Bezrobocie wśród absolwentów szkół wyższych. W: D. Kopycińska (red.), Kapitał ludzki w gospodarce, Szczecin: PTE, 123-133.

Kowalska, I. (2011). Doświadczenie praktyczne nauczycieli akademickich - wyznacznik wizerunku szkoły wyższej. Zarządzanie szkoła wyższą. Dylematy i wyzwania, Gdańsk: Zeszyty Naukowe WSB, 14, 121-138.

Kryńska, E. (2002). Studia i co potem? Bezrobocie wśród absolwentów szkół wyższych, Polityka Społeczna, 5-6, 6-10.

Kryńska, E. (2008). Młodzi ludzie a rynek pracy i edukacja. W: E. Sulima (red.), Rynek pracy a edukacja, Białystok: Wyd. Uniwersytetu Białostockiego.

Kryńska, E. (2011). Absolwenci szkół wyższych na rynku pracy. Oczekiwania i rzeczywistość. W: K. Jędralska, J. Bernais (red.), Kompetencje absolwentów studiów ekonomicznych. Perspektywa biznesu i nauki, Katowice: Prace Naukowe UE, 87-101.

Kukliński, A. (2003). O nowym modelu polityki regionalnej. Studia regionalne i lokalne, 4, 5-14.

Kurek, S., Rachwał, T. (2011). Development of entrepreneurship in ageing populations of The European Union. Procedia. Social and Behavioral Sciences, 19, 397-405.

Leja, K. (2008). Uniwersytet organizacją służącą otoczeniu. W: K. Leja (red.), Społeczna odpowiedzialność uczelni, Gdańsk: Wyd. Politechnika Gdańska, 53-72.

Mikuła-Bączek, E. (2009). Przeobrażenia instytucjonalne a jakość edukacji szczebla wyższego w Polsce w latach 1990-2006. Nierówności Społeczne a Rozwój Gospodarczy, 4, 461-472.

Ministerstwo Pracy i Polityki Społecznej. (2012, 10 października). Zawody deficytowe i nadwyżkowe w I pótroczu 2011 roku. Pozyskane z: http://www.mpips.gov.pl /analizy-i-raporty/raporty-sprawozdania/rynek-pracy/zawody-deficytowe-i-nadwyzkowe/rok-2011/ .

Orczykowska, A. (2006). Szkolnictwo wyższe a wymagania rynku pracy. Nauka i Szkolnictwo Wyższe, 2/28, 49-64.

Osuch, W. (2012). Podstawy przedsiębiorczości w opinii uczniów krakowskich liceów - szanse i oczekiwania. Przedsiębiorczość - Edukacja, 8, 37-47.

Pawson, E., Fournier, E., Haigh, M., Muniz, O., Trafford, J., Vajoczki, S. (2006). Problem-based Learning in Geography: towards critical assessment of its purposes, benefits and risks. Journal of Geography in Higher Education, 30 (1), 103-116.

Piróg, D. (2011a). Graduates of geographical studies on the labour market in the process of transformation in higher education. Prace i Studia Geograficzne, 48, Prace Instytutu Geografii UJK, 18, 161-172.

Piróg, D. (2011b). Usługi edukacyjne na poziomie akademickim w kontekście wymagań rynku pracy. Prace Komisji Geografii Przemystu Polskiego Towarzystwa Geograficznego, 18, 23-36. 
Piróg, D. (2012a). Aspiracje i plany zawodowe młodzieży akademickiej w Polsce na przykładzie studentów geografii. W: A. Dudak, K. Klimkowska, A. Różański (red.), Przygotowanie zawodowe młodych pedagogów, Kraków: Oficyna Wydawnicza Impuls, 125-144.

Piróg, D. (2012b). Changes to the conception of geography curricula within university education in Poland in the 21st century in the face of labour market challenges, European Journal of Geography, 3 (2), 24-41.

Piróg, D. (2012c). Methods for efficiency improvement of geographical studies within the scope of procurement of work by graduates exemplified by solutions applied in Great Britain and in Germany. W: B. Wójtowicz (red.), Natural sciences in educational systems of European countries in the 21st century, Kraków: Wyd. DEHON, 129-141.

Rachwał, T. (2006). Kształtowanie postaw przedsiębiorczych w edukacji szkolnej. W: B. Muchacka (red.), Szkoła w nauce i praktyce edukacyjnej, t. II, Kraków: Oficyna Wydawnicza „Impuls”, Akademii Pedagogicznej w Krakowie, 427-434.

Skórska, A. (2004). Młodzież na rynku pracy w Polsce i w Unii Europejskiej. Poznań: Wyd. WSB.

Sztanderska, U., (red.). (2007). Edukacja dla pracy. Raport o rozwoju społecznym. Polska, Warszawa: UNDP.

Sztanderska, U., Minkiewicz, B., Bąba, M. (2005a). Absolwent na rynku pracy, Forum Akademickie, 6.

Sztanderska, U., Minkiewicz, B., Bąba, M. (2005b). Absolwent na rynku pracy.cz II, Forum Akademickie, 7-8.

Teichler, U. (2011). Bologna - Motor or Stumbling Block for the Mobility and Employability of Graduates? Employability and mobility of Bachelor Graduates in Europe. Key results of the Bologna process, Rotterdam/Boston/Taipei: Sense Publishers, 1-2, 3-41.

Tracz, M. (2006). Rola i znaczenie podstaw przedsiębiorczości w kształceniu ogólnym. Przedsiębiorczość - Edukacja, 2, 222-225.

Zarycki, T. (2009). Kapitał kulturowy - założenia i perspektywy zastosowań teorii Pierre’a Bourdieu. Psychologia Spoleczna, 4, (1-2), 12-25.

Zioło, Z. (2008). Ekonomiczne i społeczne uwarunkowania rozwoju gospodarki opartej na wiedzy. Przedsiębiorczość - Edukacja, 4, 12-23.

Danuta Piróg, dr, Uniwersytet Pedagogiczny im. Komisji Edukacji Narodowej w Krakowie, Instytut Geografii, Zakład Dydaktyki Geografii.

Adiunkt w Instytucie Geografii Uniwersytetu Pedagogicznego w Krakowie Zainteresowania naukowe autorki ogniskują się wokół dwóch nurtów: zróżnicowania kulturowego Europy i tożsamości jej mieszkańców oraz efektywności studiów geograficznych w aspekcie potrzeb rynku pracy. Aktualnie D. Piróg jest kierownikiem projektu badawczego Ministerstwa Nauki i Szkolnictwa Wyższego w zakresie dyscyplin: polityka regionalna, polityka społeczna i demografia pt. „Absolwenci studiów geograficznych na rynku pracy w Polsce i wybranych krajach Unii Europejskiej”.

Danuta Piróg, PhD, Pedagogical University of Cracow, Institute of Geography, Department of Didactics of Geography.

Author is an assistant professor at the Pedagogical University of Cracow (Institute of Geography, Department of Didactics of Geography). Her research interests are focused on intercultural education, European education, practical preparation of students - candidates for the profession of a geography teacher, and the effectiveness of geographical studies in the context of the needs of the labour market. The author currently manages a research grant of the Ministry of Research and Higher Education: 'Graduates of geography studies on the labour market in Poland and in selected European Union countries'.

Adres/Address: Uniwersytet Pedagogiczny im. Komisji Edukacji Narodowej w Krakowie Instytut Geografii, Zakład Dydaktyki Geografii

ul. Podchorążych 2, 30-084 Kraków, Polska e-mail: dbutryn@up.krakow.pl 


\section{SPIS TREŚCI}

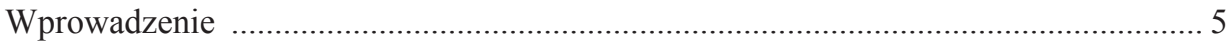

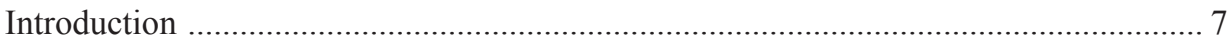

\section{Część 1}

Uwarunkowania rozwoju firm w okresie kryzysu gospodarczego

Zbigniew Zioło, Uwarunkowania rozwoju przedsiębiorczości w warunkach kryzysu gospodarczego

Monika Borowiec, Etyka chrześcijańska w kształtowaniu ładu moralnego

w biznesie w warunkach kryzysu społeczno-gospodarczego

Piotr Możyłowski, Prawno-administracyjne bariery prowadzenia działalności gospodarczej w Polsce w świetle opinii przedsiębiorców oraz raportów Doing Business

Paweł Marek Woroniecki, Ulgi podatkowe jako czynnik wspierający podmioty gospodarcze w okresie dekoniunktury rynkowej

Sławomir Dorocki, Agnieszka Świętek, Działania wybranych instytucji publicznych na rzecz wsparcia przedsiębiorczości w dobie kryzysu gospodarczego w Polsce

Wojciech Sadkowski, Oferta sektora bankowego dla małych i średnich przedsiębiorstw w czasach kryzysu gospodarczego w Polsce

\section{Część 2}

Funkcjonowanie firm, instytucji i sektorów gospodarki w warunkach kryzysu

Danuta Janczewska, Zachowania organizacyjne mikroprzedsiębiorstw w warunkach kryzysu

Sabina Sanetra-Półgrabi, Instytucje ekonomii społecznej w warunkach kryzysu gospodarczego (na przykładzie podmiotów w województwie śląskim)

Sławomir Dorocki, Paweł Brzegowy, Rozwój przemysłu turystycznego

departamentów Francji zamorskiej w warunkach światowego kryzysu

gospodarczego

Kamila Ziółkowska-Weiss, Ewolucja tradycyjnych funkcji muzeum w narracyjne muzea multimedialne na przykładzie muzeum Fabryka Emalia

Oskara Schindlera

Sławomir Dorocki, Anna Irena Szymańska, Małgorzata Zdon-Korzeniowska,

Polskie gospodarstwa agroturystyczne w dobie kryzysu gospodarczego

Mirosław Włodarczyk, Jerzy Janczewski, Zarządzanie logistyką zwrotną w usługach motoryzacyjnych 
Jadwiga Gałka, Nina Grad, Odnowa bielskiej starówki w opinii mieszkańców

Monika Płaziak, Technologia tanich domów energooszczędnych jako

odpowiedź na kryzys w budownictwie mieszkaniowym ......................................... 214

Piotr L. Wilczyński, Inwestycje w zbrojenia w czasach kryzysu gospodarczego .... 227

\section{Część 3}

Rola edukacji w zakresie przedsiębiorczości w okresie kryzysu gospodarczego

Krzysztof Wach, Edukacja na rzecz przedsiębiorczości wobec współczesnych wyzwań cywilizacyjno-gospodarczych

Tomasz Tadeusz Brzozowski, Status przedsiębiorczości w warunkach kryzysu edukacji

Wioletta Kilar, Sławomir Kurek, Tomasz Rachwał, Kształtowanie kompetencji osobistych i społecznych w szkolnictwie zawodowym dla sektora handlu detalicznego w świetle opinii partnerów społecznych

Agata Pradela, Rola systemu poradnictwa zawodowego w edukacji i tworzeniu inicjatyw klastrowych w systemie oświaty na przykładzie miast: Zabrza, Gliwic i Rybnika

Danuta Piróg, Absolwenci szkół wyższych na rynku pracy w warunkach kryzysu 


\section{CONTENTS}

Introduction

\section{Part 1}

The conditions of development of companies in times of an economic crisis

Zbigniew Zioło, The conditions for entrepreneurship development during an economic crisis

Monika Borowiec, The role of Christian ethics in shaping the moral order of business during a socio-economic crisis

Piotr Możyłowski, Legal and administrative barriers to business in Poland in the light of the opinions of entrepreneurs and the 'Doing Business' reports

Paweł Marek Woroniecki, Tax reliefs as an instrument of supporting economic agents during a market recession

Sławomir Dorocki, Agnieszka Świętek, The functioning of selected public institutions for supporting entrepreneurship during an economic crisis in Poland

Wojciech Sadkowski, The offer of the banking sector to small and medium-sized Polish enterprises during a crisis

\section{Part 2}

The functioning of companies, institutions and sectors of economy within the conditions of a crisis

Danuta Janczewska, Organizational behaviour of micro enterprises in the conditions of a crisis

Sabina Sanetra-Półgrabi, Social economy institutions in the conditions of an economic crisis (on the example of the Silesia region)

Sławomir Dorocki, Paweł Brzegowy, Development of the tourism industry in overseas departments and collectivities of France in the conditions of a global economic crisis

Kamila Ziółkowska-Weiss, The evolution of museums from their traditional form into a narrative multimedia experience on the example of Oskar Schindler's Factory

Sławomir Dorocki, Anna Irena Szymańska, Małgorzata Zdon-Korzeniowska, Polish agritourism farms in times of an economic crisis

Mirosław Włodarczyk, Jerzy Janczewski, Reverse logistics management in automotive services

Jadwiga Gałka, Nina Grad, Renovation of Bielsko-Biała’s Old Town in the opinion of residents 
Monika Płaziak, Technology of constructing cheap, energy-efficient house as an answer to the housing industry crisis

Piotr L. Wilczyński, Armaments in the period of an economic crisis

\section{Part 3}

The role of entrepreneurship education in times of an economic crisis

Krzysztof Wach, Entrepreneurship education towards modern civilization and economic challenges

Tomasz Tadeusz Brzozowski, Status of entrepreneurship in the conditions of an educational crisis

Wioletta Kilar, Sławomir Kurek, Tomasz Rachwał, Developing personal and social competencies in vocational training for the retail sector in the opinions of social partners

Agata Pradela, The role of vocational advisory services in the creation of cluster initiatives in the educational systems in Zabrze, Gliwice and Rybnik 289

Danuta Piróg, Higher education graduates on the labour market in times of an economic crisis 


\section{„Przedsiębiorczość - Edukacja”}

„Przedsiębiorczość - Edukacja” (ang. Entrepreneurship - Education) to czasopismo wydawane corocznie od 2005 r. (początkowo jako seria wydawnicza o charakterze monograficznym) przez Zakład Przedsiębiorczości i Gospodarki Przestrzennej Instytutu Geografii Uniwersytetu Pedagogicznego w Krakowie oraz wydawnictwo Nowa Era. Poszczególne tomy zawierają prace wpisujące się w problematykę określoną tytułem danego numeru. Część prac każdego tomu poświęcona jest zagadnieniom edukacji w zakresie przedsiębiorczości. Według listy B czasopism MNiSW z 2013 r. posiada ono 6 pkt. Czasopismo jest indeksowane w bazach czasopism, m.in. Google Scholar, BazEkon oraz IndexCopernicus.

Zapraszamy do lektury i nadsyłania artykułów.

Strona internetowa czasopisma $\mathrm{w}$ języku polskim $\mathrm{i}$ angielskim $\mathrm{z}$ dostępem do archiwalnych numerów: www.p-e.up.krakow.pl

e-mail redakcji: pe@up.krakow.pl

\section{Wykaz opublikowanych dotychczas tomów:}

- Zioło Z., Rachwał T. (red.), 2005, Przedsiębiorczosśc a współczesne wyzwania cywilizacyj$n e$, Przedsiębiorczość - Edukacja, nr 1, Zakład Przedsiębiorczości i Gospodarki Przestrzennej Instytutu Geografii Akademii Pedagogicznej w Krakowie, Wydawnictwo „MiWa”, Kraków.

- Zioło Z., Rachwał T. (red.), 2006, Rola przedsiębiorczości w podnoszeniu konkurencyjności spoteczeństwa i gospodarki, Przedsiębiorczość - Edukacja, nr 2, wydawnictwo Nowa Era, Zakład Przedsiębiorczości i Gospodarki Przestrzennej Instytutu Geografii Akademii Pedagogicznej w Krakowie, Warszawa - Kraków.

- Zioło Z., Rachwał T. (red.), 2007, Rola przedsiębiorczości w aktywizacji gospodarczej, Przedsiębiorczość - Edukacja, nr 3, wydawnictwo Nowa Era, Zakład Przedsiębiorczości i Gospodarki Przestrzennej Instytutu Geografii Akademii Pedagogicznej w Krakowie, Warszawa - Kraków.

- Zioło Z., Rachwał T. (red.), 2008, Rola przedsiębiorczości w gospodarce opartej na wiedzy, Przedsiębiorczość - Edukacja, nr 4, wydawnictwo Nowa Era, Zakład Przedsiębiorczości i Gospodarki Przestrzennej Instytutu Geografii Uniwersytetu Pedagogicznego w Krakowie, Warszawa-Kraków.

- Zioło Z., Rachwał T. (red.), 2009, Rola przedsiębiorczości w ksztaltowaniu społeczeństwa informacyjnego, Przedsiębiorczość - Edukacja, nr 5, wydawnictwo Nowa Era, Zakład Przedsiębiorczości i Gospodarki Przestrzennej Instytutu Geografii Uniwersytetu Pedagogicznego w Krakowie, Warszawa - Kraków.

- Zioło Z., Rachwał T. (red.), 2010, Przedsiębiorczość w warunkach integracji europejskiej, Przedsiębiorczość - Edukacja, nr 6, wydawnictwo Nowa Era, Zakład Przedsiębiorczości i Gospodarki Przestrzennej Instytutu Geografii Uniwersytetu Pedagogicznego w Krakowie, Warszawa - Kraków. 
- Zioło Z., Rachwał T. (red.), 2011, Przedsiębiorczość w warunkach globalizacji / Entrepreneurship in the Conditions of Globalization, Przedsiębiorczość - Edukacja / Entrepreneurship - Education, nr 7, wydawnictwo Nowa Era, Zakład Przedsiębiorczości i Gospodarki Przestrzennej Instytutu Geografii Uniwersytetu Pedagogicznego w Krakowie, Warszawa - Kraków.

- Zioło Z., Rachwał T. (red.), 2012, Rola przedsiębiorczości w edukacji / The Role of Entrepreneurship in Education, Przedsiębiorczość - Edukacja / Entrepreneurship - Education, nr 8, wydawnictwo Nowa Era, Zakład Przedsiębiorczości i Gospodarki Przestrzennej Instytutu Geografii Uniwersytetu Pedagogicznego w Krakowie, Warszawa - Kraków.

- Zioło Z., Rachwał T. (red.), 2013, Przedsiębiorczość w warunkach kryzysu gospodarczego / Entrepreneurship in the Conditions of Economic Crisis Przedsiębiorczość - Edukacja / Entrepreneurship - Education, nr 9, wydawnictwo Nowa Era, Zakład Przedsiębiorczości i Gospodarki Przestrzennej Instytutu Geografii Uniwersytetu Pedagogicznego w Krakowie, Warszawa - Kraków.

oprac. Tomasz Rachwał 


\section{Wykaz ogólnopolskich i międzynarodowych konferencji naukowych z cyklu poświęconego problematyce przedsiębiorczości}

\section{Organizatorzy:}

- Zakład Przedsiębiorczości i Gospodarki Przestrzennej Instytutu Geografii Uniwersytetu Pedagogicznego im. Komisji Edukacji Narodowej w Krakowie

- wydawnictwo Nowa Era

- Fundacja „Edukacja dla Społeczeństwa”

- Komisja Geografii Przemysłu Polskiego Towarzystwa Geograficznego

\section{Wykaz konferencji:}

- I Ogólnopolska Metodyczna Konferencja Naukowa „Przedsiębiorczość a współczesne wyzwania cywilizacyjne”, Kraków, 27-28 września 2004 r.

- II Ogólnopolska Metodyczna Konferencja Naukowa „Rola przedsiębiorczości w podnoszeniu konkurencyjności społeczeństwa i gospodarki” ze specjalną sesją „Rola etyki w przedsiębiorczości”, Kraków, 10-11 października 2005 r.

- III Ogólnopolska Metodyczna Konferencja Naukowa „Rola przedsiębiorczości w aktywizacji gospodarczej”, Kraków, 9-10 października 2006 r.

- IV Ogólnopolska Metodyczna Konferencja Naukowa „Rola przedsiębiorczości w gospodarce opartej na wiedzy” ze specjalną sesją pt. „Rola etyki w przedsiębiorczości”, Kraków, 8-9 października $2007 \mathrm{r}$.

- V Ogólnopolska Metodyczna Konferencja Naukowa „Rola przedsiębiorczości w kształtowaniu społeczeństwa informacyjnego" połączona z I Ogólnopolskim Zjazdem Nauczycieli Przedsiębiorczości, Kraków, 6-7 października 2008 r.

- VI Ogólnopolska Metodyczna Konferencja Naukowa „Przedsiębiorczość w warunkach integracji europejskiej” połączona z II Ogólnopolskim Zjazdem Nauczycieli Przedsiębiorczości, Kraków, 5-6 października 2009 r.

- VII Ogólnopolska Metodyczna Konferencja Naukowa „Rola przedsiębiorczości w warunkach globalizacji” połączona z III Ogólnopolskim Zjazdem Nauczycieli Przedsiębiorczości, Kraków, 4-5 października 2010 r.

- 8. Międzynarodowa Konferencja Naukowa „Rola przedsiębiorczości w edukacji” (The Role of Entrepreneurship in Education) połączona z 4. Ogólnopolskim Zjazdem Nauczycieli Przedsiębiorczości, Kraków, 3-4 października 2011 r.

- 9. Międzynarodowa Konferencja Naukowa „Przedsiębiorczość w warunkach kryzysu gospodarczego" (Entrepreneurship in the Conditions of Economic Criris) połączona z 5. Ogólnopolskim Zjazdem Nauczycieli Przedsiębiorczości, Kraków, 8-9 października $2012 \mathrm{r}$.

- 10. Międzynarodowa Konferencja Naukowa „Rola przedsiębiorczości w rozwoju firm i układów przestrzennych" (The Role of Entrepreneurship in the Development of Enterprises and Spatial Systems) połączona z 6. Ogólnopolskim Zjazdem Nauczycieli Przedsiębiorczości, Kraków, 7-8 października 2012 r. 


\section{Zapraszamy}

na 11. Międzynarodową Konferencję Naukową

\section{„Rola przedsiębiorczości w rozwoju społeczno-gospodarczym układów przestrzennych"}

The Role of Entrepreneurship in Socio-Economic Development of Spatial Systems

połączoną z

7. Ogólnopolskim Zjazdem Nauczycieli Przedsiębiorczości

która odbędzie się w Krakowie w dniach 6-7 października 2014 r. 